\title{
GEOQUÍMICA E GÊNESE DAS FORMAÇÕES FERRÍFERAS BANDADAS E DO MINÉRIO DE FERRO DA MINA DE ÁGUAS CLARAS, QUADRILÁTERO FERRÍFERO, MG
}

\section{CARLOS ALBERTO SPIER}

Orientadora: Prof ${ }^{a}$. Dr ${ }^{a}$. Sonia Maria Barros de Oliveira

TESE DE DOUTORAMENTO

COMISSÃO JULGADORA

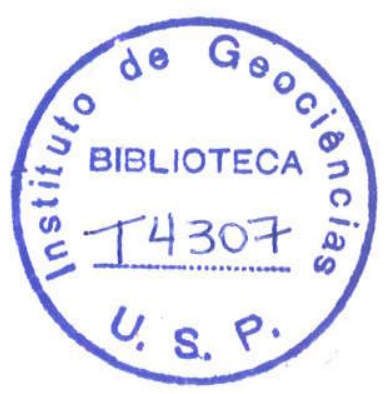

Nome

Presidente: $\quad \operatorname{Prof}^{a}$. Dr ${ }^{a}$. Sonia Maria Barros de Oliveira

Examinadores: Prof. Dr. Basile Kotschoubey

Prof. Dr. João Carlos Biondi

Prof ${ }^{\mathrm{a}}$. Dr $\stackrel{\mathrm{a}}{ }$. Lydia Maria Lobato

Prof ${ }^{\mathrm{a}}$. Dr $\stackrel{\mathrm{a}}{\text {. }}$ Maria Cristina Motta de Toledo

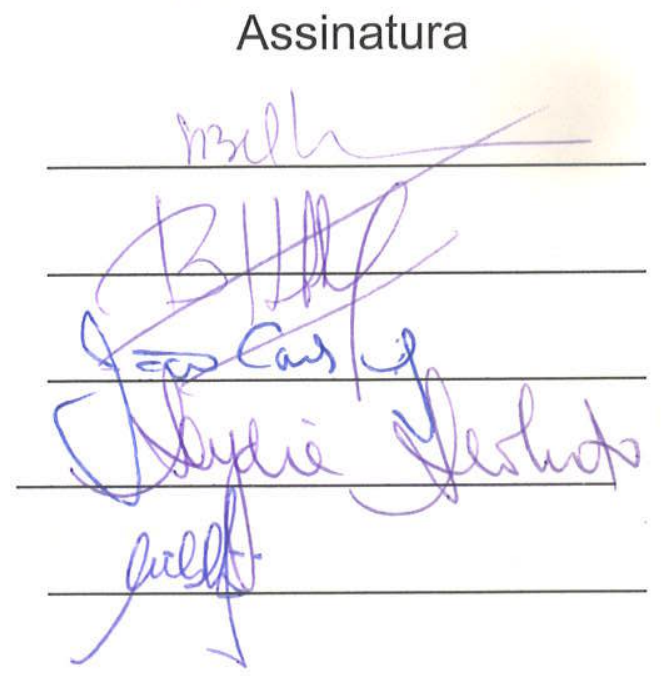

SÃO PAULO

2005 


\section{UNIVERSIDADE DE SÃO PAULO INSTITUTO DE GEOCIÊNCIAS}

\section{GEOQUÍMICA E GÊNESE DAS FORMAÇÕES FERRÍFERAS BANDADAS E DO MINÉRIO DE FERRO \\ DA MINA DE ÁGUAS CLARAS, QUADRILÁTERO FERRÍFERO, MG}

Carlos Alberto Spier

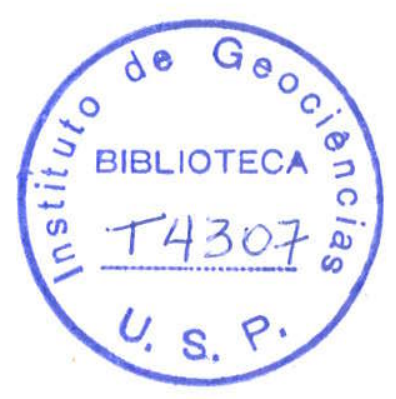

Orientadora: Profa. Dra. Sonia Maria Barros de Oliveira Co-orientador: Prof. Dr. Carlos Alberto Rosière

TESE DE DOUTORAMENTO

Programa de Pós-Graduação em Geoquímica e Geotectônica

$$
\begin{aligned}
& \text { SÃO PAULO } \\
& 2005
\end{aligned}
$$

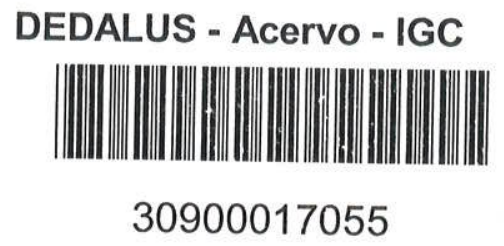


Ficha catalográfica preparada pelo Serviço de Biblioteca e Documentação do Instituto de Geociências da Universidade de São Paulo

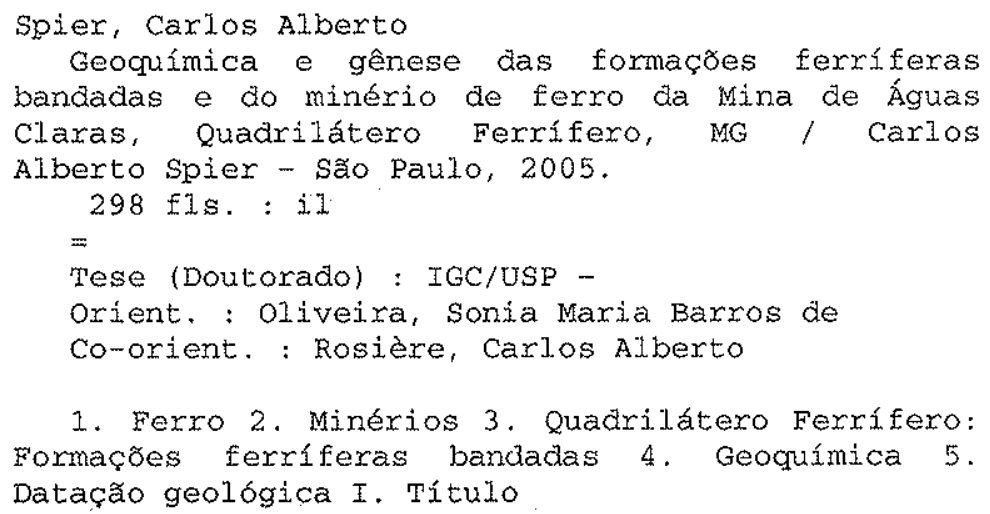


À minha mãe Lorena, à minha esposa Madalena e aos meus filhos, Guilherme e Nathália. 


\section{AGRADECIMENTOS}

À minha esposa Madalena e aos meus filhos Guilherme e Nathália pelo apoio incondicional, estímulo e compreensão pelas muitas e longas horas de ausência do convívio familiar.

A MBR, que permitiu a realização deste trabalho, dando todo o apoio material e financeiro necessário. Agradeço especialmente ao geólogo Oscar Tessari, gerente de geologia e planejamento de lavra, pela compreensão e tolerância às minhas ausências da empresa.

À professora Sonia Oliveira, não apenas pela dedicada orientação e prontidão em auxiliar-me em tudo o que fosse necessário à realização deste trabalho, mas também pelo exemplo de pesquisadora incansável, sempre a procura de novos desafios.

Ao professor Carlos Alberto Rosière, pelos conhecimentos transmitidos, pela boa vontade $\mathrm{e}$ disposição em auxiliar-me e pelas muitas e longas discussões sobre a gênese das BIFs e do minério de ferro, que certamente influenciaram decisivamente nos resultados deste trabalho.

Ao professor e workaholic Paulo Vasconcelos pelos ensinamentos transmitidos de geologia isotópica, e por todo o apoio dado por ocasião de minha estadia na Universidade de Queensland. Suas sugestões e colaborações foram fundamentais para a elaboração do quarto artigo desta tese.

A CAPES, pelo auxílio financeiro durante a realização do doutorado sanduíche.

As tradutoras Rosa Silva e Eliana Sampaio, pela paciência durante inúmeras revisões dos textos em inglês "macarrônico".

À geóloga e Dra Isabela Carmo, pelo treinamento e auxílio na preparação das amostras para geocronologia, por todos os conhecimentos gentilmente transmitidos e, particularmente, pela ajuda na elaboração de muitas das figuras desta tese.

À geóloga Gislaine, pela ajuda no microscópio eletrônico e pelo ótimo convívio durante minha estada em Brisbane.

Aos amigos do CDTN, Javier, James, José Domingos e professores Kazuo e Correia Neves, por terem permitido o uso de seus laboratórios, o que facilitou muitíssimo a realização deste trabalho.

Ao professor Alcides Sial, pela realização das análises isotópicas de carbono e oxigênio. 
Aos meus colegas da MBR, Diniz, Victor, Marcela, Antônio Vitor, Zaneti, Vanuti, Stael e Adriana Zaparoli pelas muitas discussões sobre a geologia dos itabiritos e do minério de ferro, assim como pelo estímulo a realização deste trabalho.

Ao professor George Rossman, pelo apoio e simpatia durante minha estada na CALTECH.

Ao geólogo Jonathan Heim e ao engenheiro Ron Rash, pela revisão e sugestões de dois dos manuscritos deste trabalho.

Ao pessoal do CMM da Universidade de Queensland, em especial Ron Rash e Graeme Auchterlonie, pela paciência e dedicação no ensinamento do uso dos microscópios eletrônicos e microssonda.

À geóloga Fabiana Cruz, pelo auxílio nos momentos finais da montagem da tese.

$\grave{A}$ todas as demais pessoas que direta ou indiretamente contribuíram de alguma maneira para que este trabalho pudesse ser realizado. 


\section{SUMÁRIO}

Dedicatória $\quad$ ii

Agradecimentos iii

Sumário $\quad v$

Lista de figuras $\quad$ xi

Lista de tabelas $\quad \mathrm{XV}$

Lista de siglas e abreviaturas $\quad$ xvi

Resumo xviii

Abstract $\quad x x$

1 Introdução 1

1.1 Apresentação 1

1.2 Objetivos 3

1.3 Localização e aspectos gerais 3

1.4 Estrutura da tese

2 Amostragem e técnicas analíticas 9

2.1 Amostragem 9

2.1.1 Mina de Águas Claras 9

$\begin{array}{ll}\text { 2.1.2 Minas do Sapecado e Andaime } & 10\end{array}$

2.2 Técnicas analíticas 15

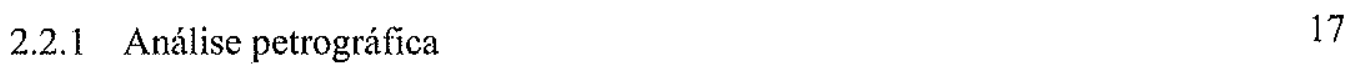

$\begin{array}{ll}\text { 2.2.2 Análise por difração de raios-X (DRX) } & 18\end{array}$

$\begin{array}{lll}2.2 .3 & \text { Análise por microscopia eletrônica de varredura (MEV) } & 18\end{array}$

2.2.4 Análise por microssonda eletrônica (MSE) 19

2.2.5 Análise química 20

2.2.6 Determinação de densidade 21

2.2.7 Análise de isótopos de carbono e oxigênio 21

2.2.8 Análise por espectroscopia Mössbauer (MS) 22 
2.2.9 Análise geocronológica pelo método ${ }^{40} \mathrm{Ar} r^{39} \mathrm{Ar}$

3 Geologia e geoquímica do minério de ferro da Mina de Águas Claras, Quadrilátero Ferrífero, Minas Gerais, Brasil

4 Geoquímica e gênese das formações ferriferas bandadas da Formação Cauê, Quadrilátero Ferrífero, Minas Gerais, Brasil

5 Os minérios de ferro de alto teor da Mina de Águas Claras, Quadrilátero Ferrífero, Brasil

6 Geocronologia ${ }^{40} \mathrm{Ar}{ }^{39} \mathrm{Ar}$ e evolução dos depósitos de ferro lateríticos do Quadrilátero Ferrifero, Minas Gerais, Brasil

7 Considerações finais e conclusões

\section{ANEXOS}

Anexo 1 GEOLOGY AND GEOCHEMISTRY OF THE AGUAS CLARAS AND PICO MINES, QUADRILÁTERO FERRÍFERO, MINAS GERAIS, BRAZIL

Abstract

Introduction

Geological setting

The Quadrilátero Ferrifero district

The itabirites of the Itabira Group

The iron ores of the Itabira Group

Genetic models for the iron ores

The Aguas Claras orebody

General description

Structure and stratigraphy of the mine area 48

The dolomitic itabirite: mesoscopic features, petrography and chemistry 51

The high grade ore at the Águas Claras mine $\quad 57$

The Pico Orebody

General description $\quad 62$

Structure and stratigraphy of the mine area 62

Itabirites at the Pico Mine 64

The iron ores $\quad 67$ 
$\begin{array}{ll}\text { Discussion } & 70\end{array}$

Major differences between the Águas Claras and Pico Mines $\quad 70$

Considerations about the iron ore genesis 73

$\begin{array}{ll}\text { Conclusion } & 76\end{array}$

$\begin{array}{ll}\text { Acknowledgements } & 77\end{array}$

References

Anexo 2 GEOCHEMISTRY AND GENESIS OF THE BANDED IRON FORMATIONS OF THE CAUÊ FORMATION, QUADRILÁTERO FERRÍFERO, MINAS GERAIS, BRAZIL

Abstract

Introduction

$\begin{array}{lr}\text { Geological setting } & 84\end{array}$

$\begin{array}{ll}\text { Local geology } & 87\end{array}$

Sampling and analytical procedures 94

Mineralogy and petrography 96

$\begin{array}{lr}\text { Sericitic phyllite } & 96\end{array}$

$\begin{array}{lr}\text { Argillaceous dolomite } & 96\end{array}$

$\begin{array}{lr}\text { Granular iron formation } & 97\end{array}$

$\begin{array}{lr}\text { Ferruginous dolomite } & 97\end{array}$

Dolomitic and quartz itabirites 99

Quartz-carbonate rocks of the transition zone to the Gandarela Fm. $\quad 100$

$\begin{array}{ll}\text { Mineral chemistry } & 103\end{array}$

$\begin{array}{ll}\text { Geochemistry } & 105\end{array}$

Ranges and stratigraphic variation of major elements 109

Ranges and stratigraphic variation of trace elements $\quad 111$

$\begin{array}{ll}\text { Some linear interelement correlations } & 118\end{array}$

REE results 123

$\begin{array}{ll}C \text { and } O \text { isotopes } & 126\end{array}$ 
Comparison with other iron-formations

Discussion

The question of terrigenous contamination

Effects of post-depositional processes

Dolomitization and genesis of the dolomitic itabirite

The high degree of oxidation

The source of sediments and depositional environment

The depositional model

Conclusions

Acknowledgements

References

Appendix 1

Appendix 2

Anexo 3 THE HIGH-GRADE IRON ORES OF THE ÁGUAS CLARAS MINE, QUADRILÁTERO FERRÍFERO, MINAS GERAIS, BRAZIL

Abstract

Introduction

Geological setting

The dolomitic itabirite (protore)

The iron ore

Sampling and analytical procedures

Mineralogical and geochemical characteristics

The dolomitic itabirite (protore)

Soft iron ores

Mineralogy and petrology 
Geochemistry 186

$\begin{array}{ll}\text { Some linear interelement correlations } & 194\end{array}$

Hard iron ores 196

$\begin{array}{ll}\text { Mineralogy and petrology } & 196\end{array}$

XRD and Mössbauer analyses $\quad 198$

Geochemistry 199

$\begin{array}{ll}\text { Discussion } & 200\end{array}$

Comparison between hard and soft ores $\quad 200$

Formation of tabular and granular hematite within martite crystals 202

Comparison with other iron mines on the western side of the Quadrilatero 204

Ferrifero

204

Capão Xavier

Tamanduá Mine 204

$\begin{array}{lr}\text { Ore Genesis } & 208\end{array}$

$\begin{array}{lr}\text { Conclusions } & 214\end{array}$

$\begin{array}{ll}\text { Acknowledgements } & 215\end{array}$

$\begin{array}{ll}\text { References } & 215\end{array}$

$\begin{array}{ll}\text { Appendix } 1 & 220\end{array}$

$\begin{array}{ll}\text { Appendix } 2 & 222\end{array}$

$\begin{array}{ll}\text { Appendix } 3 & 227\end{array}$

Anexo $4{ }^{40} \mathbf{A r}{ }^{39}$ Ar GEOCHRONOLOGY AND THE EVOLUTION OF

LATERITIC IRON DEPOSITS IN QUADRILÁTERO FERRÍFERO, 230 MINAS GERAIS, BRAZIL

$\begin{array}{ll}\text { Abstract } & 230\end{array}$

Introduction $\quad 230$

Geological setting 234

$\begin{array}{ll}\text { Regional geology } & 234\end{array}$ 
Local geology 236

Sampling and analytical procedure 239

Results and discussion 241

Mineralogy and petrography 241

Electron microprobe analysis $\quad 244$

Manganese oxide paragenesis 246

${ }^{40}$ Ar ${ }^{39}$ Ar Geochronological analysis $\quad 246$

How old are the Quadrilátero Ferrifero weathering profiles?

Continuous or episodic weathering record? 258

$\begin{array}{ll}\text { Paleoclimatic implications } & 259\end{array}$

Landscape evolution implications $\quad 259$

Implications for the supergene enrichment of banded iron formations 260

Conclusions 261

Acknowledgements 261

$\begin{array}{ll}\text { References } & 262\end{array}$

$\begin{array}{ll}\text { Appendix } 1 & 265\end{array}$

Anexo 5 Relação das amostras, coordenadas e procedimentos analíticos aplicados 281

Referências bibliográficas $\quad 285$ 


\section{LISTA DE FIGURAS}

FIGURA 1 Localização da área de estudo

FIGURA 2 Vista geral da Mina de Águas Claras 5

FIGURA 3 Vista geral da Mina do Sapecado 5

FIGURA 4 Modelo digital do terreno da região do Quadrilátero Ferrífero 6

FIGURA 5 Vista geral da parede leste da Mina de Águas Claras 11

FIGURA 6 Mapa geológico da Mina de Águas Claras com a localização dos locais amostrados

FIGURA 7 Seção geológica 6.300E da Mina do Sapecado com a localização dos locais amostrados

FIGURA 8 Intervalos de furo de sonda da Mina do Sapecado mostrando as concreções de manganês

FIGURA 9 Seção geológica 3.500E da Mina de Andaime com a localização dos locais amostrados

FIGURA 10 Fluxuograma dos procedimentos analíticos utilizados para filitos, metachert e dolomitos

FIGURA 11 Fluxuograma dos procedimentos analíticos utilizados para itabiritos

FIGURA 12 Fluxuograma dos procedimentos analíticos utilizados para o minério

FIGURA 13 Diagrama esquemático da análise geocronológica por ${ }^{40} \mathrm{Ar} /{ }^{39} \mathrm{Ar}$

ANEXO 1

FIGURA 1 Location and geological sketch map of the Quadrilatero Ferrifero region

FIGURA 2 Birds eye view of the Aguas Claras and Pico mines

FIGURA 3 Stratigraphic colum of the Quadrilátero Ferrifero region

FIGURA 4 Cross section 2.200E and geological sketch map of the Aguas Claras mine

FIGURA 5 Hand specimen and drill core samples showing dolomitic itabirite and iron ore of the Aguas Claras mine

FIGURA 6 Photomicrographs of the dolomitic itabirite

FIGURA 7 Photomicrographs of the dolomitic itabirite 
FIGURA 8 SEM images of the iron ores-Aguas Claras mine 58

FIGURA 9 Particle size with correspondent chemical composition of the iron ore - Aguas Claras mine

FIGURA 10 Cross section 8.400E and geological sketch map of the Pico mine 63

FIGURA 11 Hand specimen and mine exposures of iron ores at the Pico mine 65

FIGURA 12 Photomicrographs of the quartz itabirite 66

ANEXO 2

FIGURA 1 Location and geological sketch map of the Quadrilatero Ferrifero region

FIGURA 2 Stratigraphic colum of the Quadrilátero Ferrifero region

FIGURA 3 Cross section 2.550E and geological sketch map of the Aguas Claras mine

FIGURA 4 Location of samples within stratigraphy and photographs of the studied rocks

FIGURA 5 Photographs of granular iron formation

FIGURA 6 Photographs of dolomitic itabirite

FIGURA 7 Ternary plot showing major element composition of the samples studied, grouped into five groups

FIGURA 8 Photomicrographs of various rock types of the base of the Cauê Formation

FIGURA 9 Photomigraphs of dolomitic itabirite

FIGURA 10 SEM images of dolomitic and quartz itabirites

FIGURA 11 Photomigraphs of quartz itabirite and dolomite of the transition zone to the Gandarela Formation

FIGURA 12 Plots of $\mathrm{Ca} / \mathrm{Mg}$ and $\mathrm{Ca} /(\mathrm{Fe}+\mathrm{Mn})$ ratios, and $\mathrm{C}$ and $\mathrm{O}$ isotopes of dolomitic itabirite as function of stratigraphy

FIGURA 13 Chemostratigraphy of the Caue Formation

FIGURA 14 Plots of average trace element composition of the studied rocks

FIGURA 15 Plots of interelement correlations

FIGURA 16 Plots of PAAS-normalized data for the studied rocks

FIGURA 17 Comparison of major and trace element composition of BIFs 
FIGURA 18 Comparison of $C$ and $O$ isotopes from carbonates of the Quadrilátero Ferifero, Australia and South Africa

FIGURA 19 Plot of Sc versus Th composition for all samples of the Itabira Group

FIGURA 20 Plot of the Y/Ho and Zr/Hf ratio for all samples of the Itabira Group

FIGURA 21 Plot of $(\mathrm{Co}+\mathrm{Ni}+\mathrm{Cu})$ abundances versus total REE content for itabirites and others BIFS

FIGURA 22 Geological cross sections of the Águas Claras (2.550E) and Pico (8.550E) Mines

FIGURA 23 Schematic depositional model for the Cauê Formation

\section{ANEXO 3}

FIGURA 1 Location and geological sketch map of the Quadrilatero Ferrifero region

FIGURA 2 Cross section 2.200E and geological sketch map of the Aguas Claras mine

FIGURA 3 Photographs of dolomitic itabirite and iron ores

FIGURA 4 Photomicrographs and SEM images of dolomitic itabirite

FIGURA 5 SEM images of soft ore

FIGURA 6 Powder XRD patterns and Mössbauer spectra of dolomite-rich bands of dolomitic itabirite

FIGURA 7 Photomicrographs of soft ore

FIGURA 8 SEM images of gangue minerals in soft ore

FIGURA 9 TEM image of the porous band of soft ore

FIGURA 10 Powder XRD patterns of massive and porous bands of soft ore

FIGURA 11 Mössbauer spectra at $300 \mathrm{~K}$ and at $50 \mathrm{~K}$ of the massive and porous band of the sample MAC127 (Soft ore)

FIGURA 12 Plots of the average major composition of the ores

FIGURA 13 Plots of the average trace element composition of the ores

FIGURA 14 Plots of PAAS-normalized REEY data for the ores

FIGURA 15 Interelement correlations for the soft ore samples

FIGURA 16 Photomicrographs and SEM images of the hard ores 
FIGURA 17 Powder XRD patterns of the hard ore samples

FIGURA 18 Mössbauer spectra at room tempeature of the hard ore samples

FIGURA 19 Photomicrographs and SEM images showing development of hematite

FIGURA 20 Geological cross sections of the Capão Xavier and Tamanduá Mines 205

FIGURA 21 Drilling cores and mine exposure showing contact between quartz itabirite and high-grade ores

\section{ANEXO 4}

FIGURA 1 Location and geological sketch map of the Quadrilatero Ferrifero region

FIGURA 2 Digital elevation model for the Quadrilatero Ferrifero region illustrating location of weathering profiles investigated

FIGURA 3 Studied geological sections showing distribution of weathering profile at the Andaime and Sapecado Mines

FIGURA 4 Drill core showing the manganiferous itabirite

FIGURA 5 Reflected-light photomicrographs of Mn-oxides

FIGURA 6 SEM images showing several generations of Mn-oxides

FIGURA 7 Ternary plots showing the major chemical composition of the Mnoxides

FIGURA 8 Histograms of the $M n$ and $K$ contents of Mn-oxides grains

FIGURA 9 Incremental-heating spectra for the Mn-oxide samples

FIGURA 10 Geological sections of the Andaime and Sapecado deposits showing distribution of the samples and age plateau

FIGURA 11 Probability density plot (ideogram) for samples from the Moeda Syncline region

FIGURA 12 Correlation of age plateau and elevation for grains of Mnoxides analyzed at the Moeda Syncline region 


\title{
LISTA DE TABELAS
}

TABELA 1 Relação dos elementos químicos analisados por laboratório

\begin{abstract}
ANEXO 1
TABELA 1 Synthesis of the tectonic events at the Quadrilatero Ferrifero region

TABELA 2 Chemical composition of the products of the Aguas Claras and Pico mines

TABELA 3 Averages and ranges of major components of dolomitic itabirite 56

TABELA 4 Chemical composition of the iron ores-Aguas Claras mine 60

TABELA 5 Chemical composition of the itabirites - Pico mine 67

TABELA $6 \quad$ Chemical composition of the iron ores - Pico mine 70

TABELA 7 Summary of the major differences between the Aguas Claras and Pico mines

\section{ANEXO 2}

TABELA 1 Average electron microprobe analyses of dolomite

TABELA 2 Average major and trace element composition of the studied rocks

TABELA 3 Average REE composition of the studied rocks

TABELA 4 Linear interelement correlations

TABELA $5 \quad C$ and $O$ Isotope composition of dolomite in dolomitic itabirite

APPENDIX 1 Major and trace element compositions

\section{ANEXO 3}

TABELA 1 Mössbauer hyperfine parameters of iron ore and dolomitic itabirite sample.

TABELA 2 Unit cell parameters of hematite in the iron ores

TABELA 3 Average major and trace element composition of the soft and hard 
TABELA 5 Linear interelement correlations of the soft ore

TABELA 6 The $C$ and O isotopic composition of carbonate samples from Aguas Claras and Carajás

APPENDIX 1 List of the samples, location and analytical procedures

APPENDIX 2 Major and trace element composition of the hard and soft ores

APPENDIX 3 REE composition of the hard and soft ores

ANEXO 4

TABELA 1 Average composition of the Mn-oxides

TABELA 2 Summary of the ${ }^{40}$ Ar ${ }^{39}$ Ar geochronology

APPENDIX 1 Analytical results

\section{LISTA DE SIGLAS E ABREVIATURAS}

ACTLABS Activation Laboratories

AND Depósito de Andaime

CDTN Centro de Desenvolvimento de Tecnologia Nuclear

CMM-UQ Center for Microscopy and Microanalysis da Universidade de Queensland

CPX Mina do Capão Xavier

CVRD Companhia Vale do Rio Doce

MAC Mina de Águas Claras

MBR Minerações Brasileiras Reunidas

NEG-LABISE Laboratório de Isótopos Estáveis da Universidade Federal de Pernambuco

QF Quadrilátero Ferrífero

SAP Mina do Sapecado

TAM Mina de Tamanduá

UFMG Universidade Federal de Minas Gerais 
UFOP Universidade Federal de Ouro Preto

UQ Universidade de Queensland

UQ-AGES University of Queensland Argon Geochronoly in Earth Sciences

USP Universidade de São Paulo 


\section{RESUMO}

O minério de ferro e os itabiritos da Mina de Águas Claras foram estudados em detalhe do ponto de vista mineralógico, petrológico e geoquímico, com os objetivos de caracterizá-los e de contribuir para o melhor entendimento da gênese dos mesmos. Dois tipos de itabiritos ocorrem em Águas Claras: dolomítico e quartzo itabirito. Os minérios de alto teor (\%Fe $>64 \%)$ foram formados a partir do primeiro. Tanto um como outro tipo de itabirito apresentam meso e microbandamento. No itabirito dolomítico alternam-se bandas ricas em hematita com bandas ricas em dolomita, enquanto que no quartzo itabirito a alternância ocorre entre bandas ricas em quartzo com bandas ricas em hematita. Dolomita, quartzo e hematita são os principais constituintes mineralógicos, ocorrendo clorita, sericita, talco e apatita como minerais acessórios. A composição química dos itabiritos é muito simples. $\mathrm{Fe}_{2} \mathrm{O}_{3}, \mathrm{CaO}, \mathrm{MgO}$ e PF são os principais componentes do itabirito dolomítico e $\mathrm{Fe}_{2} \mathrm{O}_{3}$ e $\mathrm{SiO}_{2}$ do quartzo itabirito. Os teores de elementos menores são geralmente inferiores a $10 \mathrm{ppm}$, tanto no itabirito dolomítico como no quartzo itabirito, sem evidenciarem uma maior concentração em um ou outro tipo de BIF. Apenas $\mathrm{Zn}, \mathrm{Sr}$ e $\mathrm{Pb}$ estão mais caracteristicamente associados com o itabirito dolomítico, e $\mathrm{Cd}, \mathrm{Sb}$ e $\mathrm{Ge}$ com o quartzo itabirito. O padrão de fracionamento dos ETR, quando normalizados pelo padrão PAAS, assemelha-se aos de outras BIFs paleoproterozóicas, com anomalias positivas de Eu e $\mathrm{Y}$ e aumento gradativo dos ETR leves em direção aos pesados. Os isótopos de $\mathrm{C}$ e $\mathrm{O}$ do itabirito dolomítico apresentaram valores negativos de $\delta^{13} \mathrm{C}$ variando entre $-2,5 \%$ e $-0,8 \%$, enquanto que os dados isotópicos de $\mathrm{O}$ mostraram valores de $\delta^{18} \mathrm{O}$ entre $-12,4 \%$ e $-8,5 \%$, compatíveis com os valores de $\delta^{13} \mathrm{C}$ e $\delta^{18} \mathrm{O}$ encontrados em outras seqüências carbonáticas paleoproterozóicas. As observações de campo e os dados de laboratório sugerem que o itabirito dolomítico e o quartzo itabirito representem variações faciológicas laterais e verticais dos sedimentos originais da Formação Cauê.

Dois tipos principais de minério de alto teor foram reconhecidos: friável e compacto. $\mathrm{O}$ minério friável é o principal tipo, ocorrendo na forma de uma lente contínua de cerca de $2,5 \mathrm{~km}$ de extensão, no interior da qual ocorrem lentes subordinadas de minério compacto. $O$ minério friável passa lateral e verticalmente para o itabitito dolomítico (protominério). Nesta transição, as bandas ricas em hematita do itabirito passam a ser as bandas maciças do minério, enquanto que as bandas dolomíticas passam a constituir as bandas porosas. A hematita é o mineral minério tanto do minério friável como do minério compacto, ocorrendo sob a forma de hematita granular 
e tabular, com tamanho de cristal entre 10 e $30 \mu \mathrm{m}$. Os minerais de ganga são raros e consistem de apatita, clorita, sericita, talco e, eventualmente, dolomita, além de ferridrita e minerais de manganês, estes últimos originados na dissolução da dolomita. Os minérios friável e compacto consistem quase que totalmente de $\mathrm{Fe}_{2} \mathrm{O}_{3}$, com teores médios superiores a $96 \%$ no primeiro e a 98\% no segundo. As impurezas consistem de $\mathrm{Al}_{2} \mathrm{O}_{3}, \mathrm{SiO}_{2}, \mathrm{MnO}$ e $\mathrm{P}_{2} \mathrm{O}_{5}$, cujos teores são ligeiramente maiores no minério friável do que no minério compacto. Os dois tipos de minério são muito pobres em elementos traços. Uma grande parte destes elementos ficou abaixo do limite de deteç̧ão do método analítico, sendo que a quase totalidade dos mesmos apresentou teor médio inferior a $30 \mathrm{ppm}$, com exceção do $\mathrm{Ba}, \mathrm{V}, \mathrm{Zn}$ e $\mathrm{Cr}$, que apresentaram teores médios entre 30 e $100 \mathrm{ppm}$. Os teores de elementos traços são significativamente maiores na banda porosa do que na banda maciça, indicando que a maior parte dos mesmos está associado aos minerais de ganga do minério, presentes em maior volume na banda porosa. Tanto um como outro tipo de minério apresentaram baixos totais de ETR. Quando normalizados pelo PAAS, o minério friável mostra padrão de fracionamento dos ETR similar ao do protominério. Já o minério compacto apresenta padrão de fracionamento distinto com relação aos ETR pesados, os quais sofrem discreto empobrecimento em relação aos ETR médios. Os dados de campo, petrológicos, geoquímicos e geocronológicos indicam uma origem hipogênica para o minério compacto e supergênica para o minério friável.

A datação pelo método ${ }^{40} \mathrm{Ar} /{ }^{39} \mathrm{Ar}$ de minerais de manganês presentes no itabirito manganesífero das Minas do Sapecado e Andaime trouxe importantes informações sobre a evolução do perfil de intemperismo das BIFs no Quadrilátero Ferrífero e sobre o minério de ferro supergênico nele contido. Os resultados geocronológicos forneceram idades entre $61.5 \pm 1.2 \mathrm{Ma}$ a $14.2 \pm 0.18 \mathrm{Ma}$, sugerindo uma prolongada história de intemperismo na região. A maior parte dos óxidos de $\mathrm{Mn}$, entretanto, precipitou no intervalo entre 51 e $41 \mathrm{Ma}$, com um pico em 46.7 $\mathrm{Ma}$, indicando um período de intenso intemperismo químico, durante o qual formou-se a maior parte do minério friável da mina de Águas Claras.

Os dados apresentados neste trabalho mostraram que, sob idênticas condições estruturais, topográficas e climáticas, o itabirito dolomítico é muito mais favorável à formação de depósitos de ferro de alto teor do que o quartzo itabirito. Forneceram também indicações de que a gênese de depósitos gigantes de minério friável de alto teor a partir do quartzo itabirito requer a atuação de outros controles além do litológico, possivelmente envolvendo processos hipogênicos e supergênicos. 


\section{ABSTRACT}

Iron ore and itabirites from Águas Claras mine were accurately examined and assessed for their mineralogical, petrological and geochemical features, in order to appropriately characterize and better understand their respective genesis. Two types of itabirite were identified in the Águas Claras mine, to wit: dolomitic itabirite and quartz itabirite. High-grade ores (\%Fe $>64 \%$ ) were originally formed from dolomitic itabirite. Both itabirite types feature meso and microbanding. Dolomitic itabirite consists of alternating hematite-rich and dolomite-rich bands, whereas quartz itabirite consists of alternating quartz-rich and hematite-rich bands. Dolomite, quartz and hematite are the major minerals, the accessory minerals being chlorite, sericite, talc and apatite. Itabirites have a quite simple chemical composition. $\mathrm{Fe}_{2} \mathrm{O}_{3}, \mathrm{CaO}, \mathrm{MgO}$ and $\mathrm{PF}$ are the major elements in dolomitic itabirite's composition, whereas $\mathrm{Fe}_{2} \mathrm{O}_{3}$ and $\mathrm{SiO}_{2}$ are predominant in quartz itabirite. The contents of minor elements generally equal less than $10 \mathrm{ppm}$ in both dolomitic and quartz itabirites, and no higher concentration is found in any other BIF type. Only $\mathrm{Zn}, \mathrm{Sr}$ and $\mathrm{Pb}$ are more specifically associated with dolomitic itabirite, whereas $\mathrm{Cd}, \mathrm{Sb}$ and $\mathrm{Ge}$ are associated with quartz itabirite. Itabirite's REE (Rare Earth Elements) fractionation pattern, when normalized by PAAS standard, is similar to other Paleoproterzoic BIFs' patterns, displaying $\mathrm{Eu}$ and $\mathrm{Y}$ positive anomalies and gradual increase of light REE towards the heavy REE. $\mathrm{C}$ and $\mathrm{O}$ isotopes of dolomitic itabirite have shown negative values for $\delta^{13} \mathrm{C}$, ranging from $-2,5 \%$ to $-0,8 \%$, while $O$ isotopic data has shown values for $\delta^{18}$ O between $-12,4 \%$ and $-8,5 \%$, which are compatible with the $\delta^{13} \mathrm{C}$ and $\delta^{18} \mathrm{O}$ values identified in other Paleoproterozoic carbonate sequences. Field relationships and laboratory data suggest that both dolomitic and quartz itabirite represent the lateral and vertical facies transitions of the Cauê Formation's original sediments.

Two main high-grade ore types have been identified: soft and hard ores. Soft ore is dominant and occurs as a continuous lens approximately $2,5 \mathrm{~km}$ long, comprising subordinate lenses of hard ore. Soft itabirite undergoes a lateral and vertical transition and turns into dolomitic itabirite (protore). During the above-mentioned transition, the hematite-rich bands turn into massive ore bands, whereas the dolomitic bands turn into porous bands. Hematite is the ore mineral of both soft and hard ore and occurs as granular and tabular hematite, its crystal size ranging from 10 to $30 \mu \mathrm{m}$. Gangue minerals are scarce and consist of apatite, chlorite, sericite, talc and, occasionally, dolomite, ferrihydrite and Mn-minerals, the latter two resulting from dolomite dissolution. Soft and hard ores consist almost entirely of $\mathrm{Fe}_{2} \mathrm{O}_{3}$, with average contents exceeding $96 \%$ for soft ores and $98 \%$ for hard ores. Impurities consist of $\mathrm{Al}_{2} \mathrm{O}_{3}, \mathrm{SiO}_{2}, \mathrm{MnO}$ and 
$\mathrm{P}_{2} \mathrm{O}_{5}$. Their contents are slightly higher in soft ore than in hard ore. Trace element content is quite low in both ore types. The level of most trace elements stand below the analytical method detection limit, having almost all of them showing an average content of less than $30 \mathrm{ppm}$, except for $\mathrm{Ba}, \mathrm{V}, \mathrm{Zn}$ e $\mathrm{Cr}$, whose average contents range between 30 and $100 \mathrm{ppm}$. The trace element contents are significantly higher within the porous band than within the massive band, thus indicating that most of them are associated with ore gangue minerals, which are concentrated in the porous band. Both types of ore feature low REE totals. When normalized by PAAS, the soft ore presents a REE fractionation pattern similar to the protore pattern. On the other hand, the hard ore displays a different fractionation pattern with regard to heavy REE, which undergoes a slight depletion when compared to middle REE. The petrological, geochemical and geochronological field relationships indicate a hipogene origin for the hard ore and a supergene origin for the soft ore.

${ }^{40} \mathrm{Ar} /{ }^{39} \mathrm{Ar}$ dating of the $\mathrm{Mn}$-minerals detected in the manganesiferous itabirite from the Sapecado and Andaime Mines has provided significant information on the development of the weathering profile of BIFs in the Quadrilátero Ferrifero and on the supergene iron ore therein contained. According to the geochronological results, ages from $61.5 \pm 1.2 \mathrm{Ma}$ to $14.2 \pm 0.18 \mathrm{Ma}$ were obtained, therefore suggesting this region underwent a long, lasting weathering period experienced. However, most of Mn oxides precipitated between 51 and $41 \mathrm{Ma}$, a peak being identified in $46.7 \mathrm{Ma}$. The data above indicates a period of intense chemical weathering during which most of the soft ore found in Águas Claras Mine was formed.

The data contained in this paper shows that under identical structural, topographic and climatic conditions, dolomitic itabirite is much more liable to forming high-grade iron deposits than quartz itabirite. There are also indications that the genesis of the huge high-grade soft ore deposits originally formed from quartz itabirite requires the action of other controls, besides the lithological one, possibly involving hipogene and supergene processes. 


\section{CAPÍTULO 1 - INTRODUÇÃO}

\section{1 - APRESENTAÇÃO}

A indústria da mineração do ferro tem grande importância econômica na economia mineral brasileira. O valor de sua produção representa $15 \%$ do valor da produção mineral nacional, sendo superado apenas pelo petróleo. O minério de ferro é um dos principais itens da pauta de exportação do país, representando cerca de $80 \%$ das exportações dos bens minerais primários e cerca de 5\% das exportações totais (Quaresma, 2001).

Dada a sua importância econômica, inúmeros trabalhos envolvendo a caracterização tecnológica e mineralógica do minério de ferro têm sido realizados nas áreas de geologia, mineração e siderurgia. Particularmente na região do Quadrilátero Ferrífero, diversas dissertações de mestrado e teses de doutorado trataram da geologia dos corpos de minério, do comportamento estrutural dos mesmos, de características químicas e mineralógicas, assim como de aspectos relacionados ao beneficiamento e metalurgia do minério de ferro (Casquet, 1995; Ramos, 1997; Ribeiro, 2003; Silva, 2004; Silva, 1999; Trzaskos-Lipski, 2001; Veríssimo, 1999; Zavaglia, 1995).

A economicidade do aproveitamento dos minérios está também intrinsicamente ligada às condições geológicas e metalogenéticas das jazidas. A mineralogia do minério, os teores de ferro, a estrutura e a textura das rochas que contêm o mineral-minério, a paragênese e toda uma série de parâmetros geológicos influem para que os empreendimentos minerários possam se tornar uma realidade econômica (Pinheiro, 2000). Além disto, as características estruturais, texturais e mineralógicas do minério de ferro têm grande impacto na obtenção de elevados índices de produtividade nos processos siderúrgicos de aglomeração e redução do minério de ferro, sendo ainda insuficientemente conhecidas e pouco exploradas na seleção dos minérios a serem processados na siderurgia (Pimenta et al., 1999). Além de ser extremamente importante nas etapas industriais de lavra, beneficiamento e metalurgia, a caracterização química e mineralógica do minério de ferro contribui para o entendimento da gênese dos jazimentos.

O Quadrilátero Ferrífero responde por cerca de $60 \%$ da produção de minério de ferro brasileira, a maior parte da mesma ainda oriunda de minérios de alto teor em ferro (\%Fe> 64$)$, denominados de minérios hematíticos, ou simplesmente hematitas. Os minérios hematíticos estão próximos de serem exauridos, e estão sendo substituídos pelos minérios de baixo teor $(\% \mathrm{Fe}$ 
$\sim 40 \%$ ), denominados de minérios itabiríticos ou itabiritos. Os minérios itabiríticos representam mais de $70 \%$ dos 29 bilhões de toneladas de recursos geológicos de minério de ferro remanescente no Quadrilátero Ferrífero (MBR e CVRD, relatórios internos) e sua gênese é atribuída ao enriquecimento supergênico das formações ferríferas bandadas (BIFs) metamorfizadas, denoMinadas de itabiritos, encaixantes do minério de ferro (Dorr II, 1964).

Apesar da importância econômica do minério de ferro na economia nacional, poucos trabalhos foram realizados objetivando a sua gênese. No Quadrilátero Ferrífero, estes trabalhos estão limitados ao estudo do minério de ferro formado a partir de quartzo itabirito (Dorr II, 1964, 1965; Eichler, 1968; Guild, 1953; Veríssimo, 1999).

O presente estudo trata da caracterização e gênese do minério de ferro na Mina de Águas Claras, onde o protominério é o itabirito dolomítico. A Mina de Águas Claras é propriedade da Minerações Brasileiras Reunidas S/A - MBR, e foi explotada por esta empresa no período de 1973 a 2002, quando foram lavradas cerca de 290 Mt de minério de ferro de altíssimo teor $(\sim 68 \% \mathrm{Fe})$. Esta mina foi selecionada para este trabalho devido às excelentes exposições de itabirito dolomítico presentes na mesma e pelo pouquíssimo volume de informações disponíveis na literatura sobre estas rochas ou sobre o minério formado a partir delas. $O$ autor era $o$ responsável pelas atividades de geologia de Mina da Mina de Águas Claras por ocasião do início deste trabalho, o que também contribuiu para a seleção da mesma como alvo do estudo e facilitou os trabalhos de campo.

Inicialmente serão apresentados dados sobre a geologia, mineralogia e geoquímica das BIFs da Mina de Águas Claras, sugerindo-se um modelo genético para as mesmas. Formações ferríferas bandadas constituem um dos temas que têm gerado enorme acervo de publicações na literatura geológica, dada a sua grande importância na compreensão dos fenômenos que levaram a evolução da vida, dos oceanos e da atmosfera no pré-Cambriano. Entretanto, poucas informações existem publicadas sobre as BIFs do Quadrilátero Ferrífero. A disponibilização destes novos dados será muito útil no entendimento do quadro evolutivo da geologia regional, assim como contribuirá para o conhecimento da formação das BIFs no Paleoproterozóico.

Em seguida, o assunto focalizado será o minério, cujas características mineralógicas, petrológicas e geoquímicas serão detalhadas e comparadas com as do protominério, visando a um melhor entendimento de sua gênese.

Finalmente, serão apresentadas datações pelo método ${ }^{40} \mathrm{Ar} /{ }^{39} \mathrm{Ar}$ de óxidos de manganês formados no decorrer do intemperismo de quartzo itabiritos das Minas de Sapecado e Andaime. Estas minas foram selecionadas por apresentarem corpos de itabiritos manganesíferos 
intercalados ao minério de ferro, interceptados em furos de sonda em diferentes níveis do perfil de intemperismo, permitindo desta forma a coleta de amostras de óxidos de manganês passíveis de serem datados pelo método ${ }^{40} \mathrm{Ar} /{ }^{39} \mathrm{Ar}$ desde a superfície topográfica até próximo ao contato com o itabirito compacto. Estes dados são relevantes para a compreensão da cronologia dos processos de formação do perfil de alteração intempérica das BIFs e, conseqüentemente, para o melhor entendimento da gênese dos depósitos supergênicos de minério de ferro no Quadrilátero Ferrífero.

\section{2 - OBJETIVOS}

Os objetivos propostos neste trabalho foram traçados a partir da necessidade de estudos mais detalhados envolvendo a caracterização do minério de ferro e sua gênese. As investigações de campo e de laboratório envolveram diferentes análises e ensaios que tiveram como metas principais estudar:

- a mineralogia e petrologia do minério de ferro e do protominério (BIFs),

- a geoquímica dos elementos maiores, menores e de terras-raras destas rochas,

- a evolução mineralógica e geoquímica do itabirito dolomítico até o minério,

- a gênese dos minérios de ferro friáveis no Quadrilátero Ferrífero; e

- a idade dos perfis de intemperismo das BIFs no Quadrilátero Ferrífero.

\section{3 - LOCALIZAÇÃO E ASPECTOS GERAIS}

A Mina de Águas Claras situa-se na porção noroeste do Quadrilátero Ferrífero, no Estado de Minas Gerais, a sul da capital Belo Horizonte (Figuras 1 e 2). As Minas de Sapecado e Andaime, onde foram coletadas as amostras de óxidos de manganês para datação do perfil de intemperismo, da mesma forma que a Mina de Águas Claras, são pertencentes a MBR. Estas Minas localizam-se no flanco leste do Sinclinal da Moeda (Figura 1), a cerca de $50 \mathrm{~km}$ da cidade de Belo Horizonte. A Mina do Sapecado é atualmente a principal mina em operação pela MBR 
no Complexo Pico, integrado pelas Minas do Pico, Galinheiro e Sapecado, com uma produção anual bruta de $12 \mathrm{Mt}$ de minério (Figura 3).

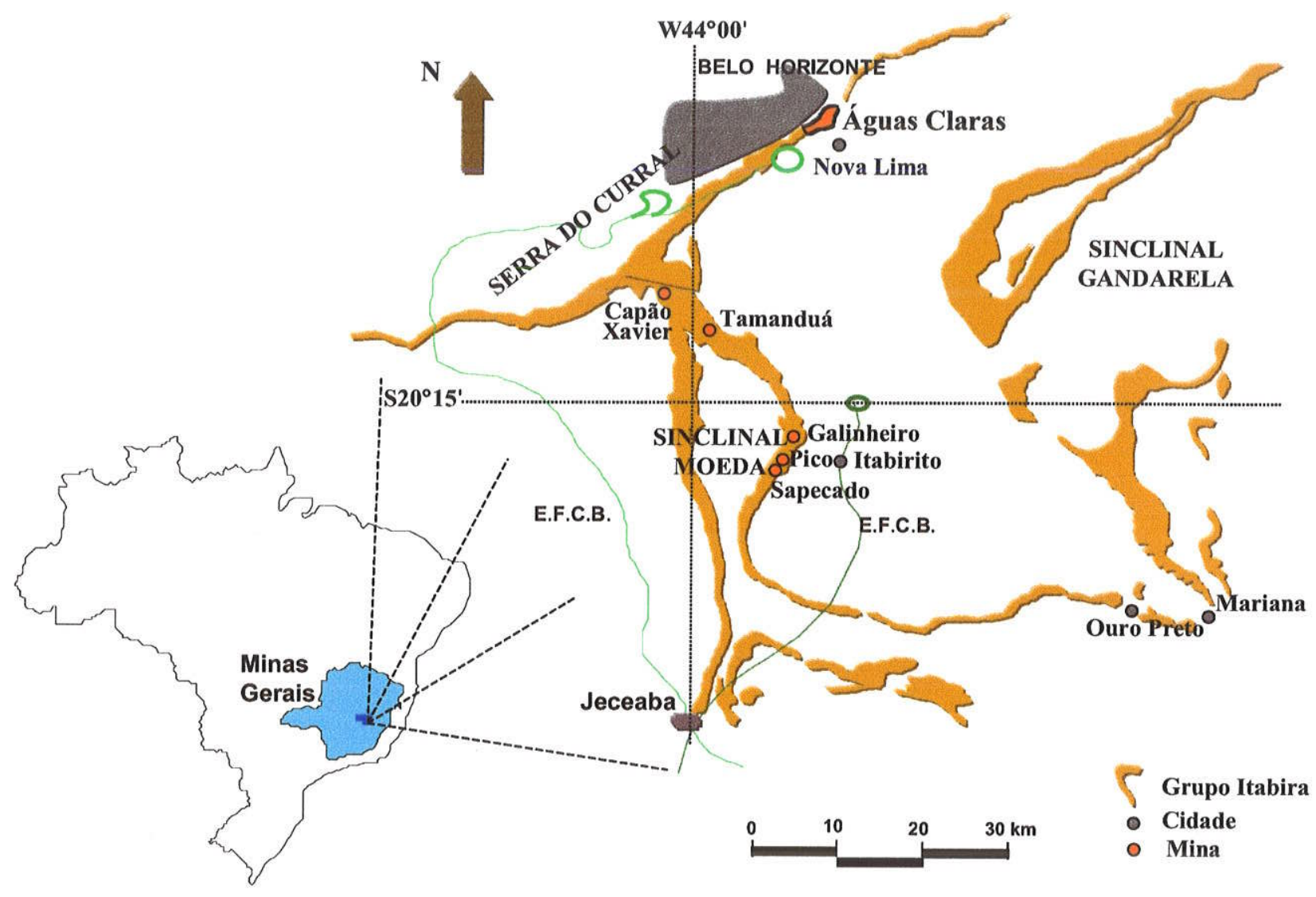

Figura 1: Localização da área de estudo. 


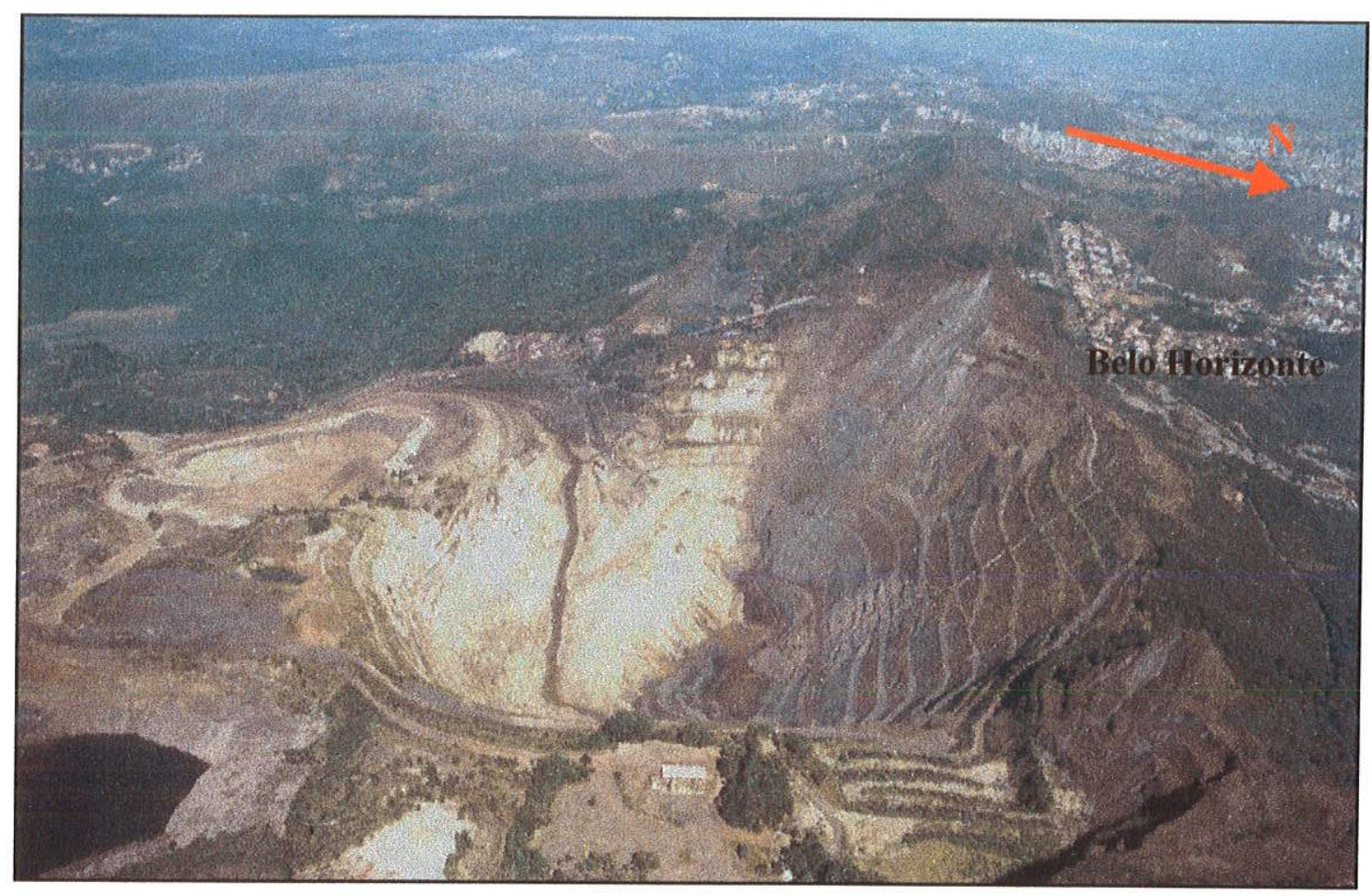

Figura 2: Vista geral da Mina de Águas Claras.

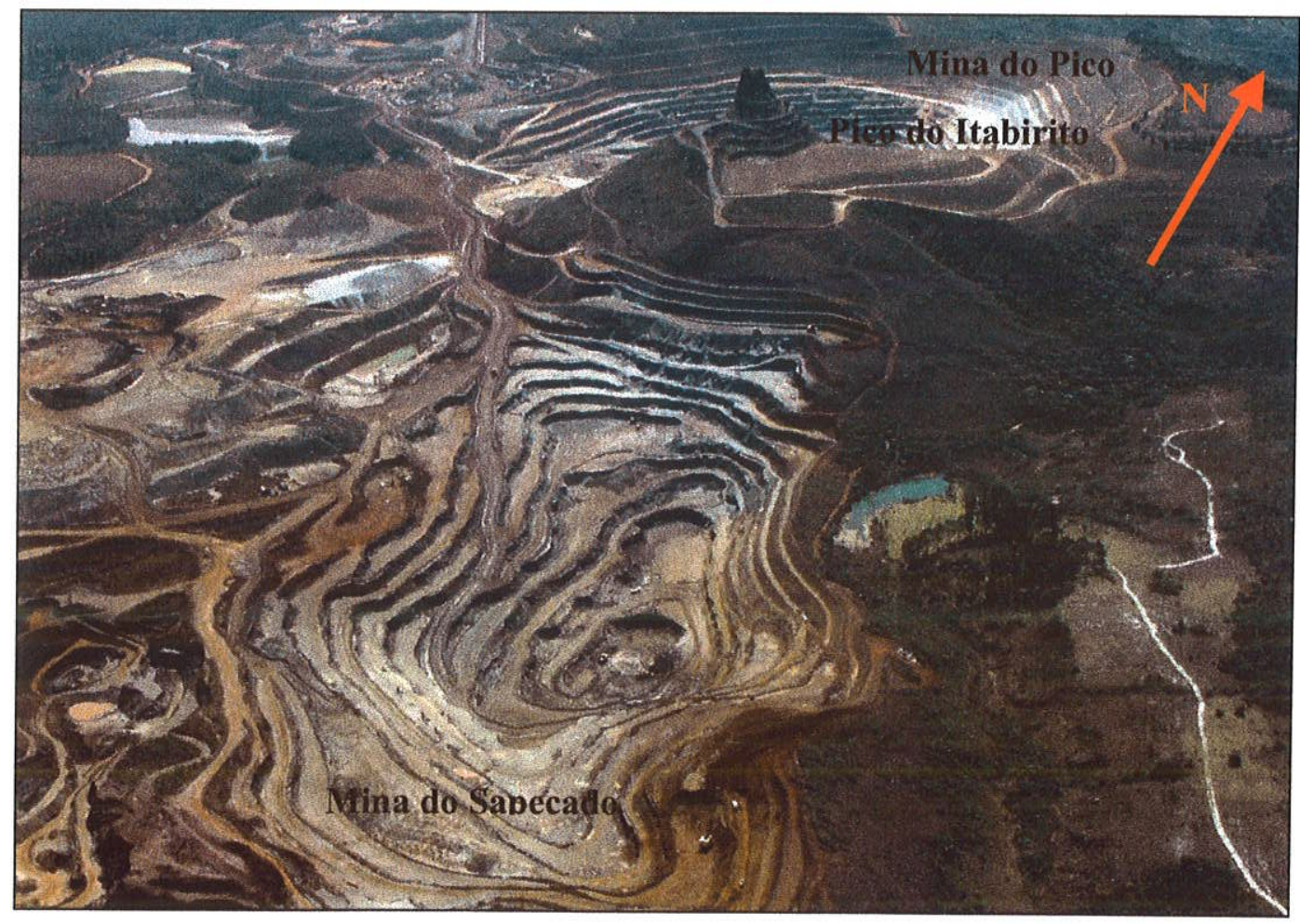

Figura 3: Vista geral da Mina do Sapecado. Ao fundo está o Pico do Itabirito, formado por hematita compacta, e a cava da Mina do Pico. 
O relevo na região do Quadrilátero Ferrífero é caracterizado por um conjunto de serras e planaltos, com elevações variando entre 700 e $2.000 \mathrm{~m}$, e faz parte da unidade representada pelos "Planaltos Dissecados do Leste de Minas" (Baltazar and Raposo, 1993). A topografia é caracterizada por um controle lito-estrutural. Sustentando o topo das serras encontram-se rochas metassedimentares do Supergrupo Minas (quartzitos e formações ferríferas bandadas). Nas regiões menos elevadas, ocorrem rochas proterozóicas do tipo greenstone belt do Supergrupo Rio das Velhas, e rochas granítico-gnáissicas do embasamento arqueano - Complexo Bação (Dorr II, 1969; Schobbenhaus, 1984). Em diferentes locais e altitudes são reconhecidas superfícies "aplainadas" interpretadas como testemunhos residuais de antigas superfícies de aplainamento geradas em diferentes ciclos erosivos (Barbosa, 1965; King, 1956), ou como produto de erosão diferencial das várias unidades geológicas (Varajão, 1991).

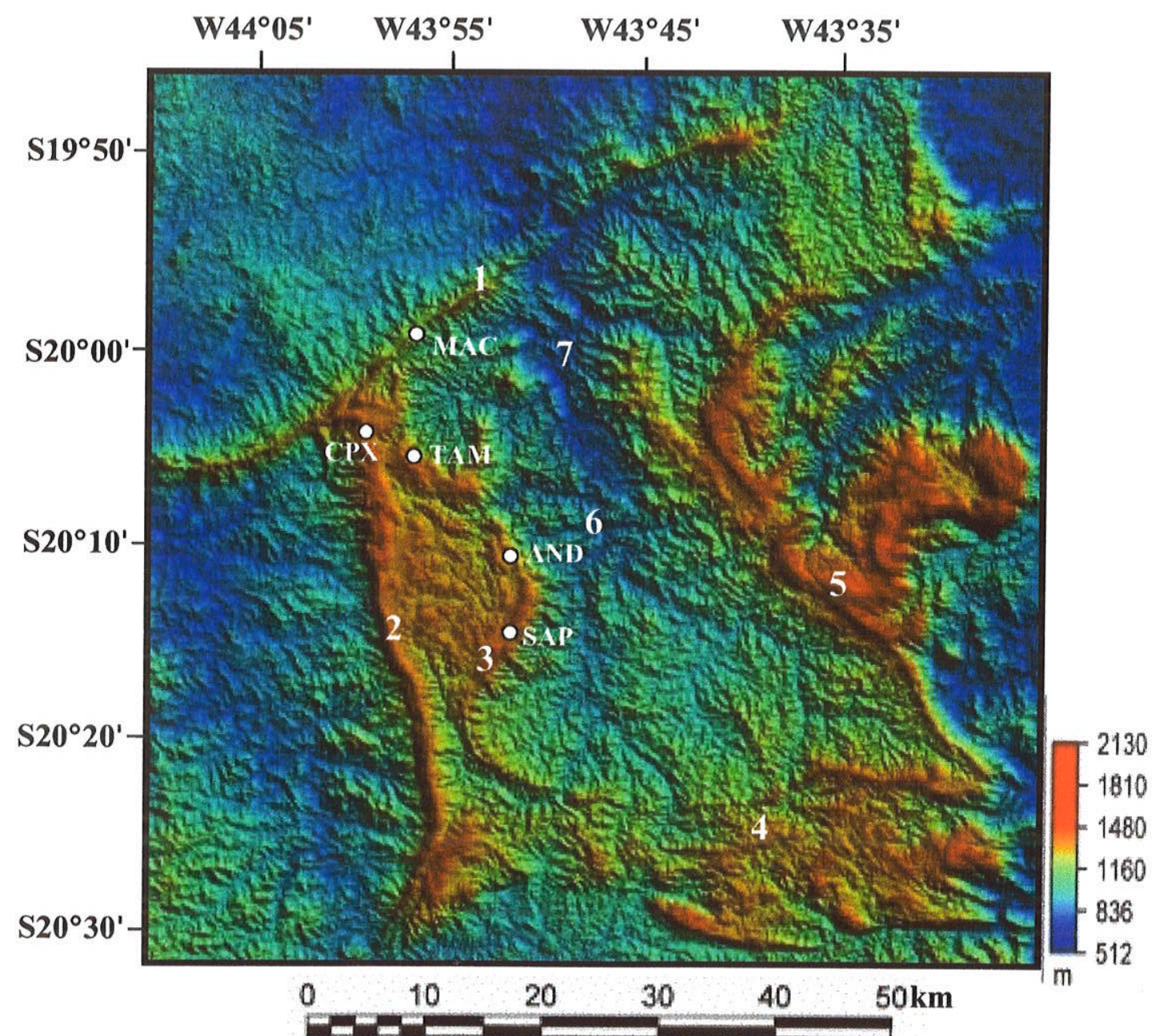

1=Serra do Curral, 2=Serra da Moeda, 3=Serra do Itabirito, 4=Serra do Ouro Branco, 5=Serra do Caraça, 6 e $7=$ vale do rio das Velhas, $\mathbf{M A C}=$ Mina de Águas Claras, $\mathbf{C P X}=$ Mina do Capão Xavier, $\mathbf{T A M}=\mathbf{M i n a}$ de Tamanduá, AND= Depósito de Andaime, SAP = Mina do Sapecado

Figura 4: Modelo digital do terreno (base de dados: Prodemge, MG; resolução 27 m). 
O clima na região do Quadrilátero Ferrífero é quente e úmido, com precipitações médias anuais de $1.900 \mathrm{~mm}$, concentradas no período vai de outubro a março (Nimer, 1989). A temperatura média anual varia em torno de $20-24{ }^{\circ} \mathrm{C}$, com valores menores $\left(18-20^{\circ} \mathrm{C}\right) \mathrm{em}$ regiões de elevadas altitudes.

\section{4 - ESTRUTURA DA TESE}

Esta tese está estruturada na forma de dois capítulos introdutórios, onde são apresentados os objetivos do trabalho e resultados esperados, e os materiais e métodos utilizados. Seguem-se quatro capítulos que contêm os resultados e discussões. Estes capítulos são apresentados na forma de artigos publicados ou submetidos para publicação em revistas especializadas com ampla divulgação no meio científico nacional e internacional. Cada capítulo trata de um dos temas centrais da tese de forma independente, e foi escrito de modo a permitir ao leitor a compreensão do tema tratado sem a necessidade de leitura dos demais artigos. Este procedimento tem o inconveniente de levar a uma certa superposição da parte inicial dos textos de cada artigo, quando os mesmos são lidos conjuntamente.

O primeiro artigo (Capitulo 3, Anexo 1), denominado "Geology and geochemistry of the Águas Claras and Pico iron mines, Quadrilátero Ferrifero, Minas Gerais, Brazil" foi publicado em 2003 no volume 38 do periódico "Mineralium Deposita". Ele apresenta a geologia geral da Mina de Águas Claras, recuperando e divulgando o conjunto de dados geológicos e geoquímicos obtidos no decorrer da vida da mina. Para efeito de comparação com o minério formado a partir de quartzo itabiritos, este artigo apresenta também a geologia e geoquímica dos minérios de ferro da Mina do Pico.

O segundo artigo (Capitulo 4, Anexo 2), intitulado "Geochemistry and genesis of the banded iron formations of the Cauê Formation, Quadrilátero Ferrifero, Minas Gerais, Brazil" foi submetido para publicação em maio de 2004 ao periódico "Precambrian Research". Este artigo foi devolvido para revisões em janeiro de 2005, as quais estão sendo processadas. O artigo apresenta a geologia e geoquímica das formações ferríferas bandadas da Mina de Águas Claras, e propõe um modelo genético para as mesmas.

O terceiro artigo (Capítulo 5, Anexo 3), trata da geologia e geoquímica do minério de ferro da Mina de Águas Claras, e tece comparações com as Minas de Capão Xavier e Tamaduá. 
Este artigo, denominado "The iron ore of the Aguas Claras mine, Quadrilátero Ferrifero, Brazil", foi submetido para publicação em junho de 2005 ao periódico "Mineralium Deposita".

O último artigo (Capítulo 6, Anexo 4), denominado "A0 Ar ${ }^{\beta 9} A r$ geochronology and the evolution of lateritic iron deposits in the Quadrilatero Ferrifero, Minas Gerais, Brazil", foi submetido para publicação em janeiro de 2005 ao periódico "Chemical Geology". Este artigo trata da idade do perfil de intemperismo das formações ferríferas bandadas (e conseqüentemente da idade de formação dos minérios supergênicos) no Quadrilátero Ferrífero, e foi devolvido para pequenas revisões em junho de 2005.

Finalizando a tese, apresenta-se um capítulo que integra o conteúdo dos artigos e enuncia as principais conclusões obtidas. 
Este artigo, denominado "The iron ore of the Aguas Claras mine, Quadrilatero Ferrifero, Brazil", foi submetido para publicação em junho de 2005 ao periódico "Mineralium Deposita".

$O$ último artigo (Capítulo 6, Anexo 4), denominado " ${ }^{40} A r{ }^{39} A r$ geochronology and the evolution of lateritic iron deposits in the Quadrilatero Ferrifero, Minas Gerais, Brazil", foi submetido para publicação em janeiro de 2005 ao periódico "Chemical Geology". Este artigo trata da idade do perfil de intemperismo das formações ferríferas bandadas (e conseqüentemente da idade de formação dos minérios supergênicos) no Quadrilátero Ferrífero, e foi devolvido para pequenas revisões em junho de 2005.

Finalizando a tese, apresenta-se um capítulo que integra o conteúdo dos artigos e enuncia as principais conclusões obtidas. 


\section{CAPÍTULO 2 - AMOSTRAGEM E TÉCNICAS ANALÍTICAS}

\section{1 - AMOSTRAGEM}

\subsection{1 - MINA DE ÁGUAS CLARAS}

Três grupos distintos de rochas foram amostrados e estudados na Mina de Águas Claras: (1) filito sericítico, dolomito argiloso e quartzo dolomito, (2) BIFs representadas por itabirito dolomítico e quartzo itabirito, (3) minério de ferro. No Anexo 5 encontram-se relacionadas todas as amostras estudadas, com suas respectivas coordenadas e procedimentos analíticos realizados.

A amostragem foi realizada em diferentes oportunidades, entre agosto de $2000 \mathrm{e}$ dezembro de 2002, época em que a mina estava em operação e o autor trabalhava na mesma. Foram coletadas amostras em afloramentos e testemunhos de sondagem, com massa variando, conforme a finalidade da amostragem, entre $200 \mathrm{~g}$ e $3 \mathrm{~kg}$. Para estudos petrográficos e análises de isótopos de $\mathrm{C}$ e $\mathrm{O}$ foram coletadas amostras pequenas, em torno de $200 \mathrm{~g}$, enquanto que para as análises químicas foram coletadas amostras de até $3 \mathrm{~kg}$.

A amostragem do filito sericítico, do dolomito argiloso e do itabirito dolomítico foi realizada ao longo da bancada situada na cota $1.000 \mathrm{~m}$, na parede leste da mina (Figuras 5 e 6). Neste local as rochas encontram-se a mais de $200 \mathrm{~m}$ abaixo da superficie topográfica e não apresentam sinais de alteração intempérica. Nesta parede, o itabirito dolomítico foi lavrado quase que perpendicularmente à direção do acamamento, em uma extensão de mais de $300 \mathrm{~m}$. Este afloramento possivelmente representa a melhor exposição desta rocha em todo o Quadrilátero Ferrífero. Foram coletadas amostras de itabirito dolomítico a partir da base da Formação Cauê até o contato com o minério de ferro, seguindo um espaçamento de aproximadamente $30 \mathrm{~m}$ entre amostras, as quais foram utilizadas nos estudos petrográficos e análises químicas. Amostras adicionais de itabirito dolomítico foram coletadas no centro da mina e nos furos de sonda PZ55 e FS09. Em uma segunda etapa de amostragem, neste mesmo local e obedecendo a um espaçamento de aproximadamente $10 \mathrm{~m}$ entre amostras, foram coletados fragmentos centimétricos da banda carbonática do itabirito dolomítico para análise de isótopos de $\mathrm{C}$ e $\mathrm{O}$. Todas estas amostras foram analisadas ao microscópio óptico. A fim de complementar a amostragem realizada ao longo da bancada 1.000 , de forma a se ter toda a Formação Cauê estudada desde a sua base até a transição para a Formação Gandarela, foram coletadas amostras 
de itabirito dolomítico, quartzo itabirito e quartzo dolomito nos furos de sonda PZ03, PZ54 e PZ55 (Figura 6).

A amostragem do minério friável e compacto foi efetuada em diferentes pontos da mina e também nos furos de sonda FS08, FS09 e FS11, onde foram coletadas amostras para ensaios de densidade e análises químicas. Para algumas amostras de minério friável procedeu-se a coleta em separado das bandas maciça e porosa do mesmo.

\subsection{2 - MINA DO SAPECADO E ANDAIME}

A amostragem realizada nas Minas do Sapecado e Andaime teve por objetivo a coleta de óxidos de manganês susceptíveis à datação pelo método ${ }^{40} \mathrm{Ar} /{ }^{39} \mathrm{Ar}$ (óxidos de $\mathrm{Mn}$ do grupo da hollandita), com o intuito de se obter a idade do perfil de intemperismo das BIFs no Quadrilátero Ferrífero e, por consequiência, do minério de ferro supergênico. A escolha do local levou em consideração o objetivo de obter amostras distribuídas o mais regularmente possível no perfil de intemperismo, e foi realizada em conjunto com o Dr. Paulo Marcos de Vasconcelos, da Universidade de Queensland (UQ), Austrália, que treinou o autor na amostragem e orientou-o nas etapas posteriores de preparação das amostras, análises e interpretação dos dados. Planejouse a coleta de amostras de minerais de manganês presentes no minério de ferro desde a superfície topográfica original até junto ao contato do minério com a BIF hospedeira. Estes minerais são mais comumente encontrados próximos ao contato do minério com as rochas intemperizadas das Formações Batatal e Gandarela. A inexistência de testemunhos de sondagem nas regiões propícias à ocorrência de minerais de manganês na Mina de Águas Claras, aliada à dificuldade de acesso aos locais favoráveis à ocorrência dos mesmos no interior da cava, inviabilizou a utilização desta mina para o estudo geocronológico do perfil de intemperismo das BIFs. Por este motivo, foi necessária a escolha de outro local para este trabalho, sendo selecionada a Mina do Sapecado como alvo prioritário e a Mina de Andaime para amostragem complementar (Figuras 1 e 4). A Mina do Sapecado estava em fase inicial de lavra por ocasião da amostragem, com regiões ricas em minerais de manganês aflorantes, e intensa campanha de sondagem em desenvolvimento. A maior facilidade de acesso aos minerais de manganês nesta mina motivou a sua escolha.

Os minerais de manganês estão presentes no minério de ferro da Mina do Sapecado em uma rocha denominada de itabirito manganesífero. Foram consultadas as seções geológicas da mina, buscando-se identificar aquelas onde o itabirito manganesífero ocorre em maior volume, selecionando-se os furos de sonda das seções mais favoráveis. A maior parte destes furos está 


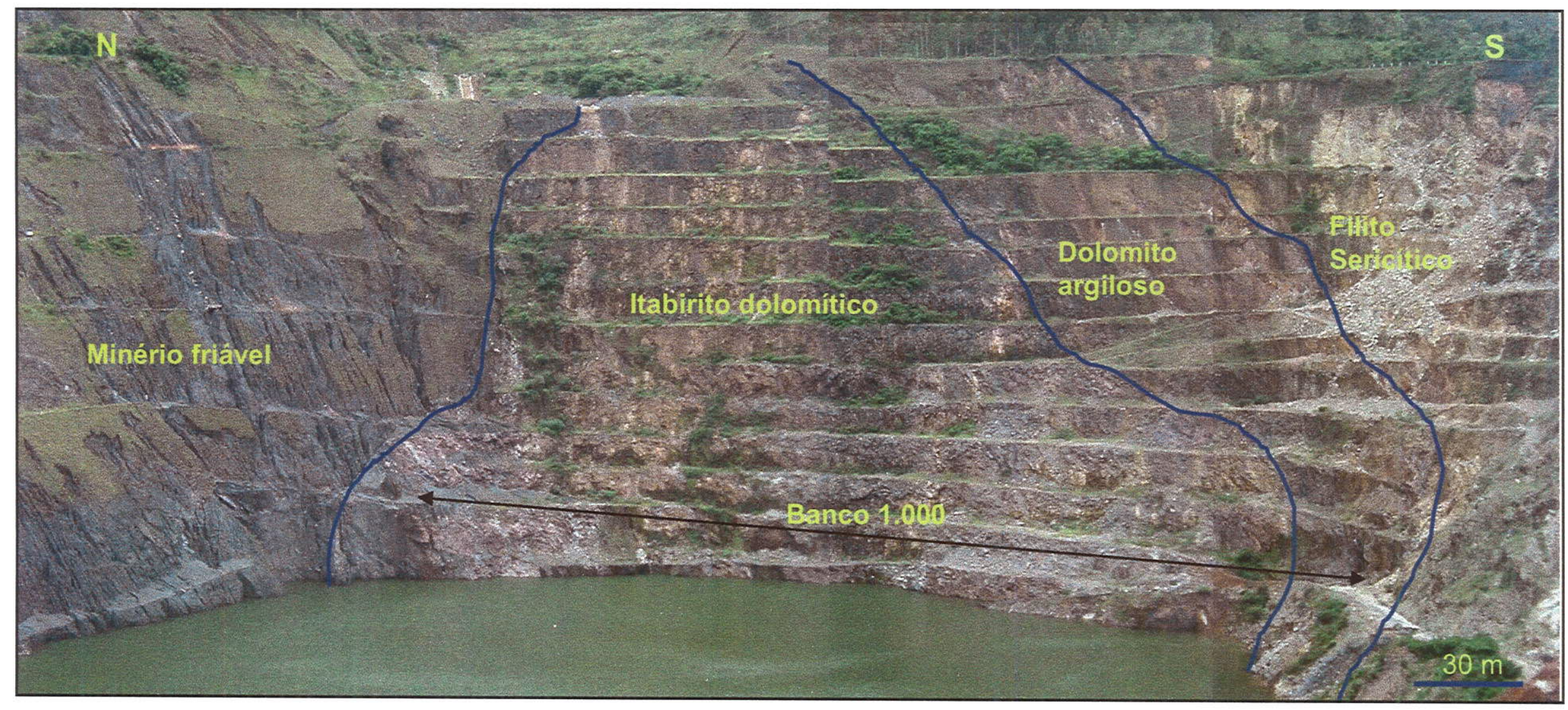

Figura 5: Vista geral da parede leste da Mina de Águas Claras mostrando o Banco 1.100, onde foram coletadas a maioria das amostras dos Grupos 1 e 2 . 


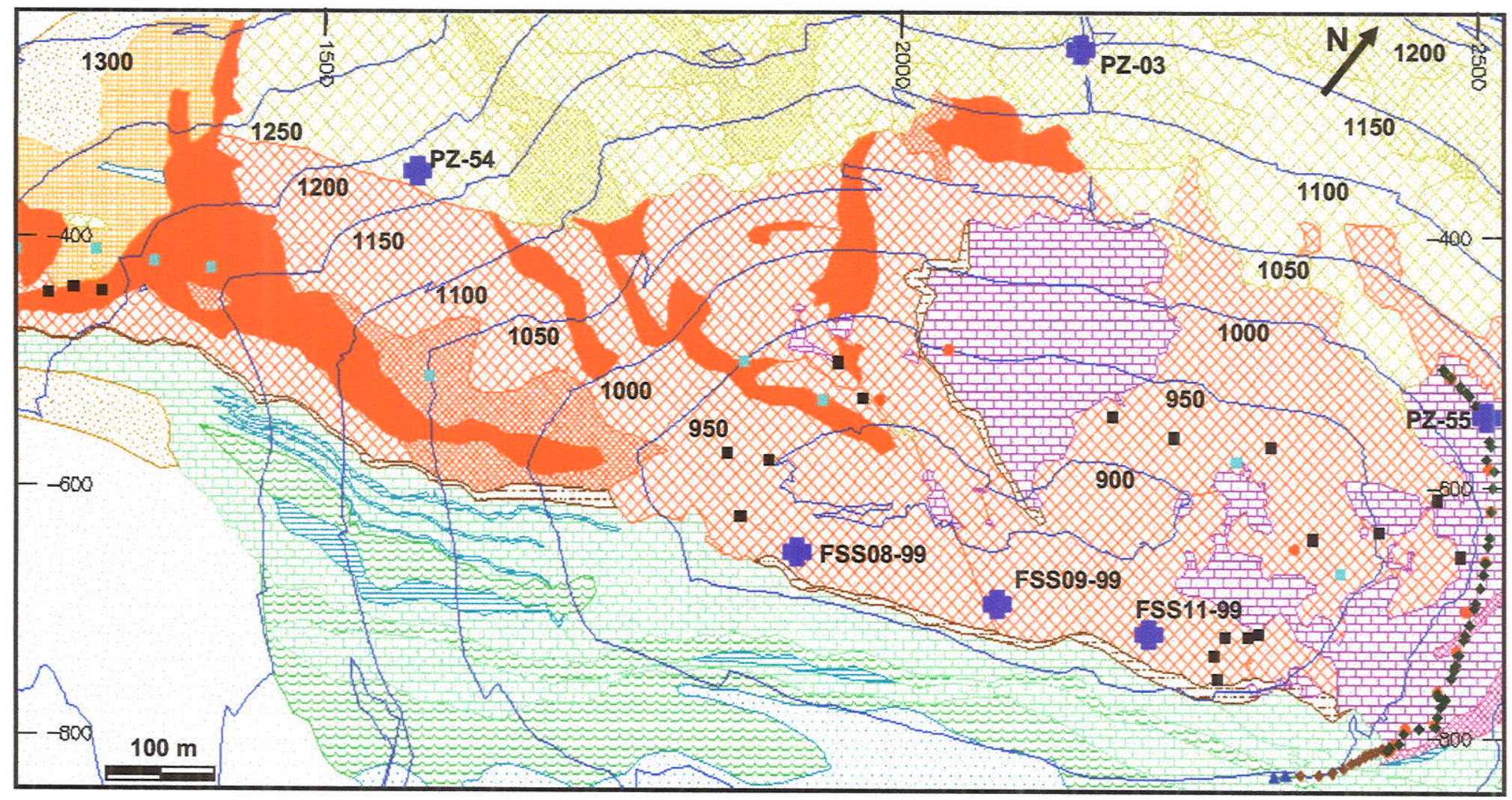

Formação Batatal Filito

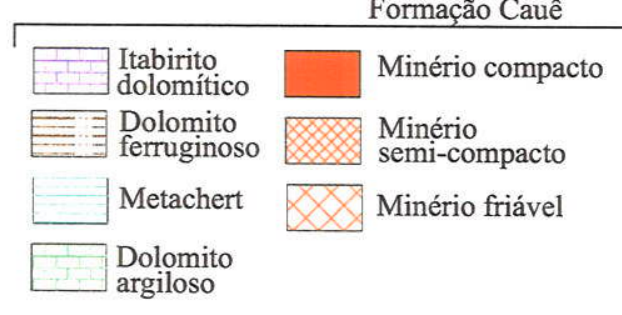

\begin{tabular}{|l}
$\square$ \\
$\square \begin{array}{l}\text { Quartzo itabirito } \\
\text { friável rico }\end{array}$ \\
$\begin{array}{l}\text { Quartzo itabirito } \\
\text { friável }\end{array}$ \\
$\square \quad \begin{array}{l}\text { Quartzo itabirito } \\
\text { semi-compacto }\end{array}$ \\
$\square \begin{array}{l}\text { Quartzo itabirito } \\
\text { compacto }\end{array}$
\end{tabular}

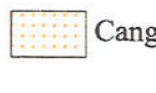

\section{Amostras de
Afloramentos \\ Minério friável}

- Minério compacto

Furos de Sonda

Amostrados

Formação Moeda

Quartzito
Quartzo
filito argiloso

compacto

- Itabirito dolomítico

- Dolomito argiloso

$\Delta$ Filito sericítico

Figura 6: Mapa geológico simplificado da Mina de Águas Claras mostrando os locais amostrados. 
localizada na seção 6.300 (Figura 7), a qual foi escolhida para a amostragem principal. Foram consultados os resultados das análises químicas dos furos de interesse, disponibilizados pela MBR, objetivando a identificação dos intervalos com teores de Mn superiores a 3\%. Estes intervalos foram observados com lupa de mão, procurando-se identificar a presença dos minerais de manganês e coletando-se fragmentos centimétricos da rocha, a intervalos de aproximadamente $1 \mathrm{~m}$, sempre que os mesmos eram encontrados (Figura 8). Procedimento idêntico foi adotado na Mina do Andaime, a qual foi selecionada pela ocorrência de itabiritos manganesíferos tanto aflorantes quanto em profundidade, permitindo desta forma a comparação dos dados geocronológicos em dois locais distintos. Foram coletadas 19 amostras de itabirito manganesífero na Mina do Sapecado, estando 15 localizadas na seção 6.300E e as 4 restantes na seção 4.700E. Na Mina do Andaime foram coletadas 4 amostras (Figura 9).

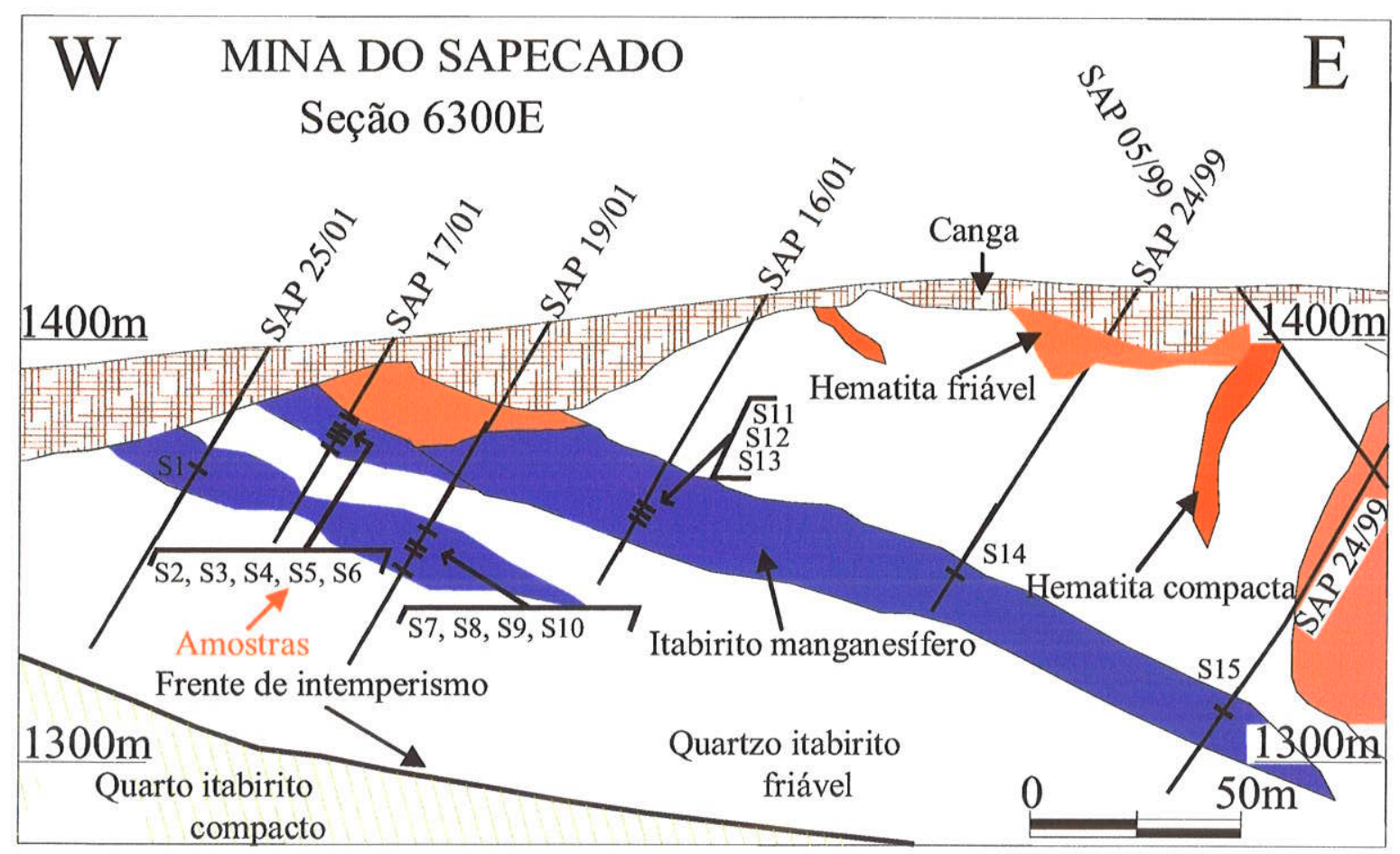

Figura 7: Seção geológica 6.300E da Mina do Sapecado mostrando pontos de coleta das amostras para datação ${ }^{40} \mathrm{Ar} /{ }^{39} \mathrm{Ar}$. 

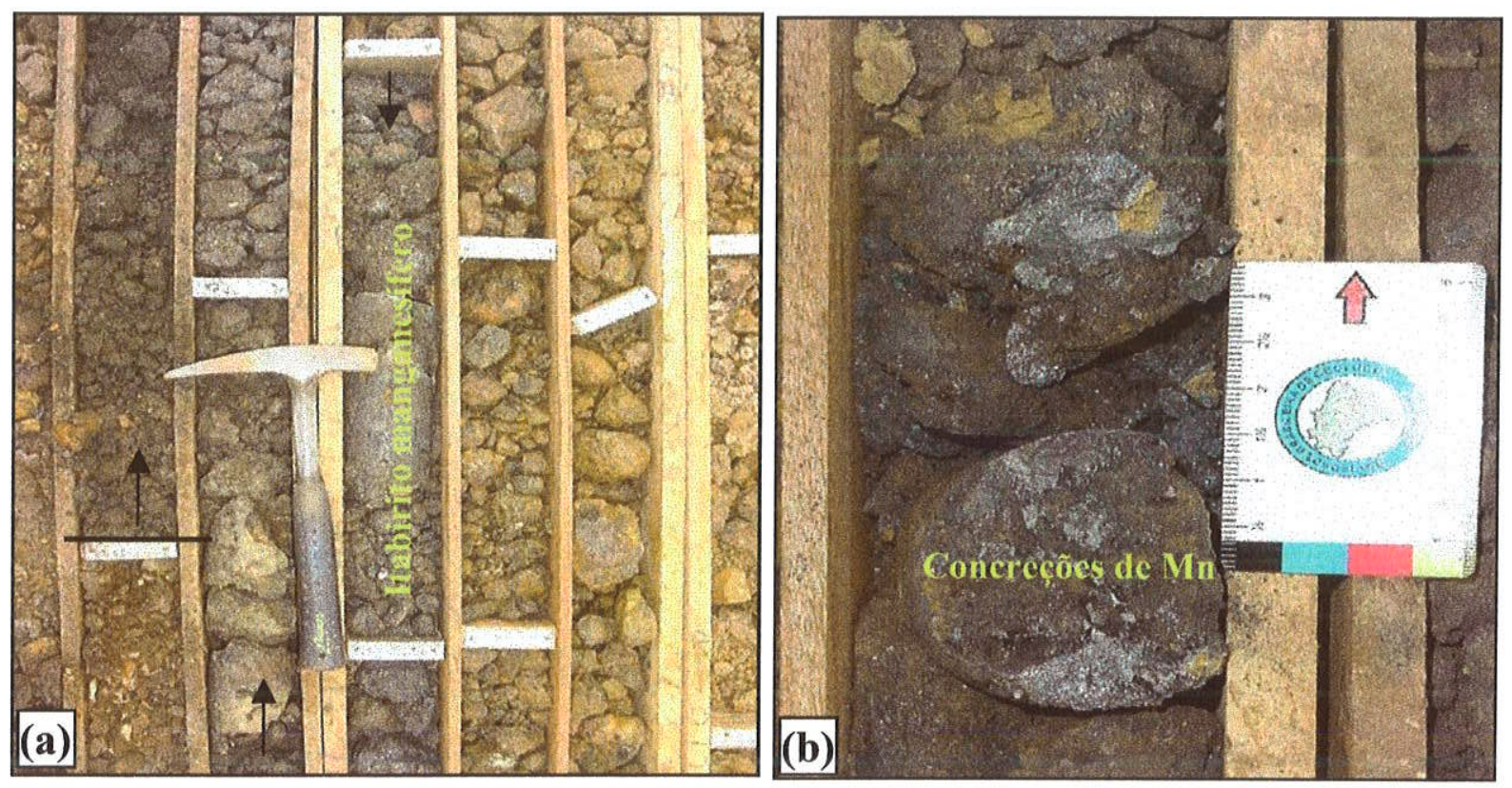

Figura 8: (a) Furo de sonda da Mina do Sapecado mostrando itabirito manganesífero intercalado no itabirito limonítico. (b) Detalhe dos minerais de manganês formando concreções.

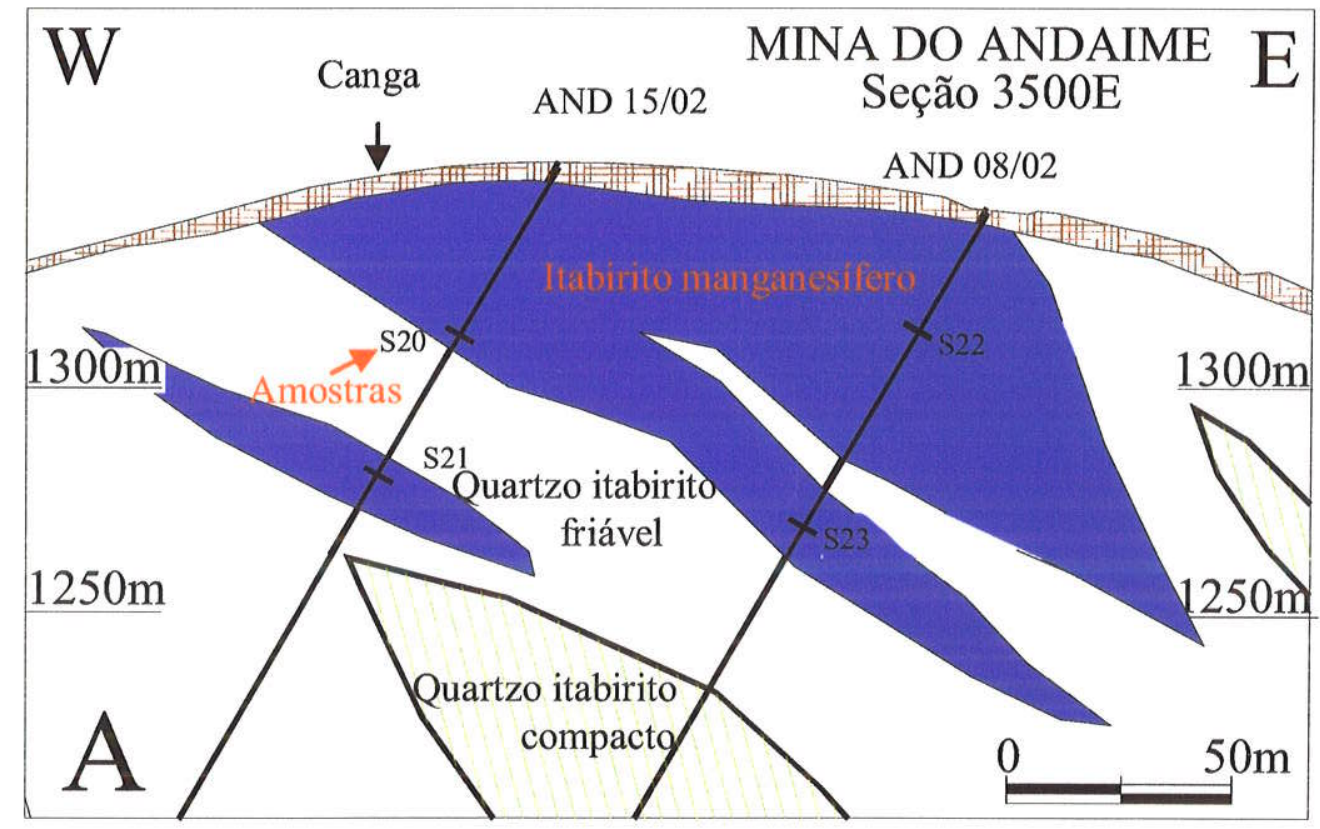

Figura 9: Seção geológica 3.500E da Mina do Andaime mostrando pontos de coleta das amostras para datação ${ }^{40} \mathrm{Ar} /{ }^{39} \mathrm{Ar}$. 


\section{2 - TÉCNICAS ANALITICAS}

Diversos tipos de análise foram empregados no estudo das BIFs e do minério de ferro da Mina de Águas Claras, e no estudo geocronológico do itabirito manganesífero das Minas do Sapecado e Andaime. Nas Figuras 10 a 12 apresenta-se um roteiro simplificado do tipo de análise a que cada grupo litológico amostrado na Mina de Águas Claras foi submetido, assim como o número de amostras analisadas. Detalham-se a seguir as principais técnicas analíticas utilizadas.

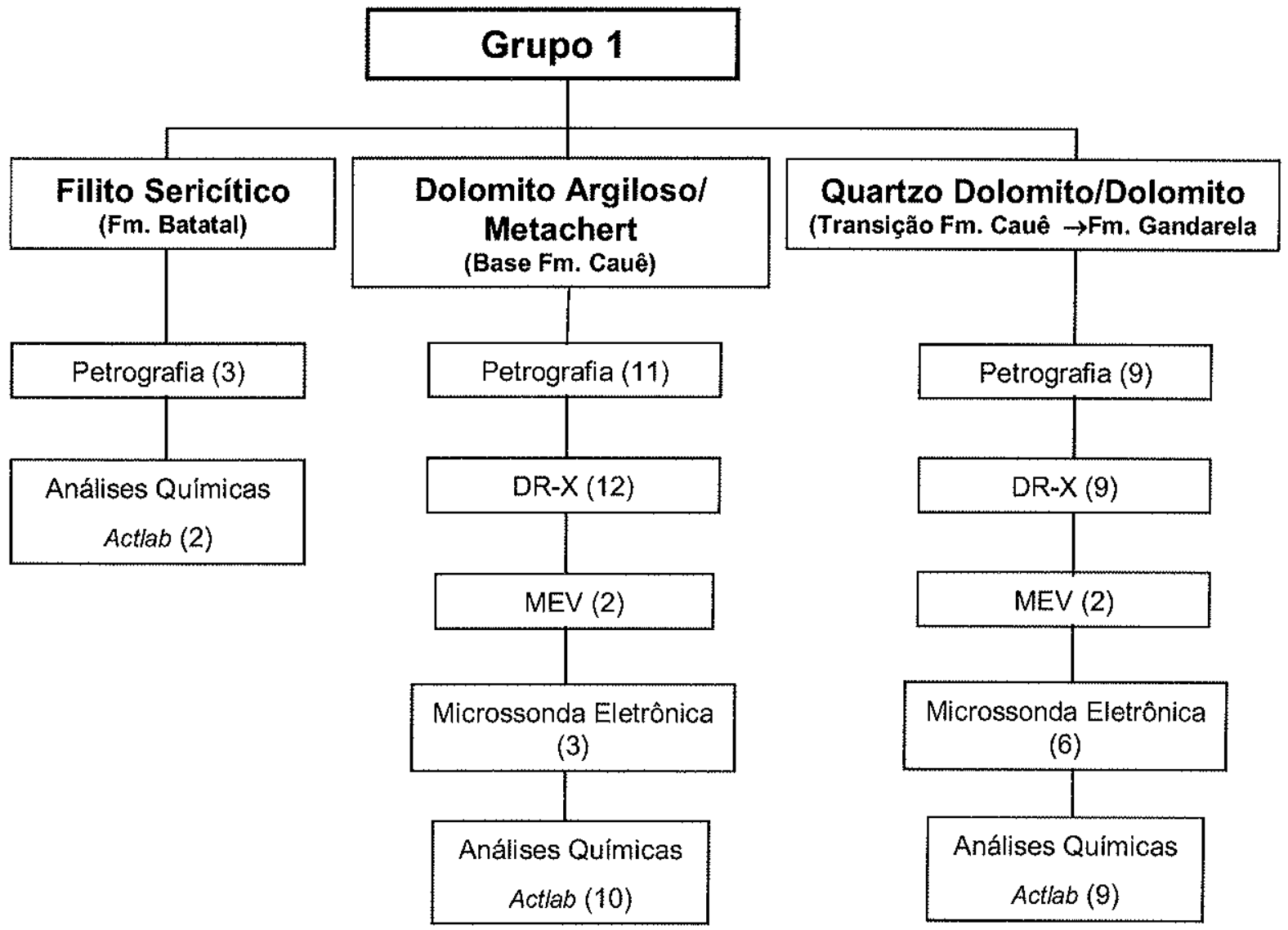

Figura 10: Fluxuograma ilustrando os procedimentos analíticos utilizados para as rochas do Grupo 1 e o número de amostras (entre parênteses) analisado em cada procedimento. 


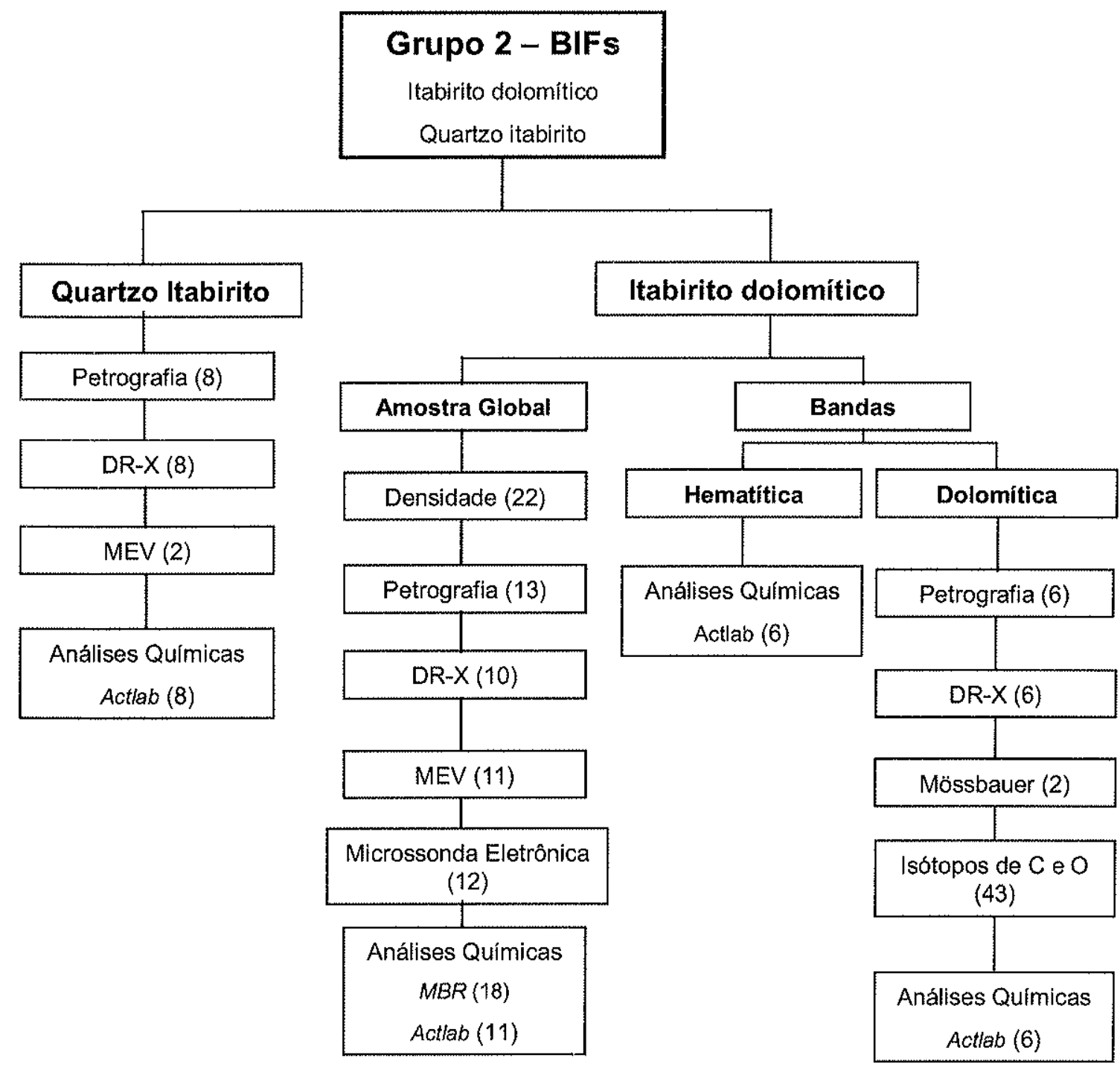

Figura 11: Fluxuograma ilustrando os procedimentos analíticos utilizados para as rochas do Grupo 2 e o número de amostras (entre parênteses) analisado em cada procedimento. 


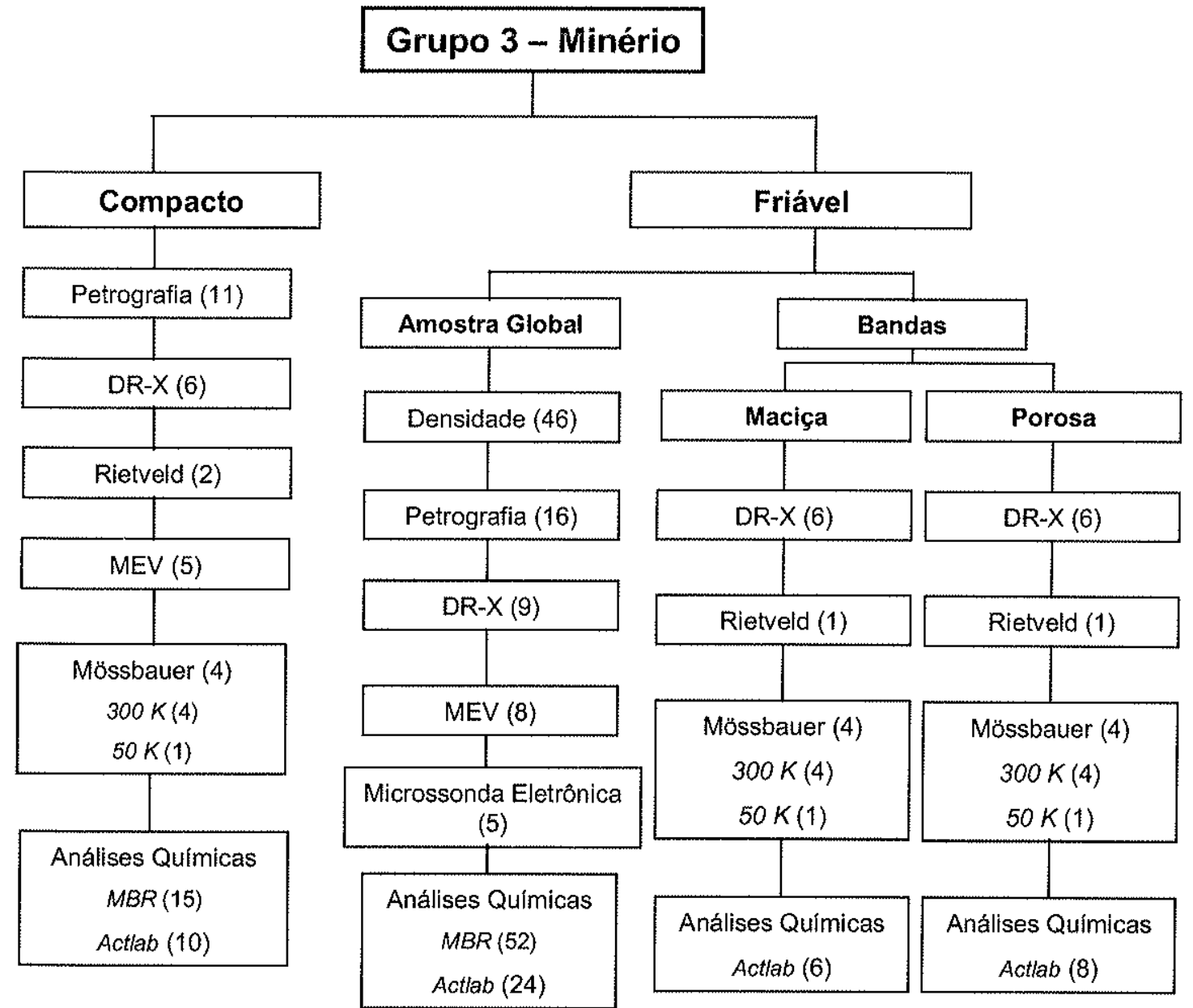

Figura 12: Fluxuograma ilustrando os procedimentos analíticos utilizados para as rochas do Grupo 3 e o número de amostras (entre parênteses) analisado em cada procedimento.

\subsection{1 - ANÁlISE PETROGRÁFICA}

A análise petrográfica envolveu a descrição de seções delgadas e polidas ao microscópio óptico (luz natural e refletida), observando se aspectos texturais, estruturais e composicionais do minério de ferro, das BIFs e dos minerais de manganês.

Grande parte das amostras, tais como as de minério friável e de itabirito dolomítico parcialmente alterado, foram impregnadas com uma mistura de resina polyester cristal e monômero de estireno, antes de seguirem para corte com serra, preparação de seções e polimento. As lâminas delgado-polidas e polidas foram preparadas nos laboratórios de laminação da Universidade de São Paulo (USP), da Universidade Federal de Ouro Preto (UFOP) e da UQ. 


\subsection{2 - ANÁLISE POR DIFRAÇÃO DE RAIOS-X (DRX)}

As análises por DRX foram realizadas em algumas das amostras de minério e BIFs, como complemento às análises petrográficas, e para o cálculo dos parâmetros de rede da hematita. As amostras selecionadas foram preparadas através do método do pó, utilizando almofariz e pilão de ágata, sendo cada amostra colocada em um suporte adequado. As análises foram realizadas nos laboratórios de difração de raios-X do Departamento de Mineralogia e Geotectônica do Instituto de Geociências da USP, e do Instituto de Física da Universidade Federal de Minas Gerais (UFMG).

O equipamento utilizado na USP foi um difratômetro Siemens-Brucker modelo D5000, operando a $40 \mathrm{kV}$ e $40 \mathrm{~mA}$ com $2 \theta$ entre 3 e $65^{\circ}$, em passos de $0,05^{\circ}$ e $1 \mathrm{~s} /$ passo, sendo usada a radiação $\mathrm{Cu}-\mathrm{K} \alpha(\lambda=1,5118 \AA)$. $\mathrm{Na}$ UFMG as análises de $\mathrm{DRX}$ foram realizadas em um difratômetro Rigaku-Geigerflex, na geometria de Bragg-Bretano, sendo também usada a radiação $\mathrm{Cu}-\mathrm{K} \alpha$, e monocromador de grafite, com $30 \mathrm{~mA}$ de corrente e $40 \mathrm{kV}$ de tensão. Os dados foram coletados no modo $2 \theta-\theta$, com $2 \theta$ entre 4 e $140^{\circ}$, em passos de $0,05^{\circ}$.

Os parâmetros de rede da hematita foram obtidos em quatro amostras de minério de ferro fazendo-se refinamentos de estrutura, empregando o Método de Rietveld com o programa DBWS-9807 (Young et al., 1998). Para a interpretação dos difratogramas utilizou-se o programa de computador DIFFRAC Plus conjuntamente com o banco de dados PDF2-release 2001 do International Center for Diffraction Data (http://www.icdd.com).

\subsection{3 - ANÁLISE POR MICROSCOPIA ELETRÔNICA DE VARREDURA (MEV)}

Amostras de BIFs e de minério de ferro foram examinadas ao MEV para verificação de aspectos texturais e investigação de fases minerais não detectadas na microscopia óptica, seja por se apresentarem em pequenas quantidades, seja pelo baixo grau de cristalinidade. Os minerais de manganês foram investigados para comprovar a presença de fases minerais portadoras de $\mathrm{K}$, obter uma análise qualitativa da composição dos mesmos, e identificar a presença em potencial de minerais contaminantes nas amostras, tais como micas e argilas, passíveis de prejudicarem os resultados geocronológicos. Foram utilizados microscópios eletrônicos de varredura do Instituto de Geociências da USP e do Centre for Microscopy and Microanalysis da UQ (CMM-UQ).

As amostras estudadas por MEV na USP foram recobertas com carbono, utilizando-se para tanto uma máquina evaporadora Emitech K250. Fitas de carbono dupla face foram utilizadas para fixação da amostra no suporte amostral. Foi utilizado para observação um 
microscópio eletrônico de varredura LEO440I, sendo procedidas as microanálises por espectrometria dispersiva de raios-X com espectrômetro Oxford e detector de estado sólido SiLi.

As amostras estudadas no CMM-UQ foram metalizadas com carbono (Carbon Coater JEOL JEE-4X). Para as análises foram utilizados dois microscópios eletrônicos: (i) Philips XL30 equipado com sistema de elétron retro-espalhado (back-scattered electron - BSE) e um espectrômetro de energia dispersiva (energy dispersive spectrometer -.. EDS) capaz de detectar elementos entre boro e urânio (condições analíticas: corrente a $20 \mathrm{kV}$ e diâmetro do feixe de elétrons $=6 \mu \mathrm{m}$ ); e (ii) JEOL JSM6400F (a corrente e diâmetro do feixe de elétrons foram variáveis, dependendo das características do material analisado). Todos os equipamentos utilizados no CMM-UQ, incluindo a microssonda eletrônica, foram operados diretamente pelo autor, que passou por treinamento prévio, teórico e prático.

\subsection{4 - ANÁLISE POR MICROSSONDA ELETRÔNICA (MSE)}

Através da microssonda eletrônica foi determinada a composição química do carbonato do itabirito dolomítico e dos minerais de manganês do itabirito manganesífero. Em algumas amostras de itabirito dolomítico e de minério de ferro procedeu-se à determinação da composição química da hematita. Todas as análises deste mineral, entretanto, apresentaram teores de $\mathrm{Fe}_{2} \mathrm{O}_{3}$ superiores a $99 \%$, motivo pelo qual optou-se por não dar seguimento às análises do mesmo.

As análises por MSE dos carbonatos (e algumas de hematita) do itabirito dolomítico foram realizadas no laboratório de microssonda eletrônica do Departamento de Mineralogia e Geotectônica do Instituto de Geociências da USP. As amostras foram previamente metalizadas com carbono e analisadas em uma microssonda eletrônica JEOL-JXA 8600 operando a $15 \mathrm{kV}$ e corrente de $20 \eta \mathrm{A}$, com diâmetro do feixe de elétrons variando entre 1 e $5 \mu \mathrm{m}$. Foram analisados 8 elementos ( $\mathrm{Si}, \mathrm{Sr}, \mathrm{Fe}, \mathrm{Mn}, \mathrm{Mg}, \mathrm{Ca}, \mathrm{Zn}, \mathrm{Ba}$ ) no carbonato e 7 elementos na hematita ( $\mathrm{Si}, \mathrm{Ti}, \mathrm{Al}$, $\mathrm{Cr}, \mathrm{Fe}, \mathrm{Mn}$ e P). O método de correção para as análises foi o "ZAF".

As análises de minerais de manganês, assim como de algumas hematitas, foram realizadas no CMM-UQ em uma microssonda eletrônica JEOL JXA8800 dotada de quatro espectrômetros de dispersão de comprimento de onda (wavelength dispersion spectrometer WDS) e utilizando quatro cristais (LDE1, LIFH, PET e TAP), um detector (EDS) Oxford Ge Model-6640, e operada por uma estação de trabalho Hewlett Packard Apollo 9000/425t para 
aquisição e redução dos dados, operando a $15 \mathrm{kV}$ e corrente de $15 \eta \mathrm{A}$, com diâmetro do feixe de elétrons variando entre 0 e $10 \mu \mathrm{m}$. Foram analisados 13 elementos $(\mathrm{O}, \mathrm{Mn}, \mathrm{Zn}, \mathrm{P}, \mathrm{Co}, \mathrm{Fe}, \mathrm{Si}, \mathrm{Al}$, $\mathrm{Pb}, \mathrm{Ba}, \mathrm{Ca}, \mathrm{K}$, e $\mathrm{Na}$ ), sendo o oxigênio analisado como amostra desconhecida e os demais elementos como metal. A aquisição dos dados e redução dos resultados foi feita através do programa JXA-8800L "Basic Software 1", e o método de correção para as amostras foi "metal PRZ".

\subsection{5 - ANÁLISE QUÍMICA}

As amostras destinadas a análises químicas foram preparadas nos laboratórios de preparação de amostras da MBR. A preparação consistiu de britagem, seguida de pulverização em panela de carbeto de tungstênio. Em algumas amostras de itabirito dolomítico, as bandas dolomítica e hematítica foram analisadas separadamente, para fins de comparação com as bandas correspondentes no minério de ferro friável. Para tanto, procedeu-se à coleta em separado das bandas, mediante britagem da amostra global abaixo de $5 \mathrm{~mm}$, e catação manual, com auxílio de lupa binocular, de fragmentos de cada tipo de material. Quatro amostras das bandas maciça e porosa do minério friável, correspondentes às bandas hematítica e dolomítica do protominério, respectivamente, foram também coletadas e analisadas separadamente, para fins de estudo das alterações ocorridas na composição química e mineralógica.

A maioria das análises químicas foi realizada no Laboratório de Análises Químicas da MBR. As análises para Fe total e FeO foram realizadas por Dicromatometria (Titulação do teor de $\mathrm{Fe} / \mathrm{FeO}$ por Dicromato de Potássio 0, IN). $\mathrm{SiO}_{2}, \mathrm{Al}_{2} \mathrm{O}_{3}, \mathrm{P}_{2} \mathrm{O}_{5}, \mathrm{MnO}_{2}, \mathrm{TiO}_{2}, \mathrm{CaO}, \mathrm{MgO}, \mathrm{Ba}$, $\mathrm{V}, \mathrm{Ni}, \mathrm{Cu}, \mathrm{Zn}$ e $\mathrm{Cr}$ foram determinados por espectrometria de plasma (ICP). $\mathrm{Na}_{2} \mathrm{O}$ e $\mathrm{K}_{2} \mathrm{O}$ foram analisados por absorção atômica. A perda ao fogo (PF) foi determinada mediante calcinação da amostra em mufla, a uma temperatura de $1.000^{\circ} \mathrm{C}$.

Algumas das amostras previamente analisadas na MBR foram selecionadas para análise de um conjunto maior de elementos no Activation Laboratories, Canadá (ACTLABS/Canadá). Neste laboratório, $\mathrm{SiO}_{2}, \mathrm{Al}_{2} \mathrm{O}_{3}, \mathrm{Fe}_{2} \mathrm{O}_{3}, \mathrm{P}_{2} \mathrm{O}_{5}, \mathrm{MnO}, \mathrm{TiO}_{2}, \mathrm{CaO}, \mathrm{MgO}, \mathrm{Na}_{2} \mathrm{O}, \mathrm{K}_{2} \mathrm{O}, \mathrm{Ba}, \mathrm{Sr}, \mathrm{Y}, \mathrm{Sc}$, $\mathrm{Zr}$, Be e V foram analisados por ICP, enquanto que $\mathrm{Ni}, \mathrm{Cu}, \mathrm{Zn}, \mathrm{Ga}, \mathrm{Ge}, \mathrm{Rb}, \mathrm{Nb}, \mathrm{Mo}, \mathrm{Ag}$, In, $\mathrm{Sn}$, Cs, La, Ce, Pr, Nd, Sm, Eu, Gd, Tb, Dy, Ho, Er, Tm, Yb, Lu, Hf, Ta, W, Tl, Pb, Bi, Cr, Th e U foram determinados por ICP-MS, após a abertura da amostra com fusão por metaborato/tetraborato de $\mathrm{Li}$, a qual foi rapidamente dissolvida em solução de ácido nítrico fraco. $\mathrm{Au}, \mathrm{As}, \mathrm{Br}, \mathrm{Co}, \mathrm{Ir}, \mathrm{Sb}, \mathrm{Sc}$ e Se foram analisados por ativação neutrônica instrumental 
(INAA). Na Tabela 1 estão relacionados os limites de detecção das análises realizadas na MBR e no ACTLABS.

\begin{tabular}{|c|c|c|c|c|c|c|c|c|c|c|c|}
\hline \multirow[b]{2}{*}{$\%$} & \multirow[t]{2}{*}{ MBR } & \multirow[t]{2}{*}{ ACTLABS } & \multirow[b]{2}{*}{$\mathrm{ppm}$} & \multirow[t]{2}{*}{ MBR } & \multirow[t]{2}{*}{ ACTLABS } & \multicolumn{6}{|c|}{ ACTLABS } \\
\hline & & & & & & ppm & & ppm & & ppm & \\
\hline $\mathrm{SiO}_{2}$ & 0,1 & 0,01 & $\mathrm{Ba}$ & 10 & 3 & Ge & 0,5 & $\mathrm{Sm}$ & 0,01 & W & 0,5 \\
\hline $\mathrm{TiO}_{2}$ & 0,01 & 0,001 & V & 10 & 5 & $\mathrm{Rb}$ & 1 & Eu & 0,005 & $\mathrm{~T} 1$ & 0,05 \\
\hline $\mathrm{Al}_{2} \mathrm{O}_{3}$ & 0,1 & 0,01 & $\mathrm{Ni}$ & 10 & 20 & $\mathrm{Nb}$ & 0,2 & $\mathrm{Gd}$ & 0,01 & $\mathrm{~Pb}$ & 5 \\
\hline $\mathrm{Fe}_{2} \mathrm{O}_{3}$ & 0,1 & 0,01 & $\mathrm{Cu}$ & 10 & 5 & Mo & 2 & $\mathrm{~Tb}$ & 0,01 & $\mathrm{Bi}$ & 0,1 \\
\hline $\mathrm{FeO}$ & 0,1 & $\mathrm{Na}$ & $\mathrm{Zn}$ & 10 & 30 & $\mathrm{Ag}$ & 0,5 & Dy & 0,01 & $\mathrm{Th}$ & 0,05 \\
\hline $\mathrm{MnO}$ & 0,01 & 0,001 & $\mathrm{Cr}$ & 10 & 20 & In & 0,1 & Ho & 0,01 & $\mathrm{U}$ & 0,01 \\
\hline $\mathrm{MgO}$ & 0,01 & 0,01 & $\mathrm{Sr}$ & $\mathrm{Na}$ & 2 & $\mathrm{Sn}$ & 1 & $\mathrm{Er}$ & 0,01 & & \\
\hline $\mathrm{CaO}$ & 0,01 & 0,01 & $\mathrm{Y}$ & $\mathrm{Na}$ & 0,5 & $\mathrm{Cs}$ & 0,1 & $\operatorname{Tm}$ & 0,005 & & \\
\hline $\mathrm{Na}_{2} \mathrm{O}$ & 0,001 & 0,01 & $\mathrm{Sc}$ & $\mathrm{Na}$ & 0,1 & $\mathrm{La}$ & 0,05 & $\mathrm{Yb}$ & 0,01 & & \\
\hline $\mathrm{K}_{2} \mathrm{O}$ & 0,001 & 0,01 & $\mathrm{Zr}$ & $\mathrm{Na}$ & 1 & $\mathrm{Ce}$ & 0,05 & Lul & 0,002 & & \\
\hline $\mathrm{P}_{2} \mathrm{O}_{5}$ & 0,01 & 0,01 & $\mathrm{Be}$ & $\mathrm{Na}$ & 1 & $\operatorname{Pr}$ & 0,01 & $\mathrm{Hf}$ & 0,1 & & \\
\hline PF & 0,1 & 0,01 & $\mathrm{Ga}$ & $\mathrm{Na}$ & 1 & $\mathrm{Nd}$ & 0,05 & $\mathrm{Ta}$ & 0,01 & & \\
\hline
\end{tabular}

$\mathrm{Na}=$ não analisado

Tabela 1: Relação dos elementos analisados em cada laboratório químico com seus respectivos limites de detecção.

\subsection{6 - DETERMINAÇÃO DE DENSIDADE}

A determinação de densidade foi realizada em fragmentos de 20 a $30 \mathrm{~cm}$ de comprimento de minério friável e itabirito dolomítico, coletadas em testemunhos de sondagem. Apesar do minério friável ser muito friável, foi possível coletar fragmentos contínuos, medindo cerca de 5 $\mathrm{cm}$ de diâmetro por $20 \mathrm{~cm}$ de comprimento, os quais foram secos em estufa por $12 \mathrm{~h}$, pesados, e revestidos por um filme de PVC, quando foram novamente pesados ao ar e, posteriormente, imersos em água. As amostras de itabirito dolomítico foram processadas da mesma forma. A densidade aparente foi obtida diretamente, através da relação entre massa e volume. Após a determinação da densidade aparente, todos os fragmentos foram submetidos à análise química.

\subsection{7 - ANÁLISE DE ISÓTOPOS DE CARBONO E OXIGÊNIO}

Isótopos de $\mathrm{C}$ e $\mathrm{O}$ foram analisados em amostras da banda dolomítica do itabirito dolomítico e em veios carbonáticos que cortam esta rocha. As análises isotópicas foram realizadas no Laboratório de Isótopos Estáveis da Universidade Federal de Pernambuco (NEGLABISE). A metodologia consistiu na extração do gás $\mathrm{CO}_{2}$ de amostras de carbonato pulverizadas, colocadas em solução de ácido fosfórico a 100\% durante três dias, o qual foi criogenicamente limpo de acordo com o método descrito por McCrea (1950). Os isótopos de C e 
$\mathrm{O}$ do $\mathrm{CO}_{2}$ liberado foram analisados em um espectrômetro de massa SIRA, o qual foi calibrado com os padrões NBS-18, NBS-19 e NBS-20, usando o gás BSC (Borborema skarn calcite) como referência $\left(\delta^{18} \mathrm{O}\right.$ e $\delta^{13} \mathrm{C}=-11.28 \%$ opdB $\mathrm{e}-8.58 \%$ opdB, respectivamente).

\subsection{8 - ANÁLISE POR ESPECTROSCOPIA MÖSSBAUER (MS)}

As análises por espectroscopia Mössbauer foram realizadas em amostras de minério de ferro compacto e friável. As bandas maciça e porosa do minério friável foram analisadas separadamente, com o intuito de investigar-se a presença de diferentes fases minerais portadoras de ferro nas mesmas. Foram também analisadas duas amostras da banda dolomítica do itabirito dolomítico, para efeito de comparação com a banda porosa do minério de ferro friável, a qual resulta da dissolução da primeira. As análises foram realizadas no Laboratório de Física Aplicada do Centro de Desenvolvimento de Tecnologia Nuclear (CDTN), em Belo Horizonte. Os espectros Mössbauer de transmissão do ${ }^{57} \mathrm{Fe}$ foram obtidos a $300 \mathrm{~K}$ em um espectrômetro de aceleração constante usando uma fonte ${ }^{57} \mathrm{Co} / \mathrm{Rh}$. Quatro amostras foram também analisadas a 50 K. Um programa de mínimos quadrados (programa NORMOS) foi utilizado para o cálculo dos parâmetros hiperfinos. Todas as amostras estudadas por MS foram também analisadas por DRX no Instituto de Física da UFMG.

\subsection{9 - ANÁliSE GEOCRONOLÓGICA PELO MÉTODO ${ }^{40} \mathrm{Ar} /{ }^{39} \mathrm{Ar}$}

$\mathrm{O}$ método de datação ${ }^{40} \mathrm{Ar} /{ }^{39} \mathrm{Ar}$ é uma variante do método $\mathrm{K}$-Ar e, assim como este, fornece o tempo em função do decaimento radioativo, espontâneo e natural do ${ }^{40} \mathrm{~K}$ para ${ }^{40} \mathrm{Ar}^{*}$ (argônio radiogênico), a uma taxa conhecida. Uma descrição detalhada da técnica pode ser obtida em McDougall et al. (1999). O método ${ }^{40} \mathrm{Ar} /{ }^{39} \mathrm{Ar}$ é um dos métodos geocronológicos mais confiáveis e versáteis atualmente disponíveis, em função de fatores tais como:

(1) somente razões isotópicas, e não quantidades absolutas de ${ }^{40} \mathrm{Ar}$, precisam ser determinadas para uma amostra (Renne, 2000);

(2) várias sub-alíquotas de gases são analisadas em uma mesma amostra, a diferentes temperaturas (aquecimento gradual), o que permite a determinação da história de retenção do Ar (história térmica) em um mineral ou rocha;

(3) a quantidade de material utilizada na técnica de ${ }^{40} \mathrm{Ar} /{ }^{39} \mathrm{Ar}$ (um grão de 0,2-2 mm de diâmetro) é bem menor que a necessária no $\mathrm{K}-\mathrm{Ar}(0,1-1 \mathrm{~g})$, permitindo que problemas de contaminação sejam evitados;

(4) a análise por aquecimento gradual permite testar a presença de várias gerações do mineral datável em uma mesma amostra; 
(5) a análise por aquecimento gradual permitir testar a presença de argônio herdado ou em excesso, de contaminantes, ou a presença de várias gerações da fase datável em uma mesma amostra;

(6) a análise por aquecimento gradual permite a extração e análise de gases hospedados em diferentes reservatórios em um mineral, facilitando a separação dos gases atmosféricos dos gases radiogênicos na amostras, aumentando a precisão das análises;

(7) o método é passível de completa automação, permitindo a realização de um número estatisticamente válido de análises em um curto período de tempo.

No método de ${ }^{40} \mathrm{Ar} /{ }^{39} \mathrm{Ar}$, o potássio é medido indiretamente através da geração do isótopo nucleogênico de ${ }^{39} \mathrm{Ar}$ pela reação ${ }^{39} \mathrm{~K}(\mathrm{n}, \mathrm{p}){ }^{39} \mathrm{Ar}$ (Merrihue \& Turner, 1966), que implica na absorção de um nêutron rápido e na emissão de um próton. A amostra é irradiada (isto é, bombardeada por nêtrons), juntamente com um padrão, em um reator nuclear, com fluxo de nêutrons apropriado para a geração de ${ }^{39} \mathrm{Ar}$. O tempo é obtido através da relação:

$$
t=\left(\lambda^{-1}\right) \cdot \ln \left[J \cdot\left({ }^{40} \operatorname{Ar}^{*}{ }^{39} \operatorname{Ar}_{k}\right)+1\right]
$$

(Equação 1)

onde,

$\lambda$ representa a constante de decaimento total do ${ }^{40} \mathrm{~K}\left(5.543 \pm 0.010 \times 10^{-10}\right)$ (soma de $\lambda_{\beta} \mathrm{e}$ $\left.\lambda_{\varepsilon}\right)$ - (Steiger \& Jager, 1977);

$\lambda_{\beta}$ representa a constante de decaimento do ${ }^{40} \mathrm{~K}$ ao ${ }^{40} \mathrm{Ca}\left(4.962 \pm 0.009 \times 10^{-10}\right)$;

$\lambda_{\varepsilon}$ a constante de decaimento do ${ }^{40} \mathrm{~K}$ ao ${ }^{40} \mathrm{Ar}\left(5.508 \pm 0.004 \times 10^{-11}\right)$;

${ }^{40} \mathrm{Ar}^{*}$ é a quantidade total do ${ }^{40} \mathrm{Ar}$ radiogênico (obtida subtraindo-se a quantidade de ${ }^{40} \mathrm{Ar}$ atmosférico e ${ }^{40} \mathrm{Ar}_{k}$ da quantidade total de ${ }^{40} \mathrm{Ar}$ obtida em uma alíquota da amostra, e onde ${ }^{40} \mathrm{Ar}_{k}$ é a quantidade de ${ }^{40} \mathrm{Ar}$ gerada pela reação ${ }^{39} \mathrm{~K}(\mathrm{n}, \mathrm{p}){ }^{39} \mathrm{Ar}$;

${ }^{39} \mathrm{Ar}_{k}$ é a quantidade de ${ }^{39} \mathrm{Ar}$ gerada pela reação ${ }^{39} \mathrm{~K}(\mathrm{n}, \mathrm{p}){ }^{39} \mathrm{Ar}$ (obtida subtraindo-se o ${ }^{39} \mathrm{Ar}_{\mathrm{Ca}}$ da quantidade total de ${ }^{39} \mathrm{Ar}$ medido em uma alíquota da amostra, onde ${ }^{39} \mathrm{Ar} \mathrm{Ca}$ é a quantidade de ${ }^{39} \mathrm{Ar}$ gerada pela reação $\left.{ }^{42} \mathrm{Ca}(\mathrm{n}, \alpha)^{39} \mathrm{Ar}\right)$.

$\mathrm{O}$ parâmetro de irradiação $\mathbf{J}$ (fator $\mathrm{J}$ ), adimensional, é determinado irradiando-se um padrão de fluência de nêutrons de idade conhecida colocado próximo à amostra cuja idade quer se determinar. O padrão deve ficar fisicamente o mais próximo possível da amostra para evitar incertezas causadas por heterogeneidades no fluxo de nêutrons (Renne, 1998). A determinação das quantidades de ${ }^{40} \mathrm{~K} \mathrm{e}{ }^{39} \mathrm{Ar}_{k}$ produzidos no padrão fornece as informações necessárias para o cálculo do fator $\mathrm{J}$ :

$$
\mathbf{J}=\left(\mathrm{e}^{\lambda t}-1\right) /\left({ }^{40} \operatorname{Ar}^{*}{ }^{39} \operatorname{Ar}_{k}\right)
$$

onde,

té a idade do padrão, determinada independentemente; 
$\lambda$ é definido na Equação 1;

${ }^{40} \mathrm{Ar}^{*}$ é a quantidade total de ${ }^{40} \mathrm{Ar}$ presente no padrão;

${ }^{39} \mathrm{Ar}_{k}$ é a quantidade de ${ }^{39} \mathrm{Ar}$ nucleogênico gerado pela reação ${ }^{39} \mathrm{~K}(\mathrm{n}, \mathrm{p}){ }^{39} \mathrm{Ar}$ no padrão.

O método ${ }^{40} \mathrm{Ar} /{ }^{39} \mathrm{Ar}$ pode ser aplicado a uma ampla escala de tempo, abrangendo desde o recente (ca. 2.000 anos) até a idade do sistema solar (Renne, 2000). Em minerais supergênicos, as idades mais nova já obtidas estão em torno de 100.000 anos (Feng \& Vasconcelos, 2001).

As amostras de óxidos de Mn das Minas do Sapecado e Andaime foram datadas no Laboratório de Geocronologia de Argônio da Universidade de Queensland (University of Queensland Argon Geochronology in Earth Sciences - UQ-AGES). A aplicação do método ${ }^{40} \mathrm{Ar}{ }^{39} \mathrm{Ar}$ consiste de uma série de etapas descritas por Vasconcelos (1999) e Vasconcelos et al., (2002), resumidamente ilustradas na Figura 17. As amostras foram quebradas com o auxilio de um martelo em fragmentos milimétricos $(0,5-2 \mathrm{~mm})$ e lavadas em ultrassom para retirada de materiais finos (argilominerais, minerais finamente ou pouco cristalizados) por cerca de 1 hora, até a limpeza total do material, sendo utilizados água destilada e álcool etílico absoluto na lavagem. Os fragmentos limpos foram examinados em lupa binocular, e seis a oito grãos visualmente homogêneos de cada amostra foram colocados em um disco de alumínio para irradiação por nêutrons. Aproximadamente a mesma quantidade de grãos de foi colocada em discos plásticos, ao qual foi adicionada resina epóxi. Após polimento, estas amostras foram examinadas ao MEV e MES, permitindo desta forma que as análises mineralógicas e geocronológicas sejam realizadas em praticamente uma mesma alíquota da amostra.

As amostras foram irradiadas por 14 horas, juntamente com o padrão Fish Canyon Sanidine $(28.02 \pm 0.28 \mathrm{Ma})$ no reator nuclear Triga da Oregon State University (OSU - CLICIT Facility). Após um período de resfriamento de três semanas, três grãos de cada amostra foram colocados em um disco de cobre, secos em estufa a $180^{\circ} \mathrm{C}$ por 13 horas, e aquecidos gradualmente em um laser contínuo (Coherent $10 \mathrm{~W}$ continous Ar-ion laser) no UQ-AGES. Os gases liberados durante o aquecimento foram limpos criogenicamente, sendo a fração limpa dos gases analisadas em um espectrômetro de massa MAP-215-50 especialmente construído para a análise de gases raros. O sistema a laser é totalmente automatizado pelo programa Mass Spec v. 5.11 , escrito especificamente para análises pelo método ${ }^{40} \mathrm{Ar} /{ }^{39} \mathrm{Ar}$. Este mesmo programa faz o cálculo da idade aparente para cada estágio de aquecimento (step heating), levando em consideração as correções necessárias (análise de amostras em branco, interferências nucleogênicas, contaminação por ${ }^{36} \mathrm{Ar}$ atmosférico, fator $\mathfrak{J}$ ). 
$\mathrm{O}$ método ${ }^{40} \mathrm{Ar}{ }^{39} \mathrm{Ar}$ fornece idades aparentes, obtidas para cada estágio de aquecimento, uma idade integrada, que é aquela calculada a partir do gás total liberado pela amostra, e uma idade isocrônica, obtida a partir da reta de regressão entre as razões ${ }^{39} \mathrm{Ar} /{ }^{40} \mathrm{Ar} v s .{ }^{36} \mathrm{Ar} /{ }^{40} \mathrm{Ar}$. Fornece ainda uma idade patamar, que é calculada conforme definição de Fleck et al. (1977), a partir de estágios de aquecimento contíguos que juntos representam mais de $50 \%$ do total de ${ }^{39} \mathrm{Ar}$ liberado da amostra, para os quais inexista diferença entre as idades ao nível de confiança de 95\%. Em condições ideais, as idades integrada, isocrônica e patamar devem apresentar os mesmos resultados. Vasconcelos (1999) discute o significado geológico de cada uma destas idades, apresentando diferentes tipos de espectros obtidos na datação ${ }^{39} \mathrm{Ar} /{ }^{40} \mathrm{Ar}$ de minerais supergênicos e a interpretação dos mesmos. 


\section{Microscopia}

ótica

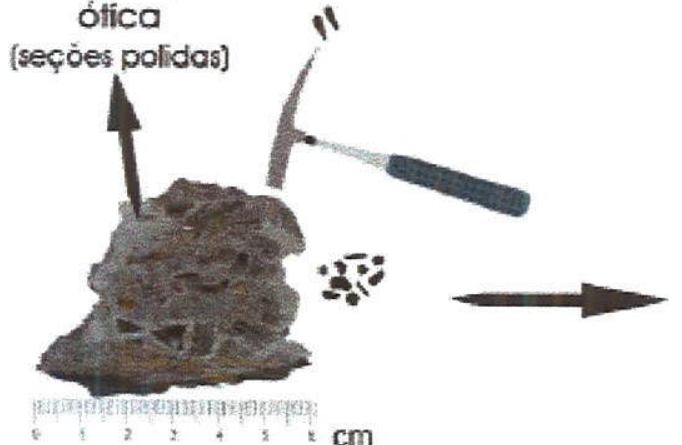

Quebra manual da amostra em frogmentos milimétricos

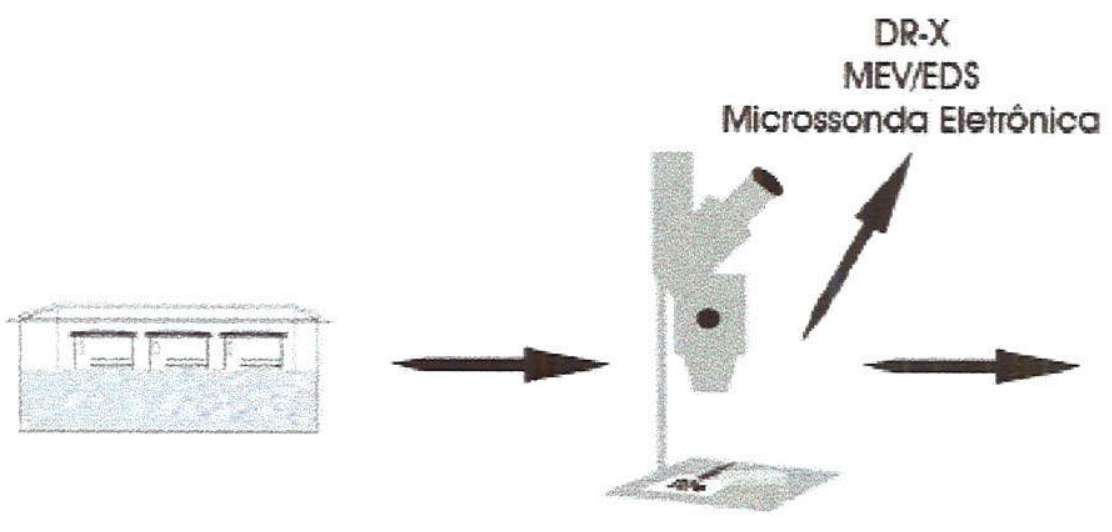

Limpeza

borho em uftossom

água destlade

dicool etlico abociuto

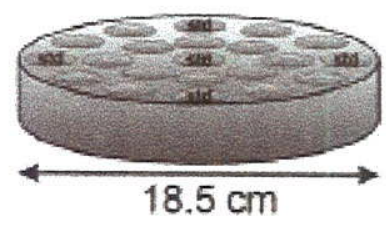

Montagem do Al-disco - anostras + podróes

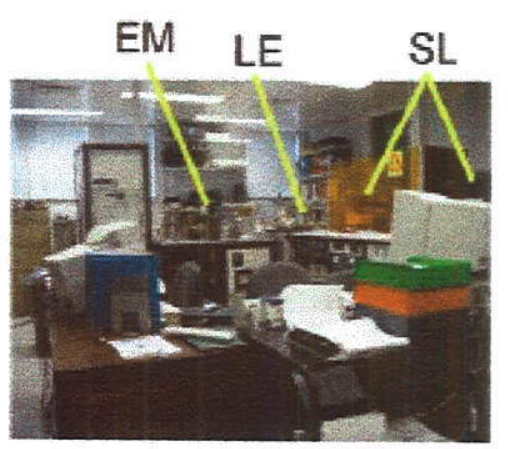

\section{Reator nuclear}

- bornbondecinento de neutrons

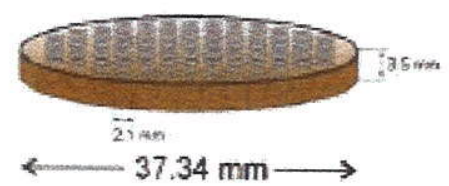

Montagem do Cu-disco - Crnostics + padoúes -745 orficios

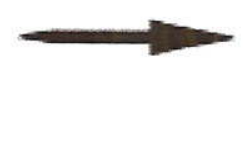

Análises automatizadas por aquecimento gradual a laser pelo método ${ }^{43} \mathrm{Ar} /{ }^{30} \mathrm{Ar}$

- Iisterna a laser - argónio (SL)

- espectuómetio de massa MaP.215.50 (GM

Figura 13: Diagrama esquemático mostrando as principais etapas da análise pelo método geocronológico por ${ }^{40} \mathrm{Ar}{ }^{39} \mathrm{Ar}(\mathrm{Carmo}, 2004)$. 


\section{CAPÍTULO 3 - GEOLOGIA E GEOQUÍMICA DO MINÉRIO DE FERRO DA MINA DE ÁGUAS CLARAS, QUADRILÁTERO FERRÍFERO, MINAS GERAIS, BRASIL}

Este tema é apresentado sob a forma do artigo "Geology and geochemistry of the Aguas Claras and Pico iron mines, Quadrilátero Ferrifero, Minas Gerais, Brazil" (Spier, C.A; Oliveira, S.M.B.; Rosiére, C.A. 2003. Mineralium Deposita, 38:751-774), no Anexo 1. Este artigo sintetiza as informações geológicas e geoquímicas adquiridas ao longo dos 30 anos de existência da Mina de Águas Claras, apresentado-os de forma sistemática, e trazendo-os ao conhecimento público. Apresenta, ainda, o mesmo tipo de informação para a Mina do Pico, de modo a familiarizar o leitor com os diferentes tipos de protominério do minério de ferro existentes no Quadrilátero Ferrífero, e apresentá-lo àcom plexidade do tema que é a gênese do minério de ferro. Segue-se, abaixo, uma síntese do artigo.

As Minas de Águas Claras e Pico são duas minas de ferro de classe mundial, hospedadas dentro de formações ferríferas bandadas paleoproterozóicas (regionalmente conhecidas como itabiritos) do Supergrupo Minas, localizadas no Quadrilátero Ferrífero, Minas Gerais. O Depósito de Águas Claras consiste de um corpo de minério lenticular, com cerca de $2.500 \mathrm{~m}$ de extensão, alojado dentro de itabirito dolomítico da Formação Cauê. O itabirito dolomítico é o protominério do minério de ferro friável de alto teor, o qual foi o principal tipo de minério lavrado, e representou mais de $85 \%$ dos $284 \mathrm{Mt}$ de minério mineradas entre 1973 e 2002 , quando a mina foi fechada. Os restantes $15 \%$ são formados por minério compacto de alto teor. A hematita é o principal constituinte mineralógico do minério, ocorrendo como martita, hematita granular, tabular e, localmente, especular. Magnetita ocorre de forma subordinada, como relictos no interior dos cristais de martita e hematita. Minerais de ganga são muito raros, consistindo de dolomita, clorita, talco e apatita, sendo especialmente comuns no contato com o protominério. $\mathrm{O}$ baixíssimo conteúdo de minerais de ganga está refletido na composição química dos minérios, caracterizada por teores muito elevados de Fe (média de $68,2 \%$ ).

O Depósito do Pico é constituído por um corpo de minério lenticular, com aproximadamente $3.000 \mathrm{~m}$ de extensão, alojado dentro que quartzo itabirito, o qual foi o protominério dos minérios de alto e baixo teor de ferro da Mina do Pico. O minério friável de alto teor, juntamente com o minério friável de teores de ferro um pouco mais baixos (itabirito 
friável rico) são os principais tipos de minério, representando cerca de $51 \%$ e $29 \%$ das reservas. Os restantes $20 \%$ consistem de minério compacto de alto teor. Os minerais de ferro do minério são os mesmos do minério de Águas Claras. Minerais de ganga são raros nos minérios de alto teor, aumentando em quantidade no itabirito rico. O quartzo é o principal mineral de ganga, com clorita ocorrendo subordinada. A composição química dos minérios de alto teor é caracterizada pelos elevados teores de $\mathrm{Fe}$ (média de 67\%) e baixos de $\mathrm{P}, \mathrm{Al}_{2} \mathrm{O}_{3}$ e $\mathrm{SiO}_{2}$, os quais estão concentrados nas frações finas do minério. $\mathrm{O}$ itabirito rico apresenta teores médios de $\mathrm{Fe}$ e $\mathrm{SiO}_{2}$ de $58,6 \%$ e $13,5 \%$, respectivamente.

A gênese do minério friável de alto teor e do itabirito rico das Minas de Águas Claras e Pico está relacionada a processos supergênicos. Os minerais de ganga dos itabiritos foram lixiviados pela água subterrâea, o que promove u o enriquecimento residual em ferro na rocha. Este processo foi favorecido pelo clima tropical e topografia favorável. A composição mineralógica original do itabirito e a presença de estruturas controlando a circulação da água subterrâea influenciou o grau de enriquecimento em ferro da rocha. O minério compacto de alto teor é de origem supergênica. Sua gênese é atribuída a soluções hidrotermais que lixiviaram os minerais de ganga, preenchendo os poros formados com hematita. Este processo ainda não está completamente entendido e permanece uma fonte de debates na literatura. 


\section{CAPÍTULO 4 - GEOQUÍMICA E GÊNESE DAS FORMAÇÕES FERRÍFERAS BANDADAS DA FORMAÇÃO CAUÊ, QUADRILÁTERO FERRÍFERO, MINAS GERAIS, BRASIL}

Este tema é apresentado sob a forma do artigo "Geochemistry and genesis of the banded iron formations of the Cauê Formation, Quadrilátero Ferrifero, Minas Gerais, Brazil" (Spier, C.A; Oliveira, S.M.B.; Sial, A.N.; Rios, F.J. 2005. Precambrian Research - submetido), no Anexo 2. O artigo descreve a geologia, mineralogia e petrologia dos itabiritos da Formação Cauê na Mina de Águas Claras, dando especial atenção ao itabirito dolomítico (protominério do minério friável). Apresenta, ainda, dados sobre a geoquímica dos itabiritos e resultados de análises de isótopos de $\mathrm{C}$ e $\mathrm{O}$ do itabirito dolomítico, sugerindo um modelo genético para estas rochas. Apresenta-se, a seguir, um resumo do artigo.

A Formação Cauê, do Supergrupo Minas, é composta por formações ferríferas bandadas (BIFs) paleoproterozóicas do tipo "Lago Superior", denominadas regionalmente de itabiritos. Dois tipos composicionais de itabiritos ocorrem na região noroeste do Quadrilátero Ferrífero: itabirito dolomítico e quartzo itabirito. O primeiro consiste de bandas ricas em dolomita, alternadas com bandas ricas em hematita, enquanto que o segundo é formado por bandas ricas em quartzo alternadas com bandas ricas em hematita. Dolomita, quartzo e hematita são os principais constituintes mineralógicos destes itabiritos, com clorita, sericita e apatita ocorrendo como minerais acessórios.

A composição química dos itabiritos da Formação Cauê é tão simples quanto a de outras BIFs mundiais. No itabirito dolomítico $\mathrm{Fe}_{2} \mathrm{O}_{3}$ mais $\mathrm{CaO}, \mathrm{MgO}$ e $\mathrm{PF}$ variam entre $95.8 \%$ e $97.8 \%$, enquanto que no quartzo itabirito $\mathrm{Fe}_{2} \mathrm{O}_{3}$ mais $\mathrm{SiO}_{2}$ variam entre $94.4 \%$ e $99.6 \%$. Os dois tipos de itabiritos estão intensamente oxidados, apresentando razões $\mathrm{Fe}^{3+} /\left(\mathrm{Fe}^{2+}+\mathrm{Fe}^{3+}\right)$ maiores do 0.98 , muito superiores as razões médias de outras BIFs paleoproterozóicas. Os teores de elementos traços são muito baixos, variando entre $<10 \mathrm{ppm}(\mathrm{Y}, \mathrm{Sc}, \mathrm{Be}, \mathrm{Cu}, \mathrm{Ga}, \mathrm{Ge}, \mathrm{Rb}, \mathrm{Nb}$, Mo, Ag, In, Sn, Cs, Hf, Tl, Pb, Bi, As, Cd, Th, U, Sb) até concentrações entre 10 e 55 ppm (Ba, $\mathrm{Sr}, \mathrm{Zr}, \mathrm{V}, \mathrm{Ni}, \mathrm{Zn}, \mathrm{Co}, \mathrm{Cr}$ e $\left.\sum \mathrm{ETR}\right)$.

A dolomita do itabirito dolomítico apresenta valores negativos de $\delta^{13} \mathrm{C}$ variando entre $-2.5 \%$ a $-0.8 \%$, enquanto que os dados de isótopos de oxigênio exibem valores de $\delta^{18} \mathrm{O}$ variando entre $-12.4 \%$ to $-8.5 \%$. Os valores do $\delta^{13} \mathrm{C}$ mostram um enriquecimento em ${ }^{13} \mathrm{C}$ da 
base para o topo da Formação Cauê, o qual possivelmente continua para cima na estratigrafia, nos dolomitos estromatolíticos da Formação Gandarela. Os dados isotópicos de $\mathrm{C}$ e $\mathrm{O}$, as assinaturas de ETR e as razões $\mathrm{Y} / \mathrm{Ho}$ indicam uma origem marinha para os sedimentos do itabirito dolomítico.

O padrão de enriquecimento em ETRP apresentado pelos itabiritos é característico do padrão de fracionamento dos ETR da água do mar moderna, superimposto pelo padrão de ETR dos fluidos hidrotermais exalados nas vents das dorsais meso-oceânicas, os quais estão refletidos nas anomalias positivas de $\mathrm{Eu}$. A forte correlação positiva entre $\mathrm{Al}_{2} \mathrm{O}_{3}$ e $\mathrm{TiO}_{2}(r>0.9)$ indica uma pequena participação de componentes terrígenos nos sedimentos predominantemente químicos e marinhos da Formação Cauê. As diferenças no padrão de fracionamento dos ETRP dos itabiritos sugerem que seus sedimentos foram precipitados a partir de diferentes profundidades do mar, com os sedimentos do itabirito dolomítico sendo precipitados em águas marinhas mais rasas, carregando maior quantidade de sedimentos continentais, e os sedimentos do quartzo itabirito sendo precipitados a partir de águas mais profundas. Variações do nível do mar, causadas por transgressões e regressões, seriam responsáveis por mudanças na composição da água durante a deposição da Formação Cauê. Estas mudanças estariam refletidas pelo itabirito dolomítico, quartzo itabirito e itabirito anfibolítico, os quais representariam variações faciológicas laterais e verticais de BIFs carbonática, quartzosa (cherty) e argilosa (shaly). 


\section{CAPÍTULO 5 - OS MINÉRIOS DE FERRO DE ALTO TEOR DA MINA DE ÁGUAS CLARAS, QUADRILÁTERO FERRÍFERO, BRASIL}

Este tópico é apresentado sob a forma do artigo "The high-grade iron ores of the Águas Claras mine, Quadrilátero Ferrífero, Brazil" (Spier, C.A; Oliveira, S.M.B.; Rosière, C.A; Ardisson, J.D. 2005. Mineralium Deposita - submetido), no Anexo 3. O artigo trata do tema central da tese, que é a caracterização e a gênese do minério de ferro da Mina de Águas Claras. São apresentados dados mineralógicos, petrológicos e geoquímicos para os minérios friável e compacto, e discutidos os processos envolvidos nas suas gêneses. Na discussão da gênese dos minérios, é feita uma rápida apresentação da geologia dos Depósitos de Capão Xavier e Tamanduá, de modo a melhor ilustrar a complexidade dos processos que levaram a formação dos vários tipos de minério de ferro no Quadrilátero Ferrífero. Apresenta-se, a seguir, uma síntese do artigo.

Muitos depósitos de ferro de classe mundial ocorrem no Quadrilátero Ferrífero, na região sudeste do Brasil, onde formações ferríferas bandadas metamorfísadas e heterogeneamente deformadas, regionalmente denominadas de itabiritos, foram convertidas em minérios hematíticos de alto $(\mathrm{Fe}>64 \%)$ e baixo $(30 \%<\mathrm{Fe}<64 \%)$ teor de ferro. Com base em sua composição mineralógica, são descritos três tipos principais de itabiritos no Quadrilátero Ferrífero: quartzo itabirito, itabirito dolomítico e itabirito anfibolítico. Diferentemente de outras minas no Quadrilátero Ferrífero, onde os minérios de alto teor ocorrem associados a minérios de baixo teor, na Mina de Águas Claras os minérios de alto teor são largamente predominantes, tendo sido formados a partir do itabirito dolomítico. Dois tipos principais de minério de alto teor ocorrem em Águas Claras: friável e compacto. O minério friável é o principal tipo, e representou cerca de $85 \%$ do minério lavrado entre 1973 e 2002, quando a mina foi fechada. O minério friável tem porosidade muito elevada e preserva parcialmente a estrutura original do itabirito dolomítico (protominério), particularmente o meso e microbandamento, característica esta refletida nas bandas maciças e porosas do minério. O minério compacto é muito denso e duro. Ele ocorre como lentes métricas a decimétricas, isoladas, tanto no meio do minério friável como no interior do itabirito dolomítico inalterado. Os minérios friável e compacto são formados essencialmente por hematita, a qual ocorre na forma de martita, hematita anédrica, granular e 
tabular e, localmente, especular. Os minerais de ganga são muito raros, consistindo de dolomita, sericita, clorita e apatita nos minérios compacto e friável, e minerais de manganês e ferrihidrita no minério friável, onde estes últimos minerais ocorrem em maior quantidade na banda porosa. As análises químicas mostraram que os minérios friável e compacto consistem quase que totalmente de $\mathrm{Fe}_{2} \mathrm{O}_{3}$, com maiores quantidades de impurezas, especialmente $\mathrm{MnO}$, no minério friável. Tanto o minério friável como o minério compacto são extremamente pobres em elementos traços.

Os minérios de alto teor da Mina de Águas Claras tem origens distintas, envolvendo processos hipogênicos e supergênicos. A ocorrência do minério compacto no interior do itabirito dolomítico inalterado é uma boa indicação de sua origem hipogênica. Apesar dos questionamentos em relação àgênese do itabirito dolomítico (se esta rocha representa uma fácies carbonática da Formação Catê ou se resulta da substituição hidrotermal do chert/quartzo por dolomita), diversas características observadas no minério friável indicam a sua origem supergênica, como, por exemplo: (1) a transição lateral e vertical para o itabirito dolomítico, (2) o gradual desaparecimento em profundidade, formando interdigitações com esta rocha, (3) a presença em meio ao minério de blocos isolados do protominério, em tudo similares ao itabirito dolomítico que ocorre fora da área mineralizada, (4) a presença de dobras do tipo kink e slump, ausentes no protominério, as quais em conjunto com a ocorrência de depressões preenchidas por sedimentos terciários recobrindo parcialmente o corpo de minério, indicam o colapso do mesmo após a lixiviação da dolomita, (5) a presença de ferrihidrita e de minerais de manganês formados a partir da dissolução da dolomita, (6) padrões de fracionamento dos ETR idênticos aos do itabirito dolomítico.

A composição mineralógica dos itabiritos teve um papel importante na gênese dos minérios de alto e baixo teor no Quadrilátero Ferrífero. A comparação entre a geologia da Mina de Águas Claras com a de Capão Xavier e Tamandúá, mostrou que, sob idênticas condições estruturais, topográficas e climáticas, o itabirito dolomítico é muito mais favorável à formação de depósitos de ferro de alto teor do que o quartzo itabirito. Forneceu também indicações de que a gênese de depósitos friáveis de alto teor a partir do quartzo itabirito requer a atuação de outros controles além do litológico, possivelmente envolvendo processos hipogênicos e supergênicos, com predominâcia de um ou outro processo em cada depósito em particular. 


\section{CAPÍTULO 6 - GEOCRONOLOGIA ${ }^{40} A r r^{39} A r$ E EVOLUÇÃO DOS DEPÓSITOS DE FERRO LATERÍTICOS DO QUADRILÁTERO FERRÍFERO, MINAS GERAIS, BRASIL}

Este tema é tratado sob a forma do artigo " ${ }^{* 40} \mathrm{Ar} /{ }^{39} \mathrm{Ar}$ geochronology and the evolution of lateritic iron deposits in the Quadrilátero Ferrífero, Minas Gerais, Brazil" (Spier, C.A; Vasconcelos, P.M.; Oliveira, S.M.B. 2005. Chemical Geology - submetido), no Anexo 4. O artigo trata da datação do perfil de intemperismo dos itabiritos no Quadrilátero Ferrífero, e por extensão da idade do minério de ferro supergênico nele contido, apresentando idades obtidas através da técnica de datação ${ }^{40} \mathrm{Ar} /{ }^{39} \mathrm{Ar}$, aplicada em minerais de manganês supergênicos presentes no minério de ferro friável. A dificuldade de acesso ao locais mais favoráveis para a ocorrência destes minerais na Mina de Águas Claras, e a indisponibilidade de testemunhos de sondagem contendo minerais de manganês passíveis de serem datados pela técnica ${ }^{40} \mathrm{Ar} /{ }^{39} \mathrm{Ar}, \mathrm{fez}$ com que fossem escolhidas as Minas de Sapecado e Andaime para este estudo. Apresenta-se, a seguir, um resumo do artigo.

Os perfis de intemperismo recobrindo os depósitos de minério de ferro de Sapecado, Pico e Andaime, localizados no Quadrilátero Ferrífero, em Minas Gerais, atingem profundidades de 140-400 m, e hospedam depósitos de minério de ferro supergênicos de classe mundial. Além de hematita, goethita e algum quartzo remanescente, o minério de ferro friável e os itabiritos profundamente intemperizados contem criptomelano, holandita e pirolusita supergênicos. Estes minerais de manganês ocorrem preferencialmente na região de contato entre os itabiritos e dolomitos intemperizados das Formações Cauê e Gandarela, respectivamente. A sua distribuição no perfil de intemperismo dos itabiritos fornece informações sobre a propagação da frente de alteração intempérica e sobre a formação do minério de ferro supergênico.

Os resultados de datação ${ }^{40} \mathrm{Ar} /{ }^{39} \mathrm{Ar}$ por aquecimento gradual a laser de 69 grãos de minerais de manganês, obtidos em 23 amostras coletadas em profundidades entre 5 e $150 \mathrm{~m}$, revelam idades entre 70 e $12 \mathrm{Ma}$. Os óxidos de manganês mais antigos ocorrem próximos da superfície, enquanto que os mais jovens ocorrem em profundidade. Entretanto, a maioria das amostras coletadas na interface rocha alterada-rocha sã apresentaram idades entre $51 \mathrm{e} 41 \mathrm{Ma}$, sugerindo que os perfis de intemperismo no Quadrilátero Ferrífero já tivessem atingido as profundidades atuais no Paleógeno. A partir dai o avanço da frente de alteração foi limitado. 


\section{CAPÍTULO 7 - CONSIDERAÇÕES FINAIS E CONCLUSÕES}

Os estudos mineralógicos e geoquímicos das BIFs e do minério de ferro da Mina de Águas Claras permitiram a caracterização destas rochas, em especial do itabirito dolomítico e do minério de ferro friável, contribuindo para o seu melhor conhecimento, o qual poderá ser útil no planejamento da lavra e beneficiamento do minério de ferro de outros depósitos da região com características geológicas similares, como, por exemplo, Capão Xavier. Permitiram, ainda, a elaboração de algumas considerações sobre suas gêneses.

A gênese do minério de ferro vem sendo explicada, recentemente, através de modelos híbridos, hipogênico-supergênicos (Beukes et al., 2002; Dalstra \&Guedes, 2004; Taylor et al., 2001). De acordo com estes modelos, no estágio hipogênico haveria a substituição metassomática do chert/quartzo da BIF por carbonatos (dolomita ou ankerita), os quais seriam lixiviados por fluidos meteóricos no estágio posterior. A substituição do quartzo por carbonato parece ter sido uma etapa importante na gênese dos depósitos gigantes de ferro de Carajás (Guedes et al., 2002; Lobato et al., 2004; Silva et al., 2005; Silva et al., 2004; Zuccheti \&obato, 2005) e da Província de Ham ersley (Taylor et al., 2001; Thorne et al., 2004; Webb et al., 2004), embora existam diversos depósitos em Hamersley onde esta associação é inexistente, como, por exemplo, Paraburdoo e Mt. Walleback (Morris, 2002, Webb et al., 2003; Webb et al., 2004). O mesmo acontece no Quadrilátero Ferrífero, onde existem muitos depósitos, como por exemplo os de Tamanduá, Capitão do Mato, Abóboras, Galinheiro, Pico e Sapecado, onde o quartzo itabirito foi claramente o protominério, inexistindo evidências de metassomatismo do quartzo por carbonato.

Por outro lado, a ocorrência de grandes corpos de itabirito dolomítico no Quadrilátero Ferrífero, associados a depósitos gigantes de minério de ferro de alto teor, poderia ser um indicativo de que estes depósitos também teriam sido resultantes do enriquecimento de BIFs quartzosas, através da atuação conjunta de processos hipogênicos-supergênicos. De acordo com esta hipótese, o itabirito dolomítico da Mina 
de Águas Claras representaria a primeira etapa da gênese do minério de ferro, e teria sido formado por substituição metassomática do quartzo do quartzo itabirito por dolomita, conforme sugerido por Beukes et al. (2002). Entretanto, neste trabaho não pode ser constatada uma relação direta desta substituição metassomática.

Concluímos que a formação de depósitos gigantes de minério de alto teor nem sempre envolve uma fase de substituição metassomática do quartzo por carbonato, e que o itabirito dolomítico é produto de dolomitização, metamorfīsmo e oxidação de BIFs originalmente carbonáticas, que representariam tão somente uma variação faciológica dos sedimentos da Formação Cauê.

Uma forte indicação da origem sedimentar do itabirito dolomítico é dada pelos resultados das análises dos isótopos de $\mathrm{C}$ e $\mathrm{O}$, que apresentaram valores negativos de $\delta^{13} \mathrm{C}$ variando entre $-2,5 \%-0,8 \%$ nquanto que os dados isotópicos de $\mathrm{O}$ mostraram valores de $\delta^{18} \mathrm{O}$ entre $-12,4 \%-8,5 \%$ imilares aos encontrados por Bekker et al. (2003) e Sial et al. (2000) em dolomitos estromatolíticos da Formação Gandarela, e compatíveis com os valores de $\delta^{13} \mathrm{C}$ e $\delta^{18} \mathrm{O}$ encontrados em outras sequências carbonáticas paleoproterozóicas bem preservadas (Bekker et al., 2003; Veizer et al., 1992; Veizer et al., 1990; Veizer et al., 1989).

A composição química global tanto do itabirito dolomítico como do quartzo itabirito indica uma origem a partir de sedimentos químicos muito puros. Por outro lado, a presença em pequena quantidade de $\mathrm{Al}, \mathrm{Ti}, \mathrm{Zr}$ e Th e a elevada correlação linear positiva entre eles nestas rochas, indica que houve pelo menos uma limitada participação de componentes detríticos nos sedimentos das BIFs na região da Mina de Águas Claras. Os teores ligeiramente maiores de $\mathrm{Al}_{2} \mathrm{O}_{3}, \mathrm{TiO}_{2}, \mathrm{Zr}$ e $\mathrm{Th}$ no itabirito dolomítico indicam que os sedimentos originais desta rocha receberam uma contribuição ligeiramente maior de componentes detríticos do que os sedimentos do quartzo itabirito. Estes componentes detríticos estão representados nos itabiritos pelos minerais micáceos, como clorita $\mathrm{e}$ sericita.

As análises petrográficas e químicas do quartzo itabirito inalterado das Minas de Águas Claras e Pico apresentaram resultados muito similares, sugerindo que este tipo de BIF formou-se nas mesmas condições deposicionais, em diferentes locais do Quadrilátero Ferrifero. Por outro lado, as associações litológicas reconhecidas nas duas minas são 
distintas: itabirito dolomítico e quartzo itabirito em Águas Claras e quartzo itabirito e itabirito anfibolítico na Mina do Pico. Na base da Formação Cauê em Águas Claras ocorre itabirito dolomítico, enquanto que na mesma posição estratigráfica na Mina do Pico ocorre quartzo itabirito. Estas relações sugerem variações laterais e verticais no ambiente de sedimentação da Formação Cauê, que propiciaram a formação de diferentes tipos de BIFs - carbonática, cherty e argilosa - as quais, no decorrer da evolução geológica da região, originaram os itabiritos dolomítico, quartzo itabirito e anfibolítico, respectivamente.

A participação de processos hipogênicos na gênese dos itabiritos do Quadrilátero Ferrífero ainda não está inteiramente compreendida. Entretanto, é inquestionável o envolvimento dos mesmos na gênese do minério compacto, conforme evidenciado, na Mina de Águas Claras, pela ocorrência em grandes profundidades deste tipo de minério intercalado ao itabirito dolomítico inalterado. Os dados microtermométricos obtidos por Rosière \&Rios (2004) em hematitas de miné rios compactos da Mina de Conceição sustentam esta conclusão. Os resultados obtidos neste trabalho não permitiram avanços significativos no conhecimento da gênese dos minérios compactos, indicando apenas que os mesmos foram formados por processos hipogênicos, em fase(s) anterior(es) àda formação do minério friável.

Por outro lado, diversas características apresentadas pelo minério friável, tais como: (1) a transição lateral e vertical para o itabirito dolomítico, (2) o gradual desaparecimento em profundidade, formando interdigitações com rocha fresca, (3) a presença em meio ao minério de blocos isolados do protominério, em tudo similares ao itabirito dolomítico que ocorre fora da área mineralizada, (4) a presença de dobras do tipo kink e slump, ausentes no protominério, as quais em conjunto com a ocorrência de depressões preenchidas por sedimentos terciários recobrindo parcialmente o corpo de minério, indicam o colapso do mesmo após a lixiviação da dolomita, (5) a presença de ferrihidrita e de minerais de manganês formados a partir da dissolução da dolomita, indicam uma origem supergênica para este tipo de minério. O resultado das análises químicas para ETR sustenta esta conclusão, na medida em que tanto o minério friável como o itabirito dolomítico apresentam padrão de fracionamento muito similares, com forte enriquecimento do lantâio em direção ao lutécio e anomalias positivas de Eu e Y. 
Por outro lado, este padrão é distinto do padrão de fracionamento do minério compacto, onde se verifica uma diferença nos ETR pesados, os quais sofrem discreto empobrecimento em relação aos ETR médios.

Os estudos petrográficos, combinados com as análises por DRX e MEV mostraram que a dissolução da dolomita pelos fluidos supergênicos produz um resíduo, cuja caracterização por espectrometria Mösbauer e microscopia de transmissão eletrôica revelou ser formado por ferrihidrita e minerais de manganês. A ocorrência destes novos minerais, preferencialmente na banda porosa do minério friável, é uma indicação de que o $\mathrm{Fe}^{2++}$ e o $\mathrm{Mn}^{2++}$, originalmente presentes na composição da dolomita, foram rapidamente oxidados pelas soluções que lixiviaram este mineral e promoveram a concentração residual de hematita na rocha. A identificação da ferridrita, mineral típico do intemperismo, no resíduo da dissolução da dolomita, é uma forte evidência de que a dissolução ocorreu pela ação da água subterrâea. Este mineral é meta-estável e transforma-se em hematita em temperaturas a partir de $4{ }^{\circ} \mathrm{C}$ (Schwertmann et al., 1985), a menos que esteja associado a minerais de manganês (Cornell, 1988), como é o caso em Águas Claras. A ocorrência de múltiplas gerações de minerais de manganês no itabirito manganesífero das Minas de Sapecado e Andaime, exibindo texturas botrioidal e radial, típicas de minerais precipitados a partir de soluções intempéricas, corroboram a conclusão anterior sobre a origem supergênica do minério friável da Mina de Águas Claras. As análises por DRX, MEV e MES mostraram que estes minerais consistem de pirolusita, criptomelano e hollandita, e que estão freqüntemente associados a goethita e gibbsita.

A ocorrência de depósitos de bauxita formados a partir de sedimentos caoliníticos depositados nas bacias terciárias que recobrem os corpos de minério friável em algumas minas do Quadrilátero Ferrífero (Boulangé et al., 1997; Pomerene, 1964), como, por exemplo, Capão Xavier, reflete a alta intensidade do intemperismo químico que atuou na região. Esse processo permitiu a completa dissolução da dolomita e a formação de minerais de manganês a partir das BIFs. A datação pelo método ${ }^{40} \mathrm{Ar} /{ }^{39} \mathrm{Ar}$ de minerais de manganês do grupo da hollandita, presentes no itabirito manganesífero das Minas do Sapecado e Andaime, trouxe importantes informações sobre a evolução do perfil de intemperismo das BIFs no Quadrilátero Ferrífero e, conseqüntemente, sobre o minério 
de ferro supergênico nele contido. Os resultados geocronológicos obtidos em 69 grãos de óxido de Mn forneceram idades patamar entre 61.5 $\pm 1.2 \mathrm{Ma}$ a $14.2 \pm 0.18 \mathrm{Ma}$, sugerindo uma prolongada história de intemperismo na região. A ausência de idades mais antigas do que $61.5 \pm 1.2 \mathrm{Ma}$ na Minas de Sapecado e Andaime não elimina a possibilidade de ocorrência de perfis de intemperismo ainda mais antigos na região, uma vez os minerais de manganês mais antigos podem não ter sido amostrados, terem sido erodidos, ou dissolvidos por soluções intempéricas mais jovens.

A maior parte dos óxidos de $\mathrm{Mn}$, entretanto, precipitou no intervalo entre 51 e 41 Ma, com um pico em 46.7 Ma. Este intervalo coincide com a deposição das bacias que recobrem o minério de ferro e os dolomitos da Formação Gandarela, conforme indicado por estudos palinológicos dos sedimentos de algumas delas (Lima \&alard-Cheboldaeff, 1981; Maizatto, 2001). Essa é, portanto, a idade de formação do minério friável em Águas Claras e Capão Xavier.

Os resultados geocronológicos mostraram também uma distribuição de idades muito similares no interior do perfil de intemperismo da Mina do Sapecado. Embora tenham sido obtidas algumas idades mais antigas próximo àsuperfície topográfica, e outras mais jovens em partes profundas do perfil, a maior parte dos óxidos de Mn que ocorrem próximo àinterface entre a BIF altera da e a BIF sã apresentou idades de $\sim 46$ Ma. Estes dados confirmam àconclusão de que o perfil de intemperismo das BIFs no Quadrilátero Ferrífero já havia atingindo o atual estágio de desenvolvimento há cerca de $50 \mathrm{Ma}$, sugerindo que a frente de alteração intempérica tenha avançado muito pouco durante o Neógeno. A partir dessa época as soluções intempéricas devem ter se tornado ineficientes na promoção do avanço da alteração.

A comparação entre a geologia da Mina de Águas Claras e Capão Xavier de um lado, e Tamanduá de outro, mostrou que, sob idênticas condições estruturais, topográficas e climáticas, o itabirito dolomítico é muito mais favorável àformação de depósitos de ferro de alto teor do que o quartzo itabirito, dando origem a corpos de maior volume. Forneceu também indicações de que a gênese de depósitos fríveis de alto teor a partir do quartzo itabirito requer a atuação de outros controles além do litológico, possivelmente envolvendo processos hipogênicos e supergênicos, com predominâcia de um ou outro processo em cada depósito em particular. 


\title{
ANEXO 1 - GEOLOGY AND GEOCHEMISTRY OF THE ÁGUAS CLARAS AND PICO IRON MINES, QUADRILÁTERO FERRÍFERO, MINAS GERAIS, BRAZIL
}

\begin{abstract}
The Águas Claras and Pico mines are two world-class iron-ore mines hosted within the Lower- Proterozoic banded iron-formations (locally known as itabirites) of the Minas Supergroup located in the Quadrilátero Ferrífero District, Minas Gerais, Brazil. The Águas Claras orebody consists of a $2,500 \mathrm{~m}$ long roughly tabular-shaped lens hosted within the dolomitic itabirite of the Cauê Formation. Dolomitic itabirite is the protore of the soft high-grade iron ore, which is the main ore type of the Águas Claras orebody, representing about $85 \%$ of the $284 \mathrm{Mt}$ mined since 1973, with the remaining $15 \%$ comprising hard high-grade ore. Hematite is the main constituent of the iron ores. It occurs as martite, granular hematite and locally as specularite. Magnetite appears subordinately as relicts within martite and hematite crystals. Gangue minerals are very rare. These consist of dolomite, chlorite, talc and apatite, and are especially common in contact with the protore. This virtual absence of gangue minerals is reflected in the chemistry of ores which are characterized by very high Fe contents (an average of $68.2 \% \mathrm{Fe}$ ).

The Pico orebody is a continuous $\sim 3,000 \mathrm{~m}$ long body of a lenticular shape hosted within quartz itabirite, which is the protore of the soft high- and low-grade ores at the Pico mine. The soft high-grade ores, together with the low-grade ores, called iron-rich itabirite, are the main types of ore and respectively represent approximately $51 \%$ and $29 \%$ of the reserves. The remaining $20 \%$ consists of hard high-grade ore. The iron oxide mineralogy is the same as that of the Águas Claras mine, but in different proportions. Gangue minerals are very rare in the highgrade ores, but are slightly more common in the iron-rich itabirite. Quartz is the dominant gangue mineral, and is found with minor quantities of chlorite. The chemistry of the high-grade ores is characterized by high $\mathrm{Fe}$ contents (an average of $67.0 \%$ ) and low $\mathrm{P}, \mathrm{Al}_{2} \mathrm{O}_{3}$, and $\mathrm{SiO}_{2}$ which are concentrated in the fines. Iron-rich itabirites average $58.6 \% \mathrm{Fe}$ and $13.5 \% \mathrm{SiO}_{2}$.

The genesis of the soft high-grade ores and iron-rich itabirites is related to supergene processes. Leaching of the gangue minerals by ground-water promoted the residual iron enrichment of the itabirites. This process was favored by the tropical climate and topographic
\end{abstract}


situation. The original composition of the itabirites and the presence of structures controlling the circulation of the ground-water have influenced the degree of iron enrichment. The hard highgrade ores are of a hypogene origin. Their genesis is attributed to hydrothermal solutions that leached the gangue minerals and filled the spaces with hematite. This process remains a source of debate and is not yet fully understood.

Keywords: banded iron-formation itabirite iron ore Quadrilátero Ferrífero Águas Claras Pico

\section{INTRODUCTION}

The Quadrilatero Ferrifero is one of the most important iron-ore mining districts in the world. It is located on the southeastern border of the São Francisco Craton, in the State of Minas Gerais, Brazil (Fig. 1). The Águas Claras and Pico mines of Minerações Brasileiras Reunidas MBR are both located at the western low-strain domain of the Quadrilatero Ferrifero but display different characteristics. The quality of the products of these mines, especially those of the Águas Claras mine (probably the world's richest iron mine in terms of ore grade) has turned MBR into the most important supplier of high-quality iron ore in the world.

The Águas Claras mine is located near the Serra do Curral Range, on the northern border of the Quadrilátero Ferrífero (Figs. 1 and 2a). It contains high-grade soft ores ( $\mathrm{Fe}>64 \%$ ) and subordinate hard ores hosted mainly within dolomitic iron formation, locally called itabirite. The Pico mine is located in the Itabirito Range, close to its eponymous settlement (Figs. 1 and $2 b$ ). In this mine high-grade, hard, massive, banded ores and soft ores occur interbedded with weathered and fresh quartz itabirite.

Although a significant volume of data has been gathered since mining began in 1973, very little geological information concerning the deposits is available in the literature (e.g. Pomerene 1964; Wallace 1965; Gomes 1986; Viel et al. 1987; Klein and Ladeira 2000). Hackspacher (1979) studied the structure of the Águas Claras mine and Rosière (1981) developed a structural analysis of the Pico mine. The purpose of this paper is to present a description of the geology of these world-class iron ore mines, thus improving the limited geological information available, and offering new geochemical and petrographic data which may provide a background for further studies. 


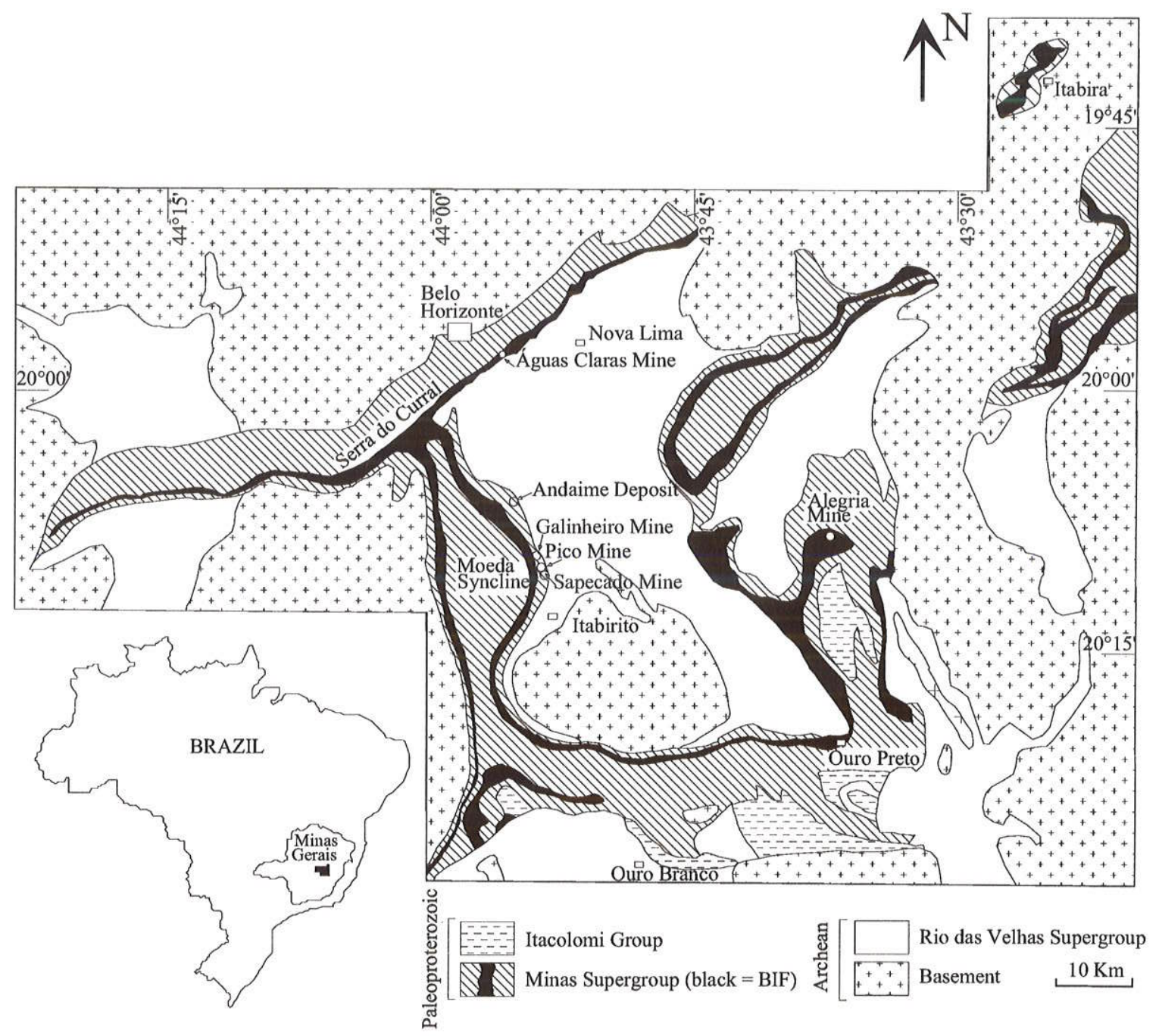

Figure 1 Location and geological sketch map of the Quadrilátero Ferrifero region (After Alkmim and Marshak 1998).
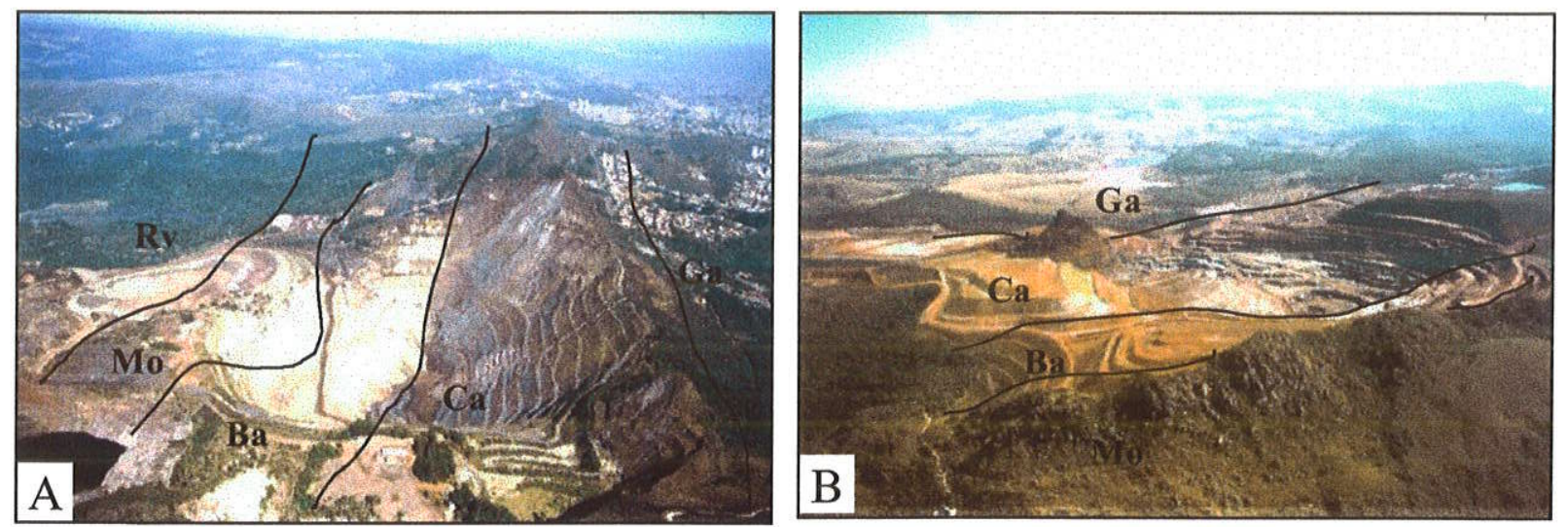

Figure 2 a Birds-eye view of the Águas Claras mine, looking west. b Birds-eye view of the Pico mine, looking northwest. $\mathrm{Rv}=$ Rio das Velhas Supergroup, $\mathrm{Mo}=$ Moeda Formation, $\mathrm{Ba}=$ Batatal Formation, $\mathrm{Ca}=$ Cauê Formation, $\mathrm{Ga}=$ Gandarela Formation. 


\section{GEOLOGICAL SETTING}

\section{The Quadrilátero Ferrífero District}

The geology and lithostratigraphy of the Quadrilátero Ferrifero were described in detail by the USGS-DNPM team between 1946 and 1963, and summarized by Dorr (1969). Since then, the subject has been reviewed by several authors (Ladeira and Viveiros 1984, Marshak and Alkmim 1989, Chemale Jr. et al. 1994, Renger et al. 1994, Alkmim and Marshak 1998). The most important lithostratigraphic units of the Quadrilatero Ferrifero (Figs. 1 and 3) are the Archean to Paleoproterozoic granite-gneiss terrains, the Archean greenstone belt sequences (Rio das Velhas Supergroup), the Minas Supergroup and the post-Minas intrusive rocks.

The giant iron ore deposits of the Quadrilátero Ferrifero are hosted in the metamorphosed sedimentary rocks of the Minas Supergroup, which consists of three Paleoproterozoic sequences (Renger et al. 1994; Noce 1995; Babinsky et al. 1995). The lowest unit is the Caraça Group, which consists of alluvial conglomerate and sandstone grading upwards into shallow-water marine pelites. The middle Itabira Group consists mainly of chemical sedimentary rocks. An extensive iron formation layer with variable composition occurs at the base of the Itabira Group and, together with hematitic and dolomitic phyllites, marbles and dolomites, comprises the Cauê Formation. The sequence grades upward to dolomites and dolomitic/manganiferous itabirites of the 2.4 Ga Gandarela Formation (Babinsky et al. 1995). Clastic sediments (with subordinate dolomites) of the Piracicaba Group occur over the Itabira Group. The uppermost sequence of the Minas Supergroup is the Sabará Group, a sequence of metamorphosed volcanoclastics, turbidites, banded iron- formations (BIFs) and conglomerates, considered to belong to the Transamazonian orogenic period (2.1 - 1.7 Ga., Renger et al. 1994).

Post-Minas intrusives, namely granite, pegmatite, metamorphosed mafic dykes and diabase, cut the Rio das Velhas and Minas Supergroups. Granite and pegmatite cutting basement rocks yield monazite and zircon U-Pb ages of 2.06 and 2.08 Ga respectively (Noce 1995). Foliated and metamorphosed mafic dykes occur throughout the Quadrilatero Ferrífero. One of them yielded a 1.714 Ga age (Alkmim and Marshak 1998). Diabase and gabbros, not affected by metamorphism, are also encountered locally (Pomenere 1964, Wallace 1965).

A supergene cap locally called canga covers the iron ores and other rocks in the Quadrilátero Ferrifero. It consists of a lithified superficial or near-surface iron-rich rock formed with various quantities of detrital fragments, commonly iron ores or itabirites, cemented by limonite into a blanketing body (Dorr 1964). 


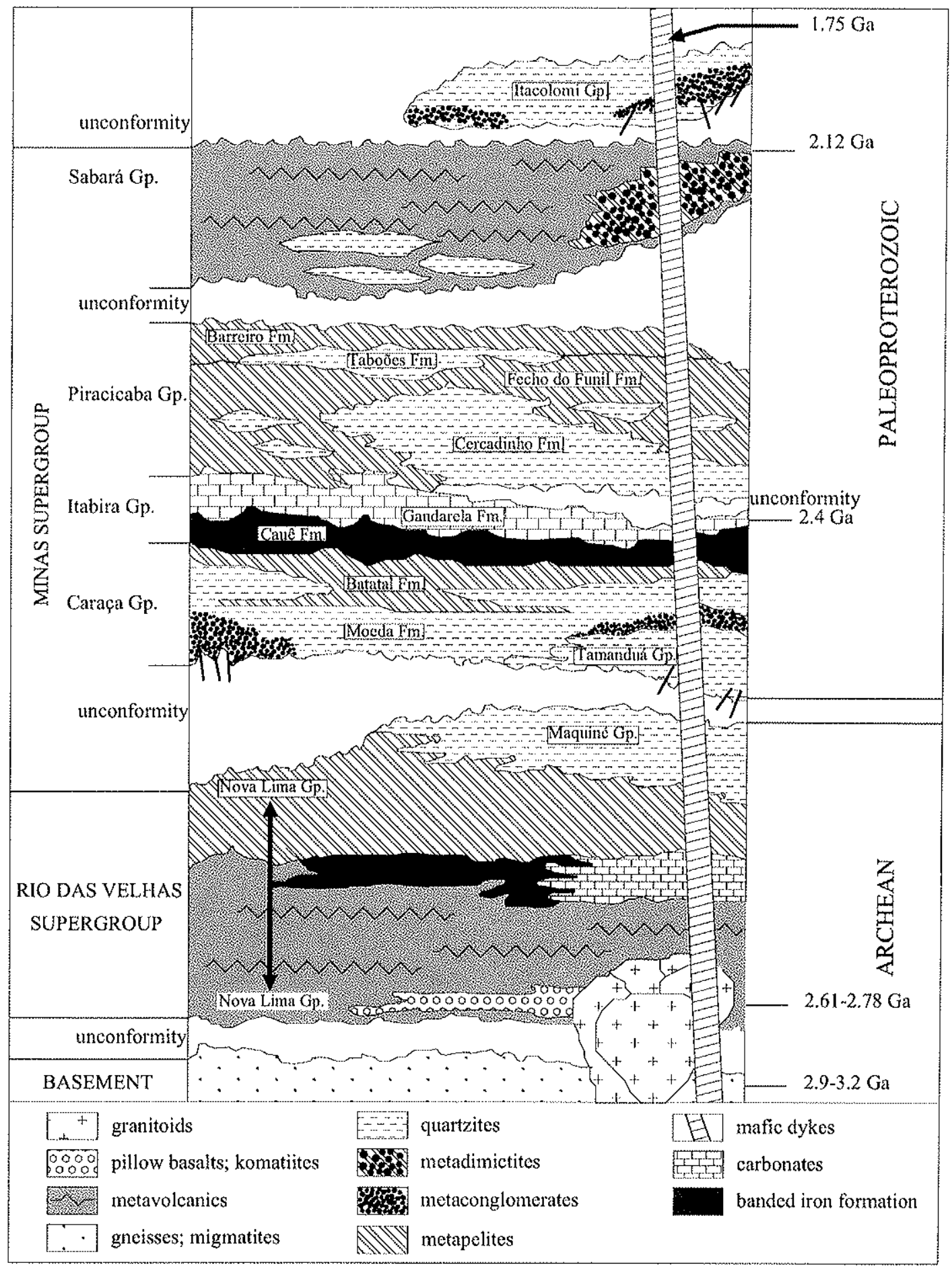

Figure 3 Stratigraphic column of the Quadrilatero Ferrifero region. The right-hand portion of the column represents the relationships in the eastern part of the Quadrilatero Ferrifero, while the left-hand side of the chart represents the relationships in the western part of the Quadrilatero Ferrifero (After Alkmim and Marshak 1998). 
Structurally, the Quadrilátero Ferrífero District consists of two distinct domains: an eastern high-strain domain and a western low-strain domain (Rosière et al. 2001). The former is dominated by thrusts and transcurrent shear zones which generate tight to isoclinal folds and thick mylonitic zones. The main regional structures of the latter are well-preserved megasynclines with discontinuous shear zones and thrust faults that intersect with the megascopic structures (Almeida 1977; Chemale et al. 1994; Rosière et al. 2001). Iron deposits occur in both domains and present structural particularities due to local deformation. Table 1 presents a synthesis of the tectonic events in the Quadrilátero Ferrifero region.

Table 1 Synthesis of the tectonic events at the Quadrilátero Ferrifero Region

\begin{tabular}{ccc}
\hline Age (Ga) & Event & $\begin{array}{c}\text { Lithological groups of rock formation } \\
\text { and other characteristics }\end{array}$ \\
\hline$>2.6$ & $\begin{array}{c}\text { Amalgamation of an Archean Granite- } \\
\text { Greenstone terrain }\end{array}$ & \\
$<2.6$ to $>2.4$ & $\begin{array}{c}\text { Extensional event. Development of an } \\
\text { ensialic or passive-margin basin (Minas } \\
\text { Basin) }\end{array}$ & $\begin{array}{c}\text { Deposition of the Caraça and } \\
\text { Itabira Groups }\end{array}$ \\
$<2.12$ to $>$ & $\begin{array}{c}\text { Transamazonian northwest-verging } \\
\text { thrusting and folding (D1) }\end{array}$ & $\begin{array}{c}\text { Development of thrust-sense shear } \\
\text { zones and regional-scale folds } \\
\text { Development of a dome-and-keel } \\
<2.09\end{array}$ \\
$\begin{array}{ccc}\text { Extensional Event. Transamazonian } \\
\text { orogenic colapse }\end{array}$ & $\begin{array}{c}\text { terrain. Deposition of the } \\
\text { Itacolomi Group }\end{array}$ \\
$\sim 1.75$ & Extensional Event & Intrusion of mafic dikes \\
0.7 to 0.45 & Brasiliano west-verging thrusting (D2) & $\begin{array}{c}\text { Intrusion of mafic dikes } \\
\text { Regional folds. Reactivation and } \\
\text { overprinting of older structures } \\
\text { Intrusion of mafic dikes }\end{array}$ \\
\hline 0.13 & Extensional Event &
\end{tabular}

After Alkim and Marshak (1998)

The rocks of the Rio das Velhas Supergroup were deformed prior to the deposition of the Minas Supergroup and, together with granite-gneiss complexes, acted as the basement of the Proterozoic Minas Basin (Marshak et al. 1992). After $2.6 \mathrm{Ga}$ and prior to $2.4 \mathrm{Ga}$, the region evolved into a passive-margin basin where sediments of the Minas Supergroup were deposited.

During the Transamazonian Cycle $(2.1-1.7 \mathrm{Ga})$ the supracrustal units of the Rio das Velhas and Minas Supergroups were folded into large-scale synclines and anticlines, and the underlying crystalline basement was uplifted. Shear zones were developed at the contact between supracrustral and basement rocks. The origin of these structures remains a source of controversy. Chemale et al. (1994) attribute the development of the megasynclines and the uplift of the basement to an extensional event during the Paleoproterozoic. Chauvet et al. (1994) postulate a model in which a tectonomagmatic event was responsible for both the uplift of the basement 
domes and the generation of regional folding. On the other hand, Alkmim and Marshak (1998) interpret these structures as a consequence of a fold-thrust belt developed after 2.125 Ga during the closure of a passive-margin basin. This, they conclude, was followed by the emplacement of basement domes against supracrustal rocks at $2.095 \mathrm{Ga}$, as the consequence of an orogenic collapse.

During the Brasiliano Cycle $(650-500 \mathrm{Ma})$, west-vergent thrusts overprinted the earlier structures, causing inversion, amplification, translation and rotation of the synclines and developing thrust and fold structures represented by shear zones, tear faults, transcurrent zones and various types of folds (Chauvet et al. 1994, Chemale et al. 1994, Alkmim and Marshak 1998, Rosière et al. 2001).

The metamorphic grade increases progressively from greenshist facies in the west and central parts of the Quadrilátero Ferrifero to almandine-amphibolite facies in the east. This is demonstrated by the increase in quartz grain size and the presence of diagnostic metamorphic minerals (Dorr 1964). Herz (1978) identified the isograds of biotite and staurolite separating three metamorphic zones (chlorite, biotite and staurolite). He also noted the change from hematite to specularite under medium and higher grades of metamorphism. Pires (1995) redefined these isograds in carbonatic metalutites, which resulted in the definition of three metamorphic zones: grunerite, cummingtonite-actinolite, and tremolite-antophyllite. Moving east one may observe that the equilibration temperatures of mineral assemblages in these zones increase from about $300^{\circ} \mathrm{C}$ to $600^{\circ} \mathrm{C}$ for estimated pressures at 3 to $5 \mathrm{kbar}$.

\section{The Itabirites of the Itabira Group}

Itabirites are oxidized, metamorphosed and heterogeneously deformed banded iron formations (BIFs) containing discontinuously distributed orebodies, which vary in scale from just a few centimeters to hundreds of meters. Multiple processes have obliterated partially or totally the mineralogy, texture and structure of the original sediments, making it difficult to identify primary characteristics, especially in the high-strain domain. In the low strain domain, the itabirites have preserved several sedimentary and diagenetic features such as meso and microbanding pods formed by differential compaction and pisolites (Rosière et al. 2001). Banding is the main internal feature of the itabirites. Tight and isoclinal folds commonly showing a crenulation cleavage and pinch-and-swell structures are locally observed. Shear zones are restricted to a few places and found parallel to banding or truncating it. Kink-bands are very 
common in the weathered itabirites and have been interpreted by Ribeiro and Zavaglia (1998) as collapse structures.

Quartz itabirite is the major type of itabirite in the Quadrilatero Ferrifero. In this rock type the original chert or jasper bands have been recrystallized into granular quartz, and iron is present as hematite, magnetite or martite. Dolomitic itabirite is a dolomitized BIF consisting of alternating red carbonate and black iron oxide bands, each being between $1 \mathrm{~mm}$ and $50 \mathrm{~cm}$ thick. Amphibolitic itabirite consists of bands of many types of amphiboles (grunerite, tremolite, actinolite, cummingtonite and/or anthophilite) alternating with bands of iron oxides (Rosière et al. 1993).

Hematite is the major iron oxide in the itabirites, occuring in different forms: martite (pseudomorphs of hematite after magnetite), granular hematite and specularite (Dorr 1964, 1965; Rosière 1981, 1983, 2000). Magnetite appears subordinately as the $\mathrm{Fe}^{2+}$ deficient variety kenomagnetite (metastable magnetic phases which are somewhere between magnetite and maghemite in composition), and as relicts in martite and hematite aggregates. Both iron oxides were developed at various stages during the complex evolution of the Quadrilátero Ferrifero, as shown by Rosière $(1981,1983)$ and Rosière et al. (2001). Magnetite is the oldest recognizable iron oxide. Mostly it appears to have been totally or partially martitized. Granular hematite results from the progressive martitization, inversion and recrystallization of magnetite. Specularite results from recrystallization of kenomagnetite, martite or hematite in high-strain domains or shear zones (Rosière et al. 2001). Otherwise it occurs in extensional sites associated with quartz or carbonates (Lagoeiro 1998). Goethite occurs close to the surface, or along fracture planes, locally associated with gibbsite and kaolinite.

Quartz is the main gangue mineral of itabirites. The next most common are dolomite and amphiboles, which are present either as intercalated bands or disseminations. Chlorite, talc, apatite and various silicate minerals occur in very small quantities except in the high metamorphic-grade zones, where they can be common (Dorr 1973). Wavelite $\left(\mathrm{Al}_{3}\left(\mathrm{PO}_{4}\right)_{2}(\mathrm{OH})_{3.5} \mathrm{H}_{2} \mathrm{O}\right)$ is restricted to a few deposits in the Quadrilátero Ferrifero.

\section{The Iron Ores of the Itabira Group}

Iron ores have been formed throughout the Quadrilátero Ferrifero by the enrichment of itabirites. They are generally classified, according to the iron content, into high-grade and lowgrade ores. High-grade ores have Fe contents higher than $64 \%$, with very low contents of the 
contaminants $\mathrm{SiO}_{2}, \mathrm{Al}_{2} \mathrm{O}_{3}, \mathrm{CaO}, \mathrm{MgO}$ etc. The $\mathrm{Fe}$ contents of the low-grade ores vary from $32 \%$ to $64 \%$, with different amounts of contaminants.

The iron oxide mineralogy of ores is the same as that of the itabirites. Gangue minerals are rarely present in the high-grade ore but, where found, consist of relicts of quartz, dolomite, chlorite, amphibole and talc. Low-grade ores contain the same gangue minerals found in the protore. These vary in quantity according to the degree of iron enrichment.

The iron ores can be subdivided into hard and soft types. Hard ores can be banded, massive, lineated, schistose and secondarily brecciated. Soft ores can be foliated, lineated or free of any structure (blue dust ore) (Rosière et al. 1993; Rosière 2000).

\section{Genetic Models For The Iron Ores}

Although largely discussed in the international literature, the genesis of the high-grade iron ore deposits hosted within BIFs remains unclear. Different genetic models have been proposed worldwide to explain the iron enrichment of the BIFs. Morris (2002) identified eleven iron ore genetic models and grouped them in three classes: syngenetic, supergene and hypogene. Based on field investigations and literature surveys, Beukes et al. (2002) recognized three genetic models of high-grade iron ore deposits: ancient supergene, hydrothermal and supergenemodified hydrothermal deposits.

The supergene models explain the iron enrichment as a result of leaching of the gangue minerals by supergene fluids. (e.g. Dorr 1964, Morris 1985). These models are generally accepted as an explanation for the high-grade iron ores associated with present or past erosion surfaces. Hypogene models are more complex. They propose the action of hydrothermal fluids substituting the gangue minerals for iron oxides or iron carbonates (e.g. Dorr 1965, Gruner 1937, Powell et al. 1999, Morey 1999). Taylor et al. (2001) recently proposed a composite model to explain the genesis of the high-grade iron ore of the Hamersley Province. For a general understanding concerning the high-grade iron ores genesis see Beukes et al. (2002) and Morris (2002). For additional information see Lascelles (2002), Morey (1999), Morris (1987), Powell et al. (1999), Taylor et al. (2001), Van Schalkwyk and Beukes (1986), and references therein.

The genesis of the iron ores within the Cauê Formation in the Quadrilatero Ferrifero has been the subject of debate since the beginning of the $20^{\text {th }}$ century, and continues to be the focus of studies by several researchers (e.g. Harder and Chamberlin 1915; Guild 1953; Park 1959; Dorr 1964, 1965; Ramanaidou 1989; Ramanaidou et al. 1996; Rosière and Rios 2003). Soft ores have been explained as residual concentrations of iron oxides due to leaching of contaminants 
during supergene processes (Dorr 1964; Eichler 1968; Melfi et al. 1976; Viel et al. 1987; Ramanaidou 1989; Ramanaidou et al. 1996). They have also been viewed as a consequence of incomplete metasomatism of the BIF followed by weathering, as suggested by Dorr (1965). Hard ores have been generally considered to result from the replacement or leaching of gangue minerals (Dorr 1965). The precise timing of ore formation is also a source of controversy. Dorr (1965), for instance, postulated both syn-metamorphic and syn-deformational mineralization. But there remains debate over the importance of these events (Rosière 1981, Rosière and Rios 2003).

\section{THE ÁGUAS CLARAS OREBODY}

\section{General Description}

Mining at Águas Claras commenced in 1973 and by $2002 \mathrm{ca} .288 \mathrm{Mt}$ of high-grade iron ore had been mined. The highest annual output was in 1992 when $14 \mathrm{Mt}$ of iron ore were mined. The Águas Claras mine was closed in 2002 with an annual production of $1.2 \mathrm{Mt}$. About $88 \mathrm{Mt}$ of high-grade iron ore remains, but economic and environmental restrictions indicate that mining cannot continue. The ore was mined by open-pit methods and treated at a local ore-dressing plant. This resulted in three products: lump ore $(13 \%: 31.5-6.30 \mathrm{~mm})$, sinter feed $(43 \%: 6.30-$ $0.15 \mathrm{~mm}$ ) and pellet feed (32\%: $0.15 \mathrm{~mm}-0.038 \mathrm{~mm})$, with $12 \%$ of tailings. Table 2 presents the size distribution of the particles and the chemical composition of these products over recent years.

\section{Structure and Stratigraphy of the Mine Area}

The Águas Claras iron mine is located on the northern edge of the Serra do Curral, in a northeast-southwest trending homocline with bedding dipping steeply to the southeast (Fig. 2a). The Caraça, Itabira and Piracicaba Groups of the Minas Supergroup crop out along most of the extension of the Serra do Curral in an inverted sequence without repetition (Chemale et al. 1994). The inverted stratigraphic sequence, as well as locally preserved sedimentary structures, led Pomerene (1964), Dorr (1969), Pires (1979) and Alkmim and Marshak (1998) to propose that the homocline represents a remnant of the overturned limb of a northwest-vergent anticline. At its northern segment, the Serra do Curral is highly strained and left-laterally rotated from its original position. Wide shear zones occur at the contact of the Minas Supergroup with the Rio das Velhas Supergroup (Chemale et al. 1994). In the vicinity of the mine bedding is transposed 
by axial plane schistosity and locally developed mylonitic foliations, generally striking $N 45^{\circ} \mathrm{E}$, with dips ranging from $30^{\circ}$ to $70^{\circ}$ to the southeast.

Table 2 Chemical composition (wt \%) of the products of the Águas Claras and Pico mines

\begin{tabular}{|c|c|c|c|c|c|c|c|c|c|c|c|c|c|c|c|}
\hline & & \multicolumn{2}{|c|}{1995} & \multicolumn{2}{|c|}{1996} & \multicolumn{2}{|c|}{1997} & \multicolumn{2}{|c|}{1998} & \multicolumn{2}{|c|}{1999} & \multicolumn{2}{|c|}{2000} & \multicolumn{2}{|c|}{2001} \\
\hline Product & Variable & $\mathrm{MAC}$ & PIC & $\mathrm{MAC}$ & PIC & $\mathrm{MAC}$ & PIC & $\mathrm{MAC}$ & PIC & $\mathrm{MAC}$ & PIC & $\mathrm{MAC}$ & PIC & $\mathrm{MAC}$ & PIC \\
\hline \multirow{6}{*}{ 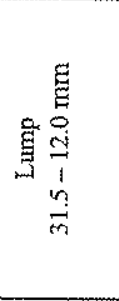 } & $\%$ & 17.50 & 13.50 & 11.19 & 13.00 & 11.77 & 16.90 & 14.18 & 16.10 & 14.59 & 13.90 & 17.33 & 16.50 & 33,43 & 15.80 \\
\hline & $\mathrm{Fe}_{\mathrm{T}}$ & 68.46 & 66.68 & 68.17 & 67.79 & 67.71 & 67.64 & 65.61 & 67.41 & 66.79 & 67.85 & 67.43 & 67.36 & 68.32 & 68.01 \\
\hline & $P$ & 0.026 & 0.042 & 0.025 & 0.033 & 0.031 & 0.040 & 0.034 & 0.047 & 0.037 & 0.035 & 0.033 & 0.031 & 0.055 & 0.031 \\
\hline & $\mathrm{Al}_{2} \mathrm{O}_{3}$ & 0.36 & 1.35 & 0.33 & 0.84 & 0.32 & 0.79 & 0.34 & 0.83 & 0.38 & 0.73 & 0.39 & 0.87 & 0.45 & 0.85 \\
\hline & $\mathrm{SiO}_{2}$ & 0.57 & 1.66 & 0.59 & 1.06 & 0.63 & 1.28 & 0,87 & 1.40 & 0.93 & 1.24 & 0.89 & 1.00 & 0.65 & 0.81 \\
\hline & $\mathrm{Mn}$ & 0.19 & 0.03 & 0.14 & 0.04 & 0.23 & 0.09 & 0.09 & 0.13 & 0.08 & 0.06 & 0.09 & 0.11 & 0.05 & 0.09 \\
\hline \multirow{6}{*}{ 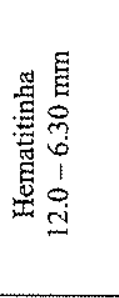 } & $\%$ & & 11.80 & & 9.60 & & 5.50 & & 3.10 & & 4.30 & & 6.30 & & 6.90 \\
\hline & $\mathrm{Fe}_{\mathrm{T}}$ & & 66.96 & & 67.34 & & 67.28 & & 67.36 & & 67.81 & & 67.94 & & 67.99 \\
\hline & $\mathrm{P}$ & & 0.044 & & 0.038 & & 0.045 & & 0.050 & & 0.035 & & 0.030 & & 0.030 \\
\hline & $\mathrm{Al}_{2} \mathrm{O}_{3}$ & & 1.25 & & 1.05 & & 0.93 & & 0.88 & & 0.77 & & 0.82 & & 0.88 \\
\hline & $\mathrm{SiO}_{2}$ & & 1.29 & & 1.22 & & 1.39 & & 1.47 & & 1.27 & & 0.97 & & 0.79 \\
\hline & $\mathrm{Mn}$ & & 0.039 & & 0.05 & & 0.10 & & 0.08 & & 0.05 & & 0.04 & & 0.05 \\
\hline \multirow{6}{*}{ 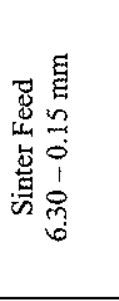 } & $\%$ & 41.76 & 36.50 & 47.58 & 36.20 & 44.55 & 32.20 & 43.30 & 31.60 & 44.90 & 35.10 & 45.11 & 32.30 & 45.31 & 32.70 \\
\hline & $\mathrm{Fe}_{\mathrm{T}}$ & 68.89 & 66.46 & 68.93 & 66.97 & 68.67 & 66.92 & 68.48 & 67.19 & 68.57 & 67.64 & 68.55 & 67.61 & 67.93 & 67.66 \\
\hline & P & 0.021 & 0.054 & 0.024 & 0.043 & 0.037 & 0.050 & 0.031 & 0.048 & 0.032 & 0.033 & 0.027 & 0.029 & 0.052 & 0.032 \\
\hline & $\mathrm{Al}_{2} \mathrm{O}_{3}$ & 0.30 & 1.25 & 0.26 & 0.95 & 0.25 & 0.89 & 0.23 & 0.82 & 0.26 & 0.66 & 0.29 & 0.72 & 0.42 & 0.78 \\
\hline & $\mathrm{SiO}_{2}$ & 0.52 & 1.93 & 0.46 & 1.80 & 0.54 & 1.95 & 0.59 & 1.82 & 0.66 & 1.69 & 0.81 & 1.54 & 0.69 & 1.40 \\
\hline & $\mathrm{Mn}$ & 0.17 & 0.06 & 0.16 & 0.07 & 0.15 & 0.07 & 0.12 & 0.08 & 0.13 & 0.06 & 0.13 & 0.09 & 0.06 & 0.055 \\
\hline \multirow{6}{*}{ 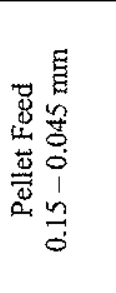 } & $\%$ & 32.26 & 16.40 & 32.99 & 23.90 & 34.02 & 26.30 & 30.48 & 28.00 & 29.37 & 29.00 & 26.38 & 28.10 & 14.12 & 25.70 \\
\hline & $\mathrm{Fe}_{\mathrm{l}}$ & 68.08 & 67.16 & 68.24 & 67.80 & 67.76 & 67.89 & 67.71 & 68.09 & 67.68 & 68.32 & 67.99 & 68.21 & 68.21 & 67.80 \\
\hline & $\mathrm{P}$ & 0.038 & 0.036 & 0.040 & 0.032 & 0.056 & 0.030 & 0.050 & 0.026 & 0.048 & 0.025 & 0.044 & 0.022 & 0.067 & 0.028 \\
\hline & $\mathrm{Al}_{2} \mathrm{O}_{3}$ & 0.48 & 0.74 & 0.39 & 0.59 & 0.43 & 0.55 & 0.40 & 0.50 & 0.42 & 0.39 & 0.40 & 0.38 & 0.55 & 0.57 \\
\hline & $\mathrm{SiO}_{2}$ & 0.84 & 2.06 & 0.76 & 1.71 & 1.10 & 1.67 & 1.21 & 1.47 & 1.25 & 1.36 & 1.12 & 1.54 & 0.87 & 1.48 \\
\hline & $\mathrm{Mn}$ & 0.46 & 0.04 & 0.41 & 0.05 & 0.42 & 0.05 & 0.39 & 0.05 & 0.42 & 0.04 & 0.35 & 0.06 & 0.13 & 0.07 \\
\hline
\end{tabular}

$\mathrm{MAC}=\mathrm{Aguas}$ Claras mine, $\mathrm{PIC}=$ Pico mine. $\%=$ percentage of each product in comparison with the feed of the beneficiation plant, differences to $100 \%$ represent taillings.

The stratigraphy of the mine (Fig. 4) area consists of clastic metasedimentary rocks of the Moeda and Batatal Formations (Caraça Group), and the predominant chemical metasedimentary rocks of the Caue Formation (Itabira group). The Moeda Formation outcrops to the south of the mine, forming the hanging wall of the deposit. This unit comprises fine quartzites with interlayered quartz-phyllites, and is generally intensely deformed. However, large lens of undeformed quartzite surrounded by anastomosing mylonitic quartzite are common. The quartzite grades to strongly foliated sericite-phyllite of the Batatal Formation. The contact between quartzite and phyllite is transitional and interfingering is common. 

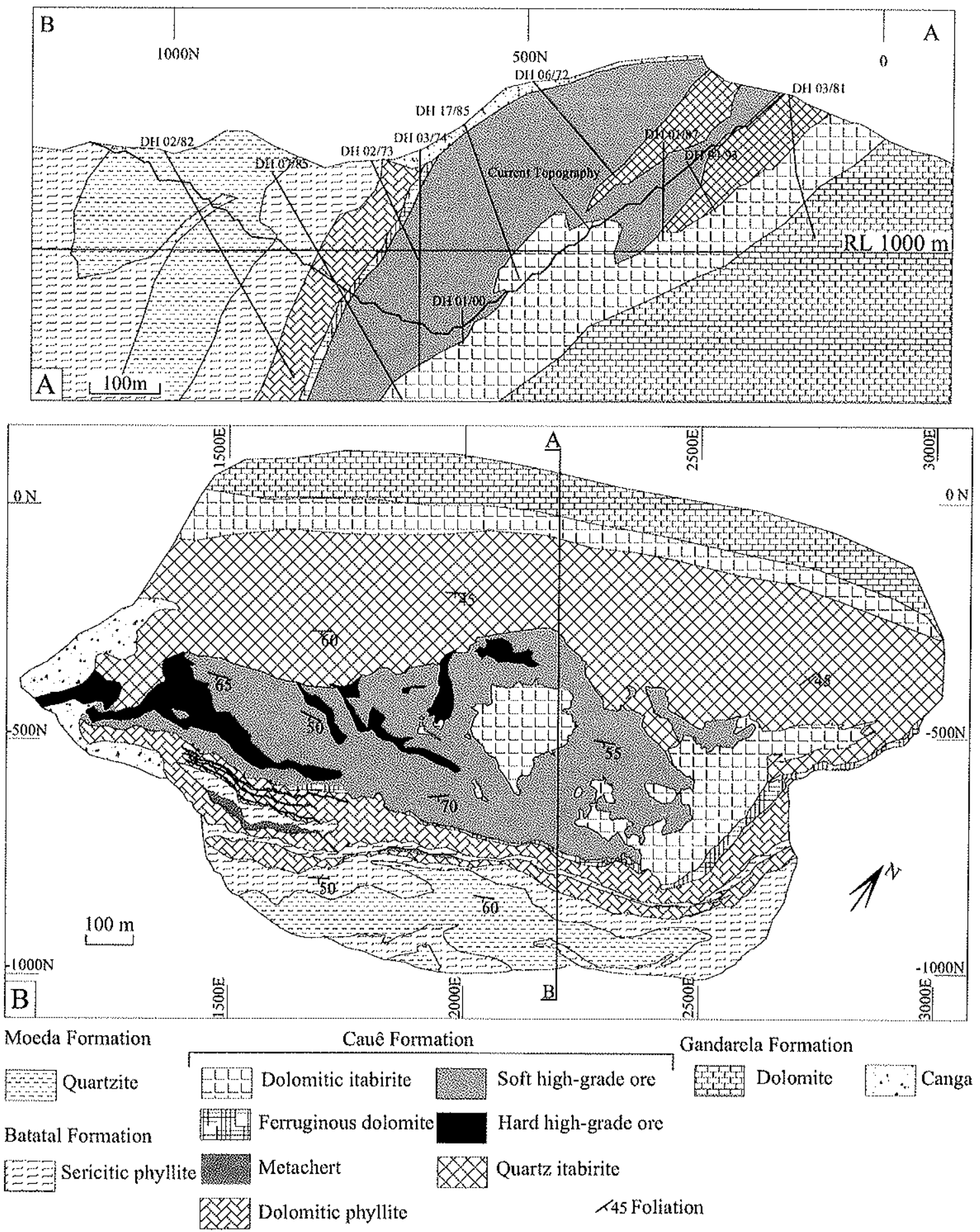

Figure 4 Águas Claras mine. a Cross section 2200E. b Geological sketch map.

A $\sim 60 \mathrm{~m}$ thick layer of dolomitic phyllite occurs at the lowermost part of the Cauê ironformation. This is interpreted by Renger et al. (1994) as the beginning of the chemical sedimentation of the Cauê Formation. Interlayered centimeter to meter thick lens of meta-chert 
occur in the middle of the dolomitic phyllite sequence. Towards the top, these lens change into $\sim 50 \mathrm{~cm}$ layers of quartz itabirite within the dolomitic phyllite.

The contact between the dolomitic phyllite and the overlying dolomite is gradational over a few meters. In the contact region, centimeter thick lenss of dolomitic phyllite are interlayered with red dolomite. Irregular fragments and pisoids of iron formation cemented by dolomite (Fig. 5a) are observed within a dolomite lens of $\sim 50 \mathrm{~cm}$ (Fig. 5a) at this zone. Those fragments and pisoids are largely made up of iron oxides, with subordinate quartz. A $\sim 8 \mathrm{~m}$ thick dolomite layer overlies this contact region forming the base of the dolomitic itabirite sequence.

The beginning of the dolomitic itabirite sequence is marked by the appearance of centimeter bands of iron oxides. These first iron-oxide bands are thinner than the predominant carbonate bands. A $\sim 400 \mathrm{~m}$ thick unweathered dolomitic itabirite layer outcrops at the east wall of the pit. This layer was cut approximately perpendicular to the strike, resulting in an excellent exposure of this otherwise easily altered rock. The absence of an easily recognizable marker layer makes it extremely difficult to define the stratigraphy of the itabirite sequence. The contact between the dolomitic itabirite and the high-grade soft ore is sharp. Unweathered pinnacles of dolomitic itabirite can be found at several levels throughout the mine (Fig. $5 \mathrm{~d}$ ).

At the Águas Claras mine, dolomitic itabirite is much more common than quartz itabirite. The latter is only found in the north wall of the mine, interlayered with the dolomitic rock. The contact between these rocks is gradational. It is characterized by the gradual appearance of quartz within the dolomite bands and by the appearance of quartz bands. A banded itabirite formed by alternate bands of quartz, dolomite and iron oxide can be locally observed at the contact region (Fig. 5e). Beyond the limits of the mine, to the north, the gradational contact between the Cauê and the Gandarela Formation can also be observed.

\section{The dolomitic itabirite: mesoscopic features, petrography and chemistry}

Banding is the most striking structure of the dolomitic itabirite. It occurs as mesobanding and microbanding of Trendall (1973). The characteristic centimeter-scale mesobanding of carbonate/oxide layers produces the reddish/dark rock banding (Fig. 5b). Mesobands range in thickness from $0.1 \mathrm{~cm}$ to $50 \mathrm{~cm}$, with an average thickness of approximately $1 \mathrm{~cm}$. At the lowermost part of the dolomitic layer, in the contact with the phyllite, the carbonate mesobands are thicker $(10-50 \mathrm{~cm})$ than the oxide mesobands $(0.5-3 \mathrm{~cm})$. The thickness of the carbonate mesobands decreases upwards, so that in the mid section of the sequence both mesobands display approximately the same thickness varying from less than $1 \mathrm{~mm}$ to $0.6 \mathrm{~cm}$. At the top of 
the sequence, the thickness of the carbonate mesobands increases again in relation to the oxide mesobands, reaching $15-50 \mathrm{~cm}$.
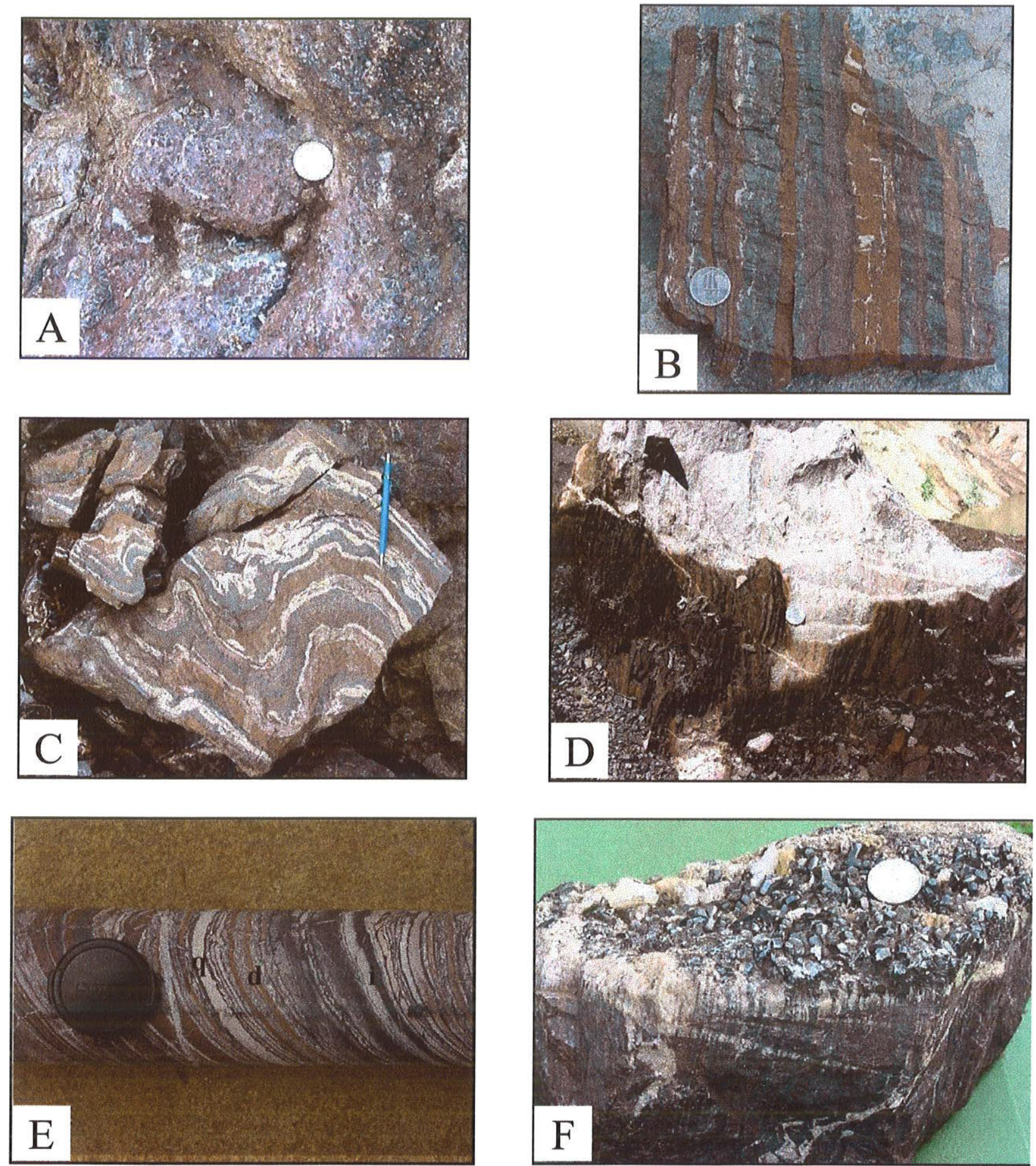

Fig. 5 Águas Claras mine. a Pisoids within the dolomitic layer of the Cauê Formation. b Hand specimen of dolomitic itabirite. Mesobanding is preserved as dolomite-rich and iron oxide-rich layers. $\mathbf{c}$ Hand specimen of folded dolomitic itabirite. Secondary dolomite lens are parallel to the mesobanding. d. Detail of the contact between soft high-grade ore and dolomitc itabirite e. Idiomorphic crystals of hematite and dolomite filling cavities in the dolomitic itabirite, forming geodes. f. Drill core sample of banded itabirite showing alternated bands of quartz (q), dolomite (d) and iron oxides (i) 

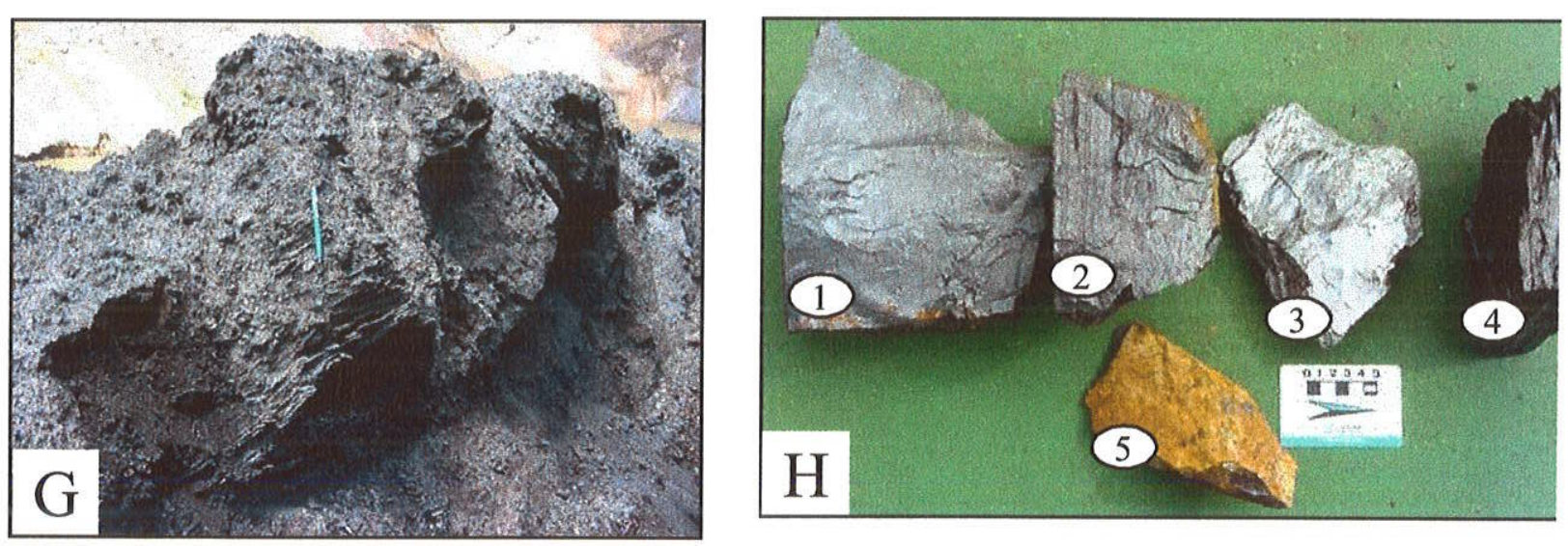

Fig. 5 Águas Claras mine. g. Banded soft high-grade ore h. Hand specimens of hard high grade ores: 1massive, 2-banded, 3-schistose, 4-banded porous and 5-coated by goethite.

Dolomite lens and veins of variable thickness - from a few millimeters to $\sim 20 \mathrm{~cm}$ - are irregularly distributed in the dolomitic itabirite, crosscutting or parallel to the bedding. Some of these dolomite lens and veins have been deformed together with the dolomitic itabirite (Fig. 5c). Especially at the base of the sequence, but also in some narrow centimeter thick zones towards the top, the dolomitic itabirite is brecciated, with the bands of carbonate and iron oxides cemented by dolomite.

The red carbonate mesobands of dolomitic itabirite consist of very fine grained spary dolomite and hematite with grain size varying from 5 - $30 \mu \mathrm{m}$ (at an average of $12 \mu \mathrm{m}$, Fig. 6ab). The volume of hematite within the carbonate mesobands is highly variable (5\% to $50 \%$ from band to band). Locally, the dolomite occurs together with hematite in extensional sites, forming geodes (Fig. 5f). Hematite occurs mainly as martite, forming euhedral crystals in masses of elongated and lobate shapes (Fig. 6b). It also occurs as euhedral to subhedral crystals in the martite aggregates, and as isolated crystals occupying the interstices or included in grains of dolomite. Platy hematite (specularite) occurs in shear planes, surrounding crystals of martite or granular hematite (Fig. 6c).

Randomly oriented red-brown microcrystals of hematite $(<1 \mu \mathrm{m})$ are found in dolomite crystals in the carbonate mesobands (Figs. 6d and 7a), resulting in the characteristic deep red color of these mesobands. Small fluid inclusions $(<8 \mu \mathrm{m})$ are abundant in dolomite. These are currently 
under investigation. Preliminary data reveal two phase fluid inclusions made up of gas and liquid, without salt crystals.

The iron oxide mesobands contain hematite $(>90 \%)$, interstitial carbonates and pores. The average hematite grain size is similar to that of the dolomite mesobands $(\sim 12 \mu \mathrm{m})$ varying from $5-20 \mu \mathrm{m}$. Hematite occurs mainly in the form of martite, and locally as specularite. Relicts of kenomagnetite are observed in the nuclei of some martite crystals, especially in the coarser mesobands of iron oxides. Martite and granular hematite crystals can be found fused together forming a dense network.

Accessory minerals are also present in the mesobands. Talc occurs intergrown with dolomite and in thin veins with chlorite. Apatite can be found in layers $(<1 \mathrm{~mm})$ as isolated euhedral crystals $(4-10 \mu \mathrm{m})$ and intergrown with or included in hematite and dolomite crystals (Fig. 6e). Chlorite occurs along veins and shear planes. An iron and nickel oxide (possibly trevorite) was identified in one sample forming fine crystals intergrown with hematite in the iron oxide band (Fig. 6f). Isolated crystals of titanite were also identified in one sample of dolomitic itabirite.

In order to assess the bulk composition of the dolomitic itabirite, 33 samples were taken from the bottom to the top of the stratigraphic sequence and analyzed for major elements in the MBR laboratory. Because of the extreme bimodal composition of the dolomitic itabirite, each sample $(\sim 100 \mathrm{~kg})$ consisted of several band couplets of alternating iron- and carbonate-rich layers. The results are shown in Table 3 . These reveal that the bulk composition is dominated by $\mathrm{Fe}_{2} \mathrm{O}_{3}, \mathrm{CaO}$ and $\mathrm{MgO}$ which, together with LOI, make up more than $97 \%$ of the rock. 

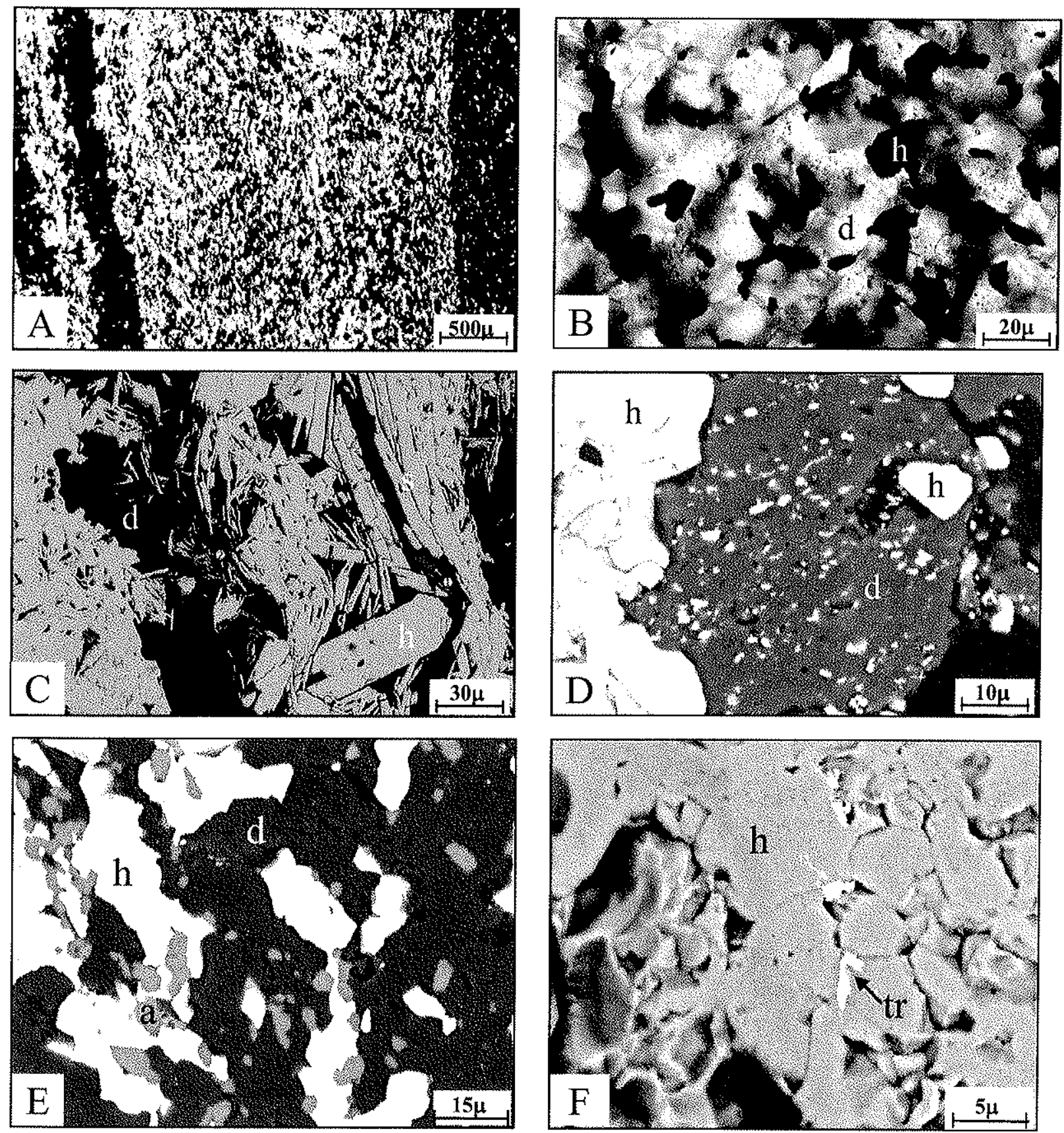

Fig. 6 Photomicrographs of the dolomitic itabirite of the Águas Claras mine. a Microbanding of dolomite-rich and iron oxide-rich laminae - transmitted light. $\mathbf{b}$ Detail of the dolomite-rich micro-band. Euhedral crystals of martite/granular hematite (h) between the dolomite crystals (d) - transmitted light. c Specularite crystals (s) grown along a shear plane surrounding a porfroblast of idiomorphic tabular hematite (h), SEM-image. d Inclusions of hematite microcrystals within a dolomite grain, SEM backscattered image e Dolomite rich micro-band. Dolomite (d) crystals are intergrown with apatite (a) and martite/granular hematite (h), SEM-image. f Fine crystals of trevorite (tr) intergrown with the martite/hematite (h), SEM-image. 
Table 3 Averages and ranges of major components of dolomitic itabirite (bulk analyses)

\begin{tabular}{lcccc}
\hline Variable & Avg & Std & Max & Min \\
\hline $\mathrm{Fe}_{\mathrm{T}}$ & 31.92 & 5.06 & 42.50 & 22.00 \\
$\mathrm{Fe}_{2} \mathrm{O}_{3}$ & 45.65 & 7.24 & 60.78 & 31.46 \\
$\mathrm{P}$ & 0.044 & 0.017 & 0.089 & 0.004 \\
$\mathrm{Al}_{2} \mathrm{O}_{3}$ & 0.24 & 0.11 & 0.67 & 0.10 \\
$\mathrm{SiO}_{2}$ & 0.89 & 0.32 & 1.84 & 0.46 \\
$\mathrm{Mn}$ & 0.24 & 0.05 & 0.36 & 0.04 \\
$\mathrm{CaO}$ & 16.22 & 2.42 & 20.67 & 11.41 \\
$\mathrm{MgO}$ & 11.47 & 1.78 & 14.87 & 8.47 \\
$\mathrm{TiO}_{2}$ & 0.011 & 0.002 & 0.017 & 0.008 \\
$\mathrm{~S}$ & 0.003 & 0.001 & 0.004 & 0.002 \\
$\mathrm{LOI}$ & 25.29 & 3.18 & 31.56 & 18.53 \\
\hline
\end{tabular}

Data from MBR, number of samples $=33, \mathrm{LOI}=$ loss on ignition
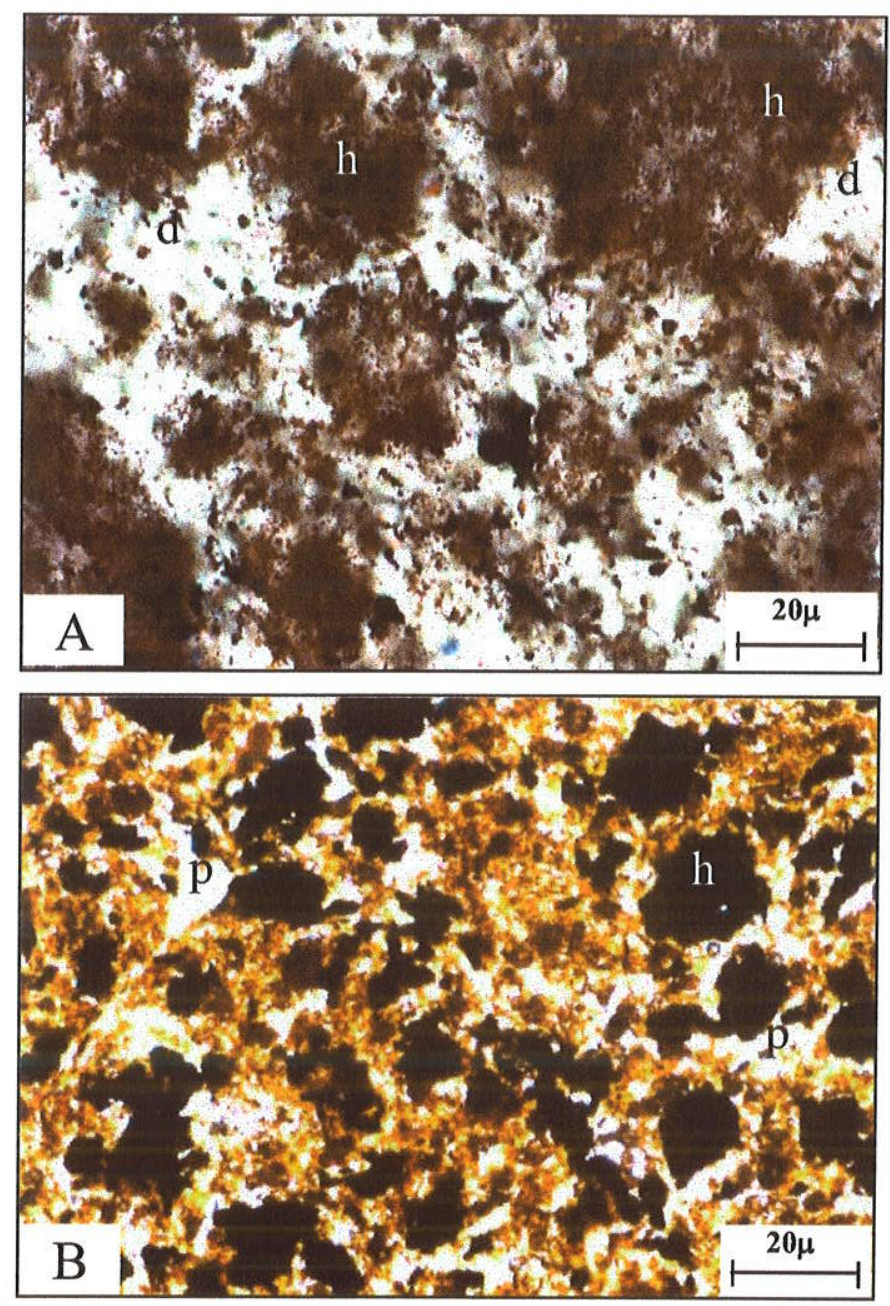

Figure 7 Photomicrographs of the dolomitic itabirite of the Águas Claras mine - transmitted light. a Detail of a dolomite-rich micro-band. Note the multitude of reddish hematite microcrystals (h) included within the dolomite grains (d) giving the crystals a dusty aspect. b Detail of a deeply weathered dolomite micro-band showing martite/granular hematite crystals (h) between pores (p) and relicts of the dolomite dissolution (brownish). 


\section{The high-grade Fe ore at the Águas Claras Mine}

Unlike other mines in the Quadrilátero Ferrífero, the Águas Claras mine contains only high-grade ores. These consist of two distinct, main types: soft and hard ore. The soft ore represents $85 \%$ of the overall resource, whereas the hard ore represents only $15 \%$. The orebody was a concordant, $2,500 \mathrm{~m}$ long, roughly tabular-shaped lens with a maximum thickness of 300 $\mathrm{m}$, formed essentially by soft ores (Fig. $4 \mathrm{~b}$ ). The depth of the ore is variable, extending to over $400 \mathrm{~m}$ below the surface at the center of the pit bottom and then grading into the parental fresh dolomitic itabirite deeper down (Fig, 4a). The hard ores generally occur within the soft ores as minor lens. These are concordant to the bedding, although locally they may be discordant and associated with shear zones. The main hard ore occurrences are concentrated to the west of the mine, close to the top of the sequence. Here they are in contact with quartz itabirite forming lens of up to $200 \mathrm{~m}$ length along the strike, with thicknesses varying from $5-60 \mathrm{~m}$ (Fig. 4b). Small concordant lens of hard ore measuring from a few centimeters to nearly a meter thick occur within the dolomitic itabirite at the east side of the pit. These lens consist of massive hard ore formed by almost pure hematite.

The soft ore is characteristically porous and very friable. It disaggregates during the mining operations and generates a low lump yield. It usually preserves the structure of the itabirite, particularly the meso and microbanding (Fig. 5g), and sometimes exhibits kink-bands not present in the protore.

The hard ore is dense, compact and generates a high lump yield. Three main subtypes of hard ore are found at the Águas Claras mine: massive, banded and schistose (Fig. 5h). Massive hard ore has a very low porosity, does not exhibit any kind of structure and commonly shows signs of conchoidal fracture. Banded hard ore varies in porosity and is characterized by conspicuous banding. This is the typical hard ore found as small lens within the soft ore. Schistose hard ore generally has low porosity, does not preserve the original structures and exhibits a conspicuous cataclastic foliation. This type of hard ore is associated with shear zones which are mainly found on the north wall of the pit. The larger bodies of hard ore are usually intensely fractured, with thin films of goethite and kaolinite along the fracture planes (Fig. 5h5). The iron oxides which form the soft and hard ores are the same as those observed in the dolomitic itabirite: hematite as martite, granular hematite and specularite with subordinated remnant kenomagnetite cores preserved in some martite grains. These minerals typically preserve the original size and shapes present in the protore. Gangue minerals are rarely found in the masses of soft ore, and consist of dolomite, chlorite, talc and apatite. They occur mainly at 
the contact zone with the protore. In this zone, the soft ore contains remnants of dolomite and a brownish residue generated from the dissolution of dolomite (Fig. 7b). Microcrystals of hematite are present, as well as apatite, chlorite and talc. The latter is observed as isolated platelets or as millimeter-sized aggregates. A few meters away from the contact zone, most of the gangue minerals disappear. In the hard ores interbedded with fresh dolomitic itabirite, the dolomite occurs as an accessory mineral. Manganese-oxides (mainly litioforite) occur in narrow zones at the contact with the protore. Goethite occurs filling pores, voids and fractures in soft and hard ores close to the land surface.

The soft ore consists of alternate microbands of lower and higher porosity, containing martite and hematite (Fig. 8a), with intergranular porosity visually estimated at $35-45$ percent (Fig. 8b). Thin bands of specularite occur parallel to or cross-cutting the banding. The hard ores have a similar mineralogical composition regardless of their physical characteristics. They consist of a dense network of martite and hematite with a varying proportion of pores (Fig. 8c-d). Kenomagnetite is regularly observed in the nuclei of martite crystals especially in the larger lens of hard ores.
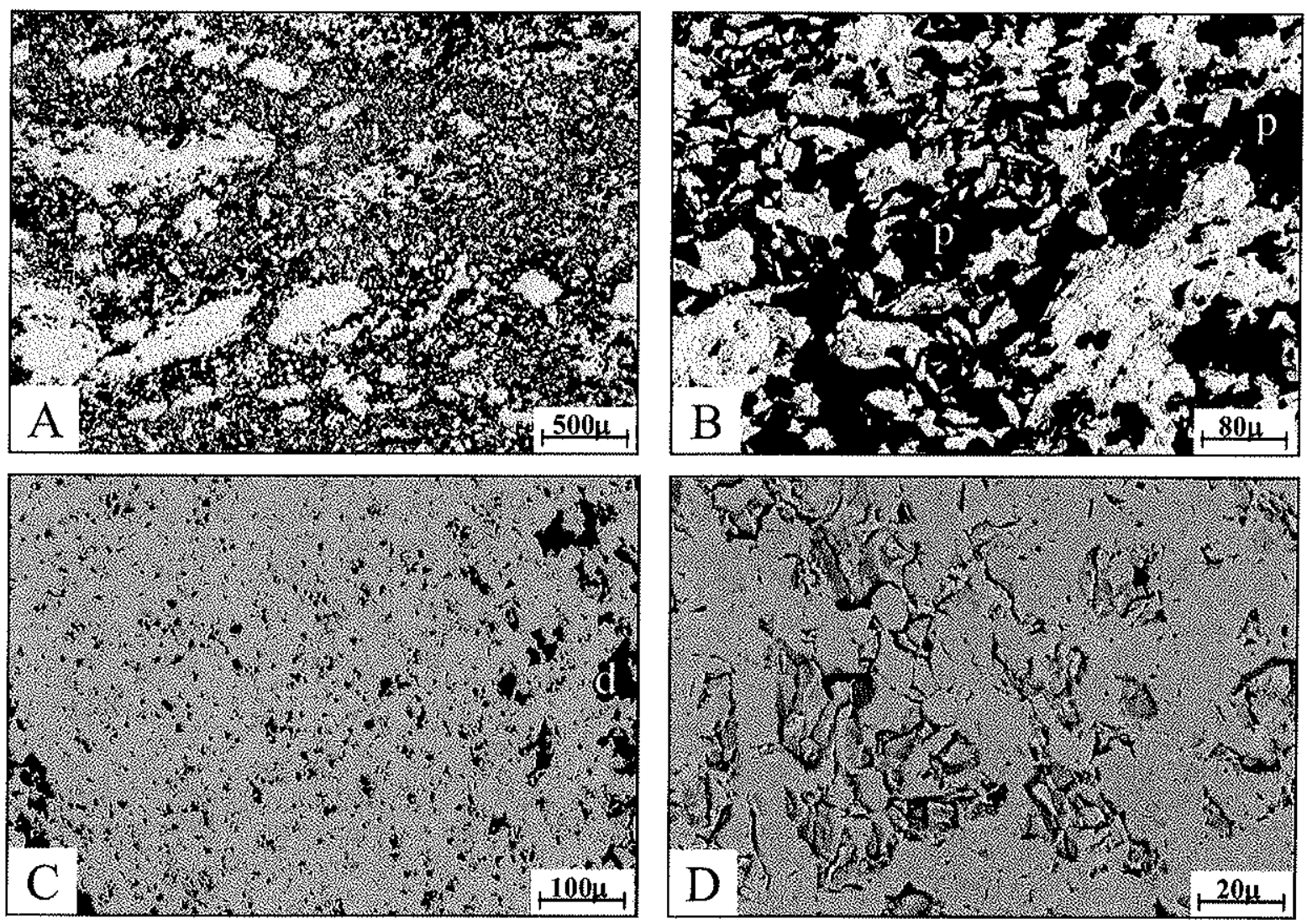

Figure 8 Photomicrographs of the high-grade ores at the Águas Claras mine, SEM backscattered images. a Soft high-grade ore. b Detail of the soft high-grade ore. Note the high volume of pores (p). $\mathbf{c}$ Unweathered hard high-grade ore with dolomite crystals (d) in the interstices within the dense network of martite/granular hematite $(h)$, $d$ Detail of the hard high-grade ore. 
The massive hard ore consists of weakly oriented aggregates of martite (with relicts of kenomagnetite) and hematite with a granoblastic texture and an average grain size ranging from 5-15 $\mu \mathrm{m}$. A visual estimation suggests that intergranular porosity is around 5-10 percent. Banded hard ores exhibit a primary banding formed by the alternation of microbands where hematite is predominant (low porosity) with microbands where martite is predominant (high porosity). The global intergranular porosity of the banded hard ores is extremely variable (from $10 \%$ to $30 \%$ ). Samples collected from thin lens of the banded ore present within the soft ores are more porous than those collected from larger lens on the west side of the mine. Schistose hard ores are essentially formed of specularite, which is strongly oriented, and exhibits a low intergranular porosity.

Table 4 shows statistics regarding the major element composition of about 5,300 samples of runof-mine iron ore collected by MBR since 1971. This geochemistry database was used by the company to estimate the quality of the products. It illustrates the size distribution of the particles, and the chemical composition of the $288 \mathrm{Mt}$ of iron ore which has been mined. The samples were screened into 3 size fractions $(50.00-6.30 \mathrm{~mm}, 6.30-0.15 \mathrm{~mm}$ and $<0.15 \mathrm{~mm})$, and analyzed together with the bulk samples. No bulk sample contained less than $64 \% \mathrm{Fe}_{\mathrm{T}}$, which was the arbitrary limit set between the high-grade iron ore and the itabirite. Lower grades of $\mathrm{Fe}$ occur in the $<0.15 \mathrm{~mm}$ size fraction, where impurities are concentrated. $\mathrm{SiO}_{2}, \mathrm{Al}_{2} \mathrm{O}_{3}, \mathrm{Mn}$ and $\mathrm{P}$ contents are higher than those observed in the coarser sized fractions. The chemistry of the hard and soft ores is very similar. The hard ore has higher $\mathrm{P}$ and $\mathrm{Al}_{2} \mathrm{O}_{3}$ contents while the soft ore is higher in $\mathrm{Mn}, \mathrm{CaO}, \mathrm{MgO}$ and $\mathrm{TiO}_{2}$.

A representative drill core (DH-17/85), which cuts all the soft ore from the bottom of the Caue Formation going through the fresh dolomitic itabirite, is shown in Figure 9. The coarse fraction is scarce in the soft ore especially when close to the contact with the canga and the fresh dolomitic itabirite. The contaminants are concentrated in the fines $(<0.15 \mathrm{~mm})$, due to their small size crystals. Their $\mathrm{SiO}_{2}$ and $\mathrm{Al}_{2} \mathrm{O}_{3}$ contents are due to talc and chlorite, $\mathrm{P}$ to apatite and Mn to Mn oxides. 
Table 4 Chemical composition (wt\%) of the in situ high-grade iron ores - Águas Claras mine

\begin{tabular}{|c|c|c|c|c|c|c|c|c|c|c|c|}
\hline & \multirow[b]{2}{*}{ Variable } & \multicolumn{5}{|c|}{ Hard high-grade ore } & \multicolumn{5}{|c|}{ Soft high-grade ore } \\
\hline & & Avg & Std & $\operatorname{Max}$ & Min & $\eta$ & Avg & Std & Max & Min & $\eta$ \\
\hline \multirow{8}{*}{ 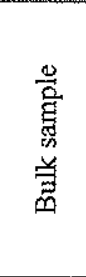 } & $\mathrm{Fe}_{\mathrm{r}}$ & 68.35 & 0.81 & 69.64 & 64.85 & 343 & 68.23 & 0.78 & 69.84 & 64.17 & 4,009 \\
\hline & $\mathrm{P}$ & 0.052 & 0.042 & 0.302 & 0.012 & 343 & 0.038 & 0.040 & 0.556 & 0.009 & 4,009 \\
\hline & $\mathrm{Al}_{2} \mathrm{O}_{3}$ & 0.63 & 0.43 & 3.08 & 0.11 & 343 & 0.54 & 0.35 & 3.09 & 0.07 & 4,009 \\
\hline & $\mathrm{SiO}_{2}$ & 0.53 & 0.30 & 2.17 & 0.11 & 343 & 0.63 & 0.38 & 3.15 & 0.03 & 4,009 \\
\hline & $\mathrm{Mn}$ & 0.178 & 0.226 & 1.380 & 0.010 & 343 & 0.365 & 0.163 & 1.278 & 0.004 & 2,766 \\
\hline & $\mathrm{CaO}$ & 0.05 & 0.05 & 0.26 & 0.01 & 80 & 0.13 & 0.18 & 0.91 & 0.01 & 224 \\
\hline & $\mathrm{MgO}$ & 0.03 & 0.04 & 0.31 & 0.01 & 80 & 0.12 & 0.14 & 1.01 & 0.01 & 224 \\
\hline & $\mathrm{TiO}_{2}$ & 0.06 & 0.07 & 0.40 & 0.01 & 80 & 0.04 & 0.02 & 0.16 & 0.01 & 224 \\
\hline \multirow{9}{*}{ 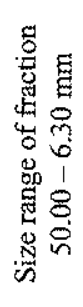 } & $\%$ Weight & 66.84 & 12.73 & 95.94 & 50 & 343 & 12.33 & 6.00 & 24.97 & 0.00 & 4,009 \\
\hline & $F e_{\mathrm{T}}$ & 68.67 & 0.86 & 69.77 & 64.70 & 343 & 68.56 & $1.3 !$ & 69.90 & 53.90 & 4,009 \\
\hline & $\mathrm{p}$ & 0.046 & 0.041 & 0.291 & 0.001 & 343 & 0.030 & 0.053 & 0.847 & 0.001 & 4,009 \\
\hline & $\mathrm{Al}_{2} \mathrm{O}_{3}$ & 0.53 & 0.49 & 3.99 & 0.01 & 343 & 0.53 & 0.64 & 7.98 & 0.01 & 4,009 \\
\hline & $\mathrm{SiO}_{2}$ & 0.42 & 0.27 & 2.72 & 0.01 & 343 & 0.54 & 0.38 & 7.73 & 0.01 & 4,009 \\
\hline & $\mathrm{Mn}$ & 0.102 & 0.172 & 1.273 & 0.001 & 343 & 0.114 & 0.122 & 2.120 & 0.001 & 2,766 \\
\hline & $\mathrm{CaO}$ & 0.06 & 0.05 & 0.28 & 0.01 & 80 & 0.22 & 0.50 & 4.78 & 0.01 & 224 \\
\hline & $\mathrm{MgO}$ & 0.03 & 0.03 & 0.16 & 0.01 & 80 & 0.18 & 0.43 & 4.29 & 0.01 & 224 \\
\hline & $\mathrm{TiO}_{2}$ & 0.04 & 0.04 & 0.25 & 0.01 & 80 & 0.03 & 0.02 & 0.15 & 0.01 & 224 \\
\hline \multirow{9}{*}{ 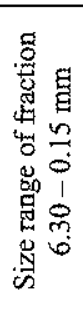 } & $\%$ Weight & 19.46 & 7.53 & 37.81 & 2.84 & 343 & 42.28 & 6.67 & 84.37 & 4.00 & 4,009 \\
\hline & $\mathrm{Fe}_{\mathrm{T}}$ & 68.21 & 1.17 & 69.60 & 59.67 & 343 & 68.91 & 0.67 & 69.98 & 61.60 & 4,009 \\
\hline & $\mathrm{P}$ & 0.058 & 0.061 & 0.315 & 0.008 & 343 & 0.024 & 0.033 & 0.480 & 0.001 & 4,009 \\
\hline & $\mathrm{Al}_{2} \mathrm{O}_{3}$ & 0.68 & 0.52 & 3.60 & 0.04 & 343 & 0.36 & 0.30 & 3.98 & 0.01 & 4,009 \\
\hline & $\mathrm{SiO}_{2}$ & 0.55 & 0.37 & 3.41 & 0.02 & 343 & 0.49 & 0.34 & 4.90 & 0.02 & 4,009 \\
\hline & $\mathrm{Mn}$ & 0.195 & 0.354 & 2.660 & 0.001 & 343 & 0.140 & 0.084 & 1.120 & 0.001 & 2,766 \\
\hline & $\mathrm{CaO}$ & 0.05 & 0.04 & 0.27 & 0.01 & 80 & 0.08 & 0.12 & 0.98 & 0.01 & 224 \\
\hline & $\mathrm{MgO}$ & 0.03 & 0.02 & 0.13 & 0.01 & 80 & 0.07 & 0.09 & 0.86 & 0.01 & 224 \\
\hline & $\mathrm{TiO}_{2}$ & 0.06 & 0.07 & 0.33 & 0.01 & 80 & 0.03 & 0,02 & 0.15 & 0.01 & 224 \\
\hline \multirow{9}{*}{ 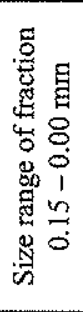 } & $\%$ Weight & 13.70 & 8.08 & 38.30 & 0.10 & 343 & 45.39 & 8.71 & 79.90 & 2.27 & 4,009 \\
\hline & $\mathrm{Fe}_{\mathrm{T}}$ & 66.63 & 1.70 & 69.70 & 51.63 & 343 & 67.48 & 1.24 & 69.90 & 59,20 & 4,009 \\
\hline & $\mathrm{P}$ & 0.084 & 0.066 & 0.399 & 0.010 & 343 & 0.053 & 0.052 & 0.800 & 0.001 & 4,009 \\
\hline & $\mathrm{Al}_{2} \mathrm{O}_{3}$ & 1.22 & 0.65 & 4.32 & 0.18 & 343 & 0.71 & 0.47 & 4.55 & 0.01 & 4,009 \\
\hline & $\mathrm{SiO}_{2}$ & 1.18 & 0.84 & 5.57 & 0.05 & 343 & 0.91 & 0.50 & 5.04 & 0.01 & 4,009 \\
\hline & Mn & 0.527 & 0.503 & 2.55 & 0.011 & 343 & 0.648 & 0.300 & 1.871 & 0.002 & 3,698 \\
\hline & $\mathrm{CaO}$ & 0.04 & 0.03 & 0.19 & 0.01 & 80 & 0.15 & 0.26 & 1.56 & 0.01 & 224 \\
\hline & MgO & 0.07 & 0.10 & 0.77 & 0.01 & 80 & 0.16 & 0.20 & 1.55 & 0.01 & 224 \\
\hline & $\mathrm{TiO}_{2}$ & 0.16 & 0.15 & 0.67 & 0.01 & 80 & 0.16 & 0.20 & 1.55 & 0.01 & 224 \\
\hline
\end{tabular}

Data from MBR, $\eta=$ number of samples 


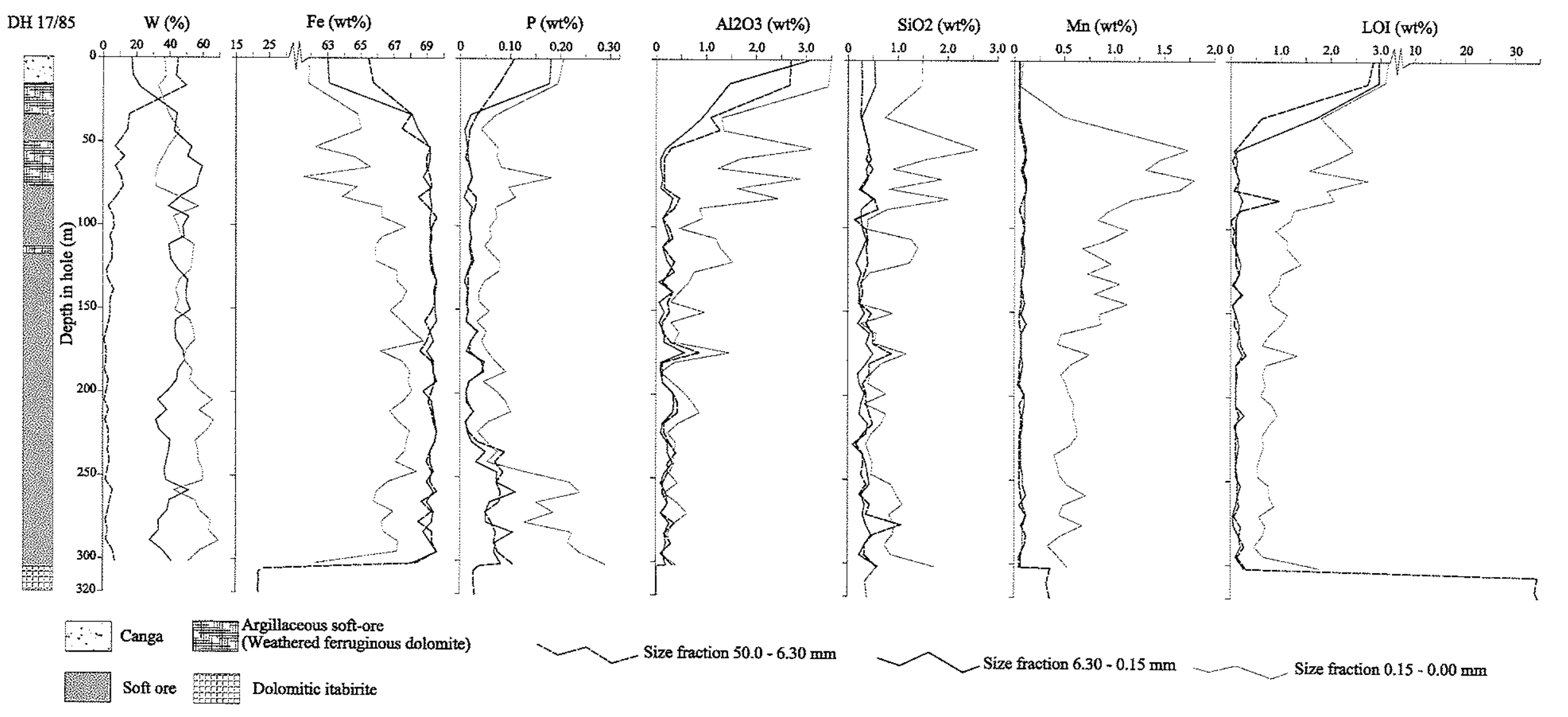

Figure 9 Particle size distribution, expressed in weight percent (W\%) with correspondent chemical composition at three selected size fraction of the samples of the drill hole DH $17 / 85$ of the Águas Claras mine. Contents of the fresh dolomitic itabirite in the size fraction $50.0-6.30 \mathrm{~mm}$, which corresponds to more than $90 \%$ of the weight of the samples. 


\section{THE PICO OREBODY}

\section{General Description}

Production of iron ore at Pico has been carried out from 1968. During this period, $120 \mathrm{Mt}$ of iron ore were mined. The Pico mine, together with the Galinheiro and Sapecado mines, form the Pico Complex and are currently responsible for 50\% of MBR's production. About $193 \mathrm{Mt}$ of high-grade ores remains at the Pico mine. The ore is mined through open-pit methods and is treated at local ore dressing plants which have an annual capacity of $12 \mathrm{Mt}$. Four products are found in the major plant: the lump ore $(31.5-12.0 \mathrm{~mm})$, the "hematitinha" (12.0-6.30 mm), the sinter feed $(<6.30-0.15 \mathrm{~mm})$ and the pellet feed $(<0.15-38 \mu \mathrm{m})$. Historically these have represented $16 \%, 7 \%, 32 \%$ and $26 \%$ of the production respectively, with $19 \%$ tailings. Table 2 shows the percentage and chemical composition of each of these products in recent years.

\section{Structure and stratigraphy of the mine area}

The Pico iron mine is located on the eastern inverted limb of the Moeda Syncline, which is one of the major structures of the Quadrilátero Ferrifero (Fig. 1). In contrast with the Serra do Curral, where the Águas Claras mine is located, the Moeda Syncline is a relatively less strained domain. Bedding and other sedimentary structures are well preserved. Ductile shear zones occur locally truncating or parallel to the bedding of the Minas Supergroup strata (Chemale et al. 1994).

The major geological units present at the mine are itabirites and iron ores of the Cauê Formation, clastic metasedimentary rocks of the Moeda and Batatal Formations and predominantly chemical metasedimentary rocks of the Gandarela Formation (Fig. 10). The rocks of these units are oriented along a general strike $\mathrm{N} 30^{\circ}-35^{\circ} \mathrm{E}$, dipping $45^{\circ}-90^{\circ}$ to SE or NW. The BIFs have been folded and dips vary from $20^{\circ}$ to $85^{\circ}$, either to the SE or to the NW. Nevertheless, the quartzites of the Moeda Formation that crop out continuously along the eastern part of the mine (Fig. 2b) show a very consistent sub-vertical dip and, in general, weakly developed foliation.

The quartzites exhibit abrupt contacts with the phyllites of the Batatal Formation. There are clearly two types of phyllites. The first, in contact with the quartzite, is grey, laminated and rich in sericite. The second, at the top of the sequence, close to the quartz itabirite, is brown, weakly laminated and highly porous. Lens of meta-chert, from several meters to 70 meters long and from 5 to 20 meters wide, occur within this second type of phyllite. The field relations suggest a transition similar to that observed at Águas Claras, from quartzite to sericitic phyllite 
and dolomitic phyllite, but no fresh samples are available to confirm this interpretation. The contact between the Batatal and Cauê Formations is abrupt and defined by a thin layer of hematitic phyllite which varies in thickness from $2-5 \mathrm{~m}$ and occurs between the phyllite and iron formations.
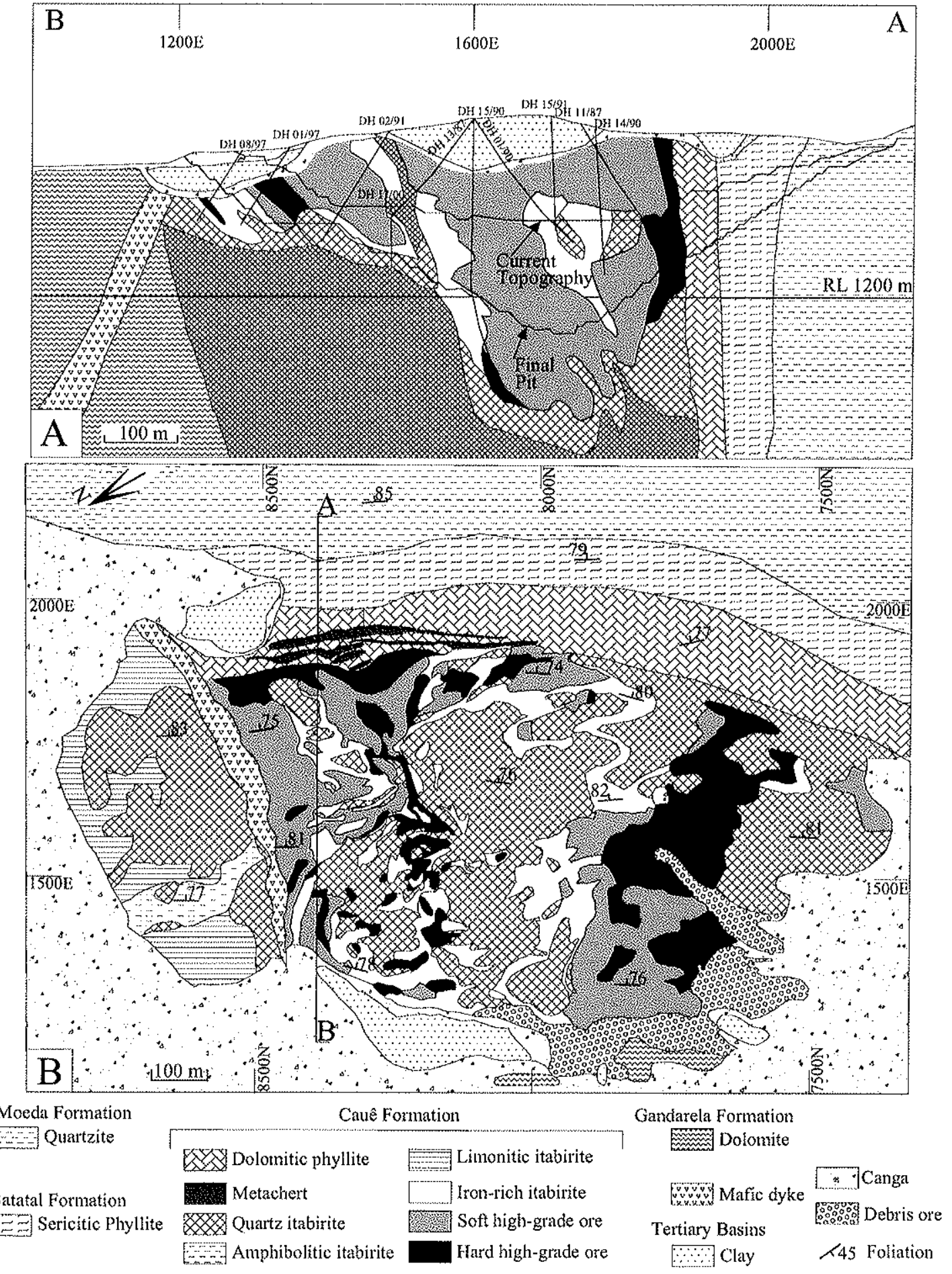

Figure 10 Pico mine. a Cross section $8400 \mathrm{~N}$. b Geological sketch map of the current pit wall. 
The main iron formation at the Pico mine is the quartz itabirite, which is the protore of the soft high- and low-grade ores. Amphibolitic itabirite occurs locally in the northern part of the mine.

The Gandarela Formation outcrops at the west wall of the pit. It consists of dolomitic phyllite and deeply weathered dolomite with a gradual contact with the itabirites. It is marked by manganese-rich layers interlayered within the itabirites. Fresh samples of the dolomites from drill cores consist essentially of sparry dolomite crystals varying from $7-40 \mu \mathrm{m}$ (average of 15 $\mu \mathrm{m})$ with accessory talc and hematite.

A dyke of metamafic rock dated at $861 \mathrm{Ma}$ (U-Pb concordia age in baddeleyite, Teixeira 2002 , personal communication) with an average thickness of $40 \mathrm{~m}$ cuts all lithologies of the Minas Supergroup in the mine area.

Gravels and boulders of itabirite and hard ore cemented by clay, quartz and hematite occur at the base of small basins irregularly distributed along the strike of the itabirite sequence at the Pico Mine. These basins are similar to those described in the region by Wallace (1965) and dated by Lima and Cheboldaeff (1981) as Paleocene to Eocene.

\section{Itabirites at the Pico Mine}

As elsewhere in the Quadrilatero Ferrifero, banding is the most typical mesoscopic structure of itabirites at the Pico mine. The thickness of the mesobands varies from a few milimeters to $2 \mathrm{~cm}(0.7 \mathrm{~cm}$ in average). The dark oxide bands of the quartz itabirite consist of martite and granular hematite with varying amounts of quartz (Figs. 11a, 12a). Euhedral martite crystals are typically porous and form irregularly shaped aggregates. They generally contain relicts of kenomagnetite in the nuclei (Fig. 12b), especially in the coarser dark bands. Subhedral to euhedral hematite crystals surround the crystals and aggregates of martite.

The light bands consist of quartz with variable amounts of interstitial granular hematite and/or martite (Fig. 12c). Locally, the fresh quartz itabirite may show a higher content of iron oxides within the quartz bands. Quartz grain size ranges from 10 to $120 \mu \mathrm{m}$ (50 $\mu \mathrm{m}$ in average) while hematite grain size varies from 6 to $80 \mu \mathrm{m}$ (35 $\mu \mathrm{m}$ in average). Quartz grains are commonly equidimensional and granoblastic-polygonal with equiangular triple points that suggest static recrystallisation. Most grains are slightly strained, showing wavy extinction. Tiny crystals of red hematite $(3-10 \mu \mathrm{m})$ occur commonly as inclusions in the quartz crystals. 

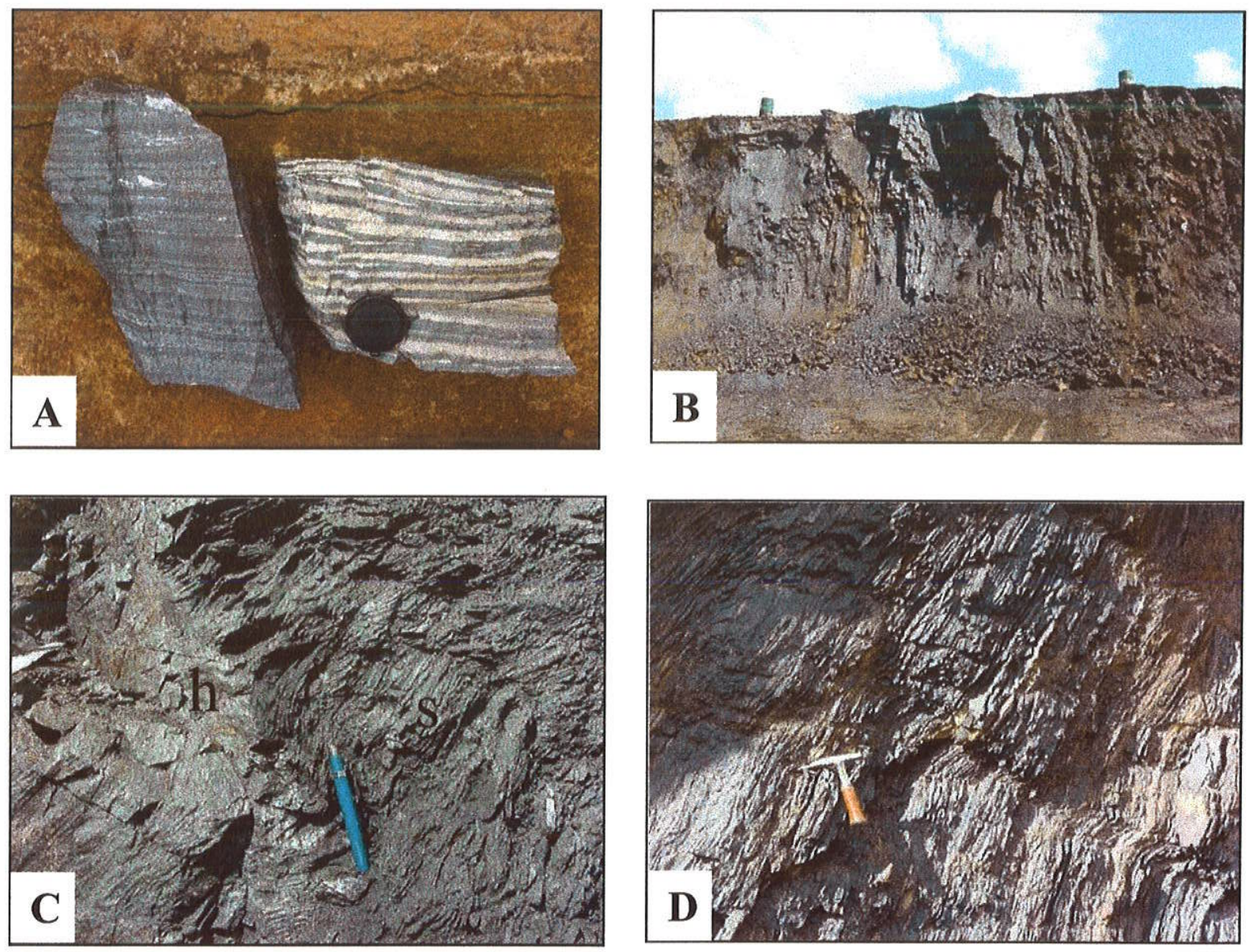

Figure 11 Photographs of the quartz-itabirite and iron ores at the Pico mine. a Hand specimen of quartz itabirite. Note the preservation of mesobanding and the variable content of iron oxides. b Mine exposure of hard high-grade ore (between drums). c Contact between hard (h) and soft (s) high-grade ores. 


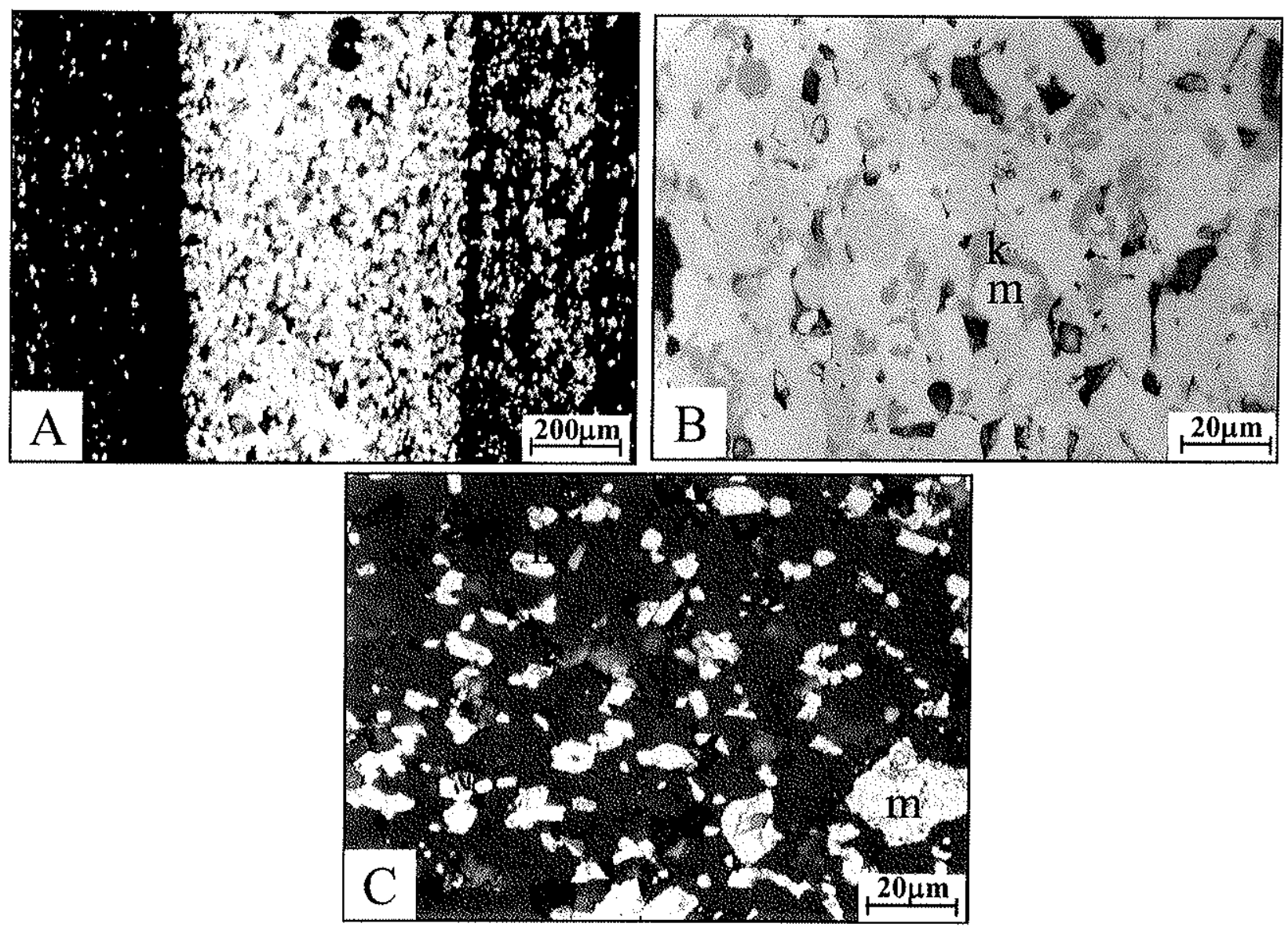

Fig. 12 Photomicrographs of the quartz itabirite of the Pico mine. a Microbanding of quartz-rich (white) and iron oxide-rich (black) laminae - polarized light. $\mathbf{d}$ Mine exposure of the iron-rich itabirite.. b Detail of an iron oxide micro-band. Note the relicts of kenomanetite (k, dark gray) surrounding the martite crystals (m, light gray) - reflected light. $\mathbf{c}$ Detail of a quartz rich-micro-band. Note the abundant granular hematite (h) and martite crystals $(\mathrm{m})$ between quartz grains $(\mathrm{q})$. Reflected light. 
Table 5 Chemical composition (wt\%) of the fresh quartz itabirite (protore) and of the iron-rich itabirite - Pico mine

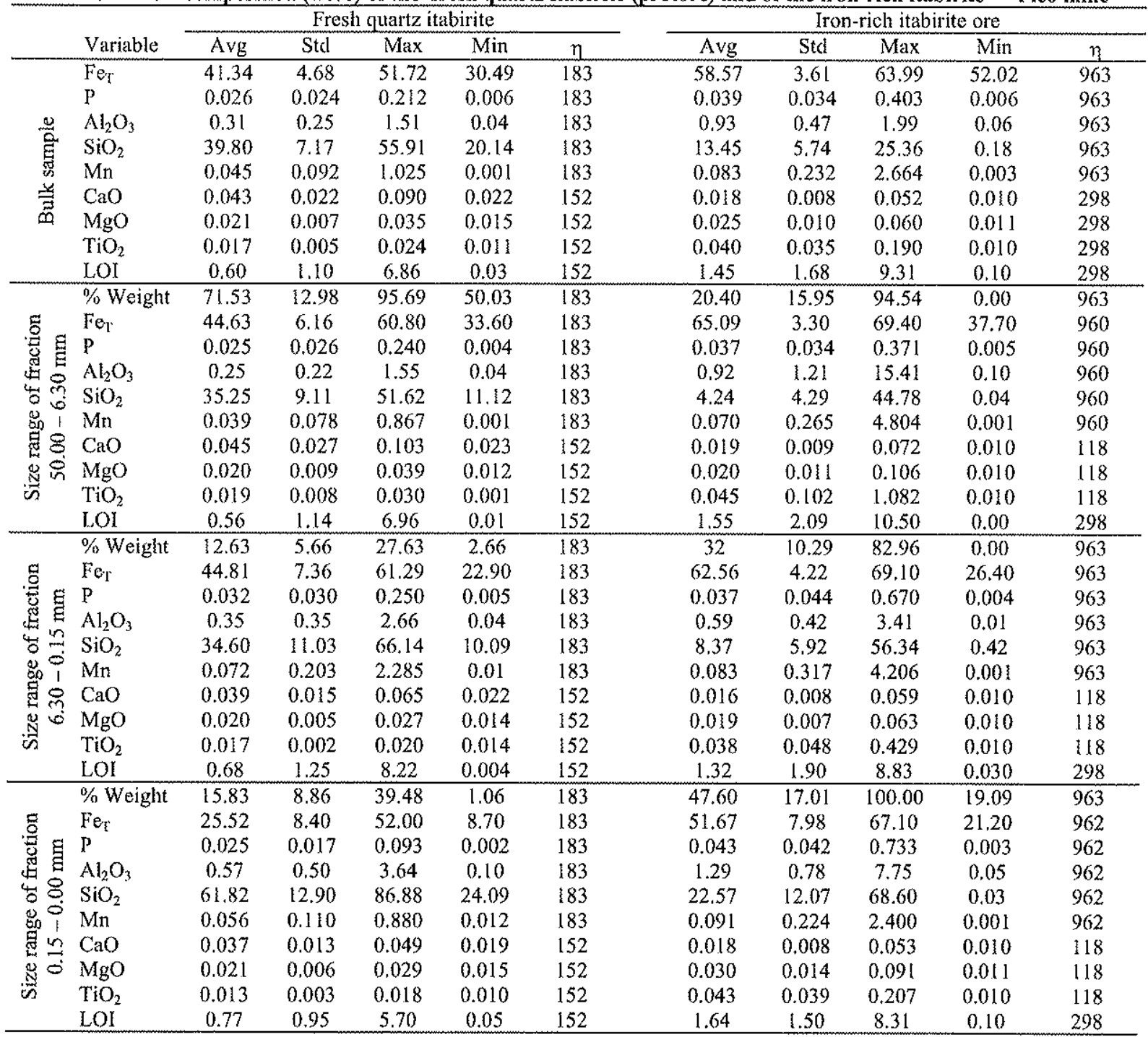

Data from MBR, $\eta=$ number of samples, $\mathrm{LOI}=$ loss on ignition

\section{The Iron Ores}

The Pico orebody, which encompasses high- and low-grade ores, is a continuous $\sim 3,000$ $\mathrm{m}$ long body of lenticular shape. It extends from the south side of the metamafic dyke to the southern limit of the Sapecado mine. There it grades into soft limonitic BIF. This lens exhibits great variation in width due to internal folding and faulting. Its average width is $300 \mathrm{~m}$ and it reaches up to $450 \mathrm{~m}$ at the contact with the metamafic dyke. The orebody extends to over $300 \mathrm{~m}$ depth (Fig. 10a). It is generally concordant with the country rock, but discordant bodies are also present.

The ores typically preserve the original structures of the itabrite, but schistosity is not well developed. Small folds superimposed on the major folds, tight folds, local shear zones and 
normal faults complete the complex structural scenario, which was developed during at least three deformational phases (Rosière 1981).

There are two distinct types of iron ore at the Pico mine: high-grade ores and iron-rich itabirite, both hosted within the quartz itabirite. The iron-rich itabirites are soft itabirites with iron contents between $52 \%$ and $64 \%$, and alumina contents under $2 \%$.

The high-grade ores occur as hard and soft ores. Pico de Itabira is the most striking example of a hard ore lens (Fig. 2b). It is $150 \mathrm{~m}$ long, $80 \mathrm{~m}$ thick, sub-vertical, and surrounded by soft ore and itabirite. Other lenticular hard bodies are up to $350 \mathrm{~m}$ long, with thickness varying from few centimeters to 150 meters. These lens occur interlayered with soft ore or itabirite and show variable lateral and vertical continuity (Fig. 11b). The contact with the itabirite is abrupt and grade over a few centimeters or a few meters into the host rock. In some places quartz-rich bands extend into the ore giving the serrated effect mentioned by Dorr (1965) (Fig. 11c). In some areas, especially close to the contact with the phyllite, hard orebodies are highly fractured. The physical aspect of the hard orebodies is essentially similar to that of Aguas Claras. Some show conspicuous relicts of primary banding, but others are massive. Porosity is highly variable in some bodies, especially those that are smaller and more thinly interlayered with soft ore or weathered itabirite.

Two distinct subtypes of high-grade soft ores are found at the Pico mine. The first one occurs immediately below the surface of the soil/canga as a $40 \mathrm{~m}$ thick blanket grading downward into iron rich itabirite. The second type of high-grade soft ore is concentrated close to the south side of the mafic dyke and reaches to a depth of 300 meters or more from the land surface. It forms a continuous lenticular body roughly parallel to the strike of the dyke. The banding of the protore is typically preserved in both types of soft high-grade ores thus resulting in banded ores of high porosity. Locally, the soft ore close to the mafic dyke does not exhibit any structure and forms a massive soft ore (blue dust ore).

Iron-rich itabirite is widespread throughout the mine, typically grading to soft ore or quartz itabirite. It consists of friable itabirite where quartz was, in great part, leached and iron oxides were concentrated (Fig. 11d).

Gangue minerals in the high-grade ores - quartz and very small amounts of sericite and chlorite - are scarce. The transition to iron-rich itabirite is marked by an increased amount of quartz. Hard ores consist of dense agglomerates of hematite and martite crystals (with relicts of kenomagnetite in the nuclei). These have an average grain size of $25 \mu \mathrm{m}$. Quartz is absent in hard ores situated below the weathering surface, but occurs as an accessory mineral in hard ores 
interlayered with fresh quartz itabirite. The hard ores generally exhibit a porous granoblastic fabric where the volume of pores is highly variable. The banded hard ore is generally more porous than the massive hard ore. It is formed by the alteration of massive bands made up of hematite with some martite and with porous bands composed of porous martite grains and hematite.

Soft ores are generally well laminated and highly porous. A visual estimation suggests intergranular porosity in the soft ore of $30-45$ percent. The soft ores consist of microbands formed by aggregates of martite and hematite which alternate with highly porous microbands where martite and hematite are dispersed between the pores. Canga is present close to the land surface.

Statistics with regard to approximately 2,300 samples of hard and soft high-grade ores obtained during production at the Pico mine until the present day are shown in Table 6. This geochemistry database is used by MBR to estimate the quality of the products of this mine. Hard ores have an average of $67.3 \%$ of $\mathrm{Fe}$ (ranging from $64.0-69.9 \%$ ), $1.0 \% \mathrm{Al}_{2} \mathrm{O}_{3}$ and $1.1 \% \mathrm{SiO}_{2}$. The soft ores average $67.0 \% \mathrm{Fe}$ (ranging from 64.0 - 69.9\%). The $\mathrm{SiO}_{2}$ content is higher (average of $1.6 \%$ ) and the $\mathrm{Al}_{2} \mathrm{O}_{3}$ (average of $1.0 \%$ ) similar to those of hard ores. A total of 963 samples of iron-rich itabirite have been sampled and analyzed by MBR (Table 5). The bulk samples have an average of $58.6 \% \mathrm{Fe}$ (ranging from $52.0-58.01 \%$ ) and $13.4 \% \mathrm{SiO}_{2}$ (ranging from $0.2 \%-25.4 \%$ ). 
Table 6 Chemical composition (wt\%) of the in situ high-grade iron ores - Pico Mine

\begin{tabular}{|c|c|c|c|c|c|c|c|c|c|c|c|}
\hline & \multirow[b]{2}{*}{ Variable } & \multicolumn{5}{|c|}{ Hard high-grade ore } & \multicolumn{5}{|c|}{ Soft high-gracle ore } \\
\hline & & Avg & Std & $\operatorname{Max}$ & Min & $\eta$ & Avg & Std & Max & Min & $n$ \\
\hline \multirow{9}{*}{ 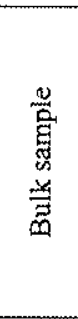 } & $\mathrm{Fe}_{\mathrm{r}}$ & 67.36 & 1.36 & 69.86 & 64.00 & 695 & 66.98 & 1.39 & 69.86 & 64.00 & 1,617 \\
\hline & $\mathrm{P}$ & 0.056 & 0.056 & 0.670 & 0.008 & 695 & 0.039 & 0.028 & 0.354 & 0.007 & 1,617 \\
\hline & $\mathrm{Al}_{2} \mathrm{O}_{3}$ & 1.02 & 0.70 & 3.84 & 0.02 & 695 & 0.96 & 0.63 & 3.74 & 0.10 & 1,617 \\
\hline & $\mathrm{SiO}_{2}$ & 1.14 & 1.07 & 7.17 & 0.11 & 695 & 1.64 & 1.39 & 8.70 & 0.10 & 1,617 \\
\hline & $\mathrm{Mn}$ & 0.040 & 0.060 & 0.950 & 0.003 & 695 & 0.127 & 0.206 & 2.275 & 0.002 & 1,617 \\
\hline & $\mathrm{CaO}$ & 0.026 & 0.013 & 0.064 & 0.012 & 255 & 0.019 & 0.006 & 0.047 & 0.010 & 433 \\
\hline & $\mathrm{MgO}$ & 0.030 & 0.020 & 0.124 & 0.016 & 255 & 0.029 & 0.013 & 0.098 & 0.010 & 433 \\
\hline & $\mathrm{TiO}_{2}$ & 0.046 & 0.031 & 0.146 & 0.011 & 255 & 0.053 & 0.045 & 0.377 & 0.010 & 433 \\
\hline & LOI & 0.80 & 0.86 & 4.88 & 0.05 & 255 & 0.99 & 0.59 & 4.24 & 0.17 & 433 \\
\hline \multirow{10}{*}{ 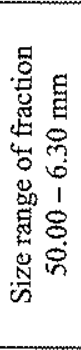 } & $\%$ Weight & 68.61 & 13.64 & 96.66 & 50.00 & 695 & 12.15 & 6.47 & 24.96 & 0.00 & 1,607 \\
\hline & $\mathrm{Fe}_{\mathrm{T}}$ & 68.09 & 1.13 & 69.90 & 63.80 & 695 & 67.11 & 2.48 & 69.90 & 51.60 & 1,607 \\
\hline & $\mathrm{P}$ & 0.047 & 0.054 & 0.691 & 0.002 & 695 & 0.035 & 0.040 & 0.953 & 0.003 & 1,607 \\
\hline & $\mathrm{Al}_{2} \mathrm{O}_{3}$ & 0.80 & 0.67 & 4.42 & 0.02 & 695 & 1.35 & 1.90 & 16.52 & 0.04 & 1,607 \\
\hline & $\mathrm{SiO}_{2}$ & 0.62 & 0.50 & 6.25 & 0.08 & 695 & 0.89 & 0.88 & 11.07 & 0.01 & 1,607 \\
\hline & $\mathrm{Mn}$ & 0.029 & 0.039 & 0.526 & 0.001 & 695 & 0.074 & 0.160 & 2.648 & 0.002 & 1,607 \\
\hline & $\mathrm{CaO}$ & 0.026 & 0.013 & 0.066 & 0.012 & 255 & 0.018 & 0.008 & 0.098 & 0.010 & 432 \\
\hline & $\mathrm{MgO}$ & 0.024 & 0.009 & 0.049 & 0.014 & 255 & 0.024 & 0.013 & 0.139 & 0.010 & 432 \\
\hline & $\mathrm{TiO}_{2}$ & 0.033 & 0.016 & 0.089 & 0.010 & 255 & 0.040 & 0.037 & 0.327 & 0.010 & 432 \\
\hline & $\mathrm{LOI}$ & 0.65 & 0.79 & 4.78 & 0.04 & 255 & 1.03 & 1.27 & 6.65 & 0.05 & 432 \\
\hline \multirow{10}{*}{ 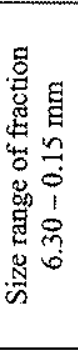 } & $\%$ Weight & 18.68 & 8.06 & 40.70 & 1.80 & 695 & 34.93 & 9.92 & 67.41 & 8.57 & 1,617 \\
\hline & $\mathrm{Fe}_{\mathrm{T}}$ & 67.16 & 1.88 & 69.70 & 55.00 & 695 & 67.89 & 1.36 & 69.90 & 56.02 & 1,617 \\
\hline & $\mathrm{P}$ & 0.068 & 0.072 & 0.581 & 0.005 & 695 & 0.028 & 0.029 & 0.335 & 0.003 & 1,617 \\
\hline & $\mathrm{Al}_{2} \mathrm{O}_{3}$ & 1.07 & 0.89 & 6.39 & 0.08 & 695 & 0.63 & 0.64 & 6.44 & 0.02 & 1,617 \\
\hline & $\mathrm{SiO}_{2}$ & 1.16 & 1.52 & 18.79 & 0.02 & 695 & 1.10 & 1.19 & 18.02 & 0.09 & 1,617 \\
\hline & $\mathrm{Mn}$ & 0.043 & 0.093 & 1.502 & 0.002 & 695 & 0.062 & 0.124 & 2.065 & 0.002 & 1,617 \\
\hline & $\mathrm{CaO}$ & 0.027 & 0.030 & 0.180 & 0.012 & 255 & 0.016 & 0.005 & 0.043 & 0.010 & 433 \\
\hline & $\mathrm{MgO}$ & 0.027 & 0.017 & 0.107 & 0.014 & 255 & 0.024 & 0.012 & 0.102 & 0.010 & 433 \\
\hline & $\mathrm{TiO}_{2}$ & 0.047 & 0.031 & 0.136 & 0.010 & 255 & 0.044 & 0.039 & 0.267 & 0.007 & 433 \\
\hline & LOI & 1.00 & 1.28 & 8.01 & 0.08 & 255 & 0.56 & 0.60 & 4.37 & 0,01 & 433 \\
\hline \multirow{10}{*}{ 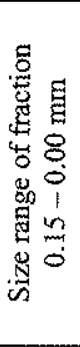 } & $\%$ Weight & 12.71 & 7.50 & 34.90 & 0.37 & 695 & 52.99 & 12.80 & 80.00 & 17.87 & 1,617 \\
\hline & $\mathrm{Fe}_{\mathrm{T}}$ & 63.03 & 4.62 & 69.60 & 39.30 & 695 & 66.17 & 2.14 & 69.90 & 55.00 & 1,617 \\
\hline & $\mathrm{P}$ & 0.105 & 0.097 & 0.835 & 0.007 & 695 & 0.049 & 0.035 & 0.420 & 0.006 & 1,617 \\
\hline & $\mathrm{Al}_{2} \mathrm{O}_{3}$ & 2.36 & 1.86 & 14.52 & 0.10 & 695 & 1.15 & 0.83 & 5.57 & 0.10 & 1,617 \\
\hline & $\mathrm{SiO}_{2}$ & 4.13 & 4.99 & 35.29 & 0.03 & 695 & 2.27 & 2.24 & 20.23 & 0.02 & 1,617 \\
\hline & $\mathrm{Mn}$ & 0.089 & 0.191 & 2.992 & 0.003 & 695 & 0.183 & 0.316 & 3.030 & 0.002 & 1,617 \\
\hline & $\mathrm{CaO}$ & 0.030 & 0.016 & 0.068 & 0.012 & 255 & 0.021 & 0.008 & 0.061 & 0.010 & 433 \\
\hline & $\mathrm{MgO}$ & 0.056 & 0.057 & 0.332 & 0.018 & 255 & 0.034 & 0.016 & 0.109 & 0.010 & 433 \\
\hline & $\mathrm{TiO}_{2}$ & 0.105 & 0.140 & 0.633 & 0.011 & 255 & 0.063 & 0.054 & 0.505 & 0.010 & 433 \\
\hline & LOI & 2.23 & 1.78 & 10.17 & 0.16 & 255 & 1.30 & 0.68 & 4,38 & 0.18 & 433 \\
\hline
\end{tabular}

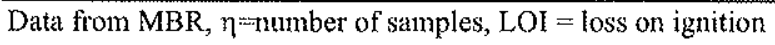

\section{DISCUSSION}

\section{Major differences between the Águas Claras and Pico mines}

Both the Águas Claras and Pico mines are hosted within the Paleoproteroic itabirites of the Cauê Formation. Although located in the western and less deformed side of the Quadrilatero Ferrifero, the two mines exhibit different patterns of deformation. At the Águas Claras mine a penetrative schistosity and a crenulation have developed as a consequence of events that folded and thrusted the rocks of the Minas Supergroup. In the Pico mine the deformation was less 
intense. The structures observed reflect shallow depths and low temperatures. Pervasive schistosity and crenulation were not developed.

The main lithological difference between the deposits is the presence of dolomitic itabirite in Águas Claras and amphibolitic itabirite in Pico. The genesis of the dolomitic and amphibolic itabirites remains a source of controversy and discussion (Dorr 1965, Veríssimo et al. 2002, Rosière and Rios 2003). For some authors (Veríssimo 1999, Veríssimo et al. 2002), they represent a sedimentary facies variation of the Minas sediments. For others (Beukes et al. 2002), the dolomitic itabirite results from the diagenetic replacement of chert by carbonate.

The gradual appearance of quartz within the dolomite bands, the absence of evidence indicating replacement of one mineral by the other and the alternating banding of quartz bands, dolomite bands and iron oxide bands (Fig. 5e) characterize a gradual contact between dolomitic and quartz itabirites at the Águas Claras mine and could represent a sedimentary facies variation. The same mineral assemblage of quartz-dolomite-iron oxides found in a very low-grade metamorphic iron-formation of the Sokoman Iron Formation in Canadá was described by Klein and Fink (1976) as a sedimentary hematite-carbonate facies of the BIF. This could also be the case in Águas Claras.

At the Pico mine, lens of amphibolitic itabirite occur interlayered with quartz itabirite. The same occurs at the Alegria mine, in the eastern region of the Quadritátero Ferrifero (Veríssimo 1999, Veríssimo et al. 2002). Based on field relations, petrology and geochemistry data, they have interpreted the amphibolitic itabirite and the quartz itabirite as representatives of the silicate facies and chert facies respectively. The difficulty in applying the concept of sedimentary facies to iron formations (James 1974) of the Quadrilátero Ferrifero is due to the fact that the mineral assemblage presently observed may not reflect the original mineralogical composition of the sediments of the Minas basin, which have undergone a complex evolution. No primary minerals are preserved, the textures of the rocks are typically metamorphic and the new mineral assemblage is strongly oxidized.

Otherwise there is no field evidence of a regional desilicification and carbonatization of the quartz itabirite as suggested by Beukes et al. (2002). Dolomitic itabirite and dolomite of the Cauê Formation occur along tens of kilometers of the Serra do Curral presenting gradual contacts. The gradual contact between the Cauê and Gandarela Formations brings an additional and important difficulty for the idea of carbonatization of the quartz itabirite. The rocks of the Gandarela Formation are typically shallow-water carbonate sediments which comprise dolomites and marbles with stromatolitic structures (Dorr 1965, Babinsky et al. 1995). At the base, the 
Gandarela Formation is composed of dolomitic itabirite and the marble facies is subordinate or absent. Quartz itabirite occurs interlayered with dolomitic itabirite, dolomite and marbles (Dorr 1965). These relations suggest again sedimentary facies variation. At the Águas Claras mine the transition from the Cauê Formation to the Gandarela Formation is marked by the gradual disappearance of iron oxides in the itabirite. If the dolomitic itabirite were a product of desilicification and carbonatization of the quartz itabirite, why would it be in gradual contact with typical marine carbonate of the Gandarela Formation? And what would be the origin of carbonates, if there is no carbonate rocks underlying the Cauê Formation?

Recent exploration works conducted by MBR along the eastern limb of the Moeda Syncline have shown that the interlayering of amphibolitic itabirite and quartz itabirite and, on a small scale, dolomitic itabirite and dolomite, is very frequent. The absence of additional data on fluid inclusions, trace and isotope geochemistry etc. precludes a final conclusion on this subject. The protore of the iron ores in the Águas Claras mine was dolomitic itabirite, whereas in the Pico mine it is the quartz itabirite. This significant difference plays an important role with regard to the type of ore in each mine. In the Águas Claras mine there are only high-grade iron ores. Soft ores predominate and exhibit sharp contacts with the protore. They consist of almost pure hematite with no relicts of carbonate. The weathering of the quartz itabirite generated only small bodies of iron-rich itabirite and left the main part of it unaltered. At the Pico mine the soft highgrade iron ore is associated with iron-rich and quartz itabirites of various degrees of alteration. The transition from the soft high-grade ore to the iron-rich itabirite, and from this to the quartz itabirite, is typically gradational especially in the soft ore close to the land surface. In this ore, relicts of quartz are common.

The iron oxide mineralogy of the ores in the Águas Claras and Pico mines is similar in grain size, crystal shape and the types of minerals found - basically martite and granular/tabular hematite. Specularite is a minor component and is restricted to shear zones in the Pico mine. It occurs more extensively in the Águas Claras mine due to a higher degree of deformation. Although the high-grade ores in both mines have very low contents of gangue minerals, they are quite different from each other. In the Águas Claras mine, dolomite is the main gangue mineral, which is found as relict in contact regions with the protore, or as an accessory mineral in the unweathered hard ores. In the Pico mine, quartz is the main gangue mineral, present as a relict in soft and hard high-grade ores, as an accessory mineral in unweathered hard high-grade ores and as an important constituent of the iron-rich itabirite. 
The different protores in the Águas Claras and Pico mines imply that the chemistry of the ores is a little different. In general, the high-grade ores of the Águas Claras mine have higher Fe, $\mathrm{Mn}, \mathrm{CaO}$ and $\mathrm{MgO}$ contents than those of the Pico mines (Tables 5 and 6). High-grade ores from the Pico mine exhibit higher contents of $\mathrm{SiO}_{2}$ and especially $\mathrm{Al}_{2} \mathrm{O}_{3}$, both of which are particularly scarce in Águas Claras. The chemical differences between Águas Claras and Pico high-grade ores are well illustrated in the size fraction $<0.15 \mathrm{~mm}$ of the soft hematite ores. The $\mathrm{Mn}, \mathrm{Ca}$ and $\mathrm{Mg}$ contents of the Águas Claras mine are respectively 3.6, 7.1 and 4.7 times higher than those of the Pico mine. In addition, the $\mathrm{SiO}_{2}$ and $\mathrm{Al}_{2} \mathrm{O}_{3}$ contents of the same size interval in the Pico mine are respectively 2.5 and 1.6 higher than those of the Águas Claras mine. Table 7 summarizes the major differences between the mines.

Table 7 Summary of the major differences between the Águas Claras and Pico mines

\begin{tabular}{|c|c|c|}
\hline & Águas Claras & Pico \\
\hline Tectonism & Moderate & Weak \\
\hline Protore & Dolomitic itabirite & Quartz itabirite \\
\hline Ore Types & $\begin{array}{l}\text { Only high-grade ore. Predominates } \\
\text { soft-ore. }\end{array}$ & $\begin{array}{l}\text { High-and low-grade ores. } \\
\text { Predominate soft ores but } \\
\text { hard ores are significant. }\end{array}$ \\
\hline Gangue minerals & $\begin{array}{l}\text { Very rare. Dolomite, talc, chlorite and } \\
\text { apatite in contact regions. }\end{array}$ & $\begin{array}{l}\text { Rare in high-grade ores. } \\
\text { Quartz in iron-rich } \\
\text { itabirites. }\end{array}$ \\
\hline Ore mineralogy & $\begin{array}{l}\text { Martite and hematite with varied } \\
\text { specularite }\end{array}$ & Martite and hematite \\
\hline $\begin{array}{l}\text { Chemistry of the } \\
\text { ores }\end{array}$ & Higher $\mathrm{Fe}, \mathrm{Mn}, \mathrm{CaO}$ and $\mathrm{MgO}$. & Higher $\mathrm{SiO}_{2}$ and $\mathrm{Al}_{2} \mathrm{O}_{3}$ \\
\hline
\end{tabular}

\section{Considerations about the iron ore genesis}

Hypotheses on the genesis of the Quadrilátero Ferrifero iron ores have long been discussed in the literature, but reseachers are still far from reaching a consensus on this matter (Harder and Chamberlin 1915, Guild 1953, Park 1959, Dorr 1964 and 1965, Rosière 1983, Pires 2002, Rosiére and Rios 2003). The complex scenario where by the Minas Supergroup rocks evolved, with a multitude of processes generating several sub-types of hard and soft-ores, and the lack of information concerning those processes make it difficult to build a genetic model.

The two major types of iron ores at the Águas Claras and Pico mines - hard and soft ores - have clearly different genesis: hard ore is hypogene whereas soft ore is supergene. In both mines, hard high-grade ore is found interbedded or cutting unweathered itabirites, which indicates its hypogene origin. The timing of its origin is unknown. However, a general indication 
can be given. In the Pico mine a $861 \mathrm{Ma}$ metamafic dyke cuts thin lens of the hard ore. On the other hand, there is no evidence of contact metamorphism in the soft ores. This indicates that the hard ore is older than $861 \mathrm{Ma}$ and that the soft ore is younger.

Recent papers concerning the genesis of the hard ores in the Quadrilatero Ferrifero (Pires et al. 2002, Rosière and Rios 2003) review old genetic models based on the metamorphicmetasomatic replacement of the gangue minerals by hematite during metamorphism and deformation (Dorr and Barbosa 1963, Dorr 1965). Hydrothermal processes, generally accepted by Brazilian geologists, are probably responsible for the genesis of the hard ores, but many questions remain regarding the timing of those processes, frequency, origin, composition and temperature of the fluids. Several sub-types of hard high-grade ores occur at the Águas Claras and Pico mines (and throughout the Quadrilátero Ferrífero). Rosiére and Rios (2003) interpret the massive hard ore as the first generation of the high-grade ore, which occurred during a first hydrothermal event (low-salinity fluids) at temperatures lower than $150^{\circ} \mathrm{C}$. This event would be related to the late diagenesis of the Minas sequence. Pires (2002) argues that this same massive ore and the brecciated hard ore were formed later during metamorphism and deformation of the sequence under brittle regime. Thin bedded, banded, micaceous and schistose hard ores were created during the same metamorphic event in a previous synkinematic, acid and oxidant metasomatism, under ductile regime.

The genesis of the soft high-grade ores and iron-rich itabirites was studied by several authors (Dorr 1964; Eichler 1968; Melfi et al. 1976; Viel et al. 1987; Ramanaidou 1989; Ramanaidou et al. 1996). According to them, field relations and petrographic observations clearly demonstrate that these ores are the result of the residual concentration of the iron oxides due to the leaching of associated gangue minerals by supergene fluids. The weathering process was enhanced by the well-defined bedding at high angles in the itabirites at the Águas Claras and Pico mines. This allowed deep penetration of weathering fluids, which are abundant in humid, tropical climates. This process was also favored by the appropriate physiographic environment where the itabirites occur along high ridges with adjacent steep slopes, enhancing the circulation of ground water (Dorr 1964).

A supergene origin seems very clear, especially for the soft ore and the iron-rich itabirite that occur close to the land surface, where it is possible to document the gradual transition from the fresh itabirite to the iron-rich itabirite and then to the soft ore. It is not so clear in the lower benches of the mine where the soft high-grade ore is in sharp contact with the soft itabirite of 
low iron content. In this case one could suppose a previous iron enrichment of the itabiritic protore, but there is no evidence of this.

Soft high-grade ores cropping out close to the land surface at the Pico mine have the same physical and chemical characteristics as those present at deeper depths, except where they are in contact with the canga. In this case, they show higher $\mathrm{Al}_{2} \mathrm{O}_{3}$ and $\mathrm{P}$ contents and higher LOI.

The soft ores of the Pico mine present Fe contents similar to those of the Águas Claras mine. This fact led to interesting discussions on why two different protores generate similar soft ores. For Viel et al. (1987) the composition of the primitive itabirite would control the type of soft ore generated. For instance, dolomitic itabirite would generate soft high-grade ore whereas quartz itabirite would generate iron-rich itabirite. This idea could explain the soft ores of the Águas Claras mine, but not those of the Pico mine. Unweathered quartz itabirite cropping out close to the soft ores at the Pico mine do not contain carbonate. Therefore, though the original composition of the itabirite represents a very important factor in the genesis of the soft ore, it is not the only factor. The presence of favorable structures must also be considered.

Faults and fractures, for instance, facilitate the access of weathering fluids to the unweathered rock. A very good example of structural control can be found at the Pico mine, where the soft ore occurs only on the south side of the metamafic dyke (Fig. 10). The dyke acted as a barrier for the fluids coming from the south and favored an intensive leaching of the gangue minerals close to its contact.

At the Águas Claras mine it is reasonable to consider that, though both dolomitic and quartz itabirite are present as protores, the majority of soft ores are derived from the carbonatic rock due to its higher susceptibility to be leached. The absence of favorable structural control preserved the quartz itabirite. This was not the case at the Pico mine, where favorable structural controls facilitated the weathering of the quartz itabirite and the formation of high-grade soft ores.

Chemically, the weathering process is characterized by a high concentration of $\mathrm{Al}_{2} \mathrm{O}_{3}$ and $P$ in the canga and in the iron ores that are in contact with it. The contents of these contaminants decrease quickly at greater depths (Fig. 9), where the soft ores consist of almost pure hematite with more than $97 \% \mathrm{Fe}_{2} \mathrm{O}_{3}$.

The high concentration of goethite close to the surface, marked by a high loss on ignition, also decreases quickly at depth, suggesting that a majority of contaminants are incorporated in the goethite structure (Ainsworth et al. 1985). Close to the contact with the dolomitic itabirite, at 
the lower levels of the Águas Claras mine, the contents of P and Mn increase greatly (Fig. 9). This fact is explained by the decreasing permeability observed in these zones. This favors the residual concentration of the $\mathrm{Mn}$ oxides produced during the dissolution of the carbonates, together with apatite, which is less soluble than dolomite.

Preliminary studies on the weathering of the Águas Claras and Pico protores indicate that the first steps of the process are iso-volumetric. No substitution of quartz by goethite septa, as described by Ramanaidou (1989) and Ramanaidou et al. (1996) in the Capanema mine have yet been identified. The continuity of the leaching process leads to the collapse of the rock, with a volume reduction of about $40 \%$ and the generation of a significant porosity in the soft ore and rich itabirite (Ribeiro et al. 1998; Ribeiro et al. 2002). The pores created during weathering close at the land surface, filled by goethite.

The weathering processes may also have had an important role on the genesis of the porosity of the hard ores, dissolving the accessory gangue mineral and oxidizing the residual magnetite not oxidized by previous processes, as suggested by Varajão et al. (2002).

High-grade soft ores and iron-rich itabirites represent more than $80 \%$ of the iron ore reserves in the Águas Claras and Pico mines. This proves the importance of the weathering processes in the genesis of these orebodies.

\section{CONCLUSION}

The Águas Claras and Pico iron mines are two world-class mines hosted within LowerProterozoic metamorphosed banded iron formations of the Lake Superior type. The Águas Claras orebody consists of a roughly tabular-shaped lens formed by high-grade iron ores hosted within dolomitic itabirite. The high-grade ores comprise more than $85 \%$ of soft ore, with the remainder $15 \%$ formed by hard ore. Hematite is the main constituent of the iron ores. Gangue minerals are very rare and consist of dolomite, chlorite, talc and apatite, especially common close to the contact with the protore. Chemically the ores are characterized by a very high $\mathrm{Fe}$ content (an average of $68.2 \% \mathrm{Fe}$ ) and low contents of the contaminants $\mathrm{P}, \mathrm{Al}_{2} \mathrm{O}_{3}$ and $\mathrm{SiO}_{2}$.

The Pico orebody consists of a lenticular shape body hosted within a quartz itabirite, which is the protore of the high- and low-grade ores. The high-grade ores comprise hard and soft ores respectively representing $20 \%$ and $51 \%$ of the reserves. These ores present the same iron oxide mineralogical composition as that found in the Águas Claras mine. Low-grade ores have a higher content of gangue minerals and account for $29 \%$ of the reserves. Quartz is the dominant 
gangue mineral and is found with minor quantities of chlorite. The chemistry of the high-grade ores is characterized by high $\mathrm{Fe}$ contents (an average of $67.0 \%$ ) and low $\mathrm{P}, \mathrm{Al}_{2} \mathrm{O}_{3}$ and $\mathrm{SiO}_{2}$ which are concentrated in the fines. Low-grade ores average $58.6 \% \mathrm{Fe}$ and $13.5 \% \mathrm{SiO} 2$.

The genesis of the hard high-grade ores is not yet well understood. It is probably related to hydrothermal processes acting during diagenesis or metamorphism of the BIF. Soft high-grade ores and iron-rich itabirites appear to be formed by supergene processes. The leaching of gangue minerals by weathering fluids leads to the residual iron enrichment. This process is favored by the presence of carbonate protores and structures which control the circulation of the ground water.

\section{Acknowledgements}

This paper is an integral part of the senior author's Ph.D. thesis at the Instituto de Geociencias of the Universidade de São Paulo-USP and is published by permission of Minerações Brasileiras Reunidas - MBR. C.A.S. thanks MBR for providing financial support and access to its database and laboratories. He is especially thankful to Mr. Oscar Tessari for his support and permission for publication of this work. We are sincerely grateful to Dr Harry Fisscher for a first review of this paper in manuscript. We thank also the reviewers H.J. Dalstra and M.E. Barley for their careful review of the manuscript and most valuable suggestions.

\section{REFERENCES}

Ainsworth CC, Sumner ME, Hurst VJ (1985) Effect of aluminum substitution in goethite on phosphorus adsorption: I. Adsortion and isotopic exchange. Soil Sci. Soc. Am. J., 49:11421149 .

Almeida FFM (1977) O Cráton do Rio São Francisco. Rev. Bras. Geociências, 7(4):349-364.

Alkmim FF, Marshak S (1998) Transamazonian orogeny in the southern São Francisco craton, Minas Gerais, Brazil: evidence for paleoproterozoic collision and collapse in the Quadrilátero Ferrífero. Precambrian Research, 90:29-58.

Babinski M, Chemale Jr F, Van Schmus WR (1995) The Pb/Pb age of the Minas Supergroup carbonate rocks, Quadrilátero Ferrífero, Precambrian Research, 72:235-245.

Beukes NJ, Gutzmer J, Mukhopadhyay (2002) The geology and genesis of high-grade iron ore deposits. Proceedings of the Iron Ore 2002 conference, Perth, 2002, Australasian Institute of Mining and Metallurgy, pp 23-29.

Chauvet A, Faure M, Dossin I, Charvet J (1994) A three-stage structural evolution of the Quadrilátero Ferrífero: consequences for the Neoproterozoic age and formation of gold concentrations of the Ouro Preto area, Minas Gerais, Brazil. Precambrian Research, 68:139167.

Chemale Jr F, Rosière CA, Endo I (1994) The tectonic evolution of the Quadrilatero Ferrifero, Minas Gerais, Brazil. Precambrian Research, 65:25-54.

Dorr II JVN (1964) Supergene iron ores of Minas Gerais, Brazil. Economic Geology, 59 (7):1203-1240. 
Dorr II JVN (1965) Nature and origin of the high-grade hematite ores of Minas Gerais, Brazil. Economic Geology, 60 (1):1-46.

Dorr II JVN (1969) Physiographic, stratigraphic and structural development of the Quadrilátro Ferrifero, Minas Gerais, Brazil. USGS profissional paper, Washington, 641-A, p. $\mathrm{A}_{1}-\mathrm{A}_{103}$.

Dorr II JVN (1973) Iron-formation in South America. Economic Geology, 68: 1005-1022.

Eichler J (1968) O enriquecimento residual e supergênico dos itabiritos através do intemperismo. Geologia, 1: 29-40.

Gomes JCM (1986) As minas de Águas Claras, Mutuca, Pico e outros depósitos de minério de ferro no Quadrilátero Ferrífero, Minas Gerais. In: Schobbenhaus C, Coelho CES (eds.). Principais depósitos minerais do Brasil, Brasília, DNPM/CPRM, 2:65-75.

Gruner JW (1937) Hydrotermal leaching of iron ores of the Lake Superior type - a modified theory. Economic Geology, 32: 121-130.

Guild PW (1953) Iron deposits of the Congonhas District, Minas Gerais, Brazil. Economic Geology, 48: 639-676.

Hackspacher PC (1979) Strukturelle und texturelle untersuchungen zur internem deformation des eisenreicherzkoerpers der grube "Aguas Claras" bei Belo Horizonte/Minas Gerais, Brasilien. Claust. Geol. Abh. 34: 1-164.

Harder EC, Chamberlin RT (1915) The geology of central Minas Gerais, Brazil. Journal Geology, 23: 341-378, 385-424.

Herz N (1978) Metamorphic rocks of the Quadrilátero Ferrifero, Minas Gerais, Brazil. USGS Profissional Paper, Washington, 641-C, p. $\mathrm{C}_{1}-\mathrm{C}_{81}$.

James HL (1954) Sedimentary facies of iron-formation. Economic Geology, 49: 235-293.

Klein C, Fink RP (1976) Petrology of the Sokoman Iron Formation in the Howells River Area, at the Western Edge of the Labrador Trough. Economic Geology, 71: 453-487.

Klein C, Ladeira EA (2000) Geochemistry and petrology of some Proterozoic Banded IronFormations of the Quadrilátero Ferrifero, Minas Gerais, Brazil. Economic Geology, 95: 405-428.

Ladeira EA, Viveiros JFM (1984) Hipótese sobre a estruturação do Quadrilátero Ferrífero com base nos dados disponíveis. Boletim da Sociedade Brasileira de Geologia de Minas Gerais, $4,14 \mathrm{pp}$.

Lagoeiro, LE (1998) Transformation of magnetite to hematite and its influence on dissolution of iron oxide minerals. Journal of Metamorphic Geology, 16: 415-423.

Lascelles D (2002) A new look at old rocks - an alternative model for the origin of in situ iron ore deposits derived from Banded iron-Formation. Proceedings of Iron Ore 2002 Conference, Perth, 2002, Australasian Institute of Mining and Metallurgy: 107-126.

Lima MR, Salardi-Cheboldaeff M (1981) Palynologie des bassins de Gandarela et Fonseca (Eocene de l'Etat de Minas Gerais, Brézil). Boletim IG-USP. Série Científica, 12:33-54.

Marshak S, Alkmim FF (1989) Proterozoic contraction/extension tectonics of the southern São Francisco craton region, Minas Gerais, Brazil. Tectonics, 8(3):555-571.

Marshak S, Alkmim FF, Jordt-Evangelista H (1992) Proterozoic crustal extension and generation of domo-and-keel structure in the Archaean granite-greenstone terrane. Nature, 357:491493. 
Melfi AJ, Pedro G, Nalovic L, Queiroz Neto JP (1976) Etude sur l'altération géochimique des itabirites du Brésil. Cah. ORSTOM, Sér. Pédologie, XIV, 3:179-192.

Morey GB (1999) High-grade ore deposits of the Mesabi Range, Minnesota - product of a continental scale Proterozoic ground-water flow system. Economic Geology, 94:133-142.

Morris RC (1985) Genesis of iron ore in banded iron-formation by supergene and supergenemetamorphic processes - a conceptual model. In: Wolf KH (ed.) Handbook of StrataBound and Stratiform Ore Deposits. Amsterdam, Elsevier, 13: 73-235.

Morris RC (1987) Iron ores derived by enrichment of Banded Iron-Formation. In: Hein JR (ed.) Siliceous Sedimentary Rock-Hosted Ores and Petroleum. New York, Van Nostrand Reinhold, pp 231-267.

Morris RC (2002) Iron ore genesis and post-ore metasomatism at Mount Tom Price. Proceedings of Iron Ore 2002 Conference, Perth, 2002, Australasian Institute of Mining and Metallurgy: 3-13.

Noce CM (1995) Geocronologia dos eventos magmáticos, sedimentares e metamórficos na região do Quadrilátero Ferrífero, Minas Gerais. Inst. de Geociências, São Paulo, Tese de Doutoramento, $128 \mathrm{p}$.

Park Jr CF (1959) Origin of hard hematite in itabirite. Economic Geology, 54: 573-587.

Pires FRM (1979) Structural geology and stratigraphy at the juntion of the Curral Anticline and the Moeda Syncline. PhD thesis. Michigan Technology University, $220 \mathrm{p}$.

Pires FRM (1995) Textural and mineralogical variations during metamorphism of the Proterozoic Itabira Iron Formation in the Quadrilátero Ferrífero, Minas Gerais, Brazil. Anais da Academia Brasileira de Ciências, 67 (1):77-105.

Pomerene JB (1964) Geology and mineral deposits of the Belo Horizonte, Ibirité and Macacos quadrangles, USGS Prof. Paper 341-D, p. 1-84.

Powell CMcA, Oliver NHS, Li ZX, Martin DMcB, Ronaszecki J (1999) Synorogenic hydrotermal origin for giant Hamersley iron oxide bodies. Geology 27:175-178.

Ramanaidou E (1989) Genèse d'un gisement latéritique. Evolution supergène des itabirites protérozoïque de la mine de fer de Capanema, Minas Gerais, Brésil. Université de Poitiers, U.F.R. Sciences fondamentales et appliquées, These de docteur, $183 \mathrm{p}$.

Ramanaidou E, Nahon D, Decarreau A, Melfi AJ (1996) Hematite and goethite from duricrusts developed by lateritic chemical weathering of Precambrian banded iron formations, Minas Gerais, Brazil. Clays and Clay Minerals, 44(1):22-31.

Renger FE, Noce CM, Romano AW, Machado N (1994) Evolução sedimentar do Supergrupo Minas: $500 \mathrm{Ma}$. de registro geológico no Quadrilátero Ferrífero, Minas Gerais, Brasil. Geonomos, 2(1):1-11.

Ribeiro DT, Zavaglia G (1998) Bacias terciárias e enriquecimento de minério de ferro. In: SBG/Núcleo de Minas Gerais, Simpósio de Geologia de Minas Gerais, 9, Belo Horizonte, Anais, 14:139-140.

Ribeiro DT, Carvalho RM (2002) Simulation of weathered iron ore facies: integrating leaching concepts and geostatistical model. In: Armstrong M, Bettini C, Champigny N, Galli A, Remacre A (eds.). Geostatistics Rio 2000. Kluwer, Dordrecht Boston London, pp 101-115. 
Ribeiro DT, Pires FRM, Carvalho RM (2002) Supergene iron ore and disorder. Proceedings of Iron Ore 2002 Conference, Perth, 2002, Australasian Institute of Mining and Metallurgy: $81-90$.

Rosière CA (1981) Strukturelle und texturelle untersuchungen in der eisenerzlagerstätte "Pico de Itabira" bei Itabirito/Minas Gerais, Brasilien. Claust. Geowiss. Dissertação de doutorado, 9:1-302.

Rosière CA (1983) A recristalização do minério de ferro da jazida do Pico de Itabirito no Quadrilátero Ferrífero, MG e suas implicações genéticas. In: SBG/Núcleo de Minas Gerais, Simpósio de Geologia de Minas Gerais, 2, Belo Horizonte, Anais, 173-1986.

Rosière CA (2000) Itabiritos e minérios de ferro de alto teor do Quadrilátero Ferrífero - uma visão geral e discussão. Geonomos, 8(2): 27-42.

Rosière CA, Chemale Jr F, Guimarães MLV (1993) Um modelo para a evolução microestrutural dos minérios de ferro do Quadrilátero Ferrífero. Parte I - estruturas e recristalização. Geonomos, 1(1):65-84.

Rosière CA, Siemes H, Quade H, Brokmeier HG, Jansen EM (2001) Microstructures, textures and deformation mechanisms in hematite. Journal of Structural Geology, 23:1429-1440.

Rosière CA, Rios FJ (2003) The origin of hematite in high grade iron ores based on infrared microscopy and fluid inclusions studies: the example of the Conceição mine, QF, Brazil. Economic Geology (submitted).

Taylor D, Dalstra HJ, Harding AE, Broadbent GC, Barley ME (2001) Genesis of high-grade hematite orebodies of the Hamersley Province, Western Australia. Economic Geology, 96:837-873.

Trendall AF (1973) Varve cycles in the Weeli Wolli Formation of the Precambrian Hamersley Group, Western Australia. Economic Geology, 68(7): 1089-1097.

Van Schalkwyk JF, Beukes NJ (1986) The Sishen iron ore deposit. In: Mineral Deposits of Southern Africa. Johannesburg, Geological Society of South Africa, pp. 157-182.

Varajão CAC, Bruand A, Ramanaidou ER, Gilkes RJ (2002) Microporosity of BIF hosted massive hematite ore. Anais da Academia Brasileira de Ciências, 74 (1): 113-126.

Viel RS, Moreira PCH, Alkmim FF (1987) Faciologia da Formação Cauê e gênese do minério de ferro friável da Mina de Águas Claras, Serra do Curral - Minas Gerais. In: SBG/Núcleo Minas Gerais, Simpósio sobre sistemas deposicionais no Pré-cambriano brasileiro, Ouro Preto, Anais, 137-153.

Wallace RM (1965) Geology and mineral resources of the Pico do Itabirito District, Minas Gerais, Brazil. U.S.Geol. Survey Prof. Paper 341-F, 68 p. 


\title{
ANEXO 2 - GEOCHEMISTRY AND GENESIS OF THE BANDED IRON FORMATIONS OF THE CAUÊ FORMATION, QUADRILÁTERO FERRÍFERO, MINAS GERAIS, BRAZIL
}

\begin{abstract}
The Cauê Formation of the paleoproterozoic Minas Supergroup hosts banded iron formations (BIFs) of the Lake Superior type, locally called itabirites. Two major compositional types of itabirite occur at the northwest of the Quadrilatero Ferrifero (QF): dolomitic itabiritic and quartz itabirite. The former consists of alternating dolomite-rich and hematite-rich bands while the latter is formed with alternating quartz-rich and hematite-rich bands. Dolomite, quartz and hematite are the major mineralogical constituents, with accessories chlorite, sericite and apatite.

The chemical composition of the itabirites is as simple as that of the BIFs which occurs worldwide. At the dolomitic itabirite $\mathrm{Fe}_{2} \mathrm{O}_{3}$ plus $\mathrm{CaO}, \mathrm{MgO}$ and $\mathrm{LOI}$ range from $95.8 \%$ to $97.8 \%$ while at the quartz itabirite $\mathrm{Fe}_{2} \mathrm{O}_{3}$ plus $\mathrm{SiO}_{2}$ range from $94.4 \%$ to $99.6 \%$. Both itabirites are highly oxidized and present $\mathrm{Fe}^{3+} /\left(\mathrm{Fe}^{2+}+\mathrm{Fe}^{3+}\right)$ ratios higher than 0.98 , much greater than the average ratio of other paleoproterozoic BIFs. Trace elements concentrations in itabirites are very low and range from $<10 \mathrm{ppm}(\mathrm{Y}, \mathrm{Sc}, \mathrm{Be}, \mathrm{Cu}, \mathrm{Ga}, \mathrm{Ge}, \mathrm{Rb}, \mathrm{Nb}, \mathrm{Mo}, \mathrm{Ag}, \mathrm{In}, \mathrm{Sn}, \mathrm{Cs}, \mathrm{Hf}, \mathrm{Tl}, \mathrm{Pb}$, $\mathrm{Bi}, \mathrm{As}, \mathrm{Cd}, \mathrm{Th}, \mathrm{U}, \mathrm{Sb})$ to concentrations between 10 and $55 \mathrm{ppm}(\mathrm{Ba}, \mathrm{Sr}, \mathrm{Zr}, \mathrm{V}, \mathrm{Ni}, \mathrm{Zn}, \mathrm{Co}, \mathrm{Cr}$ and $\sum$ REE).

Dolomite of the dolomitic itabirite shows negative $\delta^{13} \mathrm{C}$ values varying from $-2.5 \%$ to $-0.8 \%$ while the oxygen isotope data displays $\delta^{18} \mathrm{O}$ values varying from $-12.4 \%$ to $-8.5 \%$. The $\delta^{13} \mathrm{C}$ values show an enrichment trend in ${ }^{13} \mathrm{C}$ from the base to the top of the Caue Formation, probably continuing upsection through the overlying stromatolitic dolomites of the Gandarela Formation. $\mathrm{C}$ and $\mathrm{O}$ isotopes, REE signatures and $\mathrm{Y} / \mathrm{Ho}$ ratios indicate a marine origin for the sediments of the dolomitic itabirite.

The HREE enrichment pattern exhibited by the itabirites shows a modern seawater REE signature overprinted by a hydrothermal pattern marked by positive Eu anomalies. A strong correlation between $\mathrm{Al}_{2} \mathrm{O}_{3}$ and $\mathrm{TiO}_{2}(\mathrm{r}>0.9)$ indicates a minor terrigenous component for the chemically precipitated, marine sediments of the Caue Formation. Differences on the HREE signatures of itabirites suggest that they precipitated from different seawater depths, with the
\end{abstract}


dolomitic itabirite precipitating in shallower waters receiving continental sediment laiden waters while the quartz itabirite was precipitating in deeper waters. Sea-level fluctuations caused by marine transgression-regressions are responsible for changes on the composition of seawater during the deposition of the Cauê Formation. These changes are expressed by dolomitic-, quartz- and amphibolitic itabirites, which represent lateral and vertical facies transitions of carbonatic, cherty and shaly BIFs, respectively.

\section{INTRODUCTION}

Banded iron formations have long been an object of interest to research not only due to their economic aspects, as they are the major source of iron ore, but also due to their importance for the understanding of atmosphere evolution, the chemical composition of the oceans and the appearance of life on Earth. Trendall (2002) presents an interesting and updated summary of the meaning of those rocks on the Precambrian stratigraphic record, and his references introduce the readers to this vast and complex theme.

The Cauê Formation of the Minas Supergroup is worldly known for hosting giant iron ore deposits at the Quadrilatero Ferrífero of the Minas Gerais State in the southern region of Brazil (Fig. 1). It is a classical proterozoic BIF deposited on the continental shelf (Dorr II, 1969), classified as of the Superior type, according to the scheme of Gross (1980). The Caue Formation integrates the group of the great Gondwana BIFs together with the Carajás Formation of the Grão Pará Group at the Amazonic craton, the Kuruman and Penge Formations of the Transvaal Supergroup in South Africa, the Mulaingiri Formation of the Bababundan Basin in India and the BIFs of the Hamersley Basin in Australia.

Several geological processes have obliterated many of the primary characteristics of the original sediments of the Caue Formation therefore originating the itabirites, a common name adopted in Brazil for the metamorphosed and oxidized BIF. Three major compositional types of itabirite occur at the QF: quartz, dolomitic and amphibolitic (Dorr II, 1969; Rosière et al., 1993). Great doubts persist in the literature about the origin of this compositional variation and, therefore, about the genesis of itabirites. Does it represent an original sedimentary facies variation within the Minas Basin or are itabirites products of a later process after sedimentation? Dorr II (1969) correlates the quartz and dolomitic itabirites with BIFs of the oxide facies of James (1954). He considered the amphibolitic itabirite as a product of the contact metamorphism of dolomitic itabirite by nearby granitic rocks. Beukes et al. (2002) attribute the genesis of the dolomitic itabirite to be the result of hydrothermal metasomatism of the original cherty BIF 
during a hypogene enrichment stage of the iron ore. Veríssimo (1999) and Veríssimo et al. (2002), however, interpreted the variations on the compositional type of the itabirite as representative of the original sedimentary facies variation. These authors describe the quartz and amphibolitic itabirites at the Alegria Mine, East of the QF (Fig. 1), and correlate them to the oxide and silicate BIFs of James (1954).

The international literature of itabirites of the Cauê Formation is very scarce and most work was conducted during the 1960's and 1970's (e.g. Dorr II, 1969; Dorr Il 1973). Recently, Klein and Ladeira (2000) studied the petrology and geochemistry of sixteen itabirite samples collected at four different sites of the western QF. These authors interpreted minor element and REE geochemistry of the itabirite to indicate precipitation and deposition from mixed Precambrian seawater and sub-oceanic hydrothermal fluids, but with no detailed explanation for the origin of the dolomitic and quartz itabirite. They also suggest that the presence of hematite and absence of magnetite or martite in the samples examined indicates that the hematite was formed after sedimentary ferric oxide/hydroxides during diagenesis or low-grade metamorphism. The presence of martite and relicts of magnetite, as well as formations of hematite after martite, however, have long been described in itabirite samples of the QF (Dorr II, 1969; Rosière et al., 1993). Their genesis of itabirites is therefore far from a satisfactory explanation.

The Águas Claras Mine is located on the northeast segment of the Serra do Curral, North of the QF (Fig.1), where the dolomitic and quartz itabirite crop out. Mining of iron ore during thirty years has exposed a complete unweathered sequence of dolomitic itabirite. Several drill holes intersect quartz itabirite in the north side of the mine. The quality of itabirite exposed on mining benches and thousands of meters of drill core provide ideal sites to sample all the sequence of the Cauê Formation in this part of the QF. This paper presents petrological and geochemical data of 46 samples of rocks collected throughout the Caue Formation, from its base to the transition zone to dolomite of the overlying Gandarela Formation. Our aims are to combine petrographic and geochemical analyses to contribute for discussions about the genesis of the itabirites in the QF. This study represent the first comprehensive chemostratigraphic analysis of the Cauê Formation to date. $\mathrm{C}$ and $\mathrm{O}$ isotopic analysis of dolomitic itabirite further constrain the geochemistry of the fluid at the time of deposition. Special attention is given to dolomitic itabirite because this rock is the protore of the iron ore within this world class iron mine (Spier et al., 2003; Viel et al., 1987). 


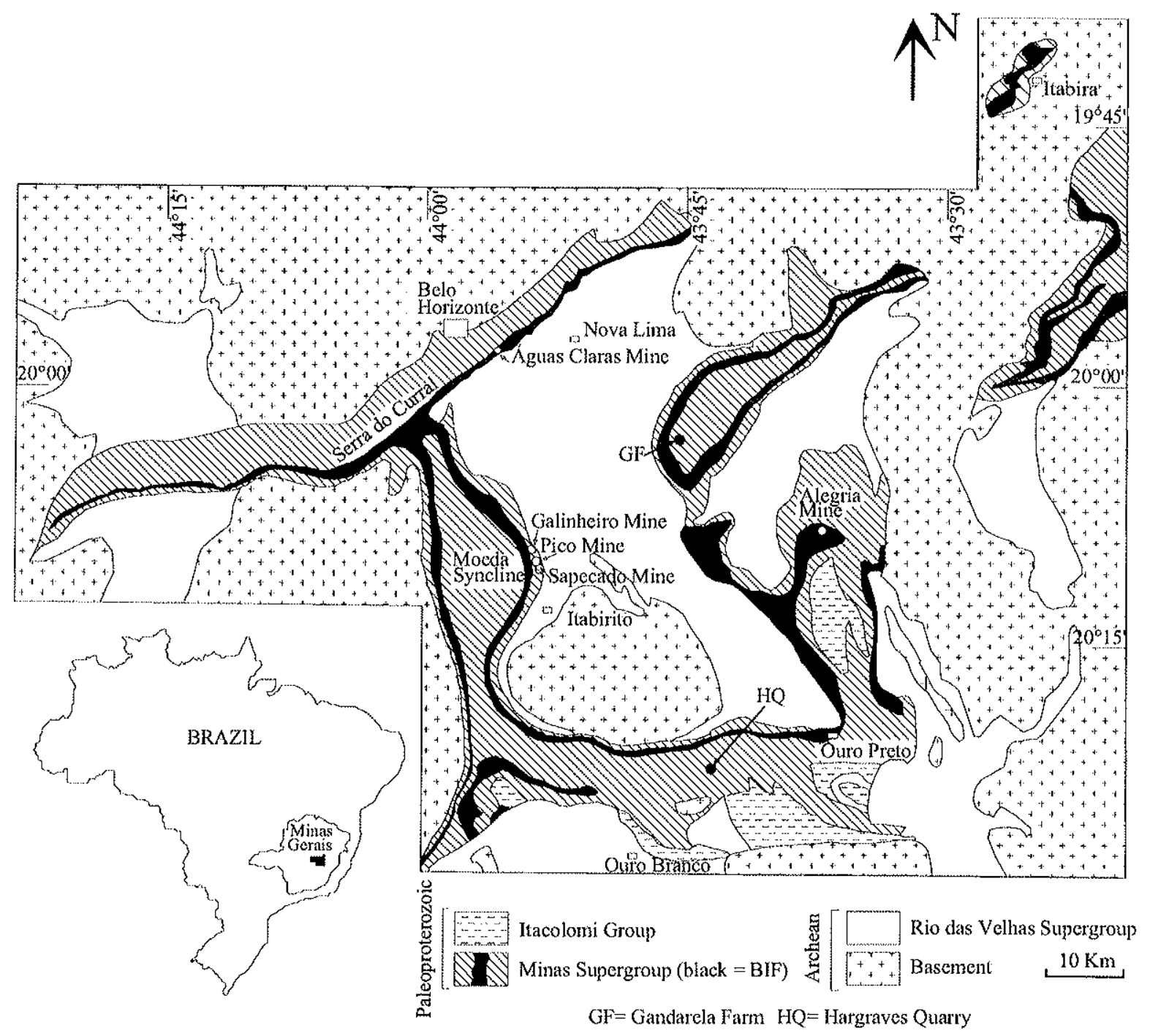

Figure 1 -.. Location and geological sketch map of the Quadrilátero Ferrifero region (After Dorr, 1969).

\section{GEOLOGICAL SETTING}

The Caue Formation and Gandarela Formation are the lower and upper rock units, respectively, of the Itabira Group, which are the predominant chemical sediments of the Paleoproterozoic Minas Supergroup (Fig. 2). The Minas basin represented by sediments of the Minas Supergroup is interpreted as either an intracratonic basin (Chemale Jr. et al., 1994) or a platform supracrustal sequence with a sialic substrate (Cordani et al., 1980; Marshak and Alkmim, 1989; Teixeira and Figueiredo, 1991). It rests unconformably on Archean greenstonesof the Rio das Velhas Supergroup and basement granite-gneiss terrains (Chemale Jr. et al, 1994). 


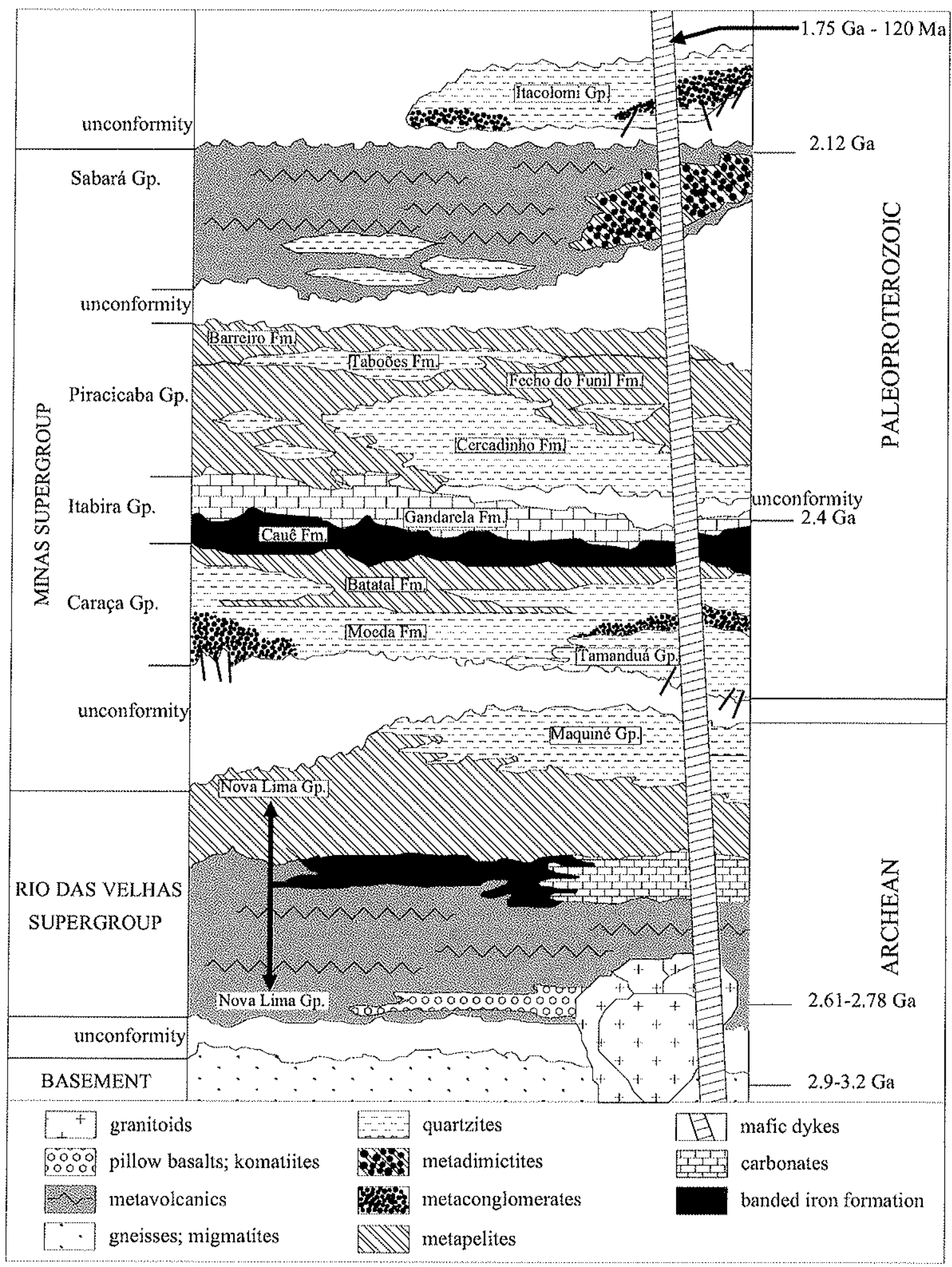

Figure 2 - Stratigraphic column of the Quadrilátero Ferrifero region. The right-hand portion of the column represents relationships in the eastern part of the Quadrilatero Ferrifero, while the left-hand side of the chart represents relationships in the western part of the Quadrilatero Ferrifero (After Alkmim et al., 1998, based on Dorr II, 1969; Schorscher et al., 1982 and Silva, 1992). 
The Minas Supergroup comprises clastic sediments of the Caraça Group at its base, which consist of an extensive quartzose (Moeda Formation) and argillaceous (Batatal Formation) formations. The Moeda Formation occurs in three facies: two alluvial coarse grained quartzite and conglomerate sediments, and a fine-grained marine quartzite and phyllite (Villaça, 1981). It is conformably overlain by the Batatal Formation, which consists of sericitic phyllite with minor graphitic phyllite. The Caraça Group is interpreted to be a transgressive sequence deposited over an old peneplaned surface (Villaça, 1981). The Moeda Formation was deposited under paralic to stable shelf environments while the Batatal Formation is an offshore sediment deposited on a slowly subsiding passive margin continental shelf or platform (Dorr II, 1969). The transition from clastic sediments of the Caraça Group to chemical sediments of the Itabira Group in the northern segment of the Serra do Curral is characterized by an argillaceous dolomite with lenses of metachert.

The Itabira Group comprises itabirites (BIFs) with minor dolomite and phyllite of the Cauê Formation and carbonate rocks of the Gandarela Formation. Both units are intergradational. Itabirites of the Cauê Formation are generally lithologically similar to most major oxide-facies BIFs known worldwide (Dorr II, 1969). Carbonate rocks of the Gandarela Formation include dolomites, limestones, dolomitic phyllite, dolomitic iron formation and phyllite. They were deposited in shallow water, and are locally rich in stromatolitic structures (Souza and Müller, 1984). $\mathrm{Pb}-\mathrm{Pb}$ dating of this stromatolitic dolomite yielded an age of $2420 \pm 19 \mathrm{Ma}$, which is considered by Babinski et al. (1995) as a depositional age. Based on this upper limit, and considering the $\mathrm{Pb}-\mathrm{Pb}$ ages on detrital zircons of the Moeda Formation which vary between 3.0 and $2.6 \mathrm{Ga}$, Babinski et al. (1995a) suggest that the deposition of the itabirites of the Itabira Group occurred between 2.6 and 2.4 Ga.

The upper unit of the Minas Supergroup is the Piracicaba Group, which consists of predominantly clastic sediments with minor chemical sediments deposited in marine shallow water and deltaic enviromments. The Piracicaba Group overlies the Itabira Group generally with structural conformity, but erosional disconformity has been locally found (Dorr II, 1969).

Although the tectonic history of the QF remains controversial (e.g. Alkmim and Marshak, 1998; Chemale Jr. et al., 1994; Davis and Hippert, 2000), there is a general consensus that the rocks of the Minas Supergroup were subjected to at least two main tectonic events during the Proterozoic. According to Chemale Jr. et al. (1994) the first event in the Transamazonian $(\sim 2.1$ Ma) was extensional and resulted in the formation of Archean granite-gneiss domes and nucleation of regional synclines in the overlying Rio das Velhas and Minas supergroups strata. 
The second event was compressional and of Brasiliano age ( $\sim 0.6 \mathrm{Ga})$. The Brasiliano event resulted in a west-verging fold-and-thrust belt causing inversion, amplification, translation and rotation of the basinal synclines, affecting mainly the eastern portion of the QF, and obliterating many of the tectonic features of the extensional event.

Two main structural domains are recognized at the QF: an eastern high strain domain with thick shear zones and important thrust systems, and a western low strain domain with well preserved synclines discontinuously cut by discrete shear zones and thrust faults (Rosière et al., 2001). The deformational gradient comes along with a metamorphic zoning which increases from west to east, and is defined by Herz (1978) as chlorite, biotite and staurolite zones. Pires (1995) redefined these metamorphic grade zones as grunerite, cummingtonite, actinolite and tremolite-antophyllite zones based on the compositional variation of the amphiboles of itabirite and phyllite of the Itabira Group. Equilibrium temperatures range from $300^{\circ} \mathrm{C}$ on the western side to $600{ }^{\circ} \mathrm{C}$ on the eastern side of the QF, with pressures ranging from 3 to $5 \mathrm{kbar}$ respectively (Pires, 1995).

\section{LOCAL GEOLOGY}

The Águas Claras mine is located at the northern segment of the Serra do Curral, a northeast-southwest trending $\sim 100 \mathrm{~km}$-long ridge that defines the northwest edge of the QF (Fig. 1). The Serra do Curral is a homocline, where bedding dips steeply to the southeast (Alkmim and Marshak, 1998; Chemale Jr. et al., 1994; Pires, 1979). Units of the Minas Supergroup crop out along most of its extension as an inverted sequence without repetition. At the northern segment of the Serra do Curral the rocks are very strained, sinistrally rotated from their original position, and beds are overturned (Chemale Jr. et al., 1994). Extensive shear zones occur at the contact between rocks of the Minas Supergroup and the Rio das Velhas Supergroup. In spite of being highly strained, the rocks of the Minas Supergroup were submitted only to green schist facies metamorphism (Pires, 1995).

At the Águas Claras mine, quartzite and phyllite of the Moeda and Batatal formations, and dolomite, itabirite and iron ore of the Cauê Formation crop out (Fig. 3a-b). The contact between these stratigraphic units is gradational. Quartzite and phyllite occur on the south wall of the pit, and cap the iron orebody (Fig. 3a). The gradational contact between the Moeda and the Batatal Formations is initially marked by interfingered lenses of coarse and fine quartzite. Upper on the sequence, lenses of fine quartzite occur interlayered with sericitic phyllite, which becomes 
predominant. Lenses of graphitic pyhillite with porphyroblasts of pyrite occur locally, interlayered within the sericitic phyllite.
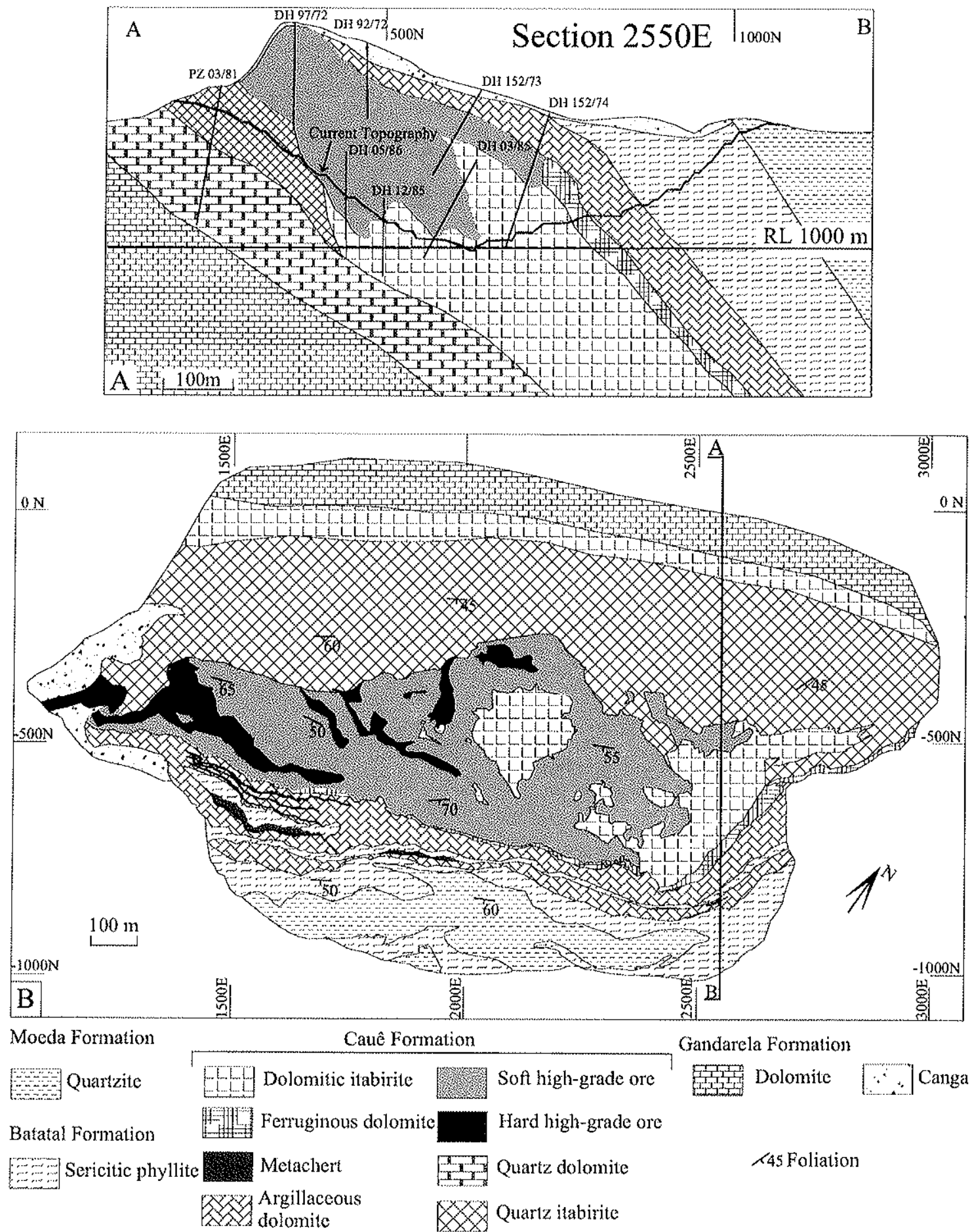

Figure 3 - Águas Claras mine. A Cross section 2550E. B Geological sketch map. 
The contact between clastic sediments of the Batatal Formation and chemical sediments of the Caue Formation is gradational over a few centimeters. It is marked by the appearance of dolomite in the Batatal Formation. Dolomite content increases markedly upwards in the Cauê Formation to form an argillaceous dolomite. Argillaceous dolomite is considered to be the base of the Cauê Formation at the Águas Claras mine. A black color and fine grained and anisotropic fabric characterize argillaceous dolomite. Lenses of metachert ranging in thickness from tens of centimeters to meters occur within the argillaceous dolomite. Within the argillaceous dolomite these lenses of metachert gradate to quartz itabirite. This is the first appearance of BIF within the Cauê Formation. It is distinguished from other BIFs in the QF by its high magnetism. Figure 4 shows detail of the transition from the Batatal to the Caue Formation, including the main lithotypes.

The contact between argillaceous dolomite and dolomitic itabirite is characterized by a complex transition zone of aproximately $10 \mathrm{~m}$ wide, where argillaceous dolomite, ferruginous dolomite and minor metachert/quartz itabirite occur interlayered. Within this transition zone a 50 $\mathrm{cm}$ to $1.2 \mathrm{~m}$ layer of ferruginous dolomite with peloids and sub-angular fragments of quartz itabirite cemented by dolomite is observed (Fig. 5). This rock, a typical Granular Iron Formation (GIF) in accordance with Trendall's (2002) description, is described at the QF for the first time. The quartz itabirite from which the fragments observed at the GIF were originated crops out within a few meters, and it is possible to accompany the lateral transition from BIF to GIF. Transitions between BIFs and GIFs are uncommon in the global stratigraphic record (Beukes and Klein, 1990). They are only described at the transition zone between the microbanded Kuruman Iron Formation and the granular Griquatown Iron Formation, both of the Lower Proterozoic of the Transvaal basin (Beukes, 1980; Beukes, 1984) and at iron formations of the Frere Formation of the Lower Proterozoic of the Naberru basin, Western Australia (Goode et al., 1983).

$\mathrm{A} \sim 6 \mathrm{~m}$-thick layer of ferruginous dolomite, characterized by a strong red color, within the uppermost part of the transition zone is overlain by dolomitic itabirite. The high proportion of microcrystalline hematite (see petrography below) is responsible for the strong red color of the ferruginous dolomite. Microcrystalline hematite producing these striking red colours is also observed in the dolomitic bands of the itabirite.

The appearance of iron mineral bands, typical of itabirite and other BIF's marks the transition from ferruginous dolomite to the dolomitic itabirite. This banding corresponds to the mesobanding of the BIF of the Hamersley basin defined by Trendall and Blockley (1970). Initially, dolomitic bands are thicker than the iron-rich mesobands (Fig. 6a). The former are one 


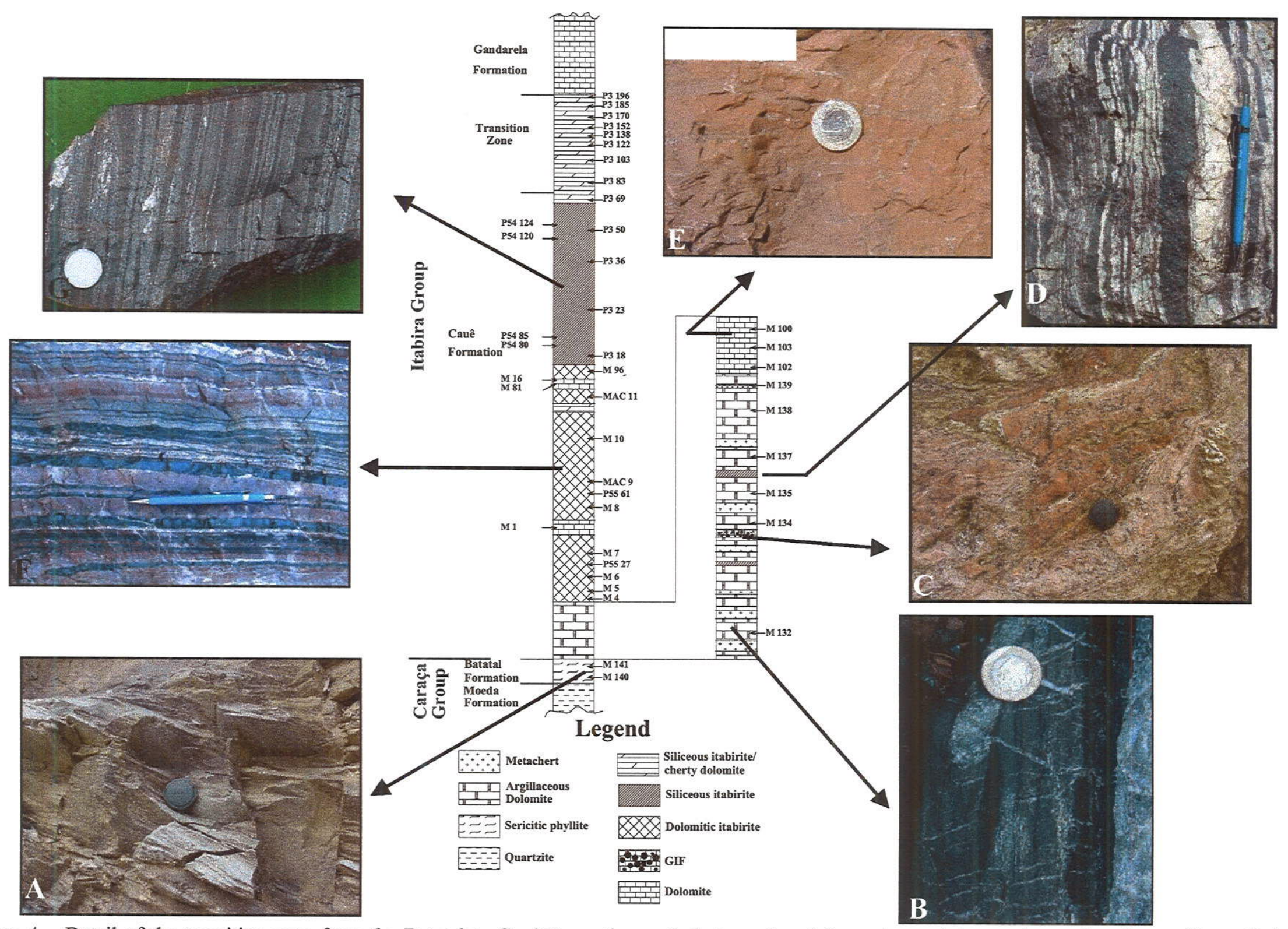

Figure 4 - Detail of the transition zone from the Batatal to Cauê Formation and photographs of the major rock types observed at the profile studied. A Sericitic phyllite. B Argillaceous dolomite. C Granular iron formation (GIF). D Quartz itabirite within argillaceous dolomite. E Ferruginous dolomite. F Dolomitic itabirite. G Quartz itabirite. 
centimeter to tens of centimeters thick and vary from deep red to pink, while iron-rich bands are generally one millimeter to three centimetres thick and grey. Approximately $50 \mathrm{~m}$ from the base of the dolomitic itabirite, dolomitic bands become thinner forming a more typical dolomitic itabirite. Typical dolomitic itabirite exhibits alternating millimeter thick dolomite and hematite bands (Fig. $6 \mathrm{~b}$ ). After $\sim 250 \mathrm{~m}$ of typical dolomitic itabirite, hematitic bands gradually disappear forming a ferruginous dolomite, which is similar to that present at the base of the Itabira Group.

Within the mining pit dolomitic itabirite is much more common than quartz itabirite, which occurs only on the north wall on the top of the sequence (Fig. 3a). The contact between both rocks is gradational and marked by small lenses of quartz itabirite within the dolomitic itabirite. Drill core indicates this contact zone contains a triply layered rock with alternating bands of quartz, iron minerals and dolomite (Fig. 6c). Outside this contact zone the quartz itabirite exhibits the typical mesobanding of quartz and iron minerals (Fig. 6d).

The transition from the quartz itabirite to the carbonate rocks of the Gandarela Formation, which was observed in drill cores, is also gradational. The gradual appearance of dolomite and the disappearance of hematite and inherent loss of the typical mesoband texture of itabirite characterize the transition zone from quartz itabirite to carbonates. Although the dolomitic itabirite and the iron ore occur throughout the whole length of the mine along the contact with the Batatal Formation, some exploratory drills completed outside of the pit found only quartz itabirite at this equivalent stratigraphic position. This indicates that the transition from dolomitic itabirite to quartz itabirite occurs not only vertically, but also laterally along the Caue Formation.

The dolomitic itabirite is locally brecciated, with clasts formed either by the hematitic bands or by the dolomitic bands cemented by white carbonate. Some of these breccias suggest a synsedimentary origin, others, however, are typically associated with tensional gash veins (Fig. 6e). Several generations of carbonate veins varying from millimeter to tens of centimeters in width crosscut or parallel banding. Some of these veins were affected by the same deformational events which affected the itabirites (Fig. 6f).

The orebody is a concordant, $2.500 \mathrm{~m}$ long, roughly tabular-shaped lens which occurs within the dolomitic itabirite with a maximum thickness of $300 \mathrm{~m}$. The depth of the ore is variable and extends to over $400 \mathrm{~m}$ below the surface, then grading into the parental dolomitic itabirite deeper down (Fig. 3a). The iron ore is typically soft (friable) and consists of almost pure hematite, with very low levels of contaminants $\left(\mathrm{Fe}_{2} \mathrm{O}_{3}>98 \%\right)$. The soft ore was formed by leaching of the dolomite from the parental rock by supergene processes fluids and the consequent residual 
enrichment of the rock (Spier et al., 2003; Viel et al., 1987). For additional information concerning the genesis of this type of ore refer to Spier et al. (2003).
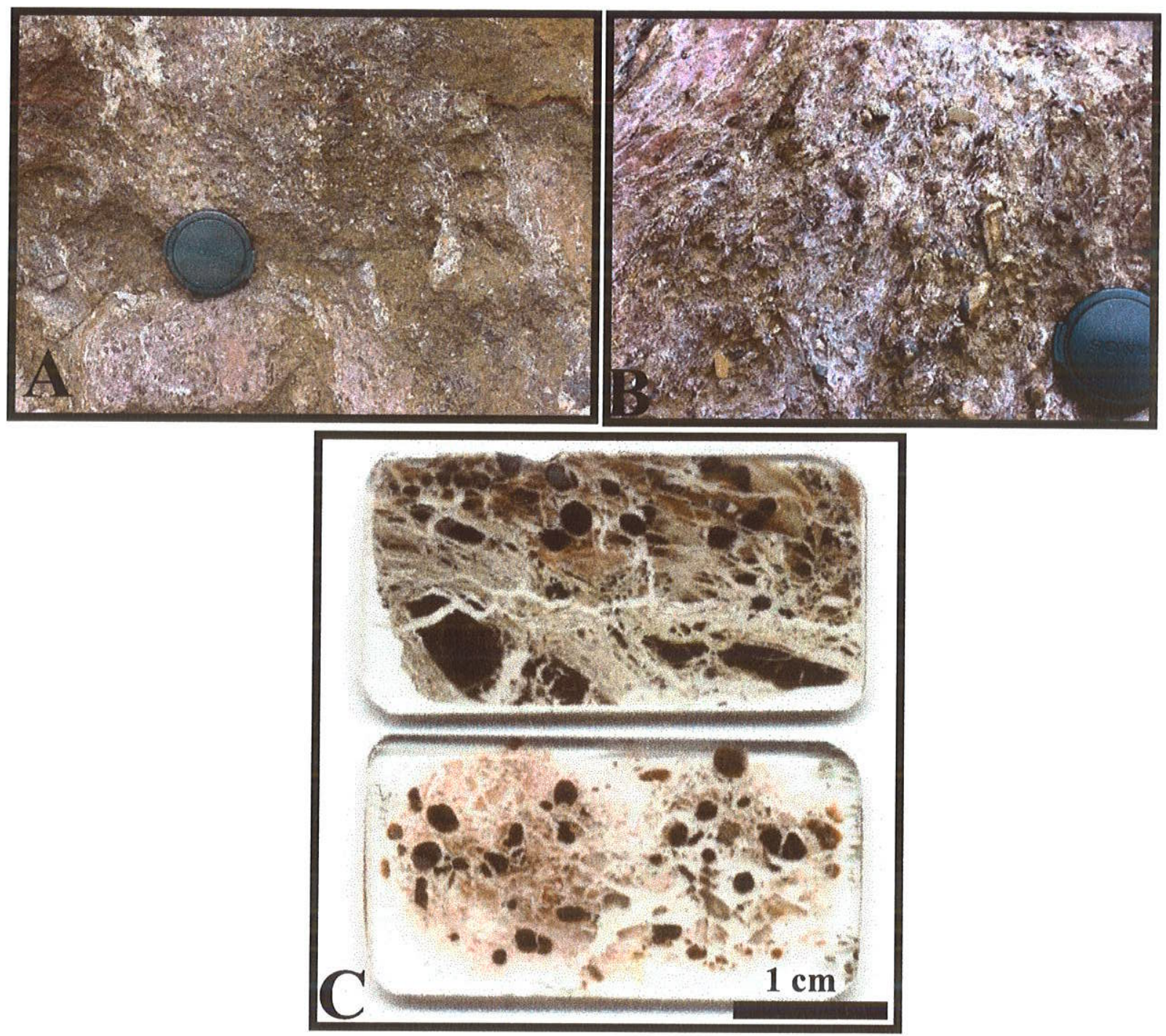

Figure 5 - Photographs of Granular Iron Formation (GIF). A Outcrop showing peloids and intraclasts cemented by dolomite and sericite/chlorite. B Detail of the GIF. C Thin section showing peloids and intraclasts cemented by dolomite and sericite/chlorite and cut by secondary dolomite and quartz veins. 

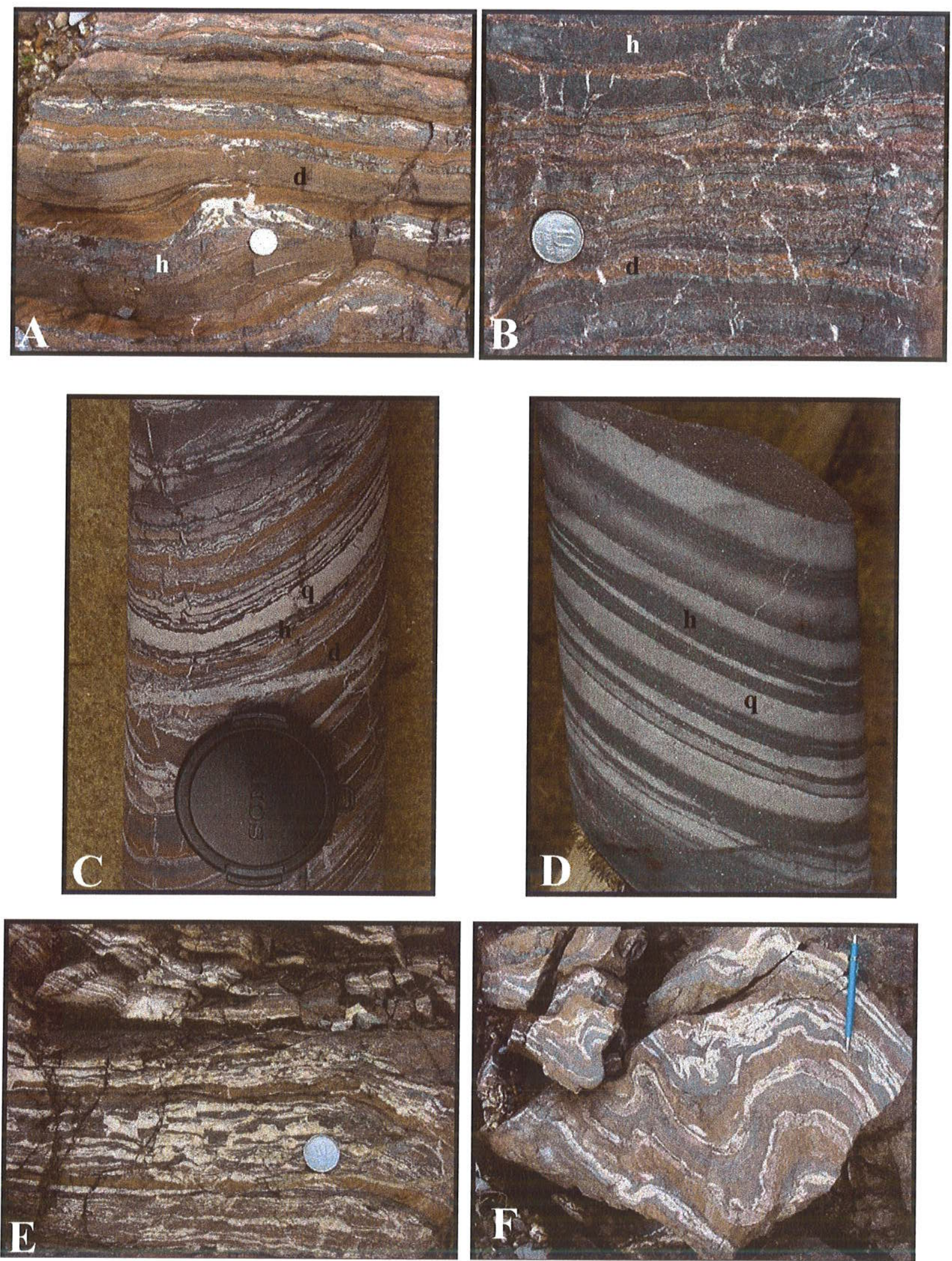

Figure 6 - Photographs of itabirites of the Cauê Formation. A Hand specimen of dolomitic itabirite showing thick dolomite mesobands. B Hand specimen of typical dolomitic itabirite. C Drill core sample of triply layered itabirite showing mesobands of dolomite $(d)$, hematite $(h)$ and quartz $(q)$. D Drill core sample of typical quartz itabirite. E Brecciated dolomitic itabirite with clasts of hematite and dolomite cemented by secondary dolomite. F Hand specimen of folded dolomitic itabirite. Secondary dolomite lens are parallel to the mesobanding. 


\section{SAMPLING AND ANALYTICAL PROCEDURES}

Thirty four samples of dolomite and itabirite of the Cauê Formation, the locations of which are shown in Figure 4, were analyzed for major, traces and rare earth elements (REE). Six samples of dolomitic itabirite had the hematitic and dolomitic bands analyzed separately. Two samples of sericitic phyllite of the Batatal Formation were also analyzed to assess the chemistry of a potentially clastic contaminant of the chemical sediments. Some samples were also analyzed for total graphitic and organic carbon. The majority of the sampling was performed at Section 2.550 E (Fig. 3), along a $\sim 300 \mathrm{~m}$ section of the $1010 \mathrm{~m}$ bench. Bench 1010 is located more than $200 \mathrm{~m}$ from the current land surface. Itabirite at bench 1010 is not altered by weathering processes and therefore provides the best samples for chemical analysis. A representative suite of rocks from the base to the top of the Caue Formation was collected. Samples of quartz itabirite and dolomite from the transition zone to the Gandarela Formation were collected in drill cores of the drill hole P3 in this same section. Additional samples of dolomitic and quartz itabirite were collected in drill cores P55 and P54 in the neighboring area of Section 2550E.

To avoid bias sampling (i.e., extreme bimodal compositional variation of the itabirite, typical of BIFs everywhere) larger samples of three to five kilograms comprising several couplets of mesobands of iron minerals and dolomite/quartz were selected for bulk analysis. We avoided samples with carbonate or quartz veins to reduce the possibility of contamination. Six samples of dolomitic itabirite were crushed in a tungsten carbide ringmill and $<0.15 \mathrm{~mm}$ fraction of the hematite-rich bands was collected by sieving. The grains were visually inspected under a binocular microscope and handpicked. We prefered to analyze six different samples of visually pure dolomitic bands to ensure pure separates for chemical analysis, and to accentuate the chemical differences between mesobands.

All samples were prepared for analysis by grinding in a tungsten carbide vessel, and because this method causes contamination by W, $\mathrm{Co}$ and $\mathrm{Ta}$, these elements are not reported. Chemical analyses were carried out at the Activation Laboratories - ACTLABS in Canada. Major and trace elements were determined by ICP/ICP-MS after the opening of the sample with a lithium tetraborate/metaborate fusion. Base metals were determined by ICP-MS/INAA after total diggestion by acid attack. Ferrous iron was determined at the laboratories of MBR by titration potassium dichromate.

Forty two samples of dolomitic bands of dolomitic itabirite were analyzed for carbon and oxygen isotopes. Fragments from thicker mesobands $(>1 \mathrm{~cm})$ weighing $\sim 200 \mathrm{~g}$ were collected 
approximately $10 \mathrm{~m}$ from the base to the top of the sequence along Section $2550 \mathrm{E}$. Dolomite samples $(\sim 200 \mathrm{~g})$ were also collected along a vertical section of Section $2550 \mathrm{E}$, while avoiding potentially contaminating hematitic bands. Isotopic analyses were carried out at the Stable Isotope Laboratory of the Federal University of Pernambuco - NEG-LABISE. $\mathrm{CO}_{2}$ gas was extracted from powdered carbonates in a high vacuum line after reaction with $100 \%$ phosphoric acid at $25^{\circ} \mathrm{C}$ for three days, and then cryogenically cleaned according to the method described by $\mathrm{McCrea}(1950)$. The $\mathrm{CO}_{2}$ gas released was analyzed for $\mathrm{O}$ and $\mathrm{C}$ isotopes in a double inlet, triple collector SIRA mass spectrometer, using the BSC reference gas (Borborema skarn calcite) that was calibrated against NBS-18, NBS-19 and NBS-20 standards, and has $\delta^{18} \mathrm{O}$ value of $-11.28 \%$ opd and $\delta^{13} \mathrm{C}$ of $-8.58 \%$ opdB. The precision of the method has been assessed by repeated analyses of the BSC reference gas, and the accuracy by comparison of NBS standard measurements. The results are expressed in the notation \%o (per mil) in relation to PeeDee belemnite (PDB).

Detailed petrographic examination using transmitted and reflected light, scanning electron microscopy (SEM) and electron microscopy analyses (EMP) were carried out to determine the mineralogy and paragenesis of all samples. SEM and EMP analyses were performed at the laboratories of the Geoscience Institute of the University of São Paulo and at the Center for Microscopy and Microanalyses of the University of Queensland, Australia. EMP analyses of dolomite were performed using a JEOL JXA-8600 electron microprobe operating at $15 \mathrm{kv}$ and $20 \eta \mathrm{A}$ current with a focussed $5 \mu \mathrm{m}$ electron beam.

For purposes of data presentation and discussion, the samples analyzed have been divided into five groups on the basis of their chemical compositions and mineral assemblages, as shown in Figure 7. These include: (I) sericitic phyllite; (II) argillaceous dolomite; (III) dolomitic itabirite; (IV) quartz itabirite, and (V) quartz-carbonate rocks (transition from Cauê to Gandarela Formations). The argillaceous dolomite was chosen as the representative lithotype of the transition zone to the dolomitic itabirite for comparison with other rocks of the Cauê Formation as it is the major lithotype of this zone and hosts both the subordinated metachert and the quartz itabirite. A limit of $2 \% \mathrm{SiO}_{2}$ is defined to separate dolomitic from quartz itabirite. We avoided sampling mixed dolomitic and quartz itabirite types to facilitate this separation. A limit of $2 \%$ $\mathrm{CaO}$ separates quartz itabirite from quartz-carbonate rocks of the transition to the Gandarela Formation. This suite of samples, described above, is the most complete chemical database of the Cauê Formation published to this date. 


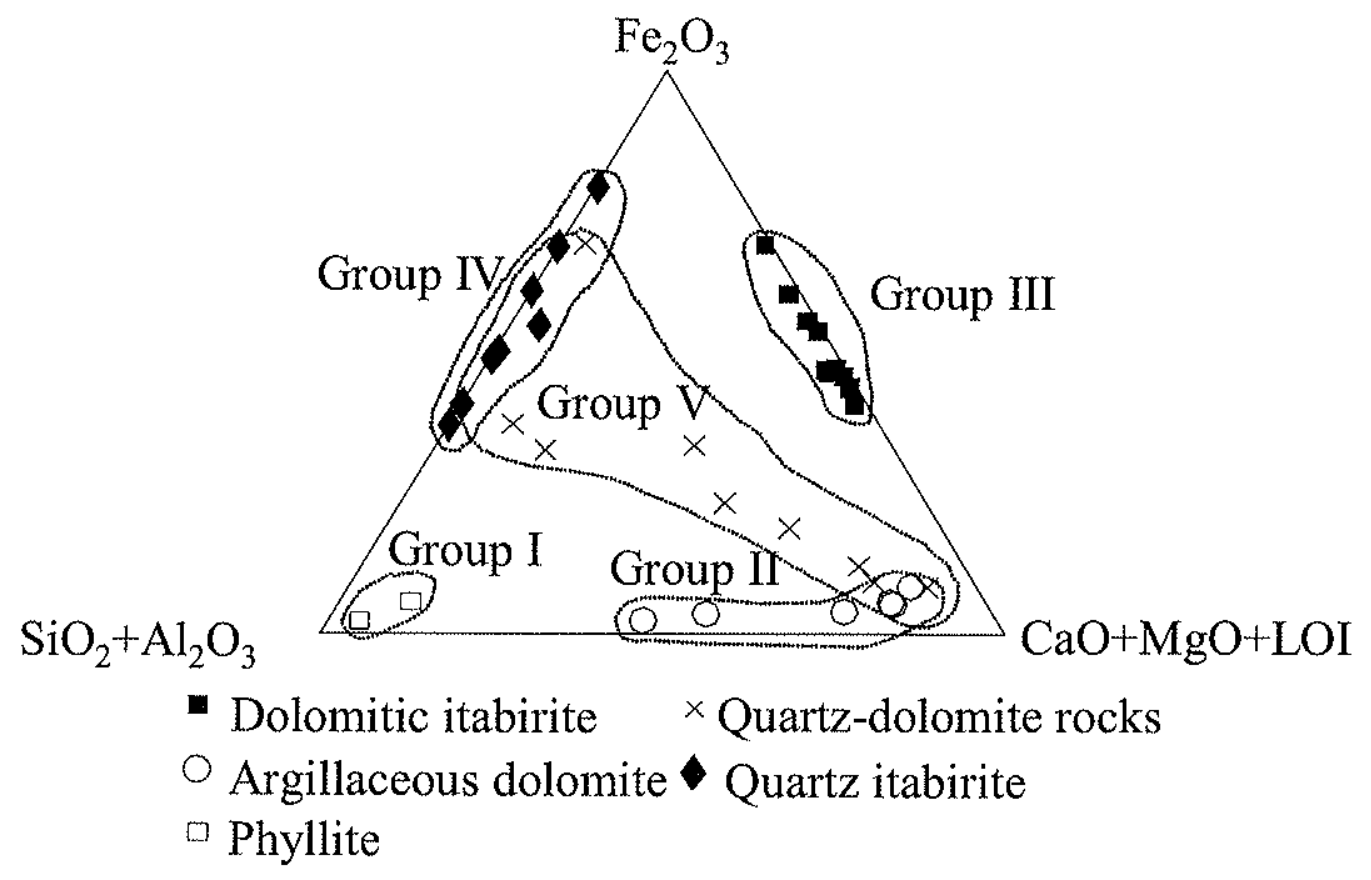

Figure 7 - Triangular diagram showing major element composition of the samples studied, grouped into five major groups.

\section{MINERALOGY AND PETROGRAPHY}

\section{Sericitic Phyllite}

Sericitic phyllite is a uniformly dark-grey very fine-grained phyllite (Fig. 4a). It is laminated on a fine scale (1-3 mm thick) and consists of quartz and sericite with minor biotite, and shows a lepidoblastic texture with foliation defined by sericite and biotite. Large porphyroclasts of quartz surrounded by sericite and quartz exhibting wavy extinction indicate strong deformation that this rock was submitted.

\section{Argillaceous Dolomite}

Argillaceous dolomite is a black, very fine-grained impure dolomite (Fig. 4b). Local geologists name this rock dolomitic phyllite because when weathered, argillaceous dolomite resembles a phyllite. However, the high dolomite content and absence of any well-defined lamination do not allow for the use of the term phyllite. Mineralogically, the argillaceous dolomite comprises dolomite (> $85 \%$ ), chlorite with minor quartz and rare pyrite (Fig. 8a-c). Quartz occurs as aggregates showing strong wavy extinction. The absence of hematite and 
magnetite in argillaceous dolomite distinguishes this rock from the overlying ferruginous dolomite. Argillaceous dolomite is strongly deformed and poorly foliated.

\section{Granular Iron Formation}

Granular iron formation is restricted to a one meter long lens which persists laterally for tens of meters along the top of the argillaceous dolomite. Generally, it is not internally banded, but coarsening reducing clasts size is locally observed. The granular texture comprises hematite clasts set in a cement or matrix of dolomite, sericite and chlorite (Fig. 5a-c). The clastic fraction is usually peloidal, but may contain angular intraclasts of hematite-rich bands of itabirite. The peloids are rounded, subspherical grains of either itabirite or dolomite ranging from 0.2 to $5 \mathrm{~mm}$ in diameter. Some peloids contain concentric layers of hematite (Fig. 8f). Angular fragments are lithologically similar to itabirite and form tabular fragments up to two centimeters long although smaller ones may be rounded and graded into peloids. Although the GIF is not weathered, indicated by the preservation of carbonate cement, the clasts are strongly goethitized, which poses a very intriguing question.

\section{Ferruginous Dolomite}

Ferruginous dolomite occurs at the base and top of the dolomitic itabirite, and as meter thick layers randomly distributed within the dolomitic itabirite. Macroscopically and microscopically the ferruginous dolomite resembles the dolomite bands of the dolomitic itabirite, but lacks larger crystals of tabular hematite and martite common to dolomitic itabirite. Ferruginous dolomite is deep red to pink, very fine-grained, and poorly banded (Fig. 4e). It consists of small crystals of dolomite (average grain size of $15 \mu \mathrm{m}$ ) with micrometer size inclusions of hematite, which appear dust-like within the dolomite crystals (Fig. 9a). These hematite inclusions are responsible for the strong red color of the rock. They are generally concentrated on the nuclei of the dolomite crystals (Fig. 9b). Talc, chlorite and apatite occur as accessory phases. 

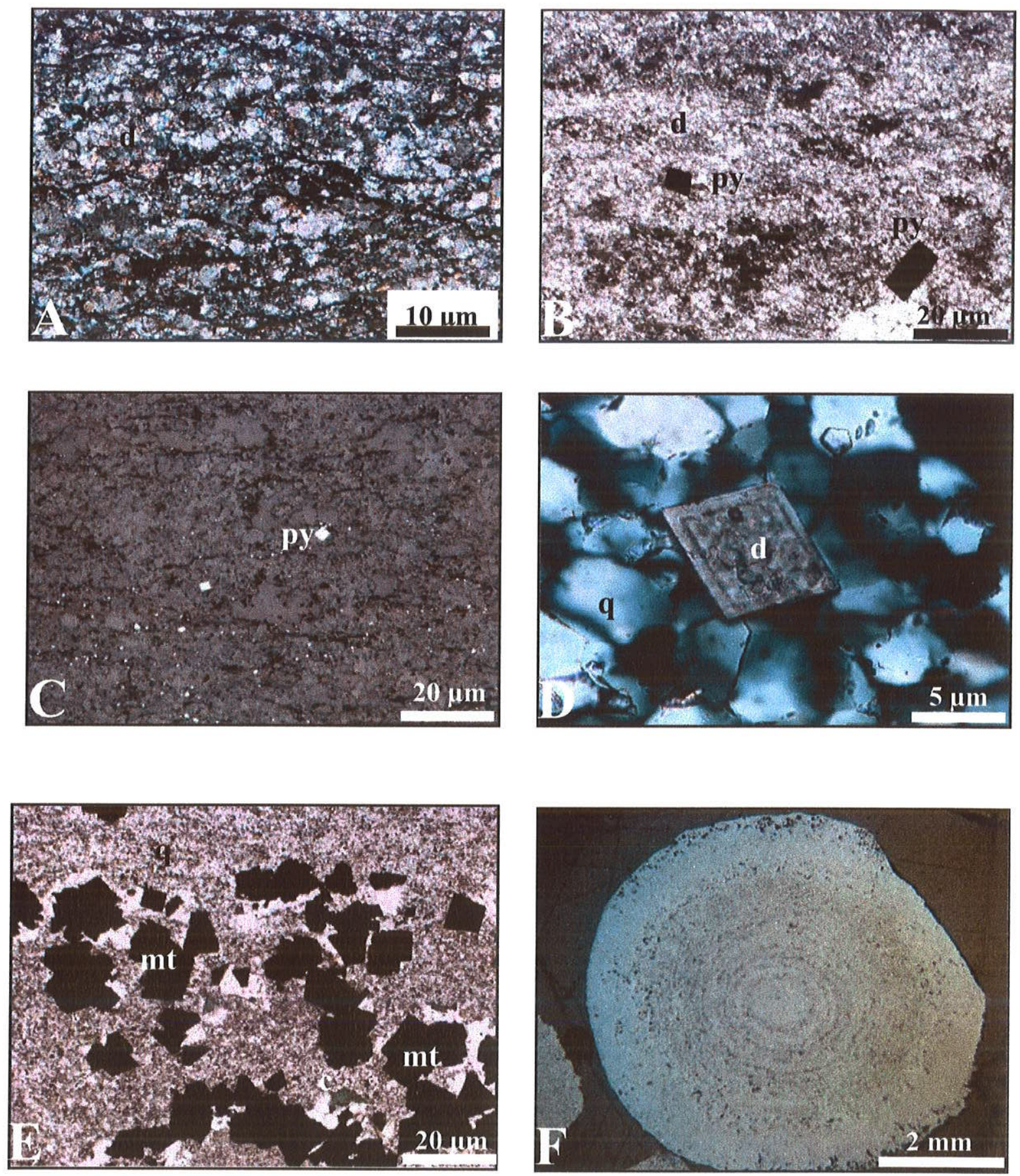

Figure 8 - Photomicrographs of various rock types of the base of the Cauê Formation. A Argillaceous dolomite; plane polarized light, $(d=$ dolomite). B and $\mathbf{C}$ Pyrite $(p y)$ crystals in argillaceous dolomite; transmitted light - B, reflected light - C. D Dolomite crystals in metachert; plane polarized light. E Quartz itabirite; transmitted light, ( $q=$ quartz). Note the shapes of martitized magnetite $(m)$ and the associated chlorite $(c)$. F Peloids within GIF. 

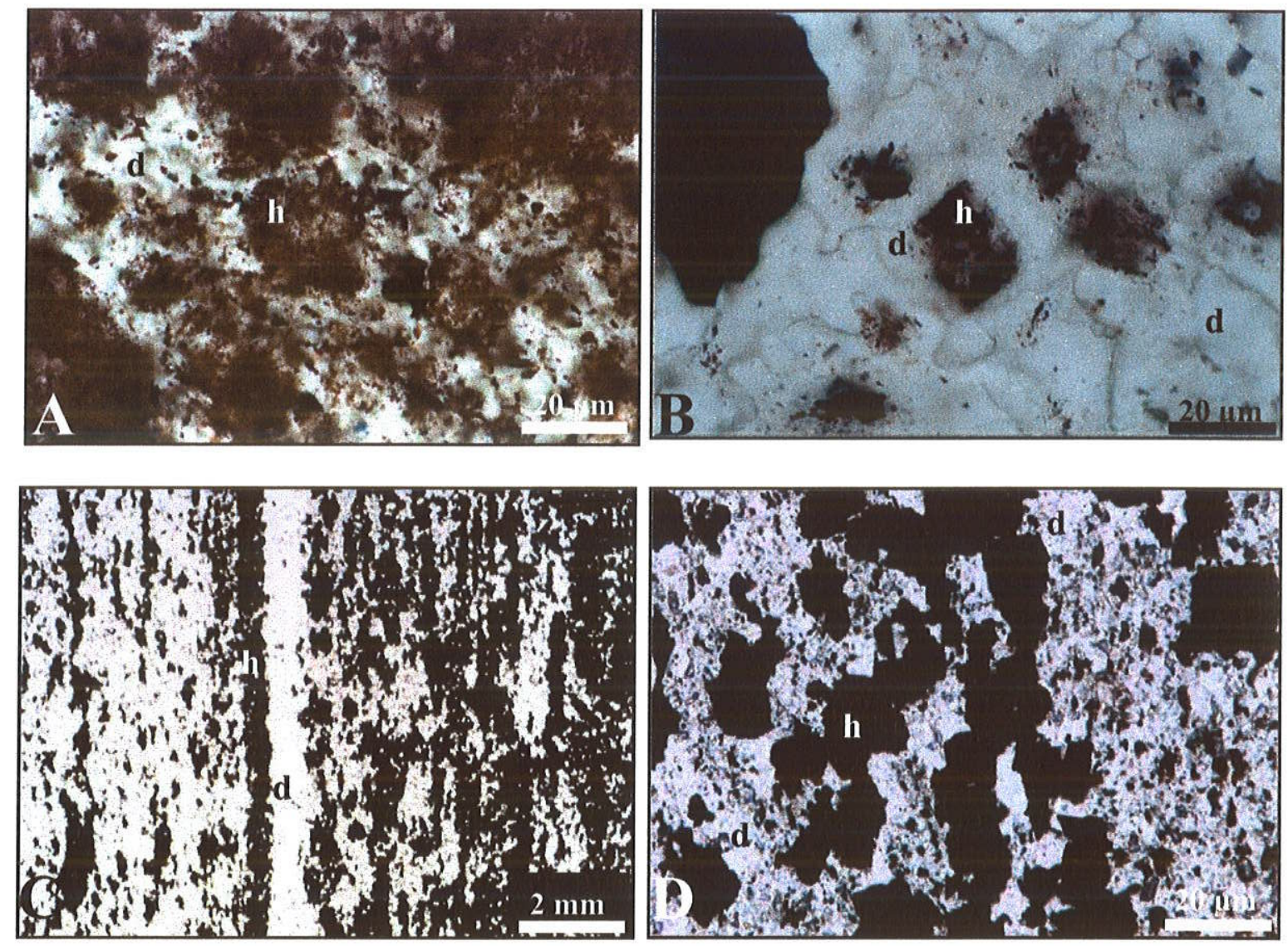

Figure 9 - Photomicrographs of the dolomitic itabirite; transmitted light. A Inclusions of hematite microcrystals within dolomite crystals forming a dust. B Inclusions of hematite microcrystals concentrated within the nuclei of the dolomite crystals which show clean rims. C Microbanding of dolomite-rich and hematite rich laminae; transmitted light. D Detail of the dolomite-rich microband. Euhedral crystals of martite $(m)$ between the dolomite crystals $(d)$; transmitted light.

\section{Dolomitic and Quartz itabirites}

Mesobanding is the most striking macroscopic characteristic of itabirites at the QF. Mesobanding is defined by alternating millimeter to decimeter hematite rich bands and dolomite/quartz bands (Fig. 6b-d). Microbanding defined by alternating sub-millimeter hematite and dolomite/quartz laminas are commonly observed within mesobands of itabirites (Fig. 9c). In dolomitic itabirite, the dolomitic bands consist largely of dolomite and up to $40 \%$ hematite (Fig. 9d). Talc, chlorite and apatite occur as accessory minerals. Thin laminas of apatite parallel to banding are locally observed (Fig. 10a). Dolomite occurs as euhedral crystals varying from $2 \mu \mathrm{m}$ to $15 \mu \mathrm{m}$ intergrown with hematite and accessory minerals (Fig. 10b). Like the ferruginous dolomite, micrometer hematite inclusions form an iron dust within dolomite crystals (Fig. 9a). Hematite in itabirites occurs as martite (pseudomorphs of magnetite after oxidation), tabular 
hematite and, locally, specularite. Specularite occurs along shear planes, parallel to or truncating the banding. The hematitic bands are largely comprised of hematite with up to $20 \%$ dolomite and traces of talc, chlorite and apatite (Fig. 10 c-d). Hematite occurs as dense aggregates of martite and tabular hematite with individual grains varying from $5 \mu \mathrm{m}$ to $10 \mu \mathrm{m}$. Thicker hematite bands preserve relict magnetite within martite crystals.

Quartz itabirite is macroscopically and texturally similar to dolomitic itabirite, but mesobands rich of quartz replace dolomite (Figs. 10e, 11a-b). Quartz is generally clean, without hematite inclusions, and exhibits wavy extinction. Relicts of magnetite are locally observed within martite crystals (Fig. 11c-d). When present, dolomite occurs intergrown with quartz (Fig. 10f). Apatite, chlorite and sericite occur as accessory phases intergrown with quartz and hematite (Fig. 10 g-h) and, locally, as fine inclusions within quartz (Fig. 11 e-f). The grain size of all minerals is very fine ( $5 \mu \mathrm{m}$ to $25 \mu \mathrm{m}$ ). Quartz bands of the quartz itabirite consist of quartz with varying proportions of hematite (up to $25 \%$ ) and accessory minerals (i.e., apatite, chlorite and sericite). Hematite-rich mesobands consist of dense aggregates of hematite with up to $15 \%$ of quartz.

\section{Quartz-Carbonate Rocks of the Transition Zone to the Gandarela Formation}

This group of rocks comprises quartz itabirite bearing dolomite, cherty dolomite and dolomite that occurs overlying quartz itabirite at the transition zone to the Gandarela Formation. The gradual appearance of dolomite and the disappearance of quartz and hematite in the quartz itabirite characterize this group. Micro and mesobanding typical of itabirites is replaced by a poor banding defined by micaceous minerals. The typical dolomite of this zone consists of very fine dolomite (average size of $15 \mu \mathrm{m}$ ) with accessory sericite, chlorite and hematite (Fig. 11g). Locally the dolomite is enriched with chlorite, which comprises up to $30 \%$ of the rock. Chlorite occurs as thin, millimeter laminas, which define conspicuous microbands (Fig. 11h). Talc with minor chlorite and hematite form thin veins that crosscut these chlorite-rich bands.

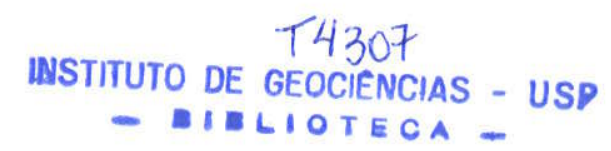



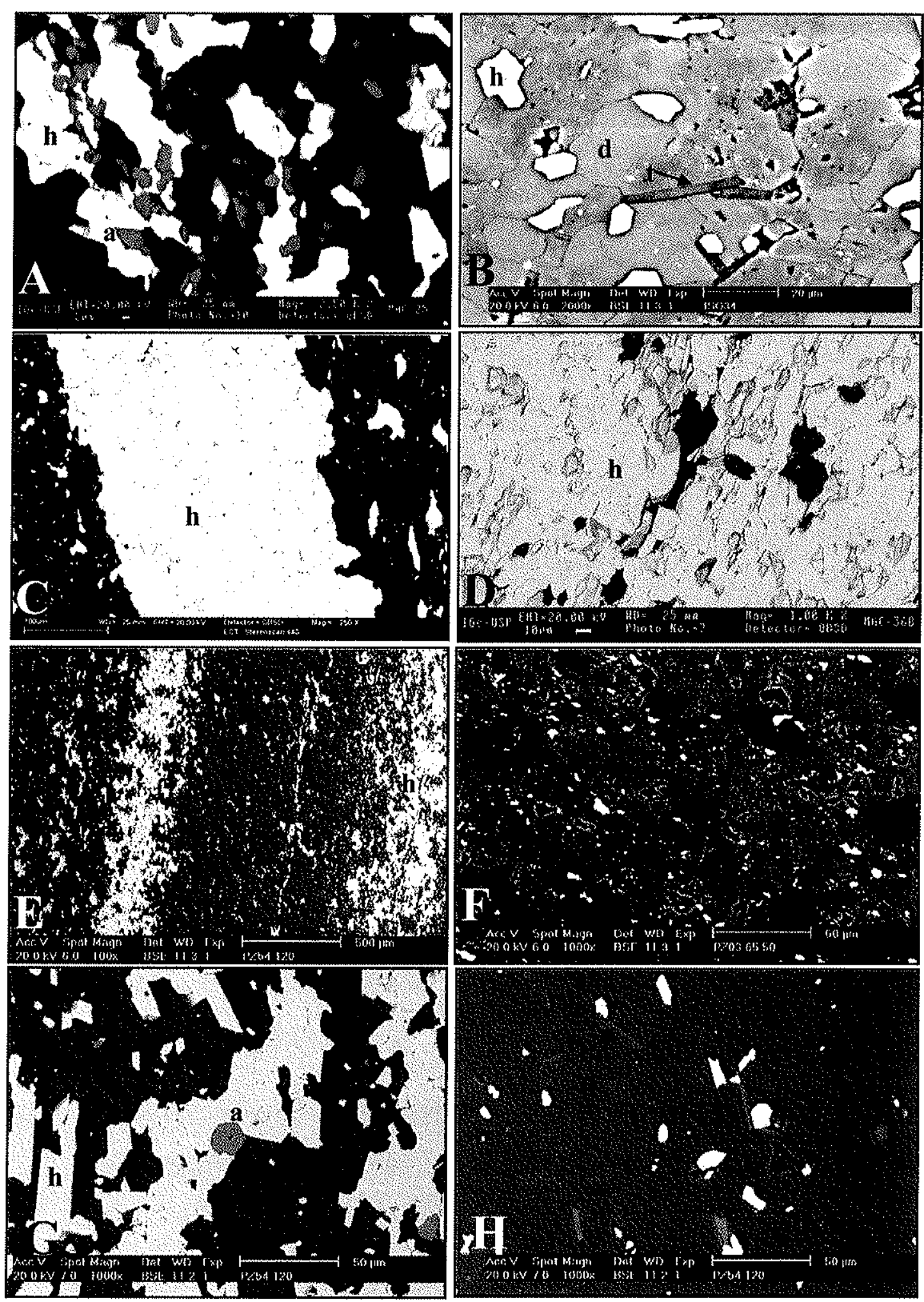

Figure 10 - SEM images of dolomitic and quartz itabirite. $\mathbf{A}$ and $\mathbf{B}$ Dolomite-rich microband of dolomitic itabirite. In $\mathbf{A}$ dolomite crystals $(d)$ are intergrown with apatite $(a)$ and martite/granular hematite $(h)$. In $\mathbf{B}$ dolomite crystals $(d)$ are intergrown with talc $(t)$. C Hematite rich microband of dolomitic itabirite. D Detail of the hematite rich microbanding showing intergrown of martite and granular/tabular hematite $(h)$ with dolomite $(d)$. E Microbanding of quartz-rich and hematite-rich laminae in quartz itabirite. F - H Detail of a quartz-rich microband of quartz itabirite showing in $\mathbf{F}$ intergrown of quartz $(q)$, hematite (h) and dolomite $(d)$, in $\mathbf{G}$ intergrown of quartz $(q)$, martite/tabular hematite $(h)$ and apatite $(a)$, in $\mathbf{H}$ intergrown of quartz $(q)$, hematite $(h)$, sericite $(s)$, chlorite $(c)$ and dolomite $(d)$. 

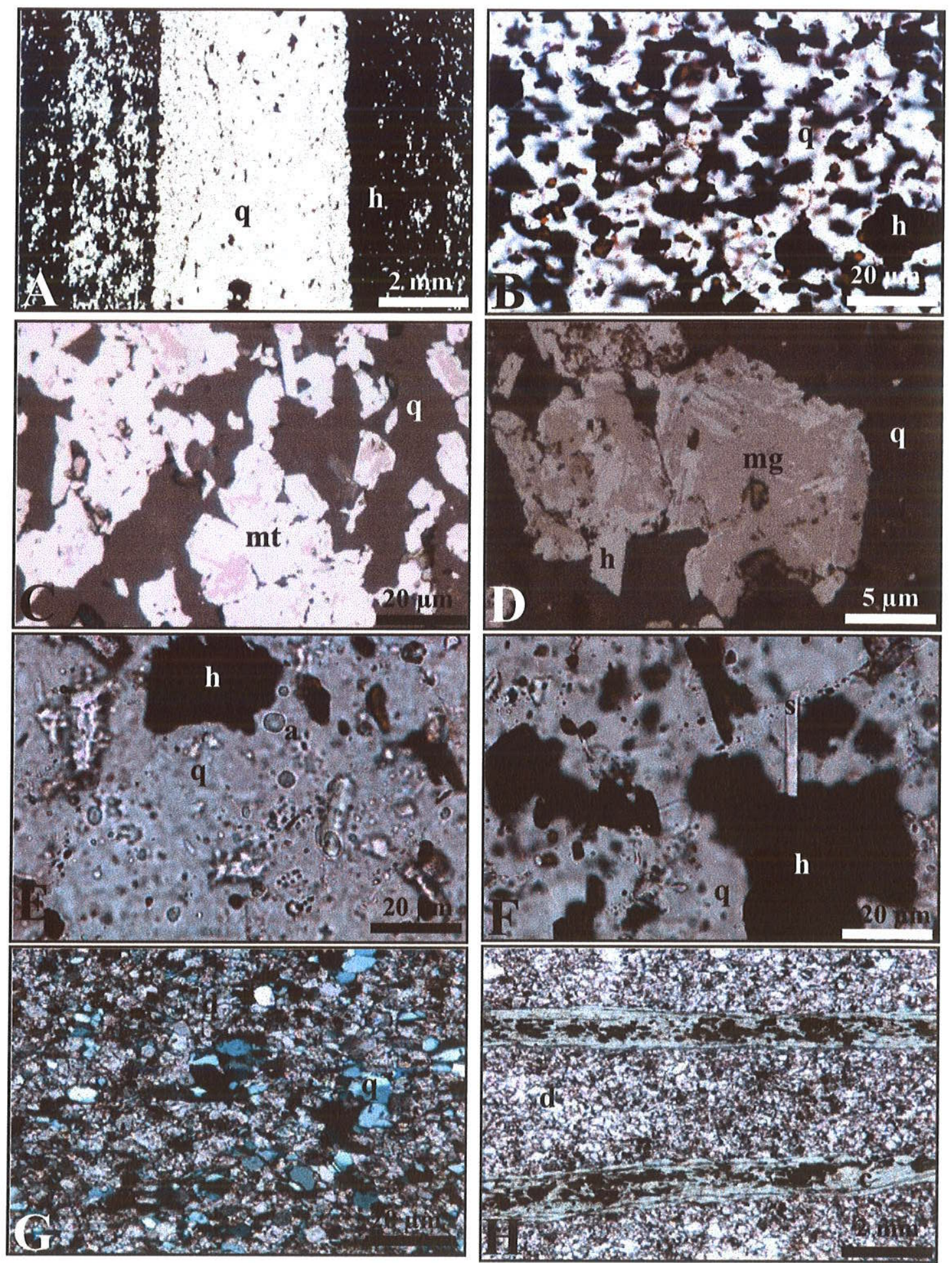

Figure 11 - Photomicrographs of quartz itabirite and dolomite of the transition zone to the Gandarela Formation. A Microbanding of quartz-rich and hematite-rich laminae; transmitted light. B Detail of a quartz-rich laminae of quartz itabirite showing intergrown of quartz $(q)$ and hematite $(h)$; transmitted light. C Relicts of magnetite $(\mathrm{mg})$ within martite; reflected light. D Detail of a martite crystal showing oxidation of magnetite; reflected light. $\mathbf{E}-\mathbf{F}$ Detail of a quartz-rich laminae of quartz itabirite showing in $\mathbf{E}$ intergrown of quartz $(q)$, apatite $(a)$ and hematite $(h)$; in $\mathbf{F}$ intergrown of quartz $(q)$, hematite $(\mathrm{h})$ and sericite $(s)$. $\mathbf{G}-\mathbf{H}$ Dolomite of the transition zone to the Gandarela Formation, showing in $\mathbf{G}$ intergrown of dolomite $(d)$, quartz $(q)$ and hematite $(h)$, plane polarized light; in $\mathbf{F}$ laminaes of chlorite $(c)$ and hematite (black minerals within laminaes), transmitted light. 


\section{Mineral Chemistry}

Electron microprobe analyses of twenty six carbonate samples of the argillaceous dolomite, ferruginous dolomite, itabiritic dolomite and dolomite of the transition zone to the Gandarela Formation indicates the dolomite has approximately $1 \mathrm{Ca}: 1 \mathrm{Mg}$ ratio and average $\mathrm{CaO}$ and $\mathrm{MgO}$ contents ranging from $29.6 \%$ to $30.5 \%$, and from $18.4 \%$ to $20.6 \%$, respectively. $\mathrm{FeO}$ and $\mathrm{MnO}$ contents are low, averaging $3.7 \%$ to $1.0 \% \mathrm{FeO}$ and $0.5 \%$ to $0.9 \% \mathrm{MnO}$, respectively. Table 1 summarizes the EMP analyses. The complete dataset is available from the authors as electronic data.

The dolomite composition changes at the transition from argillaceous dolomite to dolomitic itabirite (Fig. 12). Dolomite of the argillaceous dolomite is richer in $\mathrm{FeO}$ and poorer in $\mathrm{MgO}$ contents than dolomite of the overlying rocks. Dolomite of the dolomitic itabirite has very uniform composition through the $300 \mathrm{~m}$ of the sampled profile. $\mathrm{Ca}: \mathrm{Mg}$ and $\mathrm{Ca} /(\mathrm{Fe}+\mathrm{Mn})$ ratios remain almost constant around $1: 1$ and 20:1 respectively, from the base to the top of the sequence. A little difference in composition is observed only on the dolomite of the transition zone to the Gandarela Formation, which has a higher FeO and $\mathrm{MnO}$ contents, of up to $5.1 \%$ and $1.8 \%$, respectively.

\begin{tabular}{|c|c|c|c|c|}
\hline & $\begin{array}{c}\text { Argillaceous } \\
\text { Dolomite } \\
(\mathrm{n}=28)\end{array}$ & $\begin{array}{l}\text { Dolomitic } \\
\text { Itabirite } \\
(\mathrm{n}=331)\end{array}$ & $\begin{array}{c}\text { Dolomite } \\
\text { (Transition to } \\
\text { Gandarela Fm.) } \\
(\mathrm{n}=38)\end{array}$ & $(n=115)$ \\
\hline \multicolumn{5}{|l|}{$\mathrm{Wt} \%$} \\
\hline $\mathrm{CaO}$ & 29.63 & 30.51 & 30.00 & 30.82 \\
\hline $\mathrm{MgO}$ & 18.37 & 20.60 & 19.00 & 20.81 \\
\hline $\mathrm{FeO}$ & 3.66 & 1.01 & 2.61 & 0.74 \\
\hline $\mathrm{MnO}$ & 0.47 & 0.60 & 0.90 & 0.32 \\
\hline \multicolumn{5}{|c|}{ Recalculated on the basis of $2(\mathrm{Ca}, \mathrm{Mg}, \mathrm{Fe}, \mathrm{Mn})$} \\
\hline $\mathrm{Ca}$ & 1.003 & 1.008 & 1.013 & 1.016 \\
\hline $\mathrm{Mg}$ & 0.864 & 0.947 & 0.892 & 0.955 \\
\hline $\mathrm{Fe}$ & 0.098 & 0.026 & 0.069 & 0.014 \\
\hline $\mathrm{Mn}$ & 0.013 & 0.016 & 0.024 & 0.014 \\
\hline
\end{tabular}

EMP analyses of carbonate veins that crosscut the dolomitic itabirite indicate that dolomite contains an average $30.8 \% \mathrm{CaO}$ and $20.8 \% \mathrm{MgO}$, which are similar contents of the host rocks. Carbonates veins exhibit lower average contents of $\mathrm{FeO}$ and $\mathrm{MnO}(0.5 \%)$. Petrographic and EMP analyses indicate that dolomite is the only carbonate mineral in veins but other carbonates may be present within other generations of carbonate veins observed along mining exposures. EMP analyses performed on tabular hematite and martite indicate relatively high and invariant iron contents $\left(>99 \% \mathrm{Fe}_{2} \mathrm{O}_{3}\right)$. 


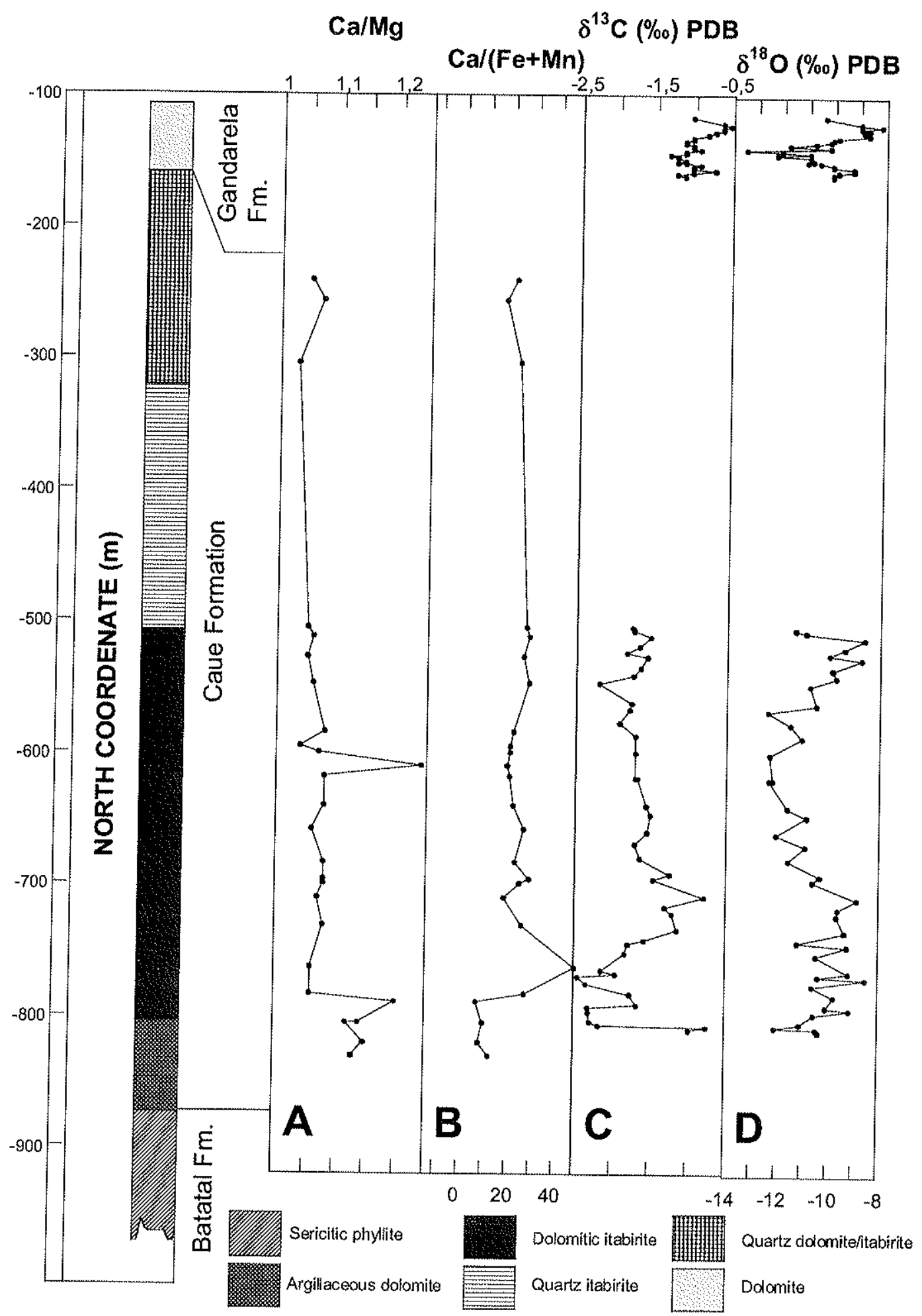

Figure $12-\mathbf{A}-\mathbf{B}$ Plots of $\mathrm{Ca} / \mathrm{Mg}$ and $\mathrm{Ca} /(\mathrm{Fe}+\mathrm{Mn})$ ratios of dolomite of the dolomitic itabirite as a function of stratigraphic location. $\mathbf{C}-\mathbf{D}$ Plots of $\delta^{13} \mathrm{C}$ and $\delta^{18} \mathrm{O}$ of dolomitic bands of the dolomitic itabirite and stromatolitic dolomites of the Gandarela Formation as a function of stratigraphic location. Data from Gandarela Formation are from (Bekker et al., 2003), obtained from samples collected at the Hargraves quarry. 


\section{Geochemistry}

The geochemical data of thirty six samples of rocks grouped into five major lithological groups and 12 separate analyses of dolomitic and hematitic bands of the dolomitic itabirite are presented in Appendixes 1 and 2. The triangular diagram of Figure 7 shows that dolomitic and quartz itabirite have simple compositions, while sericitic phyllite, argillaceous dolomite and carbonate rocks of the transition zone to the Gandarela exhibit higher compositional variation. Averages of major, trace and REE are present in Tables 2 and 3 according to their lithotype groups. We did not calculate the statistics for those variables with results always below or very close to the detection limit. In cases where the results of just a few samples where below this limit the statistics were calculated using half the detection limit for those samples. This procedure was chosen to allow for attaching some distinction to those values which stood slightly above the detection limit. It was used in all graphs presented in this paper.

Major, trace and REE data of the Post Archean Australian Shale (PAAS) obtained by McLennan (1989) are used as normalization values in this paper. Occasionally, data of the C1chondrite of Taylor and McLennan (1985) is also used. We present REE patterns with $Y$ inserted between Dy and Ho according to its ionic radius. We included $Y$ to the lanthanides for comparison with REE and $Y$ studies of other iron formations. The Eu anomaly is defined quantitatively as:

$$
\mathrm{Eu} / \mathrm{Eu}^{*}=\left(\left(\mathrm{Eu} / \mathrm{Eu}_{\mathrm{PAAS}}\right) /\left(\mathrm{Sm} / \mathrm{Sm}_{\mathrm{PAAS}}\right) \times\left(\mathrm{Gd}_{\mathrm{G}} / \mathrm{Gd}_{\mathrm{PAAS}}\right)\right)^{1 / 2}
$$

where $\mathrm{Eu}^{*}$ is the hypothetical concentration that $\mathrm{Eu}$ would have. The anomalies of $\mathrm{Ce}, \mathrm{Pr}$ and $\mathrm{X}$ were similarly calculated. The degree of light REE enrichment relative to heavy REE is presented as the ratios of PAAS-normalized $\mathrm{La}$ and $\mathrm{Yb}(\mathrm{La} / \mathrm{Yb}), \mathrm{La}$ and $\mathrm{Sm}(\mathrm{La} / \mathrm{Sm})$, and $\mathrm{Sm}$ and $\mathrm{Yb}(\mathrm{Sm} / \mathrm{Yb})$. 
Table 2 - Average major and trace element composition Sericitic Phyllite Argillaceous Dolonite

Dolomitic ltabirite

\begin{tabular}{|c|c|c|c|c|c|c|c|c|c|c|c|c|}
\hline $\mathrm{Wt} \%$ & Avg & Std & Min & Max & Avg & Std & Min & Max & $\mathrm{Avg}$ & Std & $\mathrm{Min}$ & Max \\
\hline $\mathrm{SiO}_{2}$ & 63.33 & 4.31 & 60.28 & 66.38 & 13.01 & 4.84 & 7.37 & 19.19 & 1.01 & 0.46 & 0.53 & 1.97 \\
\hline $\mathrm{Al}_{2} \mathrm{O}_{3}$ & 18.61 & 1.53 & 17.52 & 19.69 & 1.34 & 0.55 & 0.61 & 1.81 & 0.32 & 0.25 & 0.07 & 0.77 \\
\hline $\mathrm{Fe}_{2} \mathrm{O}_{3}$ & 1.67 & 0.52 & 1.31 & 2.04 & 1,17 & 0.92 & 0.42 & 2.44 & 48.90 & 8.49 & 39.65 & 67.61 \\
\hline Fetot & 3.53 & 2.55 & 1.73 & 5.33 & 5.99 & 1.83 & 4.21 & 8.54 & 49.64 & 8.48 & 40.26 & 68.11 \\
\hline $\mathrm{FeO}$ & 1.67 & 1.82 & 0.38 & 2.96 & 4.34 & 1.01 & 3.27 & 5.49 & 0.66 & 0.19 & 0.44 & 0.93 \\
\hline $\mathrm{MnO}$ & 0.03 & 0.03 & $<0.01$ & 0.05 & 0.49 & 0.16 & 0.40 & 0.72 & 0.28 & 0.07 & 0.18 & 0.43 \\
\hline $\mathrm{MgO}$ & 3.06 & 2.60 & 1.22 & 4.90 & 15.59 & 0.81 & 14,81 & 16.72 & 10.33 & 1.80 & 6.49 & 12.30 \\
\hline $\mathrm{CaO}$ & 0.11 & 0.02 & 0.09 & 0.12 & 24.39 & 1.23 & 22.63 & 25.38 & 14.36 & 2.42 & 9.47 & 17.26 \\
\hline $\mathrm{Na}_{2} \mathrm{O}$ & 0.07 & 0.04 & 0.04 & 0.09 & $<0.01$ & & & & $<0.01$ & & & \\
\hline $\mathrm{K}_{2} \mathrm{O}$ & 5.88 & 1.20 & 5.03 & 6.73 & 0,30 & 0.26 & 0.06 & 0.59 & 0.03 & 0.04 & 0.01 & 0.11 \\
\hline $\mathrm{TiO}_{2}$ & 0.77 & 0.03 & 0.74 & 0.79 & 0.06 & 0.02 & 0.03 & 0.08 & 0.02 & 0.02 & $<0.01$ & 0.06 \\
\hline $\mathrm{P}_{2} \mathrm{O}_{5}$ & 0.08 & 0.02 & 0.06 & 0.09 & 0.03 & 0.01 & 0.02 & 0.03 & 0.12 & 0.04 & 0.05 & 0.19 \\
\hline Ctot & & & & & 10.80 & 0.61 & 10.10 & 11.20 & 6.45 & 0.70 & 5.50 & 7.05 \\
\hline Cgrap & & & & & 0.30 & 0.06 & 0.25 & 0.36 & 0.03 & 0.01 & 0.03 & 0.05 \\
\hline Corg & & & & & 0.11 & 0.02 & 0.10 & 0.13 & 0.04 & 0.01 & 0.03 & 0.05 \\
\hline $\mathrm{CO} 2$ & & & & & 38.07 & 2.25 & 35.50 & 39.70 & 23.60 & 2.55 & 20.20 & 25.80 \\
\hline S & 0.008 & 0.002 & 0.006 & 0.009 & 0.07 & 0.04 & 0.03 & 0.12 & $<0.001$ & & & \\
\hline $\begin{array}{l}\text { LOI } \\
\text { ppm }\end{array}$ & 3.99 & 0.94 & 3.32 & 4.65 & 38.35 & 1.82 & 35.67 & 39.78 & 22.77 & 4.15 & 13.49 & 27.27 \\
\hline $\mathrm{Ba}$ & 328.0 & 45.3 & 296.0 & 360.0 & 17.0 & 8.2 & 8.0 & 24.0 & 12.9 & 4.3 & 5.0 & 19.0 \\
\hline $\mathrm{Sr}$ & 14.0 & 4.2 & 11.0 & 17.0 & 21.0 & 5.1 & 16.0 & 28.0 & 29.8 & 12.4 & 17.0 & 56.0 \\
\hline Y & 26.0 & 1.4 & 25.0 & 27.0 & 8.5 & 1.7 & 7.0 & 11.0 & 7.7 & 2.3 & 4.0 & 12.0 \\
\hline $\mathrm{Sc}$ & 16.5 & 0.7 & 16.0 & 17.0 & 2.3 & 0.5 & 2.0 & 3.0 & $<1.0$ & & & \\
\hline $\mathrm{Zr}$ & 178.5 & 7.8 & 173.0 & 184.0 & 18.3 & 6.6 & 11.0 & 27.0 & 14.0 & 5.7 & 5.0 & 21.0 \\
\hline $\mathrm{Be}$ & 2.5 & 0.7 & 2.0 & 3.0 & $<1.0$ & & & & $<1.0$ & & & \\
\hline V & 122.0 & & & & 13.0 & 3.2 & 10.0 & 17.0 & 25.6 & 22.2 & 5.0 & 84.3 \\
\hline $\mathrm{Ni}$ & 66.5 & 31.0 & 44.5 & 88.4 & 7.9 & 2.3 & 5.3 & 10.2 & 10.0 & 8.3 & 2.8 & 33.0 \\
\hline $\mathrm{Cu}$ & 38.2 & 14.4 & 28.0 & 48.3 & 13.0 & 5.5 & 5.7 & 18.9 & 7.0 & 4.0 & 0.5 & 10.9 \\
\hline $\mathrm{Zn}$ & 25.8 & 25.7 & 7.6 & 44.0 & $<1.0$ & & & & 13.5 & 12.3 & 0.5 & 47.4 \\
\hline $\mathrm{Ga}$ & 25.5 & 2.8 & 23.6 & 27.5 & 2.0 & 0.7 & 1.0 & 2.6 & $<1,0$ & & & \\
\hline $\mathrm{Ge}$ & 2.7 & 0.2 & 2.6 & 2.9 & $<0.5$ & & & & 1.8 & 0.7 & $<0.5$ & 3.2 \\
\hline $\mathrm{Rb}$ & 201.1 & 37.5 & 174.6 & 227.6 & 10.0 & 7.1 & 4.4 & 19.4 & $<1.0$ & & & \\
\hline $\mathrm{Nb}$ & 11.1 & 0.7 & 10.6 & 11.6 & 0.8 & 0.3 & 0.4 & 1.0 & 0.8 & 0.5 & 0.1 & 1.6 \\
\hline Mo & $<2.0$ & & & & $<2.0$ & & & & $<2.0$ & & & \\
\hline $\mathrm{Ag}$ & $<0.3$ & & & & $<0.3$ & & & & $<0.3$ & & & \\
\hline In & $<0.1$ & & & & $<0.1$ & & & & $<0.1$ & & & \\
\hline Sn & 3.3 & 0.4 & 3.0 & 3.6 & $<1.0$ & & & & $<1.0$ & & & \\
\hline Cs & 6.8 & 2.7 & 4.9 & 8.7 & 0.42 & 0.26 & 0.14 & 0.77 & $<0.1$ & & & \\
\hline$\sum R E E$ & 226.6 & 8.9 & 220.3 & 232.8 & 34.6 & 8.3 & 28.6 & 46.8 & 14.53 & 9.2 & 7.3 & 39.8 \\
\hline $\mathrm{Hf}$ & 5.3 & 0.1 & 5.2 & 5.3 & 0.5 & 0.2 & 0.2 & 0.8 & 0,12 & 0.1 & $<0,1$ & 0.2 \\
\hline $\mathrm{Tl}$ & 1.0 & 0.6 & 0.6 & 1.5 & 0.1 & 0.1 & $<0.1$ & 0.3 & $<0.1$ & & & \\
\hline $\mathrm{Pb}$ & 14.8 & 10.7 & 7.3 & 22.4 & 2.3 & 1.6 & 1.5 & 4.8 & & & & \\
\hline $\mathrm{Bi}$ & 1.5 & 0.8 & 1.0 & 2.1 & 1.3 & 0.6 & 1.0 & 2.3 & 1.2 & 2.2 & 0.1 & 6.0 \\
\hline Th & 20.4 & 1.9 & 19.1 & 21.7 & 1.8 & 0.9 & 0.7 & 2.6 & 0.5 & 0.4 & 0.1 & 1.4 \\
\hline $\mathrm{U}$ & 5.5 & 1.6 & 4.4 & 6.7 & 0.8 & 0.3 & 0.5 & 1.2 & 2.1 & 1.0 & 1.0 & 4.5 \\
\hline As & 9.3 & 9.7 & 2.5 & 16.2 & $<5.0$ & & & & 9.3 & 9.7 & 2.5 & 16.2 \\
\hline $\mathrm{Cr}$ & 222.1 & 16.6 & 210.3 & 233.8 & $<20.0$ & & & & 52.9 & 47.9 & $<20.0$ & 148.0 \\
\hline $\mathrm{Sb}$ & 2.8 & 1.7 & 1.5 & 4.0 & 0.5 & 0.3 & 0.3 & 0.8 & 1.6 & 1.0 & 0.2 & 3.4 \\
\hline $\mathrm{Cd}$ & 0.7 & 0.1 & 0.6 & 0.8 & 1.2 & 0.8 & 0.2 & 2,1 & 2.0 & 2.2 & 0.4 & 6.2 \\
\hline Fe\# & 0.57 & 0.26 & 0.38 & 0.76 & 0.18 & 0.10 & 0.07 & 0.29 & 0.98 & 0.01 & 0.98 & 0.99 \\
\hline
\end{tabular}

$\mathrm{Fe}_{\text {Tor }}$ expresssed as $\mathrm{Fe}_{2} \mathrm{O}_{3}$. $\mathrm{Fe} \#=\left(\mathrm{Fe}^{3+} /\left(\mathrm{Fe}^{3+}+\mathrm{Fe}^{2 i}\right)\right.$ 
Table 2 (Continued)

Quartz Itabirite Quartz-Carbonate Rocks

\begin{tabular}{|c|c|c|c|c|c|c|c|c|}
\hline $\mathrm{Wt} \%$ & Avg & Std & Min & $\operatorname{Max}$ & Avg & Stdl & Min & $\operatorname{Max}$ \\
\hline $\mathrm{SiO}_{2}$ & 41.74 & 14.49 & 19.71 & 61.95 & 26.61 & 17.31 & 6.56 & 53.28 \\
\hline $\mathrm{Al}_{2} \mathrm{O}_{3}$ & 0.18 & 0.15 & 0.06 & 0.52 & 0.70 & 0.98 & 0.08 & 3.07 \\
\hline $\mathrm{Fe}_{2} \mathrm{O}_{3}$ & 55.71 & 13.54 & 37.18 & 76.75 & 19.74 & 12.85 & 5.20 & 37.08 \\
\hline Fetot & 56.50 & 13.95 & 37.37 & 79.34 & 21.70 & 11.56 & 8.32 & 37.40 \\
\hline $\mathrm{FeO}$ & 0.71 & 0.79 & 0.12 & 2.33 & 1.77 & 1.44 & 0.29 & 4.32 \\
\hline $\mathrm{MnO}$ & $<0.01$ & & & & 0.38 & 0.18 & 0.09 & 0.66 \\
\hline $\mathrm{MgO}$ & 0.14 & 0.25 & 0.01 & 0.80 & 10.64 & 6.09 & 1.79 & 18.44 \\
\hline $\mathrm{CaO}$ & 0.46 & 0.58 & 0.06 & 1.69 & 15.08 & 8.26 & 2.98 & 25,87 \\
\hline $\mathrm{Na}_{2} \mathrm{O}$ & $<0.01$ & & & & 0.05 & 0.04 & 0.01 & 0.10 \\
\hline $\mathrm{K}_{2} \mathrm{O}$ & $<0.01$ & & & & 0.03 & 0.04 & 0.01 & 0.10 \\
\hline $\mathrm{TiO}_{2}$ & $<0.01$ & & & & 0.05 & 0.08 & 0.00 & 0.26 \\
\hline $\mathrm{P}_{2} \mathrm{O}_{5}$ & 0.13 & 0.09 & 0.03 & 0.32 & 0.06 & 0.05 & 0.02 & 0.17 \\
\hline Ctot & & & & & 7.58 & 2.54 & 4.80 & 9.80 \\
\hline Cgrap & & & & & $<0.05$ & & & \\
\hline Corg & & & & & $<0.05$ & & & \\
\hline $\mathrm{CO} 2$ & & & & & 27.78 & 9.29 & 17.60 & 35.90 \\
\hline S & $<0.001$ & & & & $<0.001$ & & & \\
\hline $\begin{array}{l}\text { LOI } \\
\text { ppm }\end{array}$ & 0.59 & 0.78 & $<0.02$ & 2.23 & 23.79 & 13.05 & 4.51 & 39.83 \\
\hline $\mathrm{Ba}$ & 15.4 & 6.4 & 5.0 & 21.0 & 7.3 & 3.9 & 4.0 & 16.0 \\
\hline $\mathrm{Sr}$ & 5.0 & 2.8 & 1.0 & 8.0 & 24.8 & 12.9 & 8.0 & 41.0 \\
\hline $\mathrm{Y}$ & 3.9 & 1.4 & 1.0 & 6.0 & 4.6 & 2.3 & 3.0 & 9.0 \\
\hline $\mathrm{Sc}$ & $<1.0$ & & & & $<1.0$ & & & \\
\hline $\mathrm{Zr}$ & 12.0 & 4.6 & 7.0 & 20.0 & 13.4 & 9.3 & 4.0 & 35.0 \\
\hline $\mathrm{Be}$ & $<1.0$ & & & & $<1.0$ & & & \\
\hline V & 22.6 & 16.2 & 2.5 & 52.0 & 8.9 & 9.9 & 2.5 & 32.4 \\
\hline $\mathrm{Ni}$ & 10.5 & 4.6 & 4.7 & 20.0 & 13.6 & 10.6 & 2.8 & 36.8 \\
\hline $\mathrm{Cu}$ & $<1.0$ & & & & 2.8 & 3.1 & $<1.0$ & 9.1 \\
\hline $\mathrm{Zn}$ & 2.4 & 1.8 & 0.5 & 5.2 & 7.5 & 8.1 & 0.5 & 21.0 \\
\hline $\mathrm{Ga}$ & $<1,0$ & & & & $<1.0$ & & & \\
\hline $\mathrm{Ge}$ & 3.6 & 1.2 & 2.4 & 6.3 & 1.9 & 1.7 & 0.3 & 5.2 \\
\hline $\mathrm{Rb}$ & $<1.0$ & & & & $<1.0$ & & & \\
\hline $\mathrm{Nb}$ & 0.8 & 0.8 & 0.3 & 2.9 & 0.7 & 0.5 & 0.1 & 1.8 \\
\hline Mo & $<2.0$ & & & & $<2.0$ & & & \\
\hline $\mathrm{Ag}$ & $<0.3$ & & & & $<0.3$ & & & \\
\hline In & $<0.1$ & & & & $<0.1$ & & & \\
\hline $\mathrm{Sn}$ & $<1.0$ & & & & $<0.1$ & & & \\
\hline Cs & $<0.1$ & & & & $<0.1$ & & & \\
\hline$\sum \mathrm{REE}$ & 8.2 & 3.3 & 4.1 & 13.9 & 9.1 & 3.1 & 4.7 & 15.2 \\
\hline Hf & $<0.1$ & & & & 0.2 & 0.1 & $<0.1$ & 0.5 \\
\hline $\mathrm{Tl}$ & $<0.1$ & & & & $<0.1$ & & & \\
\hline $\mathrm{Pb}$ & $<3.0$ & & & & 4.1 & 4.2 & 1.5 & 13.7 \\
\hline $\mathrm{Bi}$ & $<0.1$ & & & & $<0.1$ & & & \\
\hline Th & 0.1 & 0.1 & 0.03 & 0.4 & 0.6 & 0.5 & $<0.1$ & 1.8 \\
\hline $\mathrm{U}$ & 1.6 & 0.7 & 0.9 & 3.0 & 1.1 & 0.5 & 0.4 & 2.1 \\
\hline As & 9.7 & 4.3 & 2.5 & 15.6 & 5.8 & 6.0 & $<5.0$ & 19.7 \\
\hline $\mathrm{Cr}$ & $<20.0$ & & & & $<20.0$ & & & \\
\hline $\mathrm{Sb}$ & 2.8 & 0.5 & 1.6 & 3.3 & 1.1 & 0.8 & 0.3 & 2.5 \\
\hline $\mathrm{Cd}$ & 3.0 & 1.8 & 0.8 & 5.5 & 1.5 & 1.1 & 0.4 & 2.8 \\
\hline Fet\# & 0.99 & 0.01 & 0.97 & 1.00 & 0.84 & 0.17 & 0.57 & 0.99 \\
\hline
\end{tabular}


Table 2-(Continued)

\begin{tabular}{|c|c|c|c|c|c|c|c|c|}
\hline \multirow[b]{2}{*}{$\mathrm{Wt} \%$} & \multicolumn{4}{|c|}{ Dolomite-Rich Band } & \multicolumn{4}{|c|}{ Iron-Rich Band } \\
\hline & Avg & Std & $\mathrm{Min}$ & $\operatorname{Max}$ & Avg & Std & Min & $\operatorname{Max}$ \\
\hline $\mathrm{SiO}_{2}$ & 0.73 & 0.80 & 0.14 & 2.31 & 0.91 & 0.25 & 0.62 & 1.27 \\
\hline $\mathrm{Al}_{2} \mathrm{O}_{3}$ & 0.33 & 0.37 & 0.07 & 1.02 & 0.28 & 0.13 & 0.10 & 0.47 \\
\hline $\mathrm{Fe}_{2} \mathrm{O}_{3}$ & 10.93 & 7.42 & 4.49 & 23.92 & 77.88 & 8.32 & 65.04 & 84.77 \\
\hline Fetot & 11.74 & 7.46 & 6.15 & 25.00 & 78.23 & 8.24 & 65.57 & 85.13 \\
\hline $\mathrm{FeO}$ & 0.73 & 0.45 & 0.19 & 1.49 & 0.32 & 0.09 & $0.2 !$ & 0.48 \\
\hline $\mathrm{MnO}$ & 0.50 & 0.10 & 0.32 & 0.62 & 0.12 & 0.06 & 0.06 & 0.20 \\
\hline $\mathrm{MgO}$ & 18.50 & 1.51 & 15.99 & 19.73 & 4,11 & 1.60 & 2.92 & 6.51 \\
\hline $\mathrm{CaO}$ & 26.19 & 2.09 & 22.62 & 28.40 & 5.45 & 2.52 & 3.08 & 9.18 \\
\hline $\mathrm{Na}_{2} \mathrm{O}$ & 0.05 & 0.09 & 0.01 & 0.23 & $<0.01$ & & & \\
\hline $\mathrm{K}_{2} \mathrm{O}$ & 0.06 & 0.06 & 0.01 & 0.13 & 0.02 & 0.02 & 0.01 & 0.06 \\
\hline $\mathrm{TiO}_{2}$ & $<0,01$ & & & & $<0,01$ & & & \\
\hline $\mathrm{P}_{2} \mathrm{O}_{5}$ & 0.06 & 0.08 & 0.02 & 0.22 & 0.12 & 0.07 & 0.04 & 0.20 \\
\hline S & $<0.01$ & & & & $<0.01$ & & & \\
\hline $\begin{array}{l}\text { LOI } \\
\text { pptn }\end{array}$ & 40.98 & 3.64 & 34.51 & 43.91 & 9.91 & 4.25 & 6.07 & 16.30 \\
\hline $\mathrm{Ba}$ & 20.7 & 11.8 & 7.0 & 37.0 & 11.2 & 2.1 & 8.0 & 14.0 \\
\hline $\mathrm{Sr}$ & 46.2 & 16.2 & 29.0 & 74.0 & 12.8 & 3.9 & 8.0 & 19.0 \\
\hline$Y$ & 9.5 & 2.6 & 5.0 & 13.0 & 4.7 & 1.4 & 3.0 & 6.0 \\
\hline $\mathrm{Sc}$ & $<1.0$ & & & & $<1.0$ & & & \\
\hline $\mathrm{Zr}$ & 8.0 & 4.6 & 1.0 & 15.0 & 14.7 & 0.5 & 14.0 & 15.0 \\
\hline $\mathrm{Be}$ & $<1.0$ & & & & $<1.0$ & & & \\
\hline $\mathrm{V}$ & 10.2 & 6.4 & $<5.0$ & 20.2 & 36.3 & 42.1 & 13.0 & 121.0 \\
\hline $\mathrm{Ni}$ & 7.3 & 3.1 & 2.6 & 10.9 & 15.1 & 5.5 & 9.8 & 25.2 \\
\hline $\mathrm{Cu}$ & 5.2 & 3.7 & 1.8 & 11.6 & $<1.0$ & & & \\
\hline $\mathrm{Zn}$ & 7.4 & 5.2 & $<1.0$ & 15.0 & 12.9 & 1.2 & 11.6 & 14.3 \\
\hline $\mathrm{Ga}$ & $<1.0$ & & & & 0.8 & 0.5 & $<1,0$ & 1.5 \\
\hline $\mathrm{Ge}$ & $<0.5$ & & & & 3.6 & 0.7 & 2.6 & 4.5 \\
\hline $\mathrm{Rb}$ & $<1.0$ & & & & 1.2 & 1.3 & $<1.0$ & 3.8 \\
\hline $\mathrm{Nb}$ & 0.9 & 0.3 & 0.6 & 1.4 & 0.4 & 0.2 & $<0.2$ & 0.7 \\
\hline Mo & $<2.0$ & & & & 1.5 & 1.2 & $<2.0$ & 3.9 \\
\hline $\mathrm{Ag}$ & $<0.3$ & & & & 0.4 & 0.2 & $<0.3$ & 0.6 \\
\hline In & $<0.1$ & & & & $<0.1$ & & & \\
\hline $\mathrm{Sn}$ & $<1.0$ & & & & $<1.0$ & & & \\
\hline $\mathrm{Cs}$ & $<0.1$ & & & & 0.2 & 0.3 & $<0.1$ & 0.8 \\
\hline$\sum R E E$ & 18.8 & 8.4 & 11.8 & 33.9 & 9.6 & 1.1 & 8.2 & 10.8 \\
\hline Hf & $<0.1$ & & & & $<0.1$ & & & \\
\hline $\mathrm{Tl}$ & $<0.1$ & & & & $<0.1$ & & & \\
\hline $\mathrm{Pb}$ & 7.0 & 2.4 & $<3.0$ & 9.4 & $<3.0$ & & & \\
\hline $\mathrm{Bi}$ & $<0.1$ & & & & $<0.1$ & & & \\
\hline Th & 0.8 & 0.8 & 0.2 & 2.4 & 0.2 & 0.1 & 0.1 & 0.4 \\
\hline $\mathrm{U}$ & 1.7 & 0.6 & 0.9 & 2.4 & 2.1 & 0.7 & 1.4 & 3.0 \\
\hline As & 4.8 & 2.0 & $<5.0$ & 7.1 & 6.5 & 4.2 & $<5.0$ & 13.8 \\
\hline $\mathrm{Cr}$ & 23.5 & 19.4 & $<20.0$ & 60.0 & $<20.0$ & & & \\
\hline $\mathrm{Sb}$ & 1.5 & 1.7 & 0.3 & 4.9 & 1.3 & 0.5 & 0.5 & 1.8 \\
\hline $\mathrm{Cd}$ & 0.4 & 0.2 & 0.01 & 0.7 & 4.6 & 1.1 & 2.8 & 6.0 \\
\hline Felf & 0.91 & 0.09 & 0.73 & 0.97 & 1.00 & 0.00 & 0.99 & 1.00 \\
\hline
\end{tabular}


Table 3 - Average Rare Earth Element Composition

\begin{tabular}{|c|c|c|c|c|c|c|c|}
\hline Litho & Seric.Phyl. & $\begin{array}{l}\text { Argil. } \\
\text { Dol. }^{(1)} \\
(n=4)\end{array}$ & $\begin{array}{l}\text { Dolom. } \\
\text { Itab. } \\
(\mathrm{n})=9)\end{array}$ & $\begin{array}{l}\text { Quartz } \\
\text { Itab. } \\
(n=8)\end{array}$ & $\begin{array}{l}\text { Dolomite } \\
\text { (Transition to } \\
\text { Gandarela Fm } \\
(n \approx 9)\end{array}$ & $\begin{array}{l}\text { Iron-Rich } \\
\text { Band } \\
(n=6)\end{array}$ & $\begin{array}{l}\text { Dolonite- } \\
\text { Rich Band } \\
\qquad(n=6)\end{array}$ \\
\hline \multicolumn{8}{|l|}{ ppm } \\
\hline $\mathrm{La}$ & 49.09 & 6.24 & 2.65 & 1.40 & 1.35 & 1.85 & 3.13 \\
\hline $\mathrm{Ce}$ & 101.36 & 13.34 & 4.21 & 2.30 & 2.96 & 3.00 & 6.24 \\
\hline $\mathrm{Pr}$ & 11.00 & 1.56 & 0.53 & 0.33 & 0.34 & 0.39 & 0.76 \\
\hline $\mathrm{Nd}$ & 38.42 & 6.23 & 2,40 & 1.64 & 1.57 & 1.71 & 3.41 \\
\hline $\mathrm{Sm}$ & 7.23 & 1.47 & 0.57 & 0.44 & 0.39 & 0.39 & 0.77 \\
\hline $\mathrm{Eu}$ & 1.65 & 0.58 & 0.22 & 0.15 & 0.13 & 0.14 & 0.32 \\
\hline $\mathrm{Gd}$ & 5.46 & 1.31 & 0.74 & 0.56 & 0.52 & 0.48 & 0.99 \\
\hline $\mathrm{Tb}$ & 0.82 & 0.24 & 0.13 & 0.10 & 0.10 & 0.08 & 0.17 \\
\hline Dy & 4.54 & 1.40 & 0.86 & 0.58 & 0.60 & 0.54 & 1.11 \\
\hline $\mathrm{Y}$ & 26.00 & 8.50 & 7.44 & 4.00 & 4.44 & 4.67 & 9.50 \\
\hline Ho & 0.97 & 0.30 & 0.20 & 0.12 & 0.13 & 0.13 & 0.25 \\
\hline $\mathrm{Er}$ & 2.96 & 0.96 & 0.63 & 0.36 & 0.41 & 0.43 & 0.78 \\
\hline $\mathrm{Tm}$ & 0.41 & 0.14 & 0.10 & 0.05 & 0.06 & 0.07 & 0.11 \\
\hline $\mathrm{Yb}$ & 2.63 & 0.89 & 0.62 & 0.31 & 0.36 & 0.42 & 0.71 \\
\hline $\mathrm{Lu}$ & 0.44 & 0.14 & 0.10 & 0.05 & 0.06 & 0.07 & 0.12 \\
\hline$\sum R E E$ & 226.55 & 34.61 & 13.86 & 8.35 & 8.91 & 9.63 & 18.76 \\
\hline $\mathrm{La} / \mathrm{Yb}_{P A A S}$ & 1.38 & 0.51 & 0.27 & 0.35 & 0.31 & 0.32 & 0.34 \\
\hline $\mathrm{La} / \mathrm{Nd}_{\mathrm{PAAS}}$ & 1.15 & 0.88 & 0.85 & 0.88 & 0.79 & 0.98 & 0.82 \\
\hline $\mathrm{Ce} / \mathrm{Ce}^{*}{ }^{*} \mathrm{Ans}$ & 1.01 & 0.99 & 0.86 & 0.80 & 1.01 & 0,82 & 0.89 \\
\hline $\mathrm{Eu} / \mathrm{Eu}^{*}{ }^{*} \mathrm{AAs}$ & 1.24 & 1.91 & 1.60 & 1,49 & 1.35 & 1.57 & 1.74 \\
\hline $\mathrm{Y} / \mathrm{Y}^{*} \mathrm{PAAS}$ & 0.99 & 1.07 & 1.63 & 1.33 & 1.35 & 1.40 & 1.52 \\
\hline $\mathrm{Pr} / \mathrm{Pr}^{*}{ }^{*}{ }_{\text {PAAS }}$ & 1.04 & 1.01 & 1.00 & 1.00 & 0.93 & 1.01 & 1.00 \\
\hline $\mathrm{La} / \mathrm{Sm}_{P A A S}$ & 1.01 & 0.62 & 0.61 & 0.54 & 0.54 & 0.69 & 0.60 \\
\hline $\mathrm{Sm} / \mathrm{Yb}_{\mathrm{P} \Lambda \mathrm{AS}}$ & 1.39 & 0.83 & 0.45 & 0.70 & 0.57 & 0.47 & 0.58 \\
\hline $\mathrm{Sm} / \mathrm{Yb}$ & 2.74 & 1.62 & 0.89 & 1.38 & 1,11 & 0.93 & 1.15 \\
\hline Y/Ho & 26.78 & 28.83 & 42.66 & 36.23 & 35.81 & 36.04 & 38.89 \\
\hline
\end{tabular}

(1) Excluded samples M138 and M139 (metachert), (2) Excluded samples M4 and M7 (see text for explanation)

\section{Ranges and stratigraphic variation of major elements}

The major element composition of the rocks examined is clearly related to the lithological group that they belong to (Fig. 7). This is best observed by plotting the chemical analyses as function of stratigraphy (Fig. 13a). The compositional variation along the stratigraphy within each individual group is less obvious. $\mathrm{FeO}$ and $\mathrm{TiO}_{2}$ contents are higher in the argillaceous dolomite, but significantly reduced towards the contact with the dolomitic itabirite where they remain approximately constant. The $\mathrm{CaO}$ and $\mathrm{MgO}$ contents are reduced towards the contact with the quartz itabirite, while the $\mathrm{Fe}_{2} \mathrm{O}_{3}$ content is increased. $\mathrm{P}_{2} \mathrm{O}_{5}$ contents increase from the base towards the middle of the quartz itabirite, but this trend can be obliterated by the high $\mathrm{P}_{2} \mathrm{O}_{5}$ content of sample P3-23. 
$\mathrm{SiO}_{2}, \mathrm{Al}_{2} \mathrm{O}_{3}$ and $\mathrm{K}_{2} \mathrm{O}$ are the major constituents of the sericitic phyllite with average contents of $63.3 \%, 18.6 \%$ and $5.9 \%$ respectively. This rock is also characterized by high $\mathrm{TiO}_{2}$ (average of $0.8 \%$ ) and low $\mathrm{CaO}$ contents (average of $0.1 \%$ ).

The argillaceous dolomite group exhibits the greatest compositional variation of major elements when compared with other lithological groups. This major element variation is attributed to the presence of lenses of metachert and quartz itabirite analyzed with the dolomite. $\mathrm{CaO}$ (average of $24.4 \%$ ranging from $22.6 \%$ to $25.4 \%$ ) and $\mathrm{MgO}$ (average of $15.6 \%$ ranging from $14.8 \%$ to $16.7 \%$ ) are the main constituents together with $\mathrm{SiO}_{2}$, which ranges from $4.8 \%$ to $19.2 \%$ (average of $13 \%$ ). Loss on ignition (LOI) is high (average of $38.4 \%$ ) ranging from $35.7 \%$ to $39.8 \%$. This sample group has higher contents of $\mathrm{Al}_{2} \mathrm{O}_{3}$ than the itabirite and carbonate-rocks groups (average of $1.3 \%$ ), but an order of magnitude less $\mathrm{Al}_{2} \mathrm{O}_{3}$ than the sericitic phyllite. It is also characterized by the highest weight percent $\mathrm{FeO}$ of all sample groups, with an average 4.3 $\% \mathrm{FeO}$ and ranging from $3.3 \%$ to $5.5 \% \mathrm{FeO}$. The organic carbon content of this group, although very low (average of $0.1 \%$ ), was the highest of all studied groups.

Bulk analysis indicates dolomitic itabirite has the highest iron contents among all chemically classified groups. Iron contents range from $39.7 \%$ to $67.6 \% \mathrm{Fe}_{2} \mathrm{O}_{3}$ and average $48.9 \% \mathrm{Fe}_{2} \mathrm{O}_{3}$. $\mathrm{CaO}$ and $\mathrm{MgO}$ contents average $14.4 \%$ and $10.3 \%$, respectively. LOI produced by loss of $\mathrm{CO}_{2}$ from dolomite is highly variable and may be as high as $27 \%$ of the rock weight. $\mathrm{SiO}_{2}$ contents are very low because samples containing quartz itabirite were not analyzed. $\mathrm{Al}_{2} \mathrm{O}_{3}$ contents range from $<0.1$ and $0.8 \%$ (average of $0.3 \%$ ), and $\mathrm{Na}_{2} \mathrm{O}, \mathrm{K}_{2} \mathrm{O}$ and $\mathrm{TiO}_{2}$ contents are very low (average of $0.02 \%$ ). $\mathrm{P}_{2} \mathrm{O}_{5}$ contents range from $0.05 \%$ to $0.19 \%$ and average $0.12 \%$. FeO contents in dolomitic itabirite of the QF are very low $(0.4 \%-0.9 \% \mathrm{FeO})$ when compared to $\mathrm{FeO}$ contents of other BIF's world wide. The $\mathrm{Fe}_{2} \mathrm{O}_{3} /\left(\mathrm{Fe}_{2} \mathrm{O}_{3}+\mathrm{FeO}\right)$ ratio for the dolomitic itabirite ranges from 0.98 to 0.99 , which indicates a very high degree of oxidation.

Chemical analyses of dolomitic and hematitic bands confirm petrographical analyses and show that, although there is a predominance of dolomite or hematite in their respective bands, both minerals are always present. Therein the dolomitic bands exhibit higher contents of $\mathrm{CaO}$, $\mathrm{MgO}$ and LOI than the hematitic bands, but with the $\mathrm{Fe}_{2} \mathrm{O}_{3}$ content reaching up to $24 \%$. Hematitic bands have a $\mathrm{Fe}_{2} \mathrm{O}_{3}$ content of up to $85 \%$ with $\mathrm{CaO}$ and $\mathrm{MgO}$ contents reaching $9 \%$ and $6 \%$ respectively. The $\mathrm{FeO}$ content of the dolomitic bands range from $0.2 \%$ to $1.5 \%$ (average of $0.7 \%$ ), with the $\mathrm{Fe}_{2} \mathrm{O}_{3} /\left(\mathrm{Fe}_{2} \mathrm{O}_{3}+\mathrm{FeO}\right.$ ) ratio ranging between 0.73 and 0.97 (average of 0.91 ). In the hematitic bands the $\mathrm{FeO}$ content ranges from $0.2 \%$ to $0.5 \%$ (average of $0.3 \%$ ), with much higher $\mathrm{Fe}_{2} \mathrm{O}_{3} /\left(\mathrm{Fe}_{2} \mathrm{O}_{3}+\mathrm{FeO}\right)$ ratios ranging from 0.99 to 1.00 . Lower $\mathrm{Fe}_{2} \mathrm{O}_{3} /\left(\mathrm{Fe}_{2} \mathrm{O}_{3}+\mathrm{FeO}\right)$ ratios 
observed in the dolomitic bands indicate the presence of $\mathrm{Fe}^{+++}$in the dolomite composition, which is confirmed by EMP analyses. Otherwise the high $\mathrm{Fe}_{2} \mathrm{O}_{3} /\left(\mathrm{Fe}_{2} \mathrm{O}_{3}+\mathrm{FeO}\right)$ ratio observed in hematitic bands confirms the high degree of oxidation of the dolomitic itabirite as indicated petrographically by the significant martitization of magnetite.

Quartz itabirite consists essentially of $\mathrm{Fe}_{2} \mathrm{O}_{3}$ (average of $55.7 \%$ ) and $\mathrm{SiO}_{2}$ (average of $41.7 \%$ ). $\mathrm{CaO}, \mathrm{MgO}$ and $\mathrm{LOI}$ are very low, generally lower than $0.5 \% . \mathrm{Fe}_{2} \mathrm{O}_{3} /\left(\mathrm{Fe}_{2} \mathrm{O}_{3}+\mathrm{FeO}\right)$ ratios range from 0.97 to 1.00 , which is also an indication of advanced oxidation of this itabirite.

The lithological variation observed at the transition zone from the Cauê to the Batatal Formations is reflected by the major element data. $\mathrm{SiO}_{2}$ (average of $26.6 \%$ ) and $\mathrm{Fe}_{2} \mathrm{O}_{3}$ (average of $19.7 \%$ ) are the main components followed by $\mathrm{CaO}$ (average of $15.1 \%$ ), $\mathrm{MgO}$ (average of $10.6 \%$ ) and LOI (average of $23.8 \%$ ). $\mathrm{Al}_{2} \mathrm{O}_{3}$ (average of $0.7 \%$ ) and $\mathrm{TiO}_{2}$ (average of $0.05 \%$ ) contents are greater than itabirites and comparable to those of argillaceous dolomite.

\section{Ranges and stratigraphic variation of trace elements}

The concentration of trace elements in all samples is generally very low $<10$ ppm (Fig. 14a, Table 2). When compared to the PAAS contents only the sericitic phyllite shows similar concentrantions, except for $\mathrm{Sr}$ and As contents, which are much lower (Fig. 14b). The other lithologies are very poor chemical sediments.

The argillaceous dolomite from the base of the Cauê Formation and the dolomite from the transition zone to the Gandarela Formation have very similar trace elements concentrations while the concentrations of the minor elements are much lower than those of the PAAS. The main difference between the PAAS and the argillaceous dolomite are the higher $\mathrm{Cu}, \mathrm{Rb}, \mathrm{Cs}$, $\sum R E E$ and Th (average of 13,10,0.4, 35 and $2 \mathrm{ppm}$, respectively), and lower $\mathrm{Zn}(<1 \mathrm{ppm}$, much lower than that of PAAS) contents of the argillaceous dolomite.

Quartz and dolomitic itabirite contain low concentrations of trace elements when compared with the PAAS, except for $\mathrm{Sb}$ (average of $3 \mathrm{ppm}$ ) contents, which are higher in the quartz itabirite (Fig. 14b). The Rb, Cs, Hf and Th contents are particularly low in both itabirites. Figure $14 \mathrm{c}$ shows the average trace elements contents of quartz itabirite normalized to dolomitic itabirite. The latter is richer in $\mathrm{Sr}, \mathrm{Y}, \mathrm{Cu}, \mathrm{Zn}, \mathrm{Pb}$, Th and $\mathrm{Cr}$ while the former has higher contents of $\mathrm{Sb}$ and $\mathrm{Cd}$. 


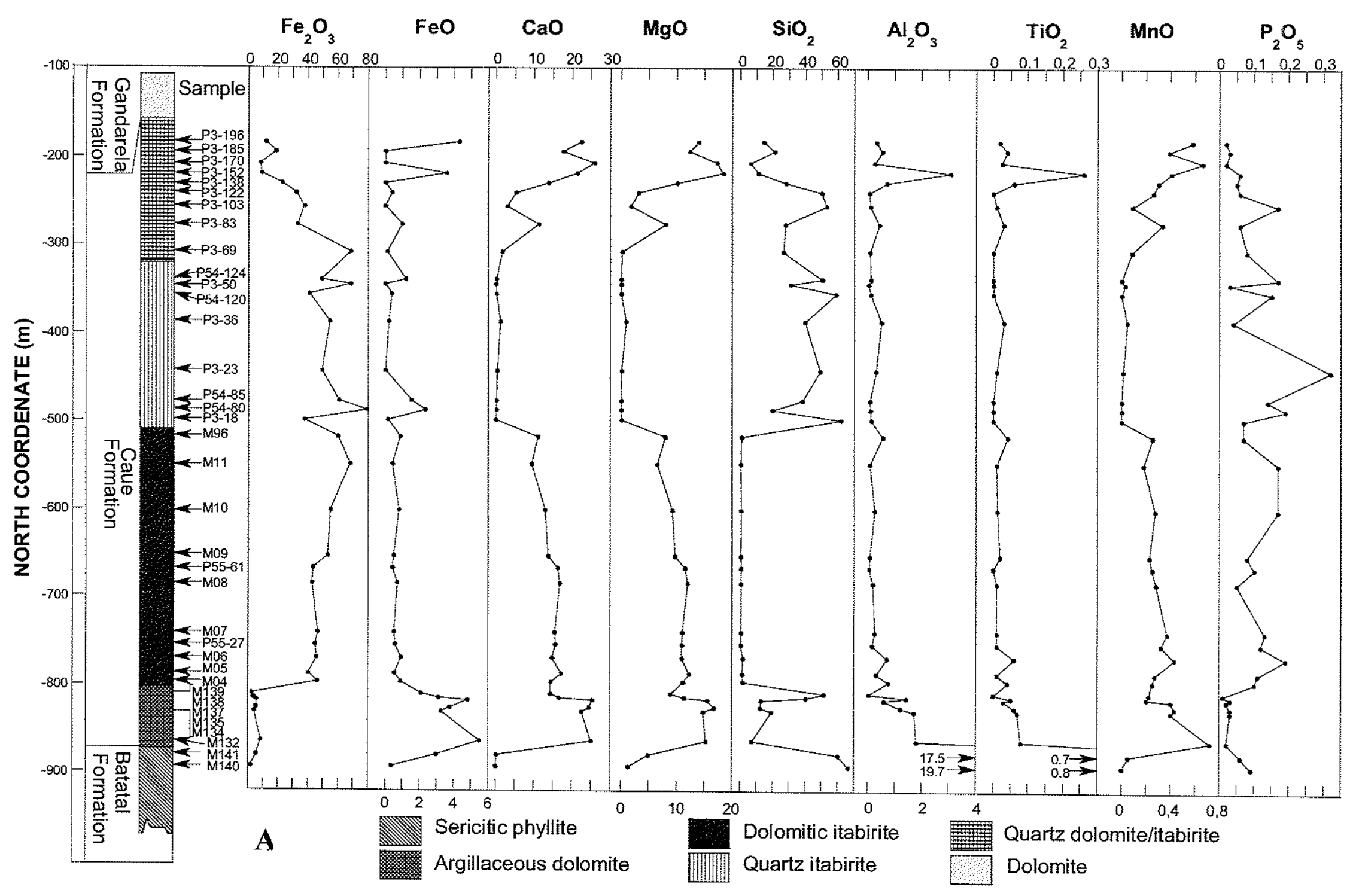

Figure 13 - Chemostratigraphic variation along the Section 2550E. A Major oxide components. B - C Trace elements. D Selected ratios. 


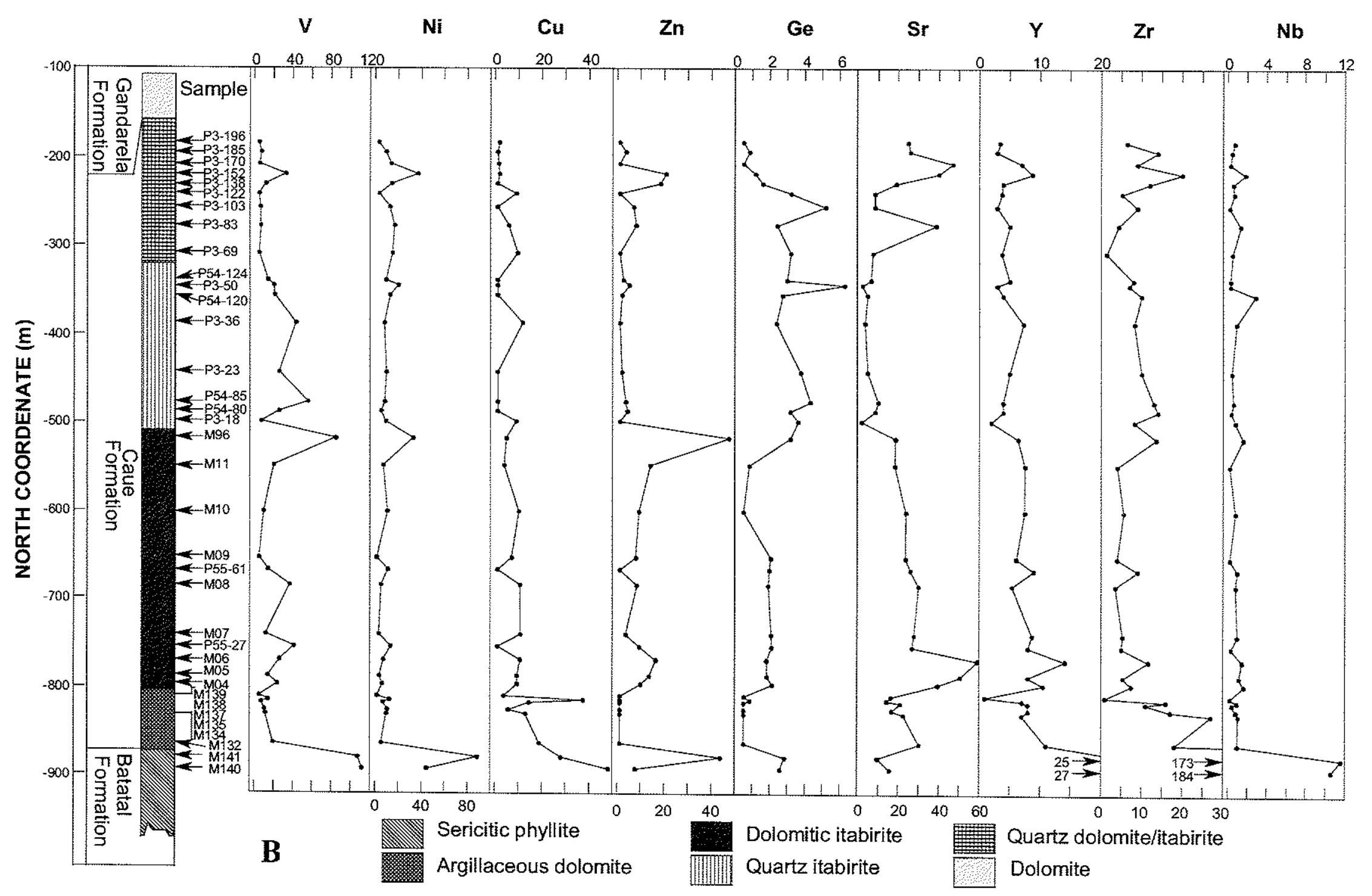

Figure 13 - Chemostratigraphic variation along the Section 2550E. A Major oxide components. B - C Trace elements. D Selected ratios. 


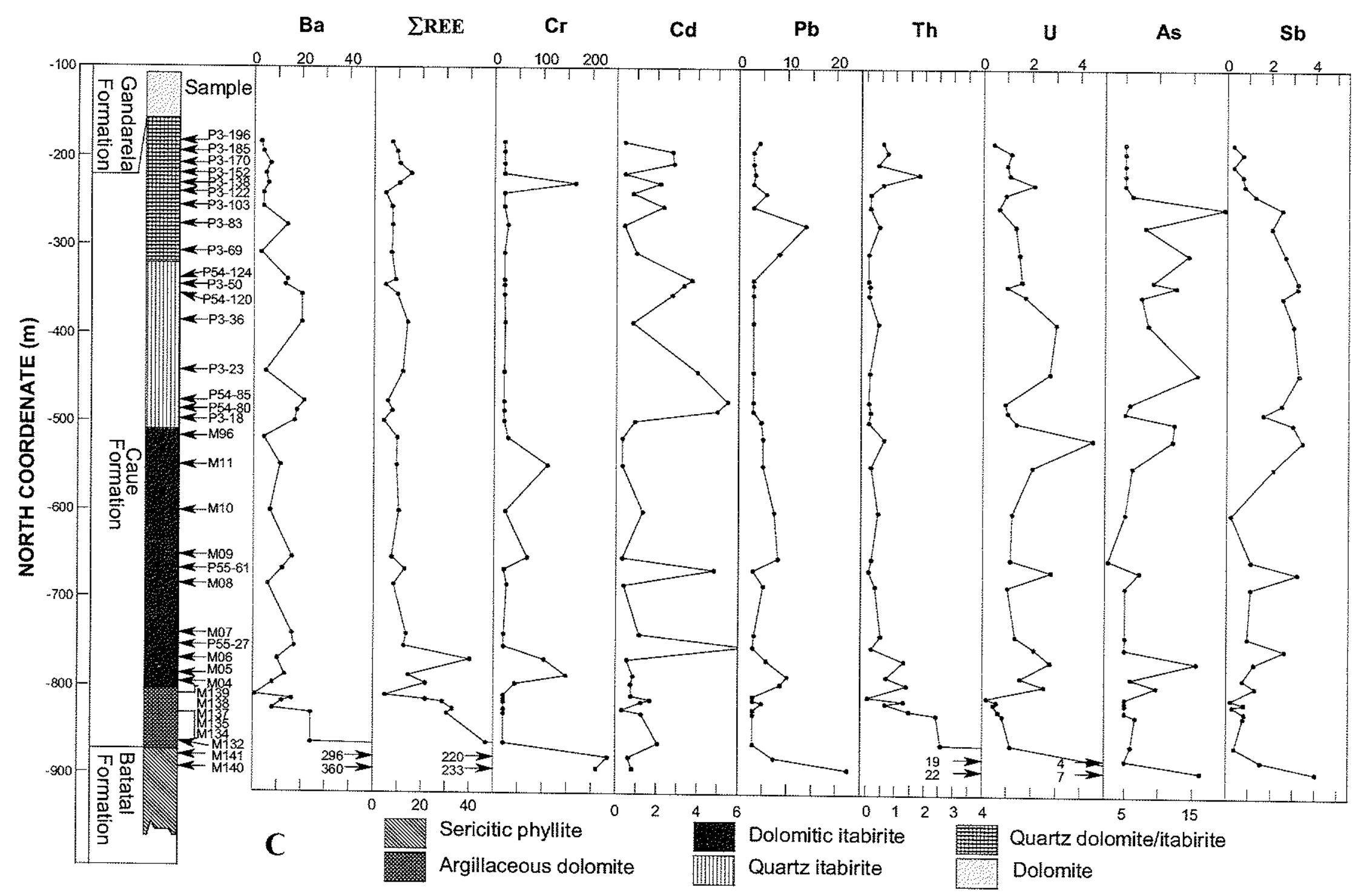

Figure 13 - Chemostratigraphic variation along the Section 2550E. A Major oxide components. B - C Trace elements. D Selected ratios. 


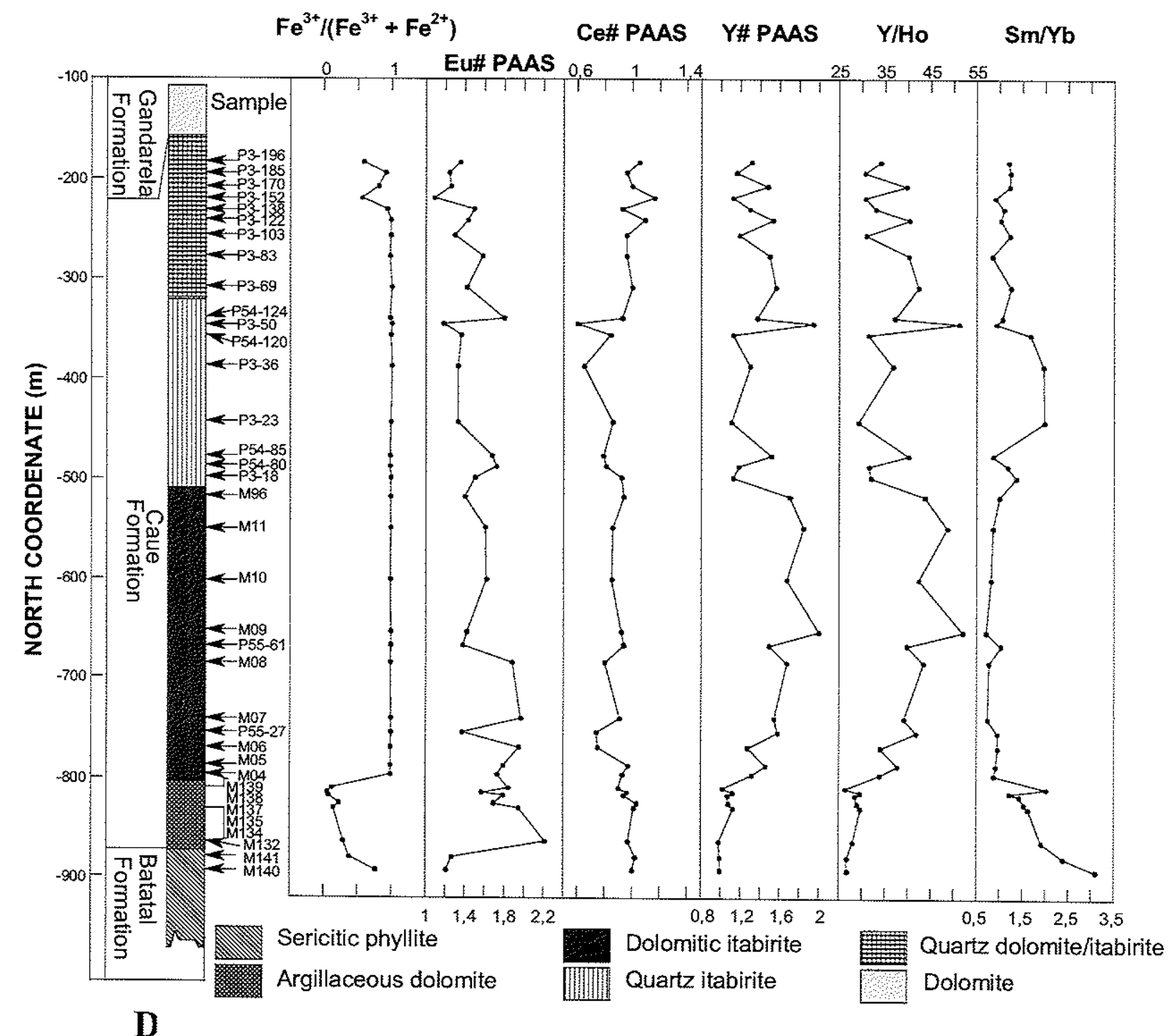

Figure 13 - Chemostratigraphic variation along the Section 2550E. A Major oxide components. B - C Trace elements. D Selected ratios. 
Figure $14 \mathrm{~d}$ shows the average trace elements contents of the hematitic bands of the dolomitic itabirite normalized to the average contents of the dolomitic bands highlighting any differences between them. The dolomitic bands have higher $\mathrm{Ba}(2 \mathrm{x}), \mathrm{Sr}(4 \mathrm{x}), \mathrm{Y}(2 \mathrm{x}), \mathrm{Cu}(10 \mathrm{x})$, $\mathrm{Nb}(2 \mathrm{x}), \sum \mathrm{REE}(2 \mathrm{x}), \mathrm{Pb}(5 \mathrm{x})$ and $\mathrm{Th}(3 \mathrm{x})$ contents than the hematitic bands. Hematitic bands, otherwise, have higher $\mathrm{Zr}(2 \mathrm{x}), \mathrm{V}(4 \mathrm{x}), \mathrm{Ni}(2 \mathrm{x}), \mathrm{Zn}(2 \mathrm{x}), \mathrm{Rb}(2 \mathrm{x}), \mathrm{Cs}(4 \mathrm{x})$ and $\mathrm{Cd}(13 \mathrm{x})$ contents than those of the dolomitic bands.

Unlike the major element chemistry which clearly distinguishes each lithotype, the trace element concentrations are not as clearly indicative of a particular rock type (Fig. 13b-c). However, four major groups of elements show some trend within and between each of the lithotypes. $\mathrm{Ni}, \mathrm{Nb}$ and $\mathrm{Cr}$ concentration are very low throughout the sequence. $\mathrm{Cu}, \mathrm{Y}, \mathrm{Zr}, \mathrm{Ba}$, $\sum R E E$ and $\mathrm{Th}$ exhibit higher average contents in the argillaceous dolomite; $\mathrm{Zn}, \mathrm{Sr}$, and $\mathrm{Pb}$ are characteristically associated with dolomitic itabirite, and $\mathrm{Cd}, \mathrm{Sb}, \mathrm{Ge}$ and to a lesser extent $\mathrm{As}, \mathrm{V}$ and $\mathrm{Zr}$ have a strong relation with quartz itabirite.

The distribution of minor elements along the sequence shows a remarkable feature at the passage from dolomitic to quartz itabirite, when contents of the last group mentioned above increase abruptly. After this point the contents of those elements reduce gradually and remain constant along the transition zone to the Gandarela Formation. Another important feature observed in Figure 13d is the abrupt change observed in the $\mathrm{Fe}_{2} \mathrm{O}_{3} /\left(\mathrm{Fe}_{2} \mathrm{O}_{3}+\mathrm{FeO}\right)$ ratio at the transition from argillaceous dolomite to dolomitic itabirite. Less clear, but still remarkable, is the gradual reduction found in the $\sum \mathrm{REE}, \mathrm{Y}$ and $\mathrm{U}$ contents from the base of the dolomitic itabirite towards the top of the transition zone to the Gandarela Formation. 


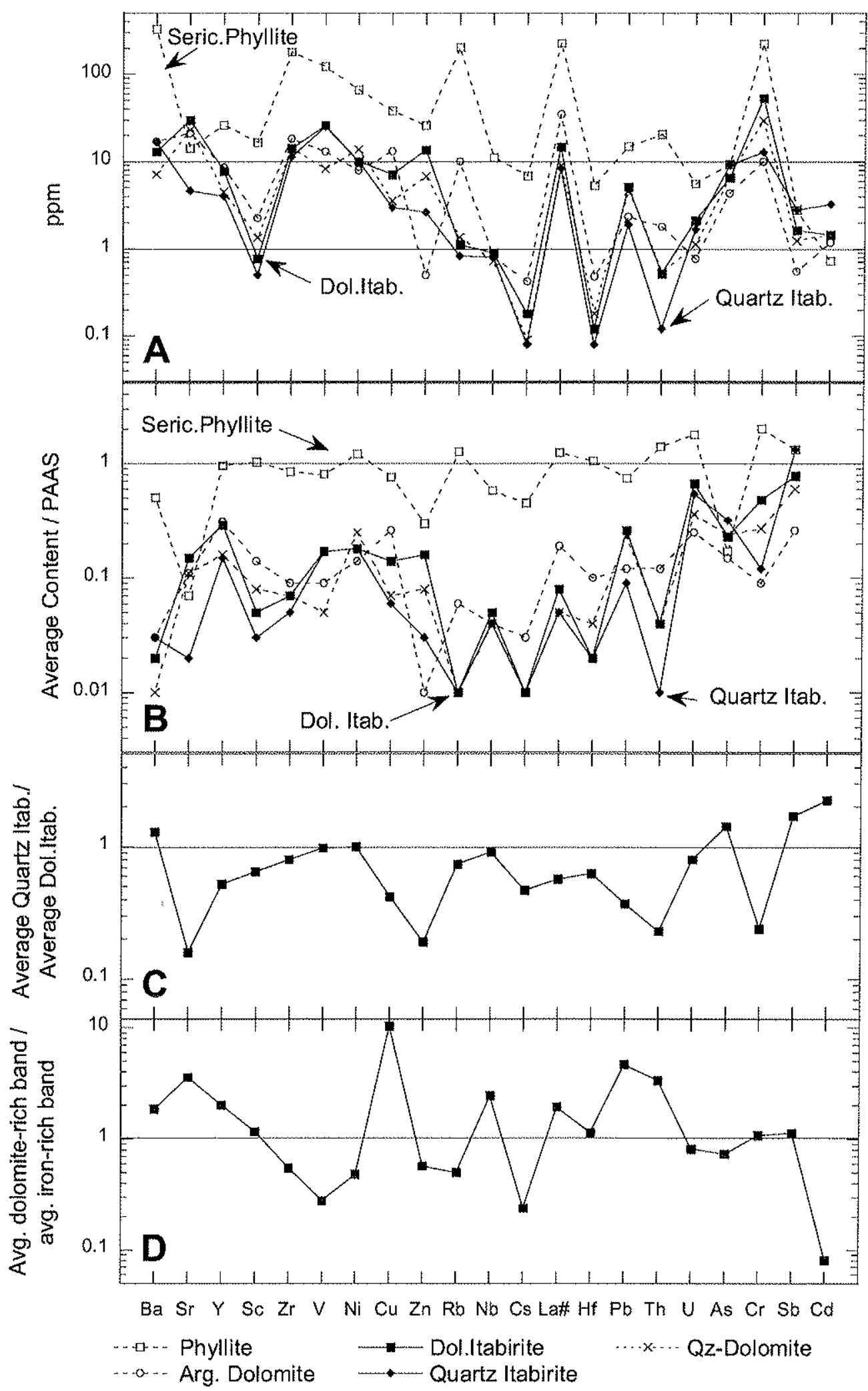

Figure $14-$ A Average trace element composition of each group studied. B Average trace element composition normalized to PAAS. C Average trace element composition of quartz itabirite normalized to average composition of dolomitic itabirite. D Average trace element composition of dolomite-rich mesoband of dolomitic itabirite normalized to hematite-rich mesoband. La\# means $\sum$ REE. 


\section{Some linear interelement correlations}

The results of some linear interelement correlations of major and trace elements are dsiplayed in Table 4. These element-element correlations include the total dataset for samples of the Cauê Formation (disregarding samples of dolomitic and hematitic bands, Table 4a) and only itabirite samples (Table 4b). We have not included results below or close to detection limit. Some significant interelement correlations are showed in Figure 15.

For the entire set of samples of the Cauê Formation, very positive correlation exists for $\mathrm{CaO}$ and $\mathrm{MgO}(\mathrm{r}=0.99)$, $\mathrm{LOI}(\mathrm{r}=1.00), \mathrm{MnO}(\mathrm{r}=0.91)$ and $\mathrm{Sr}(\mathrm{r}=0.72)$, which represent the group of elements present in the dolomite composition. $\mathrm{Al}_{2} \mathrm{O}_{3}$ correlates very well with $\mathrm{TiO}_{2}(\mathrm{r}=0.93)$, $\mathrm{Zr}(r=0.76)$ and $\mathrm{Th}(\mathrm{r}=0.89)$ and somewhat less well with $\sum \mathrm{REE}(\mathrm{r}=0.61)$. Significant concentrations of $\mathrm{Al}, \mathrm{Ti}, \mathrm{Zr}$ and $\mathrm{Th}$ are considered by several authors (e.g. Arora et al., 1995; Beukes et al., 1990; Gnaneshwar Rao and Naqvi, 1995; Horstmann and Hälbich, 1995; Manikyamba, 1998) to indicate a detrital contribution during formation of primary BIF. $\sum$ REE correlates well with $\mathrm{Th}(\mathrm{r}=0.83)$ and $\mathrm{Y}(\mathrm{r}=075)$. Fe $\mathrm{T}_{\mathrm{TOT}}$ does not correlate with any element accept a weak correlation exists for $\mathrm{Fe}_{\mathrm{T}}$ T with $\mathrm{Sb}(\mathrm{r}=0.66)$ and $\mathrm{P}_{2} \mathrm{O}_{5}(\mathrm{r}=0.59)$. Considering the great variety of rocks within the set of samples studied, the absence of good linear interelement correlations was expected and only the most significant were outlined. When each group of rocks is studied separately, the differences on the interelement correlations between them (if existent) turn more evident, as is observed in Figure 15.

We used identical interelement correlation tests as above for major and trace elements of itabirites. Dolomitic itabirite shows two complementary compositional poles organized between $\mathrm{CaO}$ and $\mathrm{Fe}_{\mathrm{TO}}$. There are very strong positive correlations of $\mathrm{CaO}$ with $\mathrm{MgO}(\mathrm{r}=0.98)$ and $\mathrm{LOI}$ $(\mathrm{r}=0.98)$, which reflects the dolomitic signature of the itabirite. $\mathrm{Fe}_{\mathrm{TO}}$ shows an antipathetic behavior with this group $\left(\mathrm{r}_{\mathrm{CaO}-\mathrm{Fe} \mathrm{roT}}=-0.98\right)$ and does not exhibit any correlation with other elements. $\mathrm{Al}_{2} \mathrm{O}_{3}$ correlates very well with $\mathrm{SiO}_{2}(\mathrm{r}=0.90), \mathrm{TiO}_{2}(\mathrm{r}=0.90)$, Th $(\mathrm{r}=0.96)$ and $\mathrm{Nb}$ $(\mathrm{r}=0.85)$, and well with $\sum \mathrm{REE}(\mathrm{r}=0.72)$, and $\mathrm{As}(\mathrm{r}=0.77) . \mathrm{SiO}_{2}$ has good correlations with these same elements and also with $\mathrm{Sr}(\mathrm{r}=0.77)$. Once the content of quartz of the samples of dolomitic itabirite is not relevant, the $\mathrm{SiO}_{2}$ present in that rock is related with sericite and chlorite and certainly reflects the detritic fraction of the BIF sediments.

In the composition of quartz itabirite there are also two complementary poles organized around $\mathrm{SiO}_{2}$ and $\mathrm{Fe}_{\text {Tот }}$ with very strong negative correlation between them $(\mathrm{r}=-0.99) . \quad \mathrm{SiO}_{2}$ correlates with $\mathrm{Sb}(\mathrm{r}=0.59)$ while $\mathrm{Fe}_{\mathrm{TOT}}$ correlates well only with $\mathrm{Zn}(\mathrm{r}=0.80)$. $\mathrm{CaO}$ correlates 
very well with $\mathrm{MgO}(\mathrm{r}=0.98), \mathrm{LOI}(\mathrm{r}=0.96), \mathrm{TiO}_{2}(\mathrm{r}=0.99)$ and $\mathrm{Th}(\mathrm{r}=0.97)$, and well with $\mathrm{MnO}$ $(\mathrm{r}=0.78), \mathrm{Cu}(\mathrm{r}=0.68), \operatorname{REE}(\mathrm{r}=0.80), \mathrm{Y}(\mathrm{r}=0.66), \mathrm{Zr}(\mathrm{r}=0.84), \mathrm{U}(\mathrm{r}=0.81)$ and $\mathrm{Cr}(\mathrm{r}=0.85) . \mathrm{Al}_{2} \mathrm{O}_{3}$ reveals a fair correlation with $\mathrm{CaO}(\mathrm{r}=0.95), \mathrm{MgO}(\mathrm{r}=0.92), \mathrm{LOI}(\mathrm{r}=0.90), \mathrm{TiO}_{2}(\mathrm{r}=0.91), \mathrm{U}$ $(\mathrm{r}=0.93)$ and $\mathrm{Cr}(\mathrm{r}=0.95)$ and good correlations with $\mathrm{MnO}(\mathrm{r}=0.66), \mathrm{Y}(\mathrm{r}=0.62), \mathrm{Zr}(\mathrm{r}=0.73), \mathrm{Cu}$ $(\mathrm{r}=0.66)$, RRE $(\mathrm{r}=0.85)$ and $\mathrm{Th}(\mathrm{r}=0.89)$.

High correlations showed by elements that usually correlate well with $\mathrm{CaO}$ with those elements usually correlated with $\mathrm{Al}_{2} \mathrm{O}_{3}$ suggest the presence of two different groups of impurities in the composition of quartz itabirite. The first group consists of chemical impurities characterized by good correlations between $\mathrm{CaO}, \mathrm{MgO}, \mathrm{LOI}$ and $\mathrm{MnO}$ and related to dolomite. The second group consists of terrigenous impurities represented by micaceous minerals and characterized by fair correlations between $\mathrm{Al}, \mathrm{Ti}, \mathrm{Y}, \mathrm{REE}, \mathrm{Cr}, \mathrm{U}$ and Th. 
Table 4a - Linear interelement correlations for all samples of the Cauê and Gandarela Fms.

\begin{tabular}{|c|c|c|c|c|c|c|c|c|c|c|c|c|c|c|c|}
\hline & $\mathrm{SiO}_{2}$ & $\mathrm{Al}_{2} \mathrm{O}_{3}$ & Feror & $\mathrm{MnO}$ & $\mathrm{MgO}$ & $\mathrm{CaO}$ & $\mathrm{TiO}_{2}$ & $\mathrm{P}_{2} \mathrm{O}_{5}$ & LOI & $\mathrm{Ba}$ & $\mathrm{Sr}$ & $\mathrm{Y}$ & $\mathrm{Sc}$ & $\mathrm{Zr}$ & V \\
\hline $\mathrm{Al}_{2} \mathrm{O}_{3}$ & -0.19 & & & & & & & & & & & & & & \\
\hline Feror & -0.06 & -0.56 & & & & & & & & & & & & & \\
\hline $\mathrm{MnO}$ & -0.59 & 0.47 & -0.66 & & & & & & & & & & & & \\
\hline $\mathrm{MgO}$ & -0.67 & 0.58 & -0.70 & 0.89 & & & & & & & & & & & \\
\hline $\mathrm{CaO}$ & -0.64 & 0.53 & -0.73 & 0.91 & 0.99 & & & & & & & & & & \\
\hline $\mathrm{TiO}_{2}$ & -0.23 & 0.93 & .0 .45 & 0.42 & 0.54 & 0.46 & & & & & & & & & \\
\hline $\mathrm{P}_{2} \mathrm{O}_{5}$ & 0.10 & -0.31 & 0.59 & -0.49 & -0.50 & -0.53 & -0.25 & & & & & & & & \\
\hline LOI & -0.64 & 0.55 & -0.73 & 0.91 & 0.99 & 1.00 & 0.48 & 0.53 & & & & & & & \\
\hline $\mathrm{Ba}$ & -0.02 & 0.14 & 0.16 & -0.11 & -0.13 & .0 .12 & 0.01 & 0.06 & -0.11 & & & & & & \\
\hline $\mathrm{Sr}$ & -0.71 & 0.33 & -0.25 & 0.68 & 0.72 & 0.67 & 0.39 & -0.09 & 0.67 & -0.02 & & & & & \\
\hline $\mathrm{Y}$ & -0.67 & 0.49 & -0.10 & 0.49 & 0.56 & 0.52 & 0.44 & 0.11 & 0.53 & 0.32 & 0.63 & & & & \\
\hline $\mathrm{Sc}$ & -0.22 & 0.91 & -0.61 & 0.54 & 0.62 & 0.58 & 0.86 & -0.34 & 0.60 & 0.05 & 0.40 & 0.49 & & & \\
\hline $\mathrm{Zr}$ & -0.36 & 0.76 & -0.10 & 0.26 & 0.36 & 0.29 & 0.73 & -0.05 & 0.30 & 0.21 & 0.35 & 0.50 & 0.63 & & \\
\hline $\mathrm{V}$ & -0.21 & 0.12 & 0.37 & -0.18 & -0.11 & -0.16 & 0.17 & 0.15 & -0.14 & 0.13 & -0.01 & 0.21 & -0.03 & 0.32 & \\
\hline $\mathrm{Ni}$ & -0.08 & 0.43 & 0.05 & -0.03 & 0.06 & -0.02 & 0.58 & -0.08 & 0.00 & -0.17 & 0.02 & 0.09 & 0.28 & 0.42 & 0.45 \\
\hline $\mathrm{Cu}$ & -0.07 & 0.36 & .0 .31 & 0.21 & 0.26 & 0.29 & 0.13 & -0.30 & 0.29 & 0.32 & 0.12 & 0.32 & 0.32 & 0.30 & -0.07 \\
\hline $\mathrm{Zn}$ & -0.41 & 0.15 & 0.27 & 0.04 & 0.13 & 0.05 & 0.31 & 0.11 & 0.07 & -0.20 & 0.31 & 0.21 & 0.09 & 0.29 & 0.63 \\
\hline $\mathrm{Rb}$ & 0.10 & 0.73 & -0.53 & 0.38 & 0.44 & 0.46 & 0.48 & -0.34 & 0.47 & 0.42 & 0.12 & 0.39 & 0.63 & 0.54 & 0.04 \\
\hline $\mathrm{Nb}$ & 0.05 & 0.38 & -0.08 & 0.08 & 0.13 & 0.07 & 0.37 & 0.00 & 0.09 & 0.26 & 0.28 & 0.31 & 0.32 & 0.48 & 0.31 \\
\hline $\mathrm{Cs}$ & -0.21 & 0.62 & -0.31 & 0.27 & 0.39 & 0.36 & 0.46 & -0.17 & 0.37 & 0.29 & 0.30 & 0.50 & 0.59 & 0.53 & 0.03 \\
\hline$\sum \mathrm{REE}$ & -0.35 & 0.61 & -0.43 & 0.56 & 0.54 & 0.57 & 0.41 & -0.13 & 0.58 & 0.33 & 0.43 & 0.75 & 0.67 & 0.47 & 0.02 \\
\hline Hf & -0.19 & 0.85 & $\sim 0.63$ & 0.51 & 0.60 & 0.60 & 0.68 & -0.45 & 0.61 & 0.22 & 0.25 & 0.40 & 0.76 & 0.63 & 0.03 \\
\hline $\mathrm{Pb}$ & -0.26 & -0.11 & 0.16 & 0.08 & 0.08 & 0.06 & -0.06 & -0.02 & 0.05 & 0.01 & 0.47 & 0.06 & 0.06 & 0.08 & -0.22 \\
\hline $\mathrm{Th}$ & -0.34 & 0.87 & -0.57 & 0.62 & 0.65 & 0.64 & 0.69 & -0.34 & 0.65 & 0.27 & 0.45 & 0.61 & 0.84 & 0.68 & 0.05 \\
\hline $\mathrm{U}$ & -0.22 & -0.10 & 0.48 & -0.19 & -0.19 & -0.24 & -0.03 & 0.36 & -0.22 & 0.02 & 0.09 & 0.33 & -0.16 & 0.16 & 0.65 \\
\hline As & 0.35 & -0.21 & 0.41 & -0.44 & -0.56 & 0.56 & -0.21 & 0.45 & -0.56 & -0.05 & -0.21 & -0.08 & -0.23 & -0.05 & 0.15 \\
\hline $\mathrm{Cr}$ & -0.30 & -0.05 & 0.15 & 0.05 & 0.12 & 0.08 & 0.04 & 0.15 & 0.08 & -0.04 & 0.42 & 0.22 & 0.05 & -0.01 & 0.00 \\
\hline $\mathrm{Sb}$ & 0.36 & -0.39 & 0.66 & -0.71 & -0.74 & -0.76 & -0.34 & 0.44 & -0.75 & 0.14 & -0.52 & -0.21 & -0.50 & -0.21 & 0.42 \\
\hline & $\mathrm{Ni}$ & $\mathrm{Cu}$ & $\mathrm{Zn}$ & $\mathrm{Rb}$ & $\mathrm{Nb}$ & $\mathrm{Cs}$ & $\sum R E E$ & Hf & $\mathrm{Pb}$ & Th & $\mathrm{U}$ & As & $\mathrm{Cr}$ & & \\
\hline $\mathrm{Cu}$ & -0.19 & & & & & & & & & & & & & & \\
\hline $\mathrm{Zn}$ & 0.63 & -0.15 & & & & & & & & & & & & & \\
\hline $\mathrm{Rb}$ & 0.03 & 0.53 & -0.18 & & & & & & & & & & & & \\
\hline $\mathrm{Nb}$ & 0.31 & 0.13 & 0.27 & 0.24 & & & & & & & & & & & \\
\hline $\mathrm{Cs}$ & -0.01 & 0.36 & -0.04 & 0.76 & 0.42 & & & & & & & & & & \\
\hline$\sum \mathrm{REE}$ & .0 .12 & 0.50 & .0 .06 & 0.66 & 0.26 & 0.57 & & & & & & & & & \\
\hline Hf & 0.26 & 0.43 & 0.07 & 0.84 & 0.24 & 0.59 & 0.67 & & & & & & & & \\
\hline $\mathrm{Pb}$ & -0.07 & 0.16 & 0.16 & -0.16 & 0.20 & 0.07 & -0.07 & -0.17 & & & & & & & \\
\hline Th & 0.11 & 0.49 & 0.06 & 0.85 & 0.36 & 0.76 & 0.83 & 0.88 & -0.03 & & & & & & \\
\hline$U$ & 0.33 & -0.15 & 0.60 & -0.22 & 0.34 & -0.01 & 0.03 & -0.14 & 0.00 & -0.09 & & & & & \\
\hline As & 0.19 & -0.14 & 0.13 & -0.16 & 0.06 & -0.05 & -0.02 & -0.23 & 0.06 & -0.17 & 0.43 & & & & \\
\hline $\mathrm{Cr}$ & -0.07 & -0.02 & 0.46 & .0 .19 & 0.02 & -0.05 & 0.08 & -0.02 & 0.29 & 0.02 & 0.30 & 0.00 & & & \\
\hline $\mathrm{Sb}$ & 0.30 & -0.34 & 0.13 & -0.35 & 0.03 & -0.29 & -0.38 & -0.43 & -0.16 & -0.50 & 0.58 & 0.68 & -0.15 & & \\
\hline
\end{tabular}


Table $4 \mathrm{~b}$ - Linear interelement correlations for all samples of itabirites

\begin{tabular}{|c|c|c|c|c|c|c|c|c|c|c|c|c|c|c|c|}
\hline & $\mathrm{SiO}_{2}$ & $\mathrm{Al}_{2} \mathrm{O}_{3}$ & $\mathrm{Fe}_{\mathrm{TOT}}$ & $\mathrm{MnO}$ & $\mathrm{MgO}$ & $\mathrm{CaO}$ & $\mathrm{TiO}_{2}$ & $\mathrm{P}_{2} \mathrm{O}_{5}$ & LOI & $\mathrm{Ba}$ & $\mathrm{Sr}$ & $\mathrm{Y}$ & $\mathrm{Sc}$ & $\mathrm{Zr}$ & V \\
\hline $\mathrm{Al}_{2} \mathrm{O}_{3}$ & -0.26 & & & & & & & & & & & & & & \\
\hline $\mathrm{Fe}_{\mathrm{TO}}$ & 0,08 & -0.19 & & & & & & & & & & & & & \\
\hline $\mathrm{MnO}$ & -0.87 & 0.42 & -0.31 & & & & & & & & & & & & \\
\hline $\mathrm{MgO}$ & -0.89 & 0.33 & $-0,38$ & 0.95 & & & & & & & & & & & \\
\hline $\mathrm{CaO}$ & -0.90 & 0,30 & -0.37 & 0.95 & 1.00 & & & & & & & & & & \\
\hline $\mathrm{TiO}_{2}$ & -0.43 & 0.90 & -0.05 & 0.55 & 0.43 & 0.40 & & & & & & & & & \\
\hline $\mathrm{P}_{2} \mathrm{O}_{5}$ & 0.17 & 0.01 & 0.09 & -0.12 & -0.20 & -0.19 & 0.09 & & & & & & & & \\
\hline LOI & -0.89 & 0.32 & -0.38 & 0.95 & 1.00 & 1.00 & 0.42 & -0.21 & & & & & & & \\
\hline $\mathrm{Ba}$ & 0.35 & -0.27 & -0.04 & -0.26 & -0.31 & -0.31 & -0.20 & -0.20 & -0.31 & & & & & & \\
\hline $\mathrm{Sr}$ & -0.76 & 0.52 & -0.35 & 0.87 & 0.86 & 0.85 & 0.59 & 0.01 & 0.85 & -0.20 & & & & & \\
\hline $\mathrm{Y}$ & -0.67 & 0.56 & -0.14 & 0.75 & 0.68 & 0.67 & 0.64 & 0.20 & 0.68 & -0.19 & 0.76 & & & & \\
\hline $\mathrm{Sc}$ & -0.26 & 0.76 & -0.19 & 0.42 & 0.34 & 0.30 & 0.74 & 0.10 & 0.32 & $-0,10$ & 0.62 & 0.63 & & & \\
\hline $\mathrm{Zr}$ & -0.32 & 0.70 & 0.10 & 0.39 & 0.26 & 0.24 & 0.65 & 0.02 & 0.24 & -0.15 & 0.37 & 0.41 & 0.42 & & \\
\hline $\mathrm{V}$ & -0.09 & 0.37 & 0.25 & 0.02 & -0.04 & -0.04 & 0.39 & -0.17 & -0.03 & -0.29 & 0.09 & 0.00 & -0.01 & 0.34 & \\
\hline $\mathrm{Ni}$ & 0.00 & 0.05 & 0.26 & 0.07 & $-0,13$ & -0.13 & 0.17 & -0.24 & 0.11 & -0.39 & -0.30 & -0.15 & -0.19 & -0.07 & 0.60 \\
\hline $\mathrm{Cu}$ & -0.35 & 0.57 & -0.34 & 0.53 & 0.48 & 0.47 & 0.52 & -0.31 & 0.46 & 0.02 & 0.53 & 0.30 & 0.36 & 0.67 & -0.07 \\
\hline $\mathrm{Zn}$ & -0.50 & 0.43 & 0.18 & 0.44 & 0.38 & 0.38 & 0.61 & -0.16 & 0.39 & -0.48 & 0.34 & 0.25 & 0.14 & 0.32 & 0.61 \\
\hline $\mathrm{Rb}$ & -0.08 & 0.55 & -0.19 & 0.12 & 0.17 & 0.14 & 0.39 & -0.14 & 0.15 & 0.06 & 0.20 & 0.33 & 0.58 & 0.32 & -0.04 \\
\hline $\mathrm{Nb}$ & 0.10 & 0.45 & -0.44 & 0.13 & 0.11 & 0.09 & 0.35 & -0.08 & 0.10 & 0.03 & 0.21 & 0.16 & 0.35 & 0.36 & 0.20 \\
\hline $\mathrm{Cs}$ & -0.17 & 0.61 & -0.22 & 0.22 & 0.27 & 0.24 & 0.44 & 0,08 & 0.25 & -0.05 & 0.36 & 0.41 & 0.71 & 0.28 & -0.08 \\
\hline$\sum \mathrm{REE}$ & -0.35 & 0.75 & -0.29 & 0.60 & 0.46 & 0.43 & 0.77 & 0.24 & 0.45 & -0.08 & 0.74 & 0.80 & 0.84 & 0.50 & 0.01 \\
\hline Hf & -0.24 & 0.67 & -0.07 & 0.34 & 0.25 & 0.23 & 0.84 & -0.27 & 0.25 & -0.04 & 0.35 & 0.29 & 0.47 & 0.40 & 0.33 \\
\hline $\mathrm{Pb}$ & -0.47 & 0.38 & -0.35 & 0.51 & 0.61 & 0.59 & 0.39 & -0.16 & 0.59 & -0.12 & 0.70 & 0.28 & 0.42 & 0.24 & -0.32 \\
\hline Th & .0 .47 & 0.90 & -0.24 & 0.62 & 0.56 & 0.52 & 0.86 & 0.03 & 0.54 & -0.19 & 0.78 & 0.69 & 0.87 & 0.63 & 0.14 \\
\hline $\mathrm{U}$ & -0.15 & 0.64 & $-0,09$ & 0.23 & 0.17 & 0.16 & 0.63 & 0.04 & 0.18 & ๓0.43 & 0.13 & 0.44 & 0.27 & 0.33 & 0.59 \\
\hline As & 0.41 & 0.44 & -0.13 & -0.20 & -0.32 & -0.34 & 0.34 & 0.19 & -0.32 & -0.27 & -0.10 & 0.04 & 0.40 & 0.00 & 0.22 \\
\hline $\mathrm{Cr}$ & -0.45 & 0.31 & -0.08 & 0.44 & 0.46 & 0.46 & 0.44 & 0.07 & 0.44 & -0.10 & 0.68 & 0.48 & 0.33 & 0.12 & -0.14 \\
\hline \multirow[t]{2}{*}{$\mathrm{Sb}$} & 0.59 & -0.18 & 0.09 & -0.58 & -0.60 & -0.59 & -0.23 & -0.04 & -0.57 & -0.05 & -0.68 & -0.34 & -0.29 & -0.42 & 0.36 \\
\hline & $\mathrm{Ni}$ & $\mathrm{Cu}$ & $\mathrm{Zn}$ & $\mathrm{Rb}$ & $\mathrm{Nb}$ & $\mathrm{Cs}$ & $\sum \mathrm{REE}$ & Hf & $\mathrm{Pb}$ & Th & U & As & $\mathrm{Cr}$ & & \\
\hline $\mathrm{Cu}$ & -0.34 & & & & & & & & & & & & & & \\
\hline $\mathrm{Zn}$ & 0.67 & 0.15 & & & & & & & & & & & & & \\
\hline $\mathrm{Rb}$ & -0.23 & 0.33 & -0.10 & & & & & & & & & & & & \\
\hline $\mathrm{Nb}$ & 0.15 & 0.19 & 0.19 & 0.43 & & & & & & & & & & & \\
\hline $\mathrm{Cs}$ & -0.26 & 0.33 & -0.02 & 0.96 & 0.38 & & & & & & & & & & \\
\hline ¿REE & -0.23 & 0.41 & 0.17 & 0.30 & 0.35 & 0.40 & & & & & & & & & \\
\hline Hf & 0.28 & 0.43 & 0.60 & 0.14 & 0.23 & 0.16 & 0.50 & & & & & & & & \\
\hline $\mathrm{Pb}$ & -0.32 & 0.64 & 0.23 & 0.28 & 0.12 & 0.43 & 0.32 & 0.38 & & & & & & & \\
\hline $\mathrm{Th}$ & -0.14 & 0.62 & 0.38 & 0.58 & 0.43 & 0.70 & 0.82 & 0.57 & 0.61 & & & & & & \\
\hline $\mathrm{U}$ & 0.54 & 0.07 & 0.57 & 0.16 & 0.36 & 0.14 & 0.41 & 0.55 & -0.15 & 0.38 & & & & & \\
\hline As & 0.37 & -0.09 & 0.14 & 0.02 & 0.20 & 0.08 & 0.37 & 0.33 & -0.18 & 0.24 & 0.54 & & & & \\
\hline $\mathrm{Cr}$ & -0.20 & 0.39 & 0.36 & -0.06 & 0.01 & 0.09 & 0.46 & 0.39 & 0.63 & 0.48 & 0.09 & 0.05 & & & \\
\hline Sb & 0.55 & -0.60 & -0.05 & -0.20 & -0.05 & -0.27 & $\sim 0.31$ & -0.07 & -0.76 & -0.47 & 0.43 & 0.57 & -0.46 & & \\
\hline
\end{tabular}



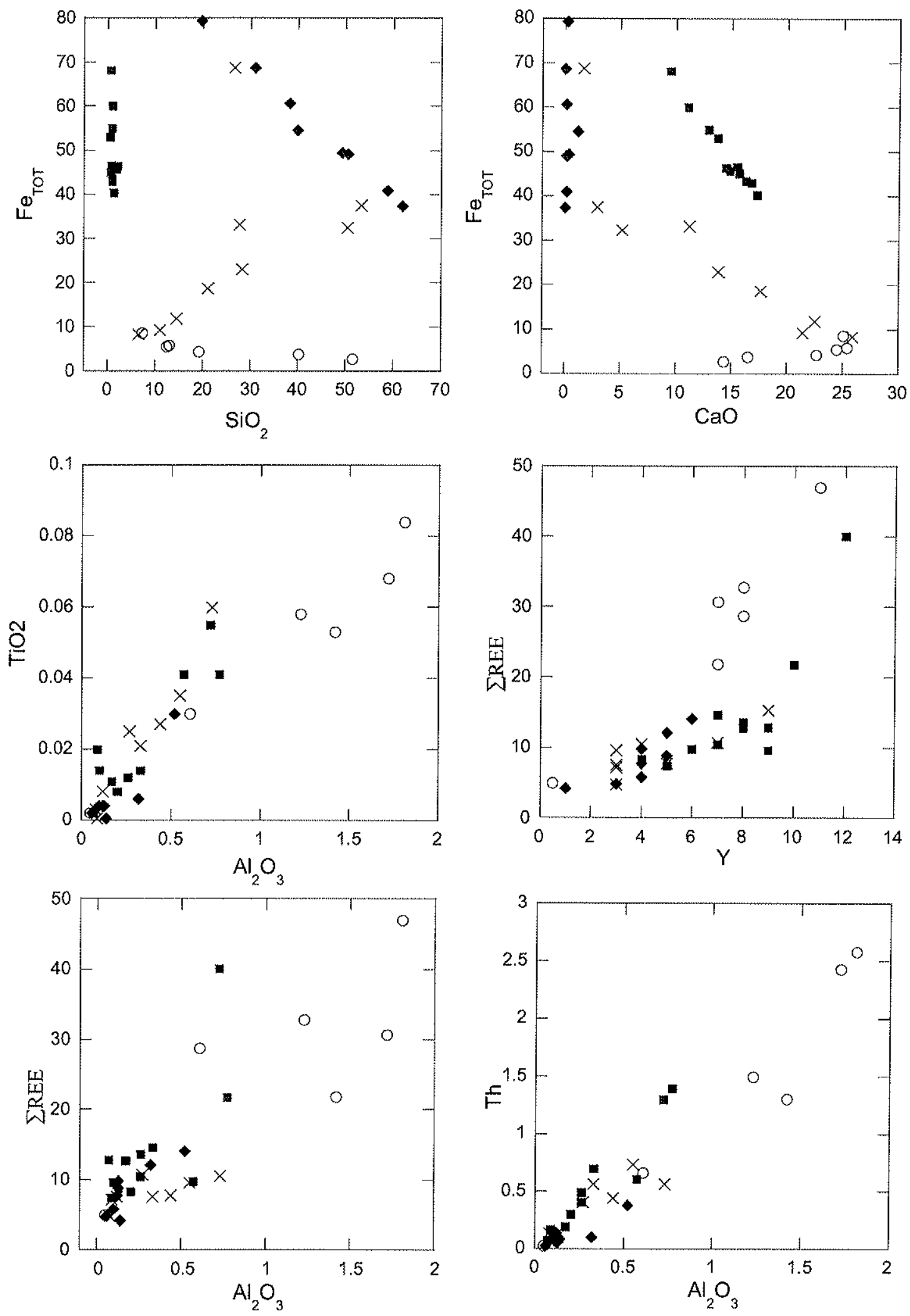

- Arg. Dolomite

- Dolomitic Itabirite

- Quartz Itabirite

$\times$ Qz-Dolomite/ltab.

Figure 15 - Interelement correlations. Note a good correlation between $\mathrm{Al}_{2} \mathrm{O}_{3}$ with $\mathrm{TiO}_{2}, \sum \mathrm{REE}$ and $\mathrm{Th}$ for all samples of the Itabira Group, which suggests participation of terriginous components during its deposition. 


\section{REE Results}

REE and $\mathrm{Y}$ abundances (REEY) of all samples are listed in Appendix 1 and averages of each major lithological group are presented in Table 3. PAAS normalized REEY patterns of all samples are also divided into the five groups shown in Figure 16a-h, With the exception of sericitic phyllite, all lithologies are characterized by depleted $\sum$ REE (ranging from 8-35 ppm).

The sericitic phyllite shows an average $\sum$ REE of $227 \mathrm{ppm}$ which is slightly higher than that of the PAAS (185 ppm; McLennan, 1989). Although they show a LREE enrichment $(\mathrm{La} / \mathrm{Yb}=1.38$ ), the contents of heavy rare earth elements (HREE) are fairly close to those of the PAAS, plotting as a flat pattern (Fig. 16e). The REEY pattern of the sericitic phyllite is identical to that of the Post-Archean shale as demonstrated when these rocks are plotted against $\mathrm{C}-1$ chondrite (Fig. 16f), except for a slightly more positive Eu anomaly for the PAAS (average $\left.\mathrm{Eu} / \mathrm{Eu}^{*}=1.24\right)$, possibly related to the presence of feldspar in the phyllite.

The argillaceous dolomite samples show depleted $\sum$ REE (average of $35 \mathrm{ppm}$ ), but less depleted than that of the overlying itabirite and dolomite. All samples display a similar REEY pattern (Fig. 16c) with HREE enrichment $(\mathrm{La} / \mathrm{Yb}=0.52)$, middle rare earth element (MREE) enrichment $(\mathrm{La} / \mathrm{Sm}=0.76)$ and no fractionation of HREE $(\mathrm{Sm} / \mathrm{Yb}=1.03)$. They show strongly positive Eu anomalies $\left(E u / E u^{*}=1.84\right)$, but do not exhibit $\mathrm{Ce}$ or $\mathrm{Y}$ anomalies, except for sample M139 which displays $\mathrm{Ce} / \mathrm{Ce}^{*}=0.90$.

Samples of dolomitic itabirite show an average $\sum$ REE of 14 ppm with concentration ranging between $7 \mathrm{ppm}$ to $40 \mathrm{ppm}$. REEY patterns of all samples are very similar (Fig. 16d) and show HREE enrichment $(\mathrm{La} / \mathrm{Yb}=0.27) . \mathrm{La} / \mathrm{Sm}(=0.62)$ and $\mathrm{Sm} / \mathrm{Yb}(=0.45)$ ratios for dolimitic itabirite indicate enrichment of heavier REE elements in both the light and heavy REE categories. Sample MAC06 shows a strong La anomaly. Significantly higher concentrations of $\mathrm{REE}$ and $\mathrm{Al}_{2} \mathrm{O}_{3}$ and $\mathrm{TiO}_{2}$ suggest that this $\mathrm{La}$ anomaly is a result of contamination by terrigenous material. All samples display strong positive $\mathrm{Eu}\left(\mathrm{Eu} / \mathrm{Eu}^{*=1.65)}\right.$ and $\mathrm{Y}\left(\mathrm{Y} / \mathrm{Y}^{*=1.59)}\right.$ anomalies and negative $\mathrm{Ce}$ anomalies, which range from 0.74 to $0.97\left(\mathrm{Ce} / \mathrm{Ce}^{*}\right)$.

Dolomite-rich bands of dolomitic itabirite are less depleted (average $\sum$ REE of $19 \mathrm{ppm}$ ) than iron-rich bands (average $\sum$ REE of $10 \mathrm{ppm}$ ). The REEY patterns of both bands are similar (Fig. $16 \mathrm{~g}-\mathrm{h}$ ) and exhibit the same HREE enrichment of the bulk samples. The major differences between the bands are the more pronounced negative $\mathrm{Ce}$ anomaly in the iron-rich bands $\left(\mathrm{Ce} / \mathrm{Ce}^{*}=0.82\right)$ and the less pronounced HREE enrichment in the dolomite-rich bands $(\mathrm{Sm} / \mathrm{Yb}=0.58)$ when compared to the iron-rich bands $(\mathrm{Sm} / \mathrm{Yb}=0.47)$. 
The samples of quartz itabirite are the most depleted of the whole set of samples studied (average $\sum \mathrm{REE}$ of $8 \mathrm{ppm}$ ). They exhibit strong heavy element enrichment within the group of LREE ( $\mathrm{La} / \mathrm{Sm}=0.54)$ similar to that shown by the dolomitic itabirite, but with a depletion of the heavy elements within the group of the HREE (Fig. 16a). This is the major distinguishing feature of the REEY patterns for both compositional types of itabirites. Positive Eu (average $\left.\mathrm{Eu} / \mathrm{Eu}^{*}=1.49\right)$ and $\mathrm{Y}\left(\mathrm{Y} / \mathrm{Y}^{*}=1.33\right)$ anomalies, and negative $\mathrm{Ce}$ anomalies (ranging between 0.60 to 0.93 ) occur in all samples.

Quartz-carbonate rocks of the transition zone to the Gandarela Formation are also, like the quartz itabirite, very depleted in REE. (average $\sum$ REE of $9 \mathrm{ppm}$ ). All but one sample (P3_170) show similar REEY pattern (Fig. 16b). There is an enrichment of heavier elements within the group of the LREE ( $\mathrm{La} / \mathrm{Sm}=0.54)$, while HREE shows a relatively flat pattern. All the samples exhibit positive Eu and $\mathrm{Y}$ anomalies, but they are not as pronounced as those of the quartz itabirite. Ce does not display an anomaly; $\mathrm{Ce} / \mathrm{Ce}$ * ranges from 0.93 to 1.16 .

$\mathrm{Eu} / \mathrm{Eu}_{\mathrm{PAAS}}$ ratios decrease continuously up the sequence, ranging from 2.21 in sample M132 of the argillaceous dolomite to 1.35 in sample P196 of the dolomite of the transition zone (Fig. 13d), with a small shift at the transition from quartz itabirite to quartz-carbonate rocks. The $\mathrm{Y} / \mathrm{Y}^{*}$ PAAS ratios increase from the argillaceous dolomite up to the transition zone from the dolomitic to the quartz itabirite, then keeping a lower and almost constant value from the quartz itabirite. $\mathrm{Ce} / \mathrm{Ce}$ * pas ratios show a decreasing trend up to the contact between quartz itabirite and quartz-carbonate rocks, and then increase from this point on.
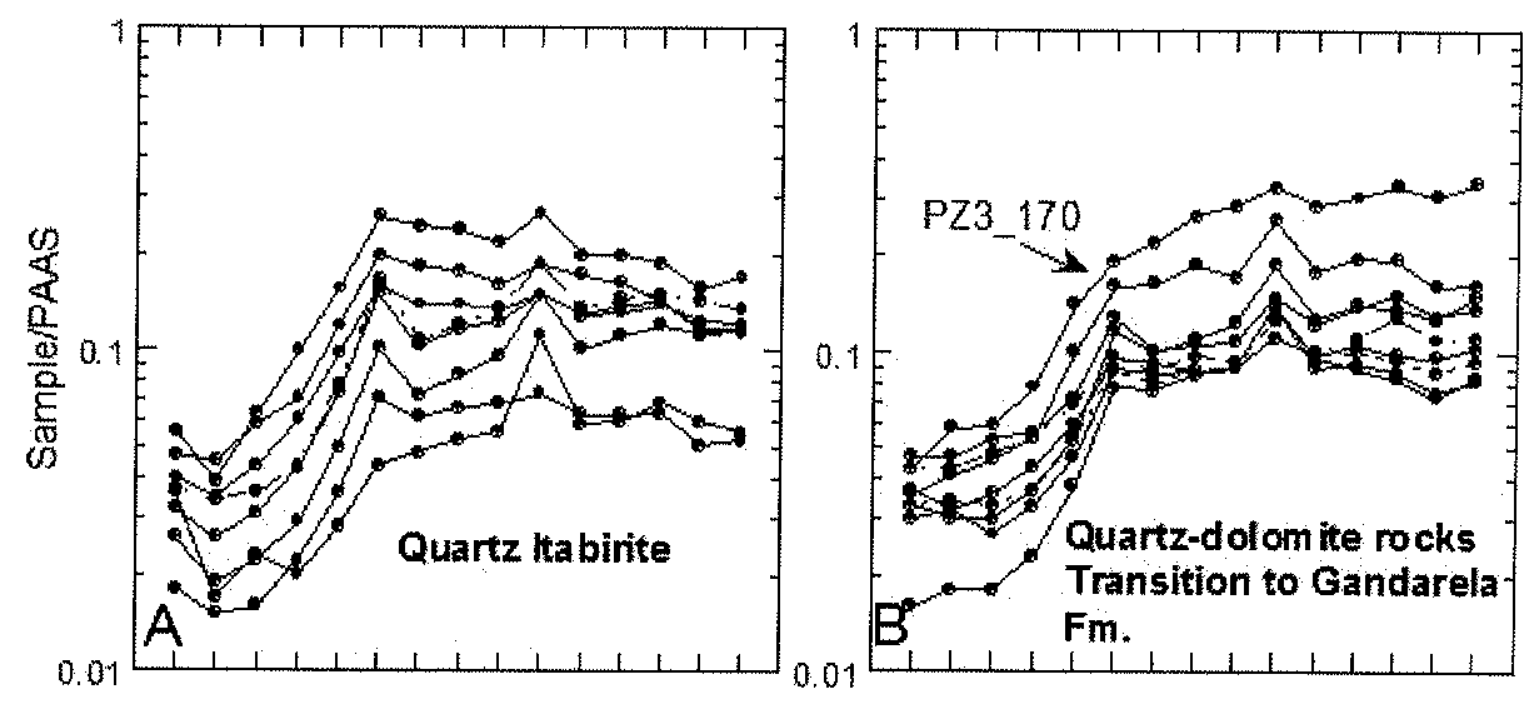

Figure 16 - PAAS-normalized REE data. A Quartz itabirite. B Quartz-dolomite rocks of the transition zone to the Gandarela Formation. 

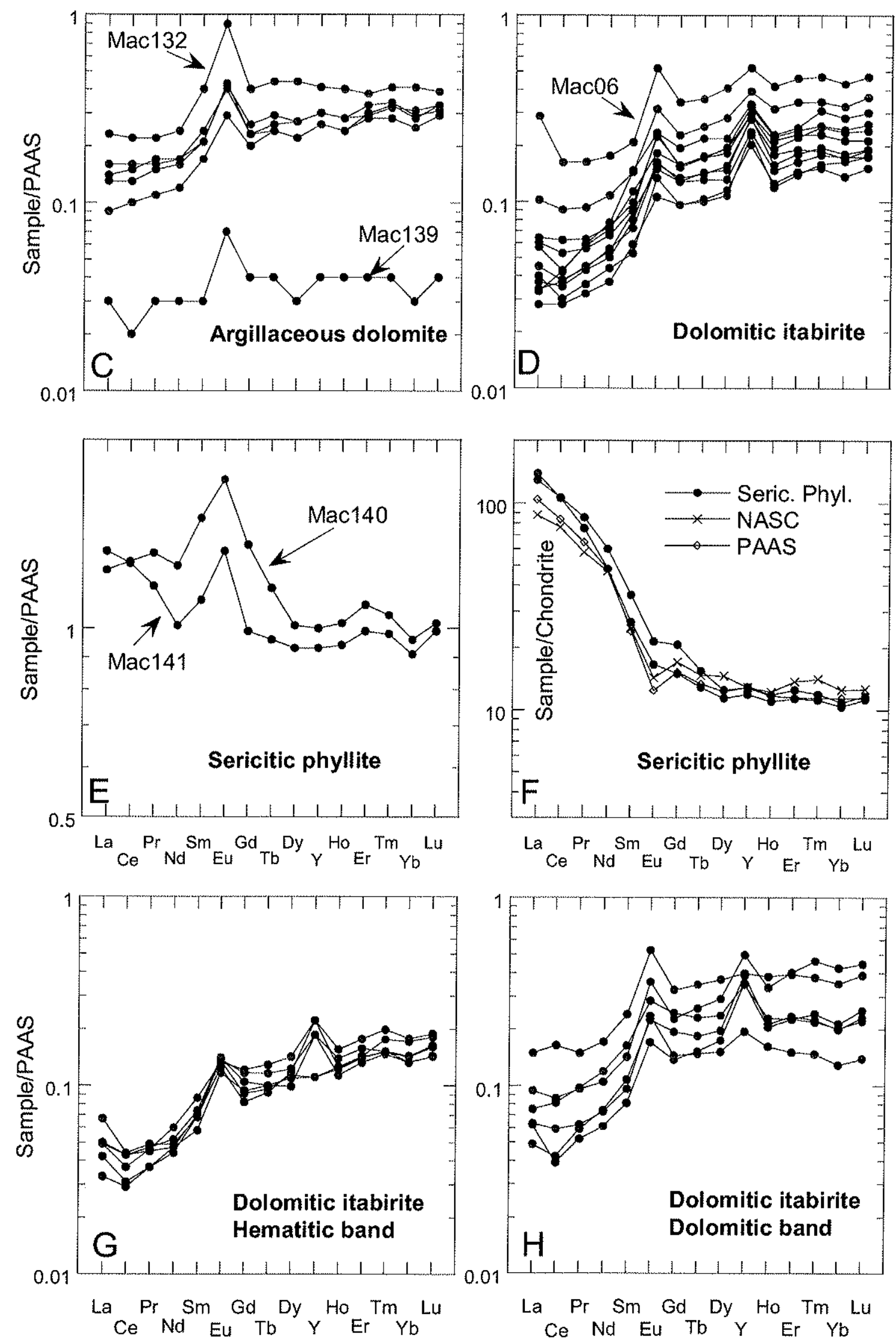

Figure 16 - PAAS-normalized REE data. C Argillaceous dolomite. D Dolomitic itabirite. E Sericitic phyllite. F Chondrite C2-normalized REE data. G-H PAAS-normalized REE data of dolomitic itabirite: $(\mathbf{G})$ hematitic band; $(\mathbf{H})$ dolomitic band. 


\section{$C$ and $O$ Isotopes}

The forty five analysed dolomite samples of the dolomitic itabirite of the Caue Formation show negative $\delta^{13} \mathrm{C}$ values varying from $-2.5 \%$ to $-0.8 \%$ while the oxygen isotope data displays $\delta^{18} \mathrm{O}$ values varying from $-12.4 \%$ to $-8.5 \%$ (Table 5). In a stratigraphic sense, there is a depletion in the ${ }^{13} \mathrm{C}$ content of dolomitic itabirite at the base of the sequence, with ferruginous dolomite exhibting lower contents (Fig, 12). Dolomitic itabirite becomes less depleted in ${ }^{13} \mathrm{C}$ up to the middle of the sequence, where there is another depletion trend. $\delta^{13} \mathrm{C}$ keeps a lower and relatively constant carbon- 13 isotopic composition from approximately the middle to the top of the dolomitc itabirite. In contrast to ${ }^{13} \mathrm{C},{ }^{18} \mathrm{O}$ contents show a different trend. ${ }^{18} \mathrm{O}$ increases from the base of dolomitic itabirite up to the middle of the sequence, and then continuously decrease up sequence. Close to the top of the dolomitic itabirite, dolomite becomes more enriched in the heavier isotope, again. $\delta^{18} \mathrm{O}$ and $\delta^{13} \mathrm{C}$ exhibit similar trends along the sequence, with $\delta^{18} \mathrm{O}$ showing small shifts, maybe due to its three order of magnitude higher sensitivity to alteration in diagenetic environment than $\delta^{13} \mathrm{C}$ (Banner and Hanson, 1990).

Figure 12 displays the $\delta^{13} \mathrm{C}$ and $\delta^{18} \mathrm{O}$ data obtained by Bekker et al. (2003) in stromatolitic dolomites in the upper part of the Gandarela Formation. $\delta^{18} \mathrm{O}$ values of the dolomitic itabirite and those of the stromatolitic itabirite are similar and exhibit similar orders of variation. Most samples of the Cauê Formation and Gandarela Formation have $\delta^{18} \mathrm{O}$ values above -10.5 per mil consistent with those found in well-preserved Paleoproterozoic carbonate successions (Bekker et al., 2003; Veizer et al., 1992; Veizer et al., 1990; Veizer et al., 1989). ${ }^{13} \mathrm{C}$ contents of the dolomitic itabirite are lower than those of dolomite of the Gandarela Formation. The most negative $\delta^{13} \mathrm{C}$ values occur at the base of the sequence $(-2.4$ per mil), grading upsection into values around -1.7 per mil. Red dolomite sampled by Bekker et al. (2003) at the base of the Gandarela Formation in the Gandarela Farm (Fig. 1) displays $\delta^{13} \mathrm{C}$ values ranging from -1.3 to -1.0 per mil. These authors found positive $\delta^{13} \mathrm{C}$ values (around +0.4 per mil) for dolomite at the top of the Gandarela Formation. Carbon isotopic data of the Caue Formation obtained in this study combined with data for dolomite rocks of the Gandarela Formation indicates a positive trend (with slight variations) in $\delta^{13} \mathrm{C}$ values within the rocks of the Minas Supergroup. Positive carbon isotope excursions in seawater composition are generally interpreted as indicating high relative burial rates of organic matter and accompanying increase in the oxygen production (Derry et al., 1992; Karhu and Holland, 1996; Kaufman et al., 1997). The record of a positive trend in the $\delta^{13} \mathrm{C}$ values during the interval of deposition of the Itabira 
Group between 2.6 and $2.4 \mathrm{Ga}$ is relevant to our current understanding of global climates during the Paleoproterozoic.

Table 5 - C and O Isotope Composition of Dolomite in Dolomitic Itabirite

\begin{tabular}{|c|c|c|c|}
\hline Sample & $\begin{array}{c}\text { North } \\
\text { Coordenate } \\
\text { (m) }\end{array}$ & $\begin{array}{c}\delta^{18} \mathrm{O}(\%) \\
\mathrm{PDB}\end{array}$ & $\begin{array}{c}\delta^{13} \mathrm{C}(\% 0) \\
\mathrm{PDB}\end{array}$ \\
\hline MAC-1 & -810 & -10.33 & -0.97 \\
\hline MAC-2 & -808 & -10.42 & -0.75 \\
\hline MAC-3 & -807 & -12.05 & -2.17 \\
\hline MAC-4 & -804 & -11.06 & -2.28 \\
\hline MAC-6 & -797 & -10.53 & -2.30 \\
\hline MAC-8 & -793 & -9.12 & -2.31 \\
\hline MAC-9 & -791 & -10.05 & -1.67 \\
\hline MAC-11 & -783 & -9.75 & -1.76 \\
\hline MAC-12 & -775 & -10.59 & -2.34 \\
\hline MAC-14 & -770 & -8.50 & -2.45 \\
\hline $\mathrm{MAC}-15$ & -768 & -10.36 & -1.95 \\
\hline MAC -16 & -765 & -9.17 & -2.14 \\
\hline MAC-18 & -752 & -10.44 & -1.83 \\
\hline MAC-19 & -745 & -9.23 & -1.79 \\
\hline MAC-20 & -742 & -11.18 & -1.58 \\
\hline MAC-21 & -734 & -9.34 & -1.14 \\
\hline $\mathrm{MAC}-23$ & -722 & -9.65 & -1.21 \\
\hline MAC-24 & -717 & -9.61 & -1.30 \\
\hline MAC-25 & -709 & -8.86 & -0.79 \\
\hline $\mathrm{MAC}-26$ & -696 & -10.60 & -1.46 \\
\hline $\mathrm{MAC}-27$ & -692 & -10.32 & -1.25 \\
\hline $\mathrm{MAC}-28$ & -680 & -11.57 & -1.64 \\
\hline MAC-29 & -669 & -10.90 & -1.71 \\
\hline MAC-30 & -660 & -12.05 & -1.55 \\
\hline MAC-32 & -647 & -10.85 & -1.51 \\
\hline $\mathrm{MAC}-34$ & -640 & -11.61 & -1.56 \\
\hline MAC-36 & -629 & -12.21 & -1.71 \\
\hline MAC-37 & -619 & -12.34 & -1.68 \\
\hline MAC 38 & -600 & -12.32 & -1.71 \\
\hline MAC 39 & -587 & -11.07 & -1.71 \\
\hline MAC 40 & -577 & -11.49 & -1.92 \\
\hline MAC 42 & -567 & -12.39 & -1.79 \\
\hline $\mathrm{MAC} 43$ & -562 & -10.49 & -1.77 \\
\hline MAC 45 & -547 & -10.74 & -2.20 \\
\hline MAC 46 & -541 & -9.73 & -1.75 \\
\hline $\mathrm{MAC} 47$ & -535 & -9.87 & -1.65 \\
\hline MAC 48 & -527 & -8.76 & -1.56 \\
\hline MAC 49 & -524 & -10.01 & -1.84 \\
\hline MAC 50 & -519 & -9.41 & -1.67 \\
\hline MAC 51 & -512 & -8.63 & -1.52 \\
\hline MAC 52 & -507 & -10.91 & -1.74 \\
\hline MAC 53 & -505 & -11.33 & -1.76 \\
\hline
\end{tabular}




\section{Comparison with other iron-formations}

The average major and trace elements contents of the dolomitic and quartz itabirite of QF are compared with BIFs of the Carajás Formation (Lindenmayer et al., 2001; Macambira and Schrank, 2002), the Kaapvall Supergroup (Klein and Beukes, 1992) and the Hamersley Group (Klein and Beukes, 1992) in Figure 17. The averages were recalculated without the LOI, according to Klein and Beukes (1992), to allow for comparisons between metamorphic and unmetamorphic BIFs. These authors assume that metamorphic reactions are essentially isochemicals for major elements except for $\mathrm{H}_{2} \mathrm{O}$ and $\mathrm{CO}_{2}$.

A very remarkable feature of dolomitic and quartz itabirites that is observed only in the QF and Carajás BIFs, which distinguishes them from the others BIFs, is their high $\mathrm{Fe}_{2} \mathrm{O}_{3}$ and low FeO contents (Fig. 17a). The $\mathrm{Fe}_{2} \mathrm{O}_{3} / \mathrm{FeO}$ ratio in BIFs from Issua, Transvaal and Hamersley is lower than or close to 1, while in Brazilian BIFs this ratio is much higher reaching an average of 39 in Carajás and values around 70 in itabirites of the QF.

The dolomitic itabirite shows a chemical composition that is very different from the others BIFs as a result of its different mineralogical composition. The $\mathrm{SiO}_{2}$ content of this rock is very low due to the almost complete absence of quartz. $\mathrm{CaO}$ and $\mathrm{MgO}$, however, showed the highest contents of all BIFs considered, which reflects the presence of dolomite. The other major elements are similar to those observed in other BIFs. The quartz itabirite shows a very simple major element composition that consists basically of $\mathrm{SiO}_{2}$ and $\mathrm{Fe}_{2} \mathrm{O}_{3}$, with $\mathrm{TiO}_{2}, \mathrm{CaO}, \mathrm{MgO}$, $\mathrm{MnO}, \mathrm{Na}_{2} \mathrm{O}, \mathrm{K}_{2} \mathrm{O}$ and $\mathrm{P}_{2} \mathrm{O}_{5}$ contents being lower than those of the other BIFs found worldwide. The only difference observed is in the $\mathrm{Al}_{2} \mathrm{O}_{3}$ content, which, although very low, is higher in $\mathrm{QF}$ BIF than BIFs of the Transvaal but similar to Carajás BIFs.

A comparison of trace element composition in BIF is problematic because there is no data available in the literature of BIFs for a number of elements presented here. Figure $17 \mathrm{~b}$ shows that the trace elements composition of itabirites is similar to that of other BIFs found worldwide. All of them contain very low trace element concentrations when compared with PAAS (Fig. 17c). The Ni, $\mathrm{Cu}, \mathrm{Zn}$ and $\mathrm{Rb}$ contents of the dolomitic and quartz itabirite are lower and $U$ contents are higher than other BIF's.

Figure 18 shows the $\mathrm{C}$ and $\mathrm{O}$ isotopic composition of dolomitic itabirite is distinct when compared to other BIFs considered above. The values of the $\delta^{13} \mathrm{C}$ and $\delta^{18} \mathrm{O}$ are quite similar to those obtained by Rivers (1998) for carbonates of the Wittenoom Formation of the Hamersley Basin, and by Sial et al. (2000) and Bekker et al. (2003) to stromatolitic dolomites of the Gandarela Formation of the Minas Basin. These similarities and the gradual ${ }^{13} \mathrm{C}$ enrichment up- 
section from the base of the Caue Formation to the top of the Gandarela Formation suggest that dolomites of the Cauê Formation preserve the depositional carbon isotope composition, likely reflecting the composition of seawater solutions.

The values of $\delta^{13} \mathrm{C}$ of dolomitic itabirite are slightly lower than those of normal marine carbonates, which are typically characterized by $\delta^{13} \mathrm{C}$ values of $\mathrm{c} .-1$, but higher than those found for BIFs of the Hamersley and Transvaal basin. The higher depletion of ${ }^{13} \mathrm{C}$ in BIFs of these basins is attributed to their formation in an isotopically depleted water mass (Beukes et al., 1990; Kaufman et al., 1990). According to the models of Beukes et al. (1990) and Becker and Clayton (1972), early Proterozoic oceans were stratified with respect to the isotopic signature of dissolved $\mathrm{CO}_{2}$, with a lower ocean water mass depleted in ${ }^{13} \mathrm{C}$. Upwelling would bring deep, anoxic waters to shelves where siderite with isotopic composition near -5 per mil formed below the chemocline, while limestones with isotopic composition near -1 per mil formed in shallow, near-shore environment. The ${ }^{13} \mathrm{C}$ enrichment from BIFs of the Transvaal basin to BIFs of the Cauê Formation, with intermediate ${ }^{13} \mathrm{C}$ contents in BIFs of the Hamersley basin, suggests variation in the seawater carbon isotopic composition within each of the basins or shelf environments where BIF's were precipitated. BIFs of the Transvaal basin have a higher contribution of light carbon in $\mathrm{CO}_{2}$ from deep, anoxic seawater, whereas BIF of the Cauê Formation which are enirched in isotopically heavy carbon would have a higher contribution of shallow, oxygenated waters. REE data of the dolomitic itabirite support deposition of BIF in near-shore environments (see discussion below). 

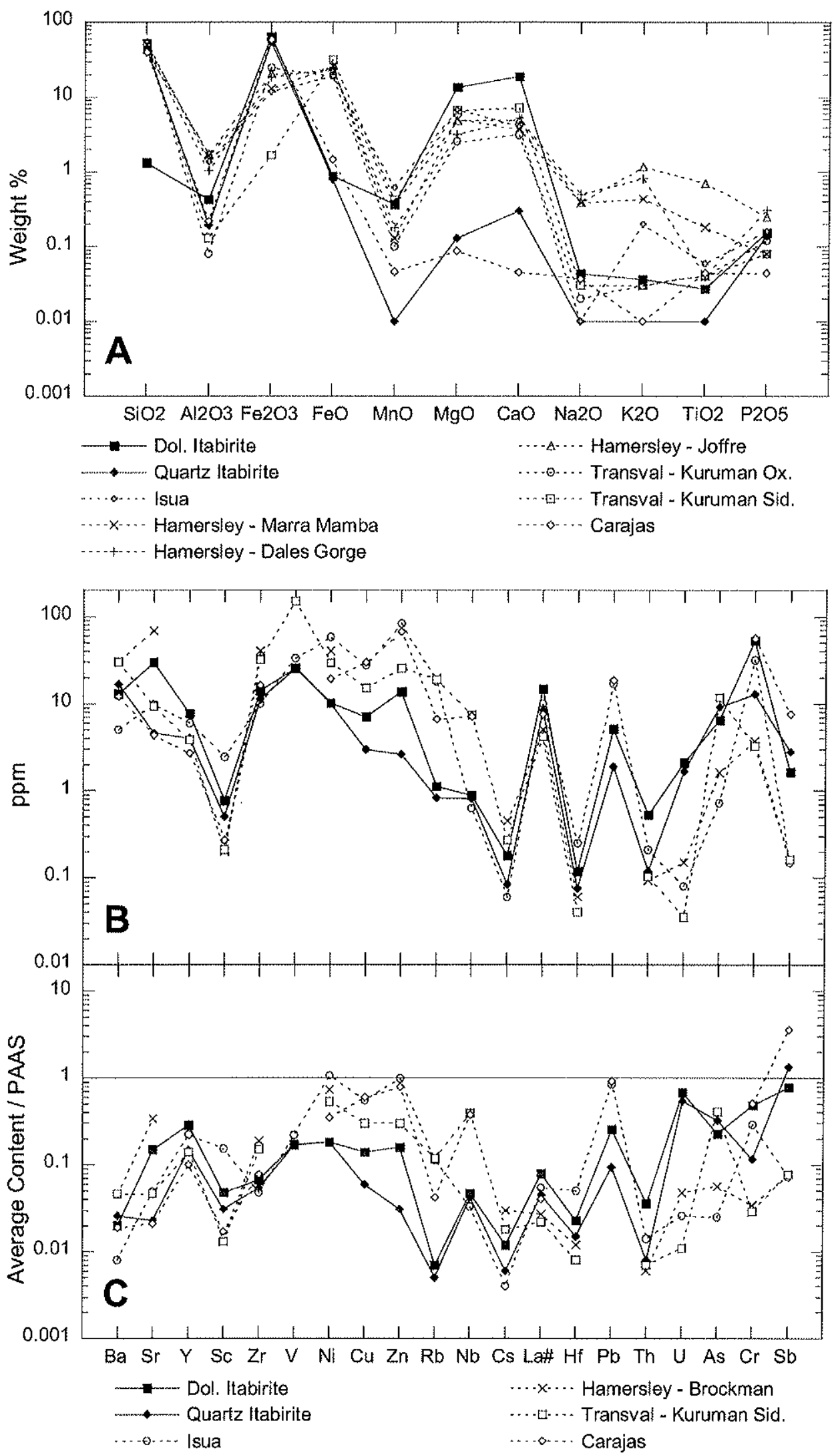

Figure 17 - Average major (A) and trace element (B) composition of BIFs of Quadrilatero Ferrifero, Isua, Hamersley, Transvaal and Carajás. C - Trace element composition normalized against PAAS of McLennan (1989), with the exception of $\mathrm{Ta}, \mathrm{Sb}$ and As contents that were normalized against NASC of Gromet et al. (1984). Data from Isua, Hamersley and Transvaal are from Klein and Beukes (1992). Data from Carajás are from Lindenmayer et al. (2001), with the exception of $\mathrm{Pb}, \mathrm{Zn}, \mathrm{Cu}, \mathrm{Sc}$, and $\mathrm{Sb}$ contents that are from Macambira and Schrank (2003). 


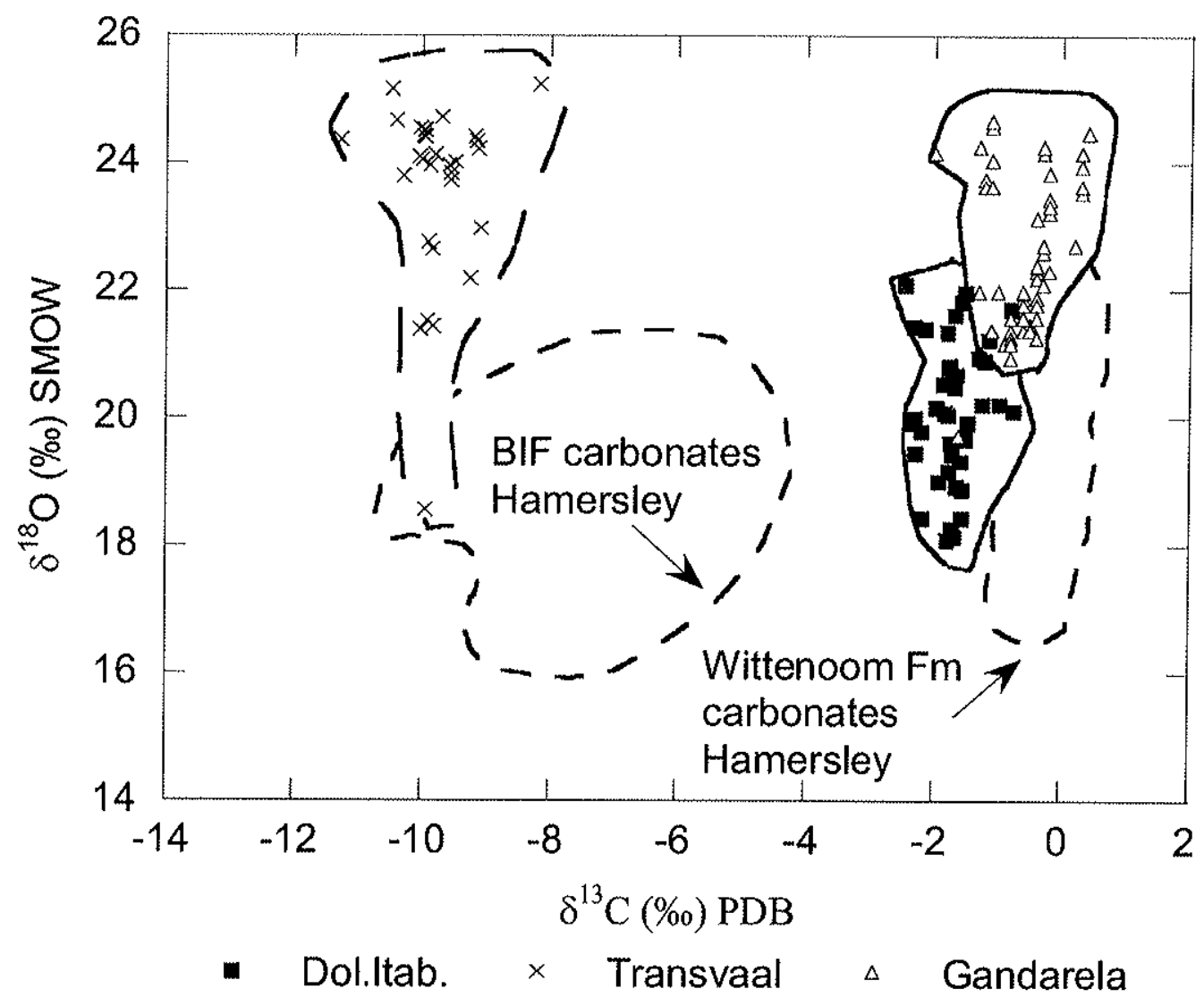

Figure 18 - Carbon and oxygen isotopes from carbonates of dolomitic itabirite of the Cauê Formation and stromatolitic dolomite of the Gandarela Formation at the Quadrilátero Ferrifero; dolomite and BIFs of the Hamersley basin; and BIFs of the Transvaal basin. Note the close association of dolomitic itabirite carbonates with carbonates of the Gandarela and Wittenoom Formations. Data from the Gandarela Formation are from Sial et al. (2000) and Bekker et al. (2003); from the Hamersley basin are from Rivers (1988) in Taylor et al. (2001); and from the Transvaal basin of Beukes and Klein (1990).

\section{DISCUSSION}

Most authors agree that BIFs are chemical sediments formed by the precipitation of iron and silica from solutions consisting of a mixture of seawater with hydrothermal fluids, with various degrees of contamination by terrigenous sediments carried by rivers or winds, or emanated from volcanic activities (e.g. Arora et al., 1995; Kato et al., 1998; Kimberley, 1989; Klein and Beukes, 1989). Hydrothermal fluids would be produced in the convection cells along mid-ocean ridges and back-arc spreading centers, where a fluid rock-interaction takes place in a reducing environment with temperatures reaching $>300{ }^{\circ} \mathrm{C}$ and $\mathrm{pH}$ staying between 2 and 4 
(Bau and Möller, 1993). Convection currents would transport the hydrothermal fluids mixed with deep seawater up to the continental shelf where they would be precipitated. This model is based on comparisons of the REE signature of BIFs with that of deep hydrothermal deposits. The patterns are essentially the same which show pronounced positive Eu anomalies and depletion in the light REE (Danielson et al., 1992; Derry and Jacobsen, 1990).

The geochemical signature of BIFs helps to understand their depositional paleoenvironment. However, the signature can be masked by a high degree of terrigenous contamination, or obliterated by later diagenetic and metamorphic processes, which would lead to wrongful interpretations. The itabirites of the Cauê Formation are the product of at least two tectonic events and metamorphism to green schist facies. The interpretation of the geochemical data for reconstructing a palaeoenvironmental and depostional model requires analysis to determine how preserved are the primary geochemical signatures. To justify our genetic model below, we discuss how our mineralogical, petrological and geochemical data of the Cauê Formation reflects that of primary BIF.

\section{The question of terrigenous contamination}

Bau and Möller (1993) showed the REE in the chemically precipitated component of BIFs is a proxy for the composition of contemporaneous seawater, bringing useful insights into the chemistry of ancient sea water, and the secular variations of the atmosphere-hydrospherelithosphere system. These REE patterns, however, are significantly modified by terrigenous contaminants, largely because REE abundances may be more than two orders of magnitude higher in clastic detritus than in seawater precipitates (Arora et al, 1995; Bau, 1993). The interpretation of REE patterns needs, therefore, a very careful monitoring of terrigenous contamination.

In BIFs of the Hamersley and Transvaal shales and lutites are considered clastic contaminants with a primary volcanogenic origin (Beukes et al., 1990; Ewers and Morris, 1981; Morris, 1993). These rocks consist essentially of stilpnomelane, and are chemically distinct from stilpnomelane in their host BIFs by higher contents of $\mathrm{Al}_{2} \mathrm{O}_{3}, \mathrm{TiO}_{2}, \mathrm{~K}_{2} \mathrm{O}$ and $\mathrm{Zr}$ (Horstmann and Hälbich, 1995). A positive correlation between the $\mathrm{TiO}_{2}$ and $\mathrm{Al}_{2} \mathrm{O}_{3}$ in $\mathrm{BIF}$ of the Hamersley Province was interpreted by Ewers and Morris (1981) as indicative of clastic contamination. However, this same relationship was not established by Horstmann and Hälbich (1995) in the Transvaal BIFs. 
Itabirites of the Cauê Formation at the Águas Claras mine do not contain interlayered shales or lutite as mentioned above. However, volcanic contribution to the chemical sediments of the Cauê Formation in the QF has very recently been suggested by Suckau et al. (oral information). The aluminous micaceous minerals found both in the argillaceous dolomite and in the dolomite of the transition zone to the Gandarela Formation, sometimes forming thin laminas (Fig. $1 \mathrm{lh}$ ), may be terrigenous. The very strong positive correlation between $\mathrm{Al}_{2} \mathrm{O}_{3}$ and $\mathrm{TiO}_{2}$ on the whole set of the samples studied (Fig. 15) suggest contribution of a terrigenous component during deposition of the Cauê Formation, and we suggest the aluminous micaceous minerals observed in all lithologies are the major contaminants. Very low $\mathrm{K}_{2} \mathrm{O}$ contents suggest a minimal amount of terrigenous contamination, which is comparable to contamination levels in BIF's of Transvaal basin but lower than that of the Hamersley basin (Fig. 17a).

Bau (1993) suggested that the abundance of elements regarded as immobile in aqueous solution, such as $\mathrm{Ti}, \mathrm{Zr}, \mathrm{Hf}, \mathrm{Y}, \mathrm{Nb}$, Ta or $\mathrm{Sc}$ should be used to examine for potentially contaminated samples. High concentrations of these elements are unlikely to be derived from seawater and most likely reflect input from terrigenous sources. Bau (1993) found linear relationships between $\mathrm{Hf}$, Th and $\mathrm{Sc}$ in variably contaminated BIFs and proposed that a $\mathrm{Sc}$ abundance of $2 \mathrm{ppm}$ is a practical limiting value above which a chemical precipitate should be excluded from interpretations using the REE's as a proxy for the chemistry of ancient seawater. This limit corresponds to c. $1 \mathrm{ppm}$ of Th according to his Figure $2 \mathrm{~b}$. Figure 19 shows a plot of Sc versus Th abundance of the studied samples. The two phyllite samples are clearly above these critical limits specified by Bau (1993), while the argillaceous dolomite and dolomite of the transition zone to the Gandarela Formation are close or above the critical limits. Two samples of dolomitic itabirite (M4 and M7) are disregarded from our interpretation because they are above critical limits. We conclude from this diagram that clastic contamination of itabirites is negligible for our interpretations using the REE's as a proxy for the chemistry of ancient seawater.

Bau (1996) also shows that in contrast to silicate melt systems, the geochemical twin pairs Zr-Hf and Y-Ho are highly fractionated in aqueous solutions, and do not exhibit a chargeand-radius-controlled (CHARAC) behavior. The geochemical behavior of these elements in aqueous solutions is constrained by their electron configuration, which affects the nature of chemical bonding in its various compounds, hence the stability of its various chemical complexes. In Precambrian and Phanerozoic shales the geochemical behavior of the Zr-Hf and $\mathrm{Y}$-Ho pairs is charge-and-radius-controlled, and therefore permits discrimination of clastic and 
chemical sediments and the degree of contamination. Figure 20 shows a plot of $\mathrm{Zr} / \mathrm{Hf}$ versus Y/Ho commonly used to identify such relationships. Samples of sericitic phyllite plot in the CHARAC field. However, argillaceous dolomite and dolomite of the transition zone to the Gandarela Formation plot in or close to this field, which indicates that these samples are contaminated by clastic material. Samples of dolomitic and quartz itabirites plot in intermediate positions between Fe-Mn crust and modern seawater sediments, therefore, corroborating our conclusions stated above of a very low level of terrigenous contamination.

The conclusion we draw from these tests is that the trace elements in itabirite samples truly reflects the chemistry of the seawater from which they were precipitated.

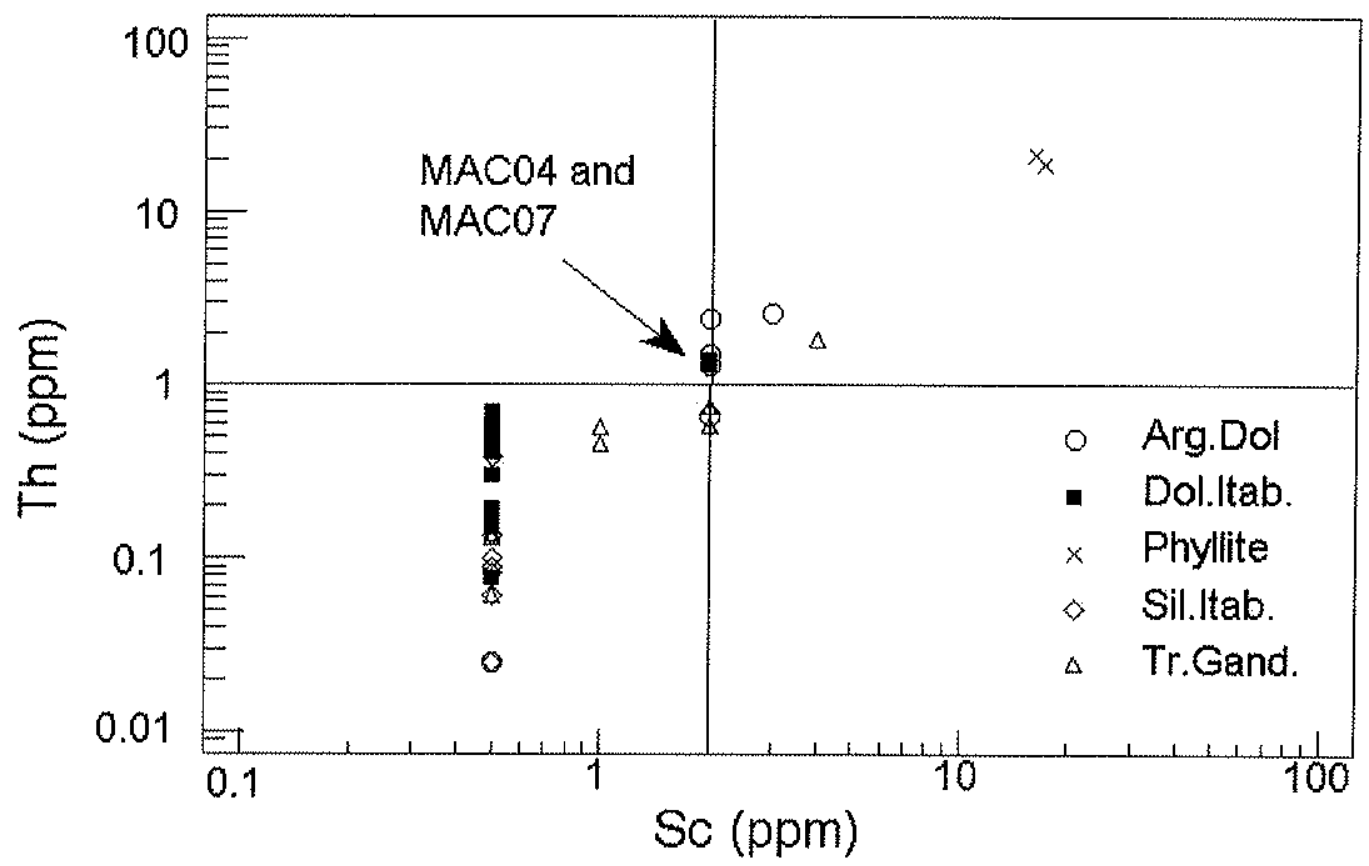

Figure 19 - Plot of Sc versus Th composition for all samples of the Itabira Group. Note that all samples of dolomitic and quartz itabirite (with exception of M4 and M7) have Sc contents lower than $2 \mathrm{ppm}$ and Th contents lower than $1 \mathrm{ppm}$, indicating small participation of terrigenous components in their sediments. Many samples have Sc content below the detection limit (1 ppm) and were plotted using the half of this value (see text for explanation). 


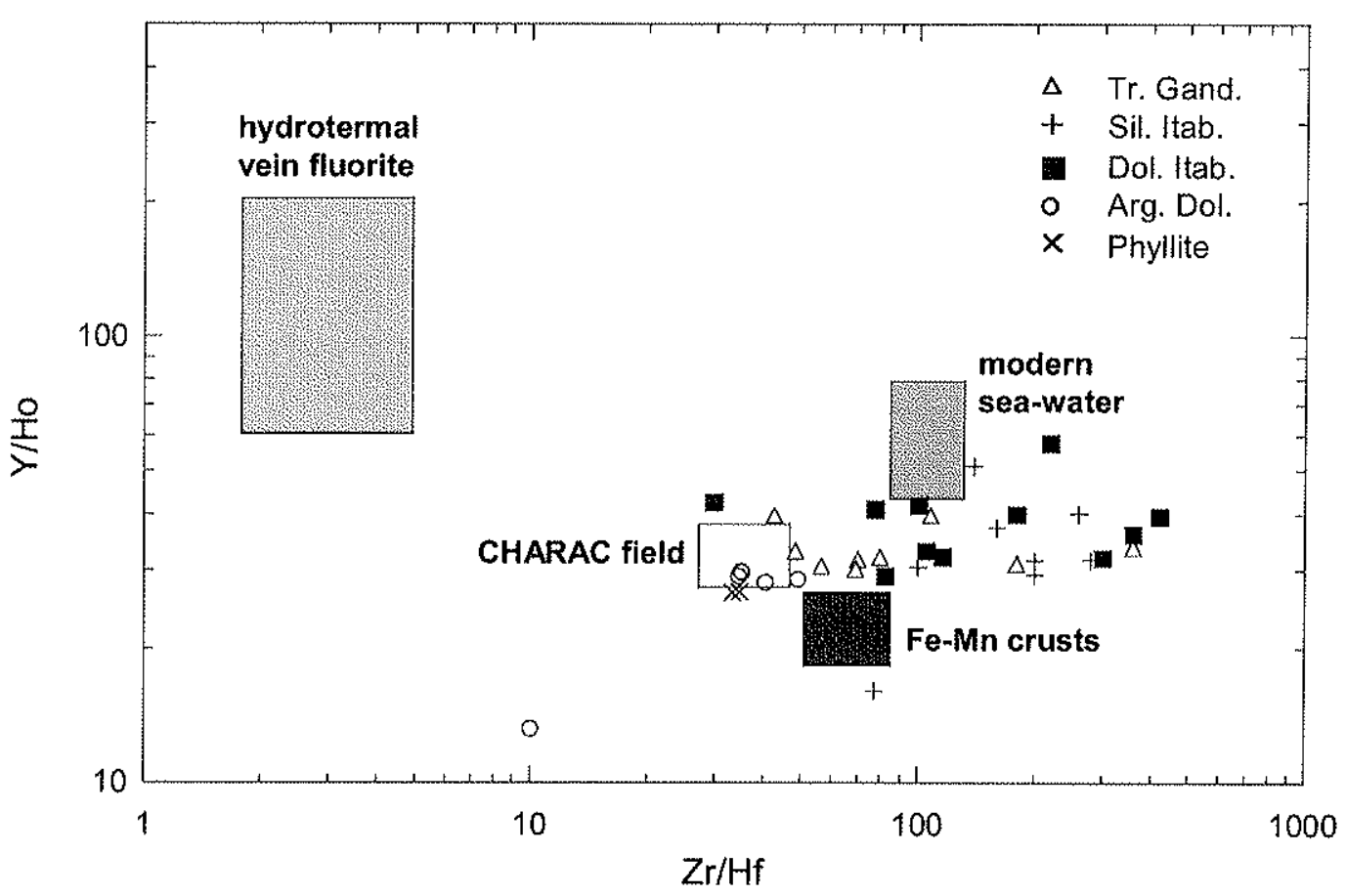

Figure 20 - Plot of the Y/Ho versus $\mathrm{Zr} / \mathrm{Hf}$ ratio with typical fields after Bau (1996). Note that samples of dolomitic and quartz itabirite plot between $\mathrm{Fe}-\mathrm{Mn}$ and modern sea-water fields, which indicate a small amount of terrigenous components on their sediments (that plot within CHARAC field) and suggest that the source of their components was the seawater mixed with hydrothermal fluids.

\section{Effects of Post-Depositional Processes}

Bau $(1991 ; 1996)$ states that the effects of the diagenesis and metamorphism on the REE distribution in IFs is only of minor importance in most cases, because in common metamorphic environments water/rock ratios are too low to have a significant effect on REE distribution. He also states that, regardless of their metamorphic grade, coeval detritus-free IFs display similar REE patterns. Banner et al. (1988) did an extensive study on the effect of diagenesis on cathodoluminescent behavior, $\mathrm{Sr}$ and $\mathrm{O}$ isotopic ratios, $\mathrm{Fe}$ and $\mathrm{Ca}$ content, and REE patterns of ancient carbonates from North America. They determined the relative REE abundance was not significantly altered during the extensive diagenetic atteration of marine limestones through two different phases of dolomitization, which represented two completely different diagenetic fluids and environments. When discussing the geochemistry of BIFs worldwide, Klein and Beukes (1992) considered that the metamorphism of these rocks is isochemical except for the loss of $\mathrm{H}_{2} \mathrm{O}$ and $\mathrm{CO}_{2}$. The chemical similarity between unmetamorphosed and highly metamorphosed Labrador Trough iron-formations is a good example. Pires and Frost (2004) state that during the metamorphism of the Cauê Formation the original bulk composition of the BIFs controlled the composition of the metamorphic fluid phase rather than the opposite. In contrast, a study of the 
effects of contact metamorphism associated with intrusion of a diabase sill on BIF from the Kuruman Formation of the Transvaal Basin showed that metamorphism altered the isotopic composition of the carbonates by depleting both ${ }^{13} \mathrm{C}$ and ${ }^{18} \mathrm{O}$ (Kaufman, 1996).

BIFs in the QF are completely metamorphosed; therefore it is not possible to compare the chemical composition of metamorphosed and unmetamorphosed rocks to estimate the degree of chemical changes which may have occurred during metamorphism. However, the chemical composition of (green schist facies) itabirites in QF is very similar to other unmetamorphosed BIFs (Fig. 17). We assume that metamorphic events did not alter the chemical composition of the original sediments of the Cauê Formation significantly, and that our geochemical data can be used for paleoenvironmental reconstructions of BIF deposition.

\section{Dolomitization and the Genesis of the Dolomitic Itabirite}

The distribution of dolomite in the dolomitic itabirite of the Caue Formation and in the dolomite and marbles of the Gandarela Formation suggest that the original sediments of these rocks were largely dolomitized. Although in specific environments, where the seawater is hotter and has higher $\mathrm{PCO}_{2}$, higher $\mathrm{Mg} / \mathrm{Ca}$ ratio, lower $\mathrm{SO}_{4}{ }^{2-}$ and organic acid effects, the direct precipitation of dolomite is possible (Tucker and Wright, 1990), it is more probable that the dolomite found in QF results from the dolomitization of earlier carbonates, a common process in the Proterozoic. According to Tucker and Wright (1990) dolomitization generally appears to be an early near-surface phenomenon, where $\mathrm{CaCO}_{3}$ minerals precipitated on the seafloor can be dolomitized by seawater with a high dolomitizing potential. Dolomite is a common mineral component in BIFs, where it is usually associated with ankerite and calcite (e.g. Arora et al., 1995; Dymek and Klein, 1988; Ewers and Morris, 1981; Floran and Papike, 1978; Klein and Beukes, 1989). In the Lake Superior region there are unmetamorphosed BIFs composed only of dolomite and iron minerals (e.g. Klein and Fink, 1976; Perry Jr. et al., 1973). The same occurs at the Nabberu basin, western Australia (Hall and Goode, 1978).

It seems likely that the dolomitic rocks of the Cauê and Gandarela Formation result from dolomitization of earlier carbonates during the diagenesis. Beukes et al. (2002), however, consider the dolomitic itabirite as the result of the desilisification and carbonatization of quartz itabirite through a hydrothermal process, without presenting any evidence for this process. There is no field evidence to support this paragenetic sequence. On the contrary, the coexistence of quartz and dolomitic itabirite is locally observed in drill cores and outcrops of the Águas Claras Mine sometimes forming a triply banded rock (Fig. 6c). Quartz and dolomite are commonly 
intergrown in metachert, dolomite and itabirite without displaying any evidence of metamorphic reaction or hydrothermal substitution (Fig. 8d).

Dolomitic itabirite and dolomite of the Cauê Formation occur throughout the Serra do Curral, along c. $110 \mathrm{Km}$ of extension, indicating a regional distribution for these rocks. It is likely that a regional hydrothermal process of dolomitization of the quartz itabirite, as suggested by Beukes et al. (2002), would leave some indication of its occurrence, which was not observed to this day. Based on the field relations, petrographical and mineralogical observations, geochemical and isotopic data, we consider that dolomitic itabirite of the Cauê Formation are carbonate sediments modified by a dolomitization process which occurred during diagenesis, instead of a product of hydrothermal metasomatism of the quartz itabirite. We also consider that these carbonate sediments represent a lateral and vertical facies variation of the cherty sediments from which the quartz itabirite originated.

$\mathrm{Y} / \mathrm{Ho}$ ratios of the dolomitic itabirite provide further constraints to their origin. Modern seawater has an $\mathrm{Y} / \mathrm{Ho}$ ratio $(>44)$ that is substantially higher than chondrite $(26-28)$. The vast majority of geologic materials, including all volcanic rocks and clastic sediments, however, have condritic ratios (Nozaki et al,, 1997). Sampled dolomitic itabirite have $\mathrm{Y} / \mathrm{Ho}$ ratios ranging from 34 to 52 with an average of 42 (Fig. 20 and Table 3), suggesting the dolomite precipitated from seawater.

A marine origin for the dolomitic itabirite is also indicated by the $\mathrm{C}$ and $\mathrm{O}$ isotopes, which present $\delta^{13} \mathrm{C}$ and $\delta^{18} \mathrm{O}$ correlated with that of the stromatolitic carbonates of the Gandarela Formation of the Minas basin, and with the Wittenoom Formation of the Hamersley basin (Fig. 18). Carbon isotope data of the Cauê Formation are similar to those found in all studied marine carbonates older than ca. 2.32 Ga supporting the interpretation that they are seawater precipitates slightly modified by diagenetic and metamorphic alteration.

\section{The High Degree of Oxidation}

The dolomitic itabirite of the Cauê Formation has $\mathrm{Fe}^{3+} /\left(\mathrm{Fe}^{2+}+\mathrm{Fe}^{3+}\right)$ ratios raging from 0.977 to 0.993 (average of 0.984 ), while in quartz itabirite this ratio ranges from 0.967 to 0.997 (average of 0.985), as observed in Table 2. Discussing the average chemical composition of the major BIFs found worldwide, Klein and Beukes (1992) presented $\mathrm{Fe}^{3+} /\left(\mathrm{Fe}^{2+}+\mathrm{Fe}^{3+}\right)$ ratios ranging from 0.05 (siderite BIF in the Kuruman Iron Formation) to 0.58 (metamorphosed iron formation in Montana), except for one value of 0.97 (Rapitan Group). 
Comparison of $\mathrm{Fe}^{3+} /\left(\mathrm{Fe}^{2+}+\mathrm{Fe}^{3+}\right)$ ratios of magnetite (0.67) and hematite (1.0) with those of itabirites in the QF shows that iron is in an average oxidation state very close to that of hematite, which reflects the high oxidation process these rocks were submitted to, and which distinguishes them from other BIFs found worldwide. This high oxidation degree is petrographically evidenced by the total predominance of hematite over magnetite; magnetite occurs only as small relicts within martite crystals (Fig. 11c-d).

The hematite present in itabirites, however, results from several geological processes that modified the original sediments of the Caue Formation. It cannot be considered as the primary iron oxide precipitated in these sediments and therefore used to reconstruct itabirite paleoenvironmental conditions. Even in unmetamorphosed and unweathered BIFs, most of the minerals observed do not represent primary precipitates, but secondary phases crystallized during early diagenesis, when the precipitated iron hydroxide and silica gels recrystallized to hematite/magnetite and quartz, respectively (Ewers and Morris, 1981; Morris, 1993; Trendall, 2002).

Several authors (Dorr II, 1969; Pires, 1995; Pires and Frost, 2004; Rosière et al., 1993; Rosière et al., 2001) who investigated the various generations of iron oxides in itabirites andiron ore in QF consider that magnetite crystallization dominated early stages of itabirite formation.. The occurrence of graphitic phyllite yielding pyrite within the sericitic phyllite of the Batatal Formation, as well as the local presence of pyrite in the argillaceous dolomite (Fig. 8b-c) at the base of the Cauê Formation, suggest that the paleoenvironmental conditions were reducing during the beginning of sedimentation, thus favoring the crystallization of magnetite during the diagenesis.

In the quartz itabirite with metachert lenses at the transition zone from argillaceous dolomite to ferruginous dolomite (Fig. 4d) there is no tabular hematite, and martite (with many relicts of magnetite) is the only iron oxide observed (Fig. 8e). Martite is also the major iron oxide found in hematitic bands of itabirite, where it occurs intergrown with tabular hematite. According to Rosière and Rios (2004), tabular hematite is formed after martite during metamorphism and deformation, and therefore originates these intergrowns. A progressive deformation led to the disappearance of martite and the predominance of aggregates of tabular hematite, with specularite forming in higher deformed areas.

The origin of the fluids responsible for the pervasive martitization of magnetite in itabirite, as well as the absolute timing of this oxidation event, is not well defined. If the formation of hematite after martite occurred during the Transamazonian metamorphism event 
$(\sim 2.1 \mathrm{Ga})$, oxidation processes occurred at least during the Paleoproterozoic. The regional distribution effects of this oxidation event and its great intensity produced a highly oxidized itabirite in the QF, which distinguishes them from other BIF's found worldwide.

\section{The Source of the Sediments and Depositional Environment}

Although controversies remain regarding the origin of $\mathrm{Fe}$ and $\mathrm{SiO}_{2}$ in $\mathrm{BIFs}$, with some authors attributing their origin to the weathering of continental rocks (e.g. Isley, 1995; Manikyamba et al., 1993) most workers consider that these components together with Mn and a very low amount of trace elements are derived from the leaching of basalt and komatiites of the ocean floor by hydrothermal fluids (e.g. Bau and Möller, 1993; Beukes and Klein, 1990; Dymek and Klein, 1988; Kato et al., 1998; Klein and Beukes, 1992; Shimizu et al., 1990). Itabirites of the Cauê Formation display geochemical signatures similar to that of other BIFs with very low trace element contents, high HREE fractionation and positive $\mathrm{Eu}, \mathrm{Y}$ and La anomalies (Tables 2 and 3). These geochemical signatures are consistent with the latter interpretation. Further support for a hydrothermal origin is illustrated by the diagram in Figure 21. All the samples of itabirites (as well as of other BIFs) fall in or near the field of the "Hydrothermal Deposits" which consist in large part of the Fe-rich layer silicate nontronite with a bulk composition similar to those of the BIFs.

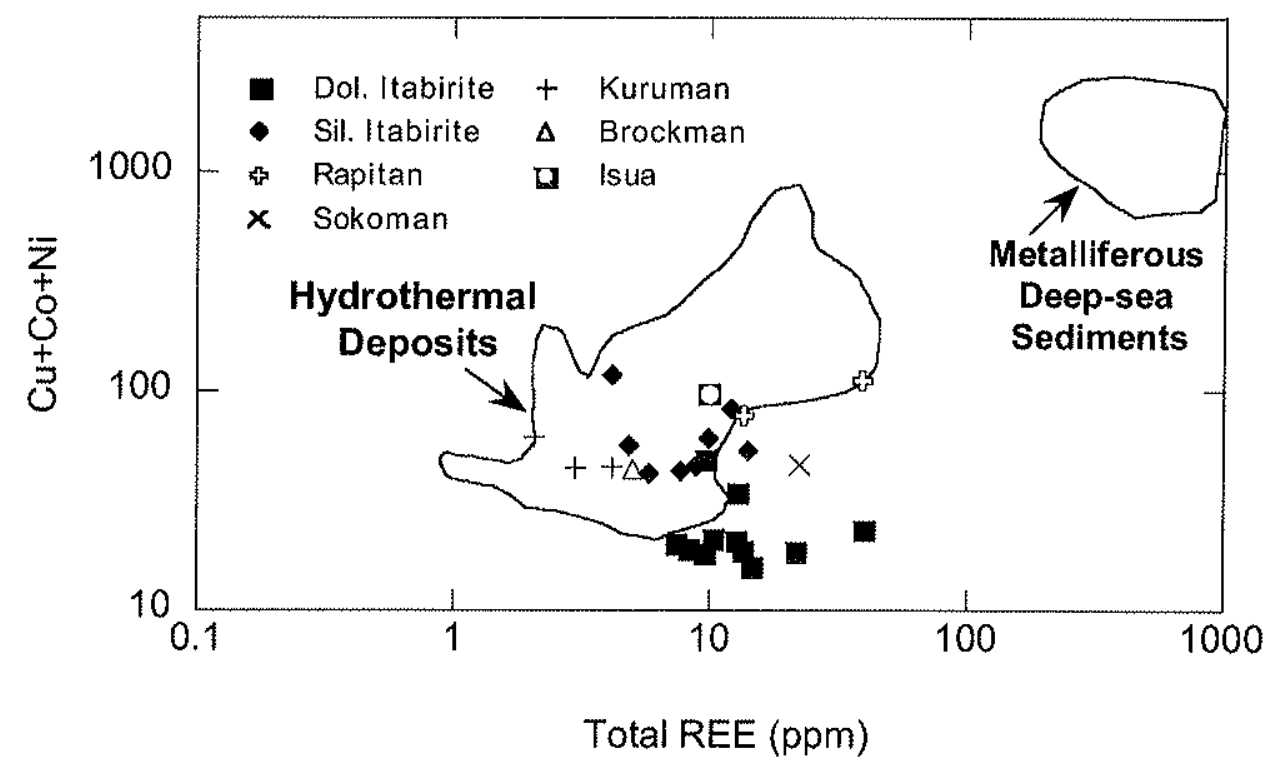

Figure 21 - Plot of $(\mathrm{Co}+\mathrm{Ni}+\mathrm{Cu})$ abundances versus total REE content for dolomitic and quartz itabirite and others BIFs (data from Klein and Beukes, 1992). Data points for all the BIFs are contained within or very close to the "hydrothermal field", suggesting a common origin. 
A small participation of terrigenous sediments in the composition of the water solutions from where itabirites precipitated, however, is suggested by the strong correlation between $\mathrm{Al}_{2} \mathrm{O}_{3}$ with $\mathrm{TiO}_{2}, \mathrm{Zr}$ and $\mathrm{Th}$ (Fig. 15, Table $4 \mathrm{~b}$ ) as demonstrated above, suggested minor contamination of itabirite by a terrigenous component. $\mathrm{Al}_{2} \mathrm{O}_{3}$ also shows a good correlation with $\sum$ REE $(r=0.75)$, which suggests part of the REE budget in seawater is of terrigenous origin (and not only hydrotermal fluids). This is also suggested by the higher amount of $\sum$ REE of the dolomitic band of dolomitic itabirite when compared with the hematitic band (Table 2). The former is twofold richer in $\sum$ REE than the latter. Several papers have mentioned that REE concentrations in seawater increase with increased fluxes of clastic material mixing with hydrothermal waters (e.g. Beukes and Klein, 1990; Gnaneshwar Rao and Naqvi, 1995; Khan and Naqvi, 1996). The nature and origin of the terrigenous sediments in BIFs of the QF is still unclear. The terrigenous component maybe suspended clastic material or a dissolved component of river waters, or possibly volcanic ash carried by winds to the ocean. The mineralogical composition of itabirites provides little information to answer this question. However, major and trace elements of itabirite provide some insights to the palaeoenvironment of deposition of the itabirite. Dolomitic itabirite at the Águas Claras mine has higher average $\mathrm{Al}_{2} \mathrm{O}_{3}$ and $\sum \mathrm{REE}$ contents than quartz itabirite, suggesting a greater contribution of terrigenous material to dolomitic itabirite. $\mathrm{Al}_{2} \mathrm{O}_{3}$ and REE contents are higher at the base of the dolomitic-quartz itabirite sequence and decrease towards the top (Fig. 13). This trend of the REE and $\mathrm{Al}_{2} \mathrm{O}_{3}$ data suggests a gradual transition from shallow to deeper waters. Beside to suggest that sedimentation of dolomitic itabirite occurred in a shallower platform than that of quartz itabirite, higher amount of terrigenous components in dolomitic itabirite also suggest a higher proximity with the continent.

Better constraints of the source of sediments and the palaeodepositional environment of itabirite comes from the REEY PAAS patterns of these rocks. The REEYPAAS patterns of the dolomitic and quartz itabirites show that both rocks precipitated from seawater mixed with hydrothermal fluids, (i.e., indicated by a positive $\mathrm{Eu}$ and $\mathrm{Y}$ anomalies and $\mathrm{La} / \mathrm{Yb}_{\mathrm{PAAS}}<1$, see Table 3). Different REE fractionation patterns of dolomitic and quartz indicate variation in the composition of this hydrothermal-seawater aqueous solution (Fig. 16a and d). This variation most likely reflects the location of BIFs relative to hydrothermal vents and continent, and variations in the intensity of the hydrothermal fluxes. According to the studies by Derry and Jacobsen (1990) and Danielson et al. (1992), slightly higher values of the Eu anomaly in the dolomitic itabirite indicate precipitation from higher temperature fluids $\left(>300^{\circ} \mathrm{C}\right)$, which suggests either a more proximal source of hydrothermal fluids or a greater contribution of higher 
temperature hydrothermal fluids. Higher temperature fluids leach more Eu from ocean-floor basalts (Bau, 1993). This enhances higher Eu anomalies in precipitates closer to the source of the hydrothermal fluids, or with the contribution of fluids with high temperatures, because the capacity of absorption of REE by hydrothermal precipitates is proportional to their concentrations in the fluids (Olivarez and Owen, 1991).

Kato et al. (1998) studying the REE fractionation pattern in BIFs and associated ferruginous/siliceous mudstone in mid-Archean rocks of the Pilbara craton, Western Australia, identified two different types of Eu anomalies. The first type occurs in BIFs and is derived from the hydrotermal solutions emanating from the mid-ocean ridge. The second type occurs in mudstone and is inferred to be caused by detrital feldspar and feldspar derived clay minerals from the exposed continental crust or island arcs. Once sericitic phyllite and all rocks of the Catê Formation shows positive Eu anomaly (Fig. 16), one could associate these anomalies in argillaceous dolomite and itabirites to clastic contamination. This is not the case, due to the small positive Eu anomaly showed by the sericitic phyllite $(\sim 1.2)$ and the great difference to the following argillaceous dolomite ( 2.2, with much lower amount of pelitic sediments). Therefore, it is reasonable to infer that the gradual decreasing of the EupAAs anomaly observed in the Caue Formation from the base of the sequence towards the contact with the quartz itabirite (Fig. 13), where it becomes almost constant, is related to a gradual reduction of hydrothermal fluid temperature, or to a higher mixture of it with the seawater.

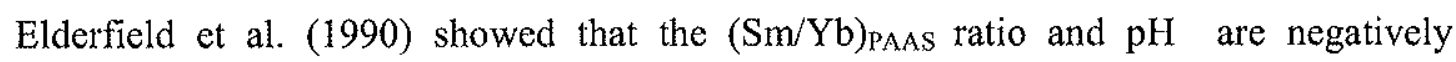
correlated in seawater. The higher $(\mathrm{Sm} / \mathrm{Yb} \text { ) })_{\text {PAS }}$ ratio of the quartz itabirite (and consequently its flatter REEY pattern) is therefore consistent with a lower $\mathrm{pH}$ solution from which silica precipitated. $(\mathrm{Sm} / \mathrm{Yb}$ ) PAAS ratio in BIFs is controlled by marine surface water component (Bau and Möller 1993). Differences on the REEY pattern of dolomitic and quartz itabirites shown in Figure 16 probably reflect variation of the $\mathrm{pH}$ of seawater, with dolomitic itabirite having a higher participation of marine (alkaline) surface water and quartz itabirite of marine (slightly acidic) bottom water.

The precipitation of chert in the seawater is independent of the Eh conditions (Kato and Nakamura, 2003), and is dependent only on the concentration of silica in solution and the $\mathrm{pH}$ of the solution. Local variation on the $\mathrm{pH}$ and concentration of silica in solution of the seawater would favor the presence of carbonate or chert components, and together with varied degree of clastic input would control the tree major compositional types of BIFs observed in the QF. The co-precipitation of chert and carbonate petrographically observed in samples of metachert and 
dolomite suggests that the sedimentation of the itabirites occurred very close to the limit of stability of both minerals. Small variations on the $\mathrm{pH}$ conditions would therefore favor the presence of one or another mineral. The occurrence of triply layered itabirite (Fig. 6c) indicates seasonal variation on the $\mathrm{pH}$ condition of the environment. It gives additional support to our suggestion that $\mathrm{pH}$ was one of the major control on the type of BIF precipitating.

An additional feature of the REEY pattern of the itabirites is the negative Ce PAAS anomaly. Ce behavior in aqueous solutions is strongly dependent on the redox conditions and it is removed from seawater by oxidation (De Baar et al., 1985; Elderfield et al., 1990). Both the dolomitic and the quartz itabirite exhibit negative Ce PAAs anomalies. These anomalies become slightly more negative from the bottom of the dolomitic itabirite towards the top of the quartz itabirite, where $\mathrm{Ce} / \mathrm{Ce}^{*}$ has values around unity (Fig. 13d). The presence of a negative Ce paAs anomaly in many samples of itabirites indicates that the waters from which these sediments precipitated from were sufficiently oxidizing to promote formation of less soluble or more reactive Ce(IV) species.

Variation of the magnitude of the Ce PAAS anomalies in both the dolomitic and quartz itabirite suggests fluctuation in the degree of oxidation of the seawater. These variations may be a function of water depth. Heterogeneous REEY distribution in the seawater where the sediments of the dolomitic and quartz itabirite precipitated from, expressed by differences in the $(\mathrm{Sm} / \mathrm{Yb})_{\text {PAAS }}$ ratio, and EupAAS and Y PAAS anomalies, may reflect variation of the water depth, once the REEY distribution in seawater is depth-dependent (Elderfield, 1988). Considering that both quartz and dolomitic itabirite are contemporaneous (see text bellow), and were precipitated in different $\mathrm{pH}$ conditions of the basin (due to its significantly differences at ( $\mathrm{Sm} / \mathrm{Yb}$ ) PAAS ratios), we suggest that the sedimentation of the BIFs of the Minas basin occurred in a restricted basin rather than in an open shelf. A restricted basin would be more propitious to local variation in the depositional environment, and would enhance the regional lithological variation observed in BIFs of the QF. This basin, otherwise, should be opened to the ocean due to the typical and very homogeneous marine signature of the $\mathrm{C}$ and $\mathrm{O}$ isotopes of the dolomitic itabirite. Considering these points, we suggest that sedimentation of the carbonatic BIF occurred in a slightly shallower (and maybe narrow) site, maybe closer to the continent, with higher participation of marine surface water. We also suggest that the sedimentation of the cherty BIF occurred in a slightly deeper site of the basin, with a higher participation of more acidic marine bottom water. The dolomitic and quartz itabirite would then represent two distinct sedimentary facies of the Cauê basin: one carbonatic and another cherty. Both characterized by oxic conditions. 


\section{The Depositional Model}

Gross (1983) suggested that iron formations interbedded with dolomite, quartzite, shales and volcanic rocks were deposited on continental shelves close to craton margins. The upward lithological gradation from conglomeratic quartzite to phyllite to BIFs to stromatolitic dolomite led Renger et al. (1994) to suggest that sediments of the Minas basin were deposited in a continental shelf environment. Changes in water depth evidenced by lithological variations in the Minas Supergroup indicate that marine transgression-regression cycles acted during the deposition of the Minas basin.

Deposition of BIFs during marine transgressions is suggested for BIFs of the Hamersley basin and the Transvaal basin (Klein and Beukes, 1989; Simonson, 1996; Simonson et al., 1993), both contemporaneous with the Minas basin (Babinski et al., 1995a). Klein and Beukes (1989) associated the deposition of the Kuruman BIF to a major transgressive event that extensively submerged the Kaapvaal craton. Renger et al. (1994) emphasized the close similarities between the Kapvaal basin and the Minas basin, and suggested that the Cauê Formation is the counterpart of the Kuruman Formation. The lithological variation in the Minas Supergroup indicate that there were progressive deeper water conditions from the Moeda Formation to the Cauê Formation associated with transgression, and indicates that BIFs in the Cauê Formation were also deposited during a marine transgression that blanketed the São Francisco craton.

Differently from the Kaapvaal craton, which was completely submerged, the continuous contribution of terrigenous sediments to BIF's during the sedimentation in QF, as previously discussed, suggest the existence of emerged areas of the São Francisco craton that could act as source for these sediments. Higher terrigenous contribution occurs in the argillaceous dolomite at the base of the Caue Formation and in the dolomite of the transition to the Gandarela Formation. Geochemical data suggests that itabirites have a very low terrigenous component, which indicates sedimentation probably occurred during the climax of the marine transgression.

Additional support of marine transgression-regression cycles during the deposition of the Cauê Formation comes from the occurrence of GIF in the transition from argillaceous dolomite to ferruginous dolomite. GIF is considered to have formed by submarine erosion and the deposition of earlier formed BIFs. Regression-transgression cycles representing sea level changes are generally responsible for such erosion, which result in the deposition of eroded 
material close to BIF (Klein and Beukes, 1989; Morris, 1993; Simonson, 1985). When the quieter conditions prevailed again, the deposition of BIFs took over and produced short scale lateral and vertical transitions. The GIF interbedded with argillaceous dolomite exhibits fining upwards graded bedding, which indicates increasing sea levels. It was formed from the erosion of older quartz itabirite, but its peloids are cemented by carbonate, which indicates the existence of not only variations in the sea level, but also changes in the seawater composition.

Regression-transgression cycles would strongly affect the bulk composition of seawater in a more restricted BIF depositional basin. We suggest these bulk compositional changes in seawater are represented in the QF by a lithological variation in the itabirites, with dolomitic-, quartz- and amphibolitic-itabirites representing carbonatic, cherty and shaly facies of the Cauê basin, respectively. Lateral and vertical transitions between different lithotypes would mean sedimentologic facies changes in response to the local variation in the aqueous solution composition, maybe related to changes in water depth, $\mathrm{pH}$ and input of clastic components.

The lack of regional maps showing facies changes within the itabirites of the Cauê Formation makes paleoenvironmental studies and the elaboration of depositional models extremely difficult. Recent exploratory works carried out by MBR in the eastern limb of the Moeda Syncline (Fig. 1) show major differences in the stratigraphy of the Cauê Formation (Fig. 22). In the Águas Claras mine dolomitic itabirite is found at the base of the sequence and is overlain by quartz itabirite, while in the Pico mine quartz itabirite occurs from the base to the top. Layers of amphibolitic itabirite occur interlayered with quartz itabirite toward to the top of the sequence at the Pico mine. This context allows us to suggest the presence of a lateral and vertical facies variation within the Caue Formation, going from dolomitic to quartz to amphibolitic itabirite as a result of variation in the seawater composition. We suggest that during the beginning of a transgressive cycle, while carbonatic sediments of dolomitic itabirite were deposited in a slightly shallower site of the basin (with a higher contribution of the marine surface waters richer in terrigenous components and alcaline $\mathrm{pH}$ ), cherty sediments of quartz itabirite were deposited in a deeper site (with very low content of terrigenous components and acid $\mathrm{pH}$ ). Gradual increasing water depths led to deposition of quartz itabirite in the Águas Claras region. This occurred during the climax of the transgression. During the regression cycle, the depositional conditions changed in the Águas Claras region from those favouring quartz itabirite to dolomite and marbles. In the Pico region, however, conditions favouring deposition of quartz itabirite alternated to those favouring formation of an itabirite containing layers rich in terrigenous material now preserved as amphibolitic itabirite. This would represent shaly 
sediments, with a much higher participation of terrigenous sediments carried by river waters. Figure 23 displays this depositional model.
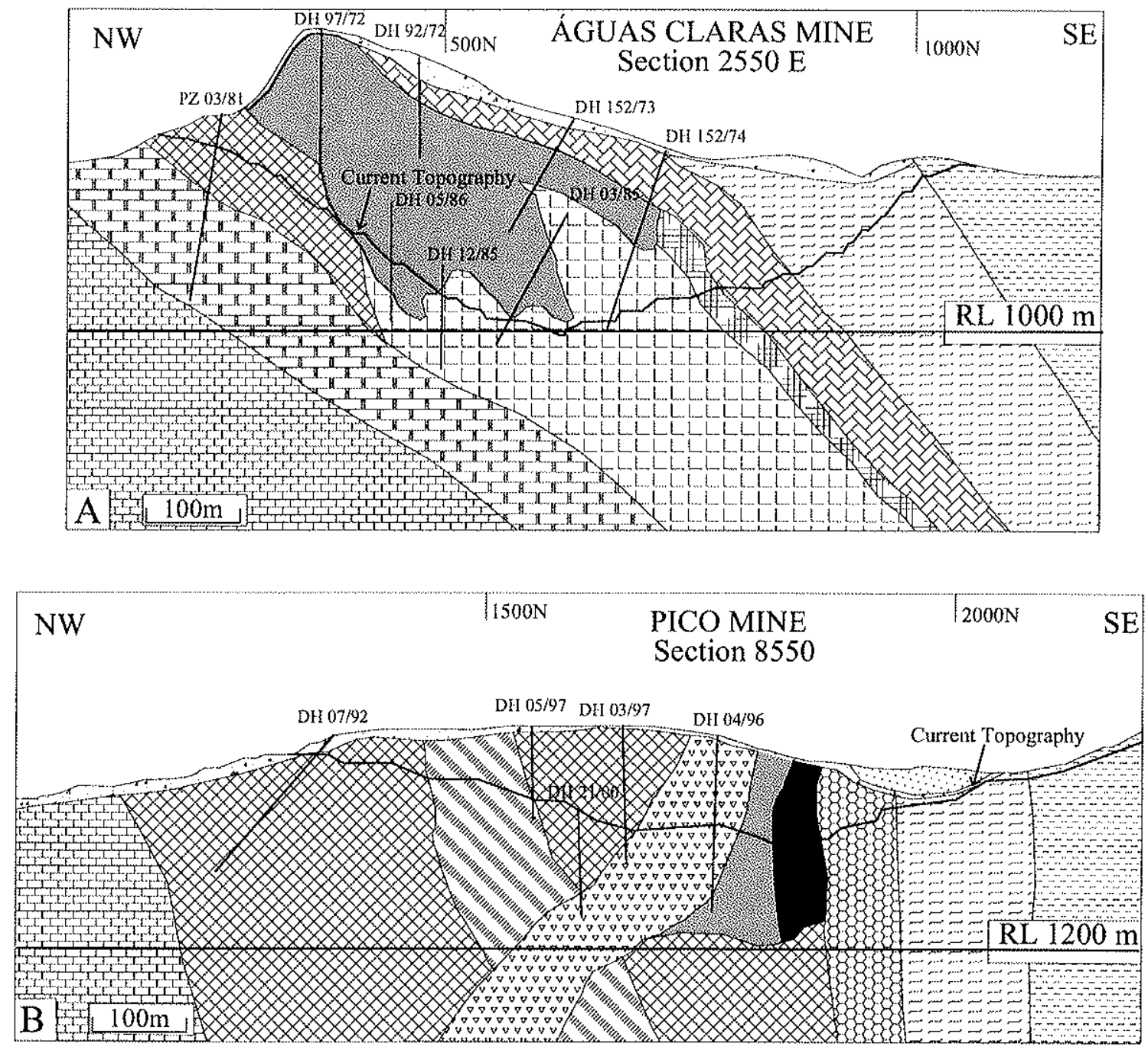

Moeda Formation

Cauê Formation

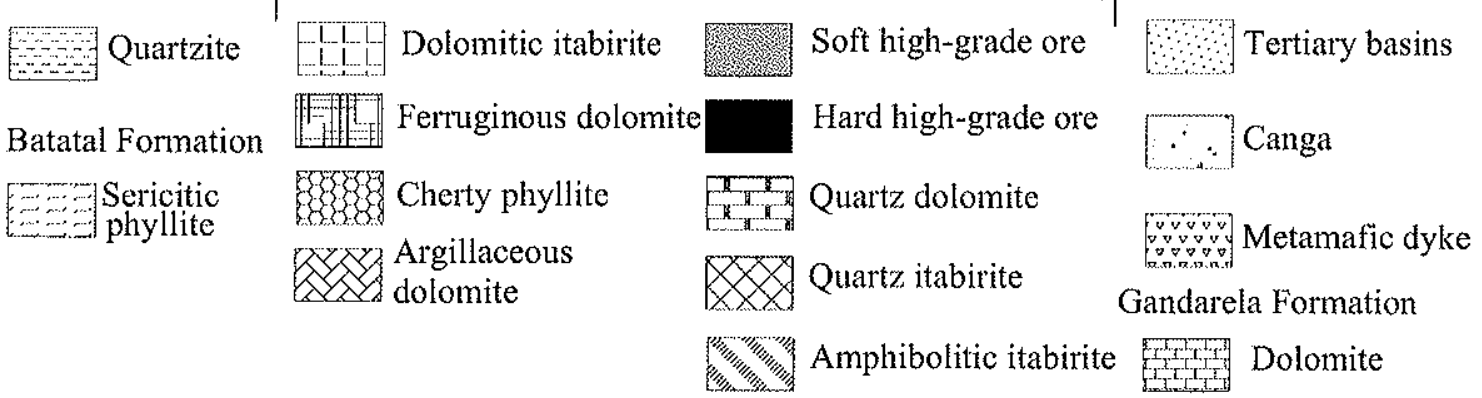

Figure 22 - Geological cross section 2550E of the Águas Claras mine (A) and $8550 \mathrm{E}$ of the Pico mine (B). Note the variation of lithotypes of the Itabira Group from the northwest to west of the Quadrilatero Ferrífero. 


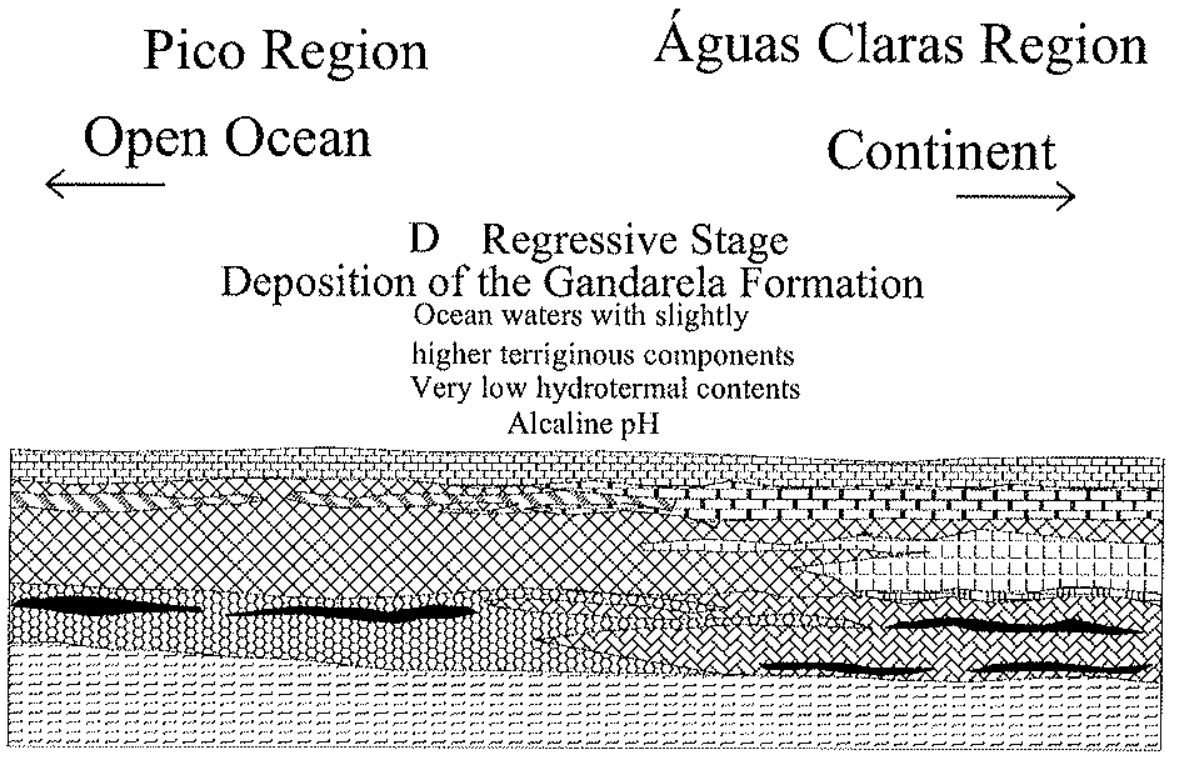

\section{Initial Regressive Stage \\ Ending of Deposition of the Cauê Formation}

Ocean waters mixed with

hidrothermal fluids

Ocean waters with low content of

Locally high participation of terriginous

hydrothermal fluids

components

$$
\text { Acid pH }
$$

Alcaline $\mathrm{pH}$

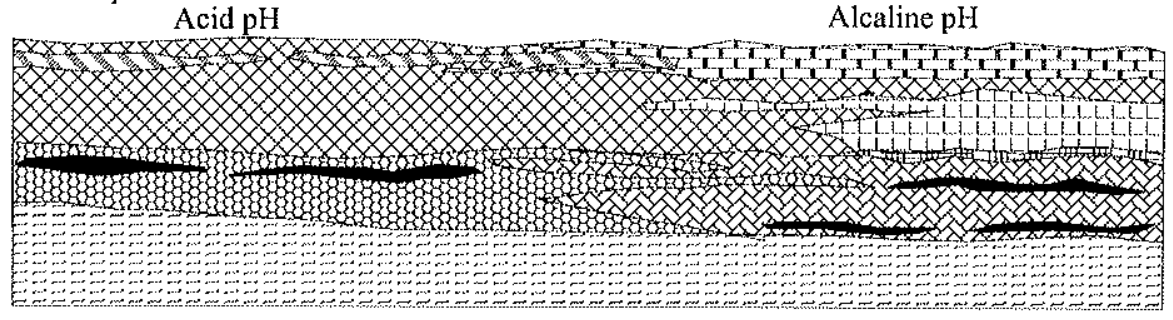

B Climax of Transgressive Stage

Ocean waters mixed with hidrothermal fluids Acid pH

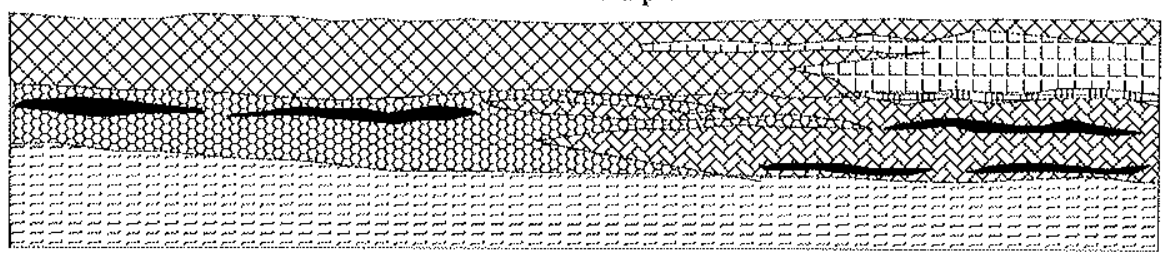

A Initial Transgressive Stage

Ocean waters mixed with Ocean waters with slightly hidrothermal fluids

higher terriginous components Acid pH Alcaline pH

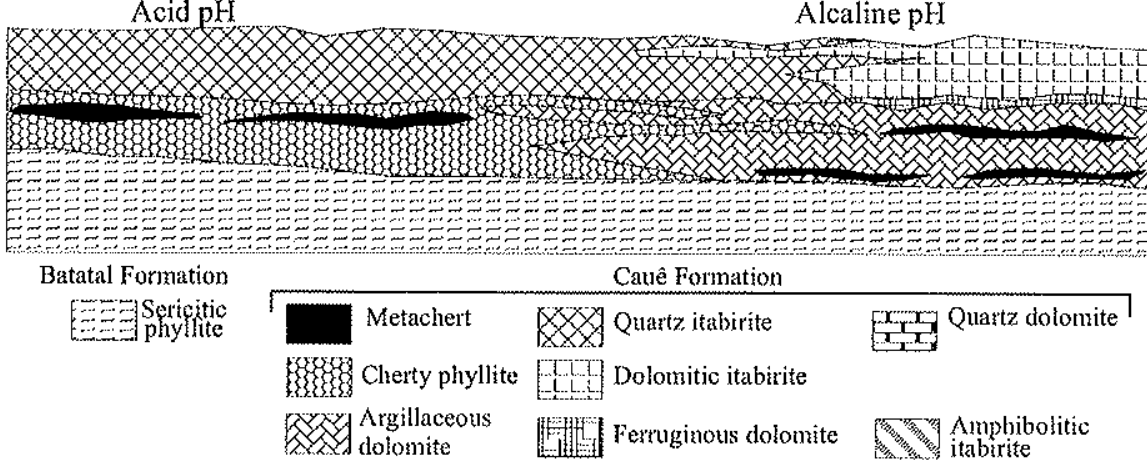

Figure 23 - Schematic depositional model for the Cauê Formation. 


\section{CONCLUSIONS}

Dolomitic and quartz itabirite are metamorphosed oxide facies BIFs of the Lake Superior type of Paleoproterozoic age, contemporaneous to the giant BIFs of the Hamersley and Transvaal basins. They consist of alternated millimetric to decimetric bands of dolomite-rich and hematite-rich, and quartz-rich and hematite-rich, respectively. Both rocks have a very simple chemical composition, with $\mathrm{Fe}_{2} \mathrm{O}_{3}, \mathrm{CaO}, \mathrm{MgO}$ and $\mathrm{LOI}$ representing more than $98 \%$ of the average composition of dolomitic itabirite and $\mathrm{Fe}_{2} \mathrm{O}_{3}$ and $\mathrm{SiO}_{2}$ constituting more than $98 \%$ of the average composition of quartz itabirite. Itabirites were highly oxidized and present $\mathrm{Fe}^{3+} /\left(\mathrm{Fe}^{2++}+\mathrm{Fe}^{3+}\right)$ ratios higher than 0.98 , much greater than the average ratio of other Paleoproterozoic BIFs.

Trace elements concentrations in itabirites are very low and range from $<10 \mathrm{ppm}$ ( $\mathrm{Y}$, $\mathrm{Sc}, \mathrm{Be}, \mathrm{Cu}, \mathrm{Ga}, \mathrm{Ge}, \mathrm{Rb}, \mathrm{Nb}, \mathrm{Mo}, \mathrm{Ag}, \mathrm{In}, \mathrm{Sn}, \mathrm{Cs}, \mathrm{Hf}, \mathrm{Tl}, \mathrm{Pb}, \mathrm{Bi}, \mathrm{As}, \mathrm{Cd}, \mathrm{Th}, \mathrm{U}, \mathrm{Sb}$ ) to concentrations between 10 and $55 \mathrm{ppm}(\mathrm{Ba}, \mathrm{Sr}, \mathrm{Zr}, \mathrm{V}, \mathrm{Ni}, \mathrm{Zn}, \mathrm{Co}, \mathrm{Cr}$ and $\mathrm{REE})$. Dolomitic and quartz itabirite do not present major differences in trace element contents.

The HREE enrichment pattern exhibited by both itabirites shows a modern seawater REE signature overprinted by a hydrothermal pattern represented by positive EupAAs anomalies. A marine sedimentary origin of the sediments of the dolomitic itabirite is reinforced by its REE signature, by the $\mathrm{C}$ and $\mathrm{O}$ isotopic composition, typical of marine carbonates, and by its $\mathrm{Y} / \mathrm{Ho}$ ratios very similar to that of seawater. A strong correlation between $\mathrm{Al}_{2} \mathrm{O}_{3}$ and $\mathrm{TiO}_{2}(\mathrm{r}>0.9)$ indicates a minor terrigenous component for the chemically precipitated, marine sediments of the Cauê Formation.

The differences on the REE signatures of the itabirites suggest that they precipitated from aqueous solutions of different compositions, with the dolomitic itabirite receiving higher contribution of marine surface waters laiden continental sediments and quartz itabirite of marine bottom waters. Sea-level fluctuations caused by marine transgression-regressions are responsible for changes in the aqueous solution composition. These changes are expressed by dolomitic-, quartz- and amphibolitic itabirites, which represent lateral and vertical facies transitions of carbonatic, cherty and shaly BIFs respectively.

\section{Acknowledgements}

This paper is an integral part of the senior author's Ph.D. thesis presented at the Instituto de Geociencias of the Universidade de São Paulo (USP). This research project was possible thanks to the grant issued by the Comissão de Aperfeiçoamento de Pessoal de Nível Superior (CAPES) to C.A.S (grant BEX2189/02 0). C.A.S, thanks Mineraçôes Brasileiras Reunidas (MBR) for liberating him of his usual activities as a mine geologist during the period of his stay at the University of Queesnland. 


\section{References}

Alkmim, F.F. and Marshak, S., 1998. Transamazonian orogeny in the São Francisco craton, Minas Gerais, Brazil: evidence for Paleoproterozoic collision and collapse in the Quadrilátero Ferrífero. Precambrian Research, 90: 29-58.

Arora, M. et al., 1995. Geochemistry and origin of Archean banded iron-formation from the Bababudan Schist Belt, India. Economic Geology, 90: 2040-2057.

Babinski, M., Chemale Jr., F. and Van Schmus, W.R., 1995a. Cronoestratigrafia do Supergrupo Minas e provável correlação de suas formações ferríferas com similares da África do Sul e Austrália. Geochimica Brasiliensis, 9(1): 33-46.

Babinski, M., Chemale Jr., F. and Van Schmus, W.R., 1995b. The Pb/Pb ages of the Minas Supergroup carbonate rocks, Quadrilátero Ferrífero, Brazil. Precambrian Research, 72: $235-245$.

Banner, J.L. and Hanson, G.N., 1990. Calculation of simultaneous isotopic and trace element variations during water-rock interaction with applications to carbonate diagenesis. Geochimica et Cosmochimica Acta, 54: 3123-3137.

Banner, J.L., Hanson, G.N. and Meyers, W.J., 1988. Rare earth elements and Nd isotopic variations in regionally extensive dolomites from the Burlington-Keokuk Formation (Mississippian): implications for REE mobility during carbonate diagenesis. Journal of Sedimentary Petrology, 58: 415-432.

Bau, M., 1991. Rare-earth element mobility during hydrothermal and metamorphic fluid-rock interaction and the significance of the oxidation state of europium. Chemical Geology, 93: $219-230$.

Bau, M., 1993. Effects of syn- and post-depositional processes on the rare-earth element distribution in Precambrian iron-formations. European Journal of Mineralogy, 1993(5): 257-267.

Bau, M., 1996. Controls on the fractionation of isovalent trace elements in magmatic and aqueous systems: evidence from $\mathrm{Y} / \mathrm{Ho}, \mathrm{Zr} / \mathrm{Hf}$, and lanthanide tetrad effect. Contribution to Mineralogy and Petrology, 123: 323-333.

Bau, M. and Dulski, P., 1996. Distribution of yttrium and rare-earth elements in the Penge and Kuruman iron-formations, Transvaal Supergroup, South Africa. Precambrian Research, 79: $37-55$.

Bau, M. and Möller, P., 1993. Rare earth element systematics of the chemically precipitated component in early Precambrian iron formations and the evolution of the terrestrial 
atmosphere-hydrosphere-lithosphere system. Geochimica et Cosmochimica Acta, 57: 2239-2249.

Becker, R.H. and Clayton, R.N., 1972. Carbon isotopic evidence for the origin of a banded ironformation in Western Australia. Geochimica et Cosmochimica Acta, 36: 577-595.

Bekker, A. et al., 2003. Chemostratigraphy of carbonates from the Minas Supergroup, Quadrilátero Ferrífero (Iron Quadrangle), Brazil: a stratrigraphic record of early proterozoic atmospheric, biogeochemical and climatic change. American Journal of Science, 303: 865-904.

Beukes, N.J., 1980. Lithofacies and stratigraphy of the Kuruman and Griquatown ironformations, northern Cape Province, South Africa. Transactions of the Geological Society of South Africa, 83: 69-86.

Beukes, N.J., 1984. Sedimentology of the Kuruman and Griquatown Iron-formations, Transvaal Supergroup, Griqualand West, South Africa. Precambrian Research, 24: 47-84.

Beukes, N.J., Gutzmer, J. and Mukhopadhyay, J., 2002. The geology and genesis of high-grade iron ore deposits, Iron Ore 2002. Australasian Institute of Mining and Metallurgy, Perth, pp. 23-29.

Beukes, N.J. and Klein, C., 1990. Geochemistry and sedimentology of a facies transition - from microbanded to granular iron-formation - in the early Proterozoic Transvaal Supergroup, South Africa. Precambrian Research, 47: 99-139.

Beukes, N.J., Klein, C., Kaufman, A.J. and Hayes, J.M., 1990. Carbonate petrography, kerogen distribution, and carbon and oxigen isotope variations in an early Proterozoic transition from limestone to iron-formation deposition, Transvaal Supergroup, South Africa. Economic Geology, 85(4): 663-690.

Bodnar, R.J. and Vityk, M.O., 1994. Interpretation of microthermometric data for $\mathrm{H}_{2} \mathrm{O}-\mathrm{NaCl}$ fluid inclusions. In: B. De Vivo and M. Frezzoti (Editors), Fluid inclusions in minerals: methods and applications. Short course of the working group inclusion in minerals (IMA), Pontignano, Italia, pp. 117-130.

Chemale Jr., F., Rosière, C.A. and Endo, I., 1994. The tectonic evolution of the Quadrilatero Ferrifero, Minas Gerais, Brazil. Precambrian Research, 65: 25-54.

Cordani, U.G. et al., 1980. Interpretação tectônica e petrológica de dados geocronológicos do embasamento na borda sudeste do Quadrilátero Ferrífero. Anais da Academia Brasileira de Ciências, 52: 785-799. 
Danielson, A., Möller, P. and Dulski, P., 1992. The europium anomalies in banded iron formations and the thermal history of the oceanic crust. Chemical Geology, 97: 89-100.

Davis, B. and Hippert, J., 2000. Dome empacement and formation of kilometre-scale synclines in a granite-greenstone terrain (Quadrilátero Ferrífero, southeastern Brazil). Precambrian Research, 102: 99-121.

De Baar, H.J.W., Bacon, M.D., Brewer, P.G. and Bruland, K.W., 1985. Rare earth elements in the Pacific and Atlantic Oceans. Geochimica et Cosmochimica Acta, 49: 1943-1959.

Derry, L.A. and Jacobsen, S.B., 1990. The chemical evolution of Precambrian seawater:Evidence from REEs in banded iron formations. Geochimica et Cosmochimica Acta, 54: 2965-2977.

Derry, L.A., Kaufman, A.J. and Jacobsen, S.B., 1992. Sedimentary cycling and environmental change in the late Proterozoic: evidence from stable and radiogenic isotopes. Geochimica et Cosmochimica Acta, 56: 1317-1329.

Dorr II, J.V.N., 1969. Physiographic, stratigraphic and structural development of the Quadrilátero Ferrífero, Minas Gerais, Brazil. U.S.G.S. Professional Paper, 614-A, Washington, $110 \mathrm{pp}$.

Dorr II , J.V.N., 1973. Iron-formation in South America. Economic Geology, 68: 1005-1022.

Dymek, R.F. and Klein, C., 1988. Chemistry, petrology and origin of banded iron-formation lithologies from the $3800 \mathrm{Ma}$ Isua supracrustal belt, West Greenland. Precambrian Research, 39: 247-302.

Elderfield, H., 1988. The oceanic chemistry of the rare-earth elements. Phil. Trans. Roy. Soc., London, pp. 105-126.

Elderfield, H., Upstill-Goddard, R. and Sholkovitz, E.R., 1990. The rare earth elements in rivers, estuaries, and coastal seas and their significance to the composition of ocean waters. Geochimica et Cosmochimica Acta, 54(971-991).

Ewers, W.E. and Morris, R.C., 1981. Studies of the Dales Gorge Member of the Brockman Iron Formation, Western Australia. Economic Geology, 76: 1929-1953.

Floran, R.J. and Papike, J.J., 1978. Mineralogy and petrology of the Gunflint Iron Formation, Minnesota-Ontario: correlation of compositional and Assemblage variations at low to moderate grade. Journal of Petrology, 19(2): 215-288.

Gnaneshwar Rao, T. and Naqvi, S.M., 1995. Geochemistry, depositional environment and tectonic setting of the BIF's of the late Archean Chitradurga Schist Belt, India. Chemical Geology, 121: 217-243. 
Goode, A.D.T., Hall, W.D.M. and Bunting, J.A., 1983. The Nabberu basin of Western Australia. In: A.F. Trendall and R.C. Morris (Editors), Iron-Formation Facts and Problems. Developments in Precambrian Geology 6. Elsevier, Amsterdam-Oxford-New YorkTokyo, pp. 295-323.

Gromet, L.P., Dymek, R.F., Haskin, L.A. and Korotev, R.L., 1984. The "North American shale composite": Its compilation, major and trace element characteristics. Geochimica et Cosmochimica Acta, 48: 2469-2482.

Gross, G.A., 1980. A classification of iron formations based on depositional environments. The Canadian Mineralogist, 18: 215-222.

Gross, G.A., 1983. Tectonic systems and the deposition of iron-formation. Precambrian Research, 20: 171-187.

Hall, W.D.M. and Goode, A.D.T., 1978. The early Proterozoic Nabberu basin and associated iron formations of western Australia. Precambrian Research, 7: 129-184.

Herz, N., 1978. Metamorfic rocks of the Quadrilátero Ferriífero, Minas Gerais, Brazil, 641-C. U.S.G.S. Professional Paper.

Horstmann, U.E. and Hälbich, I.W., 1995. Chemical composition of banded iron-formations of the Griqualand West Sequence, Northern Cape Province, South Africa, in comparison with other Precambrian iron formations. Precambrian Research, 72: 109-145.

Isley, A.E., 1995. Hydrothermal plumes and the delivery of iron to banded iron formation. The Journal of Geology, 103: 169-185.

James, H.L., 1954. Sedimentary facies of iron-formation. Economic Geology, 49: 235-293.

Karhu, J.A. and Holland, H.D., 1996. Carbon isotopes and the rise of atmospheric oxygen. Geology, 24: 867-870.

Kato, Y. and Nakamura, K., 2003. Origin and global tectonic significance of Early Archean cherts from the Marble Bar greenstone belt, Pilbara craton, Western Australia. Precambrian Research, 125: 191-243.

Kato, Y. et al., 1998. Rare earth element variations in mid-Archean banded iron formations: Implications for the chemistry of ocean and plate tectonics. Geochimica et Cosmochimica Acta, 62(21/22): 3475-3497.

Kaufman, A.J., 1996. Geochemical and mineralogic effects of contact metamorphism on banded iron-formation: an example from the Transvaal Basin, South Africa. Precambrian Research, 79: 171-194. 
Kaufman, A.J., Hayes, J.M. and Klein, C., 1990. Primary and diagenetic controls of isotopic compositions of iron-formation carbonates. Geochimica et Cosmochimica Acta, 54: $3461-3473$.

Kaufman, A.J., Knoll, A.H. and Narbonne, G.M., 1997. Isotopes, ice ages, and terminal Proterozoic Earth history, National Academy of Science Proceedings, 94, pp. 6600-6605.

Khan, R.M.K. and Naqui, S.M., 1996. Geology, geochemistry and genesis of BIF of the Kushtagi Schist Belt, Archean Dharwar Craton, India. Mineralium Deposita, 31: 123133.

Kimberley, M.M., 1989. Exhalative origins of iron formations. Ore Geology Reviews, 5: 13-145.

Klein, C. and Beukes, N.J., 1989. Geochemistry and sedimentology of a facies transition from limestone to iron-formation deposition in the Early Proterozoic Transvaal Supergroup, South Africa. Economic Geology, 84(7): 1733-1774.

Klein, C. and Beukes, N.J., 1992. Time distribution, stratigraphy, and sedimentologic setting, and geochemistry of Precambrian iron-formations. In: J.W. Schopf and C. Klein (Editors), The Proterozoic Biosphere. Cambridge University Press, Cambridge, pp. 139146.

Klein, C. and Fink, R.P., 1976. Petrology of the Sokoman Iron Formation in the Howells River Area, at the Western Edge of the Labrador Trough. Economic Geology, 71: 453-487.

Klein, C. and Ladeira, E.A., 2000. Geochemistry and petrology of some Proterozoic banded iron-formations of the Quadrilátero Ferrífero, Minas Gerais, Brazil. Economic Geology, 95: 405-428.

Klemm, D.D., 2000. The formation of Palaeoproterozoic banded iron formations and their associated $\mathrm{Fe}$ and $\mathrm{Mn}$ deposits, with reference to the Griqualand West deposits, South Africa. Journal of African Earth Sciences, 30(1): 1-24.

Lindenmayer, Z.G., Laux, J.H. and Teixeira, J.B.G., 2001. Considerações sobre a origem das formações ferríferas da Formação Carajás, Serra dos Carajás. Revista Brasileira de Geociências, 31(1): 21-28.

Macambira, J.B. and Schrank, A., 2002. Químio-estratigrafia e evolução dos jaspilitos da Formação Carajás (PA). Revista Brasileira de Geociências, 32(4): 567-578.

Manikyamba, C., 1998. Petrology and geochemistry of mixed oxide-silicate facies banded iron formations from Sandur Schist Belt, India. Journal Geological Society of India, 52: 651661. 
Manikyamba, C., Balaram, V. and Naqvi, S.M., 1993. Geochemical signatures of polygenetic origin of a banded iron formation (BIF) of the Archean Sandur greenstone belt (schist belt) Karnataka nucleus, India. Precambrian Research, 61: 137-164.

Marshak, S. and Alkmim, F.F., 1989. Proterozoic contraction/extension tectonics of the southern São Francisco craton region, Minas Gerais, Brazil. Tectonics, 8(3): 551-571.

McCrea, J.M., 1950. On the isotope chemistry of carbonates and paleotemperature scale. Jour Chem Phys, 18: 849-857.

McLennan, S.B., 1989. Rare earth elements in sedimentary rocks. Influence of provenance and sedimentary processes. In: B.R. Lipin and G.A. McKay (Editors), Geochemistry and Mineralogy of the Rare Earth Elements. Mineralogical Society of America, Washington, pp. 169-200.

Morris, R.C., 1993. Genetic modeling for banded iron formation of the Hamersley Group, Pilbara Craton, Western Australia. Precambrian Research, 60: 243-286.

Nozaki, Y., Zhang, J. and Amakawa, H., 1997. The fractionation between Y and Ho in the marine environment. Earth and Planetary Science Letters, 148: 329-340.

Olivarez, A.M. and Owen, R.M., 1991. The europium anomaly of seawater: implications for fluvial versus hydrothermal REE inputs to the oceans. Chemical Geology, 92: 317-328.

Perry Jr., E.C., Tan, F.C. and G.B., M., 1973. Geology and stable isotope geochemistry of the Biwabik Iron Formation, Northern Minnesota. Economic Geology, 68: 1110-1225.

Pires, F.R.M., 1979. Structural geology and stratigraphy at the junction of the Serra do Curral anticline and the Moeda syncline, Quadrilátero Ferrifero, Minas Gerais, Brazil. PhD Thesis, Michigan Tech. University, Ann Arbor, 220 pp.

Pires, F.R.M., 1995. Textural and mineralogical variations during metamorphism of the Proterozoic Itabira Iron Formation in the Quadrilátero Ferrífero, Minas Gerais, Brazil. Anais da Academia Brasileira de Ciências, 67(1): 77-105.

Pires, F.R.M. and Frost, B.R., 2004. Parageneses generated by the oxidation during metamorphism of the Itabira iron formation in the Quadrilátero Ferrífero, Minas Gerais, Brazil, ICAM 2004 - International Congress on Apllied Mineralogy, Águas de Lindóia.

Renger, F.E., Noce, C.M., Romano, A.W. and Machado, N., 1994. Evolução sedimentar do Supergrupo Minas: 500 Ma. de registro geológico no Quadrilátero Ferrífero, Minas Gerais, Brasil. Geonomos, 2(1): 1-11.

Rivers, J., 1998. Mineralogy and geochemistry of carbonates from Tom Price Mine in Hamersley Group rocks. B.Sc. Thesis, The University of Tasmania, Hobart, 100 pp. 
Rosière, C.A., Chemale Jr., F, and Guimarães, M.L.V., 1993. Um modelo para a evolução microestrutural dos minérios de ferro do Quadrilátero Ferrífero: Parte I - estruturas e recristalização. Geonomos, 1(1): 65-84.

Rosière, C.A. and Rios, F.J., 2004. The origin of hematite in high grade iron ores based on infrared microscopy and fluid inclusion studies: the example of the Conceição mine, Quadrilátero Ferrífero, Brazil. Economic Geology, 99: 611-624.

Rosière, C.A., Siemes, H., Quade, H., Brokmeier, H. and Jansen, E.M., 2001. Microstructures, textures and deformation mechanisms in hematite. Journal of Structural Geology, 23: 1429-1440.

Shepherd, T.J., Rankin, A.H. and Alderton, D.H.M., 1985. A practical guide to fluid inclusion studies. Blackie, New York, 239 pp.

Schorscher, H.D., Santana, F.C., Polonia, J.C. and Moreira, J.M.P., 1982. Quadrilátero Ferrífero - Minas Gerais State: Rio das Velhas greenstone belt and Proterozoic rocks. Excursion Annex. ISAP, Salvador, 44 pp.

Shimizu, H., Umemotto, N., Masuda, A. and Appel, P.W.U., 1990. Sources of iron-formations in the Archean Isua and Malene supracrustals, West Greenland: evidence from La-Ce and Sm-Nd isotopic data and REE abundances. Geochimica et Cosmochimica Acta, 54: $1147-1154$.

Sial, A.N. et al., 2000. Carbon isotope fluctuations in Precambrian carbonate sequences of several localities in Brazil. Anais da Academia Brasileira de Ciências, 72(4): 539-558.

Silva, A.M., 1992. Geologia e petroquímica dos enxames de diques máficos do Quadrilátero Ferrífero e Espinhaço Meridional, MG. M.Sc. Thesis, Universidade de Brasília, Brasília, $130 \mathrm{pp}$.

Simonson, B.M., 1985. Sedimentological constraints on the origin of Precambrian ironformations. Geollogical Society of American Bulletins, 104: 244-252.

Simonson, B.M., 1996. Was the depostion of large Precambrian iron formations linked to major marine transgressions? The Journal of Geology, 104: 665-676.

Simonson, B.M., Schubel, K.A. and Hassler, S.W., 1993. Carbonate sedimentology of the early Precambrian Hamersley Group of Western Australia. Precambrian Research, 60: 287335 .

Souza, P.C. and Müller, G., 1984. Primeiras estruturas algais comprovadas na Formação Gandarela, Quadrilátero Ferrífero. Revista Escola de Minas de Ouro Preto, 2: 13-21. 
Spier, C.A., Oliveira, S.M.B. and Rosière, C.A., 2003. Geology and geochemistry of the Águas Claras and Pico iron mines, Quadrilátero Ferrífero, Minas Gerais, Brazil. Mineralium Deposita, 38: 751-774.

Taylor, D., Dalstra, H.J., Harding, A.E., Broadbent, G.C. and Barley, M.E., 2001. Genesis of high-grade hematite orebodies of the Hamerley Province, Western Australia. Economic Greology, 96: 837-873.

Taylor, S.R. and McLennan, S.B., 1985. The Continental Crust: Its Composition and Evolution. Blackwell, $312 \mathrm{pp}$.

Teixeira, W. and Figueiredo, M.C.H., 1991. An outline of Early Proterozoic crustal evolution in the São Francisco craton, Brazil: a review. Precambrian Research, 53: 1-22.

Trendall, A.F., 2002. The significance of iron-formation in the Precambrian stratigraphic record. In: W. Altermann and P.L. Corcoran (Editors), Precambrian Sedimentary Environments: A Modern Approach to Ancient Depositional Systems. Special Publication Number 53 of the International Association of Sedimentologists. Blackwell Sciense.

Trendall, A.F. and Blockley, J.G., 1970. The iron formations of the Precambrian Hamersley Group, Western Australia, with special reference to the associated crocidolite. Western Australia Geologycal Survey Bulletim, 119,365 pp.

Tucker, M.E. and Wright, V.P., 1990. Carbonate Sedimentology. Blackwell Scientific Publications, London, $482 \mathrm{pp}$.

Veizer, J., Clayton, R.N. and Hinton, R.W., 1992. Geochemistry of Precambrian carbonates: IV. Early Paleoproterozoic (2.25ロ0.25 Ga) seawater. Geochimica et Cosmochimica Acta, 56: 2487-2501.

Veizer, J. et al., 1990. Geochemistry of Precambrian carbonates: 3-shelf seas and non-marine environments of the Archean. Geochimica et Cosmochimica Acta, 54: 2717-2729.

Veizer, J., Hoefs, J., Lowe, D.R. and Thurston, P.C., 1989. Geochemistry of Precambrian carbonates: II. Archean greenstone belts and Archean seawater. Geochimica et Cosmochimica Acta, 53: 859-871.

Veríssimo, C., 1999. Jazida de Alegria: Gênese e tipologia dos minérios de ferro (Minas 3, 4 e 5 - Porção Ocidental). PhD Thesis, Universidade Estadual Paulista - UNESP, Rio Claro, 234 pp.

Veríssimo, C.U.V. et al., 2002. Geochemical study of the itabirite iron ores of the Alegria mine Quadrilátero Ferrífero, Minas Gerais, Brazil, Iron Ore 2002. Australasian Institute of Mining and Metallurgy, Perth, pp. 95-103. 
Viel, R.S., Moreira, P.C.H. and Alkmim, F.F., 1987. Faciologia da Formação Cauê e gênese do minério de ferro friável da Mina de Águas Claras, Serra do Curral - Minas Gerais, Simpósio sobre sistemas deposicionais no Pré-Cambriano. Sociedade Brasileira de Geologia - Núcleo MG, Ouro Preto, pp. 137-153.

Villaça, J.N., 1981. Alguns aspectos sedimentares da Formação Moeda. Boletim da Sociedade Brasileira de Geologia de Minas Gerais, 2: 93-137.

Villaça, J.N. and Moura, L.A.M., 1981. Uranium in the Precambrian Moeda Formation, Minas Gerais, Brazil, U.S.G.S Professional Paper 1161-T, Washington, pp. T1-T14. 
Viel, R.S., Moreira, P.C.H. and Alkmim, F.F., 1987. Faciologia da Formação Cauê e gênese do minério de ferro friável da Mina de Águas Claras, Serra do Curral - Minas Gerais, Simpósio sobre sistemas deposicionais no Pré-Cambriano. Sociedade Brasileira de Geologia - Núcleo MG, Ouro Preto, pp. 137-153.

Villaça, J.N., 1981. Alguns aspectos sedimentares da Formação Moeda. Boletim da Sociedade Brasileira de Geologia de Minas Gerais, 2: 93-137.

Villaça, J.N. and Moura, L.A.M., 1981. Uranium in the Precambrian Moeda Formation, Minas Gerais, Brazil, U.S.G.S Professional Paper 1161-T, Washington, pp. T1-T14. 
Appendix 1 - Major and trace element composition

\begin{tabular}{|c|c|c|c|c|c|c|c|c|c|c|c|c|}
\hline Sample & M140 & M141 & M132 & $\mathrm{M} 134$ & M135 & $\mathrm{M} 137$ & $\mathrm{M} 138$ & M139 & M4 & M5 & M6 & M7 \\
\hline $\mathrm{W} t \%$ & $\begin{array}{l}\text { Seric. } \\
\text { Phyl. }\end{array}$ & $\begin{array}{l}\text { Seric. } \\
\text { Phyl }\end{array}$ & $\begin{array}{c}\text { Argil. } \\
\text { Dol. }\end{array}$ & $\begin{array}{c}\text { Argil. } \\
\text { Dol. }\end{array}$ & $\begin{array}{l}\text { Argil. } \\
\text { Dol. }\end{array}$ & $\begin{array}{c}\text { Argil. } \\
\text { Dol. }\end{array}$ & $\begin{array}{c}\text { Argil. } \\
\text { Dol. }\end{array}$ & $\begin{array}{c}\text { Argil. } \\
\text { Dol. }\end{array}$ & $\begin{array}{l}\text { Dol. } \\
\text { Itabir. }\end{array}$ & $\begin{array}{l}\text { Dol. } \\
\text { Itabir. }\end{array}$ & $\begin{array}{l}\text { Dol. } \\
\text { Itabir. }\end{array}$ & $\begin{array}{l}\text { Dol. } \\
\text { Itabir. }\end{array}$ \\
\hline $\mathrm{SiO}_{2}$ & 66.38 & 60.28 & 7.37 & 19.19 & 12.48 & 13.01 & 40.27 & 51.57 & 1.97 & 1.27 & 1.73 & 0.80 \\
\hline $\mathrm{Al}_{2} \mathrm{O}_{3}$ & 19.69 & 17.52 & 1.81 & 1.72 & 1.23 & 0.61 & 1.42 & 0.05 & 0.77 & 0.33 & 0.72 & 0.26 \\
\hline $\mathrm{Fe}_{2} \mathrm{O}_{3}$ & 1.31 & 2.04 & 2.44 & 0.58 & 1.26 & 0.42 & 0.23 & 0.33 & 45.30 & 39.65 & 44.62 & 45.86 \\
\hline Fetot & 1.73 & 5.33 & 8.54 & 4.21 & 5.43 & 5.79 & 3.71 & 2.67 & 46.30 & 40.26 & 45.65 & 46.46 \\
\hline $\mathrm{FeO}$ & 0.38 & 2.96 & 5.49 & 3.27 & 3.75 & 4.83 & 3.13 & 2.11 & 0.90 & 0.55 & 0.93 & 0.54 \\
\hline $\mathrm{MnO}$ & $<0.01$ & 0.05 & 0.72 & 0.40 & 0.43 & 0.40 & 0.20 & 0.22 & 0.25 & 0.27 & 0.43 & 0.37 \\
\hline $\mathrm{MgO}$ & 1.22 & 4.90 & 15.27 & 14.81 & 16.72 & 15.55 & 11.44 & 8.97 & 11.19 & 12.30 & 11.04 & 11.13 \\
\hline $\mathrm{CaO}$ & 0.09 & 0.12 & 25.08 & 22.63 & 24.45 & 25.38 & 16.54 & 14.36 & 14.48 & 17.26 & 14.83 & 15.51 \\
\hline $\mathrm{Na}_{2} \mathrm{O}$ & 0.09 & 0.04 & $<0.01$ & $<0.01$ & $<0.01$ & $<0.01$ & $<0.01$ & $<0.01$ & $<0.01$ & 0.05 & $<0,01$ & $<0.01$ \\
\hline $\mathrm{K}_{2} \mathrm{O}$ & 6.73 & 5.03 & 0.45 & 0.59 & 0.06 & 0.10 & 0.20 & $<0.01$ & 0.11 & 0.06 & 0.05 & $<0.01$ \\
\hline $\mathrm{TiO}_{2}$ & 0.79 & 0.74 & 0.08 & 0.07 & 0.06 & 0.03 & 0.05 & $<0.01$ & 0.04 & 0.01 & 0.06 & 0.01 \\
\hline $\mathrm{P}_{2} \mathrm{O}_{5}$ & 0.09 & 0.06 & 0.02 & 0.03 & 0.03 & 0.02 & 0.03 & 0.01 & 0.10 & 0.11 & 0.19 & 0.13 \\
\hline Ctot & & 0.25 & & 10.10 & 11.10 & 11.20 & & & & & 6.35 & \\
\hline Cgrap & & 0.18 & & 0.30 & 0.36 & 0.25 & & & & & $<0.05$ & \\
\hline Cotg & & 0.04 & & 0.10 & 0.13 & 0.10 & & & & & 0.05 & \\
\hline $\mathrm{CO} 2$ & & 0.11 & & 35.50 & 39.00 & 39.70 & & & & & 23.10 & \\
\hline $\mathrm{S}$ & 0.009 & 0.006 & 0.029 & 0.089 & 0.027 & 0.116 & 0.153 & 0.010 & $<0.001$ & $<0.001$ & $<0.001$ & $<0.001$ \\
\hline LOI & 3.32 & 4.65 & 39.78 & 35.67 & 38.92 & 39.01 & 26.21 & 22.61 & 23.79 & 27.27 & 23.95 & 24.05 \\
\hline $\begin{array}{l}\text { Total } \\
\text { ppm }\end{array}$ & 100.14 & 98.72 & 99,12 & 99.28 & 99.80 & 99.88 & 100.07 & 100.42 & 99.00 & 99.20 & 98.62 & 96.68 \\
\hline $\mathrm{Ba}$ & 360.0 & 296.0 & 24.0 & 24.0 & 8.0 & 12.0 & 16.0 & $<1.0$ & 11.0 & 15.0 & 15.0 & 19.0 \\
\hline $\mathrm{Sr}$ & 17.0 & 11.0 & 28.0 & 21.0 & 16.0 & 19.0 & 13.0 & 12.0 & 38.0 & 48.0 & 56.0 & 28.0 \\
\hline $\mathrm{Y}$ & 27.0 & 25.0 & 11.0 & 7.0 & 8.0 & 8.0 & 7.0 & $<1.0$ & 10.0 & 7.0 & 12.0 & 8.0 \\
\hline $\mathrm{Sc}$ & 16.0 & 17.0 & 3.0 & 2.0 & 2.0 & 2.0 & 2.0 & $<1,0$ & 2.0 & $<1.0$ & 2.0 & $<1.0$ \\
\hline $\mathrm{Zr}$ & 184.0 & 173.0 & 18.0 & 27.0 & 17.0 & 11.0 & 16.0 & $<1,0$ & 17.0 & 11.0 & 21.0 & 18.0 \\
\hline $\mathrm{Be}$ & 3.0 & 2.0 & 1.0 & $<1.0$ & $<1.0$ & $<1.0$ & $<1.0$ & $<1.0$ & 2.0 & $<1.0$ & 2.0 & 1.0 \\
\hline V & 122.0 & 122.0 & 17.0 & 14.0 & 11.0 & 10.0 & 13.0 & $<5.0$ & 23.5 & 14.3 & 25.8 & 11.9 \\
\hline $\mathrm{Ni}$ & 44.5 & 88.4 & 5.3 & 9.4 & 10.2 & 6.6 & 12.3 & 1.4 & 5.6 & 3.5 & 6.9 & 2.8 \\
\hline $\mathrm{Cu}$ & 48.3 & 28.0 & 18.9 & 13.0 & 5.7 & 14.5 & 37.5 & 3.9 & 9.5 & 9.4 & 10.7 & 10.9 \\
\hline $\mathrm{Zn}$ & 7.6 & 44.0 & $<1.0$ & $<1.0$ & $<1,0$ & $<1.0$ & $<1.0$ & $<1.0$ & 9.9 & 13.6 & 16.5 & 3.7 \\
\hline $\mathrm{Ga}$ & 27.5 & 23.6 & 2.6 & 2.5 & 1.9 & 1.0 & 2.2 & $<1.0$ & 1.6 & $<1.0$ & 1.4 & $<1.0$ \\
\hline $\mathrm{Ge}$ & 2.6 & 2.9 & $<0.5$ & $<0.5$ & $<0.5$ & $<0.5$ & 0.9 & 0.6 & 2.1 & 1.8 & 1.8 & 2.1 \\
\hline $\mathrm{Rb}$ & 227.6 & 174.6 & 11.5 & 19.4 & 4.4 & 4.5 & 8.7 & $<1.0$ & 5.5 & $<1.0$ & $<1.0$ & 2.2 \\
\hline $\mathrm{Nb}$ & 10.6 & 11,6 & 0.9 & 1.0 & 0.8 & 0.4 & 0.9 & $<0.2$ & 1.6 & 1.1 & 1.5 & 0.9 \\
\hline & $<2.0$ & $<2,0$ & $<2.0$ & $<2.0$ & $<2.0$ & $<2.0$ & $<2.0$ & $<2.0$ & $<2.0$ & $<2.0$ & $<2.0$ & $<2.0$ \\
\hline $\mathrm{Ag}$ & $<0.3$ & $<0.3$ & $<0.3$ & $<0.3$ & $<0.3$ & $<0.3$ & $<0.3$ & $<0.3$ & $<0.3$ & $<0.3$ & $<0.3$ & $<0.3$ \\
\hline In & $<0.1$ & $<0.1$ & $<0.1$ & $<0.1$ & $<0.1$ & $<0.1$ & $<0.1$ & $<0.1$ & $<0.1$ & $<0.1$ & $<0.1$ & $<0.1$ \\
\hline Sn & 3.6 & 3.0 & $<1.0$ & 1.1 & $<1.0$ & $<1.0$ & $<1.0$ & $<1.0$ & $<1.0$ & $<1.0$ & $<1.0$ & $<1.0$ \\
\hline $\mathrm{Cs}$ & 8.7 & 4.9 & 0.4 & 0.8 & 0.3 & 0.1 & 0.3 & $<0.1$ & 1.0 & 0.2 & 0.2 & 0.3 \\
\hline$\sum \mathrm{REE}$ & 233.3 & 220.7 & 47.0 & 30.6 & 32.7 & 28.7 & 21.8 & 4.9 & 21.7 & 14.6 & 40.0 & 13.6 \\
\hline HIf & 5.3 & 5.2 & 0.4 & 0.8 & 0.5 & 0.2 & 0.5 & $<0.1$ & 0.1 & 0.1 & 0.3 & $<0.1$ \\
\hline $\mathrm{Tl}$ & 1.5 & 0.6 & 0.1 & 0.3 & 0.1 & $<0.1$ & 0.2 & $<0.1$ & 0.1 & $<0.1$ & 0.2 & 0.1 \\
\hline $\mathrm{Pb}$ & 22.4 & 7.3 & $<3.0$ & $<3.0$ & $<3.0$ & 4,8 & $<3.0$ & $<3.0$ & 8.7 & 10.1 & 5.7 & 3.2 \\
\hline $\mathrm{Bi}$ & 2.1 & 2.0 & 2.3 & 2.5 & 3.0 & $<0.1$ & 4.0 & 3.0 & 0.4 & 0.1 & 0.2 & $<0.1$ \\
\hline Th & 21.7 & 19.1 & 2.6 & 2.4 & 1.5 & 0.7 & 1.3 & $<0.1$ & 1.4 & 0.7 & 1.3 & 0.5 \\
\hline $\mathrm{U}$ & 6.7 & 4.4 & 1.2 & 0.8 & 0.7 & 0.5 & 0.6 & 0.2 & 2.5 & 1.6 & 2.8 & 1.3 \\
\hline As & 16.2 & $<5,0$ & 5.9 & 6.5 & $<5.0$ & $<5.0$ & $<5.0$ & $<5.0$ & 9.6 & 5.9 & 15.5 & $<5.0$ \\
\hline $\mathrm{Cr}$ & 210.3 & 233.8 & $<20.0$ & $<20.0$ & $<20.0$ & $<20.0$ & $<20.0$ & $<20.0$ & 44.0 & 148,0 & 104.0 & $<20.0$ \\
\hline $\mathrm{Sb}$ & 4.0 & 1.5 & 0.4 & 0.7 & 0.8 & 0.3 & 0.8 & $<0.2$ & 1.3 & 0.7 & 1.2 & 0.9 \\
\hline $\mathrm{Cd}$ & 0.80 & 0.64 & 2.06 & 1.26 & $<0.30$ & 1.24 & 1.67 & 0.75 & 0.73 & 0.84 & 0.55 & 1.15 \\
\hline Fe\# & 0.76 & 0.38 & 0.29 & 0.14 & 0.23 & 0.07 & 0.06 & 0.12 & 0.98 & 0.98 & 0.98 & 0.99 \\
\hline
\end{tabular}




\begin{tabular}{|c|c|c|c|c|c|c|c|c|c|c|c|c|}
\hline & M8 & M9 & M10 & $M \|$ & M96 & P55 27 & P55 61 & P3 18 & P3 23 & P3 36 & P3 50 & P54 80 \\
\hline \multicolumn{13}{|l|}{ Sample } \\
\hline $\begin{array}{l}\mathrm{Wt} \% \\
\mathrm{SiO}_{2}\end{array}$ & $\begin{array}{c}\text { Dol. } \\
\text { Itabir. } \\
0.83\end{array}$ & $\begin{array}{c}\text { Dol. } \\
\text { Itabir. } \\
0.53\end{array}$ & $\begin{array}{c}\text { Dol. } \\
\text { Itabir. } \\
0.84\end{array}$ & $\begin{array}{c}\text { Dol. } \\
\text { Itabir. } \\
0.63\end{array}$ & $\begin{array}{c}\text { Dol. } \\
\text { Itabir. } \\
1.00\end{array}$ & $\begin{array}{c}\text { Dol. } \\
\text { Itabir. } \\
0.65\end{array}$ & $\begin{array}{c}\text { Dol. } \\
\text { Itabir. } \\
0.86\end{array}$ & $\begin{array}{l}\text { Sil, } \\
\text { Itabir. } \\
61.95\end{array}$ & $\begin{array}{c}\text { Sil. } \\
\text { Itabir. } \\
49.19\end{array}$ & $\begin{array}{c}\text { Sil. } \\
\text { Itabir. } \\
39.87\end{array}$ & $\begin{array}{c}\text { Sil. } \\
\text { Itabir. } \\
30.89\end{array}$ & $\begin{array}{l}\text { Sil. } \\
\text { Itabir. } \\
19.7 !\end{array}$ \\
\hline $\mathrm{Al}_{2} \mathrm{O}_{3}$ & 0.20 & 0.09 & 0.26 & 0.10 & 0.57 & 0.17 & 0.07 & 0.14 & 0.32 & 0.52 & 0.06 & 0.12 \\
\hline $\mathrm{Fe}_{2} \mathrm{O}_{3}$ & 42.14 & 52.43 & 54.03 & 67.61 & 59.05 & 44.36 & 42.84 & 37.18 & 49.10 & 54.27 & 68.44 & 76.75 \\
\hline Fetot & 42.92 & 53.00 & 54.92 & 68.11 & 60.03 & 45.02 & 43.33 & 37.37 & 49.37 & 54.51 & 68.66 & 79.34 \\
\hline $\mathrm{FeO}$ & 0.70 & 0.51 & 0.80 & 0.45 & 0.88 & 0.59 & 0.44 & 0.17 & 0.24 & 0.22 & 0.20 & 2.33 \\
\hline $\mathrm{MnO}$ & 0.28 & 0.23 & 0.27 & 0.18 & 0.25 & 0.32 & 0.25 & $<0.01$ & 0.01 & 0.04 & 0.03 & $<0.01$ \\
\hline $\mathrm{MgO}$ & 12.02 & 9.69 & 9.24 & 6.49 & 7.98 & 11.00 & 11.50 & 0.06 & 0.12 & 0.80 & 0.02 & 0.03 \\
\hline $\mathrm{CaO}$ & 16.79 & 13.74 & 12.91 & 9.47 & 11.07 & 15.68 & 16.27 & 0.09 & 0.38 & 1.21 & 0.06 & 0.22 \\
\hline $\mathrm{Na}_{2} \mathrm{O}$ & $<0.01$ & $<0.01$ & $<0.01$ & $<0.01$ & 0.27 & $<0.01$ & $<0.01$ & $<0.01$ & 0.02 & $<0.01$ & $<0.01$ & $<0.01$ \\
\hline $\mathrm{K}_{2} \mathrm{O}$ & $<0.01$ & $<0.01$ & $<0.01$ & 0.05 & $<0.01$ & $<0.01$ & $<0,01$ & $<0.01$ & $<0.01$ & 0.03 & $<0.01$ & 0.01 \\
\hline $\mathrm{TiO}_{2}$ & 0.01 & 0.02 & 0.01 & 0.01 & 0.04 & 0.01 & $<0.01$ & $<0.01$ & 0.01 & 0.03 & $<0.01$ & $<0.01$ \\
\hline $\mathrm{P}_{2} \mathrm{O}_{5}$ & 0.05 & 0.08 & 0.17 & 0.17 & 0.07 & 0.12 & 0.10 & 0.07 & 0.32 & 0.04 & 0.03 & 0.19 \\
\hline Ctot & 7.05 & & 5.50 & & & 6.90 & & & & & & \\
\hline Cgrap & 0.05 & & $<0.05$ & & & $<0.05$ & & & & & & \\
\hline Corg & $<0.05$ & & 0.05 & & & $<0.05$ & & & & & & \\
\hline $\mathrm{CO} 2$ & 25,80 & & 20.20 & & & 25.30 & & & & & & \\
\hline $\mathrm{S}$ & $<0.001$ & & $<0.001$ & & & 0.007 & 0.016 & 0.003 & 0.007 & $<0.001$ & $<0,001$ & 0.003 \\
\hline LOI & 25.97 & 21.33 & 20.10 & 13.49 & 18.33 & 25.68 & 26.49 & 0.21 & 0.46 & 2.23 & 0.40 & $<0.02$ \\
\hline $\begin{array}{l}\text { Total } \\
\text { ppm }\end{array}$ & 99.03 & 98.71 & 98.72 & 98.70 & 99.55 & 98.60 & 98.92 & 99.85 & 100.21 & 99.27 & 100.08 & 99.61 \\
\hline $\mathrm{Ba}$ & 7.0 & 17.0 & 11.0 & 13.0 & 5.0 & 17.0 & 12.0 & 21.0 & 5.0 & 21.0 & 13.0 & 18.0 \\
\hline $\mathrm{Sr}$ & 29.0 & 22.0 & 24.0 & 19.0 & 17.0 & 24.0 & 23.0 & 1.0 & 4.0 & 3.0 & 2.0 & 8.0 \\
\hline $\mathrm{Y}$ & 4.0 & 5.0 & 7.0 & 9.0 & 6.0 & 8.0 & 9.0 & 1.0 & 5.0 & 6.0 & 3.0 & 4.0 \\
\hline $\mathrm{Sc}$ & $<1.0$ & $<1.0$ & $<1.0$ & $<1.0$ & $<1.0$ & $<1.0$ & $<1.0$ & $<1.0$ & $<1.0$ & $<1.0$ & $<1.0$ & $<1.0$ \\
\hline $\mathrm{Zr}$ & 15.0 & 7.0 & 21.0 & 11.0 & 19.0 & 5,0 & 9.0 & 8.0 & 10.0 & 20.0 & 7.0 & 14.0 \\
\hline $\mathrm{Be}$ & $<1.0$ & $<1.0$ & $<1.0$ & $<1.0$ & 1.0 & $<1.0$ & 1.0 & $<1.0$ & 1.0 & 1.0 & 2.0 & 1.0 \\
\hline $\mathrm{V}$ & 36.4 & 5.0 & 9.6 & 20.0 & 84.3 & 38.0 & 13.0 & 7.2 & 27.0 & 42.8 & 21.0 & 22.0 \\
\hline $\mathrm{Ni}$ & 4.7 & 10.0 & 10.2 & 10.0 & 33.0 & 13.1 & 10.6 & 8.8 & 9.4 & 7.5 & 20.0 & 4.7 \\
\hline $\mathrm{Cu}$ & 10.6 & 5.0 & 10.2 & 5.0 & 5.0 & $<1.0$ & $<1.0$ & 9.0 & $<1.0$ & 11.8 & $<1,0$ & $<1.0$ \\
\hline $\mathrm{Zn}$ & 8.4 & 5.0 & 9.3 & 5.0 & 47.5 & 9.4 & $<1.0$ & $<1.0$ & 2.0 & $<1.0$ & 5.2 & 4.4 \\
\hline $\mathrm{Ga}$ & $<1.0$ & $<1.0$ & $<1.0$ & $<1.0$ & 1.0 & $<1.0$ & $<1.0$ & 1.2 & $<1,0$ & 1.2 & $<1.0$ & $<1.0$ \\
\hline $\mathrm{Ge}$ & 1.9 & 2.1 & $<0.5$ & 0.8 & 3.2 & 2.1 & 2.0 & 3.6 & 3.8 & 2.4 & 6.3 & 3.2 \\
\hline $\mathrm{Rb}$ & $<1.0$ & $<1.0$ & $<1.0$ & $<1.0$ & $<1.0$ & $<1.0$ & $<1.0$ & $<1.0$ & $<1.0$ & 1.9 & $<1.0$ & $<1.0$ \\
\hline $\mathrm{Nb}$ & 0.8 & $<0.2$ & 0.8 & $<0.2$ & 1.6 & 0.3 & 0.9 & 0.8 & 0.4 & 0.9 & 0.3 & 0.4 \\
\hline Mo & $<2,0$ & $<2.0$ & $<2.0$ & $<2.0$ & $<1.0$ & 53.7 & $<2.0$ & $<2.0$ & $<2.0$ & $<2.0$ & 4.7 & $<2.0$ \\
\hline $\mathrm{Ag}$ & $<0.3$ & 1.6 & $<0.3$ & 1.5 & $<0.5$ & 0.4 & 0.5 & $<0.3$ & 0.4 & $<0.3$ & 0.3 & 0.4 \\
\hline In & $<0.1$ & $<0.1$ & $<0.1$ & $<0.1$ & $<0.1$ & $<0.1$ & $<0.1$ & $<0.1$ & $<0.1$ & $<0.1$ & $<0.1$ & $<0.1$ \\
\hline Sn & $<1.0$ & $<1.0$ & $<1.0$ & 4.0 & $<1,0$ & $<1.0$ & $<1.0$ & $<1.0$ & $<1.0$ & $<1.0$ & $<1.0$ & $<1,0$ \\
\hline $\mathrm{Cs}$ & $<0.1$ & $<0.1$ & $<0.1$ & $<0 . \mathrm{l}$ & $<0.1$ & $<0.1$ & $<0,1$ & $<0.1$ & $<0.1$ & 0.1 & $<0.1$ & $<0.1$ \\
\hline$\sum \mathrm{REE}$ & 8.3 & 7.4 & 10.4 & 9.6 & 9.7 & 12.7 & 12.9 & 4.1 & 12.1 & 14.0 & 4.8 & 7.7 \\
\hline Hf & $<0.1$ & 0.2 & $<0.1$ & $<0.1$ & 0.2 & $<0.1$ & $<0.1$ & 0.1 & $<0.1$ & 0.2 & $<0.1$ & $<0.1$ \\
\hline $\mathrm{Tl}$ & $<0.1$ & $<0.1$ & $<0.1$ & $<0.1$ & $<0.1$ & $<0.1$ & $<0.1$ & $<0.1$ & $<0.1$ & $<0.1$ & $<0.1$ & $<0.1$ \\
\hline $\mathrm{Pb}$ & 5.1 & 8.0 & 7.3 & $<3.0$ & $<3.0$ & $<3.0$ & $<3.0$ & 4.6 & $<3.0$ & $<3,0$ & $<3.0$ & $<3.0$ \\
\hline $\mathrm{Bi}$ & 0.1 & 0.2 & $<0.1$ & 0.5 & 0.1 & 5.1 & 6.0 & 0.2 & 4.1 & $<0.1$ & $<0.1$ & 6.5 \\
\hline Th & 0.3 & 0.2 & 0.4 & 0.2 & 0.6 & 0.2 & 0.1 & 0.1 & 0.1 & 0.4 & $<0,1$ & 0.1 \\
\hline $\mathrm{U}$ & 1.0 & 1.1 & 1.2 & 2.0 & 4.5 & 2.1 & 2.8 & 1.4 & 2.7 & 3.0 & 1.0 & 1.0 \\
\hline As & $<5.0$ & $<5.0$ & $<5.0$ & 6.1 & 12.0 & 5.0 & 7.0 & 12.3 & 15.6 & 8.4 & 12.5 & $<5.0$ \\
\hline $\mathrm{Cr}$ & 26.0 & 68.0 & 23.0 & 110.0 & 29.0 & $<20.0$ & $<20.0$ & $<20.0$ & 20.3 & 22.0 & $<20.0$ & $<20.0$ \\
\hline $\mathrm{Sb}$ & 1.1 & 1.1 & 0.2 & 2.1 & 3.4 & 2.6 & 3.2 & 3.0 & 3.3 & 3.0 & 3.2 & 1.6 \\
\hline $\mathrm{Cd}$ & 0.37 & & 1.25 & & & 6.19 & 4.80 & 0.91 & 3.99 & 0.81 & 3.35 & 4.97 \\
\hline $\mathrm{Fe \#}$ & 0.98 & 0.99 & 0.98 & 0.99 & 0.98 & 0.99 & 0.99 & 0.99 & 0.99 & 1.00 & 1.00 & 0.97 \\
\hline
\end{tabular}


Appendix 1 - Major and trace element composition (Continued)

\begin{tabular}{|c|c|c|c|c|c|c|c|c|c|c|c|c|}
\hline Sample & P54_85 & P54_120 & P54_124 & P3_69 & P3_ 83 & P3 103 & $P 3 \quad 122$ & P3 138 & P3 152 & P3 170 & P3 185 & P3 196 \\
\hline $\mathrm{Wt} \%$ & $\begin{array}{l}\text { Sil. } \\
\text { Itabir. }\end{array}$ & $\begin{array}{l}\text { Sil. } \\
\text { Itabir. }\end{array}$ & $\begin{array}{c}\text { Sil. } \\
\text { Itabir. }\end{array}$ & $\begin{array}{l}\text { Sil. } \\
\text { Itabir. }\end{array}$ & $\begin{array}{l}\text { Mixed } \\
\text { Itab. }\end{array}$ & $\begin{array}{c}\text { Sil. } \\
\text { Itabir. }\end{array}$ & $\begin{array}{l}\text { Mixed } \\
\text { Itab. }\end{array}$ & $\begin{array}{c}\text { Cherty } \\
\text { Dol. }\end{array}$ & $\begin{array}{c}\text { Cherty } \\
\text { Dol. }\end{array}$ & $\begin{array}{c}\text { Cherty } \\
\text { Dol. }\end{array}$ & $\begin{array}{c}\text { Cherty } \\
\text { Dol. }\end{array}$ & $\begin{array}{c}\text { Cherty } \\
\text { Dol. }\end{array}$ \\
\hline $\mathrm{SiO}_{2}$ & 38.18 & 58.82 & 50.43 & 26.62 & 27.74 & 53.28 & 50.34 & 28.21 & 11.08 & 6.56 & 21.06 & 14.58 \\
\hline $\mathrm{Al}_{2} \mathrm{O}_{3}$ & 0.10 & 0.13 & 0.13 & 0.09 & 0.44 & 0.12 & 0.08 & 0.73 & 3.07 & 0.27 & 0.55 & 0.33 \\
\hline $\mathrm{Fe}_{2} \mathrm{O}_{3}$ & 58.92 & 40.43 & 47.74 & 68.58 & 31.99 & 37.08 & 31,88 & 21.29 & 5.20 & 6.64 & 16.85 & 6.96 \\
\hline Fetot & 60.63 & 40.86 & 49.07 & $68.7 \mathrm{t}$ & 33,10 & 37.40 & 32.34 & 22.95 & 9.17 & 8.32 & 18.56 & 11.76 \\
\hline $\mathrm{FeO}$ & 1.54 & 0.39 & 1.20 & 0.12 & 1.00 & 0.29 & 0.41 & 1.49 & 3.57 & 1.51 & 1.54 & 4.32 \\
\hline $\mathrm{MnO}$ & $<0.01$ & $<0.01$ & $<0.01$ & 0.08 & 0.33 & 0.09 & 0.26 & 0.30 & 0.41 & 0.66 & 0.39 & 0.58 \\
\hline MgO & 0.01 & $<0,01$ & 0.02 & 0.17 & 8.05 & 1.79 & 3.18 & 10.08 & 18.44 & 17.25 & 12.37 & 13.95 \\
\hline $\mathrm{CaO}$ & 0.13 & 0.16 & 0.18 & 1.69 & 11.24 & 2.98 & 5.20 & 13.84 & 21.42 & 25.87 & 17.63 & 22.45 \\
\hline $\mathrm{Na}_{2} \mathrm{O}$ & 0.02 & 0.02 & $<0.01$ & $<0.01$ & 0.04 & 0.01 & 0.10 & 0.02 & 0.07 & 0.02 & $<0.01$ & 0.10 \\
\hline $\mathrm{K}_{2} \mathrm{O}$ & $<0.01$ & $<0.01$ & 0.02 & 0.04 & 0.04 & $<0.01$ & 0.08 & $<0.01$ & 0.10 & $<0.01$ & $<0.01$ & $<0.01$ \\
\hline $\mathrm{TiO}_{2}$ & $<0.01$ & $<0.01$ & $<0.01$ & $<0.01$ & 0.03 & 0.01 & $<0.01$ & 0.06 & 0.26 & 0.03 & 0.04 & 0.02 \\
\hline $\mathrm{P}_{2} \mathrm{O}_{5}$ & 0.14 & 0.15 & 0.17 & 0.08 & 0.06 & 0.17 & 0.06 & 0.05 & 0.06 & 0.02 & 0.03 & 0.02 \\
\hline Ctot & & & & & 4.80 & & & 6.05 & 9.65 & & & 9.80 \\
\hline Cgrap & & & & & $<0.05$ & & & $<0,05$ & $<0.05$ & & & $<0.05$ \\
\hline Corg & & & & & $<0.05$ & & & $<0.05$ & 0.05 & & & $<0.05$ \\
\hline $\mathrm{CO} 2$ & & & & & 17.60 & & & 22,20 & 35.40 & & & 35.90 \\
\hline $\mathrm{S}$ & 0.005 & 0.013 & 0.007 & $<0.001$ & $<0.001$ & $<0.001$ & $<0.001$ & 0.004 & $<0.001$ & 0.038 & 0.014 & $<0.001$ \\
\hline LOI & 0.04 & 0.20 & 0.18 & 1.58 & 17.79 & 4.51 & 7.76 & 22.44 & 35.14 & 39.83 & 28.10 & 34.78 \\
\hline $\begin{array}{l}\text { Total } \\
\text { ppm }\end{array}$ & 99.25 & 100.34 & 100.17 & 99.05 & 98.86 & 100.33 & 99.40 & 98.62 & 99.21 & 98.81 & 98.71 & 98.56 \\
\hline $\mathrm{Ba}$ & 21.0 & 20.0 & 14.0 & 6.0 & 16.0 & 4.0 & 7.0 & 6.0 & 9.0 & 7.0 & 4.0 & 5.0 \\
\hline $\mathrm{Sr}$ & 8.0 & 4.0 & 7.0 & 8.0 & 37.0 & 9.0 & 8.0 & 19.0 & 38.0 & 41.0 & 23.0 & 23.0 \\
\hline$Y$ & 4.0 & 4.0 & 5.0 & 3.0 & 5.0 & 3.0 & 3.0 & 4.0 & 9.0 & 7.0 & 3.0 & 3.0 \\
\hline $\mathrm{Sc}$ & $<1.0$ & $<1.0$ & $<1.0$ & $<1.0$ & 1.0 & $<1.0$ & $<1.0$ & 2.0 & 4.0 & $<1,0$ & 2.0 & 1.0 \\
\hline $\mathrm{Zr}$ & 13.0 & 10.0 & 8.0 & 18.0 & 14.0 & 9.0 & 4.0 & 12.0 & 35.0 & 9.0 & 14.0 & 10.0 \\
\hline $\mathrm{Be}$ & 1.0 & $<1.0$ & 1.0 & 2.0 & 1.0 & 2.0 & $<1.0$ & 2.0 & 1.0 & 1.0 & 1.0 & $<1.0$ \\
\hline V & 52.0 & 18.0 & 11.0 & $<5.0$ & 6.5 & $<5.0$ & $<5.0$ & 10.0 & 32.4 & 6.0 & 9.0 & $<5.0$ \\
\hline $\mathrm{Ni}$ & 7.9 & 12.5 & 9.1 & 14.8 & 16.4 & 12.7 & 3.4 & 13.9 & 36.8 & 13.5 & 9.0 & 2.8 \\
\hline $\mathrm{Cu}$ & $<1.0$ & $<1.0$ & $<1.0$ & 9.6 & 5.8 & $<1.0$ & 9.1 & 1.2 & 1.8 & 1.6 & $<1,0$ & 1.9 \\
\hline $\mathrm{Zn}$ & 3.6 & 1.9 & 2.8 & $<1.0$ & 8.2 & 7.1 & $<1.0$ & 18.4 & 20.9 & $<1.0$ & 3.8 & $<1.0$ \\
\hline $\mathrm{Ga}$ & $<1,0$ & $<1.0$ & $<1.0$ & $<1.0$ & 1.2 & $<1.0$ & $<1.0$ & 1.1 & 5.2 & $<1.0$ & $<1.0$ & $<1.0$ \\
\hline $\mathrm{Ge}$ & 4.3 & 2.7 & 3.0 & 3.2 & 2.4 & 5.2 & 3.2 & 1.6 & 1.2 & $<0.5$ & 0.9 & $<0.5$ \\
\hline $\mathrm{Rb}$ & $<1,0$ & 1.7 & $<1.0$ & $<1.0$ & 1.1 & $<1.0$ & $<1.0$ & $<1,0$ & 6.3 & 1.1 & 1.3 & $<1.0$ \\
\hline $\mathrm{Nb}$ & 0.6 & 2.9 & 0.3 & 0.5 & 1.3 & $<0.2$ & 0.7 & 0.6 & 1.8 & 0.3 & 0.5 & 0.7 \\
\hline Mo & $<2.0$ & $<2.0$ & $<2.0$ & $<2.0$ & $<2,0$ & $<2.0$ & $<2.0$ & $<2.0$ & $<2.0$ & $<2.0$ & $<2.0$ & $<2.0$ \\
\hline $\mathrm{Ag}$ & 0.3 & 0.4 & 0.3 & $<0.3$ & $<0.3$ & $<0.3$ & $<0.3$ & 0.3 & $<0.3$ & $<0.3$ & $<0.3$ & $<0.3$ \\
\hline $\ln$ & $<0.1$ & $<0.1$ & $<0.1$ & $<0.1$ & $<0.1$ & $<0.1$ & $<0.1$ & $<0.1$ & $<0.1$ & $<0.1$ & $<0.1$ & $<0.1$ \\
\hline $\mathrm{Sn}$ & $<1.0$ & $<1.0$ & $<1.0$ & $<1.0$ & $<1.0$ & $<1.0$ & $<1.0$ & $<1,0$ & $<1.0$ & $<1,0$ & $<1.0$ & $<1.0$ \\
\hline Cs & $<0.1$ & 0.2 & 0.1 & $<0.1$ & $<0.1$ & $<0.1$ & $<0.1$ & $<0.1$ & 0.4 & $<0.1$ & $<0.1$ & $<0.1$ \\
\hline$\sum R E E$ & 5.8 & 9.8 & 8.8 & 7.1 & 7.7 & 7.5 & 4.8 & 10.5 & 15.3 & 10.6 & 9.6 & 7.5 \\
\hline Hf & $<0.1$ & $<0.1$ & $<0.1$ & $<0.1$ & 0.1 & $<0.1$ & $<0.1$ & 0.2 & 0.5 & 0.2 & 0.2 & 0.1 \\
\hline $\mathrm{Tl}$ & $<0.1$ & $<0.1$ & $<0.1$ & $<0.1$ & $<0.1$ & $<0,1$ & $<0.1$ & $<0.1$ & $<0.1$ & $<0.1$ & $<0.1$ & $<0.1$ \\
\hline $\mathrm{Pb}$ & $<3.0$ & $<3.0$ & $<3.0$ & 8.2 & 13.7 & $<3.0$ & 5.6 & $<3.0$ & 3.3 & $<3.0$ & $<3.0$ & 4.2 \\
\hline $\mathrm{Bi}$ & $<0.1$ & $<0,1$ & $<0.1$ & $<0.1$ & 0.1 & $<0.1$ & $<0.1$ & $<0.1$ & 0.1 & $<0.1$ & 2.1 & $<0.1$ \\
\hline Th & 0.1 & 0.1 & 0.1 & 0.1 & 0.4 & 0.1 & 0.1 & 0.6 & 1.8 & 0.4 & 0.7 & 0.6 \\
\hline $\mathrm{U}$ & 0.9 & 1.7 & 1.6 & 1.5 & 1.3 & 0.7 & 0.9 & 2.1 & 1.1 & 1.0 & 1.1 & 0.4 \\
\hline As & 5.7 & 7.4 & 9.1 & 14.3 & 7.9 & 19.6 & 6.0 & $<5.0$ & $<5.0$ & $<5.0$ & $<5.0$ & $<5.0$ \\
\hline $\mathrm{Cr}$ & $<20,0$ & $<20.0$ & $<20.0$ & $<20.0$ & 28.0 & $<20.0$ & $<20.0$ & 164.9 & $<20.0$ & $<20.0$ & $<20.0$ & $<20.0$ \\
\hline $\mathrm{Sb}$ & 2.5 & 2.5 & 3.2 & 2.6 & 2.0 & 2.5 & 1.3 & 0.8 & 0.7 & 0.3 & 0.7 & 0.3 \\
\hline $\mathrm{Cd}$ & 5.46 & 2.74 & 3.68 & 0.99 & 0.37 & 2.30 & 0.80 & 2.14 & 0.38 & 2.78 & 2.74 & 0.41 \\
\hline Fe\# & 0.97 & 0.99 & 0.97 & 1.00 & 0.97 & 0.99 & 0.99 & 0.93 & 0.57 & 0.80 & 0.91 & 0.59 \\
\hline
\end{tabular}


Appendix 1 - Major and trace element composition (Continued)

\begin{tabular}{|c|c|c|c|c|c|c|c|c|c|c|c|c|}
\hline Sample & M5A & $\mathrm{M} 6 \mathrm{~A}$ & M7A & M8A & $\mathrm{M} 10 \mathrm{~A}$ & M11A & Ml & $\mathrm{M} 16$ & M81 & $\mathrm{M} 100$ & $\mathrm{M} 102$ & M103 \\
\hline & \multicolumn{6}{|c|}{ Iron-Rich Band of Dolomitic Itabirite } & \multicolumn{6}{|c|}{ Dolomite Rich Band of Dolomitic Itabirite } \\
\hline Wt\% & & & & & & & & & & & & \\
\hline $\mathrm{SiO}_{2}$ & 1.10 & 1.27 & 0.98 & 0.79 & 0.71 & 0.62 & 0.34 & 0.77 & 0.33 & 0.14 & 2.31 & 0.49 \\
\hline $\mathrm{Al}_{2} \mathrm{O}_{3}$ & 0.37 & 0.47 & 0.26 & 0.22 & 0.28 & 0.10 & 0.10 & 0.46 & 0.12 & 0.07 & 1.02 & 0.21 \\
\hline $\mathrm{Fe}_{2} \mathrm{O}_{3}$ & 83.43 & 84.77 & 82.38 & 69.75 & 65.04 & 81.92 & 15.42 & 23.92 & 8.74 & 7.00 & 4.49 & 5.99 \\
\hline Fetot & 83.74 & 85.13 & 82.61 & 70.11 & 65.57 & 82.23 & 16.06 & 25.00 & 9.48 & 7.21 & 6.15 & 6.55 \\
\hline $\mathrm{FeO}$ & 0.28 & 0.32 & 0.21 & 0.32 & 0.48 & 0.28 & 0.58 & 0.97 & 0.67 & 0.19 & 1.49 & 0.50 \\
\hline $\mathrm{MnO}$ & 0.07 & 0.06 & 0.11 & 0.18 & 0.20 & 0.10 & 0.48 & 0.55 & 0.62 & 0.54 & 0.32 & 0.48 \\
\hline $\mathrm{MgO}$ & 3.00 & 2.92 & 3.36 & 5.76 & 6.51 & 3.09 & 17.35 & 15.99 & 18.86 & 19.73 & 19.72 & 19.34 \\
\hline $\mathrm{CaO}$ & 3.59 & 3.08 & 4.28 & 8.03 & 9.18 & 4.56 & 25.12 & 22.62 & 26.82 & 28.40 & 26.40 & 27.80 \\
\hline $\mathrm{Na}_{2} \mathrm{O}$ & $<0.01$ & $<0.01$ & $<0.01$ & $<0.01$ & $<0.01$ & $<0.01$ & 0.02 & $<0.01$ & $<0.0 \mathrm{l}$ & 0.23 & 0.02 & 0.03 \\
\hline $\mathrm{K}_{2} \mathrm{O}$ & $<0.01$ & 0.06 & 0.02 & $<0.01$ & $<0.01$ & $<0.01$ & 0.11 & $<0.01$ & 0.01 & $<0.01$ & 0.10 & 0.13 \\
\hline $\mathrm{TiO}_{2}$ & 0.02 & 0.02 & 0.02 & 0.01 & 0.02 & 0.01 & $<0.01$ & 0.03 & 0.02 & 0.01 & 0.05 & $<0.01$ \\
\hline $\mathrm{P}_{2} \mathrm{O}_{5}$ & 0.12 & 0.04 & 0.04 & 0.11 & 0.18 & 0.20 & 0.22 & 0.06 & 0.02 & 0.04 & 0.02 & 0.02 \\
\hline $\mathrm{S}$ & $<$ & $<0.001$ & $<0.001$ & $<0.001$ & 0.012 & 0.005 & $<0.001$ & $<0.001$ & $<0.001$ & $<0.001$ & $<0.001$ & $<0.001$ \\
\hline LOI & 6.83 & 6.07 & 8.13 & 14.17 & 16.30 & 7.93 & 36.88 & 34.51 & 42.63 & 43.91 & 42.39 & 43.55 \\
\hline $\begin{array}{l}\text { Total } \\
\text { ppm }\end{array}$ & 98.78 & 99.12 & 99.80 & 99.35 & 98.89 & 98.77 & 98.69 & 99.99 & 98.81 & 100.28 & 98.50 & 98.60 \\
\hline $\mathrm{Ba}$ & 10.0 & 8.0 & 14.0 & 11.0 & 11.0 & 13.0 & 30.0 & 21.0 & 37.0 & 7.0 & 8.0 & 21.0 \\
\hline $\mathrm{Sr}$ & 12.0 & 8.0 & 10.0 & 15.0 & 19.0 & 13.0 & 41.0 & 38.0 & 56.0 & 74.0 & 29.0 & 39.0 \\
\hline $\mathrm{Y}$ & 3.0 & 3.0 & 6.0 & 5.0 & 6.0 & 5.0 & 10.0 & 9.0 & 10.0 & 13.0 & 10.0 & 5.0 \\
\hline $\mathrm{Sc}$ & $<1.0$ & $<1,0$ & $<1.0$ & $<1.0$ & $<1,0$ & $<1.0$ & $<1,0$ & $<1.0$ & $<1.0$ & $<1.0$ & 1.0 & $<1.0$ \\
\hline $\mathrm{Zr}$ & 15.0 & 15.0 & 15.0 & 14.0 & 14.0 & 15.0 & 7.0 & 15.0 & 9.0 & 1.0 & 10.0 & 6.0 \\
\hline $\mathrm{Be}$ & 2.0 & 2.0 & 1.0 & 1.0 & 1.0 & 1.0 & $<1.0$ & 1.0 & $<1.0$ & $<1.0$ & 1.0 & $<1,0$ \\
\hline $\mathrm{V}$ & 14.0 & 28.0 & 29.0 & 121.0 & 13.0 & 13.0 & 15.6 & 20.2 & $<5.0$ & 6.9 & 8.8 & 7.5 \\
\hline $\mathrm{Ni}$ & 11.2 & 16.7 & 14.5 & 13.4 & 25.2 & 9.8 & 6.4 & 10.9 & 8.4 & 10.0 & 5.5 & 2.6 \\
\hline $\mathrm{Cu}$ & $<1.0$ & $<1.0$ & $<1.0$ & $<1.0$ & $<1,0$ & $<1.0$ & 7.4 & 4.8 & 2.6 & 11.6 & 1.8 & 2.9 \\
\hline $\mathrm{Zn}$ & 13.8 & 13.9 & 14.3 & 11.7 & 11.6 & 12.4 & 9.2 & 4.7 & 10.5 & 5.0 & 4.4 & $<1.0$ \\
\hline $\mathrm{Ga}$ & 1.2 & 1.5 & $<1,0$ & $<1.0$ & $<1.0$ & $<1.0$ & $<1.0$ & $<1.0$ & $<1.0$ & $<1.0$ & 1.7 & $<1.0$ \\
\hline $\mathrm{Ge}$ & 2.6 & 4.0 & 4.5 & 3.1 & 3.2 & 4.2 & 0.6 & 0.7 & $<0.5$ & $<0.5$ & $<0.5$ & $<0.5$ \\
\hline $\mathrm{Rb}$ & 1.6 & 3.8 & $<1.0$ & $<1.0$ & $<1.0$ & $<1,0$ & $<1.0$ & $<1.0$ & $<1.0$ & $<1.0$ & $<1.0$ & 1.2 \\
\hline $\mathrm{Nb}$ & 0.3 & 0.4 & 0.7 & 0.3 & 0.3 & $<0.2$ & 1.4 & 0.9 & 0.8 & 0.6 & 1.0 & 0.6 \\
\hline Mo & $<2.0$ & $<2,0$ & 3.9 & $<2.0$ & $<2.0$ & $<2.0$ & $<2.0$ & $<2.0$ & $<2.0$ & $<1.0$ & $<2.0$ & $<2.0$ \\
\hline $\mathrm{Ag}$ & 0.5 & 0.4 & 0.3 & $<0.3$ & 0.6 & 0.5 & $<0.3$ & $<0.3$ & $<0.3$ & $<0.5$ & $<0.3$ & $<0.3$ \\
\hline In & $<0.1$ & $<0.1$ & $<0.1$ & $<0.1$ & $<0.1$ & $<0.1$ & $<0.1$ & $<0.1$ & $<0.1$ & $<0.1$ & $<0.1$ & $<0.1$ \\
\hline $\mathrm{Sn}$ & $<1.0$ & $<1.0$ & $<1.0$ & $<1.0$ & 1.4 & $<1.0$ & $<1.0$ & $<1.0$ & $<1.0$ & $<1,0$ & $<1.0$ & $<1.0$ \\
\hline $\mathrm{Cs}$ & 0.3 & 0.8 & $<0.1$ & $<0.1$ & $<0,1$ & $<0.1$ & $<0.1$ & $<0.1$ & $<0.1$ & $<0.1$ & $<0.1$ & $<0.1$ \\
\hline ¿REE & 10.2 & 10.0 & 10.8 & 8.4 & 10.5 & 8.2 & 12.7 & 19.5 & 11.9 & 21.7 & 34.0 & 13.5 \\
\hline Hf & $<0.1$ & $<0.1$ & 0.1 & $<0.1$ & $<0.1$ & $<0.1$ & $<0.1$ & 0.1 & $<0.1$ & $<0.1$ & 0.2 & $<0.1$ \\
\hline $\mathrm{Tl}$ & $<0.1$ & 0.1 & $<0.1$ & $<0.1$ & $<0.1$ & $<0.1$ & $<0.1$ & $<0.1$ & $<0.1$ & $<0.1$ & $<0.1$ & 0.1 \\
\hline $\mathrm{Pb}$ & $<3.0$ & $<3.0$ & $<3.0$ & $<3,0$ & $<3.0$ & $<3.0$ & 7.0 & 9.4 & 8.2 & $<3.0$ & 8.1 & 6.9 \\
\hline $\mathrm{Bi}$ & 5.0 & $<0.1$ & $<0.1$ & 2.2 & 3.0 & $<0.1$ & $<0.1$ & 0.1 & 0.1 & $<0.1$ & 0.3 & $<0.1$ \\
\hline Th & 0.3 & 0.3 & 0.3 & 0.2 & 0.3 & 0.1 & 2.4 & 0.6 & 0.5 & 0.2 & 1.1 & 0.2 \\
\hline $\mathrm{U}$ & 2.9 & 3.0 & 1.5 & 1.7 & 1.4 & 1.9 & 1.3 & 2.3 & 2.1 & 0.9 & 2.4 & 1.1 \\
\hline As & $<5.0$ & 13.8 & 7.3 & $<5.0$ & 7.6 & 5.6 & 5.8 & 7.1 & $<5.0$ & 4.4 & $<5.0$ & 6.5 \\
\hline $\mathrm{Cr}$ & 81.1 & $<20.0$ & $<20.0$ & $<20.0$ & $<20.0$ & $<20.0$ & 27,0 & 24.0 & $<20.0$ & 60.0 & $<20.0$ & $<20.0$ \\
\hline $\mathrm{Sb}$ & 0.5 & 1.8 & 1.4 & 1.1 & 1.4 & 1.8 & 0.7 & 0.9 & 1.1 & 0.3 & 1.2 & 4.9 \\
\hline $\mathrm{Cd}$ & 2.87 & 4.75 & 6.00 & 4.99 & 4.07 & 5.14 & 0.55 & 0.33 & 0.67 & & 0.31 & 0.32 \\
\hline Fe\# & 1.00 & 1.00 & 1,00 & 0.99 & 0.99 & 1.00 & 0.96 & 0.96 & 0.92 & 0.97 & 0.73 & 0.92 \\
\hline
\end{tabular}


Appendix 2 - Rare Earth Element Composition

$\begin{array}{llllllllllllllllll} & \text { M140 } & \text { M141 } & \text { M132 } & \text { M134 } & \text { M135 } & \text { M137 } & \text { M138 } & \text { M139 } & \text { M4 } & \text { M5 } & \text { M6 } & \text { M7 } & \text { M8 } & \text { M9 } & \text { M10 } & \text { M11 }\end{array}$

Litho Ser.Phyl. Ser.Phyl Arg. Dol. Arg. Dol. Arg. Dol. Arg. Dol. Arg. Dol. Arg. Dol. Dol. Itab. Dol. Itab. Dol. Itab. Dol. Itab. Dol. Itab. Dol. Itab. Dol. Itab. Dol. Itab. ppm

\begin{tabular}{|c|c|c|c|c|c|c|c|c|c|c|c|c|c|c|c|c|}
\hline La & 47.32 & 50.86 & 8.93 & 5.18 & 5.93 & 4.92 & 3.38 & 1.01 & 3.89 & 2.46 & 10.92 & 2.29 & 1.52 & 1.08 & 1.71 & 1.43 \\
\hline $\mathrm{Ce}$ & 101.83 & 100.90 & 17.57 & 12.29 & 13.08 & 10.40 & 7.66 & 1.86 & 7.17 & 4.92 & 12.88 & 4.21 & 2.42 & 2.21 & 3.00 & 2.75 \\
\hline $\operatorname{Pr}$ & 11.68 & 10.33 & 1.95 & 1.52 & 1.46 & 1.32 & 1.00 & 0.22 & 0.82 & 0.56 & 1.44 & 0.49 & 0.32 & 0.28 & 0.39 & 0.38 \\
\hline $\mathrm{Nd}$ & 42.65 & 34.19 & 8.08 & 5.70 & 5.70 & 5.45 & 4.21 & 0.91 & 3.64 & 2.49 & 5.97 & 2.25 & 1.48 & 1.25 & 1.90 & 1.69 \\
\hline $\mathrm{Sm}$ & 8.32 & 6.15 & 2.23 & 1.16 & 1.32 & 1.17 & 0.96 & 0.19 & 0.81 & 0.55 & 1.16 & 0.51 & 0.29 & 0.33 & 0.40 & 0.44 \\
\hline $\mathrm{Eu}$ & 1.87 & 1.44 & 0.96 & 0.46 & 0.43 & 0.45 & 0.31 & 0.07 & 0.34 & 0.24 & 0.56 & 0.25 & 0.14 & 0.11 & 0.17 & 0.18 \\
\hline $\mathrm{Gd}$ & 6.32 & 4.59 & 1.88 & 1.09 & 1.07 & 1.20 & 0.93 & 0.18 & 1.06 & 0.73 & 1.59 & 0.71 & 0.45 & 0.45 & 0.62 & 0.60 \\
\hline $\mathrm{Tb}$ & 0.90 & 0.75 & 0.34 & 0.19 & 0.20 & 0.22 & 0.18 & 0.03 & 0.20 & 0.14 & 0.28 & 0.13 & 0.08 & 0.08 & 0.11 & 0.11 \\
\hline Dy & 4.75 & 4.33 & 2.04 & 1.03 & 1.27 & 1.26 & 1.04 & 0.16 & 1.32 & 0.90 & 1.91 & 0.92 & 0.54 & 0.51 & 0.73 & 0.69 \\
\hline$Y$ & 27.00 & 25.0 & 11.0 & 7.0 & 8.0 & 8.0 & 7.0 & 1.0 & 10.5 & 8.0 & 14.1 & 8.7 & 5.4 & 6.1 & 7.5 & 7.6 \\
\hline Ho & 1.01 & 0.93 & 0.39 & 0.24 & 0.28 & 0.28 & 0.24 & 0.04 & 0.31 & 0.21 & 0.41 & 0.22 & 0.13 & 0.12 & 0.18 & 0.16 \\
\hline $\mathrm{Er}$ & 3.11 & 2.81 & 1.10 & 0.80 & 0.84 & 0.93 & 0.84 & 0.12 & 0.98 & 0.66 & 1.31 & 0.69 & 0.41 & 0.40 & 0.54 & 0.51 \\
\hline $\mathrm{Tm}$ & 0.42 & 0.40 & 0.16 & 0.11 & 0.13 & 0.14 & 0.13 & 0.02 & 0.14 & 0.09 & 0.19 & 0.10 & 0.06 & 0.06 & 0.08 & 0.08 \\
\hline $\mathrm{Yb}$ & 2.69 & 2.57 & 1.17 & 0.71 & 0.87 & 0.82 & 0.79 & 0.10 & 0.92 & 0.60 & 1.21 & 0.69 & 0.38 & 0.46 & 0.48 & 0.51 \\
\hline $\mathrm{Lu}$ & 0.44 & 0.43 & 0.17 & 0.13 & 0.14 & 0.14 & 0.14 & 0.02 & 0.16 & 0.09 & 0.20 & 0.11 & 0.07 & 0.08 & 0.08 & 0.08 \\
\hline$\sum \mathrm{REE}$ & 260.29 & 245.69 & 57.96 & 37.61 & 40.71 & 36.71 & 28.82 & 5.93 & 32.27 & 22.63 & 54.11 & 22.28 & 13.74 & 13.53 & 17.93 & 17.22 \\
\hline $\mathrm{La} / \mathrm{Yb}_{\mathrm{PAAS}}$ & 1.30 & 1.46 & 0.57 & 0.54 & 0.51 & 0.44 & 0.31 & 0.78 & 0.31 & 0.30 & 0.67 & 0.25 & 0.29 & 0.17 & 0.26 & 0.21 \\
\hline $\mathrm{La} / \mathrm{Nd}_{\text {PAAS }}$ & 0.98 & 1.32 & 0.98 & 0.81 & 0.92 & 0.80 & 0.71 & 0.98 & 0.95 & 0.88 & 1.62 & 0.90 & 0.92 & 0.77 & 0.80 & 0.75 \\
\hline $\mathrm{Ce} / \mathrm{Ce}^{*}{ }_{\text {PAAS }}$ & 1.00 & 1.02 & 0.97 & 1.01 & 1.03 & 0.94 & 0.96 & 0.90 & 0.93 & 0.97 & 0.75 & 0.91 & 0.80 & 0.92 & 0.85 & 0.86 \\
\hline $\mathrm{Eu} / \mathrm{Eu}_{\mathrm{PAAS}}{ }^{*}$ & 1.21 & 1.27 & 2.21 & 1.95 & 1.69 & 1.79 & 1.57 & 1.84 & 1.73 & 1.79 & 1.95 & 1.97 & 1.88 & 1.42 & 1.62 & 1.61 \\
\hline $\mathrm{Y} / \mathrm{Y}^{*}{ }_{\text {PAAS }}$ & 0.99 & 0.99 & 0.98 & 1.13 & 1.08 & 1.07 & 1.12 & 1.02 & 1.31 & 1.46 & 1.27 & 1.54 & 1.67 & 2.00 & 1.67 & 1.84 \\
\hline $\mathrm{Pr} / \mathrm{Pr}^{*}{ }_{\mathrm{PAAS}}$ & 1.04 & 1.03 & 0.96 & 1.07 & 0.99 & 1.03 & 1.03 & 1.01 & 0.94 & 0.94 & 0.97 & 0.94 & 0.99 & 1.01 & 0.96 & 1.03 \\
\hline $\mathrm{La} / \mathrm{Sm}_{\mathrm{PAAS}}$ & 0.83 & 1.20 & 0.58 & 0.65 & 0.65 & 0.61 & 0.51 & 0.76 & 0.70 & 0.65 & 1.37 & 0.65 & 0.75 & 0.48 & 0.62 & 0.47 \\
\hline $\mathrm{Sm} / \mathrm{Yb}_{\mathrm{PAAS}}$ & 1.57 & 1.22 & 0.97 & 0.83 & 0.78 & 0.73 & 0.62 & 1.03 & 0.45 & 0.47 & 0.49 & 0.38 & 0.39 & 0.36 & 0.42 & 0.44 \\
\hline $\mathrm{Sm} / \mathrm{Yb}$ & 3.09 & 2.39 & 1.91 & 1.63 & 1.53 & 1.43 & 1.21 & 2.02 & 0.88 & 0.92 & 0.96 & 0.74 & 0.77 & 0.71 & 0.83 & 0.87 \\
\hline Y/Ho & 26.83 & 26.74 & 28.03 & 29.73 & 29.03 & 28.54 & 29.59 & 26.48 & 33.81 & 37.79 & 34.11 & 39.22 & 43.49 & 52.03 & 42.41 & 48.69 \\
\hline
\end{tabular}

Y content is not included in $\sum$ REE. $\left(\mathrm{Eu} / \mathrm{Eu}^{*}\right)_{\mathrm{PAAS}}=\left(\left(\mathrm{Eu} / \mathrm{Eu}_{\mathrm{PAAS}}\right) /\left(\mathrm{Sm} / \mathrm{Sm}_{\mathrm{PAAS}}\right)^{*}\left(\mathrm{Gd} / \mathrm{Gd}_{\mathrm{PAAS}}\right)\right)^{1 / 2}, \mathrm{Ce} / \mathrm{Ce}_{\mathrm{PAAS}}^{*}$ and $\mathrm{Y} / \mathrm{Y}^{*}{ }_{\mathrm{PAAS}}$ calculated by similar way. 
Appendix 2 - Rare Earth Element Composition (Continued)

\begin{tabular}{|c|c|c|c|c|c|c|c|c|c|c|c|c|c|c|c|c|}
\hline SAMPLE & M96 & P55_27 & P55_61 & P3_18 & P3_23 & P3 36 & P3_50 & P54_80 & P54_85 & P54_120 & P54_124 & P3_69 & P3_83 & P3_103 & P3_122 & P3_138 \\
\hline $\begin{array}{l}\text { Litho } \\
\text { ppm }\end{array}$ & Dol. Itab. & Dol. Itab. & Dol. Itab. & Sil. Ytab. & Sil. Itab. & Sil. Itab. & Sil. Itab. & Sil. Itab. & Sil. Itab. & Sil. Itab. & Sil. Itab. & Qz Dol. & Qz Dol. & Qz Dol. & Qz Dol. & Qz Dol. \\
\hline La & 1.32 & 2.17 & 1.27 & 0.68 & 1.81 & 2.15 & 1.37 & 1.22 & 1.00 & 1.53 & 1.41 & 1.41 & 1.25 & 1.14 & 0.61 & 1.79 \\
\hline $\mathrm{Ce}$ & 2.95 & 3.40 & 3.32 & 1.22 & 3.61 & 3.11 & 1.38 & 2.05 & 1.53 & 2.81 & 2.68 & 2.51 & 2.39 & 2.51 & 1.46 & 3.70 \\
\hline $\operatorname{Pr}$ & 0.40 & 0.51 & 0.52 & 0.14 & 0.52 & 0.57 & 0.21 & 0.28 & 0.20 & 0.39 & 0.31 & 0.24 & 0.26 & 0.32 & 0.15 & 0.47 \\
\hline $\mathrm{Nd}$ & 1.83 & 2.39 & 2.60 & 0.73 & 2.42 & 3.36 & 0.67 & 1.46 & 0.97 & 2.06 & 1.49 & 1.12 & 1.27 & 1.48 & 0.78 & 1.90 \\
\hline Sm & 0.49 & 0.63 & 0.82 & 0.20 & 0.66 & 0.87 & 0.16 & 0.41 & 0.28 & 0.54 & 0.43 & 0.26 & 0.30 & 0.33 & 0.21 & 0.40 \\
\hline $\mathrm{Eu}$ & 0.16 & 0.20 & 0.25 & 0.08 & 0.21 & 0.28 & 0.05 & 0.16 & 0.11 & 0.17 & 0.18 & 0.10 & 0.13 & 0.10 & 0.08 & 0.14 \\
\hline $\mathrm{Gd}$ & 0.60 & 0.73 & 0.90 & 0.29 & 0.85 & 1.14 & 0.22 & 0.48 & 0.34 & 0.65 & 0.50 & 0.40 & 0.47 & 0.43 & 0.35 & 0.47 \\
\hline $\mathrm{Tb}$ & 0.10 & 0.13 & 0.17 & 0.05 & 0.14 & 0.18 & 0.04 & 0.09 & 0.07 & 0.11 & 0.09 & 0.07 & 0.09 & 0.07 & 0.07 & 0.08 \\
\hline Dy & 0.62 & 0.86 & 1.03 & 0.32 & 0.75 & 1.01 & 0.26 & 0.58 & 0.45 & 0.63 & 0.63 & 0.42 & 0.58 & 0.42 & 0.42 & 0.51 \\
\hline$Y$ & 6.4 & 8.0 & 9.0 & 2.0 & 5.0 & 7.3 & 3.0 & 4.0 & 4.0 & 4.0 & 5.0 & 3.8 & 5.1 & 3.0 & 3.8 & 4.0 \\
\hline Ho & 0.15 & 0.19 & 0.23 & 0.06 & 0.17 & 0.20 & 0.06 & 0.13 & 0.10 & 0.13 & 0.13 & 0.09 & 0.13 & 0.10 & 0.09 & 0.12 \\
\hline $\mathrm{Er}$ & 0.47 & 0.63 & 0.71 & 0.18 & 0.46 & 0.56 & 0.17 & 0.38 & 0.32 & 0.40 & 0.41 & 0.26 & 0.40 & 0.30 & 0.26 & 0.39 \\
\hline $\mathrm{Tm}$ & 0.07 & 0.10 & 0.12 & 0.03 & 0.06 & 0.08 & 0.03 & 0.06 & 0.05 & 0.06 & 0.06 & 0.04 & 0.06 & 0.04 & 0.03 & 0.06 \\
\hline $\mathrm{Yb}$ & 0.49 & 0.66 & 0.79 & 0.14 & 0.33 & 0.44 & 0.17 & 0.35 & 0.32 & 0.32 & 0.40 & 0.21 & 0.36 & 0.27 & 0.21 & 0.36 \\
\hline $\mathrm{Lu}$ & 0.08 & 0.10 & 0.13 & 0.02 & 0.05 & 0.07 & 0.02 & 0.05 & 0.05 & 0.05 & 0.06 & 0.04 & 0.06 & 0.04 & 0.04 & 0.06 \\
\hline$\sum \mathrm{REE}$ & 16.11 & 20.71 & 21.87 & 6.13 & 17.05 & 21.27 & 7.80 & 11.70 & 9.78 & 13.85 & 13.81 & 10.91 & 12.81 & 10.54 & 8.56 & 14.47 \\
\hline $\mathrm{La} / \mathrm{Yb}_{\mathrm{PAAS}}$ & 0.20 & 0.24 & 0.12 & 0.35 & 0.40 & 0.36 & 0.60 & 0.26 & 0.23 & 0.35 & 0.26 & 0.50 & 0.26 & 0.31 & 0.22 & 0.36 \\
\hline $\mathrm{La} / \mathrm{Nd}_{\text {PAAS }}$ & 0.64 & 0.81 & 0.43 & 0.83 & 0.66 & 0.57 & 1.83 & 0.74 & 0.92 & 0.66 & 0.84 & 1.12 & 0.87 & 0.69 & 0.70 & 0.84 \\
\hline $\mathrm{Ce} / \mathrm{Ce}^{*}{ }^{*}$ AAS & 0.94 & 0.74 & 0.94 & 0.92 & 0.86 & 0.65 & 0.60 & 0.81 & 0.79 & 0.84 & 0.93 & 1.00 & 0.96 & 0.96 & 1.09 & 0.93 \\
\hline $\mathrm{Eu} / \mathrm{Eu}{ }_{\mathrm{PAAS}}$ & 1.40 & 1.37 & 1.38 & 1.50 & 1.33 & 1.33 & 1.18 & 1.72 & 1.67 & 1.36 & 1.80 & 1.42 & 1.58 & 1.30 & 1.43 & 1.49 \\
\hline $\mathrm{Y} / \mathrm{Y}^{*}{ }_{\mathrm{PAAS}}$ & 1.70 & 1.58 & 1.49 & 1.13 & 1.11 & 1.30 & 1.94 & 1.18 & 1.51 & 1.13 & 1.37 & 1.56 & 1.50 & 1.19 & 1.53 & 1.29 \\
\hline $\mathrm{Pr} / \mathrm{Pr}^{*}{ }_{\mathrm{PAAS}}$ & 1.01 & 1.06 & 1.04 & 0.87 & 1.04 & 1.03 & 1.27 & 0.94 & 0.96 & 0.96 & 0.92 & 0.83 & 0.89 & 0.97 & 0.85 & 1.04 \\
\hline $\mathrm{La} / \mathrm{Sm}_{\mathrm{PAAS}}$ & 0.39 & 0.50 & 0.22 & 0.50 & 0.40 & 0.36 & 1.26 & 0.43 & 0.53 & 0.41 & 0.48 & 0.79 & 0.60 & 0.50 & 0.42 & 0.65 \\
\hline $\mathrm{Sm} / \mathrm{Yb}_{\mathrm{PAAS}}$ & 0.51 & 0.48 & 0.52 & 0.70 & 1.01 & 0.99 & 0.48 & 0.60 & 0.44 & 0.85 & 0.54 & 0.63 & 0.43 & 0.62 & 0.52 & 0.56 \\
\hline $\mathrm{Sm} / \mathrm{Yb}$ & 1.00 & 0.95 & 1.03 & 1.37 & 1.98 & 1.96 & 0.94 & 1.18 & 0.87 & 1.68 & 1.07 & 1.25 & 0.85 & 1.23 & 1.03 & 1.10 \\
\hline $\mathrm{Y} / \mathrm{Ho}$ & 43.80 & 41.74 & 39.88 & 32.04 & 29.25 & 36.82 & 51.30 & 31.62 & 40.14 & 31.47 & 37.23 & 42.33 & 40.28 & 31.00 & 40.46 & 32.99 \\
\hline
\end{tabular}

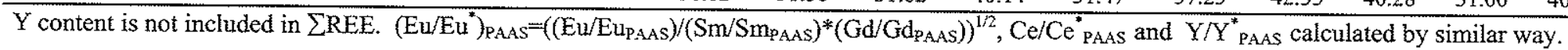




\begin{tabular}{|c|c|c|c|c|c|c|c|c|c|c|c|c|c|c|c|c|}
\hline SAMPLE & P3_152 & P3_170 & P3_185 & P3_196 & M5A & M6A & M7A & M8A & $\mathrm{M} 10 \mathrm{~A}$ & M11A & M1 & M16 & M81 & $\mathrm{M} 100$ & $\mathrm{M} 102$ & M103 \\
\hline Litho & Qz Dol. & Qz Dol. & Qz Dol. & Qz Dol. & Hem.Bd & Hem.Bd & Hem.Bd & Hem.Bd & Hem.Bd & Hem.Bd & Dol.Bd & Dol.Bd & Dol.Bd & Dol.Bd & Dol.Bd & Dol.Bd \\
\hline & 1.63 & 1.37 & 1.65 & 1.26 & 1.90 & 1.88 & 2.56 & 1.61 & 1.89 & 1.28 & 1.88 & 2.87 & 2.37 & 3.60 & 5.67 & 2.40 \\
\hline La & & & & & & & & & & & & & & & & \\
\hline $\mathrm{Ce}$ & 4.64 & 3.24 & 3.46 & 2.74 & 3.42 & 3.41 & 3.49 & 2.44 & 2.94 & 2.30 & 3.34 & 6.41 & 3.10 & 6.85 & 13.02 & 4.70 \\
\hline $\operatorname{Pr}$ & 0.52 & 0.41 & 0.42 & 0.29 & 0.41 & 0.39 & 0.43 & 0.33 & 0.41 & 0.33 & 0.52 & 0.86 & 0.46 & 0.84 & 1.31 & 0.55 \\
\hline $\mathrm{Nd}$ & 2.65 & 1.84 & 1.82 & 1.26 & 1.77 & 1.60 & 1.66 & 1.58 & 2.02 & 1.50 & 2.52 & 4.04 & 2.06 & 3.55 & 5.83 & 2.48 \\
\hline $\mathrm{Sm}$ & 0.78 & 0.55 & 0.38 & 0.29 & 0.41 & 0.39 & 0.37 & 0.32 & 0.48 & 0.38 & 0.60 & 0.91 & 0.45 & 0.79 & 1.33 & 0.53 \\
\hline Eu & 0.21 & 0.17 & 0.10 & 0.10 & 0.15 & 0.15 & 0.14 & 0.13 & 0.14 & 0.15 & 0.24 & 0.31 & 0.18 & 0.39 & 0.57 & 0.25 \\
\hline Gd & 1.04 & 0.76 & 0.41 & 0.37 & 0.49 & 0.42 & 0.38 & 0.44 & 0.57 & 0.55 & 0.90 & 1.14 & 0.64 & 1.06 & 1.51 & 0.67 \\
\hline $\mathrm{Tb}$ & 0.21 & 0.15 & 0.08 & 0.07 & 0.08 & 0.07 & 0.07 & 0.08 & 0.10 & 0.09 & 0.14 & 0.18 & 0.12 & 0.20 & 0.27 & 0.11 \\
\hline Dy & 1.35 & 0.81 & 0.43 & 0.43 & 0.51 & 0.53 & 0.55 & 0.46 & 0.66 & 0.57 & 0.92 & 1.12 & 0.81 & 1.36 & 1.73 & 0.71 \\
\hline$Y$ & 8.8 & 7.0 & 3.0 & 3.4 & 3.0 & 3.0 & 6.0 & 5.0 & 6.0 & 5.0 & 10.5 & 9.3 & 9.5 & 13.5 & 10.7 & 5.3 \\
\hline Ho & 0.29 & 0.18 & 0.10 & 0.10 & 0.13 & 0.12 & 0.12 & 0.11 & 0.15 & 0.14 & 0.21 & 0.23 & 0.20 & 0.33 & 0.38 & 0.16 \\
\hline $\mathrm{Er}$ & 0.87 & 0.56 & 0.32 & 0.28 & 0.41 & 0.40 & 0.41 & 0.38 & 0.50 & 0.45 & 0.67 & 0.65 & 0.65 & 1.15 & 1.12 & 0.43 \\
\hline $\mathrm{Tm}$ & 0.13 & 0.08 & 0.05 & 0.04 & 0.06 & 0.06 & 0.07 & 0.06 & 0.08 & 0.06 & 0.09 & 0.09 & 0.10 & 0.19 & 0.15 & 0.06 \\
\hline $\mathrm{Yb}$ & 0.86 & 0.45 & 0.31 & 0.25 & 0.40 & 0.41 & 0.48 & 0.38 & 0.50 & 0.38 & 0.56 & 0.57 & 0.60 & 1.20 & 0.99 & 0.36 \\
\hline $\mathrm{Lu}$ & 0.15 & 0.07 & 0.05 & 0.04 & 0.07 & 0.07 & 0.08 & 0.06 & 0.08 & 0.06 & 0.10 & 0.10 & 0.11 & 0.19 & 0.17 & 0.06 \\
\hline$\sum \mathrm{REE}$ & 24.10 & 17.65 & 12.57 & 10.91 & 13.21 & 12.91 & 16.83 & 13.38 & 16.53 & 13.24 & 23.19 & 28.80 & 21.35 & 35.18 & 44.77 & 18.76 \\
\hline $\mathrm{La} / \mathrm{Yb}_{\mathrm{PAAS}}$ & 0.14 & 0.22 & 0.40 & 0.38 & 0.35 & 0.34 & 0.39 & 0.32 & 0.28 & 0.25 & 0.25 & 0.37 & 0.29 & 0.22 & 0.42 & 0.49 \\
\hline $\mathrm{La} / \mathrm{Nd}_{\text {pAAS }}$ & 0.55 & 0.66 & 0.81 & 0.89 & 0.96 & 1.04 & 1.37 & 0.91 & 0.83 & 0.75 & 0.66 & 0.63 & 1.02 & 0.90 & 0.86 & 0.86 \\
\hline $\mathrm{Ce} / \mathrm{Ce}^{*}$ PAAS & 1.16 & 1.00 & 0.96 & 1.05 & 0.89 & 0.91 & 0.76 & 0.77 & 0.77 & 0.82 & 0.78 & 0.94 & 0.68 & 0.91 & 1.10 & 0.94 \\
\hline $\mathrm{Eu} / \mathrm{Eu}^{*}{ }^{*} \mathrm{PAS}$ & 1.09 & 1.26 & 1.24 & 1.35 & 1.60 & 1.70 & 1.70 & 1.59 & 1.30 & 1.53 & 1.54 & 1.42 & 1.60 & 1.98 & 1.90 & 2.01 \\
\hline $\mathrm{Y} / \mathrm{Y}_{\mathrm{PAAS}}^{*}$ & 1.13 & 1.48 & 1.16 & 1.31 & 0.94 & 0.94 & 1.84 & 1.74 & 1.50 & 1.41 & 1.89 & 1.48 & 1.86 & 1.60 & 1.06 & 1.24 \\
\hline $\mathrm{Pr} / \mathrm{Pr}^{*}{ }_{\text {PAAS }}$ & 0.88 & 0.99 & 0.99 & 0.91 & 0.99 & 0.99 & 1.06 & 0.99 & 0.99 & 1.03 & 1.06 & 0.99 & 1.08 & 1.01 & 0.89 & 0.95 \\
\hline $\mathrm{La} / \mathrm{Sm}_{\mathrm{PAAS}}$ & 0.30 & 0.36 & 0.63 & 0.62 & 0.67 & 0.70 & 0.99 & 0.72 & 0.57 & 0.49 & 0.45 & 0.46 & 0.76 & 0.66 & 0.62 & 0.66 \\
\hline $\mathrm{Sm} / Y b_{\text {PAAS }}$ & 0.46 & 0.62 & 0.63 & 0.61 & 0.52 & 0.49 & 0.39 & 0.44 & 0.49 & 0.51 & 0.54 & 0.81 & 0.38 & 0.34 & 0.68 & 0.74 \\
\hline $\mathrm{Sm} / \mathrm{Yb}$ & 0.91 & $\mathrm{I} .22$ & 1.24 & 1.20 & 1.03 & 0.96 & 0.77 & 0.86 & 0.96 & 1.01 & 1.07 & 1.60 & 0.75 & 0.66 & 1.34 & 1.46 \\
\hline $\mathrm{Y} / \mathrm{Ho}$ & 30.78 & 39.73 & 30.66 & 34.07 & 23.98 & 24.66 & 48.27 & 44.36 & 38.88 & 36.07 & 49.50 & 41.16 & 46.63 & 40.85 & 28.39 & 32.83 \\
\hline
\end{tabular}

of dolomitic itabirite; Dol.Bd=dolomite-rich band of dolomitic itabirite. 


\title{
ANEXO 3 - THE HIGH-GRADE IRON ORES OF THE ÁGUAS CLARAS MINE, QUADRILÁTERO FERRÍFERO, BRAZIL
}

\begin{abstract}
Several major iron deposits occur in Quadrilátero Ferrifero (QF), Southeastern Region of Brazil, where metamorphosed and heterogeneously deformed banded iron formation (BIF) of the Cauê Formation, regionally called itabirites, were converted to high- $(\mathrm{Fe}>64 \%)$ and low-grade $(30 \%<\mathrm{Fe}<64 \%)$ hematite ores. Based on their mineralogical composition, three major types of itabirites are described as occurring in the QF: quartz, dolomitic and amphibolitic. Unlike other mines in the QF, the Águas Claras mine contained mainly high-grade ores, which occur within dolomitic itabirite. Two distinct types of high-grade ore occurred at the mine: soft and hard. The soft ore was the most abundant and represented more than $85 \%$ of the total ore mined until the mine was depleted in 2002 . The soft ore is highly porous, friable and partially preserves the original structure of the dolomitic itabirite protore, particularly meso- and microbanding, which is characterized by the presence of massive and porous bands within the ore. The hard ore is dense, tough and compact. It occurs as small concordant lenses within the soft ore and within the fresh dolomitic itabirite. Soft and hard ores consist essentially of hematite, occurring as martite, anhedral to granular/tabular hematite and, locally specularite. Gangue minerals are very rare, consisting of dolomite, sericite, chlorite and apatite in the hard and soft ores, and Mn-oxides and ferrihydrite in the soft ore, where they are concentrated within the porous bands. Chemical analyses showed that hard and soft ores consist almost entirely of $\mathrm{Fe}_{2} \mathrm{O}_{3}$, with higher amount of detrimental impurities, especially $\mathrm{MnO}$, in the soft ore. Both hard and soft ores are very depleted in trace elements.
\end{abstract}

The high-grade ores have at least a dual origin, involving hypogene and supergene processes. The occurrence of the hard massive high-grade ore within fresh dolomitic itabirite is a good evidence of its hypogene origin. Despite the contention about the origin of the dolomitic itabirite (if this rock is a carbonatic facies of the Caue Formation or a hematite-carbonate precursor of the soft high-grade ore formed by hydrothermal alteration that removed all the chert from the BIF and replaced it with dolomite), many features observed in the soft ore, such as: (1) clear transition from the dolomitic itabirite into the soft ore; (2) disappearance of the soft ore 
down dip, forming pinnacles; (3) pockets of dolomitic itabirite within the soft ore; (4) occurrence of slump folds in the soft ore, and Tertiary basins locally blanketing the orebody; petrographic evidences of dolomite dissolution forming Mn-oxides and ferrihydrite (a metastable iron hydroxide that transforms into hematite at temperatures as low as $4{ }^{\circ} \mathrm{C}$, and (6) a similar REEY pattern for the dolomitic itabirite and the soft ore, indicate that the soft high-grade ore in the Águas Claras mine was formed by leaching of dolomite from the dolomitic itabirite by meteoric water.

The original composition of the itabiritic protore has a major role in the genesis of highand low-grade soft ores in the QF. Under the same weathering and structural conditions, the dolomitic itabirite is more likely to form high-grade deposits than quartz itabirite, due to the higher solubility of dolomite in relation to quartz. Field relationships at the Águas Claras and Capão Xavier deposits suggest that it is not possible to form huge soft high-grade supergene deposits from quartz itabirite, unless another control, such as impermeable barriers, had played an important role.

\section{INTRODUCTION}

The Águas Claras iron-ore mine is located in the Quadrilatero Ferrifero (QF), Southeastern Region of Brazil, state of Minas Gerais (Fig. 1). Open-pit mining at Águas Claras commenced in 1973 and, by 2002, when the mine was closed, approximately $288 \mathrm{Mt}$ of highgrade iron ore (average $\mathrm{Fe}>68 \%$ ) had been mined on the crest and along the slopes of a segment of the Serra do Curral. About $88 \mathrm{Mt}$ of high-grade iron ore remained, but economic and environmental restrictions prevented mining from continuing. The high quality of its products and the large tonnage obtained placed the Águas Claras mine among the most important iron mines during that time.

Despite its world-class category and the significant amount of data gathered on the mine since mining began in 1973, very little geological information on the mine is available in published literature (Gomes 1986; Viel et al. 1987; Hackspacher 1979). Recently, Spier et al. (2003) described the geology of the Águas Claras and Pico iron mines and presented data for the main chemical constituents of the iron ore at those mines. This study complements that previous work, presenting a detailed study on the mineralogy and geochemistry of the iron ores of the Águas Claras mine and aims at contributing to the discussion on their genesis. 
The majority of the iron orebodies at the QF are hosted in itabirites (oxidized, metamorphosed and heterogeneously deformed BIFs) of the Caue Formation, Itabira Group. Itabirites of the Cauê Formation are very similar in lithology to most major oxide-facies BIFs known worldwide (Dorr II 1969). Based on their mineralogical composition, three major types of itabirites are described as occurring in the QF: quartz, dolomitic and amphibolitic.

Unlike other mines of the QF, the Águas Claras mine contained mainly high-grade ore (Fe $>64 \%$ ) hosted within dolomitic itabirite. Although quartz and dolomitic itabirite crop out at the mine, the high-grade ore was developed mainly within the latter. Two distinct types of highgrade ore occur at the mine: soft and hard. The soft ore was the most abundant and represented more than $85 \%$ of the total ore mined. It was considered by Spier et al. (2003) as of supergene origin, whereas the hard ore was considered by the same authors as of hypogene origin, because it occurs within fresh dolomitic itabirite. Some features of the soft ore such as the great depth of mineralization and the lack of goethite, otherwise, could suggest that this type of ore is also of hypogene origin.

The genesis of the high-grade $(\mathrm{Fe}>64 \%)$ and low-grade $(30 \%<\mathrm{Fe}<64 \%)$ iron ores within the Caue Formation has been the object of debate since the beginning of the $20^{\text {th }}$ century and continues to be the focus of studies by several researchers (e.g. Cabral et al. 2003; Dorr II 1964; Dorr II 1965; Guild 1953; Harder and Chamberlain 1915; Park 1959; Ramanaidou 1989; Ramanaidou et al. 1996; Rosière and Rios 2004). Most studies are concentrated in ores originating from quartz itabirite, the most common type of itabirite in the region, probably because dolomitic itabirite is more restricted to and concentrated along the Serra do Curral (Fig. 1). The genesis of the iron ore originating from dolomitic itabirite in the $Q F$ has never been studied in detail, and several questions remain open. Why were the high-grade ores at the Águas Claras mine formed mainly from dolomitic itabirite and not from quartz itabirite? Why were the high-grade ores formed from quartz itabirite limited to few meters below the topographic surface? Were the hard and soft ores formed during the same event? Could the soft ore be produced only by weathering? Are new minerals formed during leaching of the carbonates? This paper address those questions, in order to contribute for discussions about the genesis of the iron ore in the QF and worldwide. 


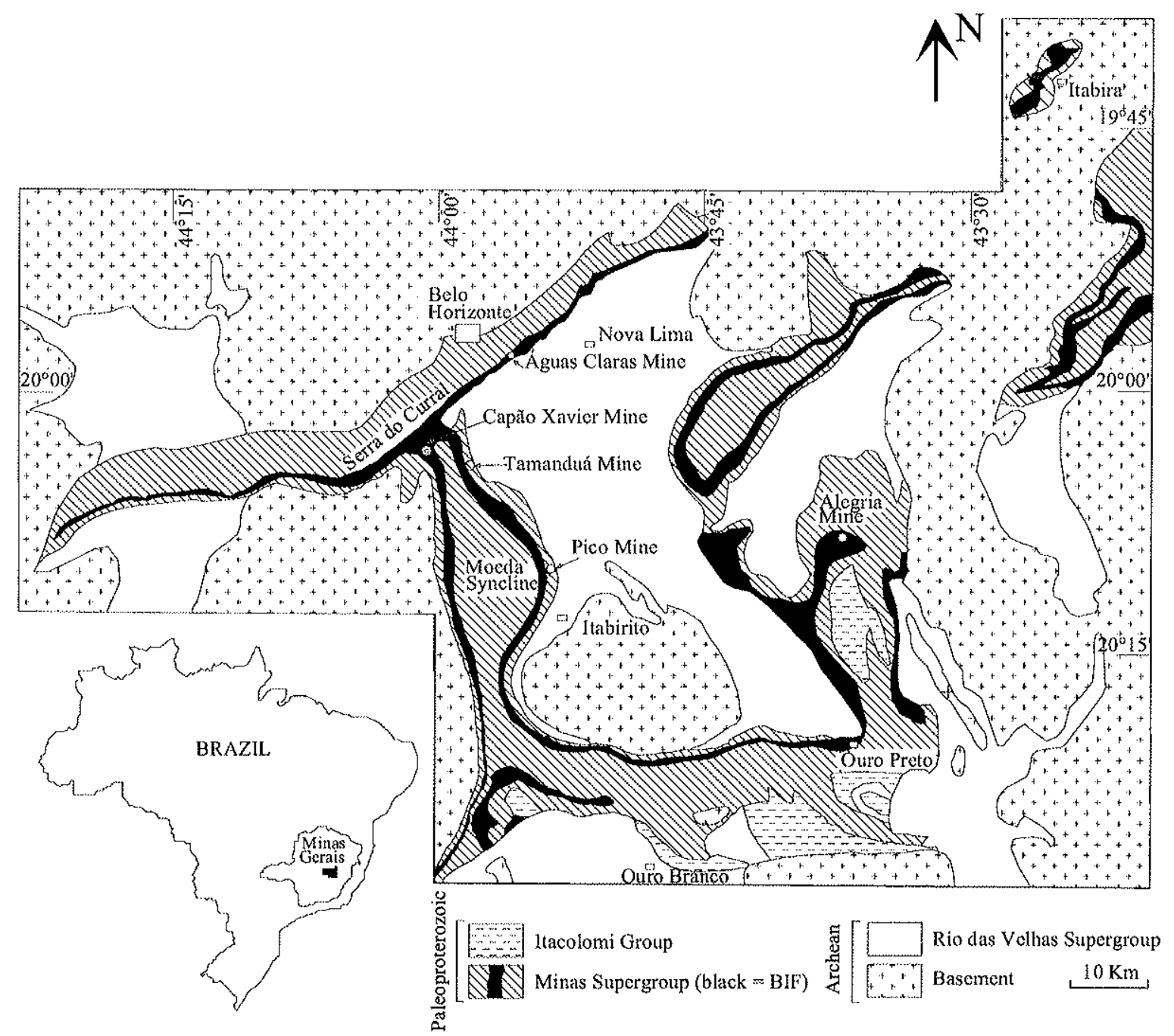

Figure 1 - Location and geological sketch map of the Quadrilátero Ferrifero region (After Alkmim and Marshak 1998).

\section{GEOLOGICAL SETTING}

Paleoproterozoic Minas Supergroup metassedimentary rocks form the mountain ranges of the QF, whereas the lowlands are occupied by Archean granite-gneiss basement rocks and the Rio das Velhas Greenstone Belt sequence (Fig. 1). The giant iron ore deposits of the QF are hosted in the platformal sediments of the Minas Supergroup and consist of three metamorphic sequences (Dorr 1969). The lowest unit is the Caraça Group, which contains clastic sediments. The middle Itabira Group comprises itabirites with minor dolomite and phyllite of the Cauê Formation and carbonate rocks of the Gandarela Formation. Itabirites grade upward to dolomites and dolomitic/manganiferous itabirites of the 2.4 Ga Gandarela Formation (Babinski et al. 1995). 
The Piracicaba Group comprises clastic sediments (with subordinate dolomites), separated by an unconformity from the underlying Itabira Group.

The Águas Claras mine is located in the northern segment of the Serra do Curral, a northeast-southwest trending $\sim 100 \mathrm{~km}$-long ridge that limits the northwest edge of the QF (Fig. 1). Units of the Minas Supergroup crop out along most of its extension as an inverted sequence without repetition. In the northern segment of the Serra do Curral, the rocks are strained, sinistrally rotated from their original position, and beds are overturned (Chemale Jr. et al. 1994). Extensive shear zones occur at the contact between the Minas Supergroup and the underlying Archean Rio das Velhas Supergroup. At this region of the QF, the rocks of the Minas Supergroup were submitted to a low-grade metamorphism of the greenschist-facies (Pires 1995).

At the Águas Claras mine, quartzite and phyllite of the Moeda and Batatal Formations, as well as dolomite, itabirite and iron ore of the Cauê Formation, crop out (Fig. 2a-b). Within the pit, the dolomitic itabirite is much more common than the quartz itabirite, which occurs only in the north wall on the top of the sequence (Fig. 2a).

\section{The Dolomitic Itabirite (Protore)}

The dolomitic itabirite occurs as a continuous 150 to $400 \mathrm{~m}$ thick layer and represents the protore of the soft iron ore. Its petrography and geochemistry were described in detail by Spier et al. (2005a) and will be briefly addressed herein. Banding of $\mathrm{cm}$-sized iron-rich and dolomite-rich bands is the most conspicuous macroscopic features of the dolomitic itabirite, characterizing the mesobanding defined by Trendall and Blockley (1970) for BIFs of the Hamersley basin. At the base of the sequence, the dolomitic bands are thicker and predominate over the iron-rich bands. The former display color shades ranging from deep red to pink and have a $\mathrm{cm}$ - to dm-sized thickness, while the latter are gray and range from less than one millimeter to $3 \mathrm{~cm}$ thick. At about $50 \mathrm{~m}$ up on the sequence, the thickness of the dolomitic band is reduced thus giving origin to the typical dolomitic itabirite, where $\sim 1 \mathrm{~cm}$ bands of dolomite alternate with hematitic bands (Fig. 3a) throughout 250 meters of itabirite. To the top, hematitic bands gradually disappear, and a ferruginous dolomite predominates. A mm-sized banding of iron-rich and dolomite-rich laminaes (microbanding) also occurs, especially within dolomite-rich mesobands (Fig. 4a).

The carbonate bands of dolomitic itabirite consist of very fine grained sparry dolomite and hematite with grain size ranging from 5-30 $\mu \mathrm{m}$ (the average being $20 \mu \mathrm{m}$, Fig. $4 \mathrm{~b}$ ). The volume of hematite within the carbonate bands is highly variable (5\% to $50 \%$ from band to band). Hematite occurs mainly as individual crystals of tabular shape intergrown with dolomite, or else 
forming aggregates of granular and tabular crystals of irregular shapes (Fig. 4c). Platy hematite (specularite) occurs in shear planes, surrounding crystals of tabular/granular hematite (Fig. 4d). Randomly oriented red-brown microcrystals of hematite $(<1 \mu \mathrm{m})$ within dolomite crystals in the carbonate bands account for the characteristic deep red color of these bands.
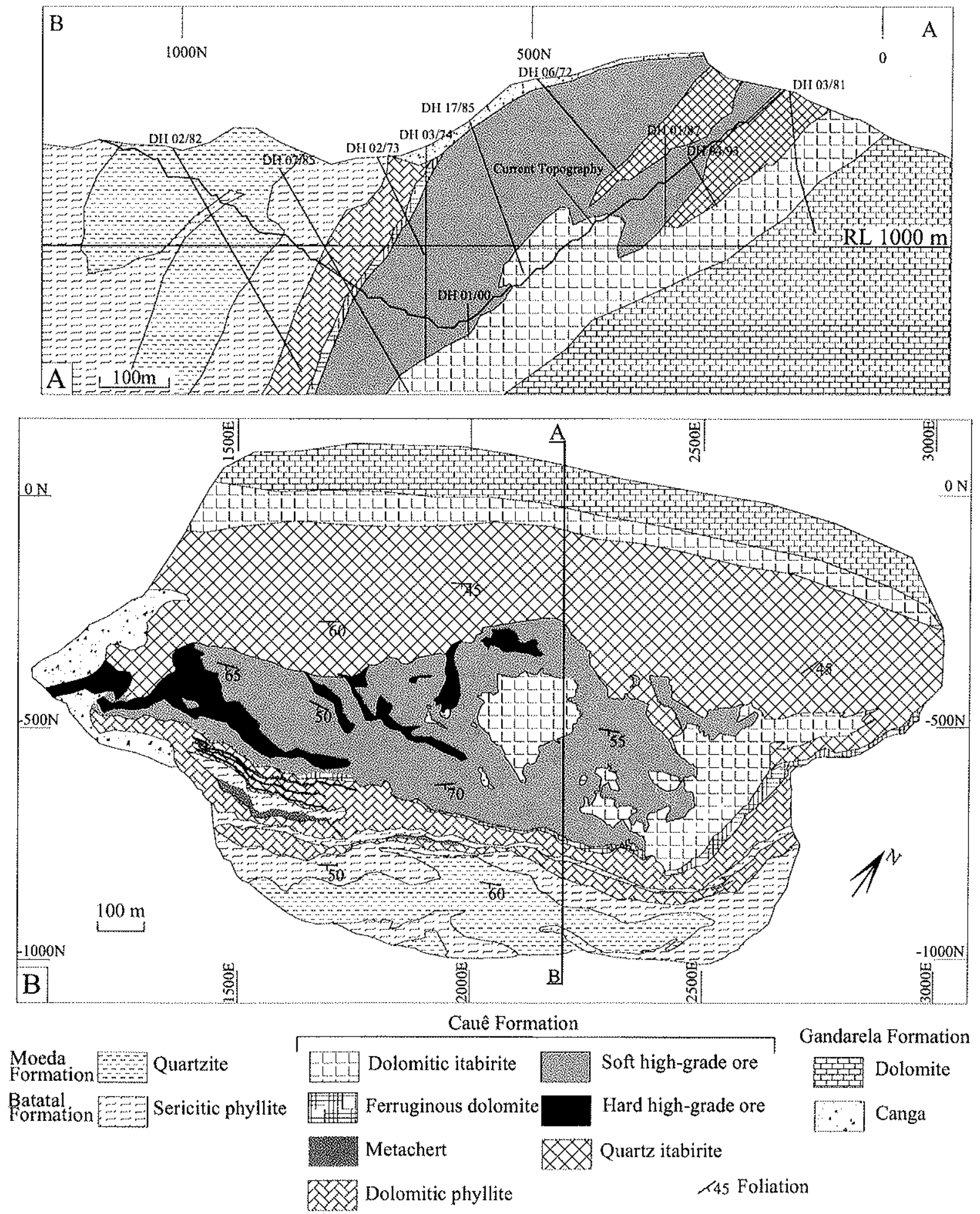

Figure 2 - Águas Claras mine. A Cross section 2200E. B Geological sketch map. 

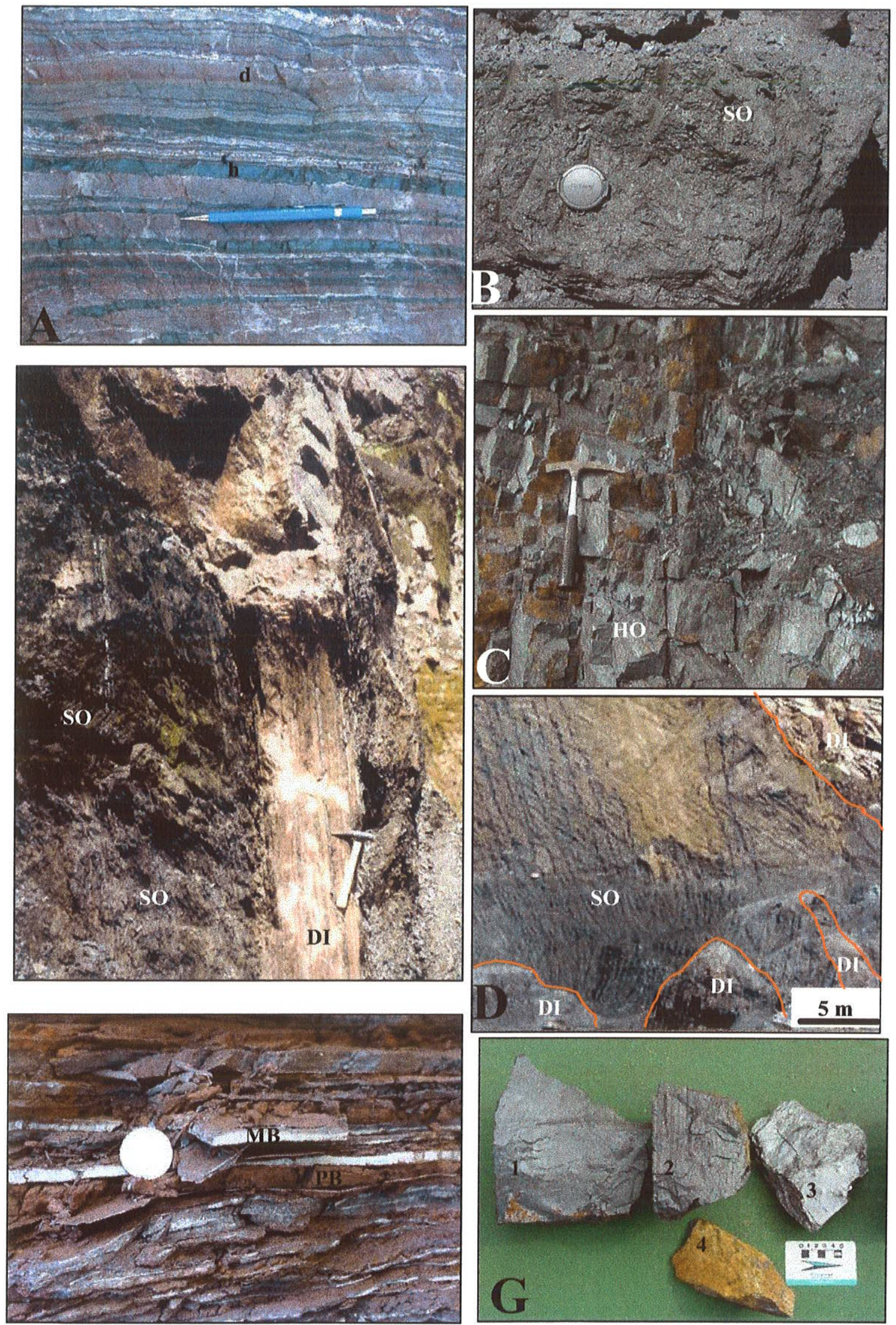

Figure 3 - A Hand specimen of dolomitic itabirite. Mesobanding is preserved as dolomite-rich (d) and iron oxide-rich (h) layers. B-C Mine exposures of the soft (SO) and hard (HO) ores. D Deeper contact zone of the soft ore and dolomitic itabirite (DI). Note the pinnacles of dolomitic itabirite surrounded by the soft ore. $\mathbf{E}$ Detail of the contact between soft ore and dolomitic itabirite. $\mathbf{F}$ Detail of the soft ore showing massive bands (MB) and porous bands (PB). G Hand specimens of hard ore: 1 massive, 2 banded, 3 schistose, 4 coated by goethite. 

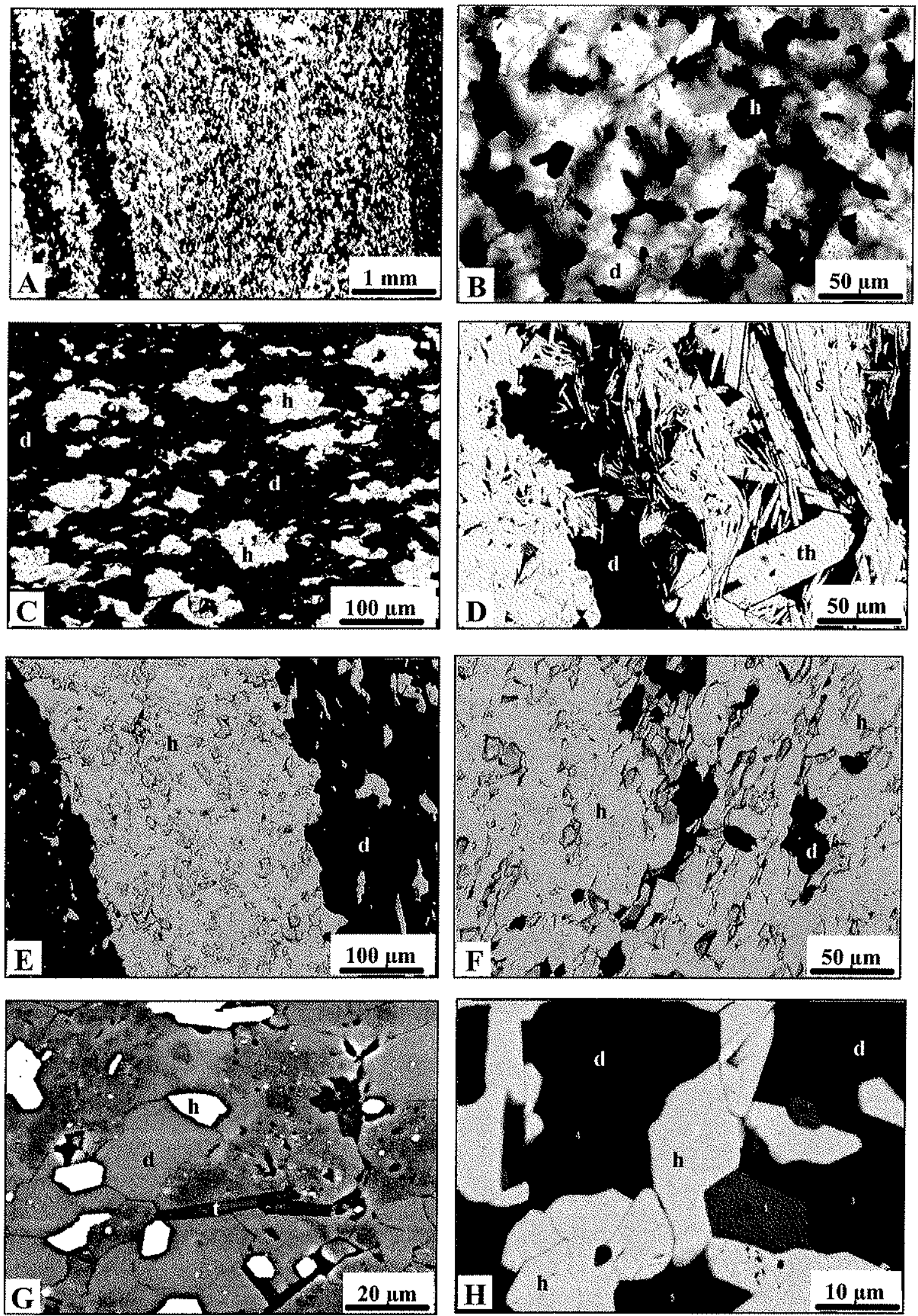

Figure $4 \ldots$ Photomicrographs and SEM images of dolomitic itabirite. A Microbanding of dolomite-rich (white) and iron oxiderich (black) laminae; transmitted light. B Detail of the dolomite-rich microband. Aggregates of euhedral crystals of tabular hematite (h) between the dolomite crystals (d); transmitted light. C SEM image of the dolomite-rich band showing aggregates of hematite (h) between dolomite (d); backscattered image. D Specularite crystals (s) grown along a shear plane surrounding a porfiroblast of idiomorphic tabular hematite (th). E SEM image of an iron oxide-rich laminae; backscattered image. F Detail of the iron oxide-rich laminae showing dolomite crystals (d) between hematite (h). G-H Detail of a dolomite-rich microband showing talc crystal ( $t$ ) intergrown with dolomite (d) and hematite (b) in $\mathbf{G}$ and apatite between dolomite and hematite in $\boldsymbol{H}$. 
The iron-rich bands contain hematite ( $>80 \%$ ), interstitial carbonates and pores (Fig. $4 \mathrm{e}-\mathrm{f})$. The average hematite grain size is similar to that of the dolomitic bands $(\sim 20 \mu \mathrm{m})$ ranging from 5-30 $\mu \mathrm{m}$. Hematite occurs mainly as tabular and granular crystals growing over martite (hematite pseudomorphous after magnetite), forming a dense network. Hematite also occurs locally as specularite. Traces of magnetite are observed in the nuclei of some hematite crystals, especially in the coarser iron-rich bands.

Accessory minerals are also present in the dolomitic itabirite. Talc occurs intergrown with dolomite (Fig. 4g) and associated with chlorite in thin veins. Apatite can be found forming monomineral layers $(<1 \mathrm{~mm})$ or as isolated euhedral crystals $(4-10 \mu \mathrm{m})$ intergrown with or included in hematite and dolomite crystals (Fig. 4h). Chlorite occurs along veins and shear planes.

\section{The Iron Ore}

The Águas Claras orebody comprises soft and hard high-grade ores (Fig. 3b-c). The orebody is a bedding-concordant, 2,500 m long, roughly tabular-shaped lens with a maximum thickness of $300 \mathrm{~m}$ and formed essentially by soft ores (Fig. 2b). The hard ores generally occur within the soft ores as minor lenses concordant to the bedding. The depth of the orebody is variable, extending to over $400 \mathrm{~m}$ below the surface at the center of the pit bottom and then grading into the parental fresh dolomitic itabirite deeper down (Fig. 2a). In this contact region, it is very common to find the presence of pinnacles of fresh dolomitic itabirite surrounded by the soft ore (Fig. 3d). Higher levels of contaminants in the iron ore, especially apatite, occur in this zone. Dip and strike of the orebody are conformable with regional trends, i.e., strike is northeastsouthwest, dip is $65^{\circ}$ to $80^{\circ} \mathrm{SE}$.

The soft ore is gray, friable and has a laminated appearance. It preserves partially the original structure of the protore, particularly meso- and microbanding, which is characterized by the presence of massive and porous bands within the ore, parallel to the banding of the itabirite (Figs. 3b, 5a-f). Adjacent bands are rarely of similar thickness. Field relationships show that iron-rich bands of dolomitic itabirite grade into the massive bands in the iron ore, while dolomite-rich bands grade into the porous bands. Even massive bands are porous, but they have less than 30 percent of pore space, and individual pores are isolated in massive hematite. Generally massive bands are broken and disrupted while porous bands show free aggregates of hematite between pores (Fig. 5f-g). Kink-bands (not present in the protore) are locally observed. 

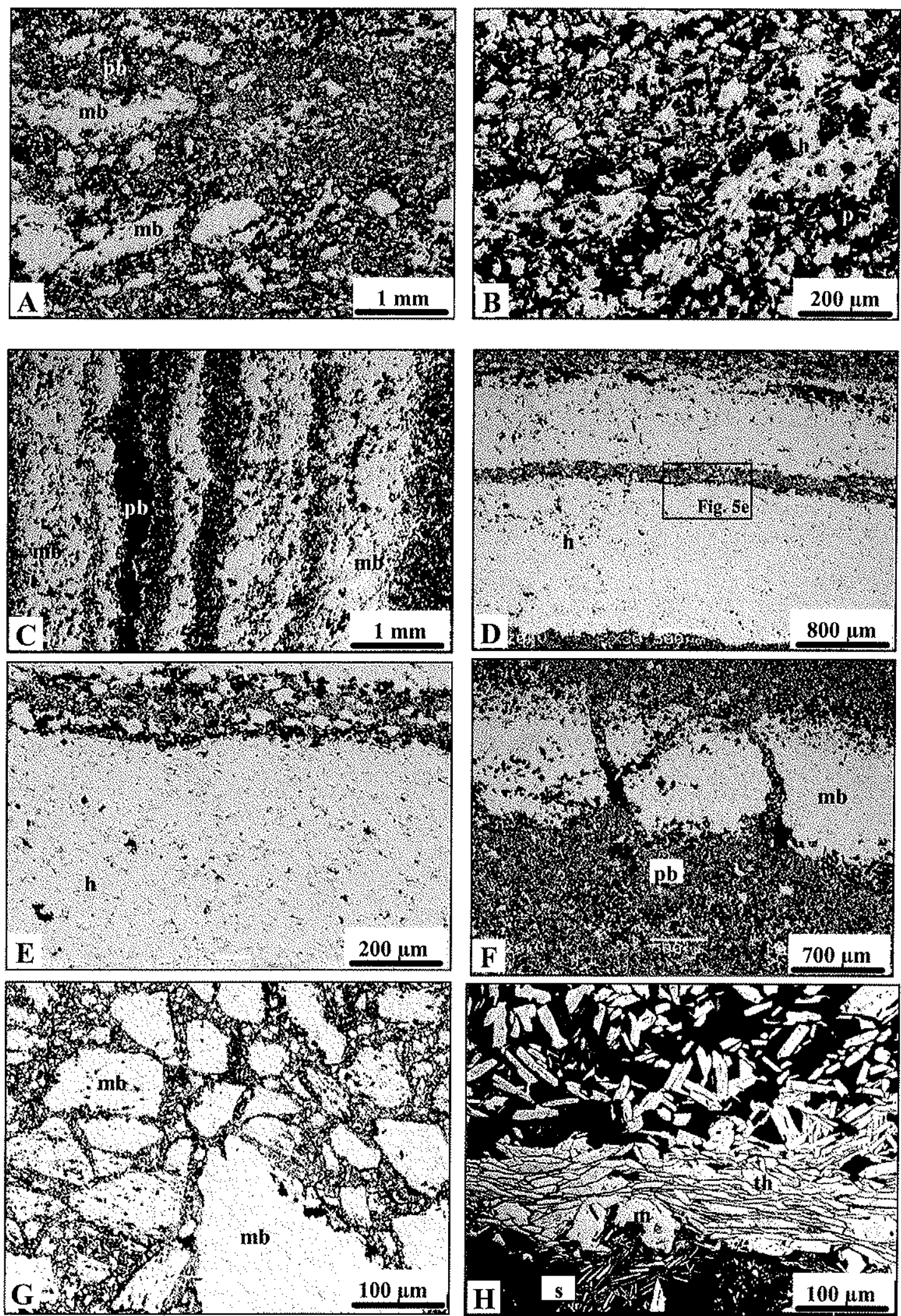

Figure 5 - SEM backscattered images of the soft ore. A-B Typical image of soft ore showing massive bands (mb, white) broken and distupted, with aggregates and individual crystals of hematite (h) between pores (black) in the porous bands (pb). C Microbanding of massive and porous bands. Note the preservation of microbanding of the protore. D-E Massive bands showing the dense packing of hematite (h). Massive and porous bands showing the beginning of breaking and disrupting of the former. G Detail of a massive band highly broken and disrupted. H Coarse crystals of tabular hematite (th) in the massive and porous bands, surrounding a porfiroblast of martite (m) in the former. Note the small crystals of spectlarite (s) in the lower part of the picture. 
The main hard ore occurrences are concentrated on the west side of the mine, close to the top of the sequence. Here, they are in contact with quartz itabirite forming lenses up to $200 \mathrm{~m}$ in length along the strike, ranging from 5 to $60 \mathrm{~m}$ in thickness (Fig. 2b). Small concordant lenses of hard ore from a few centimeters to nearly a meter thick also occur within the soft ore and within the fresh dolomitic itabirite on the east side of the pit.

The hard ore is dense, tough, compact, dark bluish gray and has a dull to metallic luster (Fig. 3c). Three main subtypes of hard ore are found at Águas Claras mine: massive, banded and schistose (Fig. 3f). Massive hard ore has visually low porosity, does not exhibit any kind of structure and usually shows signs of conchoidal fracture. Banded hard ore is the major type of hard ore, being characterized by conspicuous banding and varied porosity. Schistose hard ore generally has low porosity, does not preserve the original structures and exhibits a conspicuous foliation. This type of hard ore is associated with the shear zones which are mainly found on the northern wall of the pit.

\section{SAMPLING AND ANALYTICAL PROCEDURES}

Eighty-six samples representing the hard and soft ores were collected from diamond drill cores and outcrops along the benches of the mine. Appendix 1 presents the local coordinate of each sample and the respective analytical procedure followed. Detailed sampling was carried out in the zone of contact with the protore, in order to access the transition from the dolomitic itabirite to the iron ore. All samples were impregnated with epoxy resin and polished for petrographic analyses purposes. Samples of each type of ore were submitted to scanning electron microscopy (SEM). The porous band of the soft ore was examined by transmission electron microscopy (TEM). SEM analyses were carried out at the laboratories of the Geoscience Institute of the University of São Paulo, Brazil, and at the Center for Microscopy and Microanalyses of the University of Queensland, Australia, where TEM analyses were also carried out.

Eight ore samples were selected for Mössbauer spectroscopy (MS), consisting of four soft ore and four hard ore. For each sample of soft ore, the massive band (samples MAC-126A to MAC-129A) was carefully separated from the porous band (samples MAC-126B to MAC129B). For the hard ore, samples of sub-types massive (MAC-97), banded (MAC-67 and MAC105), and schistose (MAC-68) ores were selected. Besides the iron ore samples, two samples (MAC-96 and MAC-100) of the fresh dolomitic band of the dolomitic itabirite were examined 
by MS. Transmission ${ }^{57} \mathrm{Fe}$ Mössbauer spectra at $300 \mathrm{~K}$ were obtained on a constant acceleration spectrometer using a ${ }^{57} \mathrm{Co} / \mathrm{Rh}$ source at the Laboratory of Applied Physics of the Nuclear Technology Development Center (CDTN) in Belo Horizonte. Mössbauer spectra of four samples (MAC97, MAC127A, MAC127B and MAC100) were also recorded at $50 \mathrm{~K}$. A least-square fitprogram was employed to calculate the spectral hyperfine parameters. All samples studied by MS were characterized by X-ray diffraction (XRD) at the Institute of Physics of the Federal University of Minas Gerais (UFMG). Unit cell parameters of hematite were determined using the Rietveld refinement for samples MAC67, MAC 97 and MAC 127A and B.

Eighty-six samples of the iron ore were analyzed by ICP for major and some trace elements $(\mathrm{Ba}, \mathrm{V}, \mathrm{Ni}, \mathrm{Cu}$ and $\mathrm{Zn}$ ) at the chemical laboratory of MBR. From the total number of samples, 48 were selected for analyses of major, trace and rare earth elements (REE) at the Activation Laboratories - ACTLABS in Canada. All samples were prepared for analysis by grinding in a tungsten carbide vessel. Since this method causes contamination by W, Co and Ta, concentrations of these elements are not reported. In ACTLABS, major and trace elements were determined by ICP/ICP-MS after the opening of the sample with a lithium tetraborate/metaborate fusion. Base metals were determined by ICP-MS/INAA after total digestion by acid attack. Ferrous iron was determined at the laboratories of MBR by potassium dichromate titration. REE data on the Post Archean Australian Shale (PAAS) obtained by McLennan (1989) were used as normalization values. We present REE patterns with $\mathrm{Y}$ inserted between Dy and Ho according to its ionic radius. The reason why we included $Y$ in the lanthanides lies in the value of comparative studies of the behavior of $Y$ and REE in aqueous solutions and their precipitates (Bau and Dulski 1996). In our case, the precipitates were the original sediments of the dolomitic itabirite. The Eu anomaly is defined quantitatively as:

$\mathrm{Eu} / \mathrm{Eu}^{*}=\left(\left(\mathrm{Eu} / \mathrm{Eu}_{\mathrm{PAAS}}\right) /\left(\mathrm{Sm} / \mathrm{Sm}_{\mathrm{PAAS}}\right) \times\left(\mathrm{Gd} / \mathrm{Gd}_{\mathrm{PAAS}}\right)\right)^{1 / 2}$

where $\mathrm{Eu}^{*}$ is the hypothetical concentration of Eu. The anomalies of $\mathrm{Ce}$ and $\mathrm{Y}$ were similarly calculated. The degree of light REE enrichment relative to heavy REE is presented as the ratios of PAAS-normalized $\mathrm{La}$ and $\mathrm{Yb}(\mathrm{La} / \mathrm{Yb}), \mathrm{La}$ and $\mathrm{Sm}(\mathrm{La} / \mathrm{Sm})$, and $\mathrm{Sm}$ and $\mathrm{Yb}(\mathrm{Sm} / \mathrm{Yb})$. 


\section{MINERALOGICAL AND GEOCHEMICAL CHARACTERISTICS}

\section{The Dolomitic Itabirite (Protore)}

In order to allow comparisons between the protore and the iron ore, we present a brief summary of the dolomitic itabirite chemical data. For additional information, readers should refer to Spier et al. (2005a). The average major, trace and REE composition of the dolomitic itabirite is presented together with statistics of the iron ore. Dolomite within dolomitic bands has a very uniform composition, with $\mathrm{Ca}: \mathrm{Mg}$ ratio around $1: 1$ and average contents of $\mathrm{CaO}$ and $\mathrm{MgO}$ ranging from $29.6 \%$ to $30.5 \%$ and from $18.4 \%$ to $20.6 \%$, respectively. The average contents of $\mathrm{FeO}$ and $\mathrm{MnO}$ are low, ranging from $3.7 \%$ to $1.0 \%$ and from $0.5 \%$ to $0.9 \%$, respectively. Electron microprobe analyses (EMP) were also carried out on many grains of hematite and martite. The results, however, did not show any variation of the chemical composition, giving the $\mathrm{Fe}_{2} \mathrm{O}_{3}$ content always higher than $99 \%$.

XRD analyses of the two samples of the dolomite-rich bands (MAC-96 and MAC-100) showed only the presence of hematite and dolomite (Fig. 6a). MS identified hematite and siderite in the samples (Fig. 6b, Table 1), represented by a typical sextet and a less defined doublet, respectively. The values of the hyperfine field of hematite at $300 \mathrm{~K}(51.9 \mathrm{~T})$ and at $50 \mathrm{~K}(54.8 \mathrm{~T})$ are typical of well-crystallized pure hematite (Murad and Schwertmann 1986). The isomer shifts of the doublet at $300 \mathrm{~K}(1.2 \mathrm{~mm} / \mathrm{s})$ and at $50 \mathrm{~K}(1.4 \mathrm{~mm} / \mathrm{s})$ match well with those of siderite and represent the $\mathrm{FeCO}_{3}$ content of the dolomite. The low iron content of dolomite is responsible for the ill-defined doublet shown by the samples. As the iron content of the dolomite is relatively constant through the dolomitic itabirite sequence, the better defined doublet shown in sample MAC-100, as compared to the doublet in sample MAC-96, can be interpreted as a higher amount of dolomite in sample MAC-100. The relative abundance of these minerals is expressed by the subspectral areas of hematite and siderite in the MS of the samples MAC-100 and MAC-96 (Table 1). 

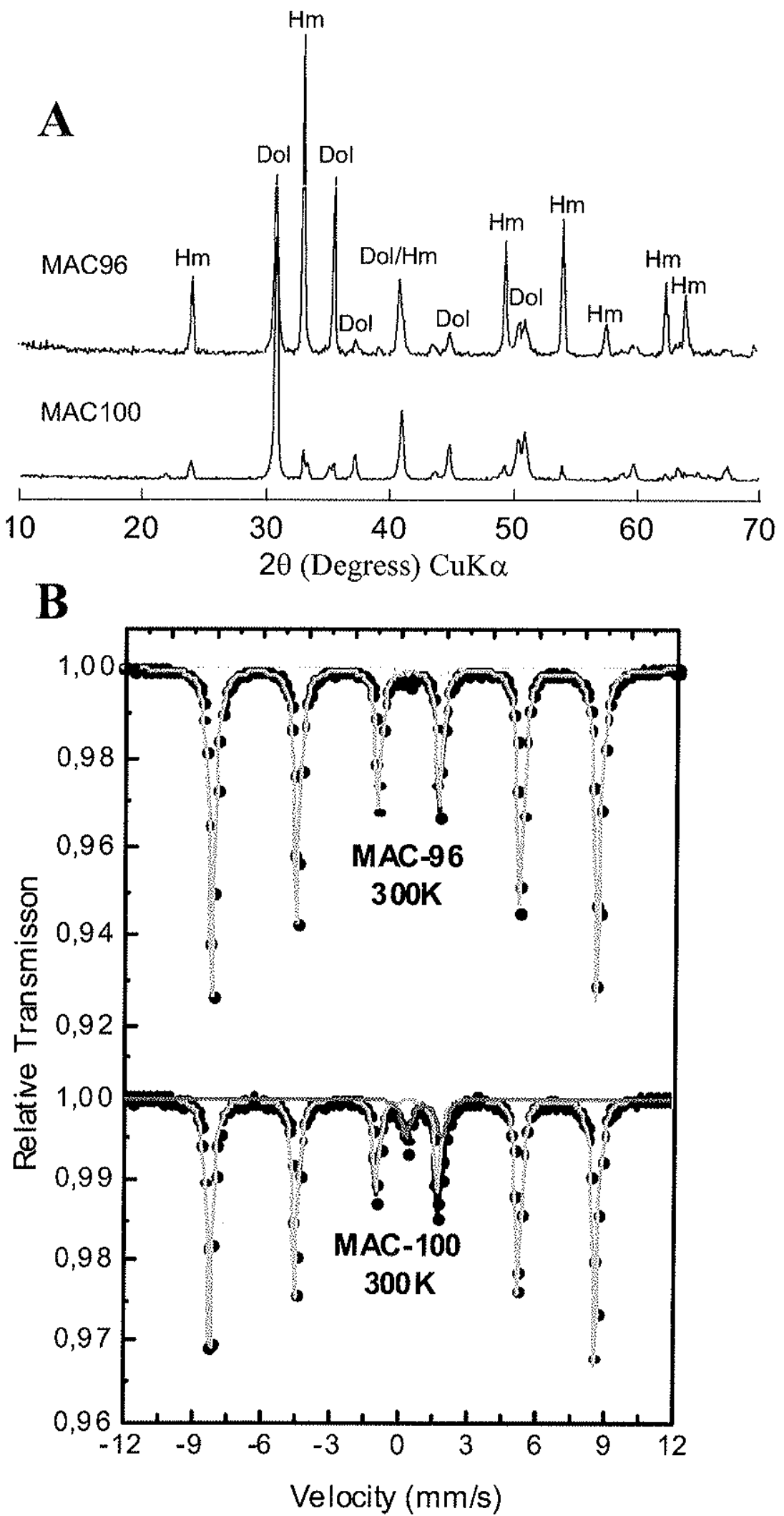

Figure 6 - A Powder XRD patterns of dolomite-rich bands of the dolomitic itabirite showing hematite (Hm) and dolomite (Dol). B Mössbauer spectra at $300 \mathrm{~K}$ of the same samples. 
Table 1 - Mössbauer hyperfine parameters of iron ore and dolomitic itabirite samples

\begin{tabular}{|c|c|c|c|c|c|c|c|c|}
\hline $\begin{array}{l}\text { Sample } \\
\text { Code }\end{array}$ & $\begin{array}{c}\text { Sample } \\
\text { Description }\end{array}$ & $\begin{array}{c}\text { Temperature } \\
\text { (K) }\end{array}$ & Subspectrum & $\begin{array}{l}\text { Isomer } \\
\text { shift } \\
( \pm 0.05) \\
\left(\mathrm{mm} \cdot \mathrm{s}^{-}\right. \\
1)\end{array}$ & $\begin{array}{l}\text { Quadrupole } \\
\text { Splitting } \\
( \pm 0.05) \\
\left(\mathrm{mm} \cdot \mathrm{s}^{-1}\right)\end{array}$ & $\begin{array}{l}\text { Hyperfine } \\
\text { Field } \\
( \pm 0.6) \\
(\mathrm{I})\end{array}$ & $\begin{array}{c}\text { Line } \\
\text { Width } \\
( \pm 0.5) \\
\left(\mathrm{mm} \cdot \mathrm{s}^{-1}\right)\end{array}$ & $\begin{array}{c}\text { Relative } \\
\text { Abundance } \\
(\%)\end{array}$ \\
\hline $\begin{array}{l}\text { Mac67 } \\
\text { Mac68 } \\
\text { Mac97 } \\
\text { Mac97 } \\
\text { Mac105 } \\
\text { Mac126A }\end{array}$ & $\begin{array}{c}\mathrm{HO} \\
\mathrm{HO} \\
\mathrm{HO} \\
\mathrm{HO} \\
\mathrm{HO} \\
\mathrm{SO}-\text { Massive }\end{array}$ & $\begin{array}{c}300 \\
300 \\
300 \\
50 \\
300 \\
300\end{array}$ & $\begin{array}{l}\text { Hematite } \\
\text { Hematite } \\
\text { Hematite } \\
\text { Hematite } \\
\text { Hematite } \\
\text { Hematite }\end{array}$ & $\begin{array}{l}0.37 \\
0.37 \\
0.37 \\
0.48 \\
0.37 \\
0.36\end{array}$ & $\begin{array}{l}-0.16 \\
-0.15 \\
-0.16 \\
0.38 \\
-0.15 \\
-0.16\end{array}$ & $\begin{array}{l}51.9 \\
51.9 \\
51.9 \\
55.8 \\
51.9 \\
51.9\end{array}$ & $\begin{array}{l}0.34 \\
0.34 \\
0.34 \\
0.37 \\
0.35 \\
0.34\end{array}$ & $\begin{array}{l}100 \\
100 \\
100 \\
100 \\
100 \\
100\end{array}$ \\
\hline $\mathrm{Mac} 127 \mathrm{~A}$ & SO - Massive & $\begin{array}{c}300 \\
50\end{array}$ & $\begin{array}{l}\text { Hematite } \\
\text { Hematite }\end{array}$ & $\begin{array}{l}0.37 \\
0.48\end{array}$ & $\begin{array}{l}-0.16 \\
0.37\end{array}$ & $\begin{array}{l}51.9 \\
54.9\end{array}$ & $\begin{array}{l}0.34 \\
0.37\end{array}$ & $\begin{array}{l}100 \\
100\end{array}$ \\
\hline $\begin{array}{l}\text { Mac128A } \\
\text { Mac129A }\end{array}$ & $\begin{array}{l}\text { SO - Massive } \\
\text { SO - Massive }\end{array}$ & $\begin{array}{l}300 \\
300\end{array}$ & $\begin{array}{l}\text { Hematite } \\
\text { Hematite }\end{array}$ & $\begin{array}{l}0.37 \\
0.37\end{array}$ & $\begin{array}{l}-0.17 \\
-0.15\end{array}$ & $\begin{array}{l}51.9 \\
51.9\end{array}$ & $\begin{array}{l}0.34 \\
0.35\end{array}$ & $\begin{array}{l}100 \\
100\end{array}$ \\
\hline $\operatorname{Mac} 126 \mathrm{~B}$ & SO-Porous & 300 & $\begin{array}{l}\text { Hematite } \\
\text { Ferrihydrite }\end{array}$ & $\begin{array}{l}0.37 \\
0.34\end{array}$ & $\begin{array}{c}-0.13 \\
0.68\end{array}$ & $\begin{array}{c}51.9 \\
-\end{array}$ & 0.34 & $\begin{array}{c}98 \\
2\end{array}$ \\
\hline Mac127B & SO-Porous & 300 & $\begin{array}{c}\text { Hematite } \\
\text { Ferrihydrite } \\
\text { Hematite } \\
\text { Ferrihydrite }\end{array}$ & $\begin{array}{l}0.37 \\
0.34 \\
0.48 \\
0.42\end{array}$ & $\begin{array}{l}-0.13 \\
0.68 \\
0.32 \\
0.76\end{array}$ & $\begin{array}{c}51.9 \\
- \\
54.9 \\
-\end{array}$ & $\begin{array}{l}0.39 \\
0.48\end{array}$ & $\begin{array}{c}98 \\
2 \\
97 \\
3\end{array}$ \\
\hline Mac128B & SO-Porous & 300 & $\begin{array}{l}\text { Hematite } \\
\text { Ferrihydrite }\end{array}$ & $\begin{array}{l}0.37 \\
0.34\end{array}$ & $\begin{array}{c}-0.13 \\
0.68\end{array}$ & $\begin{array}{c}51.9 \\
-\end{array}$ & 0.34 & $\begin{array}{c}98 \\
2\end{array}$ \\
\hline $\mathrm{Mac} 129 \mathrm{~B}$ & SO-Porous & 300 & $\begin{array}{l}\text { Hematite } \\
\text { Ferrihydrite }\end{array}$ & $\begin{array}{l}0.36 \\
0.35\end{array}$ & $\begin{array}{c}-0.13 \\
0.68\end{array}$ & $\begin{array}{c}51.9 \\
-\end{array}$ & 0.34 & $\begin{array}{c}98 \\
2\end{array}$ \\
\hline Mac96 & Dol. Itabirite & 300 & $\begin{array}{l}\text { Hematite } \\
\text { Siderite }\end{array}$ & $\begin{array}{l}0.37 \\
1.20\end{array}$ & $\begin{array}{r}-0.14 \\
1.60\end{array}$ & $\begin{array}{c}51.9 \\
-\end{array}$ & 0.34 & $\begin{array}{c}98 \\
2\end{array}$ \\
\hline Mac 100 & Dol. Itabirite & 300 & $\begin{array}{l}\text { Hematite } \\
\text { Siderite } \\
\text { Hematite } \\
\text { Siderite }\end{array}$ & $\begin{array}{l}0.37 \\
1.20 \\
0.48 \\
1.37 \\
\end{array}$ & $\begin{array}{l}-0.13 \\
1.55 \\
0.39 \\
2.03 \\
\end{array}$ & $\begin{array}{c}51.9 \\
- \\
54.8 \\
- \\
\end{array}$ & $\begin{array}{l}0.34 \\
0.51\end{array}$ & $\begin{array}{l}90 \\
10 \\
90 \\
10\end{array}$ \\
\hline
\end{tabular}

HO means hard ore; SO-Massive means massive band of soft ore; SO-Porous means porous band of the soft ore; Dol. Itabirite means dolomitic itabirite

\section{Soft Iron Ores}

\section{Mineralogy and Petrology}

The soft ore consists of alternated $\mathrm{mm}$ - to cm-sized massive and highly porous bands, both rich in iron oxides (Figs. 5 and 7). The former corresponds to the iron-rich bands of the dolomitic itabirite while the latter corresponds to the dolomite-rich bands. The soft ore as a whole is highly porous, with intergranular porosity visually estimated in thin sections at $35-45 \%$ (Fig. 5 b). Hematite is the major iron oxide in both bands, occurring as martite, anhedral to granular/tabular hematite and, locally, specularite. Magnetite is locally observed as remnants within martite and granular hematite crystals, especially within thicker massive bands. Ferrihydrite (identified by Mössbauer analyses; see text below) is more frequent within the porous bands, where it occurs as an accessory mineral (Figs. 7a-d). Gangue minerals are rare, increasing in amount in samples 

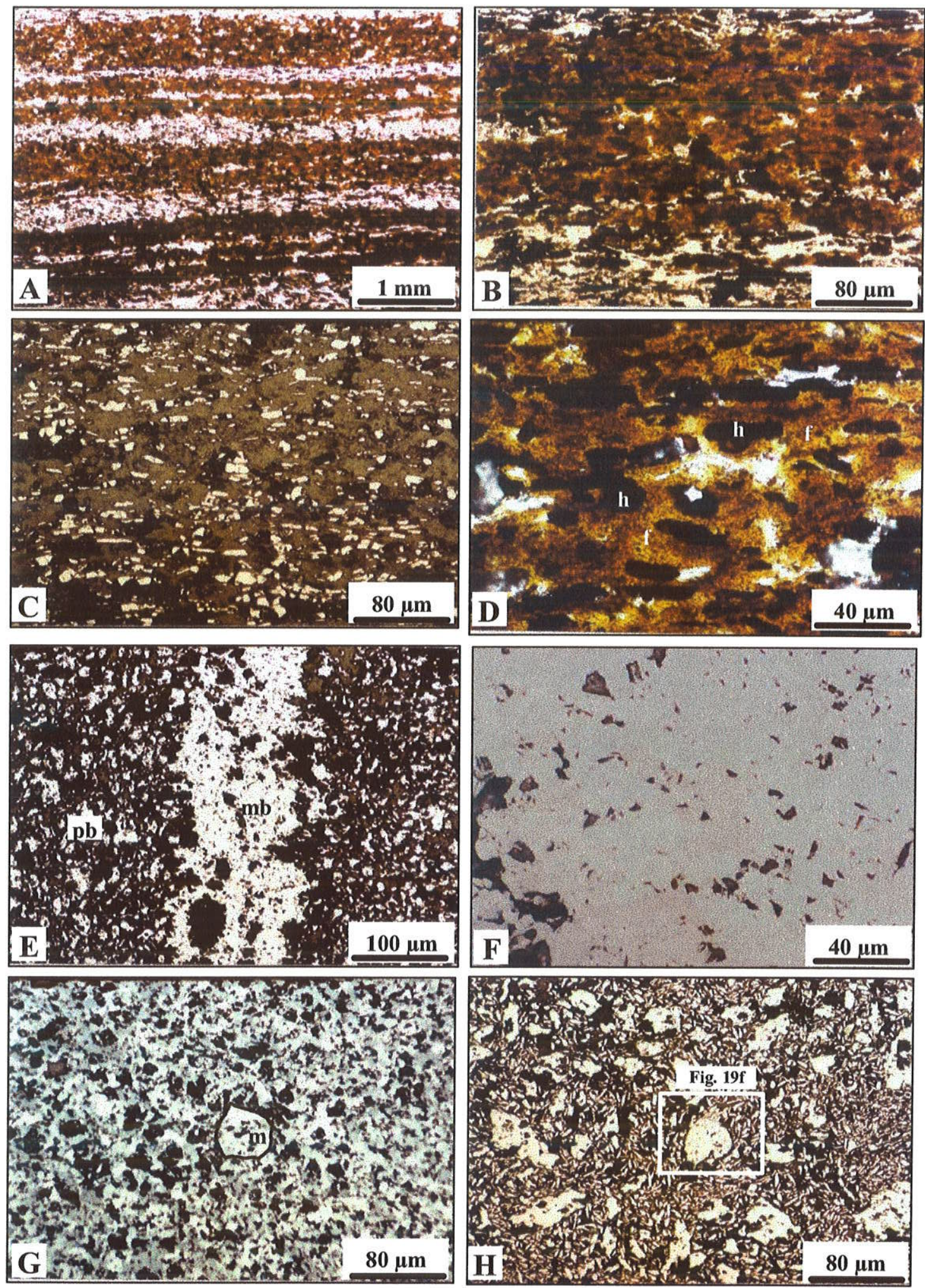

Figure 7 - Photomicrographs of the soft ore. A Microbanding of massive and porous bands, transmitted light. B-C Detail of a porous band, transmitted light (B), reflected light, PPL (C). D Detail of the previous picture showing ferrihydrite (f) surrounding aggregates and individual crystals of hematite $\mathbf{E}$ Massive band $(\mathrm{mb})$ between porous bands (pb), reflected light, PPL. F Detail of the massive band showing granoblastic fabric of granular/tabular hematite, reflected light, partially XPL. G Massive band showing granoblastic fabric of granular/tabular hematite growing over martite $(\mathrm{m})$, reflected ligth, PPL. H Detail of a porous band showing aggregates and individual crystals of tabular hematite. 
obtained close to contacts with both the protore and the phyllite. They are also more frequent within the porous bands and consist of apatite, talc, chlorite and Mn-oxides (Figs. 8a-f). Apatite is more frequent in samples from the lower levels of the mine, especially from the bottom pit, where the pinnacles occur.

The massive bands of the soft ore generally show a granoblastic fabric and consist of fine granular and tabular hematite $(5-20 \mu \mathrm{m})$, forming a dense package (Figs. 7e-g). The porous bands have variable porosity, visually estimated at $30-60 \%$. They consist of aggregates ranging from $50 \mu \mathrm{m}$ to $10 \mathrm{~mm}$ of granular and tabular hematite crystals (up to $60 \%$ ) and/or of individual crystals of tabular hematite ranging from 10 to $30 \mu \mathrm{m}$ (Figs. 7e and h). Locally, it is possible to observe the development of tabular and granular hematite growing over coarser martite crystals $(\sim 50 \mu \mathrm{m})$ and the desaggregation of these crystals, causing the release of the finer tabular hematite (Fig. $7 \mathrm{~g}$-h). Hematite crystals are surrounded by a brownish residue of poorly crystalline ferrihydrite (Figs. 7 a-d). Ferrihydrite is produced during the dissolution of dolomite, a process which is clearly represented in thin sections of partially weathered dolomitic itabirite, where it forms a brownish residue.

SEM observations of the $<0.15 \mathrm{~mm}$ size fraction of some samples of the soft ore have also shown a few small particles of Mn oxides besides hematite (Fig. 8d). TEM analyses confirm the presence of these $\mathrm{Mn}$ oxides within the porous bands (Figs. 9a-c). They occur as very small particles $(\sim 100 \eta \mathrm{m})$ mixed with the iron oxides.

In samples collected from the zone of contact with the protore, it is possible to observe remnants of dolomite intergrown with hematite and gangue minerals. Apatite is very well preserved in this zone, forming thin laminae parallel to the banding or occurring as isolated euhedral crystals (Figs. 8a-c). Talc and chlorite are also observed as isolated crystals or forming mm-sized aggregates (Figs. $8 \mathrm{e}-\mathrm{f}$ ). 

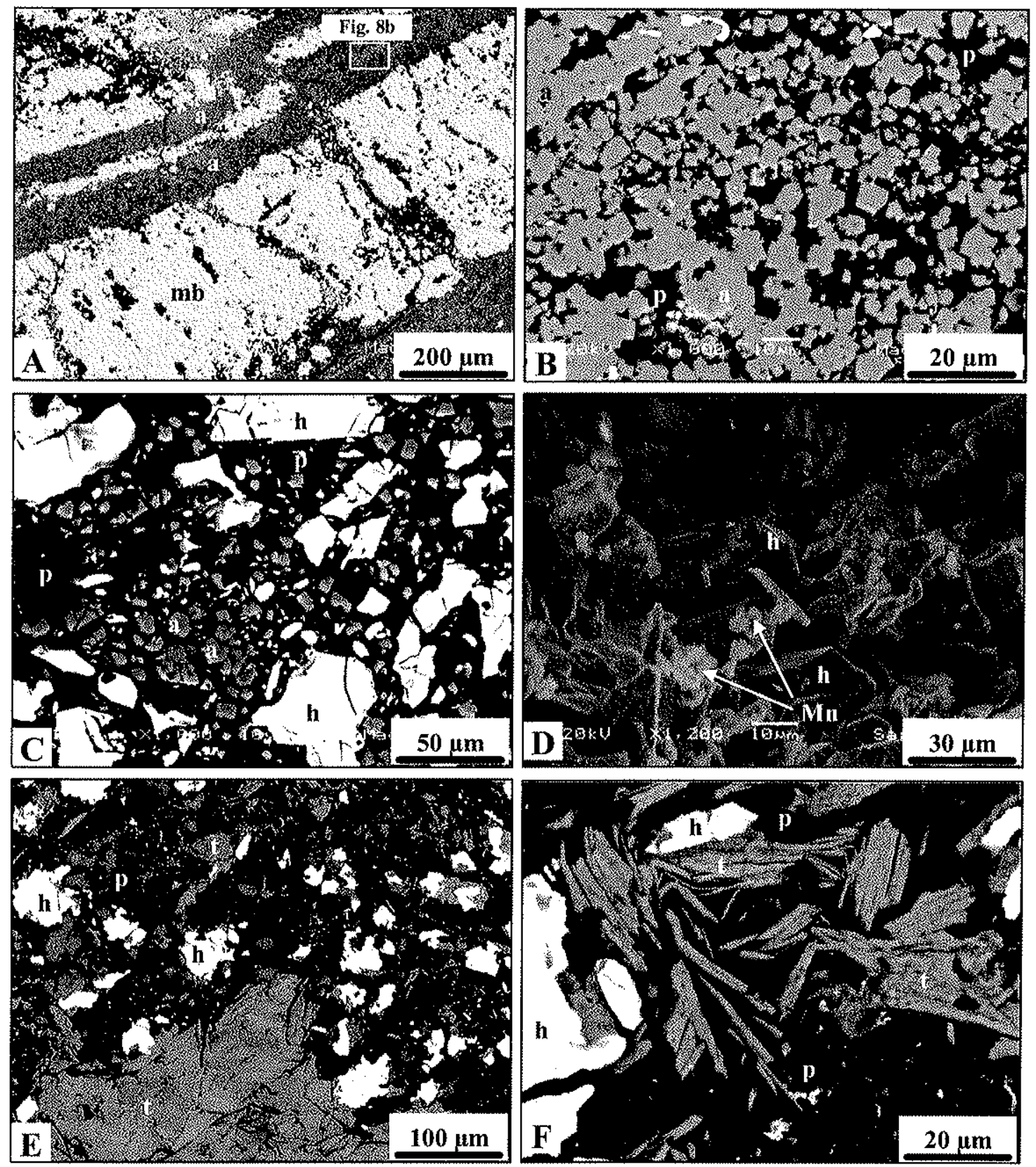

Figure 8 - SEM backscattered images of gangue minerals in the iron ore. A Microbanding of apatite-rich laminae (a) between massive bands $(\mathrm{mb})$ of hematite. B Detail of the apatite-rich laminae. C Porous band of the soft ore showing apatite (a) and aggregates of hematite (h) between pores (p). D Detail of the size fraction $<0.15 \mathrm{~mm}$ of the soft ore showing small crystals of Mn-oxides on the surface of hematite aggregates, SEM image, secondary electrons. E Porous band of the soft ore showing aggregates of talc (t) and hematite (h) between pores. F Detail of the previous picture. 

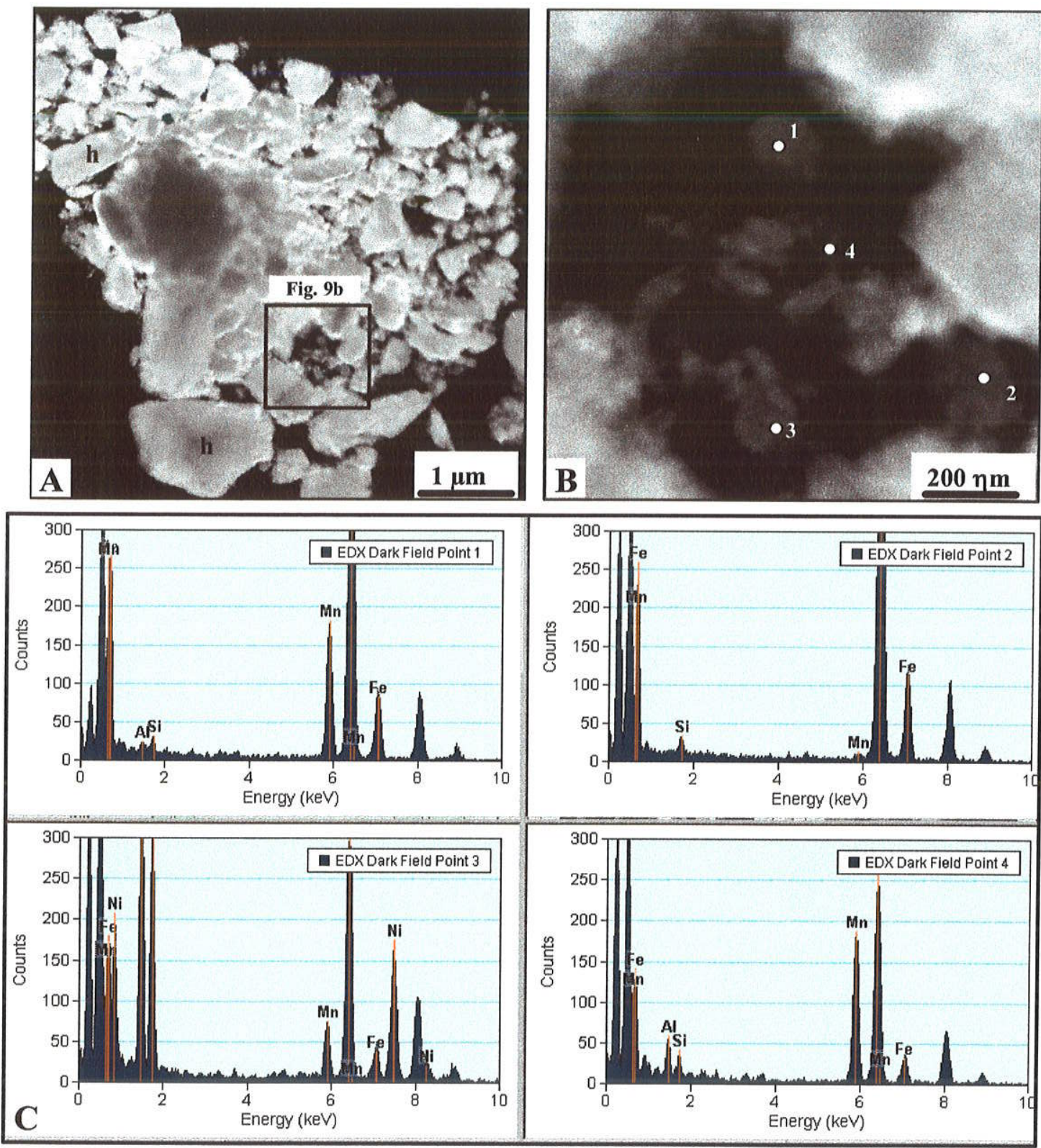

Figure 9-A TEM image of the porous band of the soft ore. Large white particles are hematite (h). B Detail of the small particles between hematite. EDS spectra (C) indicate that some of them have high contents of Mn and Ni.

\section{XRD and Mössbauer Analyses}

XRD analyses of the massive bands of the soft ore (Samples MAC-126A to MAC-129A) revealed only the presence of hematite (Fig.10). The sharp XRD peaks suggest high crystallinity. The $300 \mathrm{~K}$ Mössbauer spectra fitted perfectly with hematite, with a hyperfine field of about $52 \mathrm{~T}$, isomer shift of about $0.37 \mathrm{~mm} / \mathrm{s}$, and a quadrupole shift of about $-0.15 \mathrm{~mm} / \mathrm{s}$ (Table 1). All the spectra are very similar, consisting of $100 \%$ of hematite and are represented by the spectrum recorded at 300 and $50 \mathrm{~K}$ of sample MAC127A in Fig. 11a and b. The MS of the massive bands 


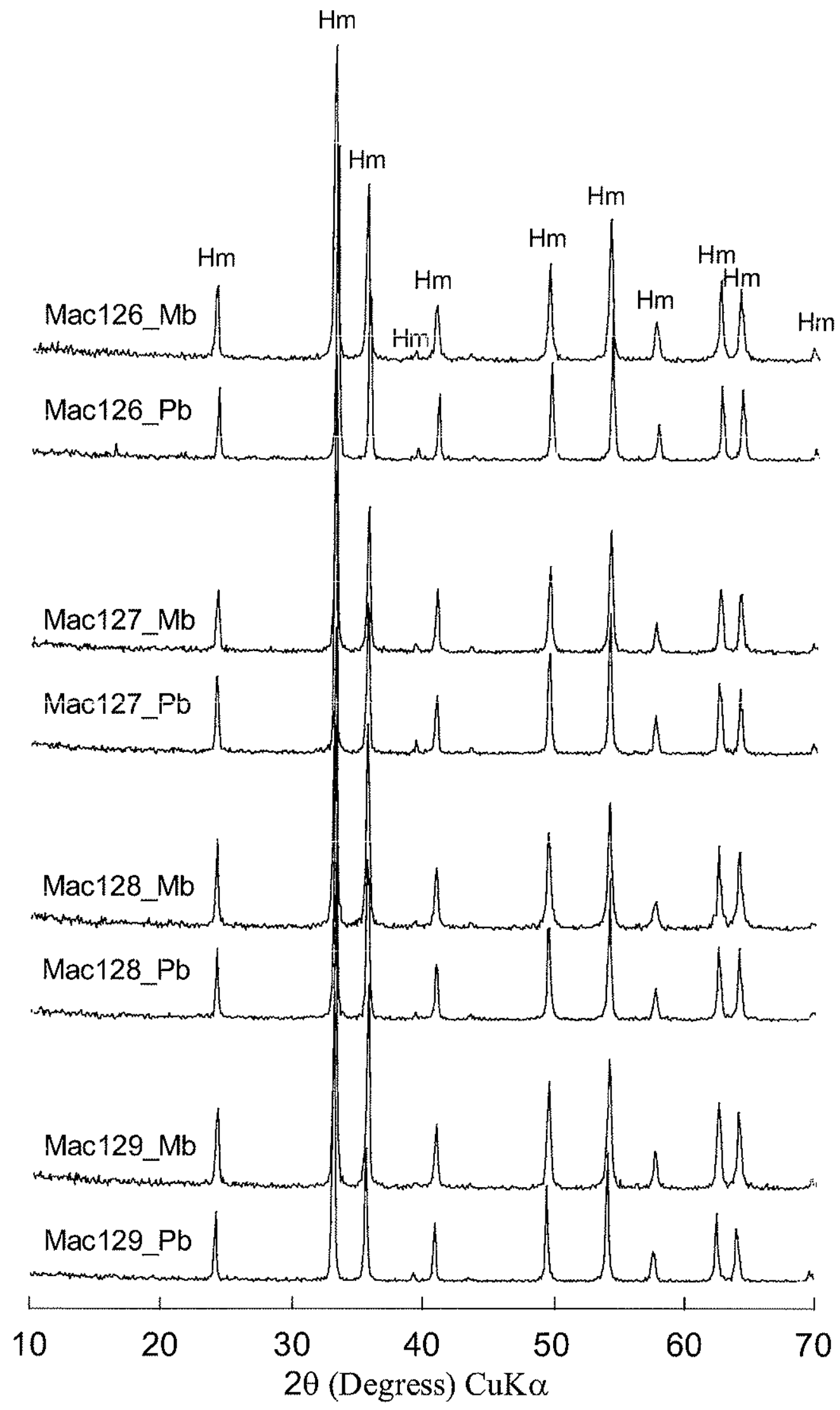

Figure $10 \cdots$ Powder XRD patterns of the massive bands $(\mathrm{mb})$ and porous bands $(\mathrm{pb})$ of the soft ore samples showing hematite $(\mathrm{Hm})$. 

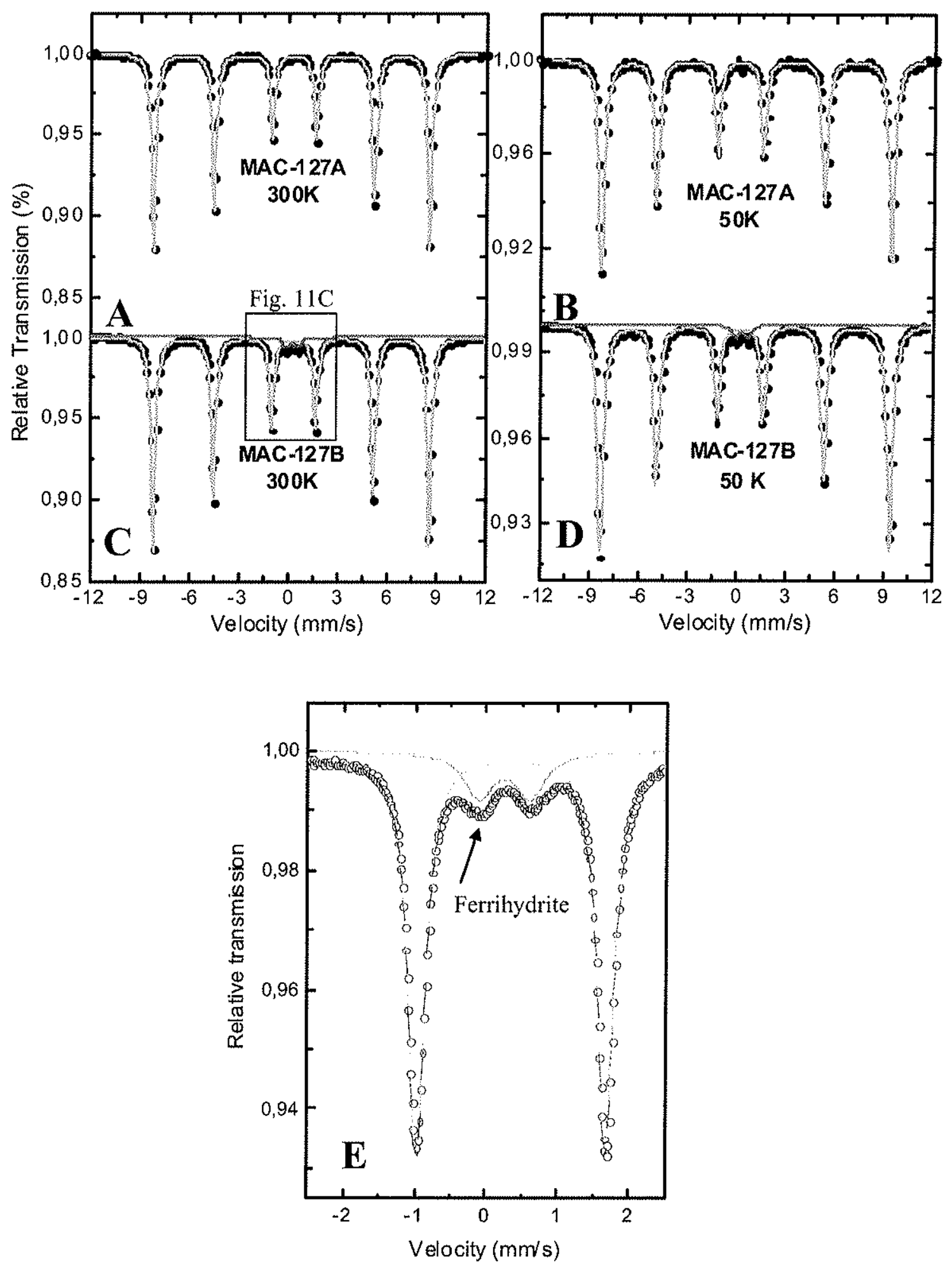

Figure 11 - Mössbauer spectra at $300 \mathrm{~K}$ and at $50 \mathrm{~K}$ of the massive (A-B) and porous bands (C-D) of the sample $\mathrm{MACl} 27$ (Soft ore). E Detail of the central part of the spectra of the porous band at $300 \mathrm{~K}$ showing the doublet of ferrihydrite. 
have also revealed the presence of the Morin transition (a transition from an antiferromagnetic to a weakly ferromagnetic state, at about $265 \mathrm{~K}$ ). This transition is very sensitive to microcrystalline effects, lattice imperfections and impurities. Its observation in the studied samples indicates a very pure composition of hematite and crystallites larger than $20 \eta \mathrm{m}$. The nearly absent variation of the Mössbauer parameters (Table 1) shows that the ore is made up of pure hematite, with a rather uniform composition, which was also indicated by XRD and by the unit cell parameters obtained for the hematite in the sample MAC127A (Table 2), which are very similar to those of the reference cell of hematite.

Table 2 - Unit cell parameters of hematite in the iron ores of the Águas Claras mine

\begin{tabular}{|c|c|c|c|}
\hline Sample & Ore Type & $\mathrm{a} \AA$ & $c \AA \AA$ \\
\hline MAC67 & Hard Ore & $5.0347(1)$ & $13.7474(2)$ \\
\hline MAC97 & Hard Ore & $5.0355(1)$ & $13.7485(2)$ \\
\hline MAC127A & $\begin{array}{c}\text { Massive band of the } \\
\text { soft ore }\end{array}$ & $5.0338(1)$ & $13.7470(2)$ \\
\hline $\mathrm{MAC127B}$ & $\begin{array}{l}\text { Porous band of the } \\
\text { soft ore }\end{array}$ & $5.0339(1)$ & $13.7468(2)$ \\
\hline $\begin{array}{c}\text { Reference cell of } \\
\text { hematite }\end{array}$ & & 5.0340 & 13.7520 \\
\hline
\end{tabular}

XRD analyses of the porous bands of the soft ore (Samples MAC-126B to MAC-129B) showed the presence of only hematite (Fig. 10). Thus, the observed diffused, limonitic, brownish material in the porous bands must be amorphous.

The Mössbauer spectra at $300 \mathrm{~K}$ of the porous bands are represented by sample MAC127B in Fig. 11c. There is a major sextet corresponding to a hyperfine field of about $52 \mathrm{~T}$ and a quadrupole shift of about $-0.13 \mathrm{~mm} / \mathrm{s}$, parameters that fit perfectly with those of hematite. MS at $50 \mathrm{~K}$ of this sample confirms the presence of hematite, characterized by an isomer shift of $0.48 \mathrm{~mm} / \mathrm{s}$ and a hyperfine field of $54.9 \mathrm{~T}$ (Table 1, Fig. 11d). The hyperfine parameters of hematite in the porous bands are quite similar to those observed for this mineral in the dolomitic itabirite and massive bands of the soft ore (Table 1). The unit cell parameters of hematite in sample MAC127B are also very similar not only to those of hematite in the massive bands of the soft and hard ores but also to the reference cell parameters of hematite (Table 2).

An ill defined doublet superimposed to the hematite sextet is present in all spectra of the porous band (Fig. 11e). This doublet can be ascribed to the limonitic, brownish material which is the residue of the dissolution of dolomite. The isomer shift $(0.34-0.35 \mathrm{~mm} / \mathrm{s})$ and the quadrupole splitting $(0.68 \mathrm{~mm} / \mathrm{s})$ at $300 \mathrm{~K}$ of these samples match well with those of ferrihydrite 
(Cornell and Schwertmann 1996, p. 149). In the MS at $50 \mathrm{~K}$ of sample MAC127B (which presents the best defined doublet at $300 \mathrm{~K}$ ), the doublet is still present, with an isomer shift of $0.42 \mathrm{~mm} / \mathrm{s}$ and a quadrupole splitting of $0.76 \mathrm{~mm} / \mathrm{s}$. These values are compatible with those found by Childs and Baker-Sherman (1984) for synthetic ferrihydrite at $77 \mathrm{~K}$. The absence of a sextet at $50 \mathrm{~K}$ indicates the poor crystallinity of this mineral, given that magnetic ordering is strongly dependent on crystallinity (Cornell and Schwertmann 1996). The low crystallinity of ferrihydrite, on the other hand, explains its absence from the XRD patterns. Mössbauer spectroscopy confirms, therefore, that the brownish material observed by optical petrography in the residue of the dolomite dissolution is ferrihydrite. Based on the values of the relative subspectral areas, the abundances of hematite and ferrihydrite were estimated. It is seen from Table 1 that ferrihydrite is a subordinate component in the soft ore.

Although remnants of magnetite were locally recognized within hematite crystals by petrographic observation, this mineral was not detected in the MS. The same occurred with siderite (present in dolomite) in sample MAC-67. The appearance of six lines in the MS and the hyperfine parameters of the hard ore samples are due to the presence of the single iron-bearing phase, i.e., hematite. The absence of magnetite lines is related to the very high degree of martitization (oxidation).

\section{Geochemistry}

Analytical results for the 48 samples analyzed for major, trace and rare earth elements (REE) of the soft and hard ores are presented in Appendixes 2 and 3. The results of the remaining 38 samples analyzed for major and some trace elements can be obtained from the authors. Average compositions and standard deviations of populations for the soft and hard iron ores are given in Tables 3 and 4. Statistics for variables below or very close to the detection limit were not calculated. When the results of just a few samples were below this limit, statistics were calculated using half the detection limit. This procedure was chosen in order to establish a distinction for those values which stood slightly above the detection limit. The following variables (with their respective detection limit) presented analytical results below or very close to the detection limit: $\mathrm{Na}_{2} \mathrm{O}(0.01 \%), \mathrm{K}_{2} \mathrm{O}(0.01 \%), \mathrm{Sc}(3 \mathrm{ppm}), \mathrm{Be}(3 \mathrm{ppm}), \mathrm{Zn}(30 \mathrm{ppm})$, Ga (1 ppm), Rb (1 ppm), Nb (0.2 ppm), Mo (2 ppm), In (0.1 ppm), Sn (1 ppm), Cs (0.1 ppm), Hf (0.1 ppm), Tl (0.1 ppm), Pb (5 ppm), Bi (0.1 ppm), Au (2 ppb), Br (0.5 ppm), Ir (5 ppm) and Se (3 ppm). 
Table 3 Average major and trace element composition

\begin{tabular}{|c|c|c|c|c|c|c|c|c|c|c|c|}
\hline \multirow{2}{*}{$\mathrm{Wt} \%$} & \multicolumn{5}{|c|}{ Hard Ore } & \multicolumn{5}{|c|}{ Soft Ore } & \multirow{2}{*}{$\begin{array}{c}\text { Dolomitic } \\
\text { Itabirite } \\
(\mathrm{n}=11)\end{array}$} \\
\hline & Avg & Std & Min & Max & $\mathrm{n}$ & Avg & $\mathrm{Std}$ & Min & $\operatorname{Max}$ & $\mathrm{n}$ & \\
\hline $\mathrm{SiO}_{2}$ & 0.66 & 0.33 & 0.24 & 1.32 & 12 & 1.06 & 0.63 & 0.18 & 3.57 & 62 & 1.01 \\
\hline $\mathrm{Al}_{2} \mathrm{O}_{3}$ & 0.24 & 0.23 & 0.02 & 0.91 & 12 & 0.46 & 0.44 & 0.08 & 2.10 & 62 & 0.32 \\
\hline $\mathrm{Fe}_{2} \mathrm{O}_{3}$ & 97.66 & 1.16 & 95.11 & 99.13 & 10 & 95.65 & 2.29 & 87.66 & 98.79 & 62 & 48.90 \\
\hline Fetot & 97.93 & 1.77 & 94.44 & 99.54 & 12 & 95.74 & 2.31 & 87.72 & 98.90 & 62 & 49.64 \\
\hline $\mathrm{FeO}$ & 0.82 & 0.80 & 0.22 & 2.70 & 10 & 0.08 & 0.07 & 0.05 & 0.50 & 62 & 0.66 \\
\hline $\mathrm{MnO}$ & 0.025 & 0.025 & 0.005 & 0.093 & 12 & 0.818 & 0.379 & 0.221 & 2.139 & 62 & 0.28 \\
\hline $\mathrm{MgO}$ & 0.22 & 0.35 & $<0.03$ & 1.20 & 12 & 0.36 & 0.32 & 0.03 & 2.04 & 62 & 10.33 \\
\hline $\mathrm{CaO}$ & 0.33 & 0.42 & 0.02 & 1.41 & 12 & 0.19 & 0.22 & $<0,03$ & 1.13 & 62 & 14.36 \\
\hline $\mathrm{Na}_{2} \mathrm{O}$ & $<0.01$ & & & & 12 & $<0.01$ & & & & 36 & $<0,01$ \\
\hline $\mathrm{K}_{2} \mathrm{O}$ & 0.044 & 0.041 & $<0.0 \mathrm{t}$ & 0.140 & 12 & $<0.01$ & & & & 36 & 0.03 \\
\hline $\mathrm{TiO}_{2}$ & 0.018 & 0.009 & 0.006 & 0.033 & 12 & 0.031 & 0.035 & 0.005 & 0.156 & 62 & 0.021 \\
\hline $\mathrm{P}_{2} \mathrm{O}_{5}$ & 0.13 & 0.07 & 0,03 & 0.22 & 12 & 0.18 & 0.27 & $<0.03$ & 1.58 & 62 & 0.12 \\
\hline $\begin{array}{l}\text { LOI } \\
\operatorname{ppm}^{(*)}\end{array}$ & 0.52 & 0.41 & 0.13 & 1.39 & 12 & 0.85 & 0.44 & 0.29 & 2.31 & 62 & 23,60 \\
\hline $\mathrm{Ba}$ & 13.1 & 10.6 & $<3.0$ & 37.2 & 12 & 32.7 & 35.1 & 6.7 & 211.0 & 62 & 12.9 \\
\hline $\mathrm{Sr}$ & 6.2 & 3.2 & $<2.0$ & 9.3 & 10 & 18.2 & 10.9 & 4.0 & 35.5 & 24 & 29.8 \\
\hline$Y$ & 5.0 & 1.5 & 2.2 & 7.6 & 10 & 18.8 & 9.5 & 5.5 & 33.7 & 24 & 7.7 \\
\hline $\mathrm{Sc}$ & $<3.0$ & & & & 10 & $<3.0$ & & & & 24 & $<3.0$ \\
\hline $\mathrm{Zr}$ & 5.8 & 3.8 & 2.4 & 15.1 & 10 & 13.6 & 9.9 & 3.5 & 40.1 & 24 & 14.0 \\
\hline $\mathrm{Be}$ & $<3.0$ & & & & 10 & $<3.0$ & & & & 24 & $<3.0$ \\
\hline V & 35.6 & 35.6 & 10.0 & 132.0 & 10 & 59.9 & 36.0 & 9.1 & 138.4 & 62 & 25.6 \\
\hline $\mathrm{Ni}$ & $<20.0$ & & & & 10 & 23.9 & 21.1 & $<20.0$ & 96.0 & 62 & 10.0 \\
\hline $\mathrm{Cu}$ & 10.0 & 6.0 & $<5.0$ & 22.0 & 10 & 10.2 & 7.3 & $<5.0$ & 45.3 & 62 & 7.0 \\
\hline $\mathrm{Zn}$ & $<30.0$ & & & & 10 & $<30.0$ & & & & 62 & 13.5 \\
\hline $\mathrm{Ga}$ & $<1.0$ & & & & 10 & $<1.0$ & & & & 24 & $<1.0$ \\
\hline $\mathrm{Ge}$ & 4.3 & 1.1 & 2.8 & 6.0 & 10 & 3.0 & 1.1 & 0.7 & 5.0 & 24 & 1.8 \\
\hline $\mathrm{Rb}$ & $<1.0$ & & & & 10 & $<1.0$ & & & & 24 & $<1.0$ \\
\hline $\mathrm{Nb}$ & 0.4 & 0.4 & $<0.2$ & 1.0 & 10 & $<0.2$ & & & & 24 & 0.9 \\
\hline Mo & $<2.0$ & & & & 10 & $<2.0$ & & & & 24 & $<2.0$ \\
\hline $\mathrm{Ag}$ & $<0.5$ & & & & 10 & 0.3 & 0.4 & $<0.5$ & 1.3 & 24 & $<0.5$ \\
\hline In & $<0.1$ & & & & 10 & $<0.1$ & & & & 24 & $<0.1$ \\
\hline $\mathrm{Sn}$ & $<1.0$ & & & & 10 & $<1.0$ & & & & 24 & $<1.0$ \\
\hline $\mathrm{Cs}$ & $<0.1$ & & & & 10 & $<0.1$ & & & & 24 & $<0.1$ \\
\hline ¿REE & 7.0 & 1.9 & 3.2 & 10.0 & 10 & 22.7 & 10.1 & 9.3 & 46.0 & 24 & 14.5 \\
\hline $\mathrm{Hf}$ & $<0.1$ & & & & 10 & $<0.1$ & & & & 24 & 0.1 \\
\hline$T !$ & $<0.1$ & & & & 10 & $<0.1$ & & & & 24 & $<0.1$ \\
\hline $\mathrm{Pb}$ & $<5.0$ & & & & 10 & $<5.0$ & & & & 24 & 5.1 \\
\hline $\mathrm{Bi}$ & $<0.1$ & & & & 10 & $<0.1$ & & & & 24 & 1.2 \\
\hline Th & 0.2 & 0.1 & 0.1 & 0.5 & 10 & 0,4 & 0.4 & 0.1 & 1.5 & 24 & 0.5 \\
\hline $\mathrm{U}$ & 4.5 & 3.4 & 0.6 & 12.3 & 10 & 3.9 & 1.8 & 1.0 & 7.2 & 24 & 2.9 \\
\hline $\mathrm{Alu}$ & $<2.0$ & & & & 8 & $<2.0$ & & & & 24 & $\mathrm{na}$ \\
\hline As & 12.4 & 6.7 & $<5.0$ & 23.1 & 10 & 13.6 & 6.6 & 3.9 & 28.4 & 24 & 9.3 \\
\hline $\mathrm{Br}$ & $<0.5$ & & & & 8 & $<0.5$ & & & & 24 & na \\
\hline $\mathrm{Cr}$ & 65.3 & 59.5 & $<20.0$ & 202.0 & 12 & 78.8 & 73.0 & 16.0 & 429,0 & 62 & 52.9 \\
\hline Ir & $<5.0$ & & & & 8 & $<5.0$ & & & & 24 & na \\
\hline $\mathrm{Sb}$ & 4.0 & 1.7 & 2,0 & 6.9 & 10 & 3.2 & 1.3 & 1.4 & 6.1 & 24 & 1.6 \\
\hline $\mathrm{Sc}$ & 0.5 & 0.3 & 0.1 & 1.0 & 8 & 1.1 & 0.9 & 0.4 & 3.5 & 24 & na \\
\hline $\mathrm{Se}$ & $<3.0$ & & & & 8 & $<3,0$ & & & & 24 & na \\
\hline Fe\# & 0.988 & 0.009 & 0,970 & 0.997 & 9 & 0.999 & 0.001 & 0.994 & 0.999 & 61 & 0.980 \\
\hline
\end{tabular}


Table 3 Average major and trace element composition (Continued)

\begin{tabular}{|c|c|c|c|c|c|c|c|c|c|c|}
\hline & \multicolumn{8}{|c|}{ Soft ore } & \multicolumn{2}{|c|}{ Dolomitic itabirite } \\
\hline & & Mas & $\begin{array}{l}\text { ve band } \\
=6 \text { ) }\end{array}$ & & & $\begin{array}{l}\text { Porot } \\
\qquad(\mathrm{n}\end{array}$ & $\begin{array}{l}\text { band } \\
\text { 8) }\end{array}$ & & $\begin{array}{l}\text { Iron-rich } \\
\text { band }\end{array}$ & $\begin{array}{c}\text { Dolomite-rich } \\
\text { band }\end{array}$ \\
\hline $\mathrm{Wt} \%$ & Avg & $\mathrm{Std}$ & Min & Max & Avg & Std & Min & Max & Avg & Avg \\
\hline $\mathrm{SiO}_{2}$ & 0.35 & 0.13 & 0.15 & 0.51 & 1.69 & 1.48 & 0.38 & 4.74 & 0.91 & 0.73 \\
\hline $\mathrm{Al}_{2} \mathrm{O}_{3}$ & 0.08 & 0.05 & 0.03 & 0.16 & 0.84 & 1.13 & 0.14 & 3.25 & 0.28 & 0.33 \\
\hline $\mathrm{Fe}_{2} \mathrm{O}_{3}$ & 98.24 & 0.85 & 96.84 & 99.15 & 92,80 & 3.84 & 86.96 & 97.07 & 77.88 & 10.93 \\
\hline Fetot & 98.58 & 0.53 & 97.90 & 99.27 & 92.98 & 3.76 & 87.22 & 97.07 & 78.23 & 11.74 \\
\hline FeO & 0.36 & 0.55 & 0.11 & 1.35 & 0.19 & 0.10 & 0.10 & 0.37 & 0.32 & 0.73 \\
\hline $\mathrm{MnO}$ & 0.10 & 0.10 & 0.02 & 0.29 & 1.69 & 0.63 & 0.77 & 2.55 & 0.12 & 0.50 \\
\hline $\mathrm{MgO}$ & 0.08 & 0.03 & 0.02 & 0.11 & 0.54 & 0.73 & 0.07 & 2.29 & 4.11 & 18.50 \\
\hline $\mathrm{CaO}$ & 0.10 & 0.14 & 0.03 & 0.38 & 0.12 & 0.11 & $<0.03$ & 0.31 & 5.45 & 26.19 \\
\hline $\mathrm{Na}_{2} \mathrm{O}$ & $<0.01$ & & & & $<0.01$ & & & & $<0.01$ & 0.05 \\
\hline $\mathrm{K}_{2} \mathrm{O}$ & $<0,01$ & & & & $<0.01$ & & & & 0.02 & 0.06 \\
\hline $\mathrm{TiO}_{2}$ & 0.006 & 0.003 & $<0.001$ & 0,010 & 0.054 & 0.076 & 0.011 & 0.223 & $<0.001$ & $<0.001$ \\
\hline $\mathrm{P}_{2} \mathrm{O}_{5}$ & 0.06 & 0.10 & $<0.03$ & 0.27 & 0.10 & 0.07 & 0.03 & 0.25 & 0.12 & 0.06 \\
\hline $\begin{array}{l}\text { LOI } \\
\text { ppm }^{\left({ }^{\circ}\right)}\end{array}$ & 0.32 & 0.10 & 0.19 & 0.45 & 1.86 & 0.81 & 0.78 & 2.97 & 9.91 & 40.98 \\
\hline $\mathrm{Ba}$ & 11.5 & 9.8 & $<3.0$ & 29.4 & 116.2 & 127.2 & 20.7 & 405.2 & 11.17 & 20.67 \\
\hline $\mathrm{Sr}$ & 3.8 & 4.5 & $<2.0$ & 12.4 & 17.4 & 12.9 & 2.3 & 42.8 & 12.83 & 46.17 \\
\hline $\mathrm{Y}$ & 3.1 & 1.6 & 2.0 & 6.1 & 32.6 & 13.6 & 13.9 & 56.0 & 4.67 & 9.50 \\
\hline $\mathrm{Sc}$ & $<3.0$ & & & & $<3.0$ & & & & $<3.0$ & $<3.0$ \\
\hline $\mathrm{Zr}$ & 3.2 & 1.1 & 2.2 & 4.8 & 9.4 & 11.9 & 2.3 & 38.6 & 14.67 & 8.00 \\
\hline $\mathrm{Be}$ & $<3.0$ & & & & $<3.0$ & & & & $<3.0$ & $<3.0$ \\
\hline V & 27.2 & 25.1 & 9.2 & 77.0 & 44.5 & 21.0 & 23.0 & 75.0 & 36.33 & 10.25 \\
\hline $\mathrm{Ni}$ & $<20.0$ & & & & 30.5 & 18.6 & $<20.0$ & 63.6 & 15.13 & 7.31 \\
\hline $\mathrm{Cu}$ & $<5.0$ & & & & 31.9 & 42.0 & $<5.0$ & 115.3 & 0.50 & 5.19 \\
\hline $\mathrm{Zn}$ & $<30.0$ & & & & 101,2 & 128.1 & $<30.0$ & 407.1 & 12.95 & 7.38 \\
\hline $\mathrm{Ga}$ & $<1.0$ & & & & 2.1 & 1.7 & $<1.0$ & 5.9 & 0.79 & $<1.0$ \\
\hline $\mathrm{Go}$ & 3.8 & 0.8 & 3.1 & 5.3 & 4.0 & 1.3 & 2.1 & 6.0 & 3.6 & $<0.5$ \\
\hline $\mathrm{Rb}$ & $<1.0$ & & & & $<1.0$ & & & & 1.24 & $<1.0$ \\
\hline $\mathrm{Nb}$ & 0.3 & 0.3 & $<0.2$ & 0.5 & 0.8 & 0.80 & $<0.2$ & 2.4 & 0.36 & 0.88 \\
\hline Mo & $<2.0$ & & & & $<2.0$ & & & & 1.49 & $<2.0$ \\
\hline $\mathrm{Ag}$ & $<0.5$ & & & & $<0.5$ & & & & 0.41 & $<0.3$ \\
\hline In & $<0.1$ & & & & $<0.1$ & & & & 0.05 & $<0.1$ \\
\hline $\mathrm{Sn}$ & $<1.0$ & & & & $<1.0$ & & & & 0.64 & $<1.0$ \\
\hline Cs & $<0.1$ & & & & $<0.1$ & & & & 0.21 & $<0.1$ \\
\hline$\sum \mathrm{REE}$ & 5.0 & 1.5 & 3.6 & 7.6 & 42.9 & 31.8 & 14.4 & 116.9 & 9.63 & 18.76 \\
\hline Hf & $<0.1$ & & & & $<0.1$ & & & & $<0,1$ & $<0.1$ \\
\hline $\mathrm{Tl}$ & $<0.1$ & & & & $<0.1$ & & & & $<0 . \mathrm{I}$ & $<0.1$ \\
\hline $\mathrm{Pb}$ & $<5,0$ & & & & 13.7 & 23.2 & 2.5 & 70.5 & 1.5 & 7.01 \\
\hline $\mathrm{Bi}$ & $<0.1$ & & & & $<0.1$ & & & & 2.2 & $<0.1$ \\
\hline Th & 0.1 & 0.1 & $<0.05$ & 0.2 & 0.8 & 1.3 & 0.1 & 3.8 & 0.25 & 0.84 \\
\hline $\mathrm{U}$ & 1.7 & 1.2 & 0.7 & 4.1 & 4.7 & 2.5 & 1.5 & 8.4 & 2.07 & 1.67 \\
\hline$A u$ & $<2.0$ & & & & 9.4 & 12.5 & $<2.0$ & 35.0 & na & na \\
\hline As & 7.4 & 1.6 & 5.5 & 9.6 & 16.0 & 6.4 & 9.2 & 26.3 & 6.55 & 4.80 \\
\hline $\mathrm{Br}$ & $<0.5$ & & & & $<0.5$ & & & & na & na \\
\hline $\mathrm{Cr}$ & 54.5 & 62.1 & 23.0 & 181.0 & 68.7 & 59.8 & 26.0 & 206.0 & 21.84 & 23.50 \\
\hline Ir & $<5.0$ & & & & $<5.0$ & & & & na & na \\
\hline $\mathrm{Sb}$ & 5.5 & 4.2 & 2.9 & 14.0 & 4.9 & 3.8 & 1.8 & 14.0 & 1.35 & 1.52 \\
\hline $\mathrm{Sc}$ & 0.2 & 0.1 & $<0.1$ & 0.3 & 1.7 & 2.7 & 0.3 & 7.7 & nat & na \\
\hline $\mathrm{Se}$ & $<3.0$ & 0.0 & 1.5 & 1.5 & $<3.0$ & & & & na & na \\
\hline Fe\# & 0.996 & 0.006 & 0.985 & 0.999 & 0.998 & 0.001 & 0.996 & 0.999 & 1.000 & 0.910 \\
\hline
\end{tabular}


Table 4-Average rare earth element composition

\begin{tabular}{|c|c|c|c|c|c|c|c|}
\hline & \multirow{2}{*}{$\begin{array}{l}\text { Hard ore } \\
(\mathrm{n}=10)\end{array}$} & \multicolumn{3}{|c|}{ Soft ore } & \multicolumn{3}{|c|}{ Dolomitic itabirite } \\
\hline & & $\begin{array}{c}\text { Bulk } \\
(n=24)\end{array}$ & $\begin{array}{c}\text { Massive } \\
\text { band } \\
(n=6)\end{array}$ & $\begin{array}{l}\text { Porous band } \\
\qquad(n=8)\end{array}$ & $\begin{array}{c}\text { Bulk } \\
(n=11)\end{array}$ & $\begin{array}{l}\text { Iron-rich band } \\
\qquad(\mathrm{n}=6)\end{array}$ & $\begin{array}{l}\text { Dolomite } \\
\text { rich band } \\
(n=6)\end{array}$ \\
\hline \multicolumn{8}{|l|}{ ppm } \\
\hline $\mathrm{La}$ & 1.06 & 3.50 & 0.85 & 6.65 & 2.65 & 1.85 & 3.13 \\
\hline $\mathrm{Ce}$ & 1.88 & 6.42 & 1.58 & 11.95 & 4.21 & 3.00 & 6.24 \\
\hline $\operatorname{Pr}$ & 0.28 & 0.98 & 0.20 & 1.70 & 0.53 & 0.39 & 0.76 \\
\hline Nd & 1.34 & 4.36 & 0.90 & 7.35 & 2.40 & 1.71 & 3.41 \\
\hline $\mathrm{Sm}$ & 0.36 & 0.98 & 0.20 & 1.72 & 0.57 & 0.39 & 0.77 \\
\hline $\mathrm{Eu}$ & 0.14 & 0.40 & 0.07 & 0.74 & 0.22 & 0.14 & 0.32 \\
\hline $\mathrm{Gd}$ & 0.53 & 1.27 & 0.28 & 2.56 & 0.74 & 0.48 & 0.99 \\
\hline $\mathrm{Tb}$ & 0.09 & 0.23 & 0.04 & 0.46 & 0.13 & 0.08 & 0.17 \\
\hline Dy & 0.55 & 1.51 & 0.30 & 3.10 & 0.86 & 0.54 & 1.11 \\
\hline$Y$ & 4.99 & 18.76 & 3.11 & 32.59 & 7.44 & 4.67 & 9.50 \\
\hline Ho & 0.12 & 0.35 & 0.07 & 0.77 & 0.20 & 0.13 & 0.25 \\
\hline $\mathrm{Er}$ & 0.34 & 1.12 & 0.24 & 2.53 & 0.63 & 0.43 & 0.78 \\
\hline $\mathrm{Tm}$ & 0.05 & 0.18 & 0.04 & 0.41 & 0.10 & 0.07 & 0.11 \\
\hline $\mathrm{Yb}$ & 0.28 & 1.17 & 0.24 & 2.59 & 0.62 & 0.42 & 0.71 \\
\hline $\mathrm{Lu}$ & 0.04 & 0.19 & 0.04 & 0.43 & 0.10 & 0.07 & 0.12 \\
\hline ¿REE & 6.96 & 22,66 & 5.04 & 42.94 & 13.86 & 9.63 & 18.76 \\
\hline $\mathrm{La} / \mathrm{Yb}_{\mathrm{P} A \mathrm{AS}}$ & 0.28 & 0.22 & 0.26 & 0.17 & 0.27 & 0.32 & 0.34 \\
\hline $\mathrm{La} / \mathrm{Sm}_{\mathrm{PAAS}}$ & 0.46 & 0.52 & 0.61 & 0.53 & 0.61 & 0.69 & 0.60 \\
\hline $\mathrm{Dy} / \mathrm{Yb}_{\mathrm{PAAS}}$ & 1.17 & 0.78 & 0.75 & 0.71 & 0.82 & 0.78 & 0.94 \\
\hline $\mathrm{Ce} / \mathrm{Ce}^{*}{ }_{\mathrm{p} A \mathrm{~S}}$ & 0.82 & 0.80 & 1.04 & 0.76 & 0.86 & 0.82 & 0.89 \\
\hline $\mathrm{Eu} / \mathrm{Eu}^{*}{ }_{\mathrm{p} A \mathrm{AS}}$ & 1.48 & 1.67 & 1.67 & 1.63 & 1.60 & 1.57 & 1.74 \\
\hline $\mathrm{Y} / \mathrm{Y}^{*} \mathrm{PANS}$ & 1.68 & 2.09 & 2.09 & 1.85 & 1.63 & 1.40 & 1.52 \\
\hline
\end{tabular}

The soft iron ore consists almost entirely of $\mathrm{Fe}_{2} \mathrm{O}_{3}$ (average of $95.6 \%$ ), with $\mathrm{FeO}$ representing less than $0.5 \%$ (average $0.1 \%$ ). LOI (average of $0.9 \%$ ), $\mathrm{SiO}_{2}$ (average of $1.1 \%$ ), $\mathrm{MnO}$ (average of $0.8 \%$ ) and $\mathrm{Al}_{2} \mathrm{O}_{3}$ (average of $0.5 \%$ ) complete the list of significant major elements (Table 3, Fig. 12a). $\mathrm{Na}_{2} \mathrm{O}$ and $\mathrm{K}_{2} \mathrm{O}$ contents are below the detection limit of $0.01 \%$. A comparison of the major element composition of the dolomitic itabirite (protore) with that of the soft ore (Table 3, Fig. 12b) shows that the mineralizing process is chemically characterized by the enrichment in $\mathrm{Fe}_{2} \mathrm{O}_{3}, \mathrm{Al}_{2} \mathrm{O}_{3}, \mathrm{MnO}, \mathrm{P}_{2} \mathrm{O}_{5}$ and $\mathrm{TiO}_{2}$, with depletion in $\mathrm{FeO}, \mathrm{MgO}, \mathrm{CaO}$ and LOI.

The average values of major elements in the massive and porous band of the soft ore analyzed separately confirm the results of petrological analyses and show that impurities are concentrated within the porous bands (Table 3, Fig. 12c). These impurities consist almost entirely of $\mathrm{SiO}_{2}$ (average of $1.7 \%$ ), $\mathrm{MnO}$ (average of $1.7 \%$ ) and $\mathrm{Al}_{2} \mathrm{O}_{3}$ (average of $0.8 \%$ ), and are in the form of chlorite, talc and Mn-oxides. The $\mathrm{Fe}_{2} \mathrm{O}_{3}$ content of the porous band is still very high (average of $92.8 \%$ ), but lower than that of the massive bands (average of $98.2 \%$ ), which 
have very low concentrations of $\mathrm{SiO}_{2}$ (average $0.3 \%$ ), $\mathrm{Al}_{2} \mathrm{O}_{3}$ (average of $0.1 \%$ ) and $\mathrm{MnO}$ (average of $0.1 \%$ ).
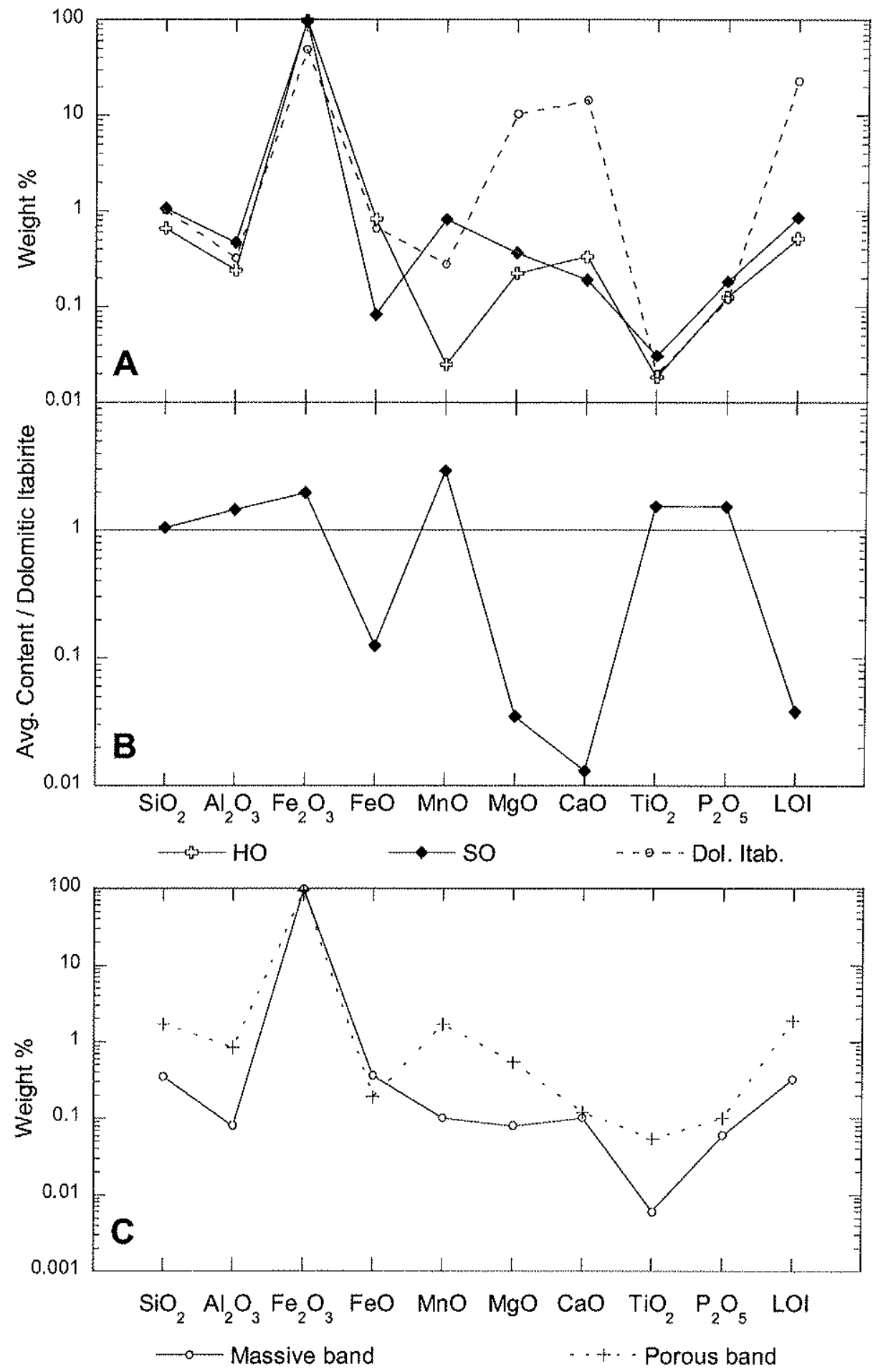

Figure 12 - A Average major element composition of the soft ore (SO), hard ore (HO) and dolomitic itabirite (Dol. Itab.). B Average major element composition of the iron ores normalized to the dolomitic itabirite. C Average major element composition of the massive and porous bands of the soft ore. 
No significant enrichments in trace elements were encountered in the soft ore (Table 3 , Fig. 13a). Most show concentrations of less than $10 \mathrm{ppm}$, except for $\mathrm{Ba}(33 \mathrm{ppm}), \mathrm{V}(60 \mathrm{ppm}), \mathrm{Cr}$ (79 ppm), Y (19 ppm), Ni (24 ppm), Cu (79 ppm) and $\sum$ REE (23 ppm). When compared to the average composition of dolomitic itabirite (Fig. 13b), the soft ore is enriched in all trace elements, except for $\mathrm{Sr}$ and $\mathrm{Nb}$. With a behavior similar to that of major elements, trace elements are concentrated in the porous bands of the soft ore (Table 3, Fig. 13c). Only Ge, Cr, $\mathrm{Sb}, \mathrm{V}$ and $\mathrm{Ni}$ have similar values in the porous and massive bands. Some elements, such as $\mathrm{Ba}$ $(10 \mathrm{x}), \mathrm{Y}(10 \mathrm{x})$, REE $(9 \mathrm{x})$ and $\mathrm{Th}(7 \mathrm{x})$ are highly enriched in the porous bands if compared to the massive bands.

The average REE composition of the soft ore is presented in Table 4. The REEY patterns are shown in Figs. 14a-b. These patterns show similar trends, characterized by a pronounced depletion in the light REE relative to heavy REE (average $\mathrm{La} / \mathrm{Yb}=0.2$ ). This depletion occurs either in the LREE group (average $\mathrm{La} / \mathrm{Sm}=0.5$ ) as in the HREE group (average $\mathrm{Dy} / \mathrm{Yb}=0.8$ ). Most samples display strong positive anomalies of $\mathrm{Eu}\left(\mathrm{Eu} / \mathrm{Eu}^{*}=1.7\right)$ and $\mathrm{Y}\left(\mathrm{Y} / \mathrm{Y}^{*}=2.1\right)$, as well as negative anomalies of Ce ranging from 0.7 to 1.0 .

The average REEY pattern of the soft ore clearly illustrates the enrichment of REEY by a factor of about 1.6 relative to dolomitic itabirite (Fig. 14c). This figure also illustrates the remarkably similar REEY pattern between the ore and the protore and suggests that weathering promoted a residual enrichment in REE in the soft ore, preserving the original pattern, without fractionation. This is also observed by comparing the average REEY pattern of the iron-rich and dolomite-rich bands of the dolomitic itabirite with that of the massive and porous bands of the soft ore (Fig. 14d). Such patterns are conspicuously similar, the only difference being a depletion in REEY of the iron-rich band compared with its correspondent massive band and, conversely, a REEY enrichment of the porous band compared with its correspondent dolomite-rich band. 


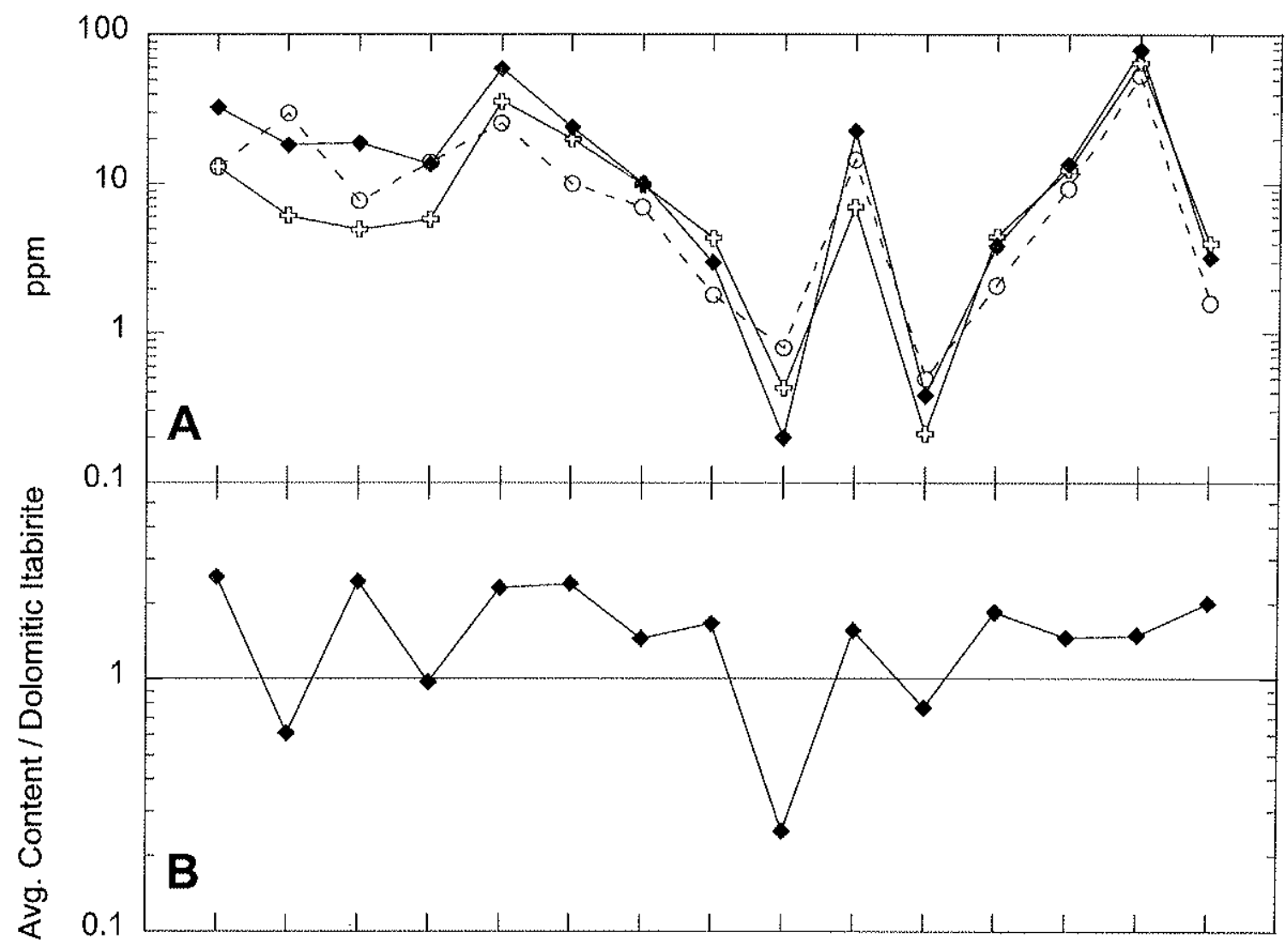

$\mathrm{Ba} \quad \mathrm{Sr} \quad \mathrm{Y} \quad \mathrm{Zr} \quad \mathrm{V} \quad \mathrm{Ni} \mathrm{CU}$ Ge $\mathrm{Nb}$ \#La $\mathrm{Th} U$ As $\mathrm{Cr} \mathrm{Sb}$ $\longrightarrow \mathrm{HO} \quad \longrightarrow \mathrm{SO} \quad \ldots-\cdots$ - Dol. Itab.

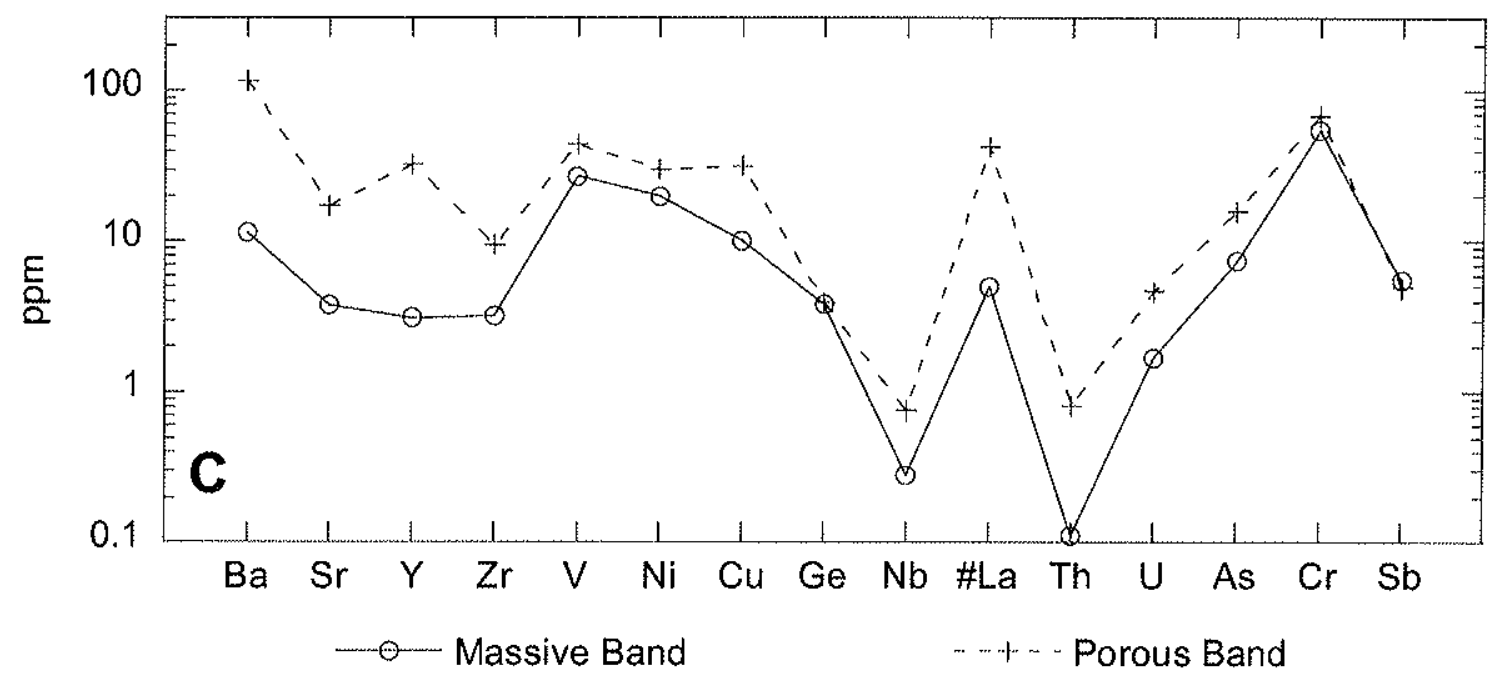

Figure 13 - A Average trace element composition of the soft ore (SO), hard ore (HO) and dolomitic itabirite (Dol. Itab.). B Average trace element composition of the soft ore normalized to the dolomitic itabirite. C Average trace element composition of the massive and porous bands of the soft ore. Latt means $\sum$ REE. 

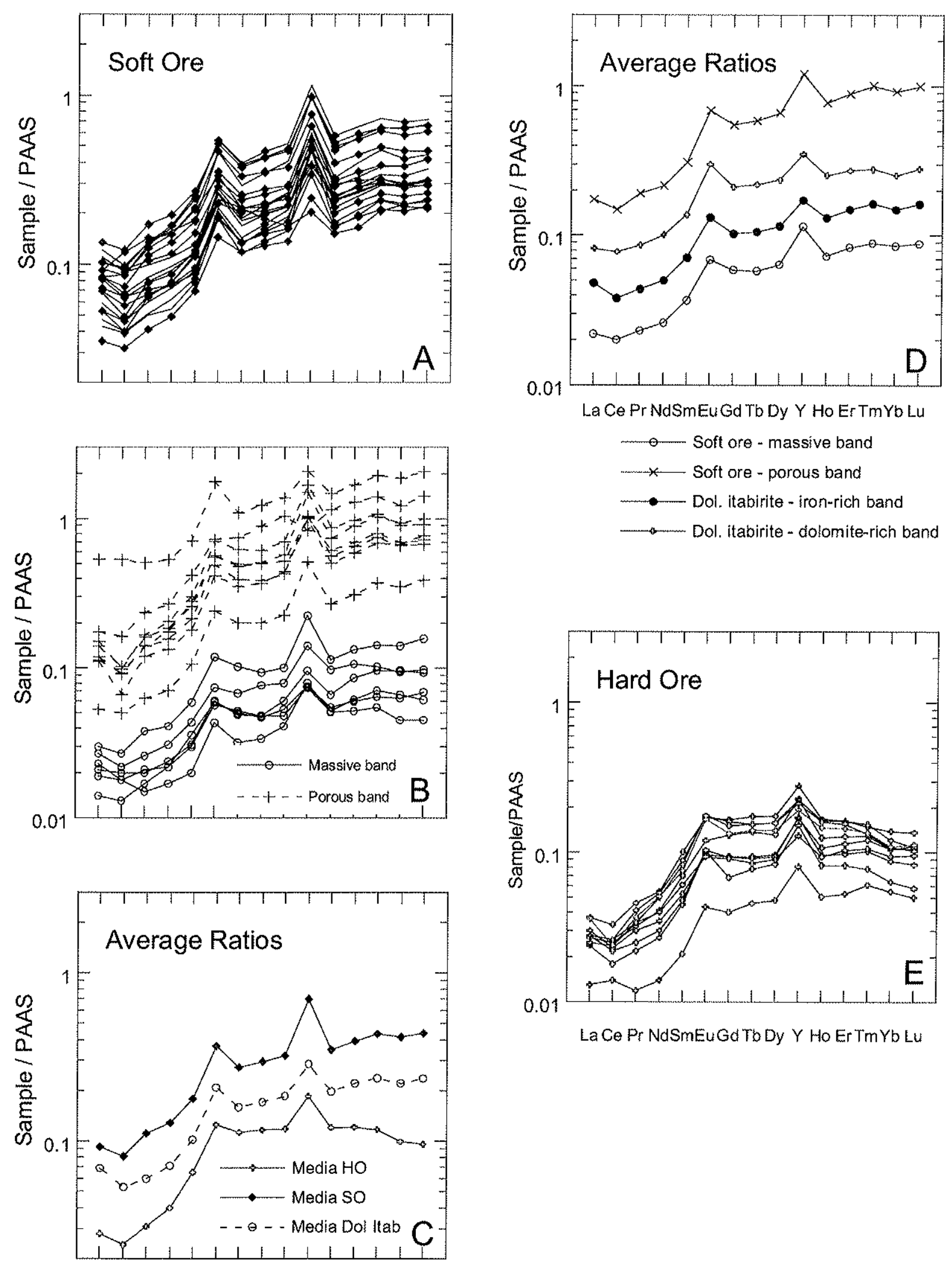

LaCe PrNdSmEuGdTo Dy Y Ho ErTmYbLu

Figure 14 - PAAS-normalized REEY data. A Soft ore. B Massive and porous bands of the soft ore. C Averaged iron ores and dolomitic itabirite. D Averaged massive and porous bands of the soft ore, and iron-rich and dolomite-rich bands of the dolomitic itabirite (protore of the soft ore). Data for the itabirites are from (Spier et al. 2005a). E Hard ore. 


\section{Some Linear Interelement Correlations}

Table 5 reveals a strong negative correlation of $\mathrm{Fe}_{\mathrm{TO}}$ with $\mathrm{LOI}, \mathrm{Al}_{2} \mathrm{O}_{3}$ and $\mathrm{SiO}_{2}$, and a significant negative correlation of $\mathrm{Fe}_{\mathrm{To}}$ with $\mathrm{MnO}, \mathrm{MgO}, \mathrm{TiO}_{2}$, and $\mathrm{Ni}$. Table 5 and Figure 15 show that LOI correlates positively with $\mathrm{SiO}_{2}, \mathrm{Al}_{2} \mathrm{O}_{3}, \mathrm{TiO}_{2}$ and $\mathrm{MnO}$, confirming that the higher amount of impurities in the iron ores is associated with dolomite or its product of dissolution.

$\mathrm{Al}_{2} \mathrm{O}_{3}$ correlates very well with $\mathrm{SiO}_{2}$ and $\mathrm{TiO}_{2}$ (Table 5, Fig. 15). These correlations are also observed in the dolomitic itabirite reflecting a slight contribution of detritic contaminants in the original sediments (Spier et al. 2005a). These detritic contaminants are concentrated in the porous band of the soft ore during the leaching process (Fig. 12c). $\mathrm{SiO}_{2}$ correlates well with $\mathrm{MgO}$, confirming the presence of talc in the group of contaminants. $\mathrm{CaO}$ has a strong correlation with $\mathrm{P}$, reflecting the occurrence of apatite in the ores.

Table 5 - Linear interelement correlations for all samples of the sof ore $(n=62)$

\begin{tabular}{|c|c|c|c|c|c|c|c|c|c|c|c|c|c|}
\hline & $\mathrm{SiO}_{2}$ & $\mathrm{Al}_{2} \mathrm{O}_{3}$ & $\mathrm{Fe}_{\mathrm{TOT}}$ & $\mathrm{MnO}$ & $\mathrm{MgO}$ & $\mathrm{CaO}$ & $\mathrm{TiO}_{2}$ & $\mathrm{P}_{2} \mathrm{O}_{5}$ & LOI & $\mathrm{Ba}$ & V & $\mathrm{Ni}$ & $\mathrm{Cu}$ \\
\hline $\mathrm{Al}_{2} \mathrm{O}_{3}$ & 0.88 & & & & & & & & & & & & \\
\hline $\mathrm{Fe}_{\mathrm{ror}}$ & -0.95 & -0.91 & & & & & & & & & & & \\
\hline $\mathrm{MnO}$ & 0.64 & 0.74 & -0.79 & & & & & & & & & & \\
\hline $\mathrm{MgO}$ & 0.67 & 0.37 & -0.60 & 0.23 & & & & & & & & & \\
\hline $\mathrm{CaO}$ & 0.09 & -0.10 & -0.16 & -0.17 & 0.24 & & & & & & & & \\
\hline $\mathrm{TiO}_{2}$ & 0.80 & 0.88 & -0.84 & 0.66 & 0.40 & -0.03 & & & & & & & \\
\hline $\mathrm{P}_{2} \mathrm{O}_{5}$ & 0.13 & 0.00 & -0.21 & -0.14 & 0.17 & 0.96 & 0.08 & & & & & & \\
\hline LOI & 0.82 & 0.90 & -0.92 & 0.91 & 0.39 & -0.10 & 0.81 & -0.04 & & & & & \\
\hline $\mathrm{Ba}$ & -0.10 & 0.08 & -0.06 & 0.09 & -0.26 & -0.23 & 0.06 & -0.14 & 0.04 & & & & \\
\hline V & 0.28 & 0.35 & -0.41 & 0.46 & 0.22 & -0.10 & 0.28 & -0.08 & 0.50 & .0 .05 & & & \\
\hline $\mathrm{Ni}$ & 0.70 & 0.79 & -0.71 & 0.57 & 0.24 & -0.09 & 0.65 & 0.02 & 0.70 & 0.16 & 0.33 & & \\
\hline $\mathrm{Cu}$ & -0.06 & 0.01 & -0.06 & 0.19 & -0.14 & -0.13 & -0.04 & -0.07 & 0.13 & 0.22 & 0.30 & 0.13 & \\
\hline $\mathrm{Cr}$ & 0.13 & 0.15 & -0.12 & 0.06 & 0.01 & -0.07 & 0.13 & 0.04 & 0.06 & -0.03 & 0.05 & 0.18 & 0.16 \\
\hline
\end{tabular}



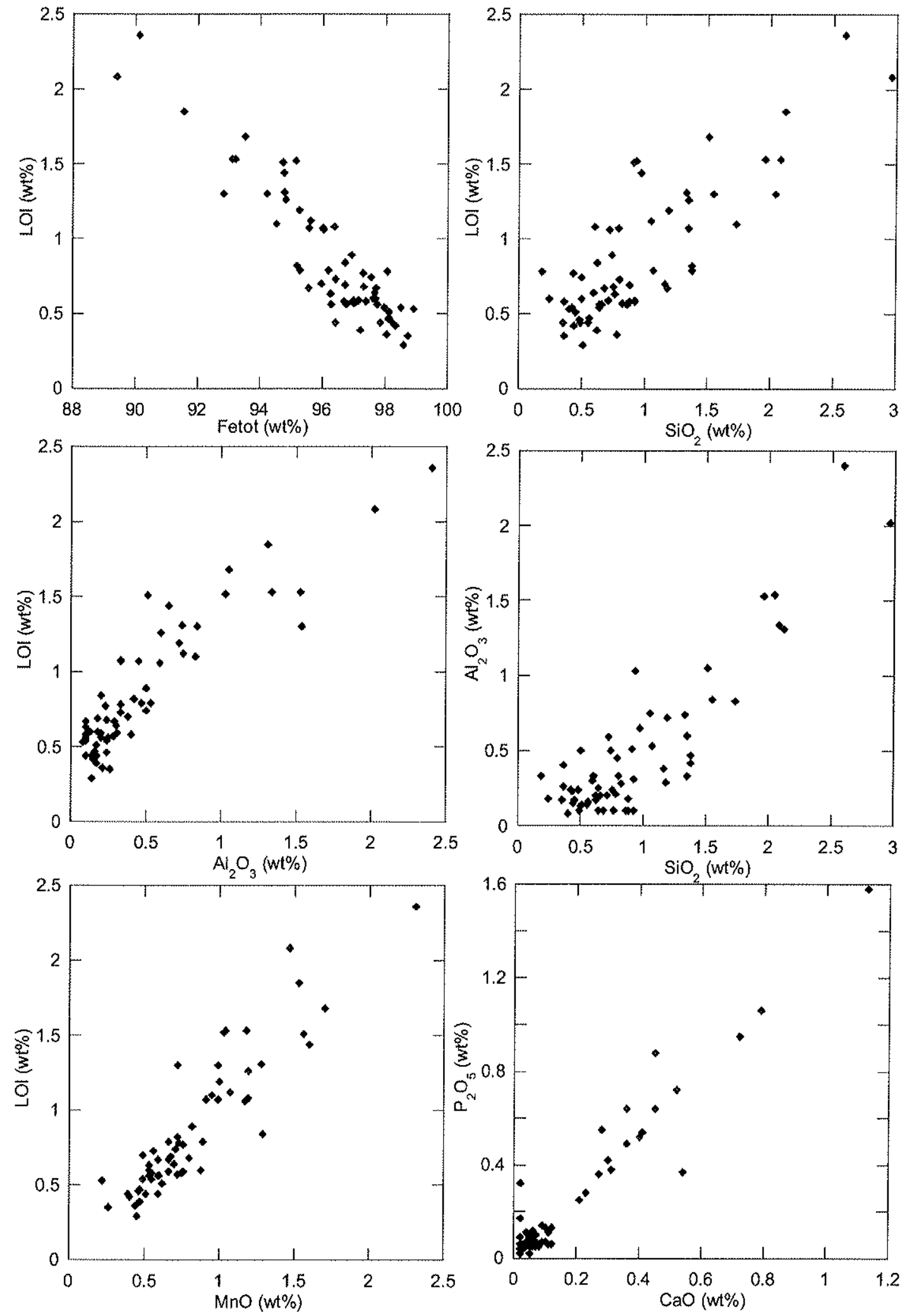

Figure 15 - Interelement correlations for the soft ore samples. 


\section{Hard Iron Ores}

\section{Mineralogy and Petrology}

Petrographic and SEM observations of the massive, banded and schistose hard iron ores have shown a very simple mineralogical composition. The iron oxide mineralogy is the same of the soft ore. Gangue minerals are very rare, consisting of dolomite and, locally, apatite and talc. In weathered hard ores gangue minerals are generally absent, creating a macroporosity. In highly fractured orebodies, goethite and kaolinite occur as thin films on the surface of the ore, even at deeper depths (Fig. 3f). There is no difference in the mineralogical composition of the three major sub-types of hard ore, except in fabric and porosity.

Massive hard ore consists of tabular and granular hematite (up to 80\%) ranging in size from 5 to $30 \mu \mathrm{m}$ (average of $20 \mu \mathrm{m}$ ), forming a granoblastic fabric (Figs. 16a-d). Martite (up to $50 \mu \mathrm{m}$ ) with remnants of magnetite occur between hematite crystals (Fig. 16e). Locally, it is possible to observe the growth of hematite over martite crystals. Porosity in hard massive ores may vary from approximately 5 to $20 \%$, and pore size from $<1$ to $50 \mu \mathrm{m}$. Fresh ores exhibit the lowest porosity of all hard ores, around $3 \%$, increasing up to $20 \%$ in weathered samples.

Banded hard ore consists of alternated massive and porous layers (Fig. 16f). Tabular and granular hematite are the main iron oxides (up to 70\%) with grain size ranging from $5-20 \mu \mathrm{m}$ (Fig. 16g). They grow over martite or occur as isolated crystals. Martite with remnants of magnetite may occur as individual crystals ranging from $30-50 \mu \mathrm{m}$ or forming dense aggregates, representing up to $5 \%$ of the volume. Specularite (up to $5 \%$ ) occurs locally, along shear planes parallel to or cutting the banding and defining a discontinuously developed foliation. Porosity is highly variable in banded iron ores, reaching up to $30 \%$ of the volume.

Schistose hard ore presents a lepidoblastic fabric which is composed mainly of tabular hematite and specularite (up to 70\%) wrapping around porphyroclastic aggregates of tabular and granular hematite (up to $50 \%$, Fig. 16h). Porosity in the schistose ore ranges from 5 to $20 \%$. 

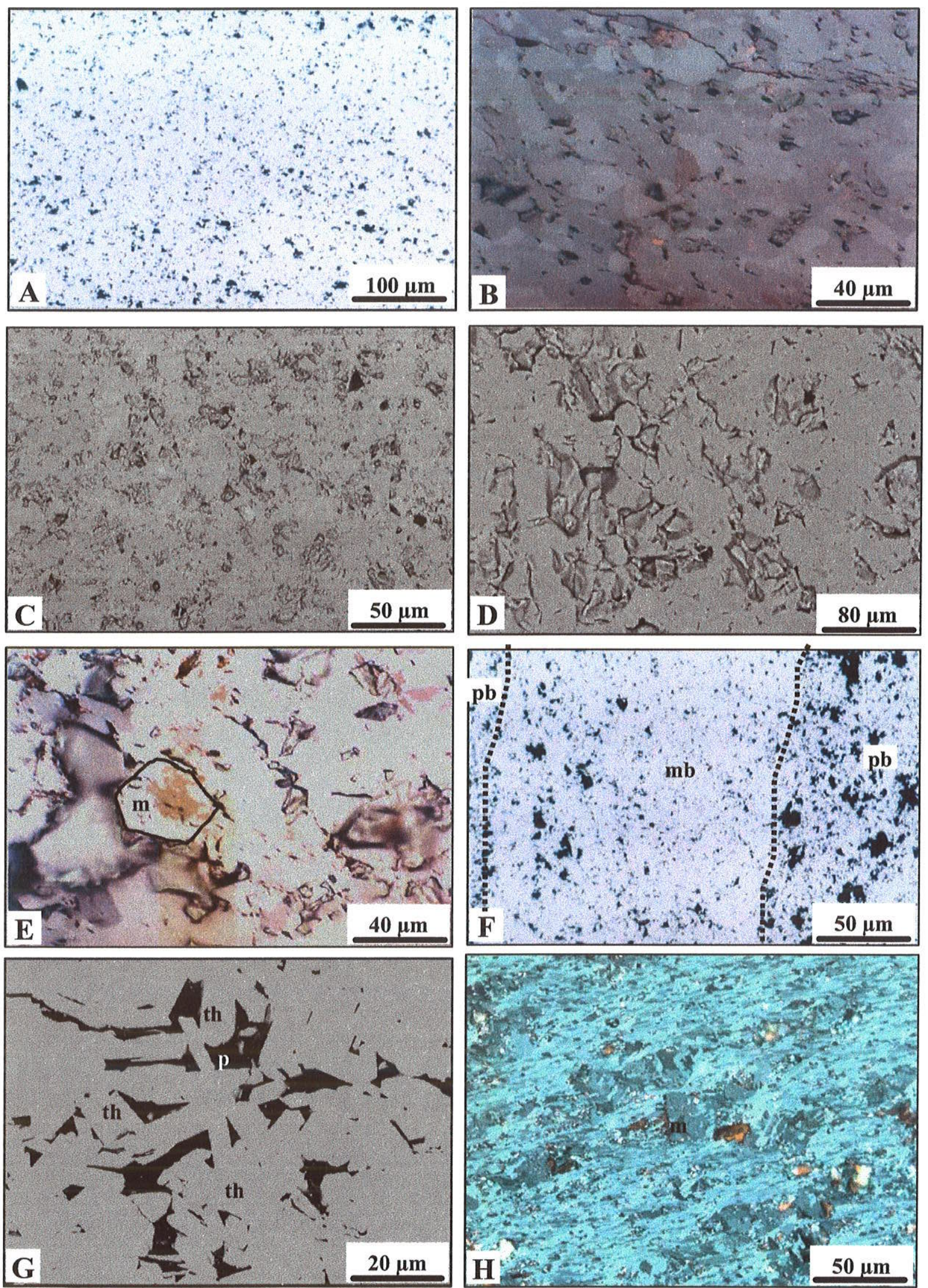

Figure 16 - Photomicrographs and SEM backscattered images of the hard ores. A Massive hard ore, reflected light, PPL. B Granoblastic fabric of massive hard ore, reflected light, partially XPL. C-D SEM image of massive hard ore. E Detail of a martite crystal in massive hard ore with relict of magnetite (m), reflected light, PPL. F Banded hard ore, reflected light, PPL. Note alternation of highly porous $(\mathrm{pb})$ with less porous bands $(\mathrm{mb})$. G Detail of the banded ore showing intergrown of tabular hematite (th), reflected light, PPL. H Schistose hard ore showing porphyroclastic aggregates of martite wrapped around by porous and platy (specularite) hematite, reflected light, XPL. 


\section{XRD and Mössbauer Analyses}

Hematite was the only iron oxide identified by XRD, with very sharp peaks (Fig. 17). Gangue minerals are almost absent, as shown by their small peaks, consisting of dolomite in sample MAC-67 and kaolinite in sample MAC-97. These results are confirmed by the $300 \mathrm{~K}$ MS (Fig. 18), with a hyperfine field of about $52 \mathrm{~T}$ and a quadrupole shift of about $-0.15 \mathrm{~mm} / \mathrm{s}$ assigned to hematite (Table 1). They are also corroborated by the Mössbaeur spectra of sample MAC97 at $50 \mathrm{~K}$, which also presents only a sextet ascribed to hematite (hyperfine field of $56 \mathrm{~T}$, isomer shift of $0.48 \mathrm{~mm} / \mathrm{s}$ and quadrupole splitting of $0.38 \mathrm{~mm} / \mathrm{s}$ ). Sharp XRD peaks and Mössbauer parameters of hematite indicate a high degree of crystallinity, with little heterogeneity. The unit cell parameters of hematite in samples MAC67 and MAC97, very similar to those of the reference cell of hematite (Table 2), corroborate this indication.

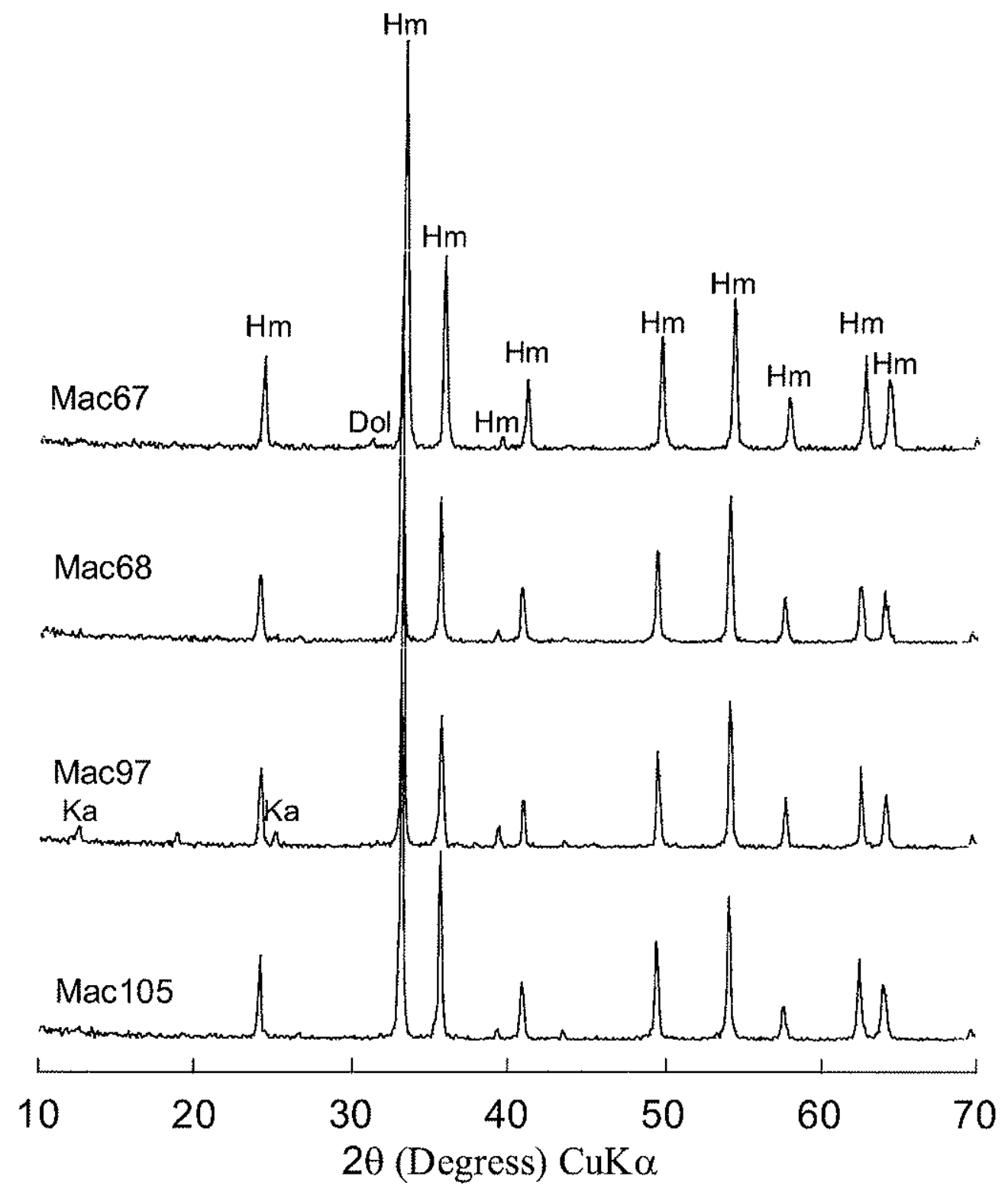

Figure 17 ... Powder XRD patterns of the hard ore samples showing hematite (HIm), dolomite (Dol) and kaolinite (Ka). 


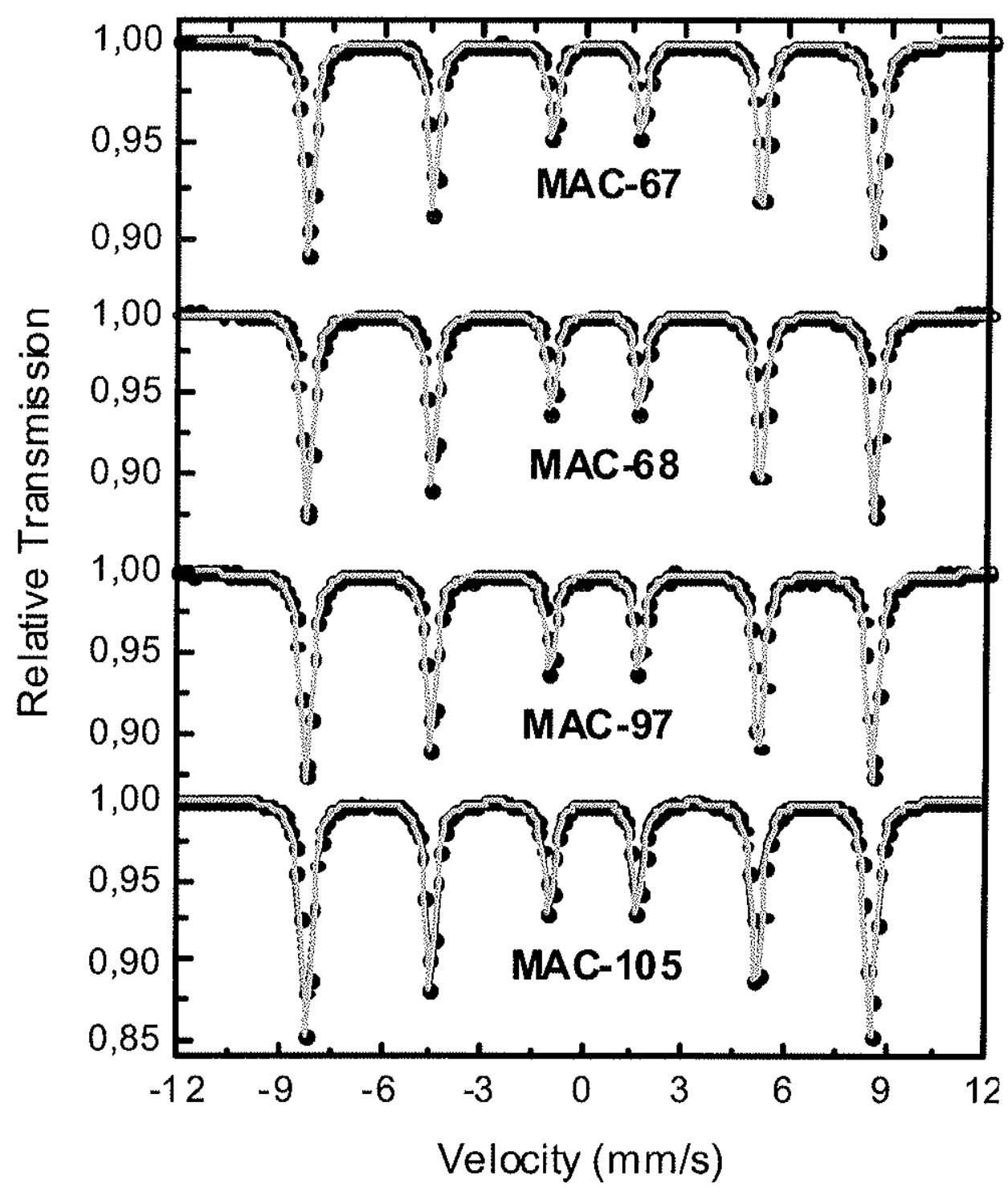

Figure 18 - Mössbauer spectra at room temperature of the hard ore samples.

\section{Geochemistry}

The bulk geochemical composition of the hard ore is very simple, consisting almost entirely of $\mathrm{Fe}_{2} \mathrm{O}_{3}$ (avg. 97.6\%), ranging from $95.0 \%$ to $99.1 \%$ (Table 3, Fig. 12a). The average $\mathrm{FeO}$ content is $0.8 \%$ (ranging from $0.2 \%$ to $2.7 \%$ ), whereas $\mathrm{SiO}_{2}$ ranges from $0.2 \%$ to $1.3 \%$ (avg. of $0.7 \%$ ). $\mathrm{CaO}$ (avg. of $0.3 \%$ ) and $\mathrm{MgO}$ (avg. of $0.2 \%$ ) contents present a similar distribution, ranging from $0.01 \%$ to $1.2 \% . \mathrm{Al}_{2} \mathrm{O}_{3}$ is the next most abundant component, ranging from $0.02 \%$ to $0.9 \%$ (avg. of $0.2 \%$ ). $\mathrm{Na}_{2} \mathrm{O}, \mathrm{K}_{2} \mathrm{O}$ and $\mathrm{P}_{2} \mathrm{O}_{5}$ contents are always below $0.5 \%$, whereas $\mathrm{TiO}_{2}$ averages $0.02 \%$. 
The trace element composition of the hard ore is also remarkably simple, with only $\mathrm{Cr}$ (avg. of $65 \mathrm{ppm}$ ) and V (avg. of $35 \mathrm{ppm}$ ) showing average values higher than $30 \mathrm{ppm}$ (Table 3 , Fig. 13a). The Zn and Ni contents of most of the samples were below the detection limits of 30 ppm and $20 \mathrm{ppm}$, respectively. As (avg. of $12 \mathrm{ppm}$ ) and Ba (avg. of $14 \mathrm{ppm}$ ) have average contents higher than $10 \mathrm{ppm}$, whereas all other trace elements present average values below 10 $\mathrm{ppm}$ and, in most cases, below the detection limits of $5 \mathrm{ppm}(\mathrm{Pb}$ and $\mathrm{Ir}$ ), $3 \mathrm{ppm}(\mathrm{Sc}, \mathrm{Be}$ and $\mathrm{Se}$ ), 2 ppm (Mo), 1 ppm (Ga, Rb, Sn) and 0.1 ppm (In, Cs, Hf, Tl and Bi).

The hard ore is depleted in REE, with an average content of $7 \mathrm{ppm}$, ranging from $3 \mathrm{ppm}$ to $10 \mathrm{ppm}$ (Table 3). The REEY patterns are all similar (Fig. 14e), being characterized by a strong depletion in light REE relative to heavy REE, negative Ce anomalies (with the exception of sample MAC68), marked positive Eu and $\mathrm{Y}$ anomalies, and depletion of the heavy REE relative to the middle REE $(\mathrm{Dy} / \mathrm{Yb}>1)$.

\section{DISCUSSION}

\section{Comparison between hard and soft ores}

The major difference between hard and soft ores, besides the mechanical strength, is their mode of occurrence. The soft ore forms a large, km-sized lens, which grades laterally and vertically to the parent dolomitic itabirite. Field relationships show the transition from the dolomite-rich bands of the dolomitic itabirite into the porous band of the soft ore. This transition is marked by dissolution of the dolomite-rich bands, thereby producing a highly porous residue which is very rich in the hematite originally present within the dolomite-rich bands. The ironrich bands of the dolomitic itabirite are little affected by this dissolution process and form the massive band of the soft ore. The hard ore occurs as discontinuous lenses within the fresh dolomitic itabirite and soft ore. These field relationships indicate that the hard iron ore was formed earlier than the soft iron ore. It also suggests that the hard iron ore, like the iron-rich bands of the dolomitic itabirite, was little affected by the dissolution process, remaining as lenses within the soft ore.

The next important difference between hard and soft ores is porosity, which control their mechanical strength. Two types of porosity are observed in the iron ores: macro and microporosity. The former is related to the spaces between the iron oxides crystals and constitutes the major factor affecting the hardness of the ore. It is formed by leaching of the gangue minerals, probably by weathering solutions (see text below). The latter is related to the presence of pores within the iron oxide crystals which are formed during the oxidation of 
magnetite into martite. The hard iron ore is much less porous than the soft ore, which accounts for its hardness. The soft ores are highly porous and, consequently, soft. A more frequent presence of carbonate in the rock prior to dissolution results in higher porosity and higher friability. Variations in the porosity and fabric of the hard ore are responsible for the different sub-types observed.

The major difference in the mineralogy of the hard and soft ores is the slightly higher amount of gangue minerals in the latter. The gangue minerals are also different in each type of ore. Although both ores have a very low amount of detrimental impurities, these are concentrated in the soft ore. Dolomite, sericite, chlorite and apatite are the most common gangue minerals, both in the hard and in the soft ore. Mn-oxides and ferrihydrite are concentrated within the porous bands of the soft ore and are absent from the hard ore. Higher amounts of gangue minerals, especially apatite and Mn-oxides, occur in deeper depths close to the contact of the soft ore with the protore. This zone has lower permeability, thus favoring the residual concentration of apatite (which is less soluble than dolomite) together with Mn-oxides produced during dolomite dissolution (see discussion below).

The iron oxide mineralogy of the hard and soft ores is exactly the same, as demonstrated by optical microscopy, SEM, XRD and MS, and consists essentially of granular and tabular hematite. This mineral occurs growing over martite crystals or as individual crystals forming the dense aggregates of a granoblastic fabric both in hard ores and in massive bands of soft ore. Hematite has the same Mössbauer hyperfine parameters both in fresh dolomitic bands and in hard and soft ores (Table 1). The Mössbauer spectra of all samples can be well fitted with only one sextet. The value of the hyperfine field (51.9 T) corresponds to that of pure, well-crystallized hematite, indicating that it does not contain detectable amounts of $\mathrm{Al}$ (Fysh and Clark 1982; Murad and Schwertmann 1986). This conclusion is also supported by the hematite unit cell parameters obtained from the Rietveld analyses, which point to the purity of this mineral. The isomer shift of all the sextets shows that iron is exclusively present in the $\mathrm{Fe}^{3+}$ state. Although remnants of magnetite are locally observed either in hard or in soft ores, this mineral was submitted to a very high degree of martitization. This phenomenon occurred prior to the genesis of the soft ore, considering the identical hyperfine parameters of the iron oxides observed in the dolomitic itabirite (protore) and in the soft ore. This is further supported by chemical analyses of the dolomitic itabirite, which reveal $\mathrm{Fe}^{3+} /\left(\mathrm{Fe}^{3+}+\mathrm{Fe}^{2+}\right)$ ratios close to one (Spier et al. 2005a).

The geochemistry of the hard and soft ores reflects a higher amount of detrimental impurities in the soft ore (Table 3, Fig. 12a), especially $\mathrm{MnO}$, whose average content in the soft 
ore is 33 times higher than in the hard ore. Other major constituents like $\mathrm{Al}_{2} \mathrm{O}_{3}(2.0 \mathrm{x}), \mathrm{SiO}_{2}$ (1.6x), $\mathrm{TiO}_{2}(1.7 \mathrm{x})$ and $\mathrm{P}_{2} \mathrm{O}_{5}(1.4 \mathrm{x})$, together with LOI (1.6x), also show the increase of impurities in the soft ore. Both hard and soft ores are very depleted in trace elements (Table 3, Fig. 13a), excepted for $\mathrm{Ba}(2.5 \mathrm{x})$, Sr (3.0x), Y (3.7x), V (1.7x), Th (1.8x) and LREE (3.2x), which show higher concentrations in the soft ore than in the hard ore. Another important difference between hard and soft ores is their respective REEY contents and fractionation patterns. While the soft ore preserves the REEY pattern of the dolomitic itabirite (Fig. 14c), even when the correspondent iron-rich/massive bands and dolomite-rich/porous bands are considered separately (Fig. 14d), the hard ore presents a distinct REEY pattern, characterized by depletion in heavy REE relative to middle REE.

\section{Formation of Tabular and Granular Hematite Within Martite Crystals}

Even though the question of which primary iron minerals precipitated on the sea floor during the growth of the BIFs remains a source of debate in literature, there is a general consensus that they were mostly ferric (hydr)oxides (goethite and/or hematite) (Ohmoto 2003; Trendall 2002). A later process during diagenesis and/or metamorphism transformed the ferric (hydr)oxides into magnetite (Morris 1993; Perry Jr. et al. 1973; Walker 1984; Walker 1987). Magnetite is found ubiquitously in BIFs throughout the world. In the QF region, it is interpreted to be the oldest iron oxide of the iron mineral assemblage (Rosière 1981; Rosière and Chemale Jr. 2000; Rosière et al. 1993; Rosière and Rios 2004). The coarse crystals of magnetite in BIFs of the QF suggest that they were formed during diagenesis and/or metamorphism, considering that primary iron precipitates must have been coloidal.

Magnetite was almost totally oxidized and recrystallized during the metamorphic and tectonic evolution of the BIFs of the Caue Formation (Rosière 1981). The transition from magnetite to martite is less well preserved in the Águas Claras rocks, but it is well documented in other sites in the QF. The most impressive feature observed in this study is the development of hematite within martite crystals. The petrographical analyses indicate that recrystallization of martite during metamorphism and deformation (probably during the Transamazonian Orogenesis) was responsible for the generation of the hematite crystals within martite, according to the mechanisms proposed by Hackspacher et al. (2001), Lagoeiro (1998), Rosière (1981) and Rosière et al. (2001). The degree of recrystallization, however, was not uniform, making it possible to observe the several steps of transformation from martite to tabular hematite, passing through anhedral and granular hematite (Fig. 19). These hematite crystals correspond to the 
Hematite II of Rosière and Rios (2004) and are conspicuously observed in our samples. The passage from martite to tabular hematite in Águas Claras is an intermediate step in the development of specularite, which occurs in high strained zones of the QF, according to Rosière and Rios (2004). Its register in our samples offers further support to the model of those authors.
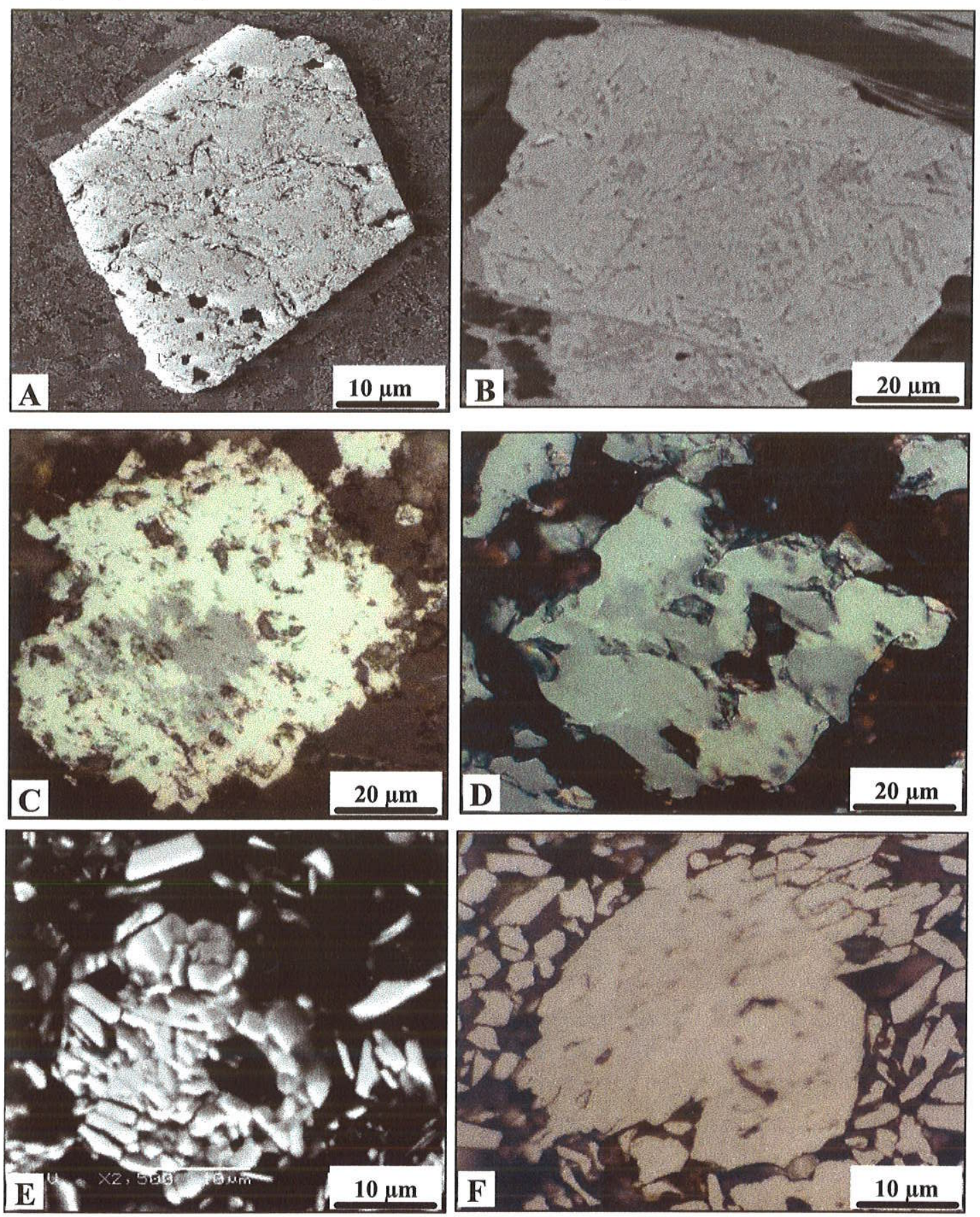

Figure 19 - SEM backscattered images and microphotographs showing several stages of development of hematite crystals after martite. A Euhedral magnetite crystal, partially oxidized, showing small pores, SEM image. B Exmagnetite grains, now completely oxidized to martite, along octahedral planes. C-D Anhedral and tabular hematite forming after martite. E Small crystals of tabular hematite within ex-martite grain. F Partially deformed martite crystal with several tabular hematite within it. 


\section{Comparisons with other iron mines on the western side of the Quadrilátero Ferrifero}

In order to contribute to the discussion on the genesis of iron ores at the Águas Claras mine, we will give a brief presentation of another two, giant, world-class iron mines on the western side of the QF: Capão Xavier and Tamanduá. Capão Xavier is located on the western side and Tamandua on the eastern side of the Moeda Syncline (Fig 1). Geological sections of each mine are presented in Figure 20.

\section{Capão Xavier Mine}

The Capão Xavier orebody is quite similar to the Águas Claras orebody. It consists of a large, concordant lense of high-grade ore hosted within dolomitic itabirite. Soft high-grade ore is largely predominant and represent $82 \%$ of the $233 \mathrm{Mt}$ of geological resources. Hard high-grade ore occurs as local, metric lenses within the soft ore. Low-grade ores $(30 \%<\mathrm{Fe}<64 \%)$, formed from quartz itabirite, are subordinated within the pit of the mine, but widespread outside of this limit, having not been considered in the geological resources mentioned above. Differently from the Águas Claras and Tamanduá, the Capão Xavier's whole structure, and particularly the BIFs, dips gently, with a maximum angle of 45 degrees to the northeast. The weathering front varies in depth from a few meters in the quartz itabirite to more than $300 \mathrm{~m}$ in the dolomitic itabirite. Soft high-grade ore reaches a maximum depth of $280 \mathrm{~m}$. A thick $(5-50 \mathrm{~m})$ transition zone, characterized by high contents of $\mathrm{Al}_{2} \mathrm{O}_{3}$ and $\mathrm{Mn}$, is usually observed in the contact of the soft ore with the dolomitic itabirite. The greater thickness of the transition zone can be attributed to the gentle dip of the dolomitic itabirite in the Capão Xavier orebody, which would have hampered the action of the downward weathering solutions through the banding.

Weathering of the quartz itabirite at the Capão Xavier deposit produced a goethitic rock, called limonitic itabirite. This rock consists essentially of hematite and goethite with subordinated quartz. The iron content of limonitic itabirite decreases in depth into the iron-rich quartz itabirite, according to the gradual reduction of the goethite content and increase of quartz (Fig. 20a). The iron-rich quartz itabirite is a low-grade iron ore $(52 \%<\mathrm{Fe}<64 \%)$ and consists of a soft, powdered, quartz itabirite made up of hematite, with subordinated quartz. The goethite content is variable. With the gradual increase of quartz in the iron-rich itabirite, the iron content reduces, and the rock is called soft itabirite. Soft itabirite is also considered a low-grade ore $(30 \%<\mathrm{Fe}<52 \%)$, with an average $\mathrm{Fe}$ content of $46 \%$ at the Capão Xavier deposit. Soft itabirite has a very low goethite content and grades to hard quartz itabirite, with an intermediate stage of weathering alteration called medium itabirite, which is not represented in the section. Figure 20a 

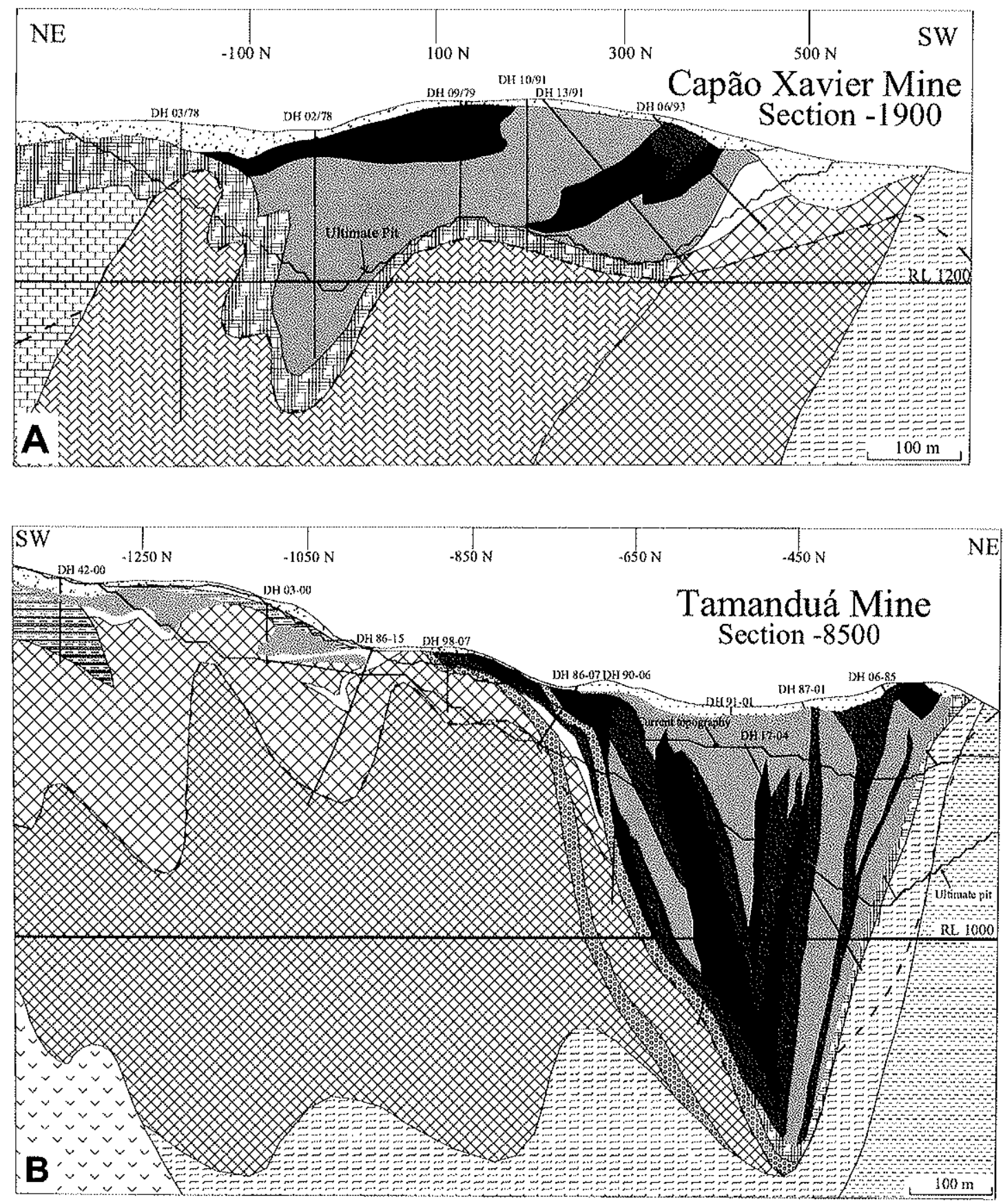

Cauê Formation

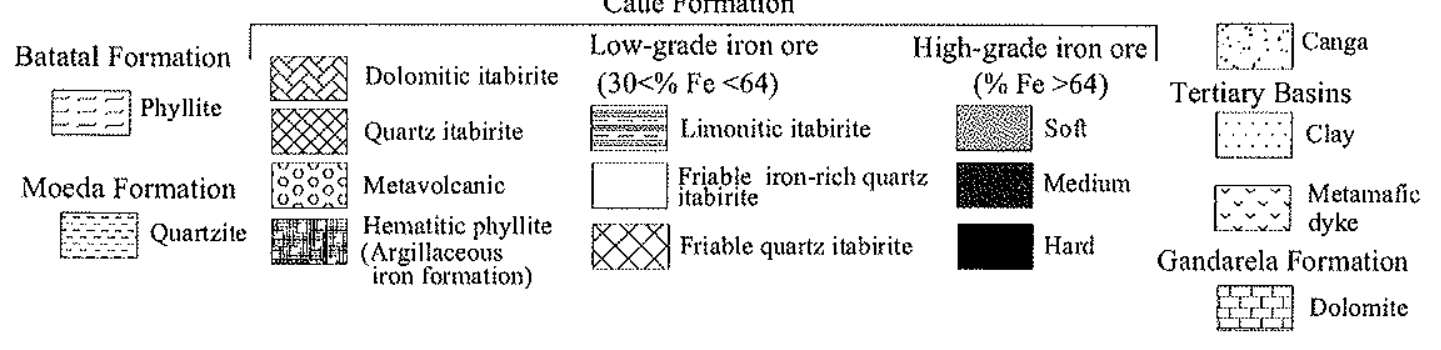

Figure $20-$ Cross sections of the Capão Xavier (A) and Tamanduá (B) mines. 
shows that, though weathering reached a similar depth in the dolomitic and quartz itabirites, its final result is quite different. While high-grade iron ore was produced from the dolomitic itabirite, from the quartz itabirite only low-grade ore was formed. Otherwise, both protores show a transition zone from the BIF to the iron ore, with an iron-enrichment from the bottom to the top of the weathering profile, more gradual in the quartz itabirite profile than in the dolomitic itabirite profile.

Tertiary basins of up to $200 \mathrm{~m}$ long and $80 \mathrm{~m}$ depth occur locally at the Capão Xavier deposit, blanketing the soft ore and the iron-rich and soft itabirites. These basins were originally filled with kaolinitic sediments that were almost totally transformed into bauxite through weathering processes (Pomerene 1964; Maizatto 2001). The occurrence of Tertiary bauxite deposits covering the high- and low-grade ores at the Capão Xavier deposit illustrates the strong action of weathering in the $\mathrm{QF}$ region during the Tertiary.

Thus, the soft high-grade ore of this mine must have been formed by weathering of the dolomitic itabirite protore. The field relationships indicate that, under the same weathering and structural conditions, dolomitic itabirite is much more favorable to the formation of high-grade iron ore deposits than quartz itabirite.

\section{Tamanduá Mine}

The Tamanduá deposit is located in the Tamanduá Syncline, which is a second-order fold of the Moeda Syncline (Fig. 1). The orebody, hosted within quartz itabirite, strikes NW/SE, subparallel to the eastern limb of the Moeda Syncline (Fig. 1). In this area, the Caue Formation is 2,000 $\mathrm{m}$ thick, due to folding. The orebody is transversally cut by two strike-slip faults hosting important dykes mostly of basic composition, which limits the orebody and divides it in three domains. The richest and thickest high-grade bodies are located in the central domain, within a syncline, in contact with phyllite (Fig. 20b).

The Tamanduá orebody is composed of soft, high-grade ore, with lenses of hard ore, and low-grade ore. Soft and hard ores represent $80 \%$ and $20 \%$, respectively, of the $297 \mathrm{Mt}$ of highgrade resources. Low-grade ore comprises $480 \mathrm{Mt}$ of iron-rich itabirite, soft-itabirite and limonitic itabirite. The orebody is approximately $2.800 \mathrm{~m}$ long and $400 \mathrm{~m}$ thick.

High-grade ores occur mainly within the syncline, in contact with the phyllite, where lenses of hard ore, strongly fractured, occur involved by medium and soft high-grade ores and by iron-rich/soft itabirites, forming a complex arrangement (Fig. 20b). The soft ore reaches more than $500 \mathrm{~m}$ depth in this site. The hard orebodies may be massive or porous, and their shapes 
are controlled by mesoscopic, acilindric, SE-plunging folds. Hard, schistose ore occurs in the central domain of the Tamanduá deposit and is related to oblique shear zones. Subordinated high-grade orebodies occur on the western side of the deposit, immediately below the canga surface. The contact between hard ore and fresh itabirite observed in drill cores are sharp or gradual for the protore into a few decimeters (Fig. 21a-b). Generally this contact is highly fractured, which would favor the circulation of ground water. The contact between the soft ore and the low-grade ore is gradual when it occurs close to the topographic surface and sharp when it occurs in greater depths (Fig. 21c).
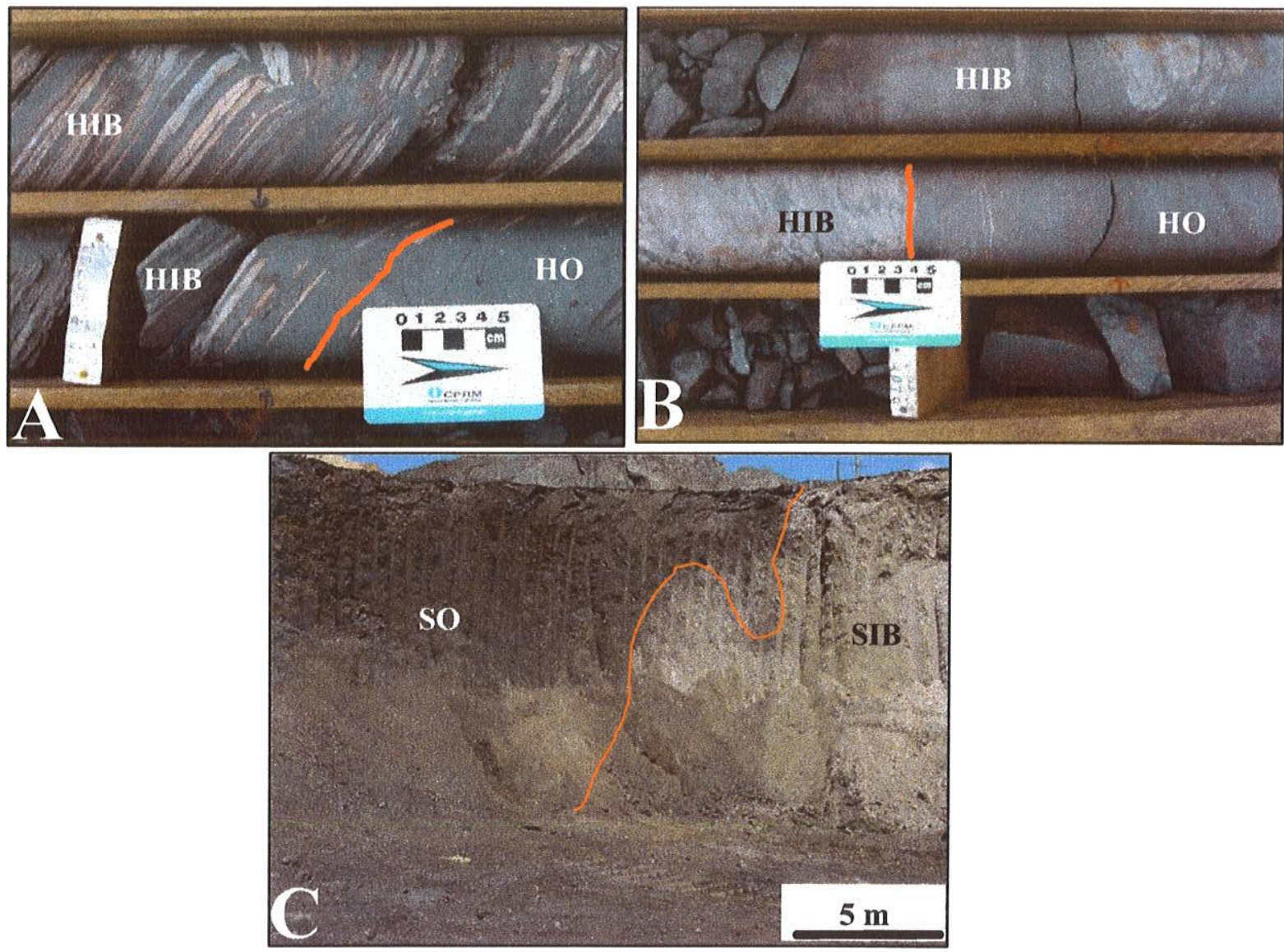

Figure 21 - Drilling cores and mine exposure and of the Pico mine showing contacts between iron ore and quartz itabirite. A-B Contact between high-grade hard ore (HO) and hard quartz itabirite (HIB). C Straight contact between high-grade soft ore (SO) and low-grade soft itabirite (SIB).

Low-grade ores consist of limonitic, iron-rich, and soft itabirites, and are predominate on the western side of the deposit, where the same transition limonitic itabirite $\rightarrow$ iron-rich itabirite $\rightarrow$ soft and medium itabirite $\rightarrow$ hard quartz itabirite observed at the Capão Xavier deposit occurs. The weathering front in the quartz itabirite in this area varies from few meters below the topographic surface down to $250 \mathrm{~m}$ depth (Fig. 20b). Iron-rich and soft itabirites have a high 
content of goethite close to limonitic itabirite, which gradually decreases (and locally disappears) toward the hard quartz itabirite.

The complex interfingering of hard, medium and soft ores within the Tamanduá Syncline (Fig. 20b), the great depths of the soft ore within the syncline and small depths outside it, associated with the gradation from massive hard ore to porous hard ore suggest suggest that mineralization of the quartz itabirite to form the soft high-grade ore in Tamanduá involved at least two different processes: hypogene and supergene. The former was responsible for the development of the hard and probably part of the soft high-grade ores. The latter was responsible for the development of the low-grade ores. This is a good indication that hypogene-supergene modified models were involved in the genesis of the soft high-grade ores of the QF.

\section{Ore Genesis}

Most of the iron ore produced in the world results from the enrichment of precambrian BIFs, but the processes responsible for this enrichment are still unclear and constitute a source of debates in the literature (Dalstra et al. 2002; Kneeshaw and Kepert 2002; Morris 2002a-c). Two end-member genetic models have been proposed: supergene versus hydrothermal enrichment of a BIF protore. Supergene iron ores are the most abundant type of iron ores either in the QF, where they represent more than $70 \%$ of the $27 \mathrm{Gt}$ of geological resources (Gomes, 1986; MBR and CVRD, internal reports), or in the Western Australian Hamersley basin, where the martitegoethite ores account for some $90 \%$ or more of the BIF-derived enrichment ores (Harmsworth et al., 1990; Morris, 2002c). Supergene ore arises by the selective leaching of gangue minerals from the BIF by ground water and the residual accumulation of the iron oxides. Hypogene ores form the richest iron orebodies. Their genesis is ascribed to the interaction of the BIFs with a hydrothermal fluid, which dissolved chert (quartz), leaving pores spaces, that were or not filled by a new generation of iron oxides.

The occurrence of the hard, massive high-grade ores within fresh itabirite at the Águas Claras and Tamanduá mines is a strong evidence of their hypogene origin. This type of ore is similar to those described, for instance, by Taylor et al. (2001), Beukes et al. (2002) and Guedes et al. (2002), which are interpreted as formed by hydrothermal fluids. However, at Águas Claras, petrographic and mineralogic data provide little information regarding the hypogene solutions and their precipitates. Hematite has a very simple chemical composition and a wide stability field, thereby restricting its use in metallogenetic studies. Additional difficulties, such as superimposition of tectonic events and weathering, turn the understanding of the genesis of this 
hard ore into a difficult puzzle. Nevertheless, there are some new insights into this subject. They arose from the infrared microscopic analysis and fluid inclusion studies in hematite carried out by Rosière and Rios (2004). These authors suggest that the formation of the hard massive highgrade orebodies occurred during the Transamazonian event (ca. 2.1-2.0 Ga; Alkmim and Marshak, 1998) and developed in two stages. In the first, contractional stage of the Transamazonian orogeny a pervasive magnetite mineralization occurred in the BIF by reduced metamorphic fluids. Hematite mineralization occurred during the collapse stage of the orogeny, coincident with the uplift of the basement, intrusion of granitic plutons and extension of the crust, and involved low-temperature meteoric fluids moving downwards from the surface along normal faults and fractures. These fluids were also responsible for the oxidation of magnetite (martitization), and were concentrated only at sites of great permeability such as fold hinges, forming the hard, massive high-grade orebodies.

Harder to explain is the origin of the giant, soft high-grade orebodies, such as the Águas Claras orebody. The general lack of typical secondary minerals as goethite in the ore could indicate leaching of gangue minerals from BIFs by hypogene solutions, but in some cases, other arguments point to a supergene origin.

The soft ore at the QF orebodies is generally interlayered with or surrounding the hard, massive, hypogene ores. This relation led many authors (Beukes et al. 2002; Dorr II 1965; Guild 1953; Rosière and Rios 2004) to propose its hypogene-supergene modified origin. Hypogenesupergene modified models comprise an initial, hypogene stage, with either leaching of all the chert from the BIF protore leaving pore spaces (Dorr II 1965; Guild 1953) or with metasomatic replacement of those minerals by carbonates, followed by a supergene stage that leached the hydrotermal minerals formed in the previous stage (Beukes et al. 2002). Águas Claras mine was mentioned by Beukes et al. (2002) as the best example, one where the dolomitic itabirite "obviously developed from the replacement of chert bands in iron-formation". Hypogenesupergene modified genetic models were also proposed for the genesis of the high-grade hematite ores at the Hamersley and Carajás Provinces (Beukes et al. 2002; Guedes et al. 2002; Taylor et al. 2001; Thorne et al. 2004; Webb et al. 2004). Recently, Dalstra and Guedes (2004) suggested that magnetite-carbonate-amphibole, magnetite-carbonate or hematite-carbonate precursors were essential in the formation of high-grade hematite ores worldwide. Their proposed genetic model involves early hydrothermal depletion of silica in the host iron formation and introduction of $\mathrm{Ca}-\mathrm{Fe}-\mathrm{Mg}$-carbonates, followed by supergene leaching of the carbonates, long after they are formed, to create the high-grade hematite ores. 
The use of hypogene- supergene models proposed by Beukes et al. (2002), Dalstra and Guedes (2004) and Rosière and Rios (2004) to explain the genesis of the soft high-grade ore at the Águas Claras and Capão Xavier mines presents some issues that need to be addressed. One of them concerns the origin of the dolomitic itabirite. Beukes et al. (2002) considered the dolomitic itabirite of the Águas Claras mine as a product of dolomitisation of a chert BIF by hydrothermal solutions. However, they did not take into account the regional geological setting. The Cauê Formation (including quartz and dolomitic itabirite) grades upward into the dolomite of the Gandarela Formation, a typical marine sequence hosting stromatolites. The contacts of the Cauê and the Gandarela Formations are laterally and vertically intergradational, and dolomitic itabirite occurs also within the dolomites of the Gandarela Formation (Dorr II, 1969). So, it seems more probable that the dolomitic itabirite represents a carbonatic facies of the Cauê Formation modified by a dolomitization process which occurred during diagenesis, instead of a product of carbonate-rich mineralization of the quartz itabirite. The marine origin of the dolomitic itabirite is also indicated by the $\mathrm{C}$ and $\mathrm{O}$ isotopes of dolomite, which present $\delta^{13} \mathrm{C}$ varying from $-2.5 \%$ оров to $-0.8 \%$ PDB (average of $-1.7 \%$ ), while the oxygen isotope data displays $\delta^{18} \mathrm{O}$ values varying from $-12.4 \%$ PDB to $-8.5 \%$ PDB (average of $-10.5 \%$ ). These values correlate well with those of the stromatolitic carbonates of the Gandarela Formation of the Minas basin (Sial et al. 2000) and also with carbonates of the Wittenoom Formation of the Hamersley basin (Veizer et al. 1990). Isotope data of the dolomitic itabirite are quite different from those found in carbonates of the dolomitised jaspilite of the N4 mine in Carajás and in hypogene carbonates of the North Deposit in Tom Price (Table 6). Depleted $\delta^{13} \mathrm{C}$ values of hypogene carbonates from these mines compared with the values of dolomite of the dolomitic itabirite are additional evidence that this rock was not formed by hydrotermalism of the quartz itabirite.

Table 6 - The $C$ and $O$ isotopic composition of carbonate samples from Águas Claras, and Carajás

\begin{tabular}{|c|c|c|c|c|c|}
\hline \multirow[b]{2}{*}{ Mine } & \multirow[b]{2}{*}{ Alteration Zone } & \multicolumn{2}{|c|}{$\delta^{18} \mathrm{O}\left(\%{ }_{0} \mathrm{PDB}\right)$} & \multicolumn{2}{|c|}{$\delta^{13} \mathrm{C}\left(\%{ }_{0} \mathrm{PDB}\right)$} \\
\hline & & Range & Average & Range & Average \\
\hline Águas Claras ${ }^{(n)}$ & & -12.4 to -8.5 & -10.5 & -2.5 to -0.8 & -1.7 \\
\hline North Deposit (Tom & $\begin{array}{l}\text { Magnetite-siderite- } \\
\text { iron silicate }\end{array}$ & -17.3 to -11.8 & -14.2 & -10.3 to -6.3 & -8.8 \\
\hline Price) ${ }^{(2)}$ & $\begin{array}{l}\text { Hematite-ankerite- } \\
\text { magnetite }\end{array}$ & -16.1 to -13.5 & -16.0 & -7.5 to -0.9 & -4.9 \\
\hline Carajás ${ }^{(3)}$ & & -24.0 to --10.0 & NA & -6.0 to -3.0 & -5.0 \\
\hline
\end{tabular}

(1) Spier et al. (2005a) (2) Thorne et al. (2004) (3) Sial et al. (2000) NA = not available 
Another issue in the hypogene-supergene models of Beukes et al. (2002) and Dalstra and Guedes (2004) regards the protore of the soft high-grade ores. According to the authors, the soft high mgrade ore could not have been formed only from quartz itabirite. Still, thousands of meters of drill cores from the Tamanduá mine and other mines of the region, such as the Capitão do Mato, Pico and Sapecado (Fig. 1), many of them in fresh itabirites, intercept only quartz itabirite. Carbonate-rich altered itabirites have never been found in deepest levels below the water table in these mines. Then, it is highly reasonable to assume that the soft high-grade ores at those mines originated from the quartz itabirite.

Despite the contentions about the origin of the dolomitic itabirite, it is unquestionable that the original composition of the itabiritic protore had a major role in the genesis of high- and low-grade soft ores in the QF, the dolomitic itabirite being the more favorable to form highgrade deposits due to the higher solubility of dolomite in relation to quartz. In fact, although the majority of the iron ore reserves in the QF come from quartz itabirite protore, the richest orebodies come from dolomitic itabirite. This is clearly verified in the Águas Claras and Capão Xavier mines, where the high-grade ores were formed only from the dolomitic itabirite. As to the nature of the mineralizing fluid, Viel et al. (1987) suggested that it was meteoric water enriched in $\mathrm{CO}_{2}$ originated from the decomposition of the superficial vegetation that would have leached dolomite. Hematite was not affected by meteoric solutions (Dorr II 1965; Eichler 1968), remaining residually enriched. Viel et al. (1987) also suggest that, depending on the Eh and $\mathrm{pH}$ of the solution, any ferrous iron present in dolomite would be oxidized and precipitated. The weathering process was highly enhanced by the marked bedding at high angle to the ground surface shown by the BIFs in the Águas Claras mine, thus allowing a deep penetration of weathering fluids, abundant in humid tropical climates, especially along fault and fracture planes.

Our petrographic and geochemical data fit well with the model proposed by Viel et al. (1997). They show that the dissolution of the the dolomitic bands of the itabirite generates a highly porous material made of hematite and a brownish residue. Petrographic and Mössbauer analyses indicate that hematite was not affected by the meteoric solutions. Thus, this brownish residue comes from the dolomite dissolution. The dolomite composition is quite constant throughout the whole sequence of dolomitic itabirite at the Águas Claras mine, with average Fe and $\mathrm{Mn}$ contents around 1.5\%. SEM and TEM analyses revealed the presence of iron and manganese oxides within the brownish residue, while MS indicate ferrihydrite in its mineralogical composition. These observations led to the conclusion that the dissolution of 
dolomite during weathering produced solutions carrying $\mathrm{Mn}^{2+}$ and $\mathrm{Fe}^{2+}$, according to the following reaction:

$$
(\mathrm{Ca}, \mathrm{Mg}, \mathrm{Fe}, \mathrm{Mn})\left(\mathrm{CO}_{3}\right)_{2}+2 \mathrm{H}_{2} \mathrm{CO}_{3} \rightarrow \mathrm{Ca}^{2+}+\mathrm{Mg}^{2+}+\mathrm{Fe}^{2++}+\mathrm{Mn}^{2+}+4 \mathrm{HCO}^{-}
$$

Calcium and magnesium were leached out from the weathering profile, while iron and manganese precipitated along pores and fracture planes forming Mn-oxides and ferrihydrite.

The supergene alteration begins along fractures close to the surface and spreads laterally and downward from these zones. At the bottom contact zone of the soft ore with the dolomitic itabirite, the weathering solutions are more saturated in $\mathrm{Ca}$ and $\mathrm{Mg}$ and are, consequently, less reactive, favoring the concentration of less soluble minerals, such as apatite. The interfingering contact observed in this zone reflects the development of the weathering front downwards, along the most favorable, fractured zones, forming the pinnacles and preserving remnants of the dolomitic itabirite.

Kink-bands and slang folds in the soft ore associated with a Tertiary basin situated in the central and deeper part of the Águas Claras orebody also suggest that the soft ore resulted from the leaching of dolomite by supergene solutions. The removal of large quantities of dolomite created large pore space volumes in the soft ore, which collapsed, forming kink-bands and slang folds, according to the model described by Ribeiro (2003) and Ribeiro and Carvalho (2002) for the soft itabirite of the Pico mine. This process produced depressions in the central part of the orebody, which were filled by sediments of Tertiary age, according to palynological studies of Lima and Salard-Cheboldaeff (1981) and Maizatto (2001). ${ }^{40} \mathrm{Ar} /{ }^{39} \mathrm{Ar}$ dating of supergene Mnoxides hosted within the soft iron ore of the Sapecado mine carried out by Spier et al. (2005b) suggests that most of the soft ore in the QF was formed during a major, intense, chemical weathering period, around 51-41 Ma.

An additional evidence to support our hypothesis comes from the presence of poorly crystalline ferrihydrite within the porous bands of the soft ore. This mineral is widespread in surface environments and, unless stabilized in some way, is transformed into more stable goethite or hematite. Ferrihydrite can be produced from $\mathrm{Fe}^{\mathrm{II}}$ solutions by fast oxidation followed by hydrolysis in $\mathrm{pH}<5$. The rate of oxidation governs the formation of goethite (slow oxidation) or ferrihydrite (fast oxidation). Due to its metastable nature, ferrihydrite can only be expected to be found in environments where its transformation into more stable oxides is inhibited or retarded (Cornell and Schwertmann 1996). According to Cornell (1988), the presence of transition elements such as $\mathrm{Mn}$ can stabilize ferrihydrite. The close association of Mn-oxides with ferrihydrite in the residue of the dolomite dissolution could, therefore, have been 
responsible for inhibiting the transformation of ferrihydrite into hematite or goethite. Ferrihydrite transforms into hematite at temperatures as low as $4^{\circ} \mathrm{C}$, and the higher the temperature, the higher the formation of hematite (Schwertmann et al. 1985). Thus, if the soft ore had been produced by the leaching of dolomite by hypogene solutions, ferrihydrite would not be expected to be found.

Another important feature shown by the soft ore is the REEY distribution pattern, very similar to that of the dolomitic itabirite (Fig. 14c). Even when the massive and porous bands of the soft ore are considered separately, the REEY pattern is the same, as shown in Figs. $14 \mathrm{~b}$ and d. Figure $14 \mathrm{~d}$ and Table 3 show that REEY are concentrated in the dolomitic bands of the protore. The leaching of dolomite promoted the REEY enrichment in the porous bands of the soft ore and depletion in the massive bands, but the original trend was preserved. This can be explained by taking into account that REEY in the dolomitic bands of the dolomitic itabirite are associated mainly with the clastic contamination of these predominantly chemical sediments (Spier et al. 2005a). Depletion in REEY in the massive bands of the soft ore in relation to the iron-rich bands of the protore (Fig. 14d) indicates that the REEY were mostly in dolomite which was leached away during weathering.

In summary, many features observed in the soft high-grade ore of the Águas Claras mine, such as: (1) gradual transition from the dolomitic itabirite into the soft ore; (2) disappearance of the soft ore down dip, leaving pinnacles formed by dolomitic itabirite; (3) pockets of dolomitic itabirite within the soft ore; (4) occurrence of slump folds in the soft ore, and Tertiary basins locally blanketing the orebody; (6) petrographic evidences of dolomite dissolution forming Mnoxides and ferrihydrite, and (7) a similar REEY pattern for the dolomitic itabirite and the soft ore indicate that soft high-grade ore in the Águas Claras mine was formed by leaching of dolomite from the dolomitic itabirite by meteoric water.

The occurrence of bauxite deposits formed from Tertiary kaolinitic sediments locally blanketing the high- and low-grade ores of the Capão Xavier mine is a strong evidence that the chemical weathering in the region was intense. It was enough to leach dolomite from the dolomitic itabirite of the Águas Claras and Capão Xavier mines, but was not able to form large volumes of soft high-grade ores from quartz itabirite in either mine. On the other hand, at the Tamanduá mine, quartz itabirite was the protore of the huge soft high-grade orebody. It is unlikely that the soft ore could have been formed by meteoric leaching from quartz itabirite in this mine, unless another structural control, such as metavolcanic or mafic dykes, acting as impermeable barriers, had played an important role. This hypothesis needs to be considered, but 
there are many field relationships previously mentioned in the text which favor the genesis of soft ores in the Tamanduá mine by hypogene solutions.

\section{CONCLUSIONS}

The detailed mineralogical and geochemical study of the soft and hard high-grade ores in the Águas Claras mine showed a very simple mineralogical and chemical composition. Both ores consist essentially of hematite, occurring as martite, anhedral to granular/tabular hematite and, locally specularite. Hematite is very pure and well crystallized. It occurs growing over martite crystals or as individual crystals. Gangue minerals are very rare, consisting of dolomite, sericite, chlorite and apatite in the hard and soft ores, and Mn-oxides and ferrihydrite in the soft ore, where they are concentrated within the porous bands. Hard and soft ores consist almost entirely of $\mathrm{Fe}_{2} \mathrm{O}_{3}$, with higher amount of detrimental impurities, especially $\mathrm{MnO}$, in the soft ore. Both hard and soft ores are very low in trace elements. The soft ore preserves the REEY pattern of the dolomitic itabirite, suggesting that weathering promoted a residual enrichment in REEY, without fractionation.

Field relationships, petrological and geochemical data indicate that the high-grade ores at the Águas Claras mine have a dual origin, involving hypogene and supergene processes. The occurrence of the hard massive high-grade ore within fresh dolomitic itabirite is a good evidence of its hypogene origin. Microstructures and granoblastic fabric of the hard ore indicate that its genesis occurred prior to or concomitant with the main deformational event that affected the rocks at the western side of the QF, during the Transamazonian orogeny (2.1-2.0 Ga). Mineralogical and geochemical data provided little information regarding the hypogene solutions and their precipitates at the Águas Claras mine. Further investigations on the detailed structural control of the hard high-grade orebodies, combined with microthermometic investigations, are necessary to determine the role of hydrothermal fluids in the formation of the hard high-grade ores at the QF.

Otherwise, despite the arguments about the origin of the dolomitic itabirite, the field relationships, mineralogical and geochemical data strongly indicate the supergene origin of the soft high-grade ore of the Águas Claras mine. Weathering of the dolomitic itabirite leached dolomite, leaving a highly porous, saprolitic ore, consisting almost entirely of hematite with very subordinated gangue minerals. Among these are Mn-oxides and ferrihydrite, precipitated along 
pores and fractures planes of the ore from solutions carrying $\mathrm{Mn}^{2+}$ and $\mathrm{Fe}^{2+}$ liberated during dolomite dissolution. The occurrence of ferridydrite in the soft ore is a good evidence of its supergene origin. Data from palynological studies carried out in sediments of basins that blanket some high-grade deposits in the $\mathrm{QF}$, associated with ${ }^{40} \mathrm{Ar} /{ }^{39} \mathrm{Ar}$ dating of supergene Mn-oxides hosted within the soft iron ore of the Sapecado mine, suggest that most of the soft ore in the QF was formed during a major, intense, chemical weathering period, around 51-41 Ma.

The original composition of the itabiritic protore has a major role in the genesis of highand low-grade soft ores in the QF. Under the same weathering and structural conditions, the dolomitic itabirite is more favorable to form high-grade deposits than quartz itabirite, due to the higher solubility of dolomite in relation to quartz. Field relationships at the Águas Claras and Capão Xavier deposits suggest that it is not possible to form huge soft high-grade deposits from quartz itabirite, unless another control, such as impermeable barriers, had played an important role.

The occurrence of huge tonnage of soft ore hosted in quartz itabirite in the Tamaduá deposit, and the close association between hard, medium and soft ores, suggest that all those ores were mostly formed during the hypogene process that generated the hard ore, representing different stages of the hypogene alteration. If this hypothesis is correct, the presence of a carbonate-rich protore is not a necessary condition to the genesis of large high-grade orebodies, as suggested by Beukes et al. (2002) and by Dalstra and Guedes (2004).

Though many issues remain to be clarified, we believe that the hypogene-supergene modified genetic model is the best one to explain the origin of the high-grade ores at the QF. The diversity of geological and structural contexts where the ore occurs suggests the local preponderancy of hypogene or supergene processes in each particular orebody.

\section{Acknowledgements}

This paper is an integral part of the senior author's Ph.D. thesis presented at the Geoscience Institute of the University of São Paulo (USP). This research project was possible thanks to the grant issued by the Comissão de Aperfeiçoamento de Pessoal de Nivel Superior (CAPES) to C.A.S (grant BEX2189/02-0). C.A.S. thanks Minerações Brasileiras Reunidas (MBR) for freeing him of his usual activities as a mine geologist during the period of his stay at the University of Queesnland. We are grateful to the staff of the Center of Microscopy and Microanalyses of the University of Queensland (CMM), particularly Ron Rasch, Grahem Auchterfolie and Kim Sewell, for their assistance. We are also very grateful to Nivaldo Lúcio Speziali for his help with the determination of the unit cell parameters of hematite.

\section{References}

Alkmim, F. F., and Marshak, S., 1998, Transamazonian orogeny in the São Francisco craton, Minas Gerais, Brazil: evidence for Paleoproterozoic collision and collapse in the Quadrilátero Ferrífero: Precambrian Research, v. 90, p. 29-58. 
Babinski, M., Chemale Jr., F., and Van Schmus, W. R., 1995, The Pb/Pb ages of the Minas Supergroup carbonate rocks, Quadrilatero Ferrífero, Brazil: Precambrian Research, v. 72, p. 235-245.

Bau, M., and Dulski, P., 1996, Distribution of yttrium and rare-earth elements in the Penge and Kuruman iron-formations, Transvaal Supergroup, South Africa: Precambrian Research, v. 79, p. $37-55$.

Beukes, N. J., Gutzmer, J., and Mukhopadhyay, J., 2002, The geology and genesis of high-grade iron ore deposits: Iron Ore 2002, Perth, 2002, p. 23-29.

Cabral, A. R., Rocha Filho, O. G., and Jones, R. D., 2003, Hydrothermal origin of soft hematite ore in the Quadrilatero Ferrífero of Minas Gerais, Brazil: petrographic evidence from the Gongo Soco iron ore deposit: Applied Earth Sciense (Trans. Inst. Min. Metall.B), v. 112, p. B279-B286.

Chemale Jr., F., Rosière, C. A., and Endo, I., 1994, The tectonic evolution of the Quadrilatero Ferrífero, Minas Gerais, Brazil: Precambrian Research, v. 65, p. 25-54.

Childs, C. W., and Baker-Sherman, 1984, Moessbauer spectra and parameters of standard samples 1.: Lower Hutt, New Zealand, Department of Scientific and Industrial Research, New Zealand Soil Bureat, p. 50.

Cornell, R. M., 1988, The influence of some divalent cations on the transformation of ferrihydrate into more crystalline products: Clays and Clay Minerals, v. 23, p. 329-332.

Cornell, R. M., and Schwertmann, U., 1996, The Iron Oxides: Weinheim; New York; Basel ;Cambridge; Tokyo, VCH, 573 p.

Dalstra, H. J., and Guedes, S., 2004, Giant hydrotermal hematite deposits with Mg-Fe metasomatism: a comparison of the Caraj'as, Hamersley, and other iron mines.: Economic Geology, v. 99, p. 1793-1800.

Dalstra, H. J., Harding, A. E., and Taylor, D., 2002, Genesis of high-grade hematite orebodies of the Hamersley Province, Western Australia - a reply: Economic Geology, v. 97, p. 174-176.

Dorr II, J. V. N., 1964, Supergene iron ores of Minas Gerais, Brazil: Economic Geology, v. 59, p. $1203-1240$.

Dorr II, J. V. N., 1965, Nature and origin of the high-grade hematite ores of Minas Gerais, Brazil: Economic Geology, v. 60, p. 1-46.

Dorr II, J. V. N., 1969, Physiographic, stratigraphic and structural development of the Quadrilátero Ferrífero, Minas Gerais, Brazil.: Washington, $110 \mathrm{p}$.

Eichler, J., 1968, O enriquecimento residual e supergênico dos itabiritos através do intemperismo: Geologia, p. 29-40.

Fysh, S. A., and Clark, P. E., 1982, Aluminous hematite: a Mössbauer study: Phy. Chem. Miner., v. 8, p. 257-267.

Gomes, J. C. M., 1986, As minas de Águas Claras, Mutuca, Pico e outros depósitos de minério de ferro no Quadrilátero Ferrífero, Minas Gerais, in Schobbenhaus, C., and Coelho, C. E. S., eds., Principais Depósitos Minerais do Brasil, 2: Brasília, DNPM/CPRM, p. 65-75.

Guedes, S. C., Rosière, C. A., Marley, M., and Lobato, L. M., 2002, Carbonate alteration associated with the Carajás high-grade hematite deposits, Brazil: Iron Ore 2002, Perth, 2002, p. 63-66. 
Guild, P. W., 1953, Iron deposits of the Congonhas District, Minas Gerais, Brazil: Economic Geology, v. 48, p. 639-676.

Hackspacher, P. C., 1979, Strukturelle und texturelle untersuchungen zur internem deformation des eisenreicherzkoerpers der grube "Aguas Claras" bei Belo Horizonte/Minas Gerais, Brasilien: Unpub. Ph.D. thesis, Claust Geol Abh, 164 p.

Hackspacher, P. C., Oliveira Jr., V. T., Siemes, H., Rosière, C. A., and Moreno, M. M. T., 2001, Textures of hematitic and itabiritic iron ores in the Conceição Mine, Quadrilátero Ferrifero, Minas Gerais, Brazil: Z. dt. geol. Ges., v. 152, p. 467-478.

Harder, E. C., and Chamberlain, R. T., 1915, The geology of the central Minas Gerais, Brazil: Journal of Geology, v. 23, p. 341-378, 385-424.

Kneeshaw, M., and Kepert, D. A., 2002, Genesis of high-grade hematite orebodies of the Hamersley Province, Western Australia - a discussion: Economic Geology, v. 97, p. 173176.

Lagoeiro, L. E, 1998, Transformation of magnetite to hematite and its influence on the dissolution of iron oxide minerals: Journal of Metamorphic Geology, v. 16, p. 415-423.

Lima, M. R., and Salard-Cheboldaeff, M., 1981, Palynologie des bassins de Gandarela et Fonseca (Eocene de L'etat de Minas Gerais, Bresil): Boletim Instituto de Geociências Universidade de São Paulo, v. 12, p. 33-54.

Maizatto, J. R., 2001, Análise bioestratigráfica, paleoecológica e sedimentológica das bacias Terciárias do Gandarela e Fonseca - Quadrilátero Ferrífero - com base nos aspectos palinológicos e sedimentares: Unpub. PhD thesis, Universidade Federal de Ouro Preto, 249 p.

McLennan, S. B., 1989, Rare earth elements in sedimentary rocks. Influence of provenance and sedimentary processes, in Lipin, B. R., and McKay, G. A., eds., Geochemistry and Mineralogy of the Rare Earth Elements: Washington, Mineralogical Society of America, p. 169-200.

Morris, R. C., 1993, Genetic modeling for banded iron formation of the Hamersley Group, Pilbara Craton, Western Australia: Precambrian Research, v. 60, p. 243-286.

Morris, R. C., 2002a, Discussion and reply. Opaque mineralogy and magnetic properties of selected banded iron-formations, Hamersley basin, Western Australia: Australian Journal of Earth Sciences, v. 49, p. 579-586.

Morris, R. C., 2002b, Genesis of high-grade hematite orebodies of the Hamersley Province, Western Australia - a discussion: Economic Geology, v. 97, p. 177-181.

Morris, R. C., 2002c, Iron ore genesis and post-ore metasomatism at Mount Tom Price: Iron Ore 2002, Perth, 2002c, p. 3-13.

Murad, E., and Schwertmann, U., 1986, The influence of Al-substitution and crystallinity on room temperature Mössbauer spectrum of hematite: Clays and Clay minerals, v. 34, p. 1-6.

Ohmoto, H., 2003, Nonredox transformations of magnetite-hematite in hydrothermal systems: Economic Geology, v. 98, p. 157-161.

Park, C. F., 1959, Origin of hard hematite in itabirite: Economic Geology, v. 54.

Perry Jr., E. C., Tan, F. C., and G.B., M., 1973, Geology and stable isotope geochemistry of the Biwabik Iron Formation, Northern Minnesota: Economic Geology, v. 68, p. 1110-1225. 
Pires, F. R. M., 1995, Textural and mineralogical variations during metamorphism of the Proterozoic Itabira Iron Formation in the Quadrilátero Ferrifero, Minas Gerais, Brazil: Anais da Academia Brasileira de Ciências, v. 67, p. 77-105.

Pomerene, J. B., 1964, Geology and mineral deposits of the Belo Horizonte, Ibirité and Macacos quadrangles, U.S.G.S. Professional Paper, 341-D, p. 84.

Ramanaidou, E., 1989, Genèse d'un gisement latéritique. Evolution supergène des itabirites protérozo de la mine de fer de Capanema, Minas Gerais, Brésil: Unpub. Ph.D. thesis, Université de Poitiers, 183 p.

Ramanaidou, E., Nahon, D., Decarreau, A., and Melfi, A. J., 1996, Hematite and goethite from duricrusts developed by lateritic chemical weathering of Precambrian banded iron formations, Minas Gerais, Brazil: Clays and Clay Minerals, v. 44, p. 22-31.

Ribeiro, D. T., 2003, Enriquecimento Supergênico de Formações Ferríferas Bandadas: Estruturas de Colapso e Desordem: Unpub. Ph.D. thesis, Universidade Federal do Rio de Janeiro, 123 p.

Ribeiro, D. T., and Carvalho, R. M., 2002, Simulation of weathered iron ore facies: integrating leaching concepts and geostatistical model, in Armstrong, M., Bettini, C., Champigny, N., Galli, A., and Remacre, A., eds., Geostatistics Rio 2000: Dordrecht, Kluwer, p. 101-115.

Rosière, C. A., 1981, Strukturelle und texturelle untersuchungen in der eisenerzlagerstaette "Pico de Itabira" bei itabirito, Minas Gerais, Brasilien. Clausthaler Geowissenschaftliche Dissertationen 9: Unpub. Ph.D. thesis, Clausthal Zellerfeld, 302 p.

Rosière, C. A., and Chemale Jr., F., 2000, Itabiritos e minérios de ferro de alto teor do Quadrilátero Ferrífero - Uma visão geral e discussão: Geonomos, v. 8, p. 27-43.

Rosière, C. A., Chemale Jr., F., and Guimarães, M. L. V., 1993, Um modelo para a evolução microestrutural dos minérios de ferro do Quadrilátero Ferrífero: Parte I - estruturas e recristalização: Geonomos, v. 1, p. 65-84.

Rosière, C. A., and Rios, F. J., 2004, The origin of hematite in high grade iron ores based on infrared microscopy and fluid inclusion studies: the example of the Conceição mine, Quadrilátero Ferrífero, Brazil: Economic Geology, v. 99, p. 611-624.

Rosière, C. A., Siemes, H., Quade, H., Brokmeier, H., and Jansen, E. M., 2001, Microstructures, textures and deformation mechanisms in hematite: Journal of Structural Geology, v. 23, p. 1429-1440.

Schwertmann, U., Cambier, P., and Murad, E., 1985, Properties of goethites of varying crystallinity: Clays and Clay Minerals, v. 33, p. 369-378.

Sial, A. N., Ferreira, V. P., De Almeida, A. R., Romano, A. W., Parente, C. V., Da Costa, M. L., and Santos, V. H., 2000, Carbon isotope fluctuations in Precambrian carbonate sequences of several localities in Brazil: Anais da Academia Brasileira de Ciências, v. 72, p. 539-558.

Spier, C. A., Oliveira, S. M. B., and Rosière, C. A., 2003, Geology and geochemistry of the Águas Claras and Pico iron mines, Quadrilátero Ferrífero, Minas Gerais, Brazil: Mineralium Deposita, v. 38, p. 751 774 .

Spier, C. A., Oliveira, S. M. B., Sial, A. N., and Rios, F. J., 2005a, Geochemistry and genesis of the banded iron formations of the Cauê Formation, Quadrilátero Ferrífero, Minas Gerais, Brazil: Precambrian Research, v. (submitted). 
Spier, C. A., Vasconcelos, P. M., and Oliveira, S. M. B., 2005b, ${ }^{40} \mathrm{Ar} /{ }^{39} \mathrm{Ar}$ Geochronology and the evolution of lateritic iron deposits in the Quadrilátero Ferrifero, Minas Gerais, Brazil: Chemical Geology, v, (submitted).

Taylor, D., Dalstra, H. J., Harding, A. E., Broadbent, G. C., and Barley, M. E., 2001, Genesis of high-grade hematite orebodies of the Hamerley Province, Western Australia: Economic Geology, v. 96, p. 837-873.

Thorne, W. S., Hagemann, S. G., and Barley, M. E., 2004, Petrographic and geochemical evidence for hydrothermal evolution of the North Deposit, Mt Tom Price, Western Australia: Mineralium Deposita.

Trendall, A. F., 2002, The significance of iron-formation in the Precambrian stratigraphic record, in Altermann, W., and Corcoran, P. L., eds., Precambrian Sedimentary Environments: A Modern Approach to Ancient Depositional Systems. Special Publication Number 53 of the International Association of Sedimentologists, Blackwell Sciense.

Trendall, A. F., and Blockley, J. G., 1970, The iron formations of the Precambrian Hamersley Group, Western Australia, with special reference to the associated crocidolite, $365 \mathrm{p}$.

Veizer, J., Clayton, R. N., Hinton, R. W., Von Burn, V., Mason, T. R., Buck, S. G., and Hoefs, J., 1990, Geochemistry of Precambrian carbonates: 3-shelf seas and non-marine environments of the Archean: Geochimica et Cosmochimica Acta, v. 54, p. 2717-2729.

Viel, R. S., Moreira, P. C. H., and Alkmim, F. F., 1987, Faciologia da Formação Cauê e gênese do minério de ferro friável da Mina de Águas Claras, Serra do Curral-Minas Gerais: Simpósio sobre sistemas deposicionais no Pré-Cambriano, Ouro Preto, 1987, p. 137-153.

Walker, J. C. G., 1984, Suboxic diagenesis in banded iron-formations: Nature, v. 309, p. 340342.

Walker, J. C. G., 1987, Was the Archean biosphere upside down?: Nature, v. 329, p. 710-712.

Webb, A. D., Dickens, G. R., and Oliver, N. H. S., 2004, Carbonate alteration of the Upper Mount McRae Shale beneath the martite-microplaty hematite ore deposit at Mount Whaleback, Westen Australia: Mineralium Deposita. 
Appendix 1 - List of the samples, location and analytical procedures

\begin{tabular}{|c|c|c|c|c|c|c|c|c|c|c|c|}
\hline \multicolumn{12}{|c|}{ Hand specimens samples } \\
\hline \multirow[t]{2}{*}{ Sample } & \multicolumn{3}{|c|}{ Coordinates (m) } & \multirow[t]{2}{*}{ Type } & \multirow[t]{2}{*}{ Petrography } & \multirow[t]{2}{*}{ MEV } & \multirow[t]{2}{*}{ XRD } & \multirow[t]{2}{*}{ Rietveld } & \multirow[t]{2}{*}{ Mössbauer } & \multirow{2}{*}{$\begin{array}{c}\text { Chemical } \\
\text { analyses } \\
\text { MBR }\end{array}$} & \multirow{2}{*}{$\begin{array}{l}\text { Chemical } \\
\text { analyses } \\
\text { ACTLAB }\end{array}$} \\
\hline & East & North & Altitude & & & & & & & & \\
\hline $\mathrm{MAC} 2$ & 1589 & -511 & 1050 & $\mathrm{HO}$ & $X$ & & $X$ & & & $\mathrm{X}$ & $\mathrm{X}$ \\
\hline MAC3A & 2272 & -753 & 939 & PB & $\mathrm{X}$ & & $\mathrm{X}$ & & & $X$ & $X$ \\
\hline $\mathrm{MACl} 2$ & 2300 & -720 & 920 & SO & $X$ & & $\mathrm{X}$ & & & $X$ & \\
\hline MACl4 & 2464 & -610 & 920 & SO & $X$ & & $\mathrm{X}$ & & & $X$ & \\
\hline MAC14A & 2464 & -610 & 969 & $\mathrm{MB}$ & & & & & & $X$ & $X$ \\
\hline MAC14B & 2464 & -610 & 969 & PB & & & & & & $X$ & $X$ \\
\hline MAC15 & 1965 & -529 & 917 & PB & $X$ & & $X$ & & & & \\
\hline $\mathrm{MAC} 17 \mathrm{~A}$ & 2270 & -735 & 931 & $\mathrm{SO}$ & $X$ & & $X$ & & & $X$ & $X$ \\
\hline MAC18A & 2308 & -717 & 928 & $\mathrm{SO}$ & $X$ & & $X$ & & & $X$ & \\
\hline MAC19A & 2483 & -655 & 978 & SO & $X$ & $\mathrm{X}$ & $X$ & & & $X$ & \\
\hline MAC20A & 1943 & -500 & 929 & SO & $X$ & & $X$ & & & $X$ & $X$ \\
\hline MAC44 & 1930 & -530 & 899 & $\mathrm{HO}$ & $X$ & & & & & $X$ & $X$ \\
\hline MAC54A & 1859 & -623 & 908 & SO & $X$ & $X$ & $X$ & & & $X$ & \\
\hline MAC55A & 1847 & -572 & 914 & SO & $\mathrm{X}$ & & & & & $X$ & \\
\hline MAC56A & 1883 & -578 & 908 & SO & $X$ & & & & & $X$ & \\
\hline MAC57A & 2181 & -543 & 925 & SO & $X$ & $X$ & & & & $X$ & \\
\hline MAC58A & 2235 & -560 & 925 & SO & $X$ & & & & & $X$ & \\
\hline MAC59A & 2413 & -636 & 954 & $\mathrm{SO}$ & $X$ & $X$ & $X$ & & & $X$ & \\
\hline MAC59H & 2413 & -636 & 954 & MB & & & & & & $X$ & $X$ \\
\hline MAC591 & 2413 & -636 & 954 & PB & & & & & & $\mathrm{X}$ & $\mathrm{X}$ \\
\hline MAC $60 \mathrm{~A}$ & 2930 & -450 & 1210 & SO & $X$ & & $X$ & & & $X$ & $X$ \\
\hline $\mathrm{MAC} 62$ & 1230 & -410 & 1229 & $\mathrm{HO}$ & $X$ & $X$ & $X$ & & & $X$ & \\
\hline MAC67 & 2289 & -579 & 918 & $\mathrm{HO}$ & $X$ & & $X$ & $X$ & $X$ & $X$ & $X$ \\
\hline MAC68 & 1862 & -499 & 965 & $\mathrm{HO}$ & $X$ & & $\mathrm{X}$ & & $X$ & $X$ & $X$ \\
\hline MAC69A & 2320 & -568 & 918 & SO & $X$ & & & & & $X$ & \\
\hline $\mathrm{MAC} 77 \mathrm{~A}$ & 2356 & -642 & 920 & SO & $X$ & & & & & $X$ & \\
\hline MAC84 & 2380 & -670 & 922 & $\mathrm{HO}$ & $X$ & & & & & $X$ & $X$ \\
\hline MAC97 & 1980 & -500 & 932 & $\mathrm{HO}$ & $X$ & $\mathrm{X}$ & $X$ & $X$ & $X$ & $X$ & $X$ \\
\hline MACI0SA & 1400 & -425 & 1167 & $\mathrm{HO}$ & $X$ & & $X$ & & $X$ & $X$ & $X$ \\
\hline $\mathrm{MAC} 105 \mathrm{~B}$ & 1400 & -425 & 1167 & $\mathrm{HO}$ & $X$ & & & & & $X$ & $\mathrm{X}$ \\
\hline $\mathrm{MAC} 107$ & 2350 & -650 & 928 & PB & $X$ & & & & & $X$ & $X$ \\
\hline $\mathrm{MAC} 112$ & 1300 & -410 & 1210 & $\mathrm{HO}$ & $\mathrm{X}$ & & & & & $X$ & \\
\hline MAC115 & 1350 & -420 & 1208 & $\mathrm{HO}$ & $X$ & & & & & $X$ & $X$ \\
\hline MAC126A & 2425 & -603 & 957 & $\mathrm{MB}$ & & & $X$ & & $X$ & $X$ & $X$ \\
\hline $\mathrm{MAC126B}$ & 2425 & -603 & 957 & PB & & & $X$ & & $X$ & $X$ & $X$ \\
\hline $\mathrm{MAC} 127 \mathrm{~A}$ & 2423 & -625 & 956 & $\mathrm{MB}$ & & & $X$ & $X$ & $\mathrm{X}$ & $X$ & $X$ \\
\hline $\mathrm{MAC} 127 \mathrm{~B}$ & 2423 & -625 & 956 & PB & & & $X$ & $X$ & $X$ & $X$ & $\mathrm{X}$ \\
\hline $\mathrm{MACl} 128 \mathrm{~A}$ & 2418 & -649 & 951 & $\mathrm{MB}$ & & & $X$ & & $\mathrm{X}$ & $\mathrm{X}$ & $X$ \\
\hline $\mathrm{MAC} 128 \mathrm{~B}$ & 2418 & -649 & 951 & PB & & & $X$ & & $X$ & $X$ & $X$ \\
\hline $\mathrm{MAC1} 29 \mathrm{~A}$ & 2459 & -594 & 966 & $\mathrm{MB}$ & & & $X$ & & $X$ & $X$ & $X$ \\
\hline $\mathrm{MAC} 129 \mathrm{~B}$ & 2459 & -594 & 966 & $\mathrm{~PB}$ & & & $X$ & & $\mathrm{X}$ & $X$ & $X$ \\
\hline
\end{tabular}

$\mathrm{HO}=$ hard ore; $\mathrm{SO}=$ soft ore; $\mathrm{PB}=$ porous band of the soft ore; $\mathrm{MB}=$ massive band of the soft ore 


\begin{tabular}{|c|c|c|c|c|c|c|c|c|c|}
\hline \multicolumn{10}{|c|}{ Drill core samples } \\
\hline Sample & $\begin{array}{l}\text { Depth along } \\
\text { the drill hole } \\
\text { (m) }\end{array}$ & Type & Petrography & MEV & XRD & Rietveld & Mössbauer & $\begin{array}{l}\text { Chemical } \\
\text { analyses } \\
\text { MBR }\end{array}$ & $\begin{array}{l}\text { Chemical } \\
\text { analyses } \\
\text { ACTLAB }\end{array}$ \\
\hline FSD08-99 & 2.20 & SO & & & & & & X & \\
\hline FSD08-99 & 4.80 & $\mathrm{SO}$ & & & & & & $X$ & \\
\hline FSD08-99 & 7.30 & $\mathrm{SO}$ & & & & & & $X$ & \\
\hline FSD08-99 & 12.50 & $\mathrm{SO}$ & & & & & & $\mathrm{X}$ & \\
\hline FSD08-99 & 13.20 & SO & & & & & & $X$ & \\
\hline FSD08-99 & 14.70 & $\mathrm{SO}$ & & & & & & $X$ & \\
\hline FSD08 99 & 14.80 & SO & & & & & & $\mathrm{X}$ & \\
\hline FSD08-99 & 16.80 & SO & & & & & & $X$ & \\
\hline FSD08 99 & 17.00 & SO & & & & & & $X$ & \\
\hline FSD08-99 & 19.00 & SO & & & & & & $X$ & \\
\hline FSD09 99 & 3.50 & SO & & & & & & $X$ & \\
\hline FSD09-99 & 4.10 & $\mathrm{SO}$ & & & & & & $X$ & \\
\hline FSD09-99 & 8.60 & SO & & & & & & $X$ & \\
\hline FSD09-99 & 10.50 & SO & & & & & & $X$ & \\
\hline FSD09-99 & 12.50 & SO & & & & & & $X$ & \\
\hline FSD09-99 & 13.50 & $\mathrm{SO}$ & & & & & & $X$ & \\
\hline FSD09-99 & 19.70 & SO & & & & & & $X$ & \\
\hline FSD09-99 & 20.90 & SO & & & & & & $X$ & \\
\hline FSD09-99 & 24.70 & SO & & & & & & $X$ & \\
\hline FSD09-99 & 27.70 & SO & & & & & & $X$ & \\
\hline FSD09-99 & 28.70 & $\mathrm{SO}$ & & & & & & $X$ & \\
\hline FSD $11 \times 99$ & 2.50 & SO & $X$ & $X$ & & & & $X$ & \\
\hline FSD11-99 & 4.80 & SO & & & & & & $X$ & $X$ \\
\hline FSD 1 1-99 & 5.50 & SO & & & & & & $X$ & \\
\hline FSD1 1 199 & 5.70 & SO & & & & & & $X$ & \\
\hline FSD 1 1-99 & 5.80 & $\mathrm{SO}$ & & & & & & $\mathrm{X}$ & \\
\hline FSD $11-99$ & 6.50 & SO & & & & & & $X$ & \\
\hline FSD $11-99$ & 6.80 & $\mathrm{SO}$ & & & & & & $X$ & \\
\hline FSD11.99 & 7.00 & $\mathrm{SO}$ & & & & & & $X$ & \\
\hline FSD $11-99$ & 7.10 & $\mathrm{SO}$ & & & & & & $X$ & \\
\hline FSD 1 1 199 & 8.30 & SO & & & & & & $X$ & \\
\hline FSD $11 \ldots 99$ & 8.50 & SO & & & & & & $\mathrm{X}$ & \\
\hline FSD11-99 & 8.60 & $\mathrm{SO}$ & & & & & & $X$ & \\
\hline FSD 1 1-99 & 8.90 & SO & & & & & & $X$ & \\
\hline FSD1 1-99 & 9.20 & SO & & & & & & $X$ & \\
\hline FSD 1 1-99 & 12,40 & $\mathrm{SO}$ & & & & & & $X$ & $X$ \\
\hline FSD1 1-99 & 13.40 & SO & & & & & & $X$ & \\
\hline FSD 11 1 99 & 20.40 & $\mathrm{SO}$ & & & & & & $X$ & \\
\hline ESD11-99 & 22.80 & SO & & & & & & $X$ & \\
\hline FSD $11 \ldots 99$ & 25.50 & SO & & & & & & $\mathrm{X}$ & \\
\hline FSD11-99 & 25.70 & $\mathrm{SO}$ & & & & & & $X$ & $X$ \\
\hline FSD 1 1-99 & 26.30 & SO & & & & & & $\mathrm{X}$ & \\
\hline FSD 1 1-99 & 26.50 & SO & & & & & & $X$ & \\
\hline FSD 1 1-99 & 26.70 & SO & & & & & & $X$ & \\
\hline FSD 1 1-99 & 28.30 & $\mathrm{SO}$ & & & & & & $\mathrm{X}$ & \\
\hline
\end{tabular}

$\mathrm{HO}=$ hard ore; $\mathrm{SO}=$ soft ore; $\mathrm{PB}=$ porous band of the soft ore; $\mathrm{MB}=$ massive band of the soft ore 


\begin{tabular}{|c|c|c|c|c|c|c|c|c|c|c|c|}
\hline Sample & $\mathrm{MAC} 2$ & $\mathrm{MAC} 44$ & $\mathrm{MAC67}$ & MAC68 & MAC84 & MAC97 & MAC105A & $\mathrm{MAC} 105 \mathrm{~B}$ & $\mathrm{MAC} 115$ & PZ55AM7 & MACI7A \\
\hline $\begin{array}{c}\text { Ore Type } \\
\text { Wt } \%\end{array}$ & $\mathrm{HO}$ & $\mathrm{HO}$ & $\mathrm{HO}$ & $\mathrm{HO}$ & $\mathrm{HO}$ & $\mathrm{HO}$ & $\mathrm{HO}$ & $\mathrm{HO}$ & $\mathrm{HO}$ & $\mathrm{HO}$ & SO \\
\hline $\mathrm{SiO}_{2}$ & 0.48 & 0.24 & 0.93 & 0.71 & 0.36 & 1.32 & 0.57 & 0.77 & 0.89 & 0.99 & 0.42 \\
\hline $\mathrm{Al}_{2} \mathrm{O}_{3}$ & 0.12 & 0.14 & 0.20 & 0.25 & 0.02 & 0.91 & 0.16 & 0.13 & 0.41 & 0.21 & 0.24 \\
\hline $\mathrm{Fe}_{2} \mathrm{O}_{3}$ & 97.46 & 96.40 & 95.11 & 98.19 & 98.58 & 95.00 & 97.86 & 97.94 & 97.51 & 94.44 & 98.38 \\
\hline Fetot & 99.46 & 99.40 & 96.00 & 98.96 & 98.84 & 95.00 & 98.40 & 98.50 & 98.00 & 94.44 & 98.49 \\
\hline $\mathrm{FeO}$ & 1.80 & 2.70 & 0.80 & 0.69 & 0.23 & na & 0.49 & 0.50 & 0.44 & na & 0.10 \\
\hline $\mathrm{MnO}$ & 0.021 & 0.034 & 0.019 & 0.010 & 0.049 & 0.005 & 0.008 & 0.005 & 0.018 & 0.093 & 0.492 \\
\hline $\mathrm{MgO}$ & $<0.03$ & 0.08 & 0.59 & 0.05 & $0.0 S$ & 1.20 & 0.04 & 0.14 & 0.23 & 0.27 & 0.06 \\
\hline $\mathrm{CaO}$ & 0.03 & 0.16 & 0.89 & 0.04 & 0.29 & 0.26 & 0.16 & 0.35 & 0.34 & 1.41 & $<0.03$ \\
\hline $\mathrm{Na}_{2} \mathrm{O}$ & $<0.01$ & $<0.01$ & 0.01 & 0.37 & $<0.01$ & 0.22 & $<0.01$ & $<0.01$ & $<0.01$ & $<0.01$ & $<0.01$ \\
\hline $\mathrm{K}_{2} \mathrm{O}$ & $<0.01$ & 0.06 & 0.06 & 0.06 & 0.08 & $<0.01$ & 0.05 & 0.05 & 0.14 & $<0.01$ & $<0.01$ \\
\hline $\mathrm{TiO}_{2}$ & 0.009 & 0,018 & 0.017 & 0.006 & 0.017 & 0,033 & 0.012 & 0.007 & 0.030 & 0.024 & 0.009 \\
\hline $\mathrm{P}_{2} \mathrm{O}_{5}$ & 0.06 & 0.12 & 0.18 & 0.03 & 0.22 & 0.17 & 0.14 & 0.18 & 0.017 & 0.18 & $<0.03$ \\
\hline LOI & 0.27 & 0.24 & 1.39 & 0.13 & 0.43 & 0.89 & 0.28 & 0.32 & 0.21 & 1.17 & 0.54 \\
\hline $\begin{array}{l}\text { Total } \\
\text { ppm }\end{array}$ & 100.34 & 100.21 & 100.20 & 100.54 & 100.34 & 100.02 & 99.78 & 100.41 & 100.40 & 98.80 & 100.26 \\
\hline $\mathrm{Ba}$ & 15.3 & 4.4 & 10.9 & 37.2 & 9.9 & 3.7 & 8.2 & 6.0 & 24.0 & $<3.0$ & 21.7 \\
\hline $\mathrm{Sr}$ & 7.8 & $<2.0$ & 7.6 & 2.3 & 8.4 & 2.1 & 8.8 & 8.7 & 9.3 & 5.6 & 9.3 \\
\hline$Y$ & 7.6 & 6.2 & 4.6 & 2.2 & 4.6 & 3.5 & 6.1 & 5.8 & 5.2 & 4.1 & 12.7 \\
\hline $\mathrm{Sc}$ & $<3.0$ & $<3.0$ & $<3.0$ & $<3.0$ & $<3.0$ & $<3.0$ & $<3.0$ & $<3.0$ & $<3.0$ & $<3,0$ & $<3.0$ \\
\hline $\mathrm{Zr}$ & 3.3 & 2.4 & 4.0 & 4.5 & 7.8 & 7.9 & 6.7 & 2.5 & 4.1 & 15.1 & 4.3 \\
\hline $\mathrm{Be}$ & $<3.0$ & $<3.0$ & $<3.0$ & $<3.0$ & $<3.0$ & $<3.0$ & $<3.0$ & $<3,0$ & $<3.0$ & $<3.0$ & $<3.0$ \\
\hline V & 132.0 & 32.0 & 10.0 & 24.0 & 17.0 & 29.7 & 17.2 & 13.1 & 36.3 & 45.0 & 30.0 \\
\hline $\mathrm{Ni}$ & $<20.0$ & 20.3 & $<20.0$ & $<20.0$ & $<20.0$ & 45.0 & $<20.0$ & $<20.0$ & $<20.0$ & $<20.0$ & 31.6 \\
\hline $\mathrm{Cu}$ & 15.1 & $<5.0$ & $<5.0$ & 22.0 & $<5.0$ & $<5.0$ & $<5.0$ & 13.6 & 13.6 & 10.2 & $<5.0$ \\
\hline $\mathrm{Zn}$ & 31.1 & $<30.0$ & $<30.0$ & $<30.0$ & $<30.0$ & $<30.0$ & $<30.0$ & $<30.0$ & $<30.0$ & $<30.0$ & 40.6 \\
\hline $\mathrm{Ga}$ & $<1.0$ & $<1.0$ & $<1.0$ & $<1,0$ & $<1.0$ & 1.2 & $<1.0$ & $<1.0$ & $<1.0$ & $<1.0$ & 1.1 \\
\hline $\mathrm{Ge}$ & 4.7 & 5.9 & 6.0 & 4.1 & 3.4 & 4.8 & 3.7 & 3.2 & 2.8 & 4.9 & 3.8 \\
\hline $\mathrm{Rb}$ & 1.2 & $<1.0$ & $<1.0$ & 1.9 & $<1.0$ & $<1.0$ & $<1.0$ & $<1.0$ & 1.1 & $<1.0$ & $<1.0$ \\
\hline $\mathrm{Nb}$ & $<0.2$ & $<0.2$ & $<0.2$ & 0.7 & $<0.2$ & 1.0 & 0.6 & 0.7 & 0.8 & $<0.2$ & $<0,2$ \\
\hline Mo & 3.4 & 3.2 & $<2.0$ & $<2.0$ & $<2.0$ & $<2.0$ & $<2.0$ & $<2.0$ & $<2,0$ & $<2.0$ & 2.4 \\
\hline $\mathrm{Ag}$ & 3.8 & 1.3 & 1.0 & $<0.5$ & 0.8 & $<0.5$ & $<0.5$ & $<0.5$ & $<0.5$ & $<0.5$ & 1.3 \\
\hline In & $<0.1$ & $<0.1$ & $<0.1$ & $<0.1$ & $<0.1$ & $<0.1$ & $<0.1$ & $<0.1$ & $<0.1$ & $<0.1$ & $<0.1$ \\
\hline $\mathrm{Sn}$ & $<1.0$ & $<1.0$ & 3.6 & $<1.0$ & $<1.0$ & $<1.0$ & $<1.0$ & $<1,0$ & $<1.0$ & $<1.0$ & $<1.0$ \\
\hline $\mathrm{Cs}$ & $<0.1$ & $<0.1$ & 0.2 & $<0.1$ & $<0.1$ & 0.1 & $<0.1$ & $<0.1$ & $<0.1$ & $<0.1$ & $<0.1$ \\
\hline ¿REE & 10.0 & 7.5 & 6.6 & 3.2 & 6.1 & 6.9 & 8.7 & 8.1 & 8.3 & 5.2 & 18.2 \\
\hline Hf & $<0.1$ & $<0.1$ & $<0.1$ & $<0.1$ & 0.1 & 0.1 & $<0.1$ & $<0.1$ & $<0.1$ & $<0.1$ & $<0.1$ \\
\hline $\mathrm{Tl}$ & $<0.1$ & $<0.1$ & $<0.1$ & $<0.1$ & $<0.1$ & $<0.1$ & $<0.1$ & $<0.1$ & $<0.1$ & $<0.1$ & $<0.1$ \\
\hline $\mathrm{Pb}$ & 29.0 & 13.2 & $<5.0$ & $<5.0$ & 21.8 & $<5.0$ & $<5.0$ & $<5.0$ & $<5.0$ & $<5.0$ & 10.6 \\
\hline $\mathrm{Bi}$ & $<0.1$ & $<0.1$ & $<0.1$ & 0.1 & $<0.1$ & 0.1 & $<0.1$ & 0.1 & $<0.1$ & $<0.1$ & $<0.1$ \\
\hline Th & 0.15 & 0.11 & 0.16 & 0.05 & 0.15 & 0.44 & 0.22 & 0.30 & 0.45 & 0.1 & 0.3 \\
\hline$U$ & 12.3 & 3.8 & 0.6 & 2.6 & 4.8 & 8.4 & 2.6 & 2.3 & 3.7 & 3.6 & 3.2 \\
\hline All & $<2.0$ & $<2.0$ & $<2.0$ & $<2.0$ & $<2.0$ & $<2.0$ & 10.0 & na & na & $<2.0$ & 18.0 \\
\hline As & 12.6 & 23.1 & 6.3 & 15.8 & 12.6 & 19.8 & 8.8 & $<5.0$ & 5.1 & 17.3 & 9.8 \\
\hline $\mathrm{Br}$ & $<0.5$ & $<0.5$ & $<0.5$ & $<0.5$ & $<0.5$ & $<0.5$ & $<0.5$ & na & na & $<0.5$ & $<0.5$ \\
\hline $\mathrm{Cr}$ & 71.0 & 202.0 & 170.0 & 36.0 & 52.0 & 23.0 & 29.0 & $<20.0$ & 25.0 & 65.0 & 192.0 \\
\hline Ir & $<5.0$ & $<5.0$ & $<5.0$ & $<5.0$ & $<5.0$ & $<5.0$ & $<5.0$ & na & $\mathrm{na}$ & $<5.0$ & $<5.0$ \\
\hline $\mathrm{Sb}$ & 6.2 & 4.6 & 2.1 & 4.1 & 6.9 & 4.4 & 3.7 & 2.0 & 2.2 & 4.1 & 2.2 \\
\hline $\mathrm{Sc}$ & 1.0 & 0.6 & 0.4 & 0.1 & 0.5 & 0.7 & 0.5 & na & na & 0.3 & 1.0 \\
\hline $\mathrm{Se}$ & $<3.0$ & $<3.0$ & $<3.0$ & $<3.0$ & $<3.0$ & $<3.0$ & $<3.0$ & $\mathrm{na}$ & ná & $<3.0$ & $<3.0$ \\
\hline Fe\# & 0.980 & 0.970 & 0.991 & 0.992 & 0.997 & na & 0.994 & 0.994 & 0.995 & na & 0.999 \\
\hline
\end{tabular}

$\mathrm{HO}=$ hard ore; $\mathrm{SO}=$ Soft ore; $\mathrm{MB}=$ Massive band of the soft ore; $\mathrm{PB}=$ Porous band. Fe expressed as $\mathrm{Fe}_{2} \mathrm{O}_{3}$.

$\mathrm{Fe} t=\left(\mathrm{Fe}^{3+} /\left(\mathrm{Fe}^{3+}+\mathrm{Fe}^{2+}\right)\right.$, na $=$ not analyzed 


\begin{tabular}{|c|c|c|c|c|c|c|c|c|c|c|c|}
\hline Sample & M20A & M60A & $\begin{array}{c}\text { FSD8/ } \\
4.8 \mathrm{~m}\end{array}$ & $\begin{array}{l}\text { FSD8/ } \\
7.30 \mathrm{~m}\end{array}$ & $\begin{array}{l}\text { FSD } 8 / \\
12.50 \mathrm{~m}\end{array}$ & $\begin{array}{l}\text { FSD81 } \\
14.70 \mathrm{~m}\end{array}$ & $\begin{array}{l}\text { FSD } 8 / \\
16.8 \mathrm{~m}\end{array}$ & $\begin{array}{l}\mathrm{FSD} 8 / \\
19.0 \mathrm{~m}\end{array}$ & $\begin{array}{l}\text { FSD9/ } \\
3.50 \mathrm{~m}\end{array}$ & $\begin{array}{l}\text { FSD9/ } \\
8.60 \mathrm{~m}\end{array}$ & $\begin{array}{l}\text { FSD9/ } \\
24.70 \mathrm{~m}\end{array}$ \\
\hline $\begin{array}{c}\text { Ore Type } \\
\text { Wt\% }\end{array}$ & SO & SO & SO & SO & so & $\mathrm{SO}$ & SO & SO & so & SO & SO \\
\hline $\mathrm{SiO}_{2}$ & 0.24 & 0.18 & 2.05 & 1.14 & 1.95 & 0.93 & 1.62 & 1.08 & 1.41 & 1.02 & 2.85 \\
\hline $\mathrm{Al}_{2} \mathrm{O}_{3}$ & 0.18 & 0.33 & 1.26 & 0.33 & 0.63 & 0.33 & 0.57 & 0.33 & 0.69 & 0.45 & 2.1 \\
\hline $\mathrm{Fe}_{2} \mathrm{O}_{3}$ & 97,43 & 97.90 & 90.49 & 95.31 & 93.21 & 95.52 & 93.09 & 94.68 & 93.48 & 95.46 & 89.19 \\
\hline Fetot & 97.59 & 98.07 & 90.55 & 95.37 & 93.27 & 95.58 & 93.15 & 94.74 & 93.54 & 95.52 & 89.25 \\
\hline $\mathrm{FeO}$ & 0.14 & 0.15 & 0.05 & 0.05 & 0.05 & 0.0 .5 & 0.05 & 0.05 & 0.05 & 0.05 & 0.05 \\
\hline $\mathrm{MnO}$ & 0.525 & 0.73 & 1.378 & 0.705 & 1.2 & 0.726 & 1.587 & 1.242 & 1.092 & 0.846 & 2.139 \\
\hline $\mathrm{MgO}$ & 0.06 & 0.06 & 0.75 & 0.3 & 0.69 & 0.24 & 0.39 & 0.27 & 0.36 & 0.36 & 0.36 \\
\hline $\mathrm{CaO}$ & 0.06 & $<0.03$ & 0.39 & 0.15 & 0.21 & 0.12 & 0.18 & 0.15 & 0.15 & 0.12 & 0.18 \\
\hline $\mathrm{Na}_{2} \mathrm{O}$ & $<0.01$ & $<0.01$ & 0.39 & 0.36 & 0.45 & 0.33 & 0.45 & 0.39 & 0.39 & 0.42 & 0.36 \\
\hline $\mathrm{K}_{2} \mathrm{O}$ & $<0.01$ & $<0.01$ & 0.03 & 0.24 & 0.3 & 0.005 & 0.21 & 0.09 & 0,09 & 0.005 & 0.005 \\
\hline $\mathrm{TiO}_{2}$ & 0.009 & 0.009 & 0.155 & 0.024 & 0.048 & 0.021 & 0.045 & 0.021 & 0.045 & 0.045 & 0.156 \\
\hline $\mathrm{P}_{2} \mathrm{O}_{5}$ & 0.06 & 0.06 & 0.28 & 0.03 & 0.06 & 0.03 & 0.06 & 0.03 & 0.03 & 0.005 & 0.09 \\
\hline LOI & 0.60 & 0.78 & 1.82 & 0.6 & 1.26 & 0.72 & 1.44 & 0.99 & 1.08 & 0.84 & 2.31 \\
\hline $\begin{array}{l}\text { Total } \\
\text { ppm }\end{array}$ & 99.33 & 100.25 & 98.55 & 99.27 & 100.08 & 98.97 & 99.75 & 99.36 & 98.91 & 99.45 & 99.72 \\
\hline Ba & 79.3 & 161.0 & 53.8 & 78.9 & 11.4 & 30.6 & 43.7 & 28.9 & 28.2 & 6.7 & 49.8 \\
\hline $\mathrm{Sr}$ & 4.0 & 4.4 & 34.1 & 10.9 & 33.7 & 15.0 & 35.5 & 29.5 & 26.6 & 24.5 & 34.8 \\
\hline $\mathrm{Y}$ & 33.7 & 5.5 & 32.2 & 26.3 & 14.6 & 20.7 & 37.7 & 30.8 & 13.3 & 9.1 & 31.7 \\
\hline $\mathrm{Sc}$ & $<3.0$ & $<3.0$ & 4.0 & 0.5 & 3.0 & 0.5 & 0.5 & 0.5 & 0.5 & 0.5 & 0.5 \\
\hline $\mathrm{Zr}$ & 4.2 & 3.5 & 26.1 & 15.2 & 14.9 & 11.2 & 28.6 & 11.3 & 15.0 & 18.4 & 33.2 \\
\hline $\mathrm{Be}$ & $<3.0$ & $<3.0$ & 4.0 & 0.5 & 3.0 & 3.0 & 6.0 & 6.0 & 3.0 & 0.5 & 3.0 \\
\hline V & 94.0 & 34.0 & 69.9 & 72.2 & 138.4 & 87.5 & 93.3 & 74.7 & 99.4 & 84.1 & 56.1 \\
\hline $\mathrm{Ni}$ & $<20.0$ & $<20.0$ & 59.8 & 12.5 & 20.1 & 18.3 & 30.5 & 27.5 & 35.0 & 9.1 & 65.0 \\
\hline $\mathrm{Cu}$ & 45.3 & $<5.0$ & 22,0 & 14.5 & 7.7 & 14.7 & 34.1 & 24.8 & 10.0 & 6.8 & 8.8 \\
\hline $\mathrm{Zn}$ & $<30.0$ & $<30,0$ & 6.0 & 0.5 & 0.5 & 0.5 & 45.1 & 29.5 & 0.5 & 0.5 & 109.8 \\
\hline Ga & $<1.0$ & $<1.0$ & 1.7 & 0.5 & 1.1 & 0.5 & 1.2 & 0.5 & 1.8 & 1.1 & 2.4 \\
\hline $\mathrm{Ge}$ & 3.8 & 3.5 & 2.4 & 0.7 & 4.1 & 3.0 & 3.0 & 0.7 & 2.2 & 3.4 & 2.7 \\
\hline $\mathrm{Rb}$ & 4.2 & $<1.0$ & 0.5 & 0.5 & 0.5 & 0.5 & 0.5 & 0.5 & 0.5 & 0.5 & 0.5 \\
\hline $\mathrm{Nb}$ & $<0.2$ & $<0.2$ & 1.2 & 0.4 & 0.5 & 0.4 & 0.5 & 0.3 & 0.4 & 0.4 & 1.6 \\
\hline Mo & 2.9 & $<2.0$ & 1.0 & 1.0 & 1.0 & 1.0 & 1.0 & 1.0 & 1.0 & 1.0 & 1.0 \\
\hline $\mathrm{Ag}$ & 1.3 & 1.1 & 0.2 & 0.2 & 0.2 & 0.2 & 0.2 & 0.2 & 0.2 & 0.2 & 0.2 \\
\hline $\ln$ & $<0.1$ & $<0.1$ & 0.1 & 0.1 & 0.1 & 0.1 & 0.1 & 0.1 & 0.1 & 0.1 & 0.1 \\
\hline Sn & $<1.0$ & 6.3 & 1.6 & 0.5 & 1.1 & 0.5 & 1.1 & 0.5 & 0.5 & 0.5 & 1.2 \\
\hline $\mathrm{Cs}$ & 0.4 & 0.1 & 0.1 & 0.1 & 0.1 & 0.1 & 0.1 & 0.1 & 0.1 & 0.1 & 0.1 \\
\hline$\sum R E E$ & 29.3 & 24.1 & 46.0 & 29.4 & 21.8 & 24.9 & 39.3 & 28.7 & 14.3 & 14.7 & 41.1 \\
\hline Hf & $<0.1$ & $<0.1$ & 0.5 & 0.1 & 0.2 & 0.1 & 0.2 & 0.1 & 0.2 & 0.1 & 0.6 \\
\hline $\mathrm{Tl}$ & $<0.1$ & $<0.1$ & 0.0 & 0.0 & 0.0 & 0.0 & 0.0 & 0.0 & 0.0 & 0.0 & 0.0 \\
\hline $\mathrm{Pb}$ & 7.8 & 12.6 & 1.5 & 1.5 & 1.5 & 1.5 & 1.5 & 1.5 & 1.5 & 1.5 & 1.5 \\
\hline $\mathrm{Bi}$ & $<0.1$ & $<0.1$ & 1.0 & 1.0 & 1.0 & 1.0 & 1.0 & 1.0 & 1.0 & 1.0 & 1.0 \\
\hline Th & 0.1 & 0.2 & 1.2 & 0.2 & 0.4 & 0.1 & 0.6 & 0.2 & 0.4 & 0.4 & 1.5 \\
\hline 0 & 4.2 & 6.9 & 6.2 & 7.2 & 3.5 & 4.5 & 3.6 & 2.9 & 3.7 & 3.0 & 5.9 \\
\hline $\mathrm{Au}$ & $<2.0$ & $<2.0$ & 1.0 & 5.5 & 1.0 & 1.0 & 1.0 & 1.0 & 1.0 & 1.0 & 1.0 \\
\hline As & 19.5 & 11.5 & 28.4 & 16.6 & 18.7 & 11.7 & 15.8 & 14.8 & 22.0 & 18.5 & 22.9 \\
\hline $\mathrm{Br}$ & $<0.5$ & $<0.5$ & 0.3 & 0.3 & 0.3 & 0.3 & 0.3 & 0.3 & 0.3 & 0.3 & 0.3 \\
\hline $\mathrm{Cr}$ & 148.0 & 29.0 & 50.0 & 18.0 & 32.0 & 29.0 & 40.0 & 38.0 & 74.0 & 42.0 & 80.0 \\
\hline Ir & $<5.0$ & $<5.0$ & 2.5 & 2.5 & 2.5 & 2.5 & 2.5 & 2.5 & 2.5 & 2.5 & 2.5 \\
\hline $\mathrm{Sb}$ & 3.7 & 5.6 & 5.0 & 6.1 & 3.4 & 3.5 & 3.9 & 3.6 & 4.4 & 3.5 & 3.4 \\
\hline $\mathrm{Sc}$ & 0.5 & 2.3 & 3.5 & 0.8 & 1.1 & 0.5 & 1.1 & 0.7 & 1.2 & 1.1 & 3.3 \\
\hline $\mathrm{Se}$ & $<3.0$ & $<3.0$ & 1.5 & 1.5 & 1.5 & 1.5 & 1.5 & 1.5 & 1.5 & 1.5 & 1.5 \\
\hline $\mathrm{FeH}$ & 0.998 & 0.998 & 1.0 & 1.0 & 1.0 & 1.0 & 1.0 & 1.0 & 1.0 & 1.0 & 1.0 \\
\hline
\end{tabular}

$\mathrm{HO}=$ hard ore; $\mathrm{SO}=$ Soft ore; $\mathrm{MB}=$ Massive band of the soft ore; $\mathrm{PB}=$ Porous band. $\mathrm{Fe}_{\text {rot }}$ expressed as $\mathrm{Fe}_{2} \mathrm{O}_{3}$. $\mathrm{Fe}=\left(\mathrm{Fe}^{3+} /\left(\mathrm{Fe}^{3+}+\mathrm{Fe}^{2+}\right)\right.$, na $=$ not analyzed 


\begin{tabular}{|c|c|c|c|c|c|c|c|c|c|c|c|}
\hline Sample & $\begin{array}{l}\text { FSD9/ } \\
27.70131\end{array}$ & $\begin{array}{l}\text { FSD9/ } \\
28.70 \mathrm{~m}\end{array}$ & $\begin{array}{c}\text { FSD11/ } \\
4.8 \mathrm{~m}\end{array}$ & $\begin{array}{c}\text { FSD11/ } \\
5.70 \mathrm{~m}\end{array}$ & $\begin{array}{l}\text { FSD11/ } \\
7.10 \mathrm{~m}\end{array}$ & $\begin{array}{l}\text { FSDII/ } \\
10.50 \mathrm{~m}\end{array}$ & $\begin{array}{c}\text { FSD11/ } \\
12.4 \mathrm{~m}\end{array}$ & $\begin{array}{c}\text { FSDI1/ } \\
13.4 \mathrm{~m}\end{array}$ & $\begin{array}{c}\text { FSD11/ } \\
20.4 \mathrm{~m}\end{array}$ & $\begin{array}{c}\text { FSD11/ } \\
25.7 \mathrm{~m}\end{array}$ & $\begin{array}{l}\text { FSDIII } \\
26.7 \mathrm{~mm}\end{array}$ \\
\hline $\begin{array}{l}\text { Ore Type } \\
\text { Wt } \%\end{array}$ & $\mathrm{SO}$ & $\mathrm{SO}$ & SO & so & so & $\mathrm{SO}$ & $\mathrm{SO}$ & SO & SO & SO & so \\
\hline $\mathrm{SiO}_{2}$ & 3.57 & 1.26 & 1.16 & 1.53 & 1.08 & 1.86 & 0.55 & 1.05 & 2.31 & 0.68 & 1.23 \\
\hline $\mathrm{Al}_{2} \mathrm{O}_{3}$ & 1.89 & 0.39 & 0.38 & 0.3 & 0.21 & 0.81 & 0.14 & 0.18 & 1.5 & 0.10 & 0.12 \\
\hline $\mathrm{Fe}_{2} \mathrm{O}_{3}$ & 87.66 & 94.62 & 95.90 & 93.18 & 96.15 & 92.22 & 98.11 & 96.48 & 91.35 & 97.63 & 95.52 \\
\hline Fetot & 87.72 & 94.68 & 95.96 & 93.24 & 96.21 & 92.28 & 98.22 & 96.54 & 91.47 & 97.69 & 0.05 \\
\hline $\mathrm{FeO}$ & 0.05 & 0.05 & 0.05 & 0.05 & 0.05 & 0.05 & 0.10 & 0.05 & 0.11 & 0.05 & 0.05 \\
\hline $\mathrm{MnO}$ & 1.479 & 0.561 & 0.49 & 0.666 & 0.756 & 1.014 & 0.39 & 0.618 & 0.996 & 0.59 & 0.552 \\
\hline $\mathrm{MgO}$ & 2.04 & 0.75 & 0.75 & 0.78 & 0.33 & 0.96 & 0.12 & 0.21 & 0.27 & 0.33 & 0.48 \\
\hline $\mathrm{CaO}$ & 0.24 & 0.48 & 0.54 & 0.6 & 0.15 & 0.15 & 0.05 & 0.12 & 0.12 & 0.12 & 0.39 \\
\hline $\mathrm{Na}_{2} \mathrm{O}$ & 0.33 & 0.39 & $<0.01$ & 0.27 & 0.42 & 0.45 & 0.15 & 0.3 & 0.45 & 0.11 & 0.42 \\
\hline $\mathrm{K}_{2} \mathrm{O}$ & 0.005 & 0.12 & $<0.01$ & 0.12 & 0.15 & 0.06 & $<0.01$ & 0.12 & 0.09 & $<0.01$ & 0.09 \\
\hline $\mathrm{TiO}_{2}$ & 0.153 & 0.021 & 0.005 & 0.21 & 0.021 & 0.024 & 0.010 & 0.024 & 0.069 & 0.011 & 0.021 \\
\hline $\mathrm{P}_{2} \mathrm{O}_{5}$ & 0.06 & 0.21 & 0.37 & 0.33 & 0.03 & 0.005 & 0.02 & 0.06 & 0.06 & 0.06 & $0.2 \mathrm{l}$ \\
\hline LOI & 2.1 & 0.51 & 0.70 & 0.72 & 0.63 & 1.26 & 0.44 & 0.54 & 1.41 & 0.67 & 0.51 \\
\hline $\begin{array}{l}\text { Total } \\
\text { ppm }\end{array}$ & 99.54 & 99.36 & 100.37 & 98.58 & 99.96 & 98.91 & 100.08 & 99.81 & 98.73 & 100.37 & 99.63 \\
\hline $\mathrm{Ba}$ & 32.2 & 24.3 & 11.0 & 22.6 & 24.5 & 13.6 & 16.1 & 24.5 & 21.7 & 14.4 & 16.4 \\
\hline $\mathrm{Sr}$ & 29.3 & 12.7 & 14.2 & 15.5 & 8.1 & 29.5 & 4.0 & 4.2 & 10.6 & 19.2 & 12.1 \\
\hline$Y$ & 26.3 & 17.7 & 10.3 & 15.9 & 11.0 & 12.4 & 6.7 & 9.8 & 26.1 & 18.0 & 12.8 \\
\hline $\mathrm{Sc}$ & 6.0 & 1.5 & $<3.0$ & 0.5 & 0.5 & 0.5 & $<3,0$ & 0.5 & 0.5 & $<3.0$ & 0.5 \\
\hline $\mathrm{Zr}$ & 40.1 & 5.2 & 5.4 & 10.4 & 14.3 & 13.7 & 4.1 & 3.8 & 19.0 & 5.4 & 12.3 \\
\hline $\mathrm{Be}$ & 3.0 & 0.5 & $<3.0$ & 0.5 & 0.5 & 3.0 & $<3.0$ & 0.5 & 0.5 & $<3.0$ & 0.5 \\
\hline V & 63.6 & 91.2 & 65.5 & 131.6 & 34.1 & 96.4 & 9.1 & 23.5 & 40.4 & 39.3 & 9.9 \\
\hline $\mathrm{Ni}$ & 89.9 & 10.1 & 25.4 & 15.6 & 13.1 & 20.2 & $<20.0$ & 11.8 & 85.3 & $<20.0$ & 0.5 \\
\hline $\mathrm{Cu}$ & 9.0 & 10.1 & $<5.0$ & 8.1 & 7.4 & 7.2 & $<5.0$ & 7.2 & 10.5 & $<5.0$ & 7.2 \\
\hline $\mathrm{Zn}$ & 17.8 & 0.5 & $<30.0$ & 0.5 & 0.5 & 0.5 & $<30.0$ & 0.5 & 39.9 & 31.3 & 0.5 \\
\hline $\mathrm{Ga}$ & 1.8 & 0.5 & 1.1 & 0.5 & 0.5 & 1.3 & $<1.0$ & 0.5 & 3.0 & $<1.0$ & 0.5 \\
\hline $\mathrm{Ge}$ & 3.2 & 1.1 & 3.6 & 3.6 & 2.9 & 5.0 & 3.0 & 3.8 & 3.4 & 4.0 & 2.3 \\
\hline $\mathrm{Rb}$ & 0.5 & 1.1 & $<1.0$ & 0.5 & 0.5 & 0.5 & $<1.0$ & 0.5 & 0.5 & $<1.0$ & 0.5 \\
\hline $\mathrm{Nb}$ & 1.5 & 0.3 & 0.3 & 0.2 & 0.4 & 0.5 & 0.3 & 0.1 & 0.6 & 0.3 & 0.1 \\
\hline Mo & 1.0 & 1.0 & $<2.0$ & 1.0 & 1.0 & 1.0 & $<2.0$ & 1.0 & 1.0 & $<2,0$ & 1.0 \\
\hline $\mathrm{Ag}$ & 0.4 & 0.2 & $<0.5$ & 0.2 & 0.2 & 0.2 & $<0.5$ & 0.2 & 0.2 & $<0.5$ & 0.2 \\
\hline In & 0.1 & 0.1 & $<0.1$ & 0.1 & 0.1 & 0.1 & $<0.1$ & 0.1 & 0.1 & $<0.1$ & 0.1 \\
\hline $\mathrm{Sn}$ & 1.2 & 0.5 & $<1.0$ & 0.5 & 0.5 & 0.5 & $<1,0$ & 0.5 & 0.5 & $<1.0$ & 0.5 \\
\hline $\mathrm{Cs}$ & 0.1 & 0.1 & $<0.1$ & 0.1 & 0.1 & 0.1 & $<0.1$ & 0.1 & 0.1 & $<0.1$ & 0.1 \\
\hline$\sum \mathrm{REE}$ & 33.5 & 21.0 & 13.5 & 16.1 & 17.6 & 17.6 & 9.3 & 13.2 & 28.4 & 15.2 & 10.6 \\
\hline Hf & 0.6 & 0.1 & $<0.1$ & 0.1 & 0.1 & 0.1 & $<0.1$ & 0.1 & 0.3 & $<0.1$ & 0.1 \\
\hline $\mathrm{Tl}$ & 0.0 & 0.0 & $<0.1$ & 0.0 & 0.0 & 0.0 & $<0.1$ & 0.0 & 0.0 & 1.8 & 0.0 \\
\hline $\mathrm{Pb}$ & 1.5 & 1.5 & $<5.0$ & 1.5 & 1.5 & 1.5 & $<5.0$ & 1.5 & 1.5 & $<5.0$ & 1.5 \\
\hline $\mathrm{Bi}$ & 1.0 & 1.0 & $<0.1$ & 1.0 & 1.0 & 1.0 & $<0.1$ & 1.0 & 1.0 & $<0.1$ & 1.0 \\
\hline Th & 1.0 & 0.2 & 0.2 & 0.2 & 0.2 & 0.2 & 0.2 & 0.1 & 0.7 & 0.20 & 0.1 \\
\hline$U$ & 7.0 & 6.1 & 2.6 & 3.1 & 1.7 & 1.7 & 1.2 & 1.9 & 2.8 & 4.0 & 1.0 \\
\hline Au & 1.0 & 1.0 & $<2.0$ & 1.0 & 1.0 & 1.0 & $<2.0$ & 1.0 & 1.0 & $<2.0$ & 1.0 \\
\hline As & 16.6 & 16.2 & 9.0 & 8.8 & 6.5 & 6.5 & $<5.0$ & 5.8 & 7.2 & 6.0 & 7.5 \\
\hline $\mathrm{Br}$ & 0.3 & 0.3 & $<0.5$ & 0.3 & 0.3 & 0.3 & $<0.5$ & 0.3 & 0.3 & $<0.5$ & 0.3 \\
\hline $\mathrm{Cr}$ & 56.0 & 16.0 & 89.0 & 61.0 & 25.0 & 25.0 & 25.0 & 24.0 & 28.0 & 64.0 & 17.0 \\
\hline Ir & 2.5 & 2.5 & $<5.0$ & 2.5 & 2.5 & 2.5 & $<5.0$ & 2.5 & 2.5 & $<5.0$ & 2.5 \\
\hline $\mathrm{Sb}$ & 3.4 & 3.9 & 2.3 & 2.6 & 2.2 & 2.2 & 1.6 & 2,0 & 2.1 & 1.7 & 1.6 \\
\hline $\mathrm{Sc}$ & 2.7 & 0.4 & 0.5 & 0.6 & 0.8 & 0.8 & 0.5 & 0.5 & 1.7 & 0.5 & 0.4 \\
\hline $\mathrm{Se}$ & 1.5 & 1.5 & $<3.0$ & 1.5 & 1.5 & 1.5 & $<3.0$ & 1.5 & 1.5 & $<3.0$ & 1.5 \\
\hline Fe\# & 1.0 & 1.0 & 0.998 & 1.0 & 1.0 & 1.0 & 0.999 & 1.0 & 1.0 & 0.999 & 1.0 \\
\hline
\end{tabular}

$\mathrm{HO}=$ hatd ore; $\mathrm{SO}=$ Soft ore; $\mathrm{MB}=$ Massive band of the soft ore; $\mathrm{PB}=$ Porous band. Fe $\mathrm{Fer}_{\text {Tor }}$ expressed as $\mathrm{Fe}_{2} \mathrm{O}_{3}$.

$\mathrm{FeH}=\left(\mathrm{Fe}^{3+} /\left(\mathrm{Fe}^{3+}+\mathrm{Fe}^{2+}\right), \mathrm{na}=\right.$ not analyzed 


\begin{tabular}{|c|c|c|c|c|c|c|c|c|c|}
\hline Sample & $\begin{array}{l}\text { FSDI1/ } \\
28.3 \mathrm{~m}\end{array}$ & MAC14A & MAC59H & MACI26A & $\mathrm{MAC} 127 \mathrm{~A}$ & MACI28A & MACI29A & $\mathrm{MAC} 3 \mathrm{~A}$ & MAC14B \\
\hline $\begin{array}{c}\text { Ore Type } \\
\text { Wt } \%\end{array}$ & SO & $\mathrm{MB}$ & $\mathrm{MB}$ & $\mathrm{MB}$ & MB & $\mathrm{MB}$ & $\mathrm{MB}$ & PB & $\mathrm{PB}$ \\
\hline $\mathrm{SiO}_{2}$ & 1.2 & 0.51 & 0.30 & 0.43 & 0.15 & 0.26 & 0,44 & 3.17 & 4.74 \\
\hline $\mathrm{Al}_{2} \mathrm{O}_{3}$ & 0.12 & 0.09 & 0.12 & 0.06 & 0.04 & 0.03 & 0.16 & 3.25 & 0.39 \\
\hline $\mathrm{Fe}_{2} \mathrm{O}_{3}$ & 94.32 & 96.84 & 97.90 & 99.15 & 98.68 & 97.99 & 98.89 & 86.96 & 87.69 \\
\hline Fetot & 0.05 & 98.34 & 97.90 & 99.27 & 98.80 & 98.15 & 99.01 & 87.22 & 86.95 \\
\hline $\mathrm{FeO}$ & 0.05 & 1.35 & $n a$ & 0.11 & 0.11 & 0.14 & 0.11 & 0.23 & 0.23 \\
\hline $\mathrm{MnO}$ & 0.525 & 0.29 & 0.03 & 0.05 & 0.07 & 0.11 & 0.020 & 2.551 & 1.929 \\
\hline $\mathrm{MgO}$ & 0.45 & 0.09 & 0.10 & 0,08 & 0.09 & 0.02 & 0.11 & 0.30 & 2.29 \\
\hline $\mathrm{CaO}$ & 0.84 & 0.06 & 0.06 & 0.03 & 0.38 & 0.03 & 0.05 & 0.08 & 0.11 \\
\hline $\mathrm{Na}_{2} \mathrm{O}$ & 0.42 & $<0.01$ & $<0,01$ & $<0.01$ & $<0.01$ & 0.15 & $<0.01$ & 0.01 & $<0.01$ \\
\hline $\mathrm{K}_{2} \mathrm{O}$ & 0.005 & $<0,01$ & 0.04 & $<0.01$ & $<0.01$ & $<0.01$ & 0.03 & 0.07 & $<0.01$ \\
\hline $\mathrm{TiO}_{2}$ & 0.024 & 0.009 & 0.010 & 0.005 & $<0,001$ & 0.005 & 0.005 & 0.223 & 0.022 \\
\hline $\mathrm{P}_{2} \mathrm{O}_{5}$ & 0.45 & $<0.03$ & 0.04 & 0.01 & 0.27 & 0.01 & 0.04 & 0.25 & 0.05 \\
\hline LOI & 0.54 & 0.45 & 0.38 & 0.23 & 0.27 & 0.39 & 0.19 & 2.97 & 2.54 \\
\hline $\begin{array}{l}\text { Total } \\
\text { ppm }\end{array}$ & 98.88 & 99.72 & 99.01 & 100.21 & 100.12 & 99.17 & 100.09 & 100.07 & 100.02 \\
\hline $\mathrm{Ba}$ & 9.6 & 9.9 & 10.3 & 13.4 & $<3.0$ & 29.5 & 4.2 & 138.4 & 20.7 \\
\hline $\mathrm{Sr}$ & 14.9 & 5.1 & 2.2 & $<2.0$ & 12.4 & $<2.0$ & $<2.0$ & 42.8 & 20.2 \\
\hline$Y$ & 15.0 & 6.0 & 2.0 & 2.6 & 2.0 & 2.2 & 3.8 & 56.0 & 27.1 \\
\hline $\mathrm{Sc}$ & 0.5 & $<3.0$ & $<3.0$ & $<3.0$ & $<3.0$ & $<3.0$ & $<3.0$ & 8.0 & $<3.0$ \\
\hline $\mathrm{Zr}$ & 7.7 & 2.3 & 2.2 & 4.2 & 4.8 & 2.6 & 3.2 & 38.6 & 4.7 \\
\hline $\mathrm{Be}$ & 0.5 & $<3.0$ & $<3.0$ & $<3.0$ & $<3.0$ & $<3.0$ & $<3.0$ & 4.0 & 4.0 \\
\hline $\mathrm{V}$ & 19.2 & 77.0 & 14,0 & 18.8 & 9.2 & 17.2 & 26.8 & 75.0 & 59.0 \\
\hline $\mathrm{Ni}$ & 2.7 & $<20.0$ & $<20.0$ & $<20.0$ & $<20.0$ & 23.0 & $<20.0$ & 63.6 & 39.0 \\
\hline $\mathrm{Cu}$ & 6.7 & $<5.0$ & $<5.0$ & $<5.0$ & 19.7 & $<5.0$ & $<5.0$ & 115.3 & 14.6 \\
\hline $\mathrm{Zn}$ & 0.5 & $<30.0$ & $<30.0$ & $<30.0$ & $<30.0$ & $<30,0$ & $<30.0$ & 407.1 & 87.3 \\
\hline $\mathrm{Ga}$ & 0.5 & $<1.0$ & $<1.0$ & $<1.0$ & $<1.0$ & $<1.0$ & $<1.0$ & 5.9 & 2.2 \\
\hline $\mathrm{Ge}$ & 2.3 & 3.4 & 5.3 & 4.3 & 3.3 & 3.6 & 3.1 & 3.5 & 6.0 \\
\hline $\mathrm{Rb}$ & 0.5 & $<1.0$ & $<1.0$ & $<1.0$ & $<1.0$ & $<1.0$ & $<1.0$ & $<1.0$ & $<1.0$ \\
\hline $\mathrm{Nb}$ & $<0.2$ & $<0.2$ & $<0.2$ & 0.4 & 0.5 & 0.3 & 0.3 & 2.4 & $<0.2$ \\
\hline Mo & 1.0 & 3.3 & 2.2 & $<2.0$ & $<2.0$ & $<2.0$ & $<2.0$ & $<2.0$ & 2.8 \\
\hline $\mathrm{Ag}$ & 0.2 & 1.5 & 1.2 & $<0.5$ & $<0.5$ & $<0.5$ & $<0.5$ & 1.7 & 1.5 \\
\hline In & 0.1 & $<0.1$ & $<0.1$ & $<0.1$ & $<0.1$ & $<0.1$ & $<0,1$ & $<0.1$ & $<0.1$ \\
\hline $\mathrm{Sn}$ & 0.5 & $<1.0$ & $<1.0$ & $<1.0$ & $<1.0$ & $<1.0$ & $<1.0$ & 2.3 & $<1.0$ \\
\hline $\mathrm{Cs}$ & 0.1 & $<0.1$ & $<0.1$ & $<0.1$ & $<0.1$ & $<0.1$ & $<0.1$ & $<0.1$ & $<0.1$ \\
\hline ¿REE & 12.4 & 7.6 & 4.5 & 4.8 & 3.6 & 3.9 & 5.9 & 116.9 & 29.0 \\
\hline $\mathrm{Hf}$ & 0.1 & $<0.1$ & $<0.1$ & $<0.1$ & $<0.1$ & $<0.1$ & $<0.1$ & 1.0 & 0.1 \\
\hline $\mathrm{Tl}$ & 0.0 & $<0.1$ & $<0.1$ & $<0.1$ & $<0.1$ & $<0.1$ & $<0.1$ & 0.06 & $<0.1$ \\
\hline $\mathrm{Pb}$ & 1.5 & 8.4 & 5.5 & $<5.0$ & $<5.0$ & $<5.0$ & $<5,0$ & 70.5 & 12.6 \\
\hline $\mathrm{Bi}$ & 1.0 & $<0.1$ & $<0.1$ & $<0.1$ & $<0.1$ & $<0.1$ & $<0.1$ & 0.2 & $<0.1$ \\
\hline Th & 0.1 & 0.20 & 0.13 & 0.15 & $<0.05$ & 0.07 & 0.1 & 3.8 & 0.2 \\
\hline $\mathrm{U}$ & 3.3 & 4.1 & 1.1 & 1.8 & 0.7 & 1.6 & 1.1 & 8.4 & 4.5 \\
\hline $\mathrm{Au}$ & 1.0 & $<2.0$ & $<2.0$ & $<2.0$ & $<2,0$ & $<2,0$ & 4.0 & 15.0 & 10.0 \\
\hline As & 7.5 & 9.6 & 5.5 & 6.3 & 7.7 & 6.2 & 8.9 & 22.8 & 26.3 \\
\hline $\mathrm{Br}$ & 0.3 & $<0.5$ & $<0.5$ & $<0.5$ & $<0.5$ & $<0.5$ & $<0.5$ & $<0.5$ & $<0.5$ \\
\hline $\mathrm{Cr}$ & 17.0 & 181.0 & 33.0 & 23.0 & 33.0 & 26.0 & 31.0 & 83.0 & 206.0 \\
\hline $\mathrm{Ir}$ & 2.5 & $<5.0$ & $<5.0$ & $<5.0$ & $<5,0$ & $<5.0$ & $<5.0$ & $<5.0$ & $<5.0$ \\
\hline $\mathrm{Sb}$ & 1.4 & 4.9 & 3.5 & 4.0 & 2.9 & 14.0 & 3.7 & 3.0 & 4.8 \\
\hline $\mathrm{Sc}$ & 0.4 & 0.3 & 0.3 & 0.3 & $<0.1$ & 0.2 & 0.2 & 7.7 & 1.2 \\
\hline $\mathrm{Se}$ & 1.5 & $<3.0$ & $<3.0$ & $<3.0$ & $<3.0$ & $<3.0$ & $<3.0$ & $<3.0$ & $<3.0$ \\
\hline Fe\# & 1.0 & 0.985 & $\mathrm{na}$ & 0.999 & 0.999 & 0.998 & 0.999 & 0.997 & 0.997 \\
\hline
\end{tabular}

$\mathrm{HO}==$ hard ore; $\mathrm{SO}=$ Soft ore; $\mathrm{MB}=$ Massive band of the soft ore; $\mathrm{PB}=$ Porouts band. Fe $\mathrm{Te}_{\mathrm{Tot}}$ expressed as $\mathrm{Fe}_{2} \mathrm{O}_{3}$.

$\mathrm{Fe} \#=\left(\mathrm{Fe}^{3+} /\left(\mathrm{Fe}^{3+}+\mathrm{Fe}^{2+}\right), \mathrm{na}=\right.$ not analyzed 


\begin{tabular}{|c|c|c|c|c|c|c|}
\hline Sample & MAC59I & $\mathrm{MAC} 107$ & MAC126B & $\mathrm{MACl} 27 \mathrm{~B}$ & MAC128B & MACI29B \\
\hline $\begin{array}{c}\text { Ore Type } \\
\text { Wt } \%\end{array}$ & $\mathrm{~PB}$ & PB & $\mathrm{PB}$ & PB & $\mathrm{PB}$ & $\mathrm{PB}$ \\
\hline $\mathrm{SiO}_{2}$ & 0.99 & 1.26 & 0.94 & 1.05 & 0.38 & 0.97 \\
\hline $\mathrm{Al}_{2} \mathrm{O}_{3}$ & 0.14 & 1.88 & 0.27 & 0.25 & 0.20 & 0.35 \\
\hline $\mathrm{Fe}_{2} \mathrm{O}_{3}$ & 97.07 & 92.17 & 95.39 & 92.03 & 96.63 & 94.44 \\
\hline Fetot & 97.07 & 92.58 & 95.51 & 92.20 & 96.74 & 94.56 \\
\hline $\mathrm{FeO}$ & na & 0.37 & 0.11 & 0.15 & 0.10 & 0.11 \\
\hline $\mathrm{MnO}$ & 0.767 & 1.612 & 0.954 & 2.452 & 1.499 & 1.716 \\
\hline $\mathrm{MgO}$ & 0.33 & 0.07 & 0.29 & 0.64 & 0.08 & 0.30 \\
\hline $\mathrm{CaO}$ & 0.26 & 0.01 & 0.04 & $0.3\}$ & 0.10 & 0.07 \\
\hline $\mathrm{Na}_{2} \mathrm{O}$ & 0.01 & $<0.01$ & 0.20 & 0.19 & $<0.01$ & 0.14 \\
\hline $\mathrm{K}_{2} \mathrm{O}$ & 0.01 & $<0.01$ & $<0.01$ & 0.01 & $<0.01$ & 0.03 \\
\hline $\mathrm{TiO}_{2}$ & 0.017 & 0.111 & 0.024 & 0.013 & 0.011 & 0.013 \\
\hline $\mathrm{P}_{2} \mathrm{O}_{5}$ & 0.13 & 0.14 & 0.06 & 0.08 & 0.03 & 0.09 \\
\hline LOI & 0.78 & 2.20 & 1.13 & 2.55 & 1.09 & 1.62 \\
\hline $\begin{array}{l}\text { Total } \\
\text { ppm }\end{array}$ & 100.50 & 99.84 & 99.42 & 99.73 & 100.14 & 99.85 \\
\hline $\mathrm{Ba}$ & 156.8 & 24.0 & 84.4 & 40.2 & 405.2 & 60.1 \\
\hline $\mathrm{Sr}$ & 13.6 & 20.6 & 2.3 & 24.5 & 5.0 & 9.7 \\
\hline $\mathrm{Y}$ & 13.9 & 22.7 & 27.2 & 40.6 & 28.1 & 45.2 \\
\hline $\mathrm{Sc}$ & $<3.0$ & 3.0 & $<3.0$ & $<3.0$ & $<3.0$ & $<3.0$ \\
\hline $\mathrm{Zr}$ & 2.3 & 8.4 & 7.9 & 5.2 & 3.9 & 4.3 \\
\hline $\mathrm{Be}$ & $<3.0$ & 3.0 & 3.0 & $<3.0$ & $<3.0$ & 6.0 \\
\hline $\mathrm{V}$ & 23.0 & 57.0 & 25.1 & 62.9 & 24.5 & 29.6 \\
\hline $\mathrm{Ni}$ & $<20.0$ & 16.9 & 23.9 & 39.3 & 41.3 & $<20.0$ \\
\hline $\mathrm{Cu}$ & $<5.0$ & 80.3 & $<5,0$ & 18.3 & 11.7 & $<5.0$ \\
\hline $\mathrm{Zn}$ & $<30.0$ & 51.1 & $<30.0$ & 91.1 & 101.8 & 40.9 \\
\hline $\mathrm{Ga}$ & $<1.0$ & 2.8 & 1.1 & 1.8 & 1.2 & 1.7 \\
\hline $\mathrm{Ge}$ & 5.1 & 2.1 & 3.6 & 5.0 & 3.1 & 3.4 \\
\hline $\mathrm{Rb}$ & $<1.0$ & $<1.0$ & $<1.0$ & $<1.0$ & $<1.0$ & $<1.0$ \\
\hline $\mathrm{Nb}$ & $<0.2$ & 1.5 & 0.6 & 0.5 & 0.4 & 0.3 \\
\hline Mo & $<2.0$ & $<2.0$ & $<2.0$ & $<2.0$ & $<2.0$ & $<2.0$ \\
\hline $\mathrm{Ag}$ & 1.3 & $<0.5$ & $<0.5$ & $<0.5$ & $<0.5$ & $<0.5$ \\
\hline In & $<0.1$ & $<0, !$ & $<0.1$ & $<0.1$ & $<0.1$ & $<0.1$ \\
\hline $\mathrm{Sn}$ & $<1,0$ & $<1.0$ & $<1,0$ & $<1.0$ & $<1.0$ & $<1.0$ \\
\hline $\mathrm{Cs}$ & $<0.1$ & $<0.1$ & $<0.1$ & $<0.1$ & $<0.1$ & $<0.1$ \\
\hline$\sum \mathrm{REE}$ & 14.4 & 52.5 & 31.5 & 35.4 & 25.6 & 38.3 \\
\hline $\mathrm{Hf}$ & $<0.1$ & 0.3 & 0.1 & $<0.1$ & $<0.1$ & $<0.1$ \\
\hline $\mathrm{Tl}$ & $<0.1$ & 0.106 & $<0.1$ & $<0.1$ & $<0.1$ & $<0.1$ \\
\hline $\mathrm{Pb}$ & $<5$ & 7.1 & $<5$ & $<5$ & 5.9 & 6.1 \\
\hline $\mathrm{Bi}$ & $<0.1$ & $<0,1$ & $<0.1$ & $<0.1$ & $<0.1$ & $<0.1$ \\
\hline $\mathrm{Th}$ & 0.1 & 1.4 & 0.4 & 0.2 & 0.2 & 0.3 \\
\hline U & 1.1 & 6.2 & 3.4 & 7.6 & 2.1 & 3.7 \\
\hline $\mathrm{Au}$ & $<2.0$ & $\mathrm{na}$ & 35.0 & 3.0 & $<2.0$ & $<2.0$ \\
\hline As & 9.2 & 10.0 & 13.7 & 13.6 & 12.0 & 20.8 \\
\hline $\mathrm{Br}$ & $<0.5$ & na & $<0.5$ & $<0.5$ & $<0.5$ & $<0.5$ \\
\hline $\mathrm{Cr}$ & 26.0 & 50.0 & 41.0 & 32.0 & 30.0 & 82,0 \\
\hline Ir & $<5.0$ & na & $<5.0$ & $<5.0$ & $<5.0$ & $<5.0$ \\
\hline $\mathrm{Sb}$ & 3.5 & 1.8 & 4.1 & 4.6 & 14.0 & 3.7 \\
\hline $\mathrm{Sc}$ & 0.3 & na & 1.0 & 0.7 & 0.6 & 0.5 \\
\hline $\mathrm{Se}$ & $<3.0$ & na & $<3.0$ & $<3.0$ & $<3.0$ & $<3.0$ \\
\hline $\mathrm{Fe}$ & na & 0.996 & 0.999 & 0.998 & 0.999 & 0.999 \\
\hline
\end{tabular}

$\mathrm{HO}=$ hard ore; $\mathrm{SO}=$ Soft ore; $\mathrm{MB}=$ Massive band of the soft ore; $\mathrm{PB}=$ Porous band. $\mathrm{Fe}_{\mathrm{TO}}$ expressed as $\mathrm{Fe}_{2} \mathrm{O}_{3}$. Fett $=\left(\mathrm{Fe}^{3+} /\left(\mathrm{Fe}^{3+}+\mathrm{Fe}^{2+}\right)\right.$, na $=$ not analyzed 
Appendix 3-Rare earth element composition of the hard and soft ores

\begin{tabular}{|c|c|c|c|c|c|c|c|c|c|c|c|c|c|c|c|c|}
\hline SAMPLE & $\mathrm{MAC2}$ & $\mathrm{MAC} 44$ & MAC67 & MAC68 & MAC84 & MAC97 & $\mathrm{MACl} 05 \mathrm{~A}$ & MAC105B & MAC115 & PZ55AM7 & MAC17A & $\mathrm{MAC} 20 \mathrm{~A}$ & MAC60A & $\begin{array}{c}\text { FSD8/ } \\
4.8 \mathrm{~m}\end{array}$ & $\begin{array}{l}\text { FSD } 8 i \\
7.3 \mathrm{~m}\end{array}$ & $\begin{array}{l}\text { FSD8 } \\
12.5 \mathrm{~m}\end{array}$ \\
\hline $\begin{array}{l}\text { Ore Type } \\
\text { ppm }\end{array}$ & $\mathrm{HO}$ & $\mathrm{HO}$ & $\mathrm{HO}$ & $\mathrm{HO}$ & $\mathrm{HO}$ & $\mathrm{HO}$ & $\mathrm{HO}$ & $\mathrm{HO}$ & $\mathrm{HO}$ & $\mathrm{HO}$ & SO & SO & SO & $\mathrm{SO}$ & SO & SO \\
\hline $\mathrm{La}$ & 1.42 & 1.05 & 1.15 & 0.49 & 1.07 & 1.06 & 0.97 & 1.08 & 1.36 & 0.91 & 3.10 & 3.08 & 3.5 & 8.74 & 3.95 & 3.92 \\
\hline $\mathrm{Ce}$ & 2.65 & 2.02 & 1.85 & 1.09 & 1.77 & 2.09 & 1.92 & 2.07 & 1.88 & 1.45 & 5.04 & 6.10 & 9.34 & 13.88 & 7.55 & 7.41 \\
\hline $\operatorname{Pr}$ & 0.41 & 0.29 & 0.26 & 0.10 & 0.22 & 0.30 & 0.30 & 0.36 & 0.33 & 0.20 & 0.69 & 1.47 & 1.26 & 1.98 & 1.19 & 0.93 \\
\hline $\mathrm{Nd}$ & 1.85 & 1.38 & 1.19 & 0.47 & 1.01 & 1.34 & 1.71 & 1.82 & 1.74 & 0.91 & 2.96 & 6.98 & 5.10 & 8.40 & 5.76 & 3.89 \\
\hline $\mathrm{Sm}$ & 0.56 & 0.39 & 0.29 & 0.12 & 0.27 & 0.34 & 0.46 & 0.49 & 0.42 & 0.25 & 0.67 & 1.97 & 1.16 & 1.81 & 1.42 & 0.85 \\
\hline $\mathrm{El}$ & 0.18 & 0.13 & 0.11 & 0.05 & 0.11 & 0.10 & 0.19 & 0.19 & 0.18 & 0.11 & 0.34 & 0.66 & 0.36 & 0.69 & 0.58 & 0.31 \\
\hline $\mathrm{Gd}$ & 0.77 & 0.61 & 0.44 & 0.18 & 0.43 & 0.42 & 0.71 & 0.75 & 0.62 & 0.32 & 1.12 & 2.95 & 1.00 & 2.19 & 1.80 & 1.00 \\
\hline $\mathrm{Tb}$ & 0.13 & 0.11 & 0.07 & 0.04 & 0.07 & 0.07 & 0.12 & 0.12 & 0.11 & 0.06 & 0.20 & 0.42 & 0.14 & 0.39 & 0.33 & 0.18 \\
\hline Dy & 0.82 & 0.62 & 0.45 & 0.22 & 0.44 & 0.42 & 0.74 & 0.74 & 0.66 & 0.40 & 1.34 & 2.30 & 0.79 & 2.62 & 2.25 & 1.14 \\
\hline $\mathrm{Y}$ & 7.60 & 6.21 & 4.59 & 2.18 & 4.64 & 3.52 & 6.08 & 5.75 & 5.22 & 4.14 & 12.70 & 33.70 & 5.50 & 32.16 & 26.30 & 14.60 \\
\hline Ho & 0.17 & 0.12 & 0.11 & 0.05 & 0.10 & 0.09 & 0.16 & 0.16 & 0.15 & 0.08 & 0.31 & 0.49 & 0.15 & 0.60 & 0.52 & 0.25 \\
\hline $\mathrm{E}_{\mathrm{T}}$ & 0.46 & 0.37 & 0.33 & 0.15 & 0.28 & 0.30 & 0.44 & 0.46 & 0.41 & 0.23 & 1.01 & 1.40 & 0.47 & 1.97 & 1.69 & 0.81 \\
\hline $\mathrm{Tm}$ & 0.06 & 0.05 & 0.05 & 0.02 & 0.04 & 0.04 & 0.05 & 0.06 & 0.05 & 0.03 & 0.15 & 0.19 & 0.08 & 0.31 & 0.26 & 0.13 \\
\hline $\mathrm{Yb}$ & 0.39 & 0.30 & 0.30 & 0.16 & 0.25 & 0.27 & 0.031 & 0.34 & 0.031 & 0.18 & 1.07 & 1.16 & 0.64 & 2.03 & 1.81 & 0.85 \\
\hline $\mathrm{Lu}$ & 0.06 & 0.05 & 0.05 & 0.02 & 0.04 & 0.04 & 0.04 & 0.05 & 0.05 & 0.02 & 0.18 & 0.18 & 0.10 & 0.34 & 0.29 & 0.14 \\
\hline$\sum \mathrm{REE}$ & 9.96 & 7.47 & 6.65 & 3.16 & 6.09 & 6.88 & 8.72 & 8.13 & 8.27 & 4.24 & 18.17 & 29.35 & 24.08 & 45.96 & 29.40 & 21.79 \\
\hline $\mathrm{La} / \mathrm{Yb}_{\text {PAAS }}$ & 0.27 & 0.26 & 0.29 & 0.23 & 0.32 & 0.29 & 0.23 & 0.23 & 0.32 & 0.37 & 0.21 & 0.20 & 0.41 & 0.32 & 0.16 & 0.34 \\
\hline $\mathrm{La} / \mathrm{Sm}_{\mathrm{PAAS}}$ & 0.37 & 0.39 & 0.57 & 0.61 & 0.58 & 0.45 & 0.32 & 0.31 & 0.47 & 0.52 & 0.68 & 0.23 & 0.44 & 0.70 & 0.41 & 0.67 \\
\hline $\mathrm{Dy} / \mathrm{Yb}_{\mathrm{PAAS}}$ & 1.26 & 1.24 & 0.93 & 0.86 & 1.06 & 0.95 & 1.30 & 1.45 & 1.28 & 1.33 & 1.18 & 1.45 & 0.86 & 0.78 & 0.75 & 0.81 \\
\hline $\mathrm{Ce} / \mathrm{Ce}^{*}{ }_{\mathrm{PAAS}}$ & 0.80 & 0.85 & 0.77 & 1.11 & 0.84 & 0.85 & 0.76 & 0.81 & 0.65 & 0.80 & 0.80 & 0.66 & 1.02 & 0.77 & 0.80 & 0.90 \\
\hline $\mathrm{Eu} / \mathrm{Eu}^{*}{ }_{\mathrm{PAAS}}$ & 1.32 & 1.27 & 1.38 & 1.48 & 1.55 & 1.26 & 1.47 & 1.58 & 1.66 & 1.84 & 1.85 & 1.29 & 1.57 & 1.64 & 1.71 & 1.59 \\
\hline $\mathrm{Y} / \mathrm{Y}_{\text {PAAS }}^{*}$ & 1.63 & 1.79 & 1.66 & 1.64 & 1.81 & 1.42 & 1.4 & 1.34 & 1.34 & 2.77 & 1.58 & 2.54 & 1.27 & 2.04 & 1.94 & 2.17 \\
\hline
\end{tabular}

$\mathrm{HO}=$ hard ore; $\mathrm{SO}=$ Soft ore; $\mathrm{MB}=$ Massive band of the soft ore; $\mathrm{PB}=$ Porous band. $\mathrm{Y}$ content is not included in $\sum \mathrm{REE} . \mathrm{Eu}^{*} / \mathrm{Eu}_{\mathrm{PAAS}}^{*}=\left(\left(\mathrm{Eu} / \mathrm{Eu}_{\mathrm{PAAS}}\right) /\left(\mathrm{Sm} / \mathrm{Sm} \mathrm{PAAS}^{*}\left(\mathrm{Gd} / \mathrm{Gd} \mathrm{PAAS}_{\mathrm{A}}\right)\right)^{1 / 2}\right.$,

$\mathrm{Ce} / \mathrm{Ce}_{\mathrm{PAAS}}^{*}$ and $\mathrm{Y} / \mathrm{Y}_{\text {PAAS }}^{*}$ calculated by similar way. 
Appendix 3 (Continued)

\begin{tabular}{|c|c|c|c|c|c|c|c|c|c|c|c|c|c|c|c|c|c|c|}
\hline SAMPLE & $\begin{array}{l}\text { FSD } 8 / \\
14.7 \mathrm{~m}\end{array}$ & $\begin{array}{l}\text { FSD8/ } \\
16.8 \mathrm{~m}\end{array}$ & $\begin{array}{l}\text { FSD81 } \\
19.0 \mathrm{~m}\end{array}$ & $\begin{array}{c}\text { FSD9/ } \\
3.5 \mathrm{~m}\end{array}$ & $\begin{array}{l}\text { FSD9/ } \\
8.6 \mathrm{~m}\end{array}$ & $\begin{array}{l}\text { FSD9/ } \\
24.7 \mathrm{~m}\end{array}$ & $\begin{array}{l}\text { FSD9/ } \\
27.7 \mathrm{~m}\end{array}$ & $\begin{array}{l}\text { FSD9/ } \\
28.7 \mathrm{~m}\end{array}$ & $\begin{array}{c}\text { FSD11/ } \\
4.8 \mathrm{~m}\end{array}$ & $\begin{array}{c}\text { FSD11/ } \\
5.7 \mathrm{~m}\end{array}$ & $\begin{array}{c}\text { FSD11/ } \\
7.1 \mathrm{~m}\end{array}$ & $\begin{array}{c}\text { FSD 11/ } \\
10.5 \mathrm{~m}\end{array}$ & $\begin{array}{c}\text { FSD11/ } \\
12.4 \mathrm{~m}\end{array}$ & $\begin{array}{l}\text { FSD11/ } \\
13.4 \mathrm{~m}\end{array}$ & $\begin{array}{l}\text { FSD11/ } \\
20.4 \mathrm{~m}\end{array}$ & $\begin{array}{c}\text { FSD11/ } \\
25.7 \mathrm{~m}\end{array}$ & $\begin{array}{c}\text { FSD11/ } \\
26.7 \mathrm{~m}\end{array}$ & $\begin{array}{c}\text { FSDI1/ } \\
28.3 \mathrm{~m}\end{array}$ \\
\hline $\begin{array}{c}\text { Ore Type } \\
\text { ppm }\end{array}$ & SO & SO & SO & $\mathrm{SO}$ & SO & SO & SO & $\mathrm{SO}$ & SO & So & SO & SO & $\mathrm{SO}$ & SO & SO & $\mathrm{SO}$ & SO & $\mathrm{SO}$ \\
\hline $\mathrm{La}$ & 3.20 & 5.14 & 3.57 & 2.62 & 2.75 & 6.49 & 5.13 & 3.18 & 2.02 & 2.59 & 3.23 & 4.18 & 1.34 & 2.25 & 4.64 & 2.02 & 1.64 & 1.81 \\
\hline $\mathrm{Ce}$ & 6.89 & 9.46 & 6.88 & 4.50 & 5.12 & 12.89 & 9.66 & 5.88 & 3.17 & 3.89 & 5.37 & 7.17 & 2.54 & 3.66 & 7.80 & 3.67 & 3.07 & 3.21 \\
\hline $\operatorname{Pr}$ & 1.10 & 1.68 & 1.16 & 0.59 & 0.63 & 1.84 & 1.51 & 1.00 & 0.56 & 0.70 & 0.74 & 0.88 & 0.36 & 0.53 & 1.19 & 0.57 & 0.44 & 0.45 \\
\hline $\mathrm{Nd}$ & 5.10 & 7.96 & 5.58 & 2.54 & 2.54 & 7.85 & 6.66 & 4.56 & 2.65 & 3.12 & 3.31 & 3.72 & 1.65 & 2.43 & 5.33 & 2.65 & 1.82 & 2.12 \\
\hline $\mathrm{Sm}$ & 1.19 & 1.90 & 1.35 & 0.49 & 0.53 & 1.76 & 1.50 & 0.99 & 0.61 & 0.65 & 0.64 & 0.73 & 0.38 & 0.50 & 1.02 & 0.64 & 0.43 & 0.46 \\
\hline Eu & 0.50 & 0.82 & 0.59 & 0.20 & 0.21 & 0.65 & 0.55 & 0.38 & 0.25 & 0.30 & 0.28 & 0.29 & 0.16 & 0.22 & 0.50 & 0.26 & 0.20 & 0.23 \\
\hline $\mathrm{Gd}$ & 1.54 & 2.56 & 1.85 & 0.62 & 0.63 & 2.13 & 1.74 & 1.19 & 0.95 & 0.87 & 0.79 & 0.84 & 0.55 & 0.61 & 1.35 & 1.00 & 0.53 & 0.67 \\
\hline $\mathrm{Tb}$ & 0.27 & 0.48 & 0.36 & 0.12 & 0.12 & 0.40 & 0.33 & 0.21 & 0.16 & 0.17 & 0.15 & 0.15 & 0.10 & 0.12 & 0.27 & 0.17 & 0.11 & 0.13 \\
\hline Dy & 1.75 & 3.24 & 2.43 & 0.83 & 0.76 & 2.60 & 2.18 & 1.37 & 1.04 & 1.23 & 1.02 & 1.03 & 0.64 & 0.90 & 1.92 & 1.21 & 0.73 & 0.98 \\
\hline$Y$ & 20.66 & 37.65 & 30.79 & 13.33 & 9.13 & 31.67 & 26.35 & 17.72 & 10.30 & 15.90 & 11.01 & 12.41 & 6.70 & 9.78 & 26.11 & 18.00 & 12.80 & 15.02 \\
\hline Ho & 0.39 & 0.73 & 0.57 & 0.20 & 0.17 & 0.56 & 0.49 & 0.30 & 0.25 & 0.29 & 0.23 & 0.24 & 0.16 & 0.21 & 0.47 & 0.32 & 0.17 & 0.24 \\
\hline Er & 1.27 & 2.27 & 1.84 & 0.66 & 0.54 & 1.72 & 1.56 & 0.89 & 0.81 & 0.94 & 0.76 & 0.77 & 0.55 & 0.72 & 1.59 & 1.14 & 0.60 & 0.84 \\
\hline $\mathrm{Tm}$ & 0.20 & 0.36 & 0.30 & 0.11 & 0.09 & 0.27 & 0.25 & 0.13 & 0.12 & 0.15 & 0.12 & 0.12 & 0.10 & 0.12 & 0.26 & 0.19 & 0.10 & 0.14 \\
\hline $\mathrm{Yb}$ & 1.32 & 2.36 & 1.95 & 0.71 & 0.58 & 1.71 & 1.63 & 0.83 & 0.80 & 1.07 & 0.82 & 0.83 & 0.62 & 0.82 & 1.79 & 1.18 & 0.64 & 0.94 \\
\hline $\mathrm{Lu}$ & 0.20 & 0.37 & 0.31 & 0.11 & 0.10 & 0.28 & 0.26 & 0.13 & 0.13 & 0.18 & 0.13 & 0.13 & 0.09 & 0.14 & 0.29 & 0.19 & 0.10 & 0.16 \\
\hline$\sum \mathrm{REE}$ & 24.94 & 39.33 & 28.74 & 14.30 & 14.74 & 41.14 & 33.46 & 21.03 & 13.52 & 16.15 & 17.59 & 21.08 & 9.26 & 13.25 & 28.41 & 15.21 & 10.60 & 12.38 \\
\hline $\mathrm{La} / \mathrm{Yb}_{\text {PAAS }}$ & 0.18 & 0.16 & 0.14 & 0.27 & 0.35 & 0.28 & 0.23 & 0.28 & 0.19 & 0.18 & 0.29 & 0.37 & 0.16 & 0.20 & 0.19 & 0.13 & 0.19 & 0.14 \\
\hline $\mathrm{La} / \mathrm{Sm}_{\mathrm{PAAS}}$ & 0.39 & 0.39 & 0.39 & 0.78 & 0.76 & 0.53 & 0.50 & 0.46 & 0.48 & 0.58 & 0.73 & 0.83 & 0.51 & 0.65 & 0.66 & 0.46 & 0.55 & 0.58 \\
\hline $\mathrm{Dy} / \mathrm{Yb}_{\mathrm{PAAS}}$ & 0.80 & 0.83 & 0.75 & 0.71 & 0.79 & 0.91 & 0.81 & 1.00 & 0.20 & 0.69 & 0.75 & 0.74 & 0.76 & 0.66 & 0.65 & 0.62 & 0.69 & 0.63 \\
\hline $\mathrm{Ce} / \mathrm{Ce}_{\text {PAAS }}^{*}$ & 0.85 & 0.74 & 0.78 & 0.83 & 0.90 & 0.86 & 0.80 & 0.76 & 0.68 & 0.67 & 0.80 & 0.86 & 0.84 & 0.77 & 0.77 & 0.79 & 0.84 & 0.82 \\
\hline $\mathrm{Eu} / \mathrm{Eu}{ }^{*} \mathrm{PAAS}$ & 1.74 & 1.76 & 1.77 & 1.73 & 1.70 & 1.59 & 1.61 & 1.65 & 1.53 & 1.91 & 1.85 & 1.72 & 1.61 & 1.87 & 2.00 & 1.54 & 1.96 & 1.98 \\
\hline $\mathrm{Y} / \mathrm{Y}_{\mathrm{PAAS}}^{*}$ & 1.99 & 1.95 & 2.09 & 2.62 & 2.05 & 2.09 & 2.03 & 2.22 & 1.60 & 2.14 & 1.80 & 2.00 & 1.64 & 1.78 & 2.20 & 2.30 & 2.85 & 2.45 \\
\hline
\end{tabular}

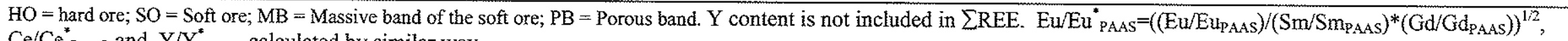

$\mathrm{Ce} / \mathrm{Ce}^{*}$ PAAS and $\mathrm{Y} / \mathrm{Y}^{*}$ PAAS calculated by similar way. 


\begin{tabular}{|c|c|c|c|c|c|c|c|c|c|c|c|c|c|c|}
\hline SAMPLE & $\mathrm{MAC} 14 \mathrm{~A}$ & MAC59H & $\mathrm{MACl26A}$ & $\mathrm{MAC1} 27 \mathrm{~A}$ & MAC128A & MAC129A & MAC3A & MAC14B & MAC59I & $\mathrm{MACI07}$ & $\mathrm{MAC126B}$ & MAC127B & $\mathrm{MAC} 128 \mathrm{~B}$ & MAC129B \\
\hline $\begin{array}{l}\text { Ore Type } \\
\text { ppm }\end{array}$ & MB & MB & $M B$ & $\mathrm{MB}$ & $\mathrm{MB}$ & $\mathrm{MB}$ & $\mathrm{PB}$ & $\mathrm{PB}$ & $\mathrm{PB}$ & PB & $\mathrm{PB}$ & $P B$ & $\mathrm{~PB}$ & PB \\
\hline $\mathrm{La}$ & 1.16 & 0.86 & 0.79 & 0.55 & 0.73 & 1.02 & 20.23 & 4.54 & 2.02 & 6.66 & 4.31 & 5.35 & 4.29 & 5.79 \\
\hline $\mathrm{Ce}$ & 2.18 & 1.44 & 1.60 & 1.04 & 1.42 & 1.79 & 42.46 & 7.35 & 3.95 & 13.00 & 7.43 & 8.19 & 5.35 & 7.89 \\
\hline $\operatorname{Pr}$ & 0.34 & 0.19 & 0.18 & 0.15 & 0.13 & 0.23 & 4.49 & 1.23 & 0.55 & 2.09 & 1.25 & 1.42 & 1.06 & 1.49 \\
\hline $\mathrm{Nd}$ & 1.39 & 0.75 & 0.81 & 0.76 & 0.58 & 1.05 & 18.06 & 5.31 & 2.41 & 9.15 & 5.98 & 6.30 & 4.59 & 6.99 \\
\hline $\mathrm{Sm}$ & 0.33 & 0.20 & 0.17 & 0.17 & 0.11 & 0.25 & 3.97 & 1.19 & 0.59 & 2.33 & 1.55 & 1.44 & 1.00 & 1.68 \\
\hline Eu & 0.13 & 0.06 & 0.07 & 0.06 & 0.05 & 0.08 & 1.90 & 0.53 & 0.26 & 0.79 & 0.60 & 0.61 & 0.45 & 0.77 \\
\hline $\mathrm{Gd}$ & 0.48 & 0.23 & 0.23 & 0.24 & 0.15 & 0.32 & 5.13 & 1.82 & 0.94 & 3.46 & 2.33 & 2.23 & 1.65 & 2.90 \\
\hline $\mathrm{Tb}$ & 0.07 & 0.04 & 0.04 & 0.04 & 0.03 & 0.06 & 0.96 & 0.30 & 0.16 & 0.69 & 0.39 & 0.39 & 0.29 & 0.48 \\
\hline Dy & 0.47 & 0.25 & 0.28 & 0.22 & 0.19 & 0.37 & 6.45 & 2.02 & 1.06 & 4.85 & 2.43 & 2.67 & 2.07 & 3.28 \\
\hline$Y$ & 6.00 & 2.00 & 2.60 & 2.00 & 2.20 & 3.80 & 56.00 & 27.10 & 13.90 & 22.70 & 27.20 & 40.60 & 28.10 & 45.20 \\
\hline Ho & 0.11 & 0.05 & 0.07 & 0.05 & 0.05 & 0.10 & 1.46 & 0.50 & 0.27 & 1.14 & 0.61 & 0.73 & 0.56 & 0.86 \\
\hline $\mathrm{Er}$ & 0.38 & 0.17 & 0.24 & 0.15 & 0.18 & 0.30 & 4.80 & 1.69 & 0.89 & 3.69 & 1.98 & 2.55 & 1.87 & 2.80 \\
\hline $\mathrm{Tm}$ & 0.06 & 0.03 & 0.04 & 0.02 & 0.03 & 0.04 & 0.79 & 0.28 & 0.15 & 0.57 & 0.32 & 0.42 & 0.30 & 0.43 \\
\hline $\mathrm{Yb}$ & 0.40 & 0.18 & 0.27 & 0.13 & 0.19 & 0.27 & 5.31 & 1.92 & 0.99 & 3.46 & 1.97 & 2.66 & 1.87 & 2.54 \\
\hline $\mathrm{Lu}$ & 0.07 & 0.03 & $0.04^{\circ}$ & 0.02 & 0.03 & 0.04 & 0.89 & 0.33 & 0.17 & 0.61 & 0.31 & 0.43 & 0.29 & 0.40 \\
\hline$\sum$ REE & 7.57 & 4.47 & 4.82 & 3.59 & 3.87 & 5.91 & 116.88 & 29.01 & 14.41 & 53.48 & 31.46 & 35.39 & 25.64 & 38.28 \\
\hline $\mathrm{La} / \mathrm{Yb}_{\mathrm{PAAS}}$ & 0.21 & 0.36 & 0.21 & 0.32 & 0.29 & 0.28 & 0.28 & 0.17 & 0.15 & 0.14 & 0.16 & 0.15 & 0.17 & 0.17 \\
\hline $\mathrm{La} / \mathrm{Sm}_{P A A S}$ & 0.52 & 0.63 & 0.67 & 0.48 & 0.94 & 0.60 & 0.74 & 0.55 & 0.49 & $0.4 \mathrm{I}$ & 0.40 & 0.54 & 0.62 & 0.50 \\
\hline $\mathrm{Dy} / \mathrm{Yb}_{\mathrm{PAAS}}$ & 0.71 & 0.84 & 0.63 & 1.05 & 0.62 & 0.84 & 0.73 & 0.63 & 0.64 & 0.84 & 0.74 & 0.61 & 0.67 & 0.78 \\
\hline $\mathrm{Ce} / \mathrm{Ce}_{\mathrm{PAAS}}^{*}$ & 0.80 & 0.83 & 0.98 & 0.84 & 1.04 & 0.85 & 1.03 & 0.72 & 0.86 & 0.80 & 0.74 & 0.69 & 0.58 & 0.62 \\
\hline $\mathrm{Eu} / \mathrm{Eu}_{\mathrm{PAAS}}^{*}$ & 1.53 & 1.41 & 1.58 & 1.45 & 1.67 & 1.35 & 1.98 & 1.70 & 1.65 & 1.31 & 1.49 & 1.61 & 1.64 & 1.65 \\
\hline$Y / Y^{*}{ }_{\text {PAAS }}$ & 2.09 & 1.41 & 1.50 & 1.50 & 1.73 & 1.59 & 1.46 & 2.15 & 2.08 & 0.77 & 1.79 & 2.32 & 2.09 & 2.15 \\
\hline
\end{tabular}

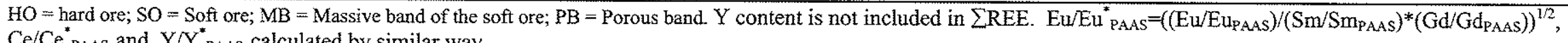

$\mathrm{Ce} / \mathrm{Ce}_{\mathrm{PAAS}}^{*}$ and $\mathrm{Y} / \mathrm{Y}_{\mathrm{PAAS}}^{*}$ calculated by similar way. 


\title{
ANEXO $4-{ }^{40} \mathrm{AR} /{ }^{39}$ AR GEOCHRONOLOGY AND THE EVOLUTION OF LATERITIC IRON DEPOSITS IN THE QUADRILÁTERO FERRÍFERO, MINAS GERAIS, BRAZIL
}

\begin{abstract}
Weathering profiles overlying the Sapecado, Pico and Andaime iron ore deposits, Quadrilátero Ferrífero (QF), Minas Gerais, Brazil, reach depths of 150-400 m and host worldclass supergene iron orebodies. In addition to hematite, goethite, and some relic quartz, the deeply weathered itabirites (metamorphosed banded iron formation) contain supergene cryptomelane, hollandite, and pyrolusite. These manganese oxides are preferentially concentrated at the contact between weathered Cauê Formation itabirites and adjacent dolomites of the Gandarela Formation, and their distribution provides information on the propagation of the weathering front as the supergene ore bodies formed.

Laser incremental-heating ${ }^{40} \mathrm{Ar} /{ }^{39} \mathrm{Ar}$ results for 69 grains extracted from 23 samples collected at depths ranging from 5 to $150 \mathrm{~m}$ reveal ages ranging from ca. 62 to $14 \mathrm{Ma}$. Older Mnoxides occur near the surface, while younger Mn-oxides occur at depth. However, many samples collected at the weathering-bedrock interface yield ages in the 51-41 Ma range, suggesting that the weathering profiles in the Quadrilatero Ferrifero had already reached their present depth in the Paleogene. The age versus depth distribution obtained in this study suggests that little further advance of the weathering front has occurred in the Quadrilatero Ferrifero lateritic profiles during the Neogene.
\end{abstract}

\section{INTRODUCTION}

The Quadrilátero Ferrifero (literally, the Iron Quadrangle), Minas Gerais (Fig. 1), hosts one of the largest concentrations of lateritic iron ore deposits on Earth. It also hosts the most complete and well-developed weathering profiles in southeastern Brazil, reaching depths of 400 $-500 \mathrm{~m}$, and averaging $150 \mathrm{~m}$. These weathering profiles are developed on Paleoproterozoic Minas Supergroup rocks which outcrop along plateaus and ridges with heights ranging from 1.100 to $2.100 \mathrm{~m}$ elevation, surrounded by dissected areas, where Archean granite-gneiss basement units and the Rio das Velhas Greenstone Belt are exposed (Fig. 2). 


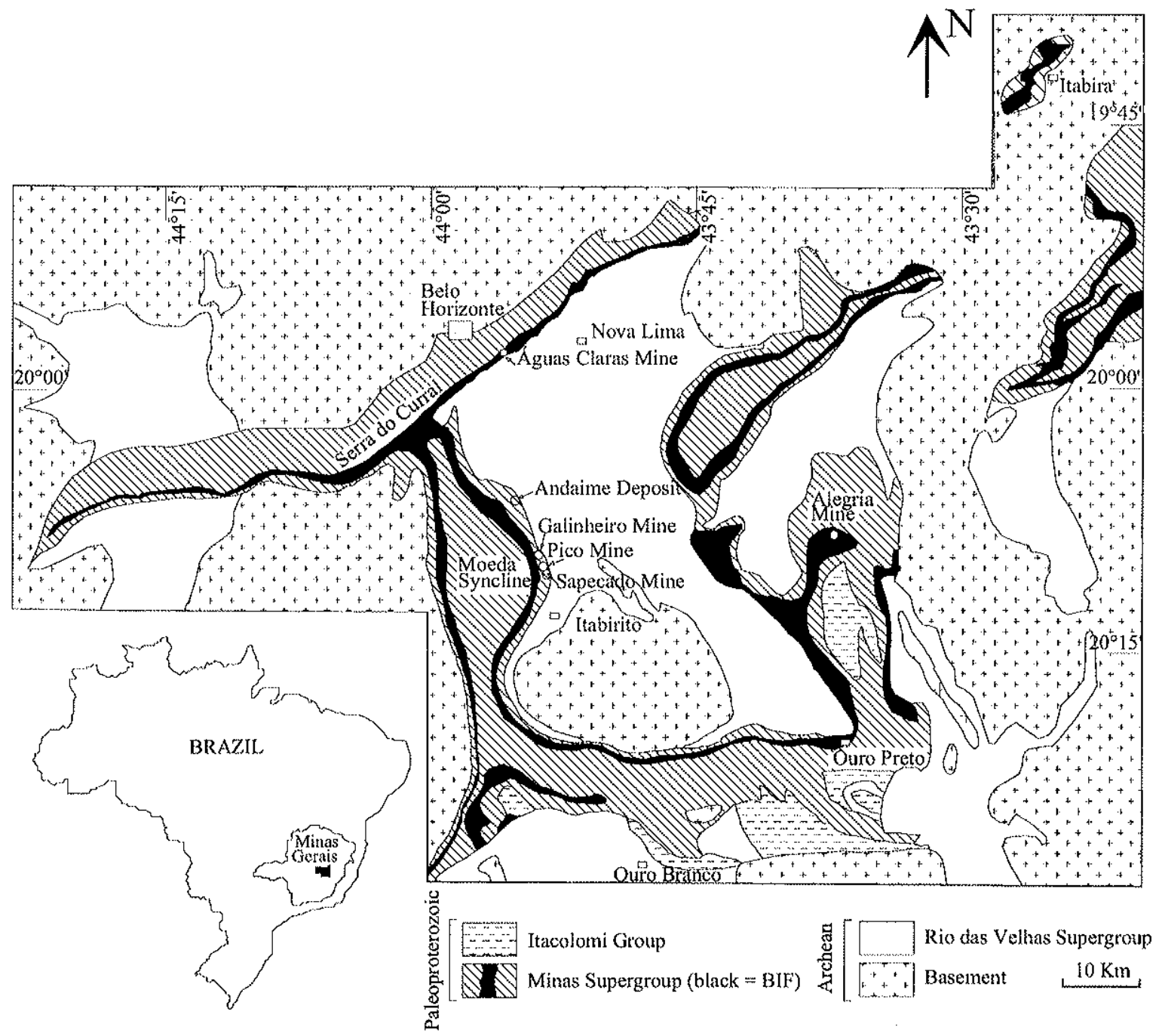

Figure 1. Location and geological sketch map of the Quadrilátero Ferrifero region (After Alkmim and Marshak, 1998).

The QF weathering profiles have great economic significance because they host worldclass supergene iron ore deposits as well as economically important manganese, bauxite, and industrial clay deposits. They also have significant geomorphologic and paleoclimatic implications because of the extreme depths and antiquity of weathering processes recorded in these profiles (Carmo and Vasconcelos, 2004; Carmo and Vasconcelos, 2003; Dorr II, 1969; King, 1956). Despite their importance, several questions regarding the genesis of QF weathering profiles remain unanswered: How did they form? How long did it take? When did it start? Under what climatic conditions did these weathering profiles evolve? Why are they preserved? Are they still forming today? Answers to these questions have many implications to our understanding of surficial processes in general and in quantifying the genesis of supergene ore deposits in particular. 


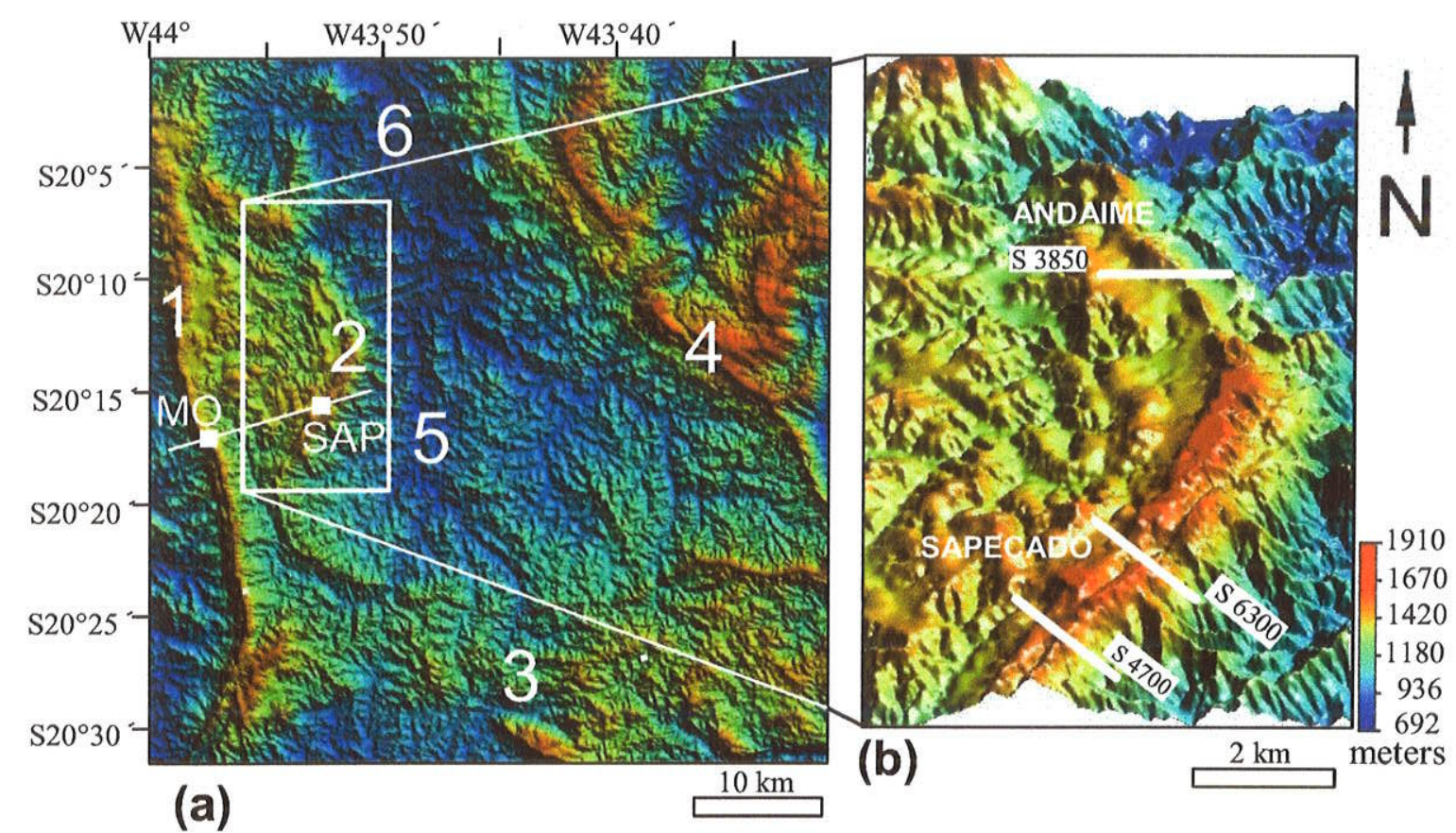

1=Serra da Moeda, 2=Serra das Serrinhas, 3=Serra do Ouro Branco, 4=Serra do Caraça, 5 e 6= vale do rio das Velhas

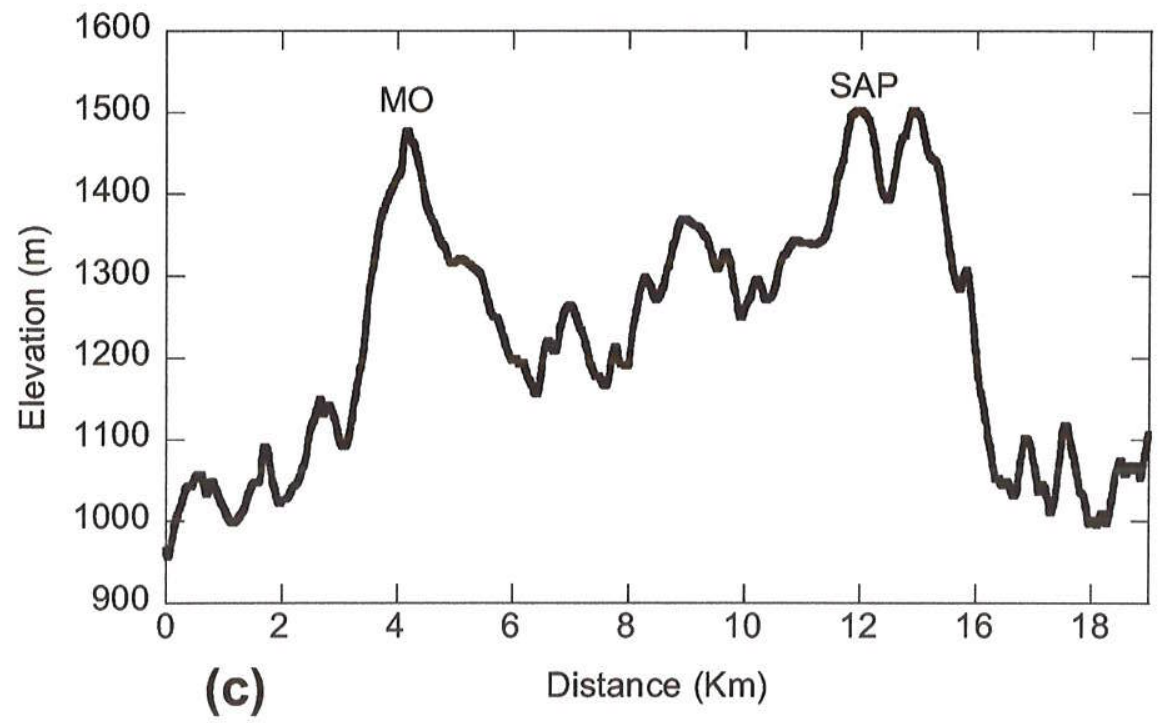

Figure 2. Digital elevation model for the Quadrilátero Ferrífero region (a) illustrating location of weathering profiles investigated in this study (b). (c) SW-NE topographic profile from the Serra da Moeda (MO) to the Sapecado mine (SAP) at the Serra das Serrinhas.

Active mining operations in the Quadrilátero Ferrífero provide a unique opportunity to answer some of these questions. Open pits and drill cores permit sampling complete weathering profiles. Extensive mining exposures and several thousands of meters of drill-cores maximize the chances of obtaining suitable samples for geochemical and geochronological studies. Abundant Mn-oxides in some of these profiles, particularly the supergene ore bodies formed on 
manganiferous itabirites at the Sapecado and Andaime MBR mines (Figs. 1-2), provide suitable samples for ${ }^{40} \mathrm{Ar} /{ }^{39} \mathrm{Ar}$ dating. ${ }^{40} \mathrm{Ar} /{ }^{39} \mathrm{Ar}$ geochronology permits dating of $\mathrm{K}$-bearing manganese oxides formed at different depths in the weathering profiles and therein allows to measure the rate of propagation of the weathering front and the timing of formation of the profiles (Vasconcelos, 1999a; Vasconcelos et al., 1994b).

The laser incremental-heating ${ }^{40} \mathrm{Ar} /{ }^{39} \mathrm{Ar}$ method has been used to date supergene hollandite-group minerals from weathering profiles across the world (Dammer et al., 1996; Dammer et al., 1999; Hénocque et al., 1998b; Li and Vasconcelos, 2002; Ruffet et al., 1996b; Vasconcelos, 1992; Vasconcelos et al., 1992; Vasconcelos et al., 1994a) providing a useful tool in the study of weathering processes. Hollandite-group Mn-oxides are suitable to ${ }^{40} \mathrm{Ar} /{ }^{39} \mathrm{Ar}$ dating due to their relatively high $\mathrm{K}$ contents $(1-5 \mathrm{wt} \%)$ and their $\mathrm{K}$ and ${ }^{40} \mathrm{Ar}$ retentivity. These hollandite-group minerals generally form clusters of oriented crystallites $(10-20 \mu \mathrm{m}$ long and 1-2 $\mu \mathrm{m}$ wide) (Vasconcelos et al., 1994c). These clusters have a large volume of intercrystalline space that may absorb and adsorb large quantities of atmospheric ${ }^{40} \mathrm{Ar}$ (Vasconcelos et al., 1995). On the other hand, hollandite-type crystallites form tunnel structures that favors the imprisonment of large cations like $\mathrm{K}, \mathrm{Ba}$, and $\mathrm{Pb}$. These tunnel sites quantitatively retain ${ }^{40} \mathrm{Ar}$ produced by ${ }^{40} \mathrm{~K}$ decay (Vasconcelos et al., 1995). Incremental-heating analyses of Mn-oxide clusters liberate atmospheric argon adsorbed or trapped in intercrystalline or damaged intracrystalline sites at low temperature heating steps; radiogenic ${ }^{40} \mathrm{Ar}^{*}$ and nucleogenic ${ }^{39} \mathrm{Ar}$ hosted in the intracrystalline tunnel sites are only liberated at higher temperatures steps. The ability to tap each argon reservoir separately permits determining accurate and precise ages for these minerals, in addition to retrieving useful information on a sample's Ar and $\mathrm{K}$ retentivity, the physical properties of the sites where these elements occur, the possible presence of contaminants, and any significant ${ }^{39} \mathrm{Ar}$ recoil losses the mineral may undergo during irradiation (Vasconcelos, 1999b).

We will present below the results of ${ }^{40} \mathrm{Ar} /{ }^{39} \mathrm{Ar}$ dating of 69 grains extracted from 23 samples of Mn-oxides distributed from $\sim 5 \mathrm{~m}$ to $\sim 150 \mathrm{~m}$ below the present surface in two distinct QF weathering profiles. We will discuss the reliability of the results obtained in light of informations obtained by petrographic observations and scanning electron microscopy (SEM), $x$ ray diffractometry (XRD), and electron microprobe (EMP) analyses. We will finally discuss the significance of the geochronological results to the formation of the weathering profiles in the $\mathrm{QF}$ region, in particular, and the genesis of the supergene iron ore bodies, in general. 


\section{GEOLOGICAL SETTING}

\section{Regional Geology}

The geology and the lithostratigraphy of the QF were described in detail by the USGSDNPM team between 1946 and 1963, and summarized by Dorr II (1969). Since then, the subject has been reviewed by several authors (Alkmim and Marshak, 1998; Chemale Jr, et al., 1994; Ladeira and Viveiros, 1984; Marshak and Alkmim, 1989; Renger et al., 1994). The most important lithostratigraphic units of the Quadrilátero Ferrifero (Fig. 1) are Archean to Paleoproterozoic granitic-gneissic basement, Archean greenstone belt sequences (Rio das Velhas Supergroup), the Paleoproterozoic Minas Supergroup and post-Minas intrusive rocks.

The giant iron ore deposits of the Quadrilatero Ferrifero are hosted in itabirites of the Minas Supergroup, which consist of three Paleoproterozoic sequences (Babinski et al., 1995; Noce, 1995; Renger et al., 1994). The lowest unit is the Caraça Group, which consists of alluvial conglomerates and sandstones grading upwards into shallow-water marine siltstones and mudstones. The intermediate Itabira Group consists mainly of chemical sedimentary rocks. A metamorphosed banded iron formation (itabirite) unit of variable composition occurs at the base of the Itabira Group and, together with hematitic and dolomitic phyllites, marbles and dolomites, constitutes the Cauê Formation. The original stratigraphic thickness of the iron formation may have been in the order of $250-300 \mathrm{~m}$, but it now ranges in apparent thickness from a few meters to more than 1,400 m, owing to tectonic rock flowage (Dorr II, 1964). The Cauê Formation grades upward into dolomites and dolomitic/manganiferous itabirites of the 2.4 Ga Gandarela Formation (Babinski et al., 1995). Clastic sediments (with subordinate dolomites) of the Piracicaba Group overlie the Itabira Group. The uppermost sequence of the Minas Supergroup is the Sabará Group, a sequence of metamorphosed volcanoclastic sediments, turbidites, BIFs (banded iron formations), and conglomerates (Renger et al., 1994) dated as Transamazonian (2.1 $-1.7 \mathrm{Ga}$.$) .$

Deep weathering of the Itabira Group BIFs, postulated to have occurred during the Mesocenozoic, produced the large supergene iron orebodies spread throughout the QF (Dorr, 1969). A total of 29 Gtons of iron ore, mined continuously since the beginning of the 40 's and having produced more than 3 Gtons of high-grade iron ore, are estimated to occur in the region (TEX Report, 2002; Walde, 1986; Wallace, 1965). Total production in 2000 in the QF region was 115 Mtons and is estimated for 2004 at 160 Mtons (TEX Report, 2002). Most of the deep weathering profiles in the region are complete stratified weathering profiles, exhibiting an 
indurated cap (canga) overlying absolute and relative enriched supergene iron ores, which immediately overlie saprolitic horizons.

Geomorphologically, the Quadrilatero Ferrifero (literally the iron quadrangle) consists of a roughly square $7000 \mathrm{~km}^{2}$ region (Fig. 2a) characterized by various plateaus, ranging in height from 1100 to $2100 \mathrm{~m}$ elevation, surrounded by dissected plains at ca. $500-600 \mathrm{~m}$ elevation. The quadrangle is delimited by steeply dipping BIFs and quartzites that constitute elevated and highly resistant barriers to erosion and scarp retreat driven by the creeks and streams draining into the plateau. The western limit of the QF is the Serra da Moeda, its northern limit the Serra do Curral, the eastern limit the Serra do Caraça, and the southern limit the Serra do Ouro Branco (Figs. 1 and 2). The core of the Quadrangle is drained by the north-flowing Rio das Velhas, creating a dissected window into the Archean Bação Complex (Fig. 2a). This inner depression is surrounded by several deeply weathered plateaus developed on BIFs and quartzites. The eastern section of the QF hosts a $700 \mathrm{~km}^{2}$ plateau, the Moeda Syncline, delimited by the Serras da Moeda (W), Serra do Curral (N), Serra das Serrinhas (E), and Serra do Ouro Branco (S) (Fig. 2a). This plateau hosts several important supergene ore bodies, included the Sapecado and Andaime deposits, located in the Serra das Serrinhas, investigated in this study (Fig. 2b). Weathering profiles along the Serra da Moeda were investigated in an associated study (Carmo and Vasconcelos, 2003).

The QF plateaus have been interpreted as remnants of an ancient erosion surface developed before the Africa-South America break-up (the Gondwana Surface of King (1956)). Weathering profiles on the plateaus are consistently deeper (up to $400 \mathrm{~m}$ ) and more developed than weathering profiles on surrounding plains and dissected valleys $(<100 \mathrm{~m})$. Landsurfaces on the plateaus are also distinct from the surrounding plains because they are blanketed by strongly iron-hydroxide cemented covers (cangas), which impart a smooth character to the plateat landsurfaces. When the cangas are breached by recent erosion, they form sharp scarps (Fig. 2c), another distinctive characteristic of this landscape. Finally, internal basins on the plateaus (e.g., Bacias do Fonseca and Gandarela), filled with argillite, lignite, sandstone, diamictite, and kaolinitic sediments now partially weathered to bauxite, are associated with collapse structures (karstic lakes) formed during weathering of underlying banded iron formations (Ribeiro, 2003) or with extensional tectonic activity during the Paleogene (Maizatto, 2001; Sant'Anna et al., 1997). We chose to study the weathering history of two supergene iron ore deposits in the Moeda Syncline because of the likelihood that these supergene systems host the most complete information about the weathering history of the Quadrilátero Ferrifero and of the hypothesized 
Gondwana landsurface of King (1956). We also chose to study these profiles because the intimate relationship between supergene iron ore and datable supergene Mn-oxides permits relating the timing of Mn-oxide precipitation with the evolution of the chemical reactions leading to the formation of supergene enriched iron orebodies in the region.

\section{Local Geology}

Three adjacent iron mines (Sapecado, Pico, and Andaime), located along the Serra das Serrinhas on the eastern margin of the Moeda Syncline (Figs. 1-2), provide access to deeply weathered and supergene enriched BIFs. Weathering profiles at these mines vary from a few meters to ca. $200 \mathrm{~m}$ below the present surface (Fig. 3a-c). This large variation in weathering profile depth results on an interlayering of unweathered itabirites with deeply weathered itabirites and soft-hematite ores. Spier et al. (2003) provides detailed characterizations of the iron ores and their hosts rocks in these deposits. In this study, we dated samples from the Sapecado and Andaime weathering profiles, briefly described below.

The Sapecado orebody represents the southern extension of the Pico orebody. It is composed of lenses of unindurated and indurated iron ores interlayered with relatively weathered quartz itabirite. The geological resources of the Sapecado orebody are of 400 Mtons (MBR, internal report). The major geological units present at the Sapecado mine are itabirites and iron ores of the Cauê Formation, clastic metasedimentary rocks of the Moeda and Batatal Formations, and predominantly chemical metasedimentary rocks of the Gandarela Formation (Fig. 3b-c). The rocks are oriented along a general strike $\mathrm{N} 30^{\circ}-35^{\circ} \mathrm{E}$, dipping $45^{\circ}-90^{\circ}$ to SE or NW. The quartzites of the Moeda Formation crop out continuously along the eastern edge of the mine and show a very consistent sub-vertical dip and, in general, weakly developed foliation. The quartzites exhibit abrupt contacts with the overlying phyllites of the Batatal Formation. The uppermost Gandarela Formation crops out at the pit's western wall. It consists of dolomitic phyllite and deeply weathered dolomite with a gradual contact with the itabirites. The main banded iron formation at the Sapecado mine is the quartz itabirite, the protore of the iron ore bodies. This quartz itabirite is a typical metamorphosed BIF and consists of alternate microbands of quartz with martite and hematite. Total or partial leaching of quartz during weathering promoted the residual enrichment of iron, generating the soft iron ores (Spier et al., 2003). Soft ores are highly porous and consist of microbands of aggregates of martite and hematite still cemented together with highly porous bands where martite and hematite grains fill 

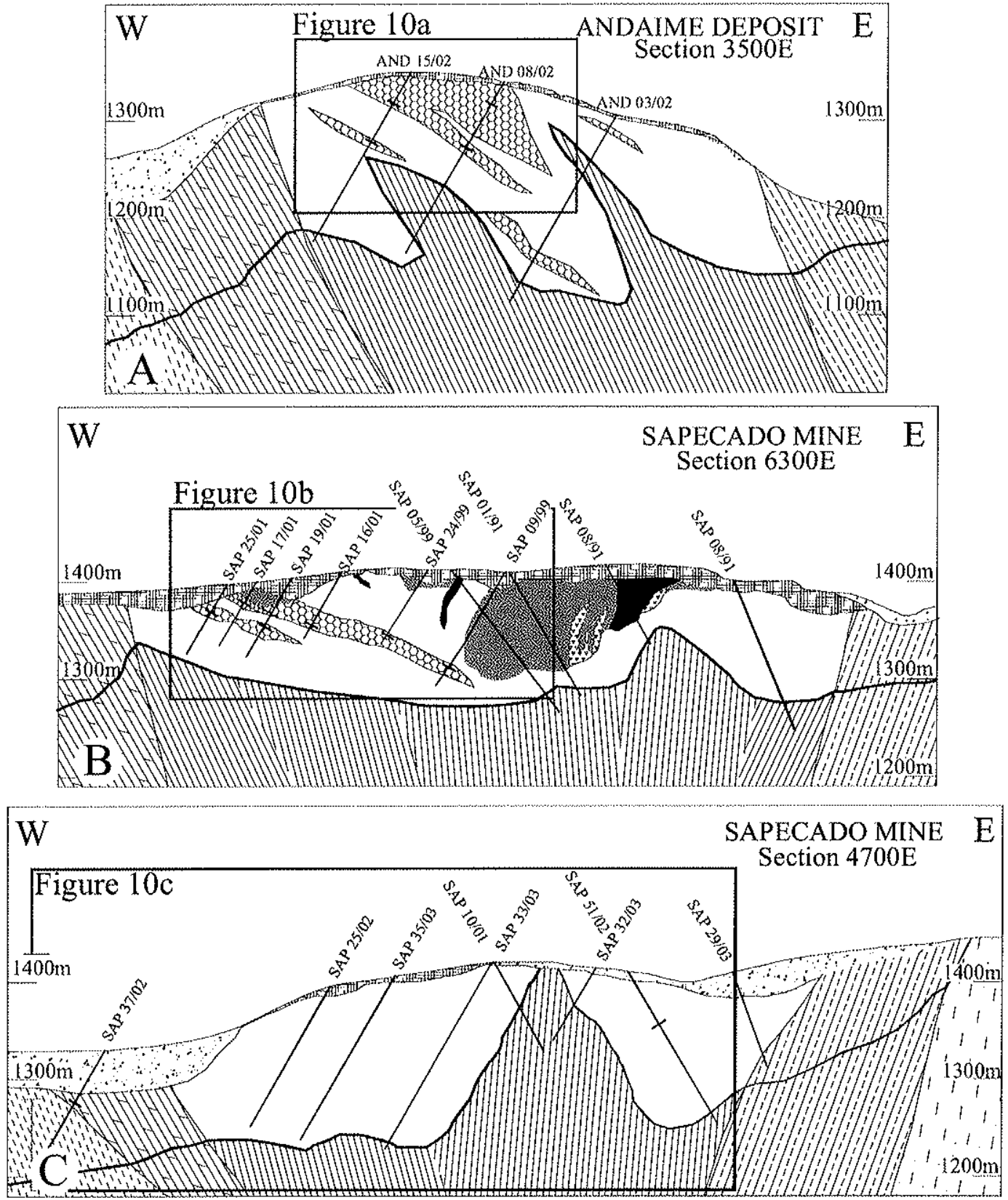

Minas Supergroup - Paleoproterozoic Tertiary-Quaternary

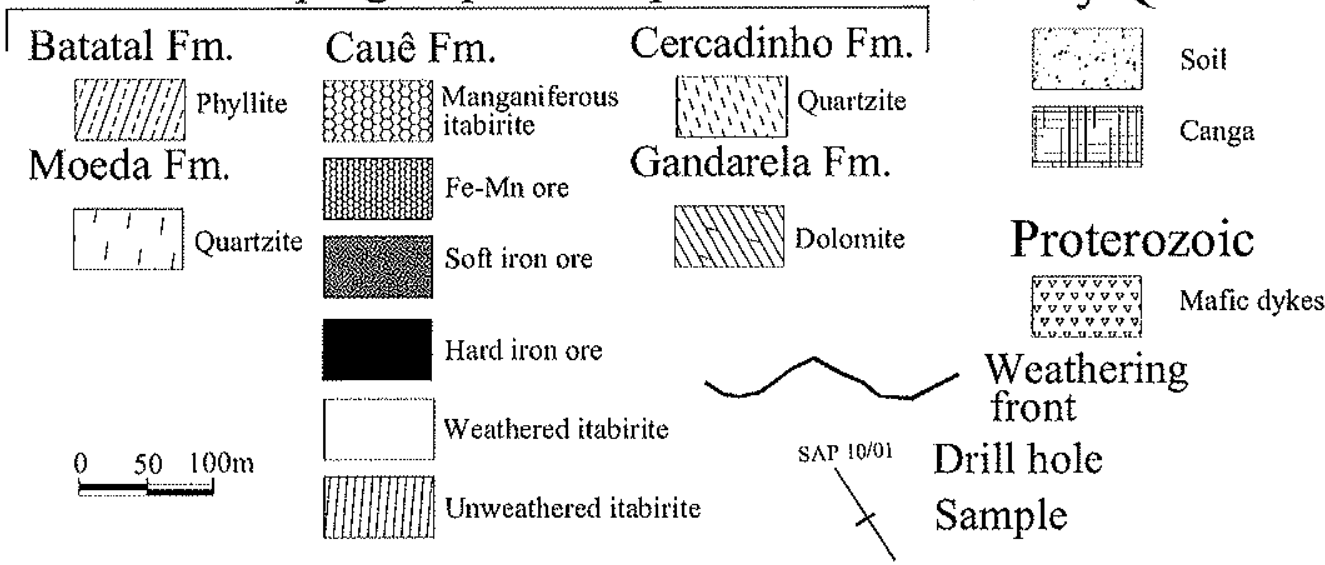

Figure 3. Studied geological sections showing distribution of weathering profile. (a) Andaime Deposit. (b-c) Sapecado Mine. 
cavities generated by the removal of large quantities of primary quartz and carbonate. Some remnant quartz, highly etched and corroded, may occur in varied proportions.

The Andaime orebody is located $10 \mathrm{~km}$ North of the Pico mine (Fig. 1), representing the northern continuity of the iron mineralization. The rocks of the Minas Supergroup at this region are oriented along strike $\mathrm{N} 10^{\circ}-30^{\circ} \mathrm{W}$, dipping $40^{\circ}-80^{\circ}$ to $\mathrm{NE}$. The exploration of the Andaime orebody started in 2004 and its geological resources, still under evaluation, are ca. 100 Mtons (MBR, internal report). The orebody consists of soft quartz itabirite which occurs within the weathering profile, along the strike of the siliceous banded iron formation. Lenses of manganiferous itabirite are interlayered with the iron ore.

Manganiferous itabirite is a particular type of soft iron ore that generally occurs at the top of the Cauê Formation, at the contact with the Gandarela Formation (Fig. 3a-b) in all three Pico, Sapecado, and Andaime - mines. It consists of irregularly distributed lenses varying from decimeters to $20 \mathrm{~m}$ width, $5-100 \mathrm{~m}$ length, with depths varying from a few meters to $150 \mathrm{~m}$. The lenses occur parallel to the itabirite units, interbedded with them (Figs. 3a-b and 4a). The manganiferous itabirite contains on average $48 \mathrm{wt} \%(11 \mathrm{wt} \%-63 \mathrm{wt} \%) \mathrm{Fe}$ and $6 \mathrm{wt} \%(3 \mathrm{wt} \%$ $14 \mathrm{wt} \%$ ) Mn. Rarely the Mn content exceeds $15 \mathrm{wt} \%$. In this case, the ore is called Fe-Mn ore. Manganese oxides in the manganiferous itabirite are irregularly distributed. They generally cement the walls of pores in the soft iron ores or form $\mathrm{cm}$-size botryoidal bands precipitated in cavities and cracks (Fig. 4b).
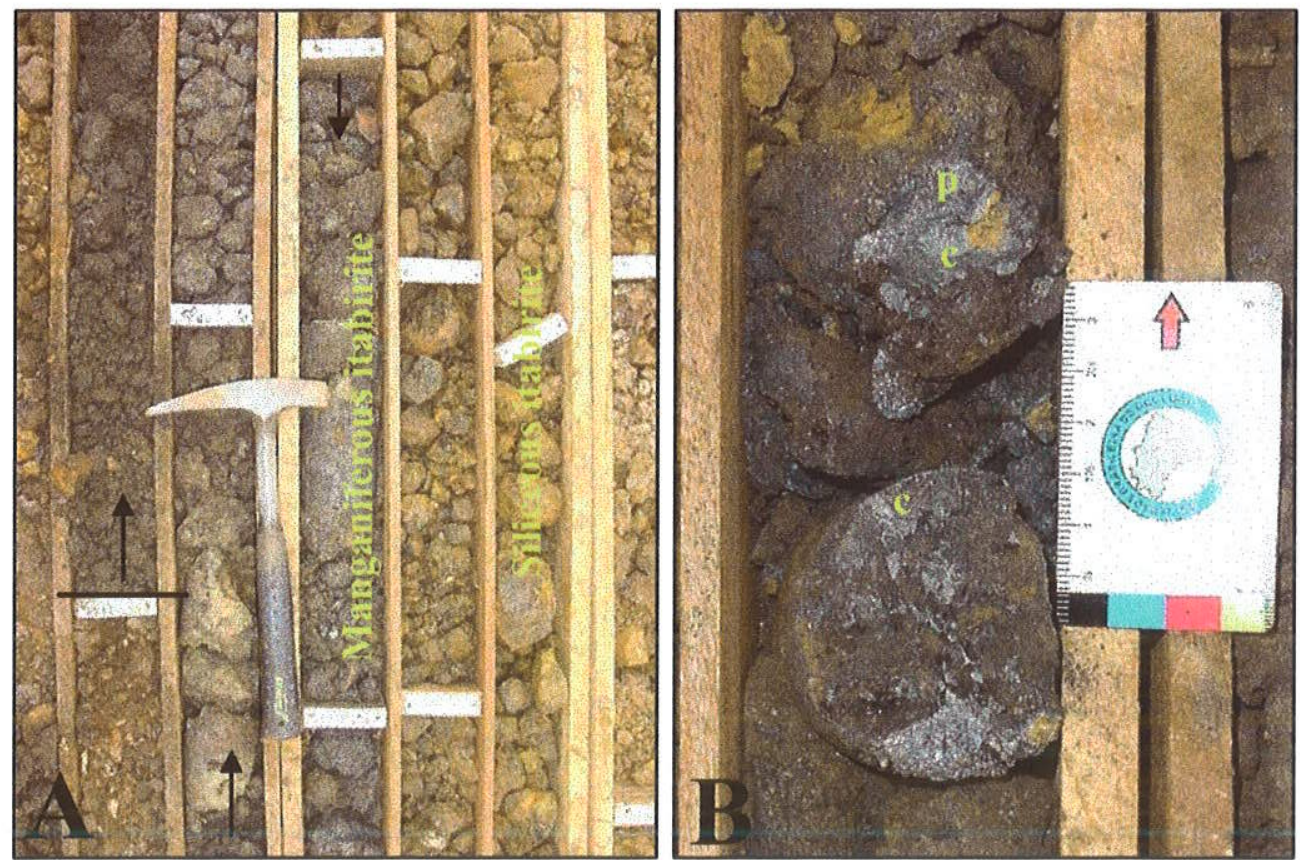

Figure 4. (a) Drill hole of the Andaime Deposit showing manganiferous itabirite between limomitic itabirite. (b) Detail of the manganiferous itabirite showing concretion formed by cryptomelane (c) and pyrolusite (p). 
The Pico, Andaime, and Sapecado orebodies are capped by small basins filled with argillites and siltstones. These type of basins, associated with karstic depressions created by the collapse of the BIF after leaching of silica and carbonate minerals during weathering (Ribeiro, 2003; Ribeiro and Carvalho, 2002), were dated as Paleocene to Eocene based on pollen assemblages (Lima and Salard-Cheboldaeff, 1981; Maizatto, 2001).

\section{SAMPLING AND ANALYTICAL PROCEDURE}

The visual identification of black Mn-oxides dispersed throughout dark hematite ores is a major challenge. To overcome this sampling difficulty, we focused our search for datable supergene Mn-oxides on drill cores previously analyzed for Mn. Sections with high Mn contents, where manganiferous itabirite and Fe-Mn ore occur, were carefully examined with a hand lens and any suitable occurrence of datable Mn-oxide sampled. Datable Mn-oxides, hollandite-group minerals, are easily recognizable based on their superior hardness $(>6)$, a steel-blue metallic luster, and a botryoidal texture. Section $6300 \mathrm{E}$ of the Sapecado mine was chosen for detailed sampling due to the presence of a prominent manganiferous itabirite unit, which forms a continuous lens from the surface down to $\sim 150 \mathrm{~m}$ (Fig, 3b). We sampled each meter of manganiferous itabirite that contained suitable Mn-oxide minerals. The samples selected are supposed to represent a time-stratigraphic sequence from the oldest samples at the near surface environment to the youngest sample at the base of the weathering profile (fresh rock-weathering interface).

Complementary sampling at Sections $4700 \mathrm{E}$ and 3500E, at the Sapecado and Andaime mines, respectively (Figs. 2-3), provide information on weathering age variation along strike. At Section 4700E (Sapecado), we sampled Mn-minerals that occur along fracture planes of deeply weathered dolomites of the Gandarela Formation (Fig. 3c); at Section 3500E (Andaime), we sampled manganiferous itabirite (Fig. 3a).

Sample preparation followed the method detailed by Vasconcelos (1999b) and Vasconcelos et al. (2002). Samples were crushed to $0.5-2 \mathrm{~mm}$, ultrasonically cleaned in distilled water and absolute ethanol, and dried under a heat lamp. The clean sample fragments were examined under a binocular microscope, and six to eight visually homogeneous grains were hand-picked and loaded into aluminum disks for neutron irradiation. The samples were irradiated for 14 hours, along with the Fish Canyon Sanidine standard $(28.02 \pm 0.28 \mathrm{Ma})$, in the Triga reactor at the B-1 CLICIT Facility, Radiation Centre, Oregon State University Reactor, Oregon, 
USA. After a cooling-off period of three weeks, three grains from each sample were loaded into a 145-pit copper disk, baked at $180^{\circ} \mathrm{C}$ for 13 hours, and incrementally heated by a continuous 10 W Ar-ion laser with a defocused beam at the UQ-AGES laboratory, Australia. Gases released during incremental-heating were cleaned by a cryocooled trap $\left(\mathrm{T}=-130^{\circ} \mathrm{C}\right)$ and two C-50 SAES $\mathrm{Zr}-\mathrm{V}-\mathrm{Fe}$ getter pumps, and the clean gas fraction expanded into a MAP-215-50 mass spectrometer. Air pipettes and blanks were run before and after each sample to correct for background and mass discrimination. Air pipettes, blanks, and unknowns were analyzed by the peak hoping method, 8-10 cycles were measured for each isotope, and 7 measurements of ${ }^{40} \mathrm{Ar}$, ${ }^{39} \mathrm{Ar},{ }^{38} \mathrm{Ar}$ and ${ }^{37} \mathrm{Ar}$ and 25 measurements of ${ }^{36} \mathrm{Ar}$ were made at each peak top. Isotope evolution was fitted with either parabolic or linear fits. Typical blank values and air pipette ${ }^{40} \mathrm{Ar} /{ }^{36} \mathrm{Ar}$ ratios are reported in Appendix 1. The neutron flux for each sample was estimated from $J$-factors (Appendix 1) calculated for each disk from the analyses of a minimum of 15 grains of FC sanidine standard placed in the disk following the geometry illustrated in Vasconcelos et al. (2002). All ages are reported using the constants of Steiger and Jägger (1977). Corrections for interfering isotopes generated during irradiation are as follows: $(2.64 \pm 0.62) \times 10^{-4}$ for $\left({ }^{36} \mathrm{Ar} /{ }^{37} \mathrm{Ar}\right)_{\mathrm{Ca}},(7.04 \pm 0.06) \times 10^{-4}$ for $\left({ }^{39} \mathrm{Ar}{ }^{37} \mathrm{Ar}\right)_{\mathrm{Ca}}$, and $(8 \pm 3) \times 10^{-4}$ for $\left({ }^{40} \mathrm{Ar}{ }^{39} \mathrm{Ar}\right)_{\mathrm{K}}$. Data corrected for blanks, mass discrimination, nucleogenic interferences, and atmospheric contamination were used to calculate apparent ages for each degassing step and are reported on Appendix 1.

From the same batch of grains used for isotope analyses, additional aliquots of 3-5 grains were mounted in an epoxy container and polished for petrographic, SEM and EMP analyses. The SEM and EMP analyses were carried out at the Centre for Microscopy and Microanalyses at the University of Queensland, Australia. A JEOL JXA 8800L Superprobe, operating at $15 \mathrm{kV}$ and 15 $\mathrm{nA}$ current and with $0.5 \mu \mathrm{m}$ probe diameter, was used for EMP analyses. Oxygen was analyzed as unknown and the following standards were used: $\mathrm{MnO}(\mathrm{Mn}$ and $\mathrm{O}), \mathrm{Cl}$-apatite $(\mathrm{P}), \mathrm{CoO}(\mathrm{Co})$, $\mathrm{TiO}_{2}(\mathrm{Ti}), \mathrm{PbS}(\mathrm{Pb}), \mathrm{Al}_{2} \mathrm{O}_{3}(\mathrm{Al}), \mathrm{Fe}_{2} \mathrm{SiO}_{4}(\mathrm{Fe}, \mathrm{Si}), \mathrm{ZnO}(\mathrm{Zn}), \mathrm{CaSO}_{4}(\mathrm{Ca}), \mathrm{BaSO}_{4}(\mathrm{Ba})$, $\mathrm{NaAlSi}_{3} \mathrm{O}_{8}(\mathrm{Na})$ and $\mathrm{KAlSi}_{3} \mathrm{O}_{8}(\mathrm{~K})$. Approximately 450 spots were analyzed on $\sim 60$ samples. Whenever possible, microprobe analyses were pre-programmed perpendicularly to the growth bands to investigate possible variations in Mn-oxide compositions during mineral precipitation. 


\section{RESULTS AND DISCUSSION}

\section{Mineralogy and Petrography}

Reflected-light microscopy and SEM investigation show that cryptomelane, pyrolusite and hollandite are the main Mn-oxides present. These minerals occur cementing pore spaces in the iron ore or form mm-size growth bands (Fig. 5a-d). Minor Al-enrichment generally occurs at the contact between Mn-oxides and the hosting iron ore. Pure lithiophorite was not detected in any of the grains analyzed. Most Mn-oxides are mineralogically complex (Fig. 5d-g). Hematite (either as martite or tabular hematite) inclusions are common within Mn-oxide grains, particularly at the contact of void-filling concretions with the iron ore (Fig. 5a). Goethite and gibbsite bands alternate with Mn-oxides in some botryoidal samples (Fig. 5h).

Manganese oxide textures are also variable. When cementing pores in the iron ore, hollandite-group Mn-oxides are generally very pure, cryptocrystalline, and characterized by botryoidal textures composed of micrometric growth bands (Fig. 5b-d). Individual microbands display uniform grain size and mineralogical composition. Cryptomelane crystals in microbands occur as 10-20 micron needle-like crystals, with 10:1 aspect ratio, and oriented perpendicularly to the growth bands (Fig. 5e). When pyrolusite is present, coarse aggregates of $0.01-0.20 \mathrm{~mm}$ grains occur. Pyrolusite may also occur as radiating prismatic crystals aligned perpendicularly to the growth bands, and it is often partially replaced by hollandite-group phases (Fig. $5 \mathrm{f}-\mathrm{g}$ ). Desiccation cracks are often observed in pyrolusite crystals (Fig. $5 \mathrm{f}-\mathrm{g}$ ).

Textural relationships and mineralogy of the samples indicate that Mn-oxides were directly precipitated from weathering solutions. Paragenetic relations among $\mathrm{Mn}$ minerals were difficult to assess. Generally, cryptomelane and hollandite are older than pyrolusite (Fig. 5c), but this is not always the case. Multiple generations of Mn-oxides, indicated by banded and colloform textures, systems of intersecting veinlets, and mutual replacements, are observed (Fig. 6a-h). The small size of the Mn-oxide growth bands (less than $20 \mu \mathrm{m}$ in average) does not allow for the selection of fragments from a single generation. In addition, many grains selected for geochronology may contain minor supergene pyrolusite, goethite, or gibbsite inclusions. Some grains also contain martite-hematite inclusions, which may cause further complications during dating (see discussion below). Petrographic and SEM examinations, however, clearly show the absence of any hypogene $\mathrm{K}$ silicate in the samples submitted to ${ }^{40} \mathrm{Ar} \mathrm{r}^{39} \mathrm{Ar}$ geochronology. 

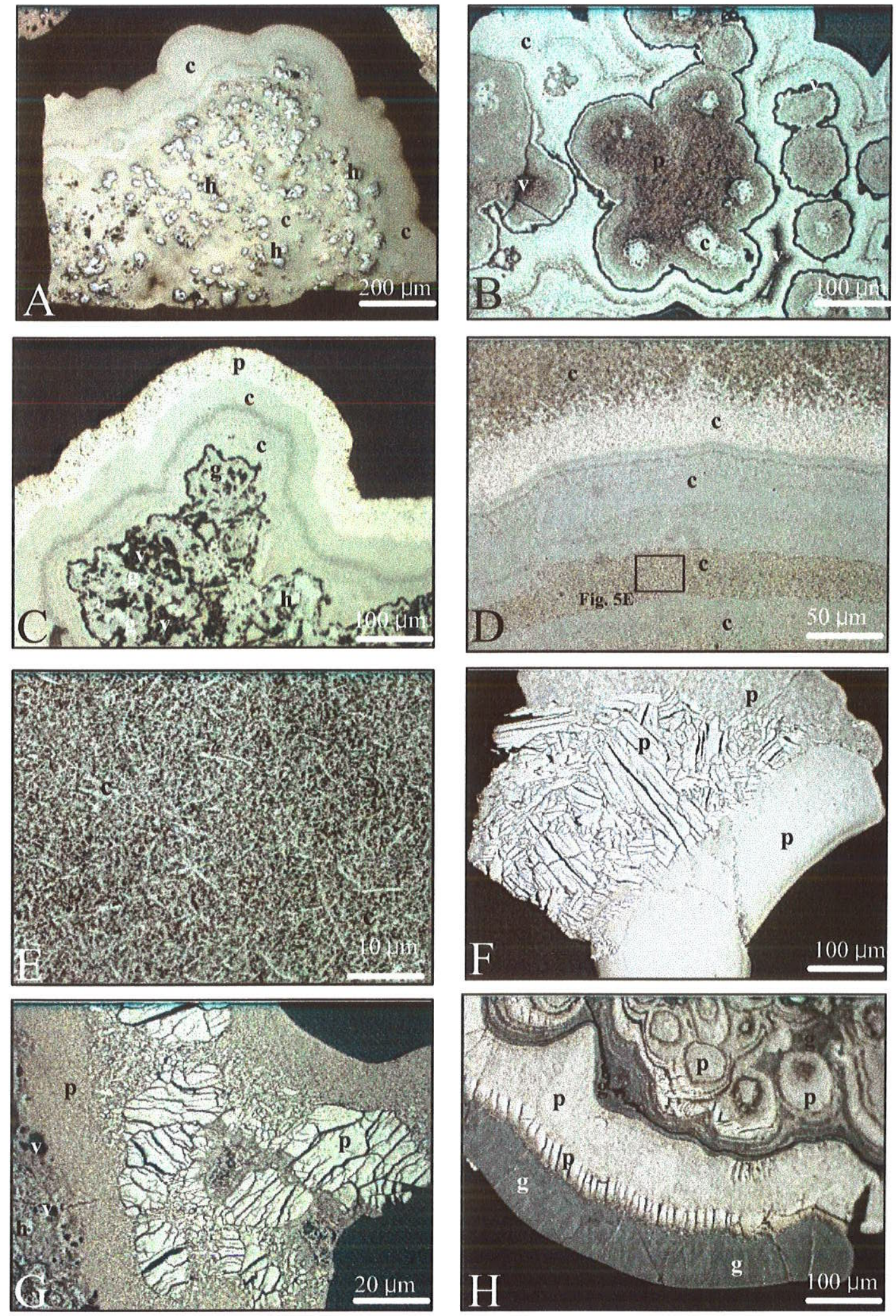

Figure 5. Reflected-light photomicrographs of Mn-oxides from the Sapecado and Andaime profiles showing textural relationships and mineralogy of the Mn-oxides investigated. (a) Cryptomelane $(c)$ filling voids between hematite crystals $(h)$, and forming a thin layer. (b) Botryoidal texture formed by alternated layers of cryptomelane and voids $(v)$. Pyrolusite $(p)$ occurs in the center of the concretion. (c) Mn-concretion formed by layers of cryptomelane and pyrolusite. Hematite and goethite $(g)$ occur in the center of the concretion. (d) Several layers of cryptomelane showing variation on the size of the crystals with crystallization. (e) Detail of a coarse layer showing needle shape crystals between voids. (f-g) Several generations of pyrolusite. (h) Botryoidal texture showing alternation between pyrolusite and goethite. 

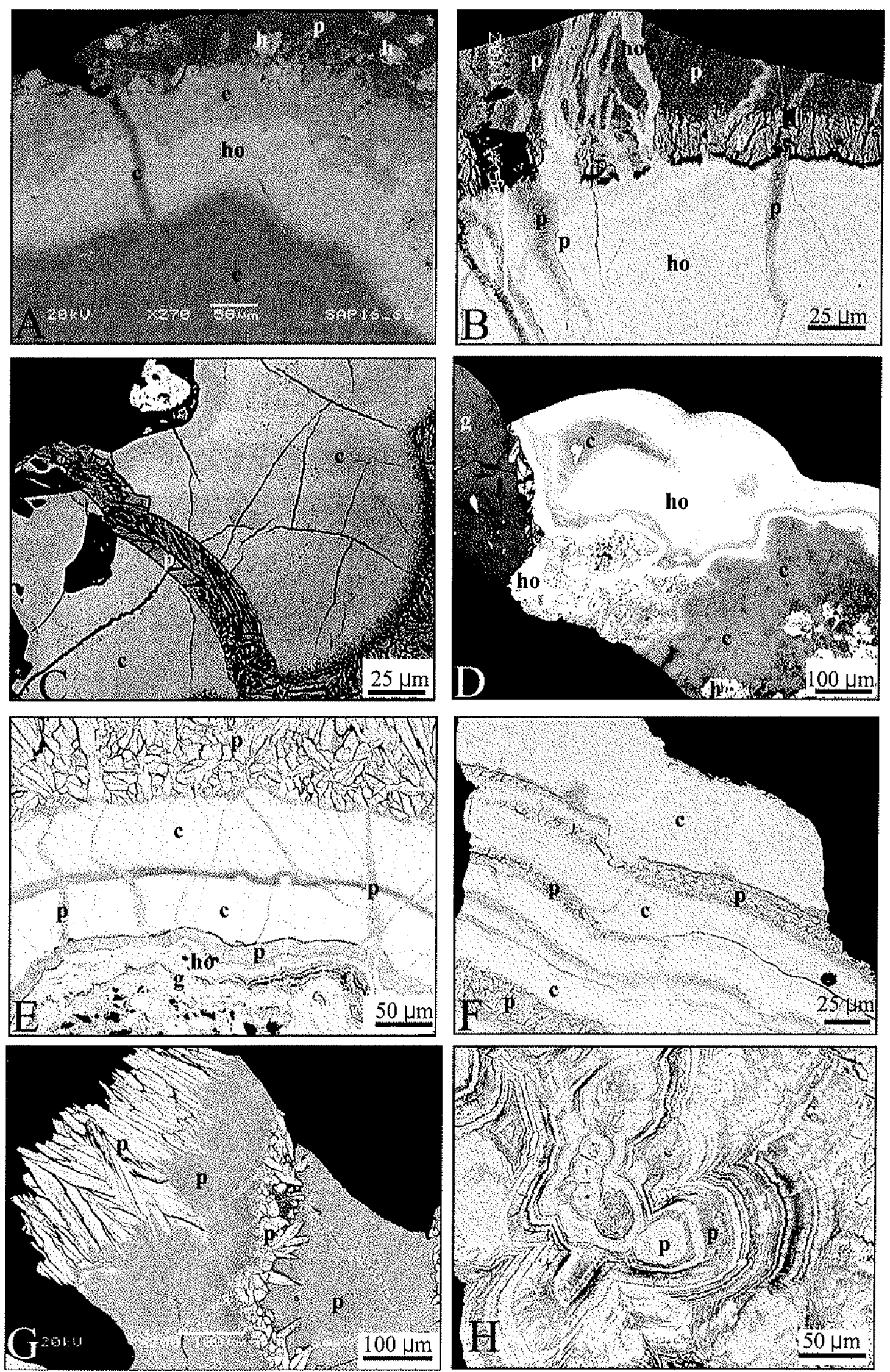

Figure 6. Backscattered electron micrograph showing several generations of Mn-oxides. (a) Layering of cryptomelane (c), hollandite (ho), cryptomelane and pyrolusite $(p)$. Hematite $(h)$ occurs in the external layer. Note the thin vein of cryptomelane cutting the layering. (b) Thin veins of hollandite and pyrolusite cutting two generations of pyrolusite. (c) Veins of pyrolusite curring cryptomelane. (d-t) Several generations of cryptomelane, hollandite and pyrolusite. Goethite $(g)$ occurs stbordinately. (g) Two generations of pyrolusite. (h) Concentric layers of pyrolusite forming a botryoidal texture. 


\section{Electron microprobe analysis}

Electron microprobe analyses for 448 spots in 60 grains of Mn-oxides show that weathering solutions from which they precipitated were rich in $\mathrm{Mn}, \mathrm{Al}, \mathrm{Fe}, \mathrm{K}$ and $\mathrm{Ba}$ (Fig. 7), consistent with cryptomelane, hollandite, and pyrolusite stoichiometries (Table 1). Total Mn contents vary from 48 - 63 wt\% (Fig. 8a). Variation on Mn concentrations reflects distinct mineralogy and variation in tunnel cation occupancy $(\mathrm{Ba}, \mathrm{K}$, etc.). When the contents of $\mathrm{K}$ and $\mathrm{Ba}$ were under $0.5 \%$ the mineral was called pyrolusite. Figure $8 \mathrm{~b}$ shows that the potassium concentrations reach $3.9 \mathrm{wt} \%$ in cryptomelane (average of $2 \mathrm{wt} \%$ ).

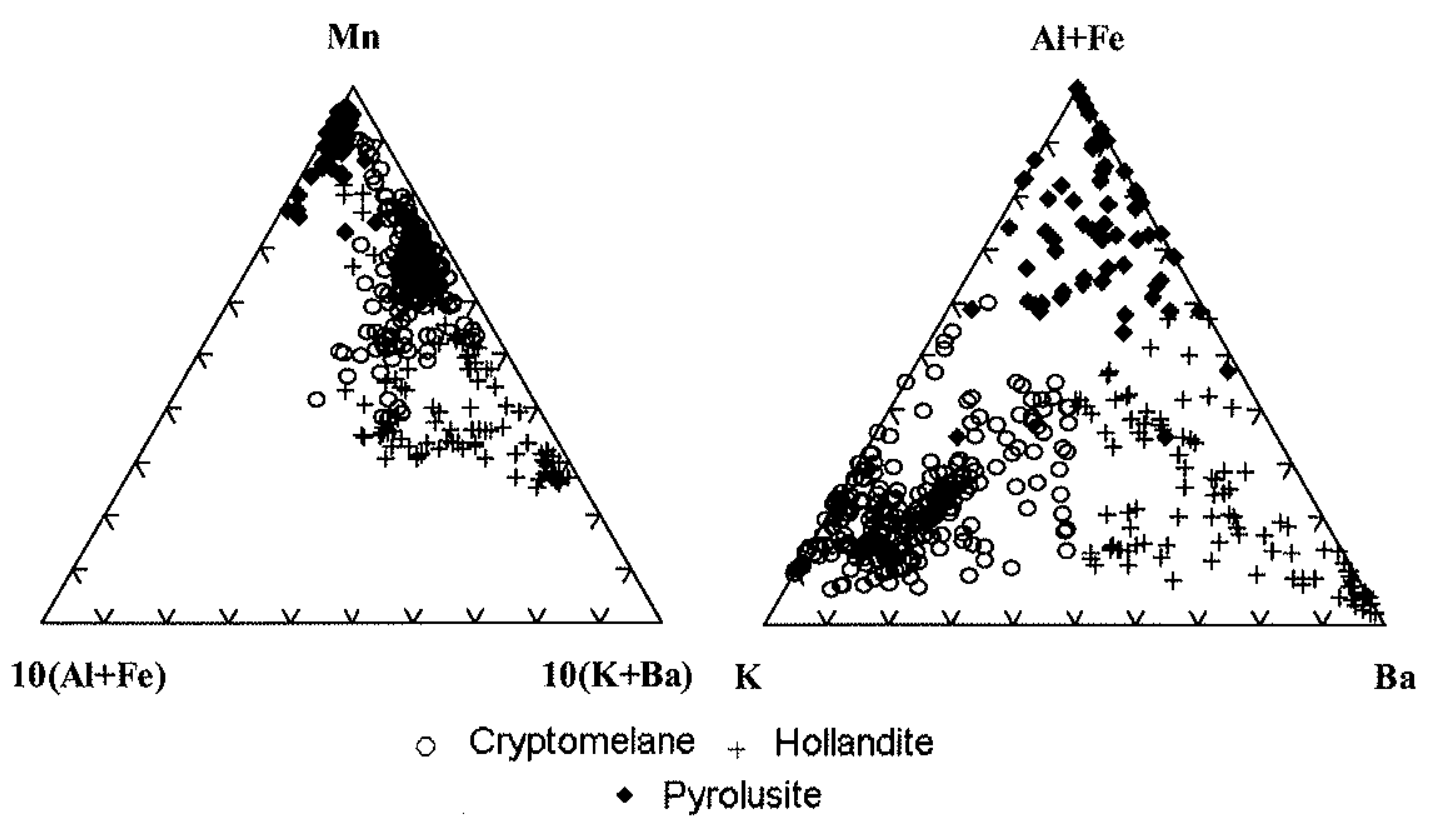

Figure 7. Ternary plots showing the major chemical composition of the Mn-oxides from the Sapecado and Andaime deposits. Note the complete exchanges between $\mathrm{Al}, \mathrm{Fe}, \mathrm{K}$ and $\mathrm{Ba}$. 
Table 1. Average composition of the Mn-oxides

\begin{tabular}{lccc}
\hline & $\begin{array}{c}\text { Cryptomelane } \\
(\mathrm{n}=253)\end{array}$ & $\begin{array}{c}\text { Hollandite } \\
(\mathrm{n}=131)\end{array}$ & $\begin{array}{c}\text { Pyrolusite } \\
(\mathrm{n}=64)\end{array}$ \\
$\mathrm{O}$ & 34.75 & 33.66 & 34.45 \\
$\mathrm{Mn}$ & 58.37 & 53.65 & 61.08 \\
$\mathrm{~K}$ & 1.99 & 1.22 & 0.08 \\
$\mathrm{Ca}$ & 0.12 & 0.10 & 0.05 \\
$\mathrm{~Pb}$ & 0.02 & - & 0.02 \\
$\mathrm{P}$ & 0.07 & 0.15 & 0.11 \\
$\mathrm{Ba}$ & 0.47 & 5.11 & 0.12 \\
$\mathrm{Fe}$ & 0.27 & 0.70 & 0.32 \\
$\mathrm{Co}$ & 0.08 & 0.05 & 0.02 \\
$\mathrm{Zn}$ & 0.05 & 0.01 & 0.03 \\
$\mathrm{Ti}$ & 0.01 & - & - \\
$\mathrm{Na}$ & 0.10 & 0.04 & 0.01 \\
$\mathrm{Al}$ & 0.51 & 1.37 & 0.22 \\
$\mathrm{Si}$ & 0.04 & 0.10 & 0.08 \\
\hline
\end{tabular}

Elements with (-) were not detected
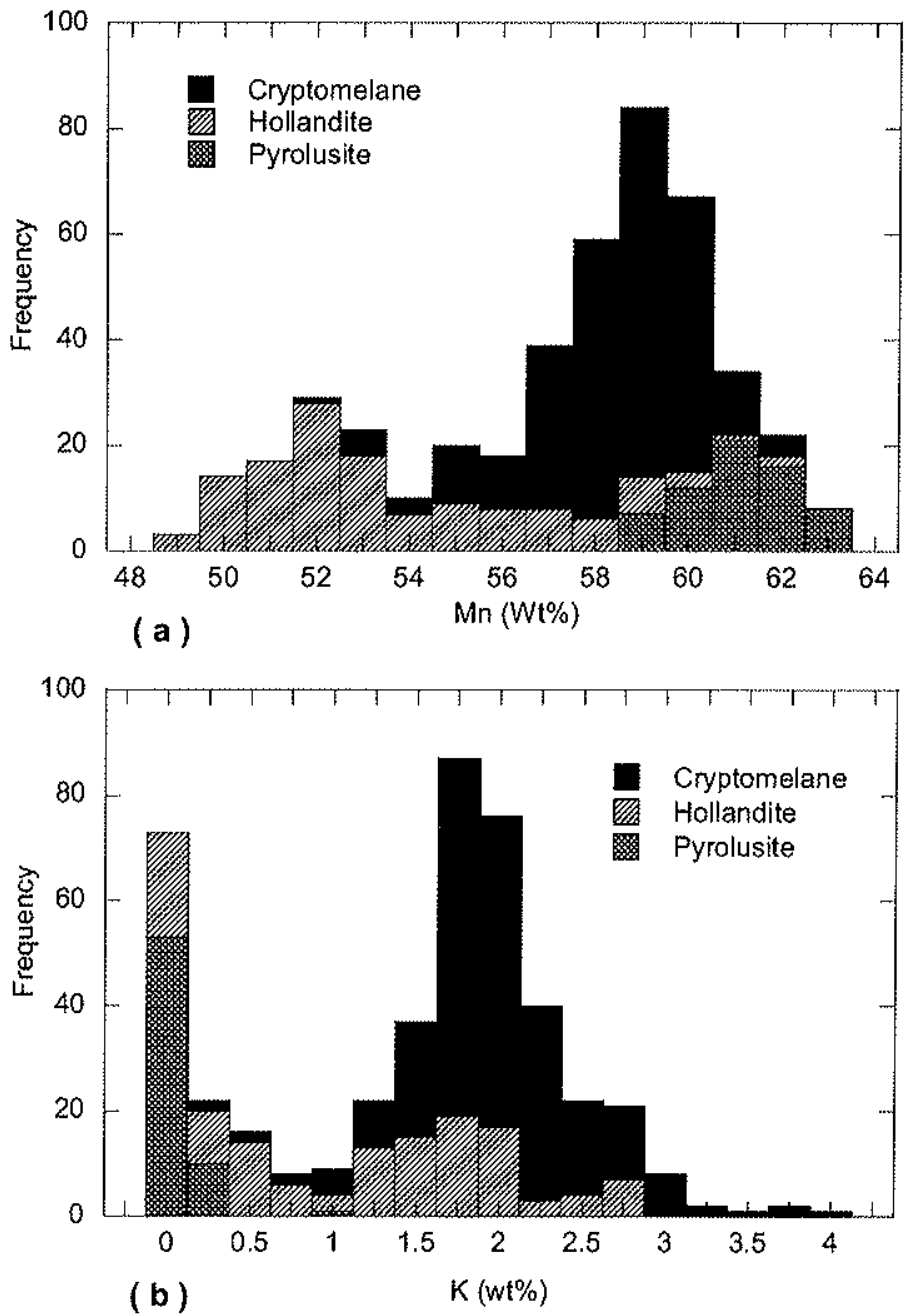

Figure 8. Histograms of the $\mathrm{Mn}$ and $\mathrm{K}$ contents of $60 \mathrm{Mn}$-oxide grains by ca. 448 spot EMP analyses. 


\section{Manganese Oxide Paragenesis}

Field and petrographic observations indicate that Mn-oxides sampled in this study formed during chemical weathering of the dolomite-bearing itabirite of the Cauê Formation and the dolomite of the Gandarela Formation. Manganese and iron are present as minor elements in the dolomite. Manganese and iron are also common in carbonate cements associated with the diagenetic or hydrothermal alteration of the BIFs. $\mathrm{Mn}^{+2}$ and $\mathrm{Fe}^{+2}$ are released into the weathering solutions during the dissolution of the Mn-bearing carbonates. As long as the weathering solutions remain relatively reducing and neutral to acidic, $\mathrm{Mn}^{+2}$ stays in solution. If the $\mathrm{Mn}^{+2}$ bearing solutions encounter descending oxygenated meteoric solutions along permeable horizons and fault planes, $\mathrm{Mn}^{+2}$ readily oxidizes and precipitates as $\mathrm{Mn}^{+4}$-oxides and -hydroxides (pyrolusite, ramsdellite, manganite). Alternatively, when $\mathrm{Mn}^{+2}$-bearing weathering solutions encounter strongly alkaline conditions, which often occurs at the contact between the BIF and the host carbonates of the Gandarela Formation, $\mathrm{Mn}^{+2}$ may also readily oxidize and precipitate as $\mathrm{Mn}^{+4}$ oxides/hydroxides. If, in addition to $\mathrm{Mn}^{+2}$, the weathering solutions also contain dissolved $\mathrm{K}^{+1}, \mathrm{Ba}^{+2}$, or other cations, complex tunnel structure manganese oxides (romanéchite, hollandite, cryptomelane, todorokite) may form. The processes above account for the common occurrence of $\mathrm{Mn}$-oxides along faults and along the contact between the BIF and the adjacent carbonate rocks. Manganese oxide paragenesis in the supergene iron orebodies suggests an intimate association of the oxides with the weathering of the banded iron formations. This, in turn, assures that geochronological analyses of the Mn-oxides provide information on the weathering history of the BIFs.

\section{${ }^{40} \mathrm{Ar} /{ }^{39} \mathrm{Ar}$ Geochonological Analysis}

Laser-heating ${ }^{40} \mathrm{Ar} /{ }^{39} \mathrm{Ar}$ dating of 69 grains extracted from 23 samples of Mn-oxides yields the results summarized in Table 2 and illustrated in Fig. 9. Complete results, corrected for interfering isotopes and mass discrimination, are listed in Appendix 1.

The incremental heating spectra in Fig. 9 reveals that 31 grains yield plateau ages, where plateaus are defined by 2 or more contiguous steps yielding $\geq 50 \%$ of the total ${ }^{39} \mathrm{Ar}$ gas released for the sample whose apparent age values are within $2 \sigma$ from the mean value. Plateau ages are interpreted to represent the age of precipitation of the grains analyzed (Vasconcelos, 1999a). Twenty-one grains do not yield plateaus according to the definition above, but these grains yield flat segments, containing $\geq 50 \%$ of total ${ }^{39}$ Ar released, that define "plateau-like" ages. Ages for 
Table 2. Summary of the ${ }^{46} \mathrm{Ar} /{ }^{39} \mathrm{Ar}$ geochronology data of the 23 samples analyzed in this study. The uncertainties are given at the $2 \sigma$ level

\begin{tabular}{|c|c|c|c|c|c|}
\hline Sample & Lor & & Elevation $(\mathrm{m})$ & Grain ID & Age $(\mathrm{Ma})$ \\
\hline \multirow{4}{*}{ SI } & Drill Hole & Depth (m) & & & \\
\hline & SAP $25 / 01$ & 45.00 & 1399.31 & $2665-1$ & $61.3 \pm 1.7$ \\
\hline & & & & $2665-2$ & $61.5 \pm 1.2^{*}$ \\
\hline & & & & $2665-3$ & $61.0 \pm 5.0^{*}$ \\
\hline \multirow[t]{3}{*}{$\mathrm{S} 2$} & SAP $17 / 01$ & 22.60 & 1380.93 & $2649-1$ & $48.6 \pm 0.9$ \\
\hline & & & & $2649-2$ & $52.0 \pm 0.8^{*}$ \\
\hline & & & & $2649-3$ & $48.8 \pm 0.8$ \\
\hline \multirow[t]{2}{*}{ \$3 } & SAP $17 / 02$ & 24.60 & 1379.20 & $2650 \sim 1$ & $56.4 \pm 1.7^{*}$ \\
\hline & & & & $2650-2$ & $58.0 \pm 0.3$ \\
\hline \multirow[t]{3}{*}{ S4 } & $\mathrm{SAP} 17 / 0 \mathrm{I}$ & 25.60 & 1378.33 & $2652-1$ & $50.7 \pm 0.5^{*}$ \\
\hline & & & & $2652 * 2$ & $51.6 \pm 0.5^{*}$ \\
\hline & & & & $2652 \cdots 3$ & $48.9 \pm 1.6^{*}$ \\
\hline \multirow[t]{3}{*}{ S5 } & SAP $17 / 01$ & 26.60 & 1377.46 & $2653-1$ & $52.9 \pm 0.7^{*}$ \\
\hline & & & & $2653-2$ & $54.1 \pm 0.4$ \\
\hline & & & & $2653 m 3$ & $53.0 \pm 0.5$ \\
\hline \multirow[t]{3}{*}{ S6 } & SAP $17 / 01$ & 28.50 & 1375.82 & $2655-1$ & $46.2 \pm 0.2$ \\
\hline & & & & $2655-2$ & $55.6 \pm 0.5^{13}$ \\
\hline & & & & $2655 m 3$ & $45.2 \pm 0.5$ \\
\hline \multirow[t]{3}{*}{ S7 } & SAP $19 / 01$ & 41.00 & 1357.71 & $2661-1$ & $49.6 \pm 0.6^{*}$ \\
\hline & & & & $2661-2$ & $46.9 \pm 0.2$ \\
\hline & & & & $2661-3$ & $49.3 \pm 0.4^{*}$ \\
\hline \multirow[t]{3}{*}{ S8 } & SAP $19 / 01$ & 45.00 & 1354.25 & $2662-1$ & $47.4 \pm 0.5^{*}$ \\
\hline & & & & $2662-2$ & $48.3 \pm 0.5^{*}$ \\
\hline & & & & $2662-3$ & $47.6 \pm 0.5$ \\
\hline \multirow[t]{3}{*}{ S9 } & SAP $19 / 01$ & 46.00 & 1353.38 & $2663-1$ & $55.9 \pm 0.4$ \\
\hline & & & & $2663-2$ & $56.1 \pm 0.3$ \\
\hline & & & & $2663-3$ & $56.5 \pm 0.2$ \\
\hline \multirow[t]{3}{*}{$\mathrm{S} 10$} & SAP $19 / 01$ & 49.00 & 1350.79 & $2664-1$ & $45.1 \pm 0.8^{*}$ \\
\hline & & & & $2664-2$ & $45.5 \pm 0.3$ \\
\hline & & & & $2664-3$ & $43.6 \pm 0.5$ \\
\hline \multirow[t]{3}{*}{ S11 } & SAP $16 / 01$ & 67.00 & 1358.74 & $2658-1$ & $45.3 \pm 0.2$ \\
\hline & & & & $2658-2$ & $44.1 \pm 0.2$ \\
\hline & & & & $2658-3$ & $44.4 \pm 0.3$ \\
\hline \multirow[t]{3}{*}{$\mathrm{S} 12$} & SAP $16 / 01$ & 68.00 & 1357.87 & $2659-1$ & $42.7 \pm 0.5^{*}$ \\
\hline & & & & $2659-2$ & $42.6 \pm 0.1$ \\
\hline & & & & $2659-3$ & $43.0 \pm 0.2$ \\
\hline $\mathrm{S} 13$ & SAP $16 / 01$ & 69.00 & 1357.01 & $2660-1$ & $41.6 \pm 0.3^{*}$ \\
\hline \multirow[t]{3}{*}{$\mathrm{S} 14$} & SAP $24 / 99$ & 83.10 & 1340.16 & $2656 \cdot 1$ & $47.1 \pm 0.4^{*}$ \\
\hline & & & & $2656-2$ & $46.9 \pm 0.2$ \\
\hline & & & & $2656-3$ & $46.5 \pm 0.2^{*}$ \\
\hline \multirow[t]{3}{*}{$\mathrm{S} 15$} & SAP 09/99 & 75.70 & 1318.4 & $2666-1$ & $48.0 \pm 3.0$ \\
\hline & & & & $2666-2$ & $53.6 \pm 0.6$ \\
\hline & & & & $2666-3$ & $46.4 \pm 1.0$ \\
\hline
\end{tabular}




\begin{tabular}{|c|c|c|c|c|c|}
\hline Sample & Loc & & Elevation (m) & Grain ID & Age (Ma) \\
\hline \multirow{4}{*}{$\mathrm{S} 16$} & Drill Hole & Depth $(\mathrm{m})$ & & & \\
\hline & SAP $37 / 02$ & 60.55 & 1277.95 & $2667-1$ & $37.0 \pm 4.0^{f}$ \\
\hline & & & & $2667-3 a$ & $33.0 \pm 5.0^{4}$ \\
\hline & & & & $2667-3 b$ & $30.0 \pm 5.0^{H}$ \\
\hline \multirow[t]{3}{*}{ S17 } & SAP 37/02 & $62.00 \mathrm{~B}$ & 1276.70 & $2673-1$ & $18.0 \pm 0.5^{*}$ \\
\hline & & & & $2673-2$ & $19.2 \pm 1.5$ \\
\hline & & & & $2673-3$ & $16.8 \pm 0.9$ \\
\hline \multirow[t]{2}{*}{$\mathrm{S} 18$} & SAP $37 / 02$ & 62.50 & 1276.27 & $2674-1$ & $14.2 \pm 0.2$ \\
\hline & & & & $2674-3$ & $47.9 \pm 1.5^{3 k}$ \\
\hline \multirow[t]{3}{*}{ S19 } & SAP 51/02 & 120.60 & 1351.07 & $2676-1$ & $49.0 \pm 4.0^{7}$ \\
\hline & & & & $2676-2$ & $39.0 \pm 2.0^{\prime \prime}$ \\
\hline & & & & $2676-3$ & $50.0 \pm 2.0^{H}$ \\
\hline \multirow[t]{3}{*}{$\mathrm{S} 20$} & AND $15 / 02$ & 53.30 & 1310.76 & $2681-1$ & $33.2 \pm 0.5^{7 t}$ \\
\hline & & & & $2681-2$ & $39.4 \pm 0.3^{\prime \prime}$ \\
\hline & & & & $2681-3$ & $31.8 \pm 0.4^{H}$ \\
\hline \multirow[t]{3}{*}{ S21 } & AND $15 / 02$ & 87.65 & 1281.01 & $2682-1$ & $32.0 \pm 0.1$ \\
\hline & & & & $2682 \sim 2$ & $32.3 \pm 0.4^{*}$ \\
\hline & & & & $2682-3$ & $32.5 \pm 0.4^{*}$ \\
\hline \multirow[t]{3}{*}{$\mathrm{S} 22$} & AND 08/02 & 33.20 & 1310.60 & $2679-1$ & $46.2 \pm 1.4^{*}$ \\
\hline & & & & $2679-2$ & $48.2 \pm 1.5$ \\
\hline & & & & $2679-3$ & $45.4 \pm 1.3$ \\
\hline \multirow[t]{3}{*}{$\mathrm{S} 23$} & AND 08/02 & 84.15 & 1266.48 & $2680-1$ & $49.1 \pm 1.3^{*}$ \\
\hline & & & & $2680-2$ & $36.0 \pm 3.0^{\#}$ \\
\hline & & & & $2680 \cdots 3$ & $46.0 \pm 3.0^{H}$ \\
\hline
\end{tabular}

Ages with $\left(^{*}\right)$ are "plateau-like" ages. Ages with (\#) are poor "plateau-like" ages (see text for explanation) 

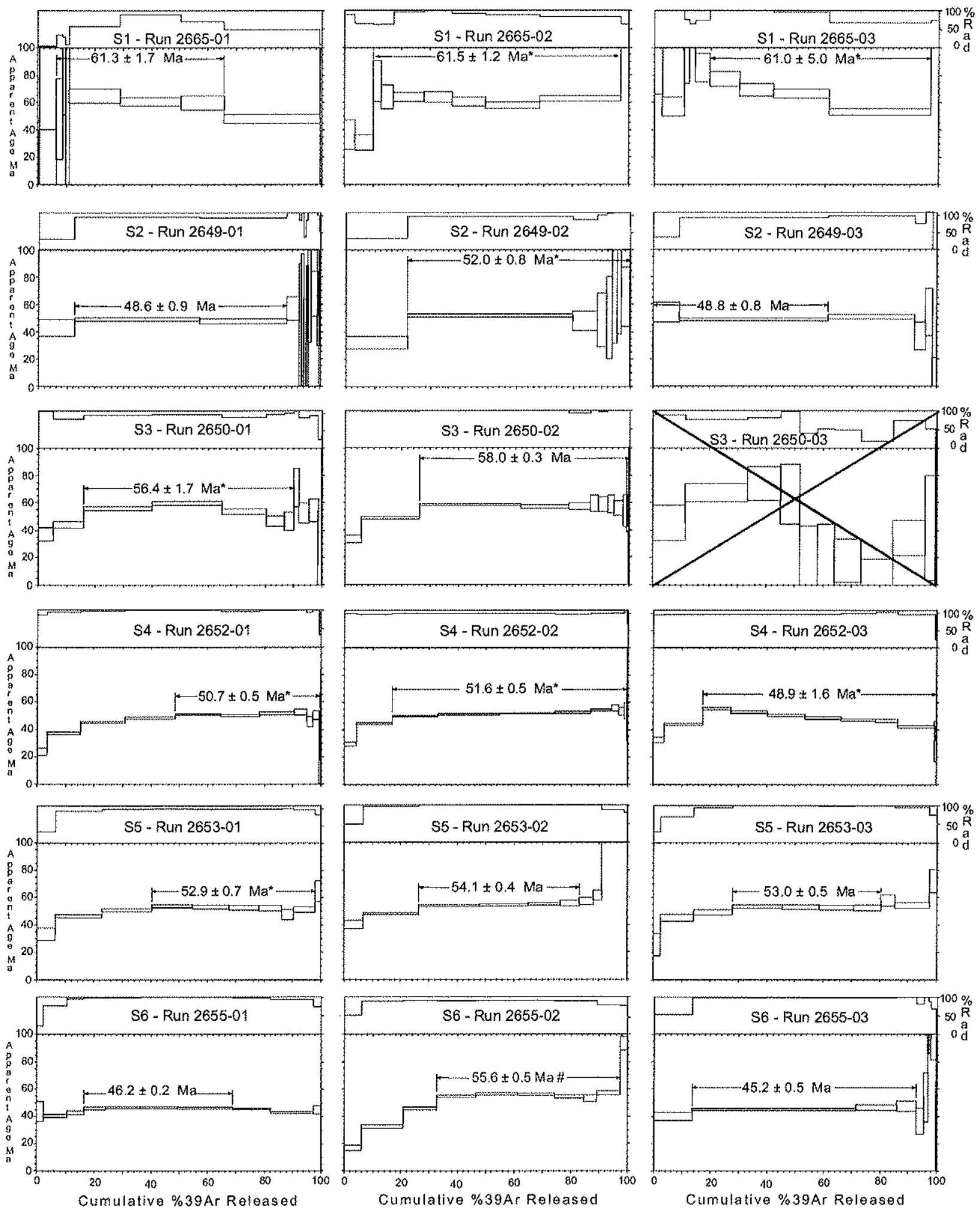

Figure 9. Incremental-heating spectra for the 3 grains of the 23 samples from the Sapecado and Andaime deposits. Ages with (*) are "plateau-like" ages. Ages with (\#) are poor "plateau-like" ages (see text for explanation), 

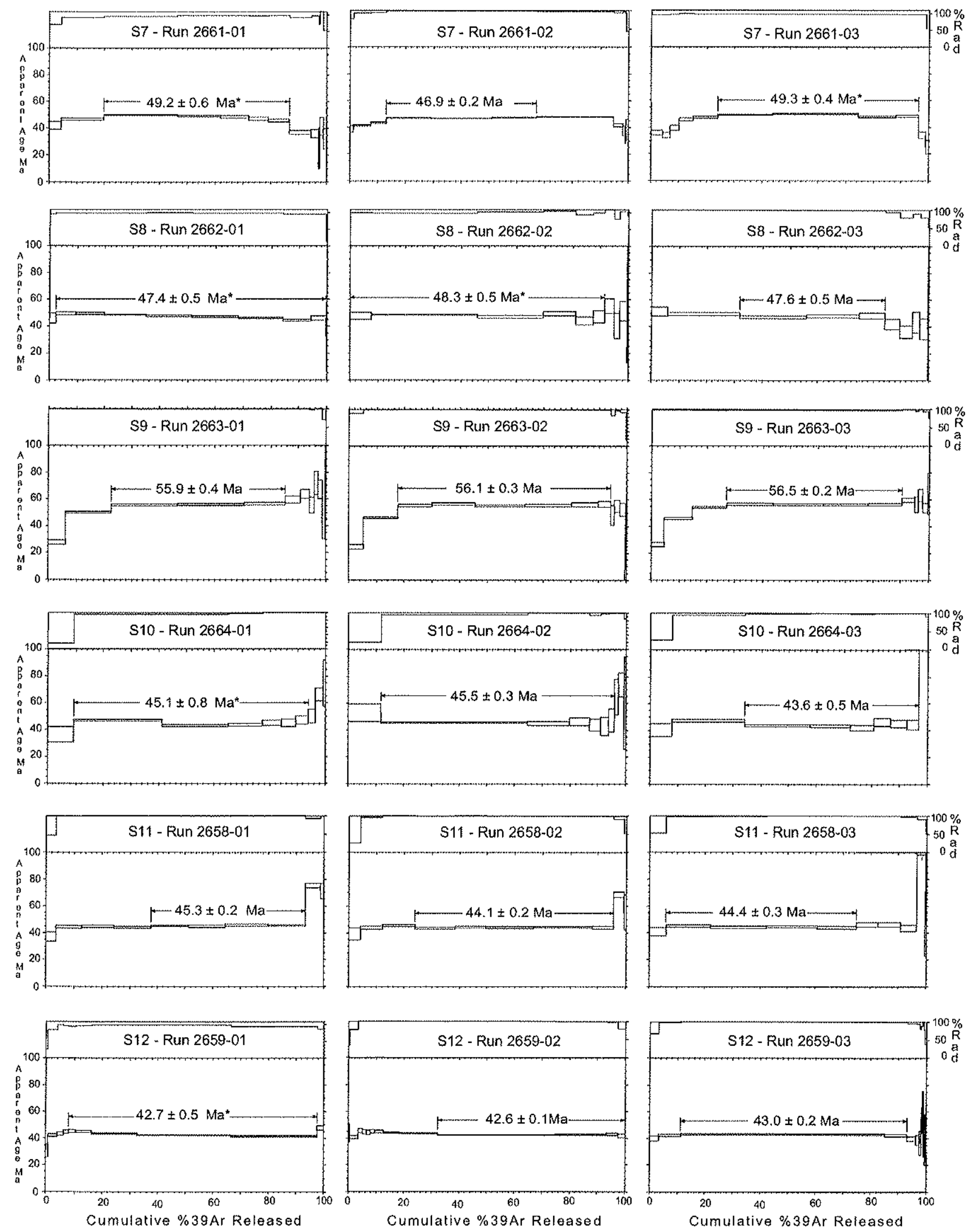

Figure 9 (Continued) 

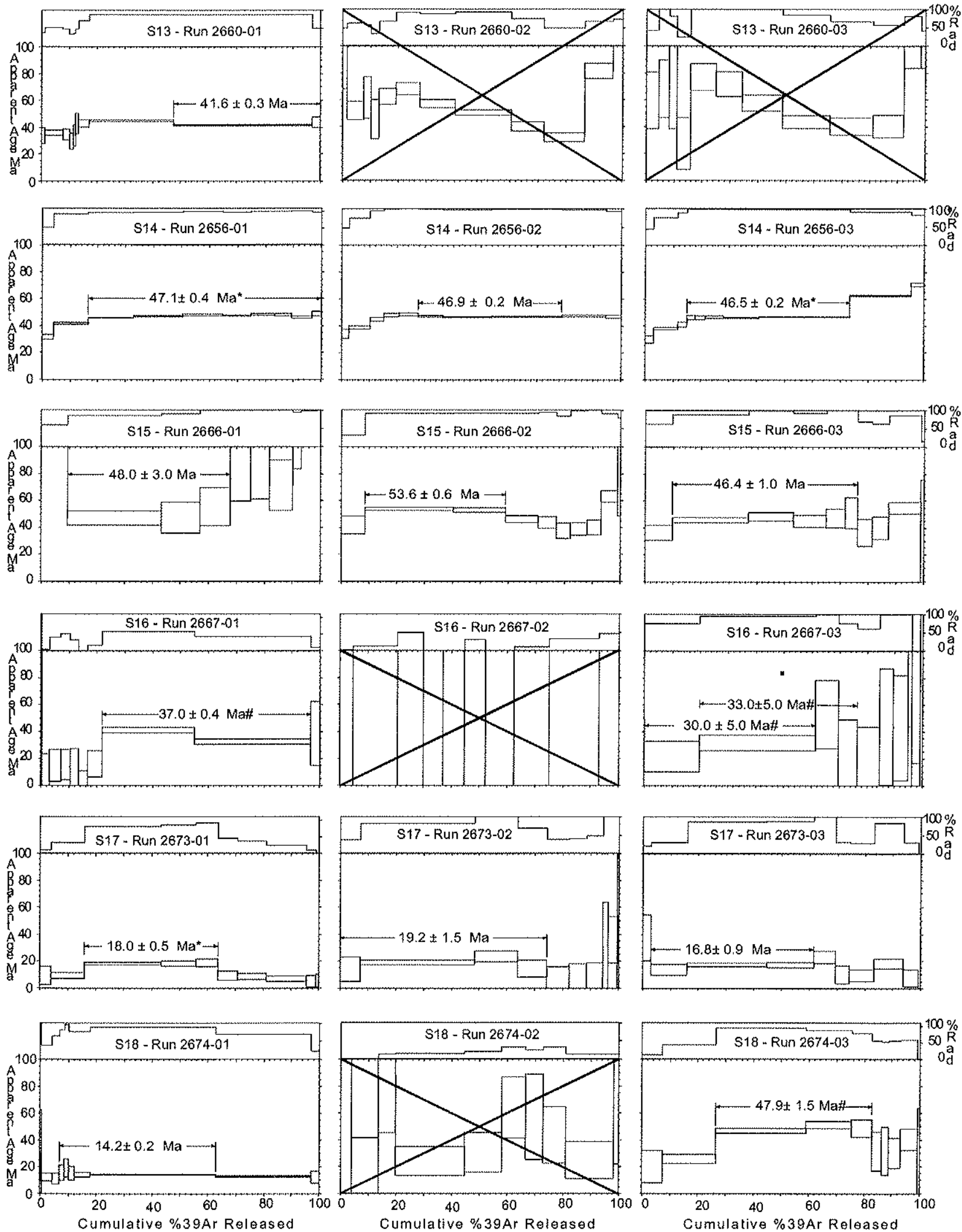

Figure 9 (Continued) 

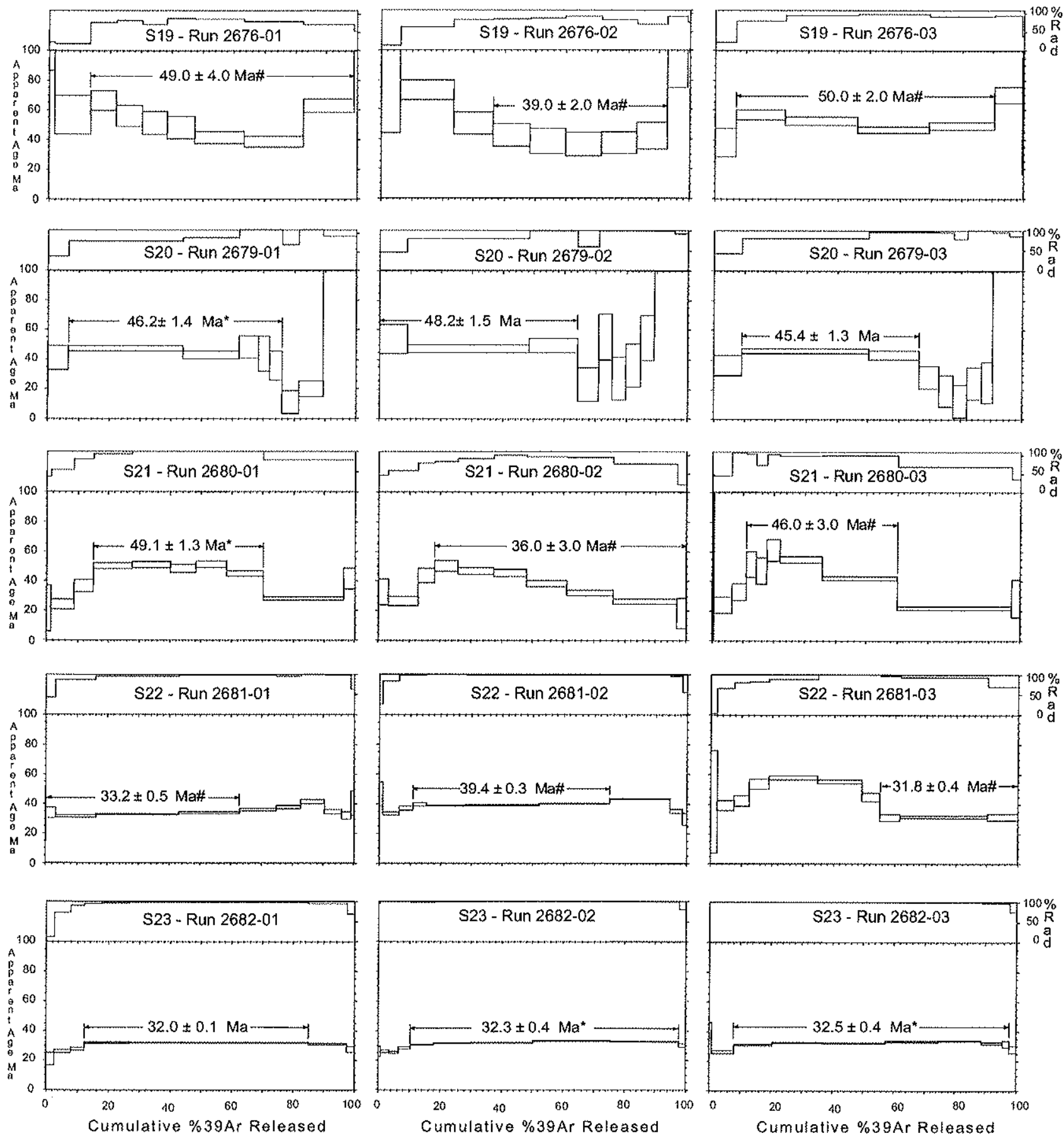

Figure 9 (Continued). 
these "plateau-like" segments, identified on Fig. 9 by an asterisk next to the age, are consistent with "true" plateau ages yielded by other grains from the same sample (e.g., grains 2665$01 / 02 / 03$ or grains 2659-01/02/03). Therefore, these "plateau-like" segments are interpreted to also represent the approximate age of precipitation of the Mn-oxide grains. Five of the 69 grains, identified on Fig. 9 by a cross, yield very little ${ }^{39} \mathrm{Ar}$ to permit calculating an age. In addition, these spectra are inconsistent with spectra displayed by other grains from the same sample. The low K-contents suggest that the grain(s) analyzed may contain Mn-minerals other than hollandite, and are not suitable for reliable geochronology. Analytical results from these 5 grains are ignored from any further consideration. The remaining 12 grains (identified on Fig. 9 by an \# next to the age) yield poor but geochronologically valid results that cannot be ignored. These grains either suggest the presence of minor contaminants and partial recrystallization (Grain 2655-02), significant recoil (Grains 2680-02, 2680-03, and 2681-03), some recoil with the presence of contaminants (Grains 2660-02 and 2660-03), or yield relative well-defined "plateaulike" age, but the ages are significantly different among the 3 grains from the same sample (Grains 2681-01, 2681-02, and 2681-03).

Petrographic and SEM examination indicates that samples whose various grains yield distinct plateau or plateau-like ages correspond to samples that contain visually distinct generations of Mn-oxides (Fig. 6d - Sample S15). These distinct generations are identified by cross-cutting relationships and may suggest the following sequence: Mn-oxide precipitation, a hiatus, partial dissolution of first generation Mn-oxide, and reprecipitation of cross-cutting veins of a younger generation (or generations) of Mn-oxides.

Despite some of the complicating factors above, a very encouraging aspect of the results is the fact that grains from samples collected in closed proximity to each other (e.g. samples S11grains 2658-01/02/03, and S12 - grains 2659-01/02/03) yield similar plateau or "plateau-like" ages, again suggesting that the ${ }^{40} \mathrm{Ar} /{ }^{39} \mathrm{Ar}$ results represent true mineral precipitation ages (Figs. 9-10 and Table 2).

Plateau and plateau-like ages for the QF samples range from $61.3 \pm 1.7$ to $14.2 \pm 0.2 \mathrm{Ma}$, but are particularly concentrated at $51-41 \mathrm{Ma}$ interval. All the analytical results, with the exception of the five samples that were eliminated for the reasons above, are plotted in the ideograms in Fig. 11. These ideograms are useful to visualize the distribution of ages of the supergene minerals formed at different times in a weathering profile (Vasconcelos, 1999a). They are also useful in evaluating whether the results obtained for a single weathering profile 

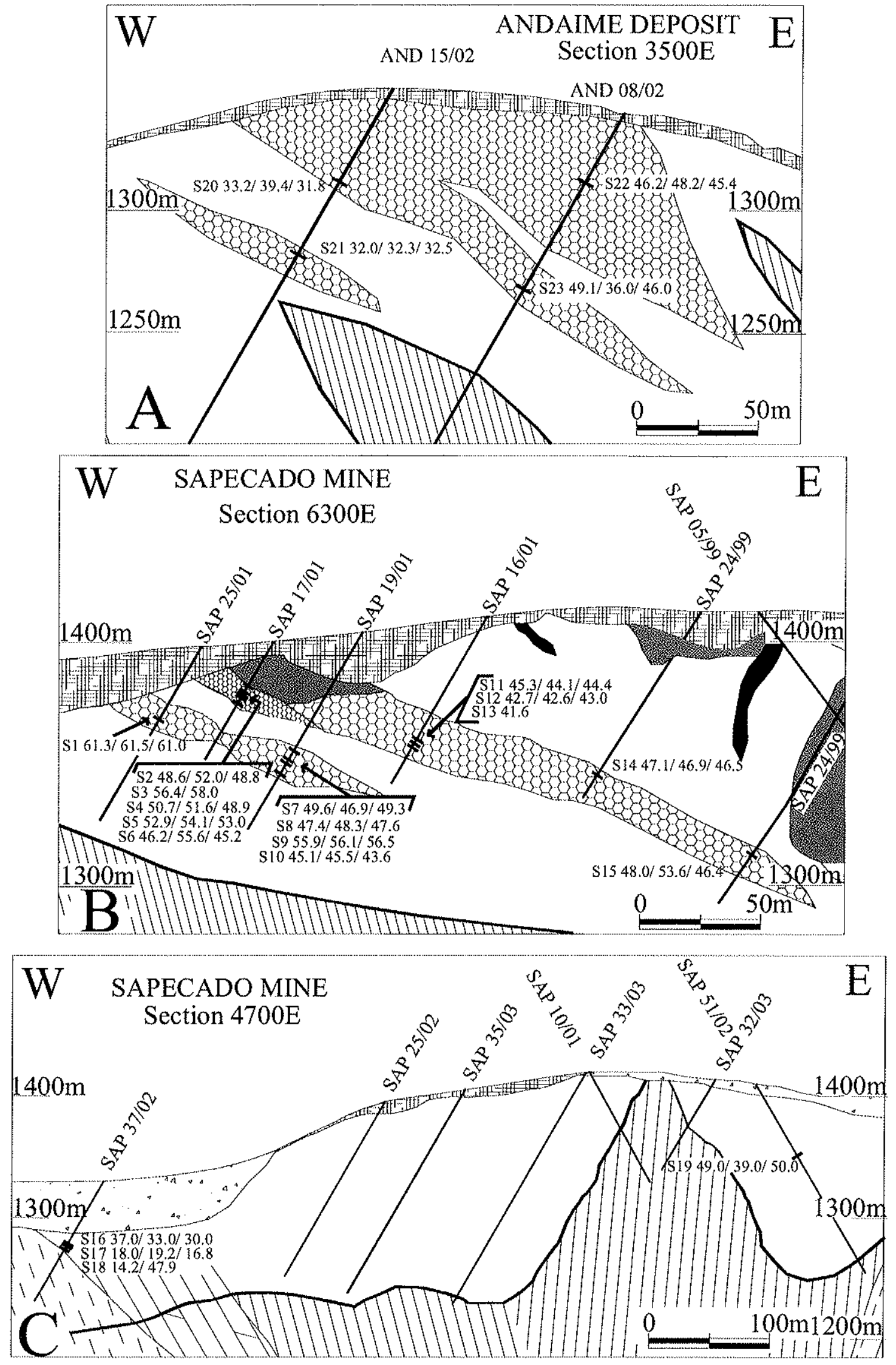

Figure 10. Geological sections of the Andaime and Sapecado deposits showing distribution of the samples and age plateau for each grain of each sample (S20 33.2/39.4/56.3 means Sample 20 and age plateau for grains 1, 2 and 3). Legend as in Fig. 3. 
reveal a continuum of ages, or whether the profile contains age clusters. The ideograms in Figure 11 reveal a discontinuous distribution of ages.

A few surface samples from the Sapecado profile had been previously dated in another study (Carmo and Vasconcelos, 2003). In order to compare results obtained from that study with our results, we plotted ideograms for Sapecado samples dated in each of these studies (Fig. 11a). The large differences in the number of grains analyzed, combined with the fact that in one of the studies (Carmo and Vasconcelos, 2003) only surface samples were dated, prevents a in-depth comparison between the two studies. However, both studies suggest that weathering at the Sapecado profile was already on going at the beginning of the Paleogene.

Another ideogram, showing ${ }^{40} \mathrm{Ar} /{ }^{39} \mathrm{Ar}$ ages from the Sapecado and Andaime (this study) and Serra da Moeda (Carmo and Vasconcelos, 2003) profiles separately (Fig. 11b), confirms that the weathering histories preserved in the Moeda Syncline profiles initiated near the K-T boundary. Unfortunately, the large variation in sample sizes, the lack of a systematic sampling strategy (some studies focused primarily on surface samples while other studies sampled deeper horizons in the weathering profiles), and the relatively small number of samples analyzed for this large region (when compared with results from Vasconcelos and Conroy, 2003) prevents an indepth interpretation of the weathering history of the three sites. Despite these limitations, the geochronological results permit answering some relevant questions regarding the weathering history of the Quadrilátero Ferrifero profiles. 

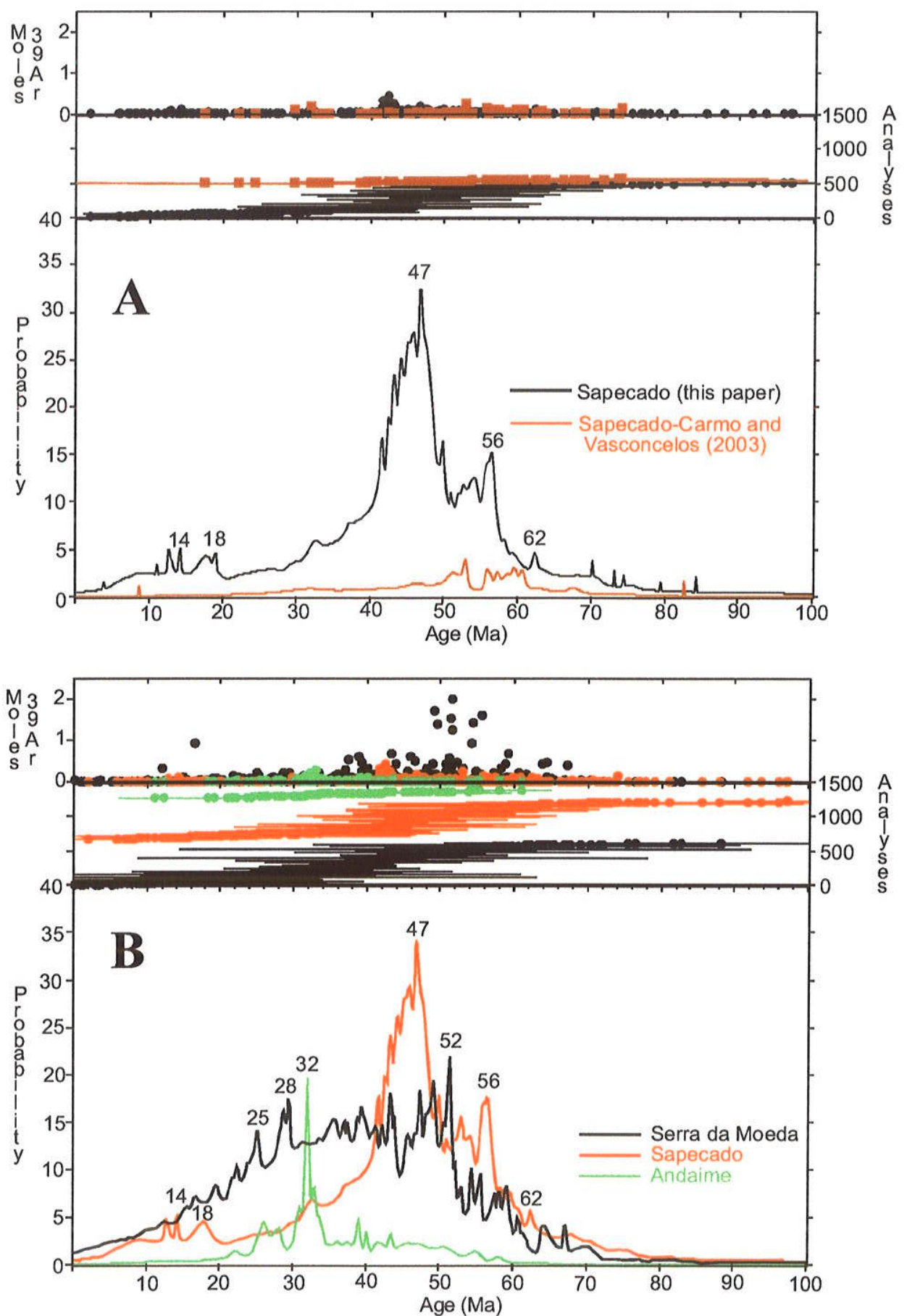

Figure 11 Probability density plot (ideogram) for all the significant steps (steps yielding negative ages, steps in which the analytical uncertainty was too great, and steps from samples showing evidence of major recoil or contamination were eliminated) analyzed for samples from the Moeda Syncline region. (a) Data for the Sapecado mine from this study compared with those of (Carmo and Vasconcelos, 2003). (b) Data for the eastern limb of the Moeda Syncline (Sapecado and Andaime Deposits, this study) compared with those of the western limb (Serra da Moeda, from Carmo and Vasconcelos, 2003). 


\section{How old are the Quadrilátero Ferrifero Weathering Profiles?}

Well-defined and reproducible plateau and plateau-like ages, ranging from $61.5 \pm 1.2 \mathrm{Ma}$ to $14.2 \pm 0.2 \mathrm{Ma}(2 \sigma)$, indicate a protracted history of chemical weathering for the Quadrilátero Ferrifero, which was already ongoing in the Paleogene and continued until the Neogene. The ages obtained are compatible with ages obtained from another study of QF weathering profiles (Carmo, 2004; Carmo and Vasconcelos, 2005). They are also in agreement with the palynologic studies of the Gandarela and Fonseca basins carried out by Lima and Salard-Cheboldaeff (1981) and by Maizatto (2001), which indicate that the sedimentation of these basins occurred during the Middle to Late Eocene. Considering that the genesis of the basins can be related to the collapse structures formed during weathering of the underlying BIFs and dolomites (Ribeiro and Carvalho, 2002), the geochronology results of the Sapecado and Andaime mines, corroborated by the palynologic data, indicate a prolonged weathering history for the Quadrilatero Ferrifero, already ongoing in the early Paleocene.

The absence of older geochronological results does not preclude a much older weathering history for the region. Older manganese oxides could exist and have not been sampled; older manganese oxides could have been dissolved by more recent weathering events; or older weathering assemblages could have been eroded from the upper parts of the profile during the past $60 \mathrm{Ma}$. At this stage, based on the results presented in this study, we can only affirm that the weathering profiles in the Quadrilatero Ferrifero are older than $61.5 \pm 1.2 \mathrm{Ma}$.

One noticeable feature of the distribution of ages in the three weathering profiles illustrated in Figure 10 is the similarity in age vs. depth obtained. Although older results are obtained from samples closer to the present surface, while younger results occur in deeper horizons in the profile (Fig. 10a-b), several Mn-oxides sampled near the bedrock-weathering interface yield ages at ca. $40 \mathrm{Ma}$ (Fig. 10b-c). Younger results ( $<30 \mathrm{Ma}$ ) occur in some deep horizons, but the occurrence of old manganese oxides at the present weathering-bedrock interface suggest that the Moeda Syncline weathering profiles had already reached their present depth ca. $40 \mathrm{Ma}$, indicating that very little advance of the weathering front has occurred in the Neogene. Neogene ages found deeper in the profile may record recrystallization of older Mnoxides during more recent events, but they do not require much advance of the weathering front since ca. 40 Ma. Figure 12 illustrates the relationship between ages and elevations for the the Moeda Syncline Mn-oxides. 


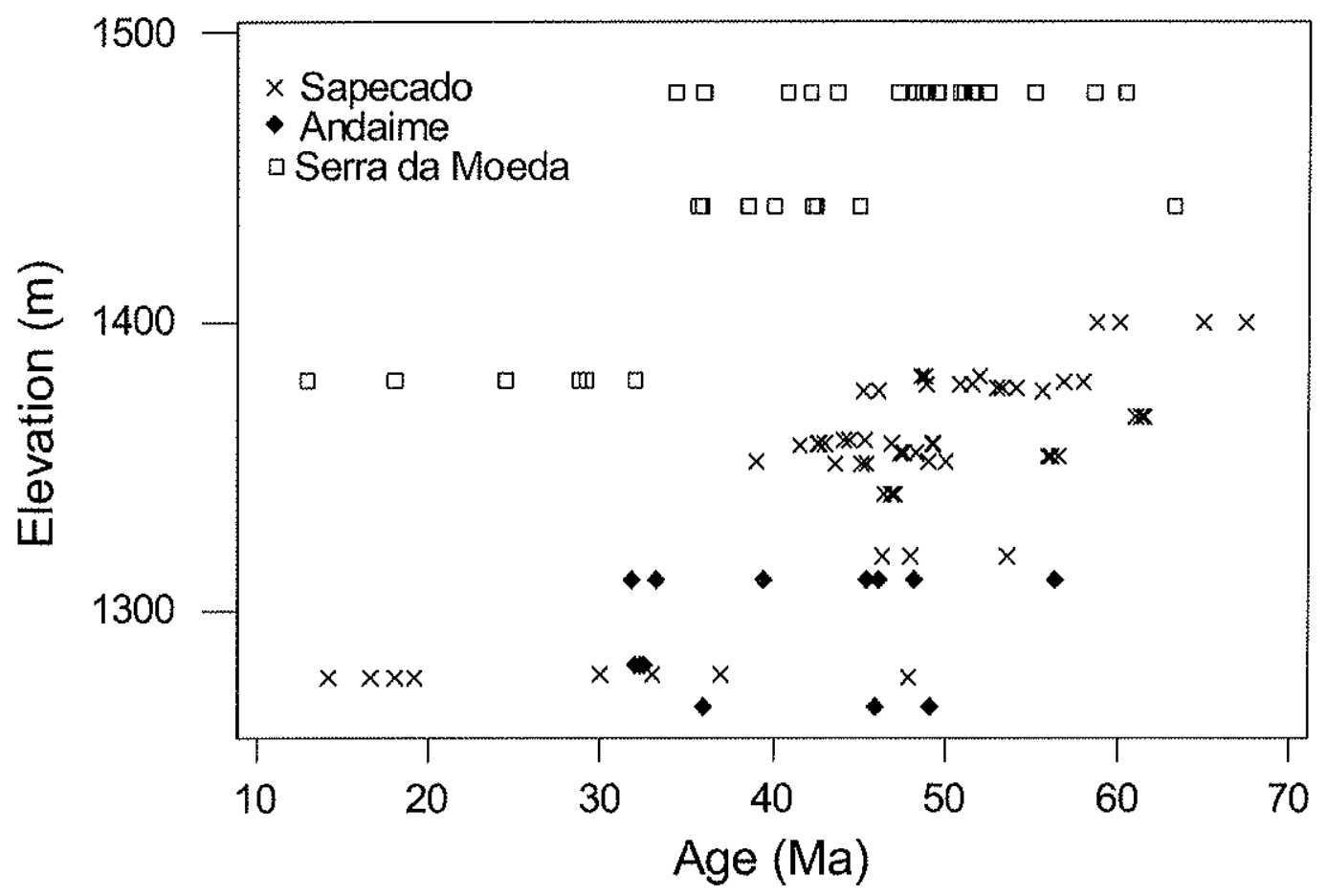

Figure 12. Correlation of age plateau and elevation for grains of Mn-oxides analyzed at the Moeda Syncline region. Data for the Andaime and Sapecado weathering profiles are from this study and for the Serra da Moeda are from (Carmo and Vasconcelos, 2003). Note the poor correlation $(r=0.3)$.

\section{Continuous or Episodic Weathering Record?}

The presence of Paleogene sediments in karstic lakes overlying the Cauê and Gandarela Formations, and the absence of other thick sedimentary units in the area, suggest that the QF lithologies have been continuously exposed to surficial conditions since the beginning of the Tertiary. Ideograms for the weathering profiles at the Sapecado and Andaime mines, however, do not yield a continuous distribution of ages. In reality, the geochronological results strongly cluster in the 50-40 Ma interval, with other prominent peaks at ca. 56 (Sapecado) and 32 (Andaime) Ma. The lack of surface samples from the Andaime profile may explain the absence of older results for that profile. Although it is not our intention to compare the ideograms, peak by peak, it is important to notice that some of the significant intervals (e.g., 50-40 Ma) of manganese oxide precipitation in the Sapecado profiles are also represented in the Serra da Moeda profiles studied by Carmo and Vasconcelos (2005) (Fig. 11b). All of the profiles do show clustering of ages at specific time periods, independently of where in the profiles the samples were collected, suggesting an episodic history of mineral precipitation. Given the longevity and the depth of the profiles, the complex history of mineral dissolution and reprecipitation, and the large area covered by this study, further studies, at different sites and 
including the analysis of a much larger number of samples, are necessary if a complete weathering history for the Quadrilátero Ferrifero is to be obtained.

\section{Paleoclimatic Implications}

The distribution of lateritic weathering profiles has been used as a paleoclimatic indicator (Crowley and North, 1991; Frakes, 1979; Nahon, 1986). The authors consider the presence of those profiles as indicative of warm temperatures with seasonal rains, favoring intense chemical weathering and consequently the development of deep weathering profiles.

A major limitation in using weathering profiles as paleoclimatic indicator is the absence of reliable numerical ages. In addition, the few studies where ages of profiles are reported (Dammer et al., 1996; Dammer et al., 1999; Ruffet et al., 1996a; Vasconcelos et al., 1994b) suggest that lateritic profiles do not form instantly but record a protracted history of mineral dissolution and reprecipitation lasting tens of millions of years. The present study confirms that lateritic profiles reflect a protracted history of exposure. The ages of the minerals in the profiles record times in the past more propitious to chemical weathering.

The majority of the supergene Mn-oxides samples analyzed precipitated between 51 and $41 \mathrm{Ma}$, suggesting hot and wet climatic conditions at that time interval. Palynologic data for the Gandarela and Fonseca basins reveals the presence of an exuberant and diversified paleoflora in the Eocene, indicative of hot and wet environmental conditions (Maizatto, 2001). This period is coincident with the major periods of chemical weathering registered at the Carajás, Amazon region, Brazil (Ruffet et al., 1996a; Vasconcelos et al., 1994b), in Australia (Dammer et al., 1996; Dammer et al., 1999) and in Burkina Faso, Africa (Hénocque et al., 1998b). This might indicate that the climatic conditions that favored intense chemical weathering in the Eocene had a more global character.

\section{Landscape Evolution Implications}

The deeply stratified weathering profiles in the Quadrilátero Ferrifero record weathering processes already ongoing at the Paleogene, and may suggest even more ancient weathering in the region. The absence of deeply stratified weathering profiles in the adjacent dissected valleys (Fig. 2a), and evidence suggesting that weathering profiles in these dissected parts of the landscape are much younger than the profiles on the plateaus (Carmo and Vasconcelos, 2004) corroborate previous suggestions that the landsurfaces blanketing the QF plateaus are much older than the adjacent dissected landsurfaces. The landsurface characterized by the QF plateaus have 
been named "Gondwana Surface" (King, 1956). A subsequent cycle of erosion (the "South America cycle", King, 1956) would have partially eroded the Gondwana Surface, creating the more dissected landscape surrounding it. Our study does not have the regional character needed to address the existence or not of these postulated landsurfaces and erosional cycles. However, the geochronological results obtained for the QF profiles suggest that profiles in the elevated landscape associated with deeply weathered banded iron formations, quartzites, and karstic paleolake sediments are distinctly older than weathering profiles in the surrounded dissected plains and valleys, consistent with the existence of a more ancient landsurface blanketing the QF plateaus.

\section{Implications for the Supergene Enrichment of Banded Iron Formations}

The geochronological results in this study permit drawing three major conclusions:

- that the supergene enrichment blankets that make the Quadrilátero Ferrifero such a prolific iron-producing region were already forming at more than $60 \mathrm{Ma}$;

- that most of the supergene processes had already reached their present extent at ca. 40 $\mathrm{Ma}$;

- and that weathering processes in the Neogene have contributed little to the further advance of the weathering fronts in the supergene orebodies.

In addition, we may safely conclude that giant supergene iron orebodies are likely to be found only in the high elevation plateaus (Gondwana Surface) that were exposed to the more intense and prolonged weathering history. Dissected plains and valleys surrounding the QF plateaus are likely to host only incipient supergene blankets.

The fact that the supergene enrichment blankets likely reached their present depths at ca. $40 \mathrm{Ma}$ suggest that weathering solutions percolating through the profile were ineffective at promoting further advances of the weathering front once the profile reached a certain depth. This diminished weathering capacity may be related to diminishing reactivity of the weathering solutions at depth (e.g., depletion in dissolved oxygen or saturation with dissolved species), or it may reflect the horizontal, as opposed to the vertical, migration of the weathering solutions once they reach certain depths. The horizontally migrating weathering solutions dewater at the sides of the cliffs (Serra da Serrinha, Figs. 1 and 2) at the headwaters of local springs. 


\section{CONCLUSIONS}

Deep weathering profiles developed within Paleoproterozoic BIFs of the Cauê Formation at the Quadrilatero Ferrífeto host Mn-oxides suitable for ${ }^{40} \mathrm{Ar} /{ }^{39} \mathrm{Ar}$ dating. These Mn-oxides are concentrated in supergene Fe-Mn ore and manganiferous itabirite at the contact with the Gandarela Formation. They consist of minerals of the hollandite group (cryptomelane and hollandite) and pyrolusite formed by precipitation from complex (Mn-, Fe-, K-, and Ba-rich) weathering solutions. Petrographic and SEM investigations reveal the presence of several generations of Mn-oxides.

Laser-heating ${ }^{40} \mathrm{Ar} /{ }^{39} \mathrm{Ar}$ data reveal ages ranging from 62 to $14 \mathrm{Ma}$, indicating a prolonged history of weathering at the Quadrilátero Ferrifero, already ongoing at least in Paleogene and continued until Neogene. The majority of Mn-oxides, however, precipitated from $51-41 \mathrm{Ma}$ with a peak at $47 \mathrm{Ma}$. This period is coincident with the development of small basins formed by the collapse of the underlying BIFs during intense chemical weathering, as indicated by palynologic data obtained in the sediments.

Samples collected near the present surface or near the contact with the weatheringbedrock interface present similar ages, indicating that the main weathering process was developed around $46 \mathrm{Ma}$ ago. Further chemical weathering had limited effect on the weathering of the BIFs, which means that giant supergene iron ore deposits were completely formed at the Paleogene.

The coincidence of the major period of precipitation of the Mn-oxides (and therefore of intense chemical weathering) at the $\mathrm{QF}$ with major periods of precipitation in the Brazilian Amazon (Ruffet et al., 1996a; Vasconcelos et al., 1994b), Australia (Dammer et al., 1996; Dammer et al., 1999) and western Africa (Hénocque et al., 1998a; Hénocque et al., 1998b) suggests that climatic conditions which favored intense chemical weathering in the Eocene had a more global character.

\section{Acknowledgements}

This paper is an integral part of the senior author's $\mathrm{Ph}$. D. thesis presented at the Instituto de Geociencias of the Universidade de São Paulo (USP). This research project was possible thanks to the grant issued by the Comissão de Aperfeiçoamento de Pessoal de Nivel Superior (CAPES) to C.A.S (grant BEX2189/02-0). C.A.S. thanks Minerações Brasileiras Reunidas (MBR) for liberating him of his usual activities as a mine geologist during the period of his stay at the University of Queensland. ${ }^{40} \mathrm{Ar} /{ }^{39} \mathrm{Ar}$ analyses were funded by UQ-AGES. We are grateful to the staff of the Center of Microscopy and Microanalyses of the University of Queensland (CMM), particularly Ronald Rasch, Graeme Auchterlonie, and Kim Sewell, for their assistance. C.A.S. is indebted to Isabela de Oliveira Carmo for the DTM images and availability of the ${ }^{40} \mathrm{Ar} /{ }^{39} \mathrm{Ar}$ data of the Serra da Moeda region. 


\section{References}

Alkmim, F.F. and Marshak, S., 1998. Transamazonian orogeny in the São Francisco craton, Minas Gerais, Brazil: evidence for Paleoproterozoic collision and collapse in the Quadrilátero Ferrífero. Precambrian Research, 90: 29-58.

Babinski, M., Chemale Jr., F. and Van Schmus, W.R., 1995. The $\mathrm{Pb} / \mathrm{Pb}$ ages of the Minas Supergroup carbonate rocks, Quadrilátero Ferrífero, Brazil. Precambrian Research, 72: 235-245.

Carmo, I.O., 2004. Geocronologia do Intemperismo Cenozóico no Sudeste do Brasil. Ph.D. Thesis, Universidade Federal do Rio de Janeiro, Rio de Janeiro, $134 \mathrm{pp}$.

Carmo, I.O. and Vasconcelos, P., 2004. Geochronological evidence for pervasive Miocene weathering, Minas Gerais, Brazil. Earth Surface Processes and Landforms, 29: 13031320.

Carmo, I.O. and Vasconcelos, P.M., 2003. 40Ar/39Ar Geochronology of weathering profiles in southeastern Brazil, IV South American Symposium on Isotope Geology. Extended abstracts, Salvador, pp. 49-52.

Carmo, I.O. and Vasconcelos, P., 2005. 40Ar/39Ar geochronology constraints on late Miocene weathering rates in Minas Gerais, Brazil (submitted). Earth and Planetary Science Letters.

Chemale Jr., F., Rosière, C.A. and Endo, I,, 1994. The tectonic evolution of the Quadrilátero Ferrífero, Minas Gerais, Brazil. Precambrian Research, 65: 25-54.

Crowley, T.J. and North, G.R., 1991. The last 100 million years, Paleoclimatology. Oxford Univ. Press, London/New York, pp. 183-211.

Dammer, D., Chivas, A.R. and McDougall, I., 1996. Isotopic dating of supergene manganese oxides from the Groote Eylandt deposit, Northern Territory, Australia. Economic Geology, 91(2): 386-401.

Dammer, D., McDougall, I. and Chivas, A.R., 1999. Timing of weathering-induced alteration of manganese deposits in Western Australia: evidence from $\mathrm{K} / \mathrm{Ar}$ and ${ }^{40} \mathrm{Ar} /{ }^{39} \mathrm{Ar}$ dating. Economic Geology, 94: 87-108.

Dorr II, J.V.N., 1964. Supergene iron ores of Minas Gerais, Brazil. Economic Geology, 59(7): 1203-1240.

Dorr II, J.V.N., 1969. Physiographic, stratigraphic and structural development of the Quadrilátero Ferrífero, Minas Gerais, Brazil. U.S.G.S. Professional Paper, 614-A, Washington, $110 \mathrm{pp}$.

Frakes, L.A., 1979. Climates Throughout Geologic Time. Elsevier, Amsterdam/ Lausanne/New York.

Hénocque, O., Ruffet, G, and Colin, F., 1998a. ${ }^{40} \mathrm{Ar} /{ }^{39} \mathrm{Ar}$ dating of African manganese pisolites: implications for Cenozoic climatic changes. Mineralogical Magazine, 62A(Part 1): 606607.

Hénocque, O., Ruffet, G., Colin, F. and Feraud, G., 1998b. ${ }^{40} \mathrm{Ar}-{ }^{39} \mathrm{Ar}$ dating of West African lateritic cryptomelanes. Geochimica et Cosmochimica Acta, 62(16): 2739-2756.

King, L.C., 1956. A geomorfologia do Brasil oriental. Revista Brasileira de Geografia(2): 3-121.

Ladeira, E.A. and Viveiros, J.F.M., 1984. Hipótese sobre a estruturação do Quadrilátero Ferrífero com base nos dados disponíveis. Boletim da Sociedade Brasileira de Geologia de Minas Gerais, 4.

Li, J.-W. and Vasconcelos, P., 2002. Cenozoic continental weathering and its implications for the palaeoclimate: evidence from ${ }^{40} \mathrm{Ar} /{ }^{39} \mathrm{Ar}$ geochronology of supergene $\mathrm{K}$-Mn oxides in Mt Tabor, central Queensland, Australia. Earth and Planetary Science Letters, 200(1-2): 223-239. 
Lima, M.R. and Salard-Cheboldaeff, M., 1981. Palynologie des bassins de Gandarela et Fonseca (Eocene de L'etat de Minas Gerais, Bresil). Boletim Instituto de Geociências Universidade de São Paulo, 12: 33-54.

Maizatto, J.R., 2001. Análise bioestratigráfica, paleoecológica e sedimentológica das bacias Terciárias do Gandarela e Fonseca - Quadrilátero Ferrífero - com base nos aspectos palinológicos e sedimentares. PhD Thesis, Universidade Federal de Ouro Preto, Ouro Preto, $249 \mathrm{pp}$.

Marshak, S. and Alkmim, F.F., 1989. Proterozoic contraction/extension tectonics of the southern São Francisco craton region, Minas Gerais, Brazil. Tectonics, 8(3): 551-571.

Nahon, D.B., 1986. Evolution of Iron Crusts in Tropical Landscapes. In: S.M. Cohen and D.P. Dethier (Editors), Rate of Chemical Weathering of Rocks and Minerals. Academic Press, New York, pp. 169-191.

Noce, C.M., 1995. Geocronologia dos eventos magmáticos, sedimentares e metamórficos na região do Quadrilátero Ferrífero, Minas Gerais. Ph. D. Thesis, Universidade de São Paulo, São Paulo, 128 pp.

Renger, F.E., Noce, C.M., Romano, A.W. and Machado, N., 1994. Evolução sedimentar do Supergrupo Minas: $500 \mathrm{Ma}$. de registro geológico no Quadrilátero Ferrífero, Minas Gerais, Brasil. Geonomos, 2(1): 1-11.

Ribeiro, D.T., 2003. Enriquecimento Supergênico de Formações Ferríferas Bandadas: Estruturas de Colapso e Desordem. Ph.D. Thesis, Universidade Federal do Rio de Janeiro, Rio de Janeiro, $123 \mathrm{pp}$.

Ribeiro, D.T. and Carvalho, R.M., 2002. Simulation of weathered iron ore facies: integrating leaching concepts and geostatistical model. In: M. Armstrong, C. Bettini, N. Champigny, A. Galli and A. Remacre (Editors), Geostatistics Rio 2000. Kluwer, Dordrecht, pp. 101115.

Ruffet, G., Innocent, C., Michard, A., Feraud, G., Beauvais, A., Nahon, D. and Hamelin, B., 1996a. A geochronological ${ }^{40} \mathrm{Ar} /{ }^{39} \mathrm{Ar}$ and ${ }^{87} \mathrm{Rb} /{ }^{87} \mathrm{Sr}$ study of K-Mn oxides from the weathering sequence of Azul, Brazil. Geochimica et Cosmochimica Acta, 60(12): 22192232.

Ruffet, G., Innocent, C., Nahon, D., Feraud, G. and Hamelin, B., 1996b. Geochronological study of weathering profile by ${ }^{40} \mathrm{Ar} /{ }^{39} \mathrm{Ar}$ analysis of supergene $\mathrm{K}-\mathrm{Mn}$ oxides. Terra Abstracts, 7(Suppl. 1): 350.

Sant'Anna, L.G., Schorscher, H.D. and Riccomini, C., 1997. Cenozoic tectonics of the Fonseca Basin region, eastern Quadrilátero Ferrífero, MG, Brazil. Journal of South American Earth Sciences, 10(3-4): 275-284.

Spier, C.A., Oliveira, S.M.B. and Rosière, C.A., 2003. Geology and geochemistry of the Águas Claras and Pico iron mines, Quadrilátero Ferrífero, Minas Gerais, Brazil. Mineralium Deposita, 38: 751-774.

Steiger, R.H. and Jägger, E., 1977. Subcommission on geochronology: Convention on the use of decay constants in geo- and cosmochemistry., Earth and Planetary Science Letters, pp. 359-362.

TEX Report, 2002. Iron ore manual 2001-2002, The TEX Report Ltd, Tokyo.

Vasconcelos, P.M., 1992. Timing and rates of evolution of hydrochemical systems in semiarid and humid environments by application of ${ }^{40} \mathrm{~K}-{ }^{40} \mathrm{Ar}$ and laser-heating ${ }^{40} \mathrm{Ar}-{ }^{39} \mathrm{Ar}$ dating of $\mathrm{K}$-bearing weathering product minerals. $\mathrm{Ph}$. D. Thesis, University of California, Berkeley.

Vasconcelos, P.M., 1999a. ${ }^{40} \mathrm{Ar} /{ }^{39} \mathrm{Ar}$ geochronology of supergene processes in ore deposits. Economic Geology, 12: 73-113.

Vasconcelos, P.M., 1999b. K-Ar and ${ }^{40} \mathrm{Ar} /{ }^{39} \mathrm{Ar}$ geochronology of weathering processes. Annu. Rev. Earth Planet. Sci., 27: 183-229. 
Vasconcelos, P.M., Becker, T.A., Renne, P.R. and Brimhall, G.H., 1992. Age and duration of weathering by ${ }^{40} \mathrm{~K}-{ }^{40} \mathrm{Ar}$ and ${ }^{40} \mathrm{Ar} /{ }^{39} \mathrm{Ar}$ analysis of potassium-manganese oxides. Science, 258: 451-455.

Vasconcelos, P.M., Brimhall, G.H., Becker, T.A. and Renne, P.R., 1994a. ${ }^{40} \mathrm{Ar} /{ }^{39}$ Ar analysis of supergene jarosite and alunite: Implications to the paleoweathering history of the western USA and West Africa. Geochimica et Cosmochimica Acta, 58: 401-420.

Vasconcelos, P.M., Renne, P.R., Brimhall, G.H. and Becker, T.A., 1994b. Direct dating of weathering phenomena by ${ }^{40} \mathrm{Ar} /{ }^{39} \mathrm{Ar}$ and $\mathrm{K}-\mathrm{Ar}$ analysis of supergene $\mathrm{K}-\mathrm{Mn}$ oxides. Geochimica et Cosmochimica Acta, 58(6): 1635-1665.

Vasconcelos, P.M., Renne, P.R., Becker, T.A. and Wenk, H.-R., 1995. Mechanisms and kinetics of atmospheric, radiogenic and nucleogenic argon release from cryptomelanes during ${ }^{40} \mathrm{Ar}{ }^{39} \mathrm{Ar}$ analysis. Geochimica et Cosmochimica Acta, 59(10): 2057-2070.

Vasconcelos, P.M., Onoe, A.T., Kawashita, K., Soares, A.J. and Teixeira, W., 2002. ${ }^{40} \mathrm{Ar} /{ }^{39} \mathrm{Ar}$ Geochronology at the Instituto de Geociências, USP: Instrumentation, Analytical Procedures, and Calibration. Anais da Academia Brasileira de Ciências, 74(2): 297-342.

Vasconcelos, P. and Conroy, M., 2003. Geochronology of weathering and landscape evolution, Dugald River Valley, NW Queensland, Australia. Geochimica et Cosmochimica Acta, 67(16): 2913-2930.

Walde, D.H.G., 1986. Geologia do ferro. In: C. Schobbenhaus and C.E.S. Coelho (Editors), Principais Depósitos Minerais do Brasil. Ferro e metais da indústria do aço. Departamento Nacional da Produção Mineral, Brasília, pp. 501.

Wallace, R.M., 1965. Geology and mineral resources of the Pico do Itabirito District, Minas Gerais, Brazil. U.S.G.S Professional Paper, 341-F, 68 pp. 


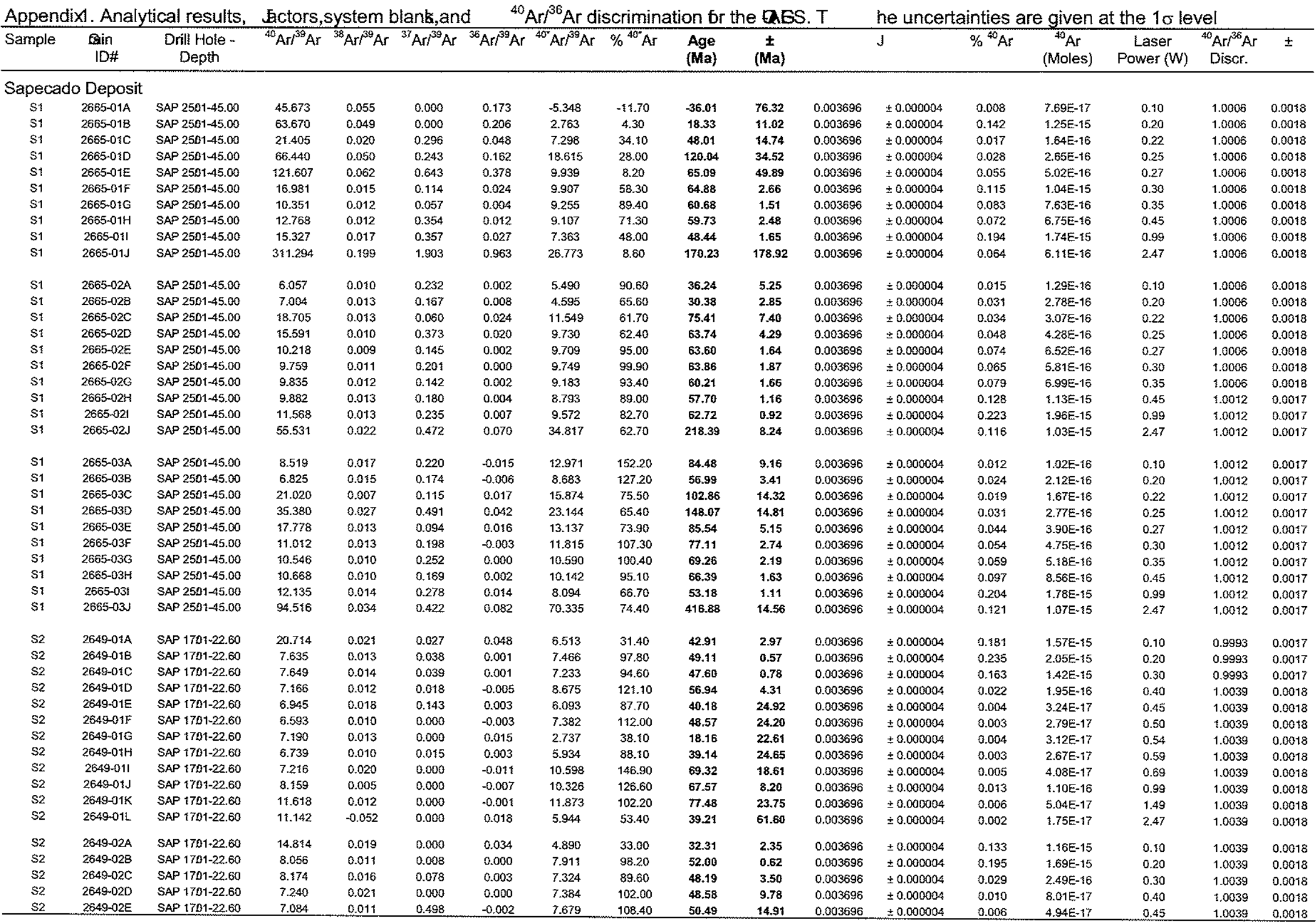


Appendix (Continued)

\begin{tabular}{|c|c|c|c|c|c|c|c|c|c|c|c|c|c|c|c|c|c|}
\hline Sample & $\begin{array}{l}\text { gain } \\
\text { ID\# }\end{array}$ & $\begin{array}{l}\text { Drill Hole - } \\
\text { Depth }\end{array}$ & ${ }^{40} \mathrm{Ar} r^{39} \mathrm{Ar}$ & ${ }^{38} \mathrm{Ar} /{ }^{39} \mathrm{Ar}$ & ${ }^{37} \mathrm{Ar}{ }^{39} \mathrm{Ar}$ & ${ }^{36} \mathrm{Ar} r^{39} \mathrm{Ar}$ & ${ }^{40^{*}} \mathrm{Ar}{ }^{339} \mathrm{Ar}$ & $\%{ }^{40} \mathrm{Ar}$ & $\begin{array}{l}\text { Age } \\
\text { (Ma) }\end{array}$ & $\stackrel{ \pm}{ \pm}$ & & $J$ & $\%{ }^{40} \mathrm{Ar}$ & $\begin{array}{l}{ }^{40} \mathrm{Ar} \\
\text { (Moles) }\end{array}$ & $\begin{array}{c}\text { Laser } \\
\text { Power }(W)\end{array}$ & $\begin{array}{l}{ }^{40} \mathrm{Ar} /{ }^{36} \mathrm{Ar} \\
\text { Discr. }\end{array}$ & \pm \\
\hline S2 & $2649-02 \mathrm{~F}$ & SAP 1701-22.60 & 6.976 & -0.013 & 0.000 & -0.011 & 10.109 & 144.90 & 66.18 & 17.19 & 0.003696 & \pm 0.000004 & 0.005 & $4.03 E-17$ & 0.50 & 1.0039 & 0.0018 \\
\hline S2 & $2649-02 G$ & SAP $1701-22.60$ & 6.859 & 0.003 & 0.917 & -0.017 & 12.036 & 175.40 & 78.52 & 20.04 & 0.003696 & \pm 0.000004 & 0.004 & $2.82 E-17$ & 0.54 & 1.0039 & 0.0018 \\
\hline S2 & $2649-02 \mathrm{H}$ & SAP $1701-22.60$ & 7.404 & 0.016 & 0.443 & -0.009 & 10.005 & 135.10 & 65.51 & 10.76 & 0.003696 & \pm 0.000004 & 0.009 & 7.t0E-17 & 0.99 & 1.0039 & 0.0018 \\
\hline s2 & 2649.021 & SAP 1701-22.60 & $14.1+1$ & 0.051 & 0.755 & 0.014 & 9.898 & 70.10 & 64.82 & 126.29 & 0.003696 & \pm 0.000004 & 0.001 & $2.46 E-18$ & 2.47 & 1.0039 & 0.0018 \\
\hline \$2 & $2649-03 \mathrm{~A}$ & SAP $1701-22.60$ & 21.521 & 0.022 & 0.044 & 0.045 & 8.225 & 38.20 & 54.03 & 3.52 & 0.003696 & \pm 0.000004 & 0.128 & $1.12 E-15$ & 0.10 & 1.0039 & 0.0018 \\
\hline \$2 & $2649-038$ & SAP $1701-22.60$ & 7.822 & 0.012 & 0.025 & 0.001 & 7.405 & 94.70 & 48.71 & 0.46 & 0.003696 & \pm 0.000004 & 0.266 & $2.33 E-15$ & 0.20 & 1.0039 & 0.0018 \\
\hline S2 & $2649-03 \mathrm{C}$ & SAP $1701-22.60$ & 7.789 & 0.013 & 0.037 & 0.000 & 7.708 & 99.00 & 50.68 & 0.74 & 0.003696 & \pm 0.000004 & 0.154 & $1.34 E-15$ & 0.30 & 1.0039 & 0.0018 \\
\hline \$2 & $2649-030$ & SAP $1701-22.60$ & 7.240 & 0.017 & 0.103 & 0.006 & 5.576 & 77.00 & 36.80 & 5.08 & 0.003696 & \pm 0.000004 & 0.019 & $1.68 \mathrm{E}-16$ & 0.40 & 1.0039 & 0.0018 \\
\hline S2 & 2649-03E & SAP 1701-22.60 & 7.324 & 0.012 & 0.336 & .0 .003 & 8.228 & 112.30 & 54.04 & 8.59 & 0.003696 & \pm 0.000004 & 0.011 & $9.58 \mathrm{E}-17$ & 0.59 & 1.0039 & 0.0018 \\
\hline S2 & $2649-03 \mathrm{~F}$ & SAP 17D1-22.60 & 10.264 & 0.017 & 0.583 & 0.037 & -0.491 & -4.80 & -3.28 & 12.15 & 0.003696 & \pm 0.000004 & 0.010 & $9.34 \mathrm{E}-17$ & 1.49 & 1.0039 & 0.0018 \\
\hline s2 & $2649-03 \mathrm{G}$ & SAP 17D1-22.60 & 17.237 & 0.200 & 0.026 & -0.002 & 17.906 & 103.90 & 115.61 & 137.32 & 0.003696 & \pm 0.000004 & 0.001 & $1.46 \mathrm{E}-17$ & 2.47 & 1.0039 & 0.0018 \\
\hline \$3 & $2650-01 \mathrm{~A}$ & SAP $1781-24.60$ & 5.057 & 0.011 & 0.000 & -0.002 & 5.567 & 110.10 & 36.74 & 2.28 & 0.003696 & \pm 0.000004 & 0.028 & $2.42 E-16$ & 0.10 & 1.0039 & 0.0018 \\
\hline s3 & $2650-018$ & SAP $1701-24.60$ & 7.880 & 0.013 & 0.029 & 0.004 & 6.641 & 84.30 & 43.75 & 1.21 & 0.003696 & \pm 0.000004 & 0.086 & $7.58 E-18$ & 0.20 & 1.0039 & 0.0018 \\
\hline$\$ 3$ & $2650-01 \mathrm{C}$ & SAP $1701-24.60$ & 8.761 & 0.011 & 0.029 & 0.001 & 8.483 & 96.80 & 55.70 & 0.59 & 0.003696 & \pm 0.000004 & 0.218 & $1.90 E-15$ & 0.25 & 1.0039 & 0.0018 \\
\hline \$3 & $2650-01 \mathrm{D}$ & SAP 1701-24.60 & 9.150 & 0.012 & 0.058 & 0.000 & 9.071 & 99.10 & 59.49 & 0.59 & 0.003696 & \pm 0.000004 & 0.231 & $2.03 E-15$ & 0.30 & 1.0039 & 0.0018 \\
\hline s3 & $2650-01 E$ & SAP $1701-24.60$ & 8.845 & 0.011 & 0.026 & 0.002 & 8.130 & 91.90 & 53.41 & 0.94 & 0.003696 & \pm 0.000004 & 0.142 & t.24E-15 & 0.35 & 1.0039 & 0.0018 \\
\hline \$3 & $2650-01 \mathrm{~F}$ & SAP $1701-24,60$ & 7.146 & 0.011 & 0.045 & 0.000 & 7.037 & 98.50 & 46.32 & 4.88 & 0.003696 & \pm 0.000004 & 0.048 & $4.25 E-16$ & 0.40 & 1.0039 & 0.0018 \\
\hline S3 & $2650-016$ & SAP $1701-24.60$ & 6.985 & 0.014 & 0.000 & 0.000 & 7.092 & 101.50 & 46.68 & 3.31 & 0.003696 & \pm 0.000004 & 0.025 & $2.26 \mathrm{E}-16$ & 0.50 & 1.0039 & 0.0018 \\
\hline s3 & $2650-01 \mathrm{H}$ & SAP $1703-24.60$ & 8.547 & 0.010 & 0.000 & -0.008 & 10.854 & 127.00 & 70.96 & 6.93 & 0.003696 & \pm 0.000004 & 0.015 & $1.45 E-16$ & 0.59 & 1.0039 & 0.0018 \\
\hline S3 & $2650-011$ & SAP $1701-24.60$ & 8.916 & 0.013 & 0.016 & 0.003 & 8.010 & 89.80 & 52.63 & 3.61 & 0.003696 & \pm 0.000004 & 0.033 & $3.06 E-16$ & 0.79 & 1.0039 & 0.0018 \\
\hline \$3 & $2650-01 \mathrm{~J}$ & SAP $1781-24.60$ & 8.587 & 0.010 & 0.162 & 0.001 & 8.277 & 96.40 & 54.36 & 4.19 & 0.003696 & \pm 0.000004 & 0.028 & $2.56 E-16$ & 0.99 & 1.0039 & $0.00 \div 8$ \\
\hline$\$ 3$ & $2650-01 K$ & SAP $1701-24.60$ & 8.793 & 0.018 & 0.002 & 0.022 & 2.155 & 24.50 & 14.31 & $\$ 2.26$ & 0.003696 & \pm 0.000004 & 0.010 & $1.06 \mathrm{E}-16$ & 1.49 & 1.0039 & 0.0018 \\
\hline \$3 & 2650-01L & SAP $1701-24.60$ & 36.986 & 0.047 & 0.000 & 0.080 & 13.306 & 36.00 & 86.61 & 77.88 & 0.003696 & \pm 0.000004 & 0.007 & $7.71 \mathrm{E}-17$ & 2.47 & 1.0005 & 0.0017 \\
\hline$\$ 3$ & $2650-02 \mathrm{~A}$ & SAP 17D?-24.60 & 4.697 & 0.013 & 0.024 & -0.001 & 5.076 & 108.10 & 33.53 & 1.38 & 0.003696 & \pm 0.000004 & 0.044 & $3.83 E-16$ & 0.10 & 1.0005 & 0.0017 \\
\hline s3 & $2650-028$ & SAP 1701-24.60 & 7.532 & 0.012 & 0.040 & 0.000 & 7.398 & 98.20 & 48.66 & 0.45 & 0.003696 & \pm 0.000004 & 0.254 & $2.21 E-15$ & 0.20 & 1.0005 & 0.0017 \\
\hline s3 & $2650-02 \mathrm{C}$ & SAP 17D1-24.60 & B.936 & 0.012 & 0.027 & 0.000 & 8.877 & 99.30 & 58.24 & 0.29 & 0.003696 & \pm 0.090004 & 0.527 & 4.59E-15 & 0.25 & 1.0005 & 0.0017 \\
\hline S3 & $2650-020$ & SAP $1701-24.60$ & 8.706 & 0.013 & 0.033 & 0.000 & 8.688 & 99.80 & 57.02 & 0.57 & 0.003696 & \pm 0.000004 & 0.244 & $2.13 E-15$ & 0.30 & 1.0005 & 0.0017 \\
\hline s3 & $2650-02 E$ & SAP $7701-24.60$ & 9.468 & 0.013 & 0.050 & 0.002 & 8.755 & 92.50 & 57.45 & 1.21 & 0.003696 & \pm 0.000004 & 0.118 & $1.02 E-15$ & 0.35 & 1.0005 & 0.0017 \\
\hline$\$ 3$ & $2650-02 \mathrm{~F}$ & SAP $1701-24.60$ & 9.018 & 0.036 & 0.119 & 0.000 & 9.060 & 100.50 & 59.42 & 2.88 & 0.003696 & \pm 0.000004 & 0.043 & $3.70 E-16$ & 0.40 & 1.0005 & 0.0017 \\
\hline s3 & $2650-02 G$ & SAP $17 D 1-24.60$ & 9.146 & 0.011 & 0.165 & 0.001 & 8.929 & 97.60 & 58.58 & 2.63 & 0.003696 & \pm 0.000004 & 0.048 & $4.14 E-16$ & 0.50 & 1.0005 & 0.0017 \\
\hline S3 & $2650-02 \mathrm{H}$ & SAP $1701-24.60$ & 8.816 & 0.011 & 0.169 & 0.000 & 8.940 & 101.40 & 58.64 & 3.20 & 0.003696 & \pm 0.000004 & 0.034 & $2.95 E-16$ & 0.59 & 1,0005 & 0.0017 \\
\hline s3 & $2650-02 z$ & SAP $1701-24.60$ & 8.536 & 0.013 & 0.116 & 0.000 & 8.524 & 99.90 & 55.96 & 2.60 & 0.003696 & \pm 0.000004 & 0.044 & $3.77 \mathrm{E}-16$ & 0.79 & 1.0005 & 0.0017 \\
\hline \$3 & $2650-02 \mathrm{~J}$ & SAP $17 D 1-24.60$ & 7.871 & 0.013 & 0.278 & -0.001 & 8.207 & 304.30 & 53.91 & 5.81 & 0.003696 & \pm 0.000004 & 0.019 & $1.65 E-16$ & 0.99 & 1.0005 & 0.0017 \\
\hline s3 & $2650-02 \mathrm{~K}$ & SAP $1701-24.60$ & 7.953 & 0.006 & 0.401 & -0.006 & 9.890 & $\{24.30$ & 64.77 & 13.28 & 0.003696 & \pm 0.000004 & 0.008 & $6.33 \mathrm{E}-17$ & 1.49 & 1.0005 & 0.0017 \\
\hline s3 & $2650-02 \mathrm{~L}$ & SAP $1701-24.60$ & 12.483 & 0.039 & 1.173 & -0.003 & 13.344 & 106.80 & 86.85 & 50.22 & 0.003696 & \pm 0.000004 & 0.003 & $2.37 E-17$ & 2.47 & 1.0005 & 0.0017 \\
\hline$\$ 3$ & $2650-03 \mathrm{~A}$ & SAP 1701-24.60 & 7.740 & 0.010 & 0.254 & 0.003 & 6.895 & 89.10 & 45.40 & 6.34 & 0.003696 & \pm 0.000004 & 0.016 & $1.40 E-16$ & 0.10 & 1.0005 & 0.0017 \\
\hline$\$ 3$ & $2650-038$ & SAP 1701-24.60 & 13.324 & 0.016 & 0.241 & 0.010 & 10.304 & 77.30 & 67.43 & 3.25 & 0.003696 & \pm 0.000004 & 0.052 & $4.57 E-16$ & 0.20 & 1.0005 & 0.0017 \\
\hline s3 & $2650.03 \mathrm{C}$ & SAP 1701-24.60 & $\{3.897$ & 0.012 & 0.352 & 0.009 & 31.299 & 81.30 & 73.81 & 6.09 & 0.003696 & \pm 0.000004 & 0.030 & $2.57 E-16$ & 0.22 & 1.0005 & 0.0017 \\
\hline s3 & $2650-030$ & SAP $1701-24.60$ & 10.328 & 0.016 & 0.280 & 0.001 & 10.117 & 97.90 & 66.23 & 10.94 & 0.003696 & \pm 0.000004 & 0.012 & $1.09 E-16$ & 0.25 & 1.0005 & 0.0017 \\
\hline s3 & 2650-03E & SAP 170 1724.60 & 7.479 & 0.009 & 0.758 & 0.015 & 2.980 & 39.80 & 19.76 & 11.56 & 0.003696 & \pm 0.000004 & 0.008 & $7.33 E-17$ & 0.27 & 1.0005 & 0.0017 \\
\hline s3 & $2650-03 \mathrm{~F}$ & SAP $1701-24.60$ & 5.895 & 0.017 & 0.497 & 0.010 & 3.049 & 51.70 & 20.22 & 11.93 & 0.003696 & \pm 0.000004 & 0.007 & $5.79 E-17$ & 0.30 & 1.0005 & 0.0017 \\
\hline s3 & $2650-03 G$ & SAP $1701-24.60$ & 5.480 & 0.021 & 0.438 & 0.010 & 2.651 & 48.40 & 17.59 & 7.84 & 0.003696 & \pm 0.000004 & 0.009 & $8.26 E-17$ & 0.35 & 5.0005 & 0.0017 \\
\hline s3 & $2650.03 \mathrm{H}$ & SAP $1701-24.60$ & 4.643 & 0.018 & 0.304 & 0.013 & 0.879 & 18.90 & 5.85 & 6.36 & 0.003696 & \pm 0.000004 & 0.009 & $8.53 E-17$ & 0.40 & 1.0005 & 0.0017 \\
\hline$\$ 3$ & $2650-031$ & SAP 1701-24.60 & 7.018 & 0.011 & 0.329 & 0.006 & 5.200 & 74.10 & 34.35 & 6.25 & 0.003696 & \pm 0.000004 & 0.014 & $1.28 E-16$ & 0.59 & 1.0005 & 0.0017 \\
\hline$\$ 3$ & $2650-03 \mathrm{~J}$ & SAP $17 D 1-24.60$ & 12.139 & 0.001 & 0.116 & 0.020 & 6.304 & 51.90 & 41.55 & 19.14 & 0.003696 & \pm 0.000004 & 0.008 & $6.72 E-17$ & 0.99 & 1.0005 & 0.0017 \\
\hline \$3 & $2650-03 K$ & SAP $17 B 1-24.60$ & 113.302 & -0.116 & 7.435 & 0.665 & -83.068 & -72.90 & .661 .65 & 706.01 & 0.003696 & \pm 0.000004 & 0.005 & $4.53 E+17$ & 1.49 & 1.0005 & 0.0017 \\
\hline s3 & $2650-03 \mathrm{~L}$ & SAP $1701-24.60$ & 357.865 & 0.081 & 15.045 & 0.573 & 191.613 & 53.00 & 965.98 & 798.38 & 0.003696 & \pm 0.000004 & 0.008 & $7.39 E-17$ & 2.47 & 1.0005 & 0.0017 \\
\hline
\end{tabular}


Appendix (Continued)

\begin{tabular}{|c|c|c|c|c|c|c|c|c|c|c|c|c|c|c|c|c|c|}
\hline \multirow{3}{*}{$\begin{array}{c}\text { Sample } \\
\text { S4 }\end{array}$} & & & & & & & & & & & & & & & & & \\
\hline & $\begin{array}{l}\text { gain } \\
\text { ID\# }\end{array}$ & $\begin{array}{l}\text { Drill Hole - } \\
\text { Depth }\end{array}$ & ${ }^{45} \mathrm{Ar} /{ }^{39} \mathrm{Ar}$ & ${ }^{38} \mathrm{Ar} /{ }^{39} \mathrm{Ar}$ & ${ }^{37} \mathrm{Ar} / f^{39} \mathrm{Ar}$ & ${ }^{36} \mathrm{Ar} r^{39} \mathrm{Ar}$ & ${ }^{40}{ }^{\circ} \mathrm{Ar} r^{39} \mathrm{Ar}$ & $\%{ }^{40^{*}} \mathrm{Ar}$ & $\begin{array}{l}\text { Age } \\
\text { (Ma) }\end{array}$ & $\stackrel{ \pm}{ \pm}$ & & J & $\%{ }^{40} \mathrm{Ar}$ & $\begin{array}{l}{ }^{40} \mathrm{Ar} \\
\text { (Moles) }\end{array}$ & $\begin{array}{c}\text { Laser } \\
\text { Power }(W)\end{array}$ & $\begin{array}{l}{ }^{40} \mathrm{Ar} i^{38} \mathrm{Ar} \\
\text { Discr. }\end{array}$ & \pm \\
\hline & $2652-01 \mathrm{~A}$ & SAP $1701-25.60$ & 4.150 & 0.013 & 0.009 & 0.002 & 3.542 & 85.40 & 23.46 & 1.19 & 0.003696 & \pm 0.000004 & 0.042 & $3.66 E-16$ & 0.10 & 1.0005 & 0.0017 \\
\hline S4 & $2652-01 B$ & SAP $1701-25.60$ & 5.959 & 0.012 & 0.022 & 0.001 & 5.641 & 94.70 & 37.23 & 0.39 & 0.003696 & \pm 0.000004 & 0.215 & t.87E-15 & 0.20 & 1.0005 & 0.0017 \\
\hline$\$ 4$ & $2652-01 \mathrm{C}$ & SAP 1701-25.60 & 7.014 & 0.041 & 0.020 & 0.001 & 6.847 & 97.60 & 45.09 & 0.35 & 0.003696 & \pm 0.000004 & 0.334 & $2.89 \mathrm{E}-15$ & 0.22 & 1.0005 & 0.0017 \\
\hline$\$ 4$ & $2652-010$ & SAP $1701-25.60$ & 7.461 & 0.012 & 0.017 & 0.001 & 7.307 & 98.00 & 48.08 & 0.29 & 0.003696 & $=0.000004$ & 0.407 & $3.55 E-15$ & 0.25 & 1.0005 & 0.0017 \\
\hline S4 & 2652-01E & SAP $1701-25.60$ & 7.742 & 0.012 & 0.013 & 0.000 & 7.700 & 99.50 & 50.62 & 0.32 & 0.003696 & $\mp 0.000004$ & 0.379 & $3.29 E-15$ & 0.27 & 1.0005 & 0.0017 \\
\hline$\$ 4$ & $2652-01 F$ & SAP 1701-25.60 & 7.922 & 0.012 & 0.016 & 0.001 & 7.608 & 96.00 & 50.03 & 0.39 & 0.003696 & \pm 0.000004 & 0.335 & $2.92 E-15$ & 0.30 & 1.0005 & 0.0017 \\
\hline$\$ 4$ & $2652-01 \mathrm{G}$ & SAP $1701-25.60$ & 7.979 & 0.012 & 0.010 & 0.000 & 7.862 & 98.50 & 51.68 & 0.43 & 0.003696 & \pm 0.000004 & 0.299 & $2.60 E-15$ & 0.35 & 1.0005 & 0.0017 \\
\hline$\$ 4$ & $2652-01 \mathrm{H}$ & SAP $1701-25.60$ & 8.013 & 0.011 & 0.054 & 0.000 & 7.995 & 99.80 & 52.54 & 1.02 & 0.003696 & $\div 0.000004$ & 0.106 & $9.33 E-16$ & 0.40 & 1.0005 & 0.0017 \\
\hline$\$ 4$ & $2652-011$ & SAP $1781-25.60$ & 7.416 & 0.011 & 0.074 & 0.002 & 6.928 & 93.40 & 45.62 & 1.87 & 0.003696 & \pm 0.000004 & 0.048 & $4.23 E-16$ & 0.59 & 1.0005 & 0.0017 \\
\hline$\$ 4$ & $2652.01 \mathrm{~J}$ & SAP $1701 \cdot 25.60$ & 7.517 & 0.014 & 0.039 & .0 .001 & 7.667 & 102.00 & 50.41 & 1.62 & 0.003696 & \pm 0.000004 & 0.055 & $4.81 E-16$ & 0.99 & 1.0005 & 0.0017 \\
\hline$\$ 4$ & $2652-01 K$ & SAP $1701-25.60$ & 7.857 & 0.010 & 0.120 & 0.018 & 2.579 & 32.80 & 17.11 & 12.99 & 0.003696 & \pm 0.000004 & 0.008 & $7.03 E-17$ & 1.49 & 1.0005 & 0.0017 \\
\hline \$4 & $2652-011$ & SAP $1701-25.60$ & 12.505 & 0.020 & 0.121 & 0.018 & 7.313 & 58.50 & 48.11 & 16.93 & 0.003696 & \pm 0.000004 & 0.010 & $8.76 E-17$ & 2.47 & 1.0005 & 0.0017 \\
\hline$\$ 4$ & $2652-02 A$ & SAP 170$\}-25.60$ & 4.449 & 0.012 & 0.000 & 0.000 & 4.466 & 100.40 & 29.54 & 0.66 & 0.003696 & \pm 0.000004 & 0.081 & $7.13 E-16$ & 0.10 & 1.0005 & 0.0017 \\
\hline$\$ 4$ & $2652-02 B$ & SAP 1701-25.60 & 6.756 & 0.013 & 0.000 & 0.000 & 6.719 & 99.50 & 44.25 & 0.31 & 0.003696 & $\mp 0.000004$ & 0.361 & $3.15 \mathrm{E}-15$ & 0.20 & 1.0005 & 0.0017 \\
\hline$\$ 4$ & $2652-02 C$ & SAP 1701-25.60 & 7.543 & 0.013 & 0.006 & 0.000 & 7.581 & 100.50 & 49.85 & 0.27 & 0.003696 & \pm 0.000004 & 0.521 & $4.55 E-15$ & 0.22 & 1.0005 & 0.0017 \\
\hline$\$ 4$ & 2652.020 & SAP $1701-25.60$ & 7.760 & 0.012 & 0.015 & 0.000 & 7.777 & 100.20 & 51.13 & 0.23 & 0.003696 & \pm 0.000004 & 0.719 & $6.27 \mathrm{E}-35$ & 0.25 & 1.0005 & 0.0017 \\
\hline 54 & $2652-02 E$ & SAP $1701-25.60$ & 7.894 & 0.012 & 0.009 & 0.000 & 7.899 & 100.10 & 51.92 & 0.25 & 0.003696 & \pm 0.000004 & 0.654 & $5.70 E-15$ & 0.27 & 1.0005 & 0.0017 \\
\hline$\$ 4$ & $2652-02 F$ & SAP $1701-25.60$ & 8.053 & 0.012 & 0.009 & 0.000 & 8.000 & 99.40 & 52.57 & 0.29 & 0.003696 & \pm 0.000004 & 0.438 & 3.81E-15 & 0.30 & 1.0005 & 0.0017 \\
\hline$\$ 4$ & $2652-02 G$ & SAP $3701-25.60$ & 8.183 & 0.012 & 0.000 & 0.800 & 8.265 & 101.00 & 54.28 & 0.47 & 0.003696 & \pm 0.000004 & 0.251 & $2.19 \varepsilon-15$ & 0.35 & 1.0005 & 0.0017 \\
\hline 54 & $2652-02 \mathrm{H}$ & SAP $1701-25,60$ & 8.302 & 0.012 & 0.000 & -0.001 & 8.475 & 102.10 & 55.64 & 1.11 & 0.003696 & \pm 0.000004 & 0.091 & $7.92 E-16$ & 0.40 & 1.0005 & 0.0017 \\
\hline \$4 & $2652-021$ & SAP $1701-25.60$ & 7.964 & 0.011 & 0.000 & -0.001 & 8.142 & 102.20 & 53.49 & 1.31 & 0.003696 & $\mp 0.000004$ & 0.066 & $5.74 E-16$ & 0.59 & 1.0005 & 0.0017 \\
\hline$\$ 4$ & $2652-02 J$ & SAP $1701-25.60$ & 7.852 & 0.010 & 0.030 & -0.001 & 8.191 & 104.30 & 53.81 & 2.90 & 0.003696 & \pm 0.000004 & 0.031 & $2.62 E-16$ & 0.99 & 1.0005 & 0.0017 \\
\hline$\$ 4$ & $2652-02 K$ & SAP $1701-25.60$ & 11.621 & 0.016 & 0.000 & 0.012 & 8.045 & 69.20 & 52.86 & 10.57 & 0.003696 & $\neq 0.000004$ & 0.014 & $1.19 E-16$ & 1.49 & 1.0005 & 0.0017 \\
\hline 54 & $2652-02 t$ & SAP $1701-25.60$ & 13.026 & 0.011 & 0.000 & -0.019 & $\{8.684$ & 143.40 & 120.47 & 25.26 & 0.003696 & \pm 0.000004 & 0.006 & $5.03 E-17$ & 2.47 & 1.0005 & 0.0017 \\
\hline$\$ 4$ & $2652-03 \mathrm{~A}$ & SAP 170\}-25.60 & 5.119 & $0.0 \div 2$ & 0.014 & 0.001 & 4.926 & 96.20 & 32.55 & 0.97 & 0.003696 & \pm 0.000004 & 0.070 & $6.09 E-16$ & 0.10 & 1.0005 & 0.0017 \\
\hline$\$ 4$ & $2652-03 B$ & SAP $1701-25.60$ & 6.844 & 0.012 & 0.057 & 0.001 & 6.680 & 97.60 & 44.00 & 0.33 & 0.003696 & \pm 0.000004 & 0.330 & $2.87 E-15$ & 0.20 & 1.0005 & 0.0017 \\
\hline$\$ 4$ & $2652-03 \mathrm{C}$ & SAP $1701-25.60$ & 8.493 & 0.011 & 0.046 & 0.000 & 8.452 & 99.50 & 55.49 & 0.45 & 0.003696 & $\mp 0.000004$ & 0.297 & $2.59 E-15$ & 0.22 & 1.0005 & 0.0017 \\
\hline$\$ 4$ & $2652-03 D$ & SAP 17D1-25.60 & 8.137 & 0.011 & 0.032 & 0.000 & 8.039 & 98.80 & 52.82 & 0.36 & 0.003696 & \pm 0.000004 & 0.375 & $3.27 E-15$ & 0.25 & 1.0005 & 0.0017 \\
\hline$\$ 4$ & 2652-03E & SAP $1701-25.60$ & 7.739 & 0.012 & 0.031 & 0.000 & 7.677 & 99.20 & 50.48 & 0.35 & 0.003696 & \pm 0.000004 & 0.365 & $3.17 E-15$ & 0.27 & 1.0005 & 0.0017 \\
\hline$\$ 4$ & $2652-035$ & SAP 170$\}-25.60$ & 7.409 & 0.012 & 0.032 & 0.060 & 7.364 & 99.40 & 48.44 & 0.35 & 0.003696 & \pm 0.000004 & 0.329 & $2.87 E-15$ & 0.30 & 1.0005 & 0.0017 \\
\hline$\$ 4$ & $2652-03 G$ & SAP 17D1-25.60 & 7.142 & 0.011 & 0.037 & 0.000 & 7.176 & 100.50 & 47.23 & 0.36 & 0.003696 & \pm 0.000004 & 0.311 & $2.72 E-15$ & 0.35 & 1.0005 & 0.0017 \\
\hline$\$ 4$ & $2652-03 \mathrm{H}$ & SAP 17D1-25.60 & 6.861 & 0.013 & 0.033 & -0.001 & 7.064 & 103.00 & 46.50 & 0.55 & 0.003696 & \pm 0.000004 & 0.195 & 1.71E-15 & 0.40 & 1.0005 & 0.0017 \\
\hline$\$ 4$ & $2652-031$ & SAP $1701+25.60$ & 8.562 & 0.012 & 0.057 & 0.001 & 6.403 & 97.60 & 42.20 & 0.36 & 0.003696 & \pm 0.000004 & 0.304 & $2.65 E-35$ & 0.99 & 1.0005 & 0.0037 \\
\hline$\$ 4$ & $2652-03 \mathrm{~J}$ & SAP $1701-25.60$ & 19.961 & 0.022 & 0.031 & 0.051 & 4.779 & 23.90 & 31.58 & 7.41 & 0.003696 & \pm 0.000004 & 0.039 & $3.55 E-16$ & 2.47 & 1.0005 & 0.0017 \\
\hline S4 & $2653-01 \mathrm{~A}$ & SAP $1701-26.60$ & 15.654 & 0.019 & 0.000 & 0.036 & 5.083 & 32.50 & 33.58 & 2.17 & 0.003696 & $\neq 0.000004$ & 0.174 & 1.51E-15 & 0.10 & 1.0005 & 0.0017 \\
\hline \$5 & $2653-03 B$ & SAP $1701-26.60$ & 7.494 & 0.012 & 0.011 & 0.002 & 7.049 & 94.30 & 46.40 & 0.59 & 0.003696 & $\mp 0.000004$ & 0.214 & $1.88 E-15$ & 0.20 & 1.0005 & 0.0017 \\
\hline $\mathrm{s} 5$ & 2653-01C & SAP $1701-26.60$ & 7.887 & 0.011 & 0.033 & 0.000 & 7.771 & 98.50 & 51.08 & 0.50 & 0.003696 & \pm 0.000004 & 0.240 & $2.08 E-15$ & 0.22 & 1.0005 & 0.0017 \\
\hline s5 & $2653-010$ & SAP 1701-26.60 & 8.158 & 0.009 & 0.055 & 0.000 & 8.212 & 100.70 & 53.94 & 0.61 & 0.003696 & \pm 0.000004 & 0.203 & $1.79 \mathrm{E}-15$ & 0.25 & 1.0005 & 0.0017 \\
\hline S5 & 2653-01E & SAP 1701-26.60 & 8.251 & 0.011 & 0.028 & 0.000 & 8.136 & 98.60 & 53.45 & 0.67 & 0.003696 & $=0.000004$ & 0.190 & $1.68 \mathrm{E}-15$ & 0.27 & 1.0005 & 0.0017 \\
\hline s5 & $2653-01 \mathrm{~F}$ & SAP $1701-26.60$ & 8.108 & 0.011 & 0.015 & 0.000 & 7.993 & 98.60 & 52.52 & 0.87 & 0.003696 & \pm 0.000004 & 0.147 & $1.29 E-15$ & 0.30 & 1.0005 & 0.0017 \\
\hline S5 & 2653-01G & SAP $1701-26.60$ & 8.014 & 0.013 & 0.011 & 0.000 & 7.957 & 99.30 & 52.29 & 0.99 & 0.003696 & \pm 0.000004 & 0.112 & $9.73 \mathrm{E}-1 \hat{\mathrm{O}}$ & 0.35 & 1.0005 & 0.0017 \\
\hline \$5 & 2653-01H & SAP 1701-26.60 & 7.113 & 0.014 & 0.132 & 0.000 & 7.247 & 101.90 & 47.69 & 1.67 & 0.003696 & \pm 0.000004 & 0.052 & $4,60 E-16$ & 0.40 & 1.0005 & 0.0017 \\
\hline$\$ 5$ & $2653-011$ & SAP $1701-26.60$ & 8.087 & 0.013 & 0.010 & 0.001 & 7.834 & 96.90 & 51.50 & 1.07 & 0.003696 & \pm 0.000004 & 0.108 & $9.46 E-18$ & 0.99 & 1.0005 & 0.0017 \\
\hline$\$ 5$ & $2653-01 \mathrm{~s}$ & SAP 17D1-26.60 & 11.992 & 0.013 & 0.034 & 0.007 & 9.906 & 82.60 & 64.87 & 3.85 & 0.003696 & \pm 0.000004 & 0.043 & $3.85 E-16$ & 2.47 & 1.0005 & 0.0017 \\
\hline S5 & $2653-02 A$ & SAP $1701-26.60$ & 12.438 & 0.017 & 0.016 & 0.022 & 6.084 & 48.90 & 40.12 & 1.37 & 0.003696 & $\mp 0.000004$ & 0.182 & $1.58 E-15$ & 0.10 & 1.0005 & 0.0017 \\
\hline$\$ 5$ & $2653-028$ & SAP 1701-26.60 & 7.619 & 0.013 & 0.022 & 0.001 & 7.279 & 95.50 & 47.89 & 0.35 & 0.003696 & \pm 0.000004 & 0.324 & $2.84 E-15$ & 0.20 & 1.0005 & 0.0017 \\
\hline$\$ 5$ & $2653-02 \mathrm{C}$ & SAP $1701-26.60$ & 8.071 & 0.012 & 0.013 & 0.000 & 8.158 & \$01.10 & 53.60 & 0.33 & 0.003696 & $=0.000804$ & 0.374 & $3.25 E-15$ & 0.22 & 1.0005 & 0.0017 \\
\hline S5 & $2653-020$ & SAP $1701-26.50$ & 8.224 & 0.011 & 0.014 & 0.000 & 8.278 & 100.70 & 54.37 & 0.39 & 0.003696 & \pm 0.000004 & 0.308 & $2.69 E-15$ & 0.25 & 0.9995 & 0.0017 \\
\hline
\end{tabular}




\begin{tabular}{|c|c|c|c|c|c|c|c|c|c|c|c|c|c|c|c|c|c|}
\hline \multicolumn{18}{|c|}{1 acer } \\
\hline Sample & ID\# & Depth & & & & & & & $\begin{array}{l}\text { Age } \\
\text { (Ma) }\end{array}$ & $(\mathrm{Ma})$ & & 3 & ${ }^{+1} \mathrm{Ar}$ & (Moles) & $\begin{array}{c}\text { Laser } \\
\text { Power (W) }\end{array}$ & $\begin{array}{l}{ }^{40} \mathrm{Ar} /{ }^{\circ} \mathrm{Ar} \\
\text { Discr. }\end{array}$ & \pm \\
\hline$\$ 5$ & $2653-02 E$ & SAP $1701-26.60$ & 8.336 & 0.012 & 0.008 & 0.000 & 8.343 & 100.10 & 54.79 & 0.55 & 0.003696 & $\mp 0.000004$ & 0.205 & 1.79E-15 & 0.27 & 0.9995 & 0.0017 \\
\hline s5 & $2653-02 F$ & SAP $1701-26.60$ & 8.313 & 0.010 & 0.007 & 0.000 & 8.435 & 101.50 & 55.38 & 0.90 & 0.003696 & \pm 0.008004 & 0.123 & $1.07 E-15$ & 0.30 & 0.9995 & 0.0017 \\
\hline S5 & $2653-02 G$ & SAP $1701-26.60$ & 8.530 & 0.011 & 0.063 & -0.001 & 8.682 & 101.80 & 56.98 & 1.11 & 0.003696 & \pm 0.000004 & 0.089 & $7.71 E-16$ & 0.35 & 0.9995 & 0.0017 \\
\hline S5 & $2653-02 \mathrm{H}$ & SAP $1701-26.60$ & 8.836 & 0.014 & 0.036 & -0.002 & 9.327 & 105.60 & 61.15 & 1.72 & 0.003696 & \pm 0.000004 & 0.060 & $5.21 E-16$ & 0.40 & 0.9995 & 0.0017 \\
\hline$\$ 5$ & $2653-021$ & SAP $1701-26.60$ & 22.570 & 0.013 & 0.008 & 0.010 & 19.638 & 87.00 & 126.41 & 1.33 & 0.003696 & $\mp 0.000004$ & 0.378 & $3.30 E-15$ & 0.99 & 0.9995 & 0.0017 \\
\hline$\$ 5$ & $2653-023$ & SAP 17D1-26.60 & 24.534 & 0.017 & 0.000 & 0.017 & 19.578 & 79.80 & 126.04 & 4.46 & 0.003696 & \pm 0.000004 & 0.070 & $6.05 E-16$ & 2.47 & 0.9995 & 0.0017 \\
\hline$\$ 5$ & $2653-03 \mathrm{~A}$ & SAP $1701-26.60$ & 12.806 & 0.016 & 0.000 & 0.030 & 3.877 & 30.30 & 25.67 & 4.10 & 0.003696 & \pm 0.000004 & 0.041 & 3.54E-16 & 0.30 & 0.9995 & 0.0017 \\
\hline \$5 & 2653-038 & SAP $1701-26.60$ & 9.896 & 0.012 & 0.033 & 0.010 & 6.876 & 69.50 & 45.27 & 1.25 & 0.003696 & \pm 0.000004 & 0.148 & $1.28 E-15$ & 0.20 & 0.9995 & 0.0017 \\
\hline s5 & $2653-03 \mathrm{C}$ & SAP $1701-28.60$ & 7.860 & 0.011 & 0.037 & 0.001 & 7.443 & 94.70 & 48.96 & 0.86 & 0.003696 & \pm 0.000004 & 0.138 & $1.20 E-15$ & 0.22 & 0.9995 & 0.0017 \\
\hline$\$ 5$ & 2653-03D & SAP $1701-26.60$ & 8.129 & 0.011 & 0.006 & 0.000 & 8.140 & 100.10 & 53.48 & 0.63 & 0.003696 & \pm 0.000004 & 0.185 & 1.6fE-15 & 0.25 & 0.9995 & 0.0017 \\
\hline$\$ 5$ & 2653-03E & SAP 1701-26.60 & 8.069 & 0.011 & 0.036 & 0.000 & 8.069 & 100.00 & 53.02 & 0.90 & 0.003696 & \pm 0.000004 & 0.133 & 1. $\{5 E-15$ & 0.27 & 0.9995 & 0.0017 \\
\hline S5 & $2653-03 F$ & SAP $1701-26.60$ & 8.047 & 0.011 & 0.054 & 0.000 & 7.973 & 99.10 & 52.40 & 0.88 & 0.003696 & \pm 0.000004 & 0.126 & 1.10E-15 & 0.30 & 0.9995 & 0.0017 \\
\hline$\$ 5$ & $2653-036$ & SAP $1721-26.60$ & 7.897 & 0.011 & 0.000 & 0.000 & 7.984 & 101.10 & 52.46 & 1.08 & 0.003696 & \pm 0.000004 & 0.099 & $8.58 E-16$ & 0.35 & 0.9995 & 0.0017 \\
\hline S5 & $2653-03 \mathrm{H}$ & SAP $1701-26.60$ & 7.838 & 0.012 & 0.032 & -0.003 & 8.824 & 112.60 & 57,90 & 2.01 & 0.003696 & \pm 0.000004 & 0.049 & $4.22 E-16$ & 0.40 & 0.9995 & 0.0017 \\
\hline \$5 & $2653-031$ & SAP $1701-26.60$ & 8.741 & 0.014 & 0.029 & 0.001 & 8.306 & 95.00 & 54.55 & 1.06 & 0.003696 & \pm 0.000004 & 0.137 & $1.19 E-15$ & 0.99 & 0.9995 & 0.0017 \\
\hline \$5 & $2653.03 \mathrm{~J}$ & SAP $17 D 1-26.60$ & 14.866 & 0.012 & 0.000 & 0.013 & 11.064 & 74.40 & 72.31 & 4.21 & 0.003696 & $\doteq 0.000004$ & 0.049 & $4.15 E-16$ & 2.47 & 0.9995 & 0.0017 \\
\hline s6 & $2655-01 \mathrm{~A}$ & SAP $1701-28.50$ & 29.727 & 0.025 & 0.052 & 0.078 & 6.592 & 22.20 & 43.42 & 3.74 & 0.003696 & \pm 0.000004 & 0.251 & $2.26 E-15$ & 0.10 & 0.9995 & 0.0017 \\
\hline S6 & $2655-018$ & SAP $1791-28.50$ & 7.883 & 0.013 & 0.027 & 0.006 & 6.115 & 77.60 & 40.32 & 0.66 & 0.003696 & $\approx 0.000004$ & 0.262 & 2.27E 15 & 0.20 & 0.9995 & 0.0017 \\
\hline S6 & $2655-01 \mathrm{C}$ & SAP 1701-28.50 & 6.850 & 0.012 & 0.034 & 0.001 & 6.515 & 95.10 & 42.92 & 0.67 & 0.003696 & \pm 0.000004 & 0.164 & 1.A4E-15 & 0.22 & 0.9995 & 0.0017 \\
\hline \$6 & $2655-010$ & SAP $1701-28.50$ & 7.120 & 0.011 & 0.024 & 0.000 & 7.012 & 98.50 & 46.16 & 0.54 & 0.003596 & \pm 0.000004 & 0.214 & $1.88 \mathrm{E}-15$ & 0.25 & 0.9995 & 0.0017 \\
\hline S6 & $2655-01 E$ & SAP $1701-28.50$ & 7.109 & 0.012 & 0.032 & 0.000 & 7.053 & 99.20 & 46.42 & 0.35 & 0.003696 & $\div 0.000004$ & 0.344 & $2.99 E-15$ & 0.27 & 0.9995 & 0.0017 \\
\hline S6 & $2655-01 \mathrm{~F}$ & SAP $17 B 1-28.50$ & 7.097 & 0.011 & 0.040 & 0.000 & 7.060 & 99.50 & 46.47 & 0.32 & 0.003696 & \pm 0.000004 & 0.375 & $3.28 \mathrm{E}-15$ & 0.30 & 0.9995 & 0.0017 \\
\hline S6 & $2655-016$ & SAP $1701-28.50$ & $7.0 \pm 2$ & 0.012 & 0.026 & 0.000 & 6.965 & 99.30 & 45.85 & 0.25 & 0.003696 & $\mp 0.000004$ & 0.546 & $4.78 E-15$ & 0.35 & 0.9995 & 0.0017 \\
\hline \$6 & $2655-01 \mathrm{H}$ & SAP $\{701-28.50$ & 6.980 & 0.011 & 0.033 & 0.000 & 6.915 & 99.10 & 45.53 & 0.33 & 0.003696 & \pm 0.000004 & 0.378 & $3.31 E-15$ & 0.40 & 0.9995 & 0.0017 \\
\hline s6 & $2655-011$ & SAP 1701-28.50 & 8.917 & 0.012 & 0.032 & 0.001 & 6.522 & 94.30 & 42.97 & 0.31 & 0.003696 & $\mp 0.000004$ & 0.420 & $3.67 E-15$ & 0.99 & 0.9995 & 0.0017 \\
\hline$\$ 6$ & $2655-01 \mathrm{~J}$ & SAP $1701-28.50$ & 9.116 & 0.013 & 0.057 & 0.008 & 6.787 & 74.40 & 44.69 & 1.40 & 0.003696 & $\mp 0.000004$ & 0.093 & $8.31 \mathrm{E}-16$ & 2.47 & 0.9995 & 0.0017 \\
\hline S6 & $2655-02 \mathrm{~A}$ & SAP $\{7 D\}-28.50$ & 4.451 & 0.013 & 0.015 & 0.007 & 2.517 & 56.60 & 16.70 & 1.04 & 0.003696 & \pm 0.000004 & 0.066 & $5.67 \mathrm{E}-16$ & 0.10 & 0.9995 & 0.0017 \\
\hline$\$ 6$ & $2655-028$ & SAP $1701-28.50$ & 5.099 & 0.014 & 0.018 & 0.001 & 4.929 & 96.70 & 32.57 & 0.54 & 0.003696 & \pm 0.000004 & 0.183 & 1.59E-15 & 0.20 & 0.9995 & 0.0017 \\
\hline$\$ 6$ & $2655-02 \mathrm{C}$ & SAP $1701-28.50$ & 6.859 & 0.013 & 0.004 & 0.000 & 6.915 & 100.80 & 45.53 & 0.57 & 0.003696 & \pm 0.000004 & 0.198 & $1.73 E-15$ & 0.22 & 0.9995 & 0.0017 \\
\hline S6 & $2655-020$ & SAP $1701-28.50$ & 8.424 & 0.011 & 0.015 & 0.000 & 8.357 & 99.20 & 54.88 & 0.44 & 0.003696 & \pm 0.000004 & 0.284 & $2.46 E-15$ & 0.25 & 0.9995 & 0.0017 \\
\hline s6 & $2655-02 E$ & SAP $1701+28.50$ & 8.516 & 0.011 & 0.001 & 0.000 & 8.599 & 101.00 & 56.45 & 0.44 & 0.003696 & \pm 0.000004 & 0.302 & 2.65E-15 & 0.27 & 0.9995 & 0.0017 \\
\hline s6 & $2655-02 \mathrm{~F}$ & SAP $1701-28.50$ & $8.5 \div 5$ & 0.012 & 0.003 & 0.000 & 8.541 & 100.30 & 56.07 & 0.47 & 0.003696 & \pm 0.000004 & 0.270 & $2.35 E-15$ & 0.30 & 0.9995 & 0.0017 \\
\hline 56 & $2655-026$ & SAP $1701-28.50$ & 8.380 & 0.011 & 0.007 & 0.000 & 8.252 & 98.50 & 54.20 & 0.59 & 0.003696 & \pm 0.000004 & 0.215 & $1.86 E-15$ & 0.35 & 0.9995 & 0.0017 \\
\hline S6 & $2655-02 \mathrm{H}$ & SAP $1701-28.50$ & 8.228 & 0.012 & 0.043 & 0.000 & 8.113 & 98.60 & 53.30 & 1.19 & 0.003696 & \pm 0.000004 & 0.088 & $7.60 E-16$ & 0.45 & 0.9995 & 0.0017 \\
\hline s6 & $2655-021$ & SAP $1701-28.50$ & 9.842 & 0.013 & 0.029 & 0.004 & 8.716 & 88.60 & 57.20 & 0.72 & 0.003696 & \pm 0.000004 & 0.198 & 1.73E-15 & 0.99 & 0.9995 & 0.0017 \\
\hline s6 & $2655-02 \mathrm{~J}$ & SAP $1721-28.50$ & 17.029 & 0.014 & 0.000 & 0.009 & 14.391 & 84.50 & 93.49 & 2.54 & 0.003696 & $\mp 0.000004$ & 0.107 & $9.31 E-36$ & 2.47 & 0.9995 & 0.0017 \\
\hline s6 & $2655-03 \mathrm{~A}$ & SAP $1701-28.50$ & 11.638 & 0.016 & 0.003 & 0.019 & 6.080 & 52.30 & 40.09 & 1.56 & 0.003696 & \pm 0.000004 & 0.154 & $1.34 E-15$ & 0.10 & 1.0025 & 0.0018 \\
\hline$\$ 6$ & $2555-038$ & SAP $1701-28.50$ & 6.948 & 0.012 & 0.035 & 0.000 & 6.823 & 98.20 & 44.93 & 0.34 & 0.003696 & \pm 0.000004 & 0.392 & $3.43 E-15$ & 0.20 & 1.0025 & 0.0018 \\
\hline$s 6$ & $2655-03 \mathrm{C}$ & SAP $1701-28.50$ & 7.183 & 0.012 & 0.027 & 0.000 & 7.059 & 98.30 & 46.46 & 0.94 & 0.003696 & $\mp 0.000004$ & 0.101 & $8.83 E-16$ & 0.22 & 1.0025 & 0.0018 \\
\hline S6 & 2655-03D & SAP $1701-28.50$ & 7.242 & 0.011 & 0.071 & 0.000 & 7.230 & 99.90 & 47.58 & 1.90 & 0.003696 & \pm 0.000004 & 0.048 & $4.21 E-16$ & 0.25 & 1.0025 & 0.0018 \\
\hline S6 & 2655-03E & SAP $1701-28.50$ & 5.748 & 0.009 & 0.034 & 0.004 & 5.556 & 82.40 & 36.57 & 4.76 & 0.003696 & \pm 0.000004 & 0.018 & $1.59 E-16$ & 0.27 & 1.0025 & 0.0018 \\
\hline s6 & $2655-03 F$ & SAP $1701-28.50$ & 4.633 & 0.012 & 0.000 & -0.012 & 8.192 & 176.80 & 53.81 & 8.86 & 0.003696 & $\mp 0.000004$ & 0.006 & $6.12 E-17$ & 0.30 & 1.0025 & 0.0018 \\
\hline So & 2655-03G & SAP $1701-28.50$ & 14.139 & 0.013 & 0.000 & -0.022 & 20.513 & 145.10 & 131.84 & 23.17 & 0.003696 & \pm 0.000004 & 0.007 & $7.24 \mathrm{E}-17$ & 0.35 & 1.0025 & 0.0018 \\
\hline s6 & $2655-03 H$ & SAP 17D1-28.50 & 29.653 & 0.006 & 0.000 & 0.012 & 26.112 & 88.10 & 166.21 & 17.27 & 0.003696 & \pm 0.000004 & 0.021 & $1.87 E-16$ & 0.45 & 1.0025 & 0.0018 \\
\hline s6 & $2655-03 !$ & SAP 1701-28.50 & 21.731 & 0.013 & 0.014 & 0.023 & 14.980 & 68.90 & 97.22 & 7.83 & 0.003696 & \pm 0.000004 & 0.036 & $3.24 E-16$ & 0.99 & 1.0025 & 0.0018 \\
\hline S6 & $2655-033$ & SAP $1701-28.50$ & 3.331 & 0.013 & 0.064 & 0.036 & -7.191 & -215.9 & -48.60 & 49.68 & 0.003696 & \pm 0.000004 & 0.001 & $1.92 E-17$ & 2.47 & 1.0025 & 0.0018 \\
\hline
\end{tabular}


Appendix (Continued)

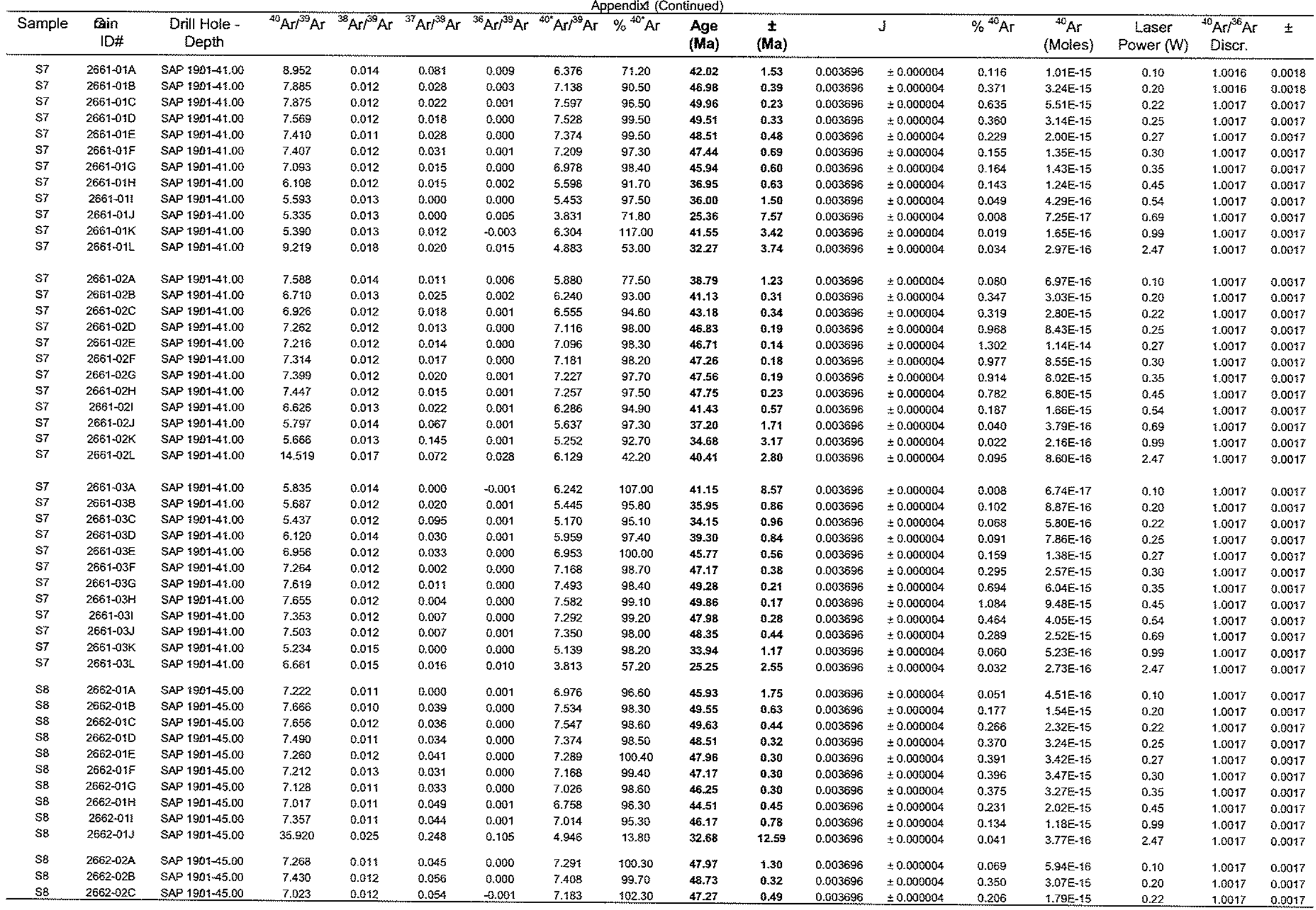




\begin{tabular}{|c|c|c|c|c|c|c|c|c|c|c|c|c|c|c|c|c|c|}
\hline \multicolumn{18}{|c|}{ Appendix (Continued) } \\
\hline Sample & $\begin{array}{l}\text { Bain } \\
\text { ID\#\# }\end{array}$ & $\begin{array}{l}\text { Drill Hole - } \\
\text { Depth }\end{array}$ & ${ }^{40} \mathrm{Ar} I^{39} \mathrm{Ar}$ & ${ }^{38} \mathrm{Ar} r^{39} \mathrm{Ar}$ & ${ }^{37} \mathrm{Ar} r^{39} \mathrm{Ar}$ & ${ }^{36} \mathrm{Ar} r^{39} \mathrm{Ar}$ & ${ }^{40} \mathrm{Ar} r^{39} \mathrm{Ar}$ & $\%^{40^{\circ}} \mathrm{Ar}$ & $\begin{array}{l}\text { Age } \\
\text { (Ma) }\end{array}$ & $\begin{array}{l} \pm \\
\text { (Ma) }\end{array}$ & & $\mathrm{J}$ & $\%{ }^{40} \mathrm{Ar}$ & $\begin{array}{l}{ }^{40} \mathrm{Ar} \\
\text { (Moles) }\end{array}$ & $\begin{array}{c}\text { Laser } \\
\text { Power }(W)\end{array}$ & $\begin{array}{l}{ }^{40} \mathrm{Ar} /{ }^{36} \mathrm{Ar} \\
\text { Discr. }\end{array}$ & \pm \\
\hline S8 & $2662.02 \mathrm{D}$ & SAP $1901-45.00$ & 7.095 & 0.012 & 0.074 & -0.001 & $7.5 \div 3$ & 105.90 & 49.44 & 0.89 & 0.003696 & \pm 0.000004 & 0.103 & $8.95 E-16$ & 0.25 & 1.0017 & 0.0017 \\
\hline s8 & $2662.02 E$ & SAP $1991-45.00$ & 7.160 & 0.010 & 0.098 & 0.002 & 6.698 & 93.60 & 44.12 & 1.55 & 0.003696 & \pm 0.000004 & 0.056 & $4.82 E-16$ & 0.27 & 1.0017 & 0.0017 \\
\hline s8 & $2662-02 F$ & SAP $190 \$-45.00$ & 7.172 & 0.014 & 0.084 & 0.000 & 7.208 & 100.50 & 47.43 & 2.19 & 0.003696 & $\mp 0.000004$ & 0.036 & $3.06 E-16$ & 0.30 & 1.0017 & 0.0017 \\
\hline s8 & $2562-02 G$ & SAP $1901-45.00$ & 7.206 & 0.012 & 0.096 & -0.004 & 8.389 & $\$ 16.40$ & 55.09 & 2.83 & 0.003696 & \pm 0.000004 & 0.031 & $2.58 E-16$ & 0.35 & 1.0017 & 0.0017 \\
\hline s8 & $2662-02 \mathrm{H}$ & SAP $1901-45.00$ & 7.533 & 0.011 & 0.030 & 0.005 & 6.126 & 81.30 & 40.39 & 4.76 & 0.003696 & \pm 0.000004 & 0.019 & $1.51 E-16$ & 0.45 & 1.0017 & 0.0017 \\
\hline s8 & $2662-021$ & SAP $1901-45.00$ & 7.572 & 0.013 & 0.019 & -0.001 & 7.861 & 103.80 & 51.67 & 3.71 & 0.003696 & \pm 0.000004 & 0.024 & $1.93 E-16$ & 0.39 & 1.0017 & 0.0017 \\
\hline$\$ 8$ & $2662.02 \mathrm{~J}$ & SAP $190:-45.00$ & 12.601 & 0.029 & 0.286 & 0.004 & 11.564 & 91.80 & 75.50 & 31.35 & 0.003696 & \pm 0.000004 & 0.005 & $2.79 E-17$ & 2.47 & 1.0017 & 0.0017 \\
\hline$\$ 8$ & $2662-03 \mathrm{~A}$ & SAP $1981-45.00$ & 7.291 & 0.013 & 0.000 & .0 .002 & 7.783 & 106.80 & 51.17 & 1.67 & 0.003696 & \pm 0.000004 & 0.048 & $4.38 E-16$ & 0.10 & 1.0017 & 0.0017 \\
\hline s8 & $2662-038$ & SAP 19001.45 .00 & 7.575 & 0.012 & 0.048 & 0.000 & 7.544 & 99.60 & 49.61 & 0.49 & 0.003696 & \pm 0.000004 & 0.218 & $1.90 E-15$ & 0.20 & 1.0017 & 0.0017 \\
\hline s8 & $2662-03 \mathrm{C}$ & SAP $1901-45.00$ & 7.210 & 0.013 & 0.016 & 0.000 & 7.165 & 99.40 & 47.15 & 0.50 & 0.003696 & \pm 0.000004 & 0.192 & $1.67 E-15$ & 0.22 & 1.0017 & 0.0017 \\
\hline$\$ 8$ & $2662-030$ & SAP $1901-45.00$ & 7.169 & 0.011 & 0.096 & 0.000 & 7.294 & 101.70 & 47.99 & 0.62 & 0.003696 & \pm 0.000004 & 0.152 & 1. $32 E-15$ & 0.25 & 1.0017 & 0.0017 \\
\hline s8 & 2662-03E & SAP $1901-45.00$ & 6.991 & 0.013 & 0.071 & -0.001 & 7.355 & 105.20 & 48.39 & 1.06 & 0.003696 & $\mp 0.000004$ & 0.074 & $6.42 E-16$ & 0.27 & 1.0017 & 0.0017 \\
\hline s8 & $2662-03 \mathrm{~F}$ & SAP 19D1-45.00 & 6.839 & 0.012 & 0.072 & 0.002 & 6.361 & 93.00 & 41.93 & 1.86 & 0.003696 & \pm 0.000004 & 0.041 & 3.59E-16 & 0.30 & 1.0017 & 0.0017 \\
\hline s8 & $2662-03 G$ & SAP $1901-45.00$ & 6.942 & 0.012 & 0.172 & 0.005 & 5.492 & 79.10 & 36.25 & 2.31 & 0.003696 & $\approx 0.000004$ & 0.036 & $3.09 E-16$ & 0.35 & 1.0017 & 0.0017 \\
\hline s8 & 2662-03H & SAP $1901-45.00$ & 7.297 & 0.011 & 0.164 & 0.002 & 6.588 & 90.30 & 43.40 & 3.82 & 0.003696 & \pm 0.000004 & 0.021 & $1.84 \mathrm{E}-16$ & 0.45 & 1.0017 & 0.0017 \\
\hline s8 & $2662-031$ & SAP $1901-45.00$ & 7.336 & 0.013 & 0.312 & 0.005 & 5.807 & 79.20 & 38.31 & 3.83 & 0.003696 & \pm 0.000004 & 0.023 & $1.98 \mathrm{E}-\mathrm{t} \hat{\mathrm{t}}$ & 0.99 & 1.0017 & 0.0017 \\
\hline \$8 & $2662-03 \mathrm{~J}$ & SAP $1901-45.00$ & 17.020 & 0.022 & 0.352 & 0.028 & 8.843 & 51.90 & 58.02 & 31.77 & 0.003696 & \pm 0.000004 & 0.006 & $5.39 E-17$ & 2.47 & 1.0017 & 0.0017 \\
\hline s9 & $2663-01 \mathrm{~A}$ & SAP 19D1-46.00 & 4.025 & 0.012 & 0.075 & 0.000 & 4.165 & 103.50 & 27.56 & 0.86 & 0.003696 & $=0.000004$ & 0.055 & $4.81 E-16$ & 0.10 & 1.0017 & 0.0017 \\
\hline s9 & $2663.01 B$ & SAP $1901-46.00$ & 7.468 & 0.012 & 0.000 & 0.000 & 7.593 & 101.70 & 49.93 & 0.43 & 0.003696 & \pm 0.000004 & 0.285 & $2.49 E-15$ & 0.20 & 1.0017 & 0.0017 \\
\hline s9 & $2663-01 c$ & SAP $1901-46.00$ & 8.464 & 0.012 & 0.012 & 0.000 & 8.461 & 100.00 & 55.55 & 0.29 & 0.003696 & \pm 0.000004 & 0.466 & $4.07 \varepsilon-15$ & 0.22 & 1.0017 & 0.0017 \\
\hline sg & $2663-010$ & SAP $1901-46.00$ & 8.528 & 0.012 & 0.013 & 0.000 & 8.522 & 99.90 & 55.95 & 0.33 & 0.003696 & \pm 0.000004 & 0.469 & $4.06 E-15$ & 0.25 & $1.00+7$ & 0.0017 \\
\hline$\$ 9$ & $2663-01 E$ & SAP $1901-46.00$ & 8.620 & 0.012 & 0.005 & 0.000 & 8.671 & 100.60 & 56.91 & 0.49 & 0.003696 & $\cong 0.000004$ & 0.294 & $2.55 E-15$ & 0.27 & 1.0017 & 0.0017 \\
\hline s9 & $2663.01 \mathrm{~F}$ & SAP $1901-46.00$ & 8.697 & 0.010 & 0.098 & -0.001 & 9.067 & $\{04.30$ & 59.47 & $\$ .18$ & 0.003696 & $\mp 0.000004$ & 0.110 & $9.52 E-16$ & 0.30 & 1.0017 & 0.0017 \\
\hline$s g$ & $2663-01 G$ & SAP $1901-46.00$ & 8.850 & 0.011 & 0.000 & -0.003 & 9.753 & $\$ 10.20$ & 63.89 & 1.67 & 0.003696 & \pm 0.000004 & 0.065 & $5.66 E-10$ & 0.35 & 1.0017 & 0.0017 \\
\hline s9 & $2663.01 \mathrm{H}$ & SAP $1901-46.00$ & 8.632 & 0.008 & 0.021 & 0.001 & 8.401 & 97.30 & 55.17 & 2.99 & 0.003696 & \pm 0.000004 & 0.037 & $3.18 E-1 a$ & 0.45 & 1.0017 & 0.0017 \\
\hline s9 & 2663-01! & SAP $\$ 901-46.00$ & 9.157 & 0.006 & 0.105 & -0.006 & 11.020 & 120.30 & 72.02 & 4.37 & 0.003696 & \pm 0.000004 & 0.025 & $2.10 E-16$ & 0.54 & 1.0017 & 0.0017 \\
\hline sg & $2663-011$ & SAP $\{90\}-46.00$ & 9.111 & 0.011 & 0.000 & -0.004 & 10.267 & $\$ 12.70$ & 67.19 & 3.49 & 0.003696 & \pm 0.000004 & 0.033 & $2.79 \varepsilon-16$ & 0.69 & 1.0017 & 0.0017 \\
\hline s9 & $2663-01 \mathrm{~K}$ & SAP $1901-46.00$ & 8.898 & 0.014 & 0.000 & 0.009 & 6.266 & 70.40 & 41.30 & 5.44 & 0.003696 & $\approx 0.000004$ & 0.021 & $1.74 E-16$ & 0.99 & 1.0017 & 0.0017 \\
\hline s9 & 2663-01L & SAP $1901-46.00$ & 12.692 & 0.008 & 0.000 & 0.003 & 11.938 & 94.30 & 77.89 & 11.95 & 0.003696 & \pm 0.000004 & 0.014 & $1.11 E-16$ & 2.47 & 1.0003 & 0.0018 \\
\hline s9 & $2663-02 \mathrm{~A}$ & SAP $1901-46.00$ & 4.175 & 0.011 & 0.000 & 0.001 & 3.735 & 89.50 & 24.74 & 0.82 & 0.003696 & $\approx 0.000004$ & 0.060 & $5.19 \varepsilon-16$ & 0.10 & 1.0003 & 0.0018 \\
\hline sg & $2663-02 B$ & SAP $1901-46.00$ & 7207 & 0.012 & 0.009 & 0.000 & 7.067 & 98.10 & 46.52 & 0.48 & 0.003696 & \pm 0.000004 & 0.239 & $2.09 E-15$ & 0.20 & 1.0003 & 0.0018 \\
\hline s9 & $2663-02 \mathrm{C}$ & SAP $1901-46.00$ & 8.501 & 0.011 & 0.011 & 0.000 & 8.499 & 100.00 & 55.80 & 0.47 & 0.003696 & \pm 0.000004 & 0.278 & $2.42 E-15$ & 0.22 & 1.0003 & 0.0018 \\
\hline sg & $2663-020$ & SAP $1901-46.00$ & 8.704 & 0.012 & 0.000 & 0.000 & 8.676 & 99.70 & 56.94 & 0.41 & 0.003696 & \pm 0.000004 & 0.364 & $3.18 E-15$ & 0.25 & 1.0003 & 0.0018 \\
\hline s9 & $2663-02 E$ & SAP $1901-46.00$ & 8.584 & 0.012 & 0.015 & 0.000 & 8.488 & 98.90 & 55.72 & 0.32 & 0.003596 & \pm 0.000004 & 0.413 & 3.59E-15 & 0.27 & 1.0003 & 0.0018 \\
\hline sq & $2663-02 F$ & SAP $1901-46.00$ & 8.581 & 0.013 & 0.013 & 0.000 & 8.498 & 99.00 & 55.79 & 0.37 & 0.003696 & \pm 0.000004 & 0.384 & $3.35 E-15$ & 0.30 & 1.0003 & 0.0018 \\
\hline s9 & $2663-02 G$ & SAP $1901-46.00$ & 8.684 & 0.012 & 0.000 & 0.000 & 8.598 & 99.00 & 56.44 & 0.61 & 0.003696 & \pm 0.000004 & 0.226 & 1.97E-15 & 0.35 & 1.0003 & 0.0018 \\
\hline s9 & $2663.02 \mathrm{H}$ & SAP $1901-46.00$ & 8.743 & 0.012 & 0.040 & 0.000 & 8.624 & 98.60 & 56.60 & 1.16 & 0.003696 & \pm 0.000004 & 0.103 & $8.96 E-16$ & 0.45 & 1.0003 & 0.0018 \\
\hline so & $2663-02 !$ & SAP $1901-46.00$ & 8.798 & 0.011 & 0.000 & 0.005 & 7.372 & 83.80 & 48.50 & 3.62 & 0.003696 & \pm 0.000004 & 0.032 & $2.79 E-16$ & 0.54 & 1.0003 & 0.0018 \\
\hline$\$ 9$ & $2663.02 \mathrm{~J}$ & SAP $1901-46.00$ & 8.692 & 0.013 & 0.000 & 0.001 & 8.403 & 96.70 & 55.18 & 221 & 0.003696 & \pm 0.000004 & 0.048 & $4.24 E-16$ & 0.69 & 1.0003 & 0.0018 \\
\hline s9 & $2663-02 K$ & SAP $1901-46.00$ & 8.657 & 0.011 & 0.000 & 0.002 & 8.033 & 92.80 & 52.79 & 2.37 & 0.003696 & \pm 0.000004 & 0.046 & $3.99 E-16$ & 0.99 & 1.0003 & 0.0018 \\
\hline \$9 & $2663-02 \mathrm{~L}$ & SAP $1901-46.00$ & 13.648 & 0.029 & 0.000 & 0.039 & 2.239 & 16.40 & 14.87 & 10.83 & 0.003696 & \pm 0.000004 & 0.017 & 1.46E-16 & 2.47 & 1.0003 & 0.0018 \\
\hline 59 & $2663-03 \mathrm{~A}$ & SAP $1901-46.00$ & 4.047 & 0.013 & 0.032 & 0.000 & 3.974 & 98.20 & 26.31 & 0.72 & 0.003696 & \pm 0.000004 & 0.066 & $5.73 E-16$ & 0.10 & 1.0003 & 0.0018 \\
\hline S9 & $2663-038$ & SAP $1901-46.00$ & 7.079 & 0.012 & 0.030 & 0.000 & $\begin{array}{l}6.977 \\
6.97\end{array}$ & 98.60 & 45.93 & 0.46 & 0.003696 & $\neq 0.000004$ & 0.255 & $2.23 E-15$ & 0.20 & 1.0003 & 0.0018 \\
\hline sq & $2663-03 \mathrm{C}$ & SAP $1901-46.00$ & 8.463 & 0.012 & 0.029 & 0.001 & 8.262 & 97.60 & 54.27 & 0.35 & 0.003696 & \pm 0.000004 & 0.364 & $3.17 E-15$ & 0.22 & 1.0003 & 0.0018 \\
\hline se & $2663-03 D$ & SAP $1901-46.00$ & 8.707 & 0.011 & 0.009 & 0.000 & 8.622 & 99.00 & 56.59 & 0.31 & 0.003696 & \pm 0.000004 & 0.513 & $4.47 \mathrm{E}-15$ & 0.25 & 1.0003 & 0.0018 \\
\hline s9 & $2663-03 E$ & SAP $1901-46.00$ & 8.682 & 0.012 & 0.021 & 0.000 & 8.601 & 99.10 & 56.46 & 0.29 & 0.003696 & \pm 0.000004 & 0.561 & $4.89 \mathrm{E}-15$ & 0.27 & 1.0003 & 0.0018 \\
\hline s9 & $2663-03 \mathrm{~F}$ & SAP $1901-46.00$ & 8.673 & 0.012 & 0.024 & 0.000 & 8.610 & 99.30 & 56.52 & 0.30 & 0.003696 & \pm 0.000004 & $\begin{array}{l}0.499 \\
\end{array}$ & 4.34E-15 & 0.30 & 1.0003 & 0.0018 \\
\hline
\end{tabular}




\begin{tabular}{|c|c|c|c|c|c|c|c|c|c|c|c|c|c|c|c|c|c|}
\hline \multicolumn{18}{|c|}{ Appendix (Continued) } \\
\hline Sample & fä\# & $\begin{array}{l}\text { Drill Hole - } \\
\text { Depth }\end{array}$ & ${ }^{40} \mathrm{Ar} r^{39} \mathrm{Ar}$ & ${ }^{38} \mathrm{Ar} i^{39} \mathrm{Ar}$ & ${ }^{37} \mathrm{Ar} r^{39} \mathrm{Ar}$ & ${ }^{36} \mathrm{Ar} r^{39} \mathrm{Ar}$ & $\left.40^{*} \mathrm{Ar}\right)^{39} \mathrm{Ar}$ & $\%{ }^{40} \mathrm{Ar}$ & $\begin{array}{l}\text { Age } \\
\text { (Ma) }\end{array}$ & $\underset{\text { (Ma) }}{ \pm}$ & & J & $\%{ }^{40} \mathrm{Ar}$ & $\begin{array}{l}{ }^{40} \mathrm{Ar} \\
\text { (Moles) }\end{array}$ & $\begin{array}{c}\text { Laser } \\
\text { Power }(W)\end{array}$ & $\begin{array}{l}{ }^{40} \mathrm{Ar} r^{36} \mathrm{Ar} \\
\text { Discr. }\end{array}$ & \pm \\
\hline sg & 2663.036 & SAP $1901-46.00$ & 8.700 & 0.012 & 0.012 & 0.000 & 8.628 & 99.20 & 56.63 & 0.36 & 0.003696 & \pm 0.000004 & 0.375 & $3.27 E-15$ & 0.35 & 1.0003 & 0.0018 \\
\hline $\mathrm{sg}$ & $2663-03 \mathrm{H}$ & SAP $190 \div-46.00$ & 8.905 & 0.011 & 0.006 & -0.001 & 9.093 & 102.10 & 59.63 & 0.82 & 0.003696 & \pm 0.000004 & 0.150 & $1.31 E-15$ & 0.45 & 1.0003 & 0.0018 \\
\hline s9 & 2663.031 & SAP $1903-46.00$ & 8.971 & 0.010 & 0.078 & 0.001 & 8.604 & 95.90 & 56.48 & 2.83 & 0.003696 & \pm 0.000004 & 0.038 & $3.35 E+\{6$ & 0.54 & 1.0003 & 0.0018 \\
\hline s9 & $2663-03 \mathrm{~J}$ & SAP $1901-45.00$ & 8.775 & 0.009 & 0.045 & -0.003 & 9.625 & 109.70 & 63.06 & 2.32 & 0.003696 & \pm 0.000004 & 0.045 & $3.96 E-16$ & 0.69 & 1.0003 & 0.0018 \\
\hline sg & $2663-03 k$ & SAP $1901-46.00$ & 8.686 & 0.008 & 0.070 & 0.002 & 8.209 & 94.50 & 53.92 & 1.80 & 0.003696 & $\div 0.000004$ & 0.057 & $5.00 E-16$ & 0.99 & 1.0003 & 0.0018 \\
\hline $\mathrm{s} 9$ & $2663.03 \mathrm{~L}$ & SAP 19D:-46.00 & 12.932 & -0.003 & 0.197 & 0.010 & 9.862 & 76.20 & 64.59 & 7.91 & 0.003696 & $\mp 0.000004$ & 0.021 & $1.86 \mathrm{E}-16$ & 2.47 & 1.0003 & 0.0018 \\
\hline s10 & $2664-01 \mathrm{~A}$ & SAP $190\{-49.00$ & 33.796 & 0.028 & 0.032 & 0.096 & 5.540 & 16.40 & 36.57 & 2.91 & 0.003696 & \pm 0.000004 & 0.559 & $4.88 E-15$ & 0.10 & 1.0003 & 0.0018 \\
\hline \$10 & $2664.01 B$ & SAP $1901-49.00$ & 7.443 & 0.013 & 0.046 & 0.001 & 7.142 & 96.00 & 47.01 & 0.33 & 0.003696 & \pm 0.000004 & 0.423 & $3.71 E-15$ & 0.20 & 1.0003 & 0.0018 \\
\hline$\$ 10$ & $2664-0+C$ & SAP $1901-49.00$ & 6.834 & 0.012 & 0.037 & 0.001 & 6.548 & 95.80 & 43.14 & 0.36 & 0.003696 & \pm 0.000004 & 0.291 & $2.53 E-15$ & 0.22 & 1.0003 & 0.0018 \\
\hline $\mathrm{s} 10$ & $2664-010$ & SAP $1901-49.00$ & 6.751 & 0.012 & 0.016 & 0.000 & 6.651 & 98.50 & 43.81 & 0.66 & 0.003696 & \pm 0.000004 & 0.147 & 1.28E-15 & 0.25 & 1.0003 & 0.0018 \\
\hline s10 & 2664-01E & SAP 1901.49 .00 & 6.759 & 0.011 & 0.034 & 0.000 & 6.865 & 101.60 & 45.20 & 1.00 & 0.003696 & \pm 0.000004 & 0.084 & 7.34E-16 & 0.27 & 1.0003 & 0.0018 \\
\hline s10 & $2664.01 \mathrm{~F}$ & SAP $1901-49.00$ & 6.613 & 0.012 & 0.019 & -0.801 & 6.843 & 103.50 & 45.06 & 1.42 & 0.003696 & \pm 0.000004 & 0.060 & 5.25E-16 & 0.30 & 1.0003 & 0.0018 \\
\hline s10 & 2664-01G & SAP $1901-49.00$ & 6.731 & 0.011 & 0.011 & -0.002 & 7.200 & 107.00 & 47.38 & 1.53 & 0.003696 & \pm 0.000004 & 0.053 & $4.66 \mathrm{E}-16$ & 0.35 & 1.0003 & 0.0018 \\
\hline s10 & $2664-014$ & SAP 1901.49 .00 & 6.882 & 0.013 & 0.043 & -0.003 & 7,671 & 111.50 & 50.44 & 2.48 & 0.003696 & \pm 0.000004 & 0.034 & $2.96 \mathrm{E}-16$ & 0.45 & 1.0003 & 0.0018 \\
\hline s10 & 2664.011 & SAP 19D1-49.00 & 8.937 & 0.010 & 0.038 & -0.004 & 10.365 & 113.70 & 66.53 & 2.36 & 0.003696 & \pm 0.000004 & 0.043 & $3.77 E-1 \hat{0}$ & 0.99 & 1.0003 & 0.0018 \\
\hline$\$ 10$ & $2664-01 \mathrm{~s}$ & SAP $1901-49.00$ & 10.499 & 0.018 & 0.098 & -0.003 & $\$ 1.410$ & 108.70 & 74.52 & 8.64 & 0.003696 & \pm 0.000004 & 0.015 & j.32E-16 & 2.47 & 1.0003 & 0.0018 \\
\hline s10 & $2664.02 \mathrm{~A}$ & SAP $19 D 1-49.00$ & 40.047 & 0.032 & 0.007 & 0.108 & 8.042 & 20.10 & 52.84 & 3.23 & 0.003696 & \pm 0.000004 & 0.576 & $5.00 \mathrm{E}-15$ & 0.10 & 1.0006 & 0.0018 \\
\hline$\$ 10$ & $2664-028$ & SAP $19 D 1-49.00$ & 7.214 & 0.013 & 0.030 & 0.001 & 6.926 & 96.00 & 45.60 & 0.32 & 0.003696 & $=0.000004$ & 0.469 & $4.08 \mathrm{E}-15$ & 0.20 & 1.0006 & 0.0018 \\
\hline$\$ 10$ & $2664-02 C$ & SAP $1901-49.00$ & 6.814 & 0.011 & 0.001 & 0.000 & 6.842 & 100.40 & 45.05 & 0.74 & 0.003696 & \pm 0.000004 & 0.127 & $1.11 \mathrm{E}-15$ & 0.22 & 1.0006 & 0.0018 \\
\hline s10 & $2664-020$ & SAP $1901-49.00$ & 6.727 & 0.011 & 0.098 & -0.001 & 7.038 & 104.60 & 46.33 & 1.42 & 0.003696 & \pm 0.000004 & 0.060 & 5.19E-16 & 0.25 & 1.0006 & 0.0018 \\
\hline \$10 & $2664-02 E$ & SAP $1901-49.00$ & 7.042 & 0.009 & 0.041 & 0.001 & 6.683 & 34.90 & 44.02 & 2.24 & 0.003696 & \pm 0.000004 & 0.036 & 3.14E-16 & 0.27 & 8.0006 & 0.0018 \\
\hline $\mathrm{s} 10$ & $2664-02 \mathrm{~F}$ & SAP $1901-49.00$ & 6.706 & 0.008 & 0.000 & 0.001 & 6.501 & 97.00 & 42.84 & 3.35 & 0.003696 & \pm 0.000004 & 0.023 & $1.97 \mathrm{E}-16$ & 0.30 & 1.0006 & 0.0018 \\
\hline s10 & $2664-02 \mathrm{G}$ & SAP $19 B 1-49.00$ & 6.965 & 0.005 & 0.000 & -0.001 & 7.177 & 103.10 & 47.23 & 4.23 & 0.003696 & $\approx 0.000004$ & 0.019 & $1.62 E-16$ & 0.35 & 1.0000 & 0.0018 \\
\hline s10 & $2664-02 \mathrm{H}$ & SAP 1901.49 .00 & 7.663 & 0.008 & 0.000 & -0.008 & 9.889 & 129.10 & 64.76 & 6.56 & 0.003696 & \pm 0.000004 & 0.013 & 1.10E-15 & 0.45 & 1.0005 & 0.0018 \\
\hline s10 & $2664-023$ & SAP 1901-49.00 & 9.626 & 0.007 & 0.000 & -0.006 & 11.277 & 117.20 & 73.67 & 4.51 & 0.003696 & $\mp 0.000004$ & 0.023 & $1.97 E-16$ & 0.99 & 1.0006 & 0.0018 \\
\hline S10 & $2664-023$ & SAP $1901-49.00$ & 10.889 & 0.001 & 0.000 & 0.006 & 9.201 & 84.50 & 60.33 & 17.16 & 0.003696 & \pm 0.000004 & 0.008 & $6.13 E-17$ & 2.47 & 8.0006 & $0.00 \div 8$ \\
\hline$\$ 10$ & $2664.03 \mathrm{~A}$ & SAP $1901-49.00$ & 22.173 & 0.020 & 0.030 & 0.054 & 6.097 & 27.50 & 40.20 & 2.40 & 0.003696 & $\mp 0.000004$ & 0.251 & $2.19 E-15$ & 0.10 & 10006 & 0.0018 \\
\hline$\$ 10$ & $2664-038$ & SAP $1901-49.00$ & 7.529 & 0.012 & 0.052 & 0.001 & 7.212 & 95.80 & 47.46 & 0.43 & 0.003696 & \pm 0.000004 & 0.284 & $2.48 \mathrm{E}-15$ & 0.20 & 1.0006 & 0.0018 \\
\hline$\$ 10$ & $2664-03 \mathrm{C}$ & SAP $19 D 1-49.00$ & 6.737 & 0.011 & 0.040 & 0.000 & 6.631 & 98.40 & 43.68 & 0.47 & 0.003696 & \pm 0.000004 & 0.228 & $1.99 \mathrm{E}-15$ & 0.22 & 1.0008 & 0.0018 \\
\hline s10 & $2664-030$ & SAP 1901-49.00 & 6.456 & 0.012 & 0.044 & 0.000 & 6.564 & 101.70 & 43.24 & 0.59 & 0.003696 & \pm 0.000004 & 0.136 & 1. $19 \mathrm{E}-15$ & 0.25 & 1.0006 & 0.0018 \\
\hline s10 & $2664-03 E$ & SAP $1901-49.00$ & 6.479 & 0.011 & 0.134 & 0.000 & 6.367 & 98.30 & 41.96 & 1.01 & 0.003696 & \pm 0.000004 & 0.079 & $6.81 E-16$ & 0.27 & 1.0006 & 0.0018 \\
\hline s10 & $2664-03 \mathrm{~F}$ & SAP $1901-49.00$ & 6.520 & 0.011 & 0.030 & -0.002 & 7.029 & 107.80 & 46.27 & $t .42$ & 0.003696 & \pm 0.000004 & 0.057 & $4.92 E-16$ & 0.30 & 1.0006 & 0.0018 \\
\hline$\$ 10$ & $2664-03 G$ & SAP $1901-49.00$ & 6.562 & 0.011 & 0.029 & -0.001 & 6.858 & 104.50 & 45.16 & 1.38 & 0.003696 & $=0.000004$ & 0.058 & $4.98 \mathrm{E}-16$ & 0.35 & 1.0006 & 0.0018 \\
\hline$\$ 10$ & $2664-033-1$ & SAP 1901.49 .00 & 6.585 & 0.013 & 0.800 & 0.000 & 6.729 & 102.20 & 44.32 & 1.87 & 0.003696 & \pm 0.000004 & 0.039 & $3.33 E-16$ & 0.45 & 1.0006 & 0.0018 \\
\hline s10 & $2664-031$ & SAP $1901-49.00$ & 19.646 & 0.009 & 0.029 & -0.004 & 20.805 & 105.90 & 133.65 & 3.50 & 0.003696 & \pm 0.000004 & 0.063 & $5.38 \mathrm{E}-16$ & 0.99 & 1.0006 & 0.0018 \\
\hline $\mathrm{s} 10$ & $2664-03 \mathrm{~J}$ & SAP $1901-49.00$ & 45.669 & 0.007 & 0.007 & 0.013 & 41.738 & 91.40 & 258.82 & 10.10 & 0.003696 & $\geq 0.000004$ & 0.057 & $4.85 E-16$ & 2.47 & 1.0006 & 0.0018 \\
\hline s1s & $2658-01 \mathrm{~A}$ & SAP $16 D 1-67.00$ & $\{1.757$ & 0.014 & 0.022 & 0.021 & 5.590 & 47.50 & 36.89 & t.61 & 0.003696 & \pm 0.000004 & 0.153 & $1.33 E-15$ & 0.10 & 1.0013 & 0.0018 \\
\hline s11 & $2658-018$ & SAP 1601.67 .00 & 6.842 & 0.013 & 0.019 & 0.000 & 6.753 & 98.70 & 44.47 & 0.51 & 0.003696 & \pm 0.000004 & 0.221 & $1.92 E-15$ & 0.20 & $\begin{array}{l}1.0013 \\
t .0013\end{array}$ & 0.0018 \\
\hline s11 & $2658-01 c$ & SAP $1601-67.00$ & 6.772 & 0.013 & 0.017 & 0.000 & 6.825 & 100.80 & 44.94 & 0.39 & 0.003696 & \pm 0.000004 & 0.282 & $2.45 E-15$ & 0.22 & 1.0013 & 0.0018 \\
\hline s1t & $2658-010$ & SAP $1601-67.00$ & 6.705 & 0.011 & 0.018 & 0.000 & 6.661 & 99.40 & 43.88 & 0.32 & 0.003696 & \pm 0.000004 & 0.324 & $2.82 E-15$ & 0.25 & 1.0013 & 0.0018 \\
\hline s1: & 2658-01E & SAP $1601-67.00$ & 6.763 & 0.012 & 0.014 & 0.000 & 6.844 & 101.20 & 45.06 & 0.34 & 0.003696 & \pm 0.000004 & 0.326 & $2.84 E-15$ & 0.27 & 1.0013 & 0.0018 \\
\hline $\mathrm{S} 1 \mathrm{t}$ & $2658-01 \mathrm{~F}$ & SAP $1601-67.00$ & 6.823 & 0.012 & 0.018 & 0.000 & 6.838 & 100.20 & 45.03 & 0.34 & 0.003696 & \pm 0.000004 & 0.325 & $2.83 E-15$ & 0.30 & 1.0013 & 0.0018 \\
\hline s1: & $2658-01 G$ & SAP $1601-67.00$ & 6.877 & 0.012 & 0.017 & 0.000 & 6.942 & 101.00 & 45.70 & 0.32 & 0.003696 & $\div 0.000004$ & 0.382 & 3.33E-15 & 0.35 & 1.0013 & 0.0018 \\
\hline$\$ 11$ & $2858-01+\mathrm{H}$ & SAP 1601-67.00 & 6.856 & 0.012 & 0.017 & 0.000 & 6.913 & 100.30 & 45.52 & 0.35 & 0.003696 & \pm 0.000004 & 0.338 & $2.94 E-15$ & 0.45 & 1.0013 & 0.0018 \\
\hline $\begin{array}{l}\text { s11 } \\
\$ 11\end{array}$ & 2658-0:1 & SAP $1601-67.00$ & 12.496 & 0.012 & 0.025 & 0.003 & 11.544 & 92.40 & 75.37 & 0.93 & 0.003696 & \pm 0.000004 & 0.240 & $2.09 E-15$ & 0.99 & 1.0013 & 0.0018 \\
\hline$\$ 11$ & & SAP 1601-67.00 & & 0.010 & 0.002 & 0.001 & 10.897 & 98.60 & 71.23 & 2.93 & 0.003696 & \pm 0.000004 & 0.048 & 4.09E-16 & 2.47 & 1.0013 & 0.0018 \\
\hline
\end{tabular}




\begin{tabular}{|c|c|c|c|c|c|c|c|c|c|c|c|c|c|c|c|c|c|}
\hline \multicolumn{18}{|c|}{ Appendix (Continued) } \\
\hline Sample & $\begin{array}{l}\text { Gain } \\
\text { ID\# }\end{array}$ & $\begin{array}{l}\text { Drill Hole - } \\
\text { Depth }\end{array}$ & ${ }^{40} \mathrm{Ar} /{ }^{39} \mathrm{Ar}$ & ${ }^{38} \mathrm{Ar} r^{39} \mathrm{Ar}$ & ${ }^{37} \mathrm{Ar} r^{39} \mathrm{Ar}$ & ${ }^{36} \mathrm{Ar}{ }^{39} \mathrm{Ar}$ & ${ }^{40^{*}} \mathrm{Ar} r^{39} \mathrm{Ar}$ & $\%{ }^{40^{\circ}} \mathrm{Ar}$ & $\begin{array}{l}\text { Age } \\
\text { (Ma) }\end{array}$ & $\begin{array}{c} \pm \\
(\mathrm{Ma})\end{array}$ & & $\mathrm{J}$ & $\%{ }^{40} \mathrm{Ar}$ & $\begin{array}{l}{ }^{40} \mathrm{Ar} \\
\text { (Moles) }\end{array}$ & $\begin{array}{c}\text { Laser } \\
\text { Power }(W)\end{array}$ & $\begin{array}{l}{ }^{40} \mathrm{Ar} r^{33} \mathrm{Ar} \\
\text { Discr. }\end{array}$ & \pm \\
\hline S11 & $2658-02 \mathrm{~A}$ & SAP $1601-67.00$ & 23.742 & 0.022 & 0.029 & 0.060 & 5.958 & 25.10 & 39.29 & 2.16 & 0.003696 & $\mp 0.000004$ & 0.371 & $3.23 E-15$ & 0.10 & 1.0013 & 0.0018 \\
\hline s11 & $2658-028$ & SAP $1601+67.00$ & 7.024 & 0.012 & 0.064 & 0.001 & 6.632 & 94.40 & 43.69 & 0.55 & 0.003696 & \pm 0.000004 & 0.208 & I. $81 E-15$ & 0.20 & 3.0013 & 0.0018 \\
\hline si1 & $2658-02 \mathrm{C}$ & SAP $1601-67.00$ & 6.867 & 0.012 & 0.033 & 0.000 & 6.879 & 100.20 & 45.30 & 0.38 & 0.003696 & \pm 0.000004 & 0.295 & $2.58 \varepsilon-15$ & 0.22 & 1.0013 & 0.0018 \\
\hline s11 & 2658.020 & SAP 1681-67.00 & 6.762 & 0.012 & 0.040 & 0.000 & 6.637 & 98.20 & 43.72 & 0.31 & 0.003696 & \pm 0.000004 & 0.367 & $3.21 \mathrm{E}-15$ & 0.25 & 1.0013 & 0.0018 \\
\hline s11 & 2658-02E & SAP $1601-67.00$ & 6.701 & 0.012 & 0.043 & 0.000 & 6.738 & 100.60 & 44.38 & 0.39 & 0.003696 & \pm 0.000004 & 0.277 & $2.40 \mathrm{E}-15$ & 0.27 & $\$ .0013$ & 0.0018 \\
\hline s11 & $2658-02 F$ & SAP $1600 t-67.00$ & 6.744 & 0.011 & 0.039 & 0.000 & 6.690 & 99.20 & 44.06 & 0.26 & 0.003696 & \pm 0.000004 & 0.435 & $3.79 E-15$ & 0.30 & 1.0013 & 0.0018 \\
\hline$s 11$ & $2658-02 G$ & SAP $16 A 1-67.00$ & 6.775 & 0.012 & 0.045 & 0.000 & 6.713 & 99.10 & 44.22 & 0.23 & 0.003696 & \pm 0.000004 & 0.532 & $4.62 E-15$ & 0.35 & 1.0013 & 0.0018 \\
\hline$s 11$ & $2658-02 \mathrm{H}$ & SAP $1601-67.00$ & 6.726 & 0.012 & 0.089 & 0.000 & 6.667 & 99.10 & 43.91 & 0.54 & 0.003696 & $\approx 0.000004$ & 0.191 & \$. $67 \varepsilon-15$ & 0.45 & 1.0013 & 0.0018 \\
\hline s11 & $2658-023$ & SAP 1601.67 .00 & $\$ 1.496$ & 0.014 & 0.047 & 0.003 & 10.474 & 98.10 & 68.52 & 1.00 & 0.003696 & \pm 0.000004 & 0.165 & t.43E-15 & 0.99 & 1.0013 & 0.0018 \\
\hline s11 & $2658.02 J$ & SAP $1601-67.00$ & 35.991 & 0.018 & 0.000 & 0.026 & 8.392 & 52.50 & 55.11 & 6.46 & 0.003696 & \pm 0.000004 & 0.033 & $2.86 E-16$ & 2.47 & 1.0013 & 0.0018 \\
\hline$\$ 11$ & $2658-03 \mathrm{~A}$ & SAP $1601-67.00$ & 11.779 & 0.016 & 0.037 & 0.019 & $8.17 \pi$ & 52.40 & 40.72 & 1.56 & 0.003696 & \pm 0.000004 & 0.159 & 1.38E-15 & 0.10 & 1.0013 & 0.0018 \\
\hline S11 & $2658-038$ & SAP $16 B 1-67.00$ & 7.047 & 0.013 & 0.024 & 0.001 & 6.818 & 96.80 & 44.90 & 0.43 & 0.003696 & \pm 0.000004 & 0.254 & $2.22 E-15$ & 0.20 & 1.0013 & 0.0018 \\
\hline si1 & $2658-03 \mathrm{C}$ & SAP $1601-67.00$ & 6.766 & 0.012 & 0.009 & 0.000 & 6.697 & 99.00 & 44.11 & 0.36 & 0.003696 & \pm 0.000004 & 0.307 & $2.68 \mathrm{E}-15$ & 0.22 & 1.0013 & 0.0018 \\
\hline \$11 & $2658-03 \mathrm{D}$ & SAP $1681-67.00$ & 6.745 & 0.012 & 0.016 & 0.000 & 6.767 & 100.30 & 44.57 & 0.38 & 0.003696 & $\mp 0.000004$ & 0.280 & $2.43 E-15$ & 0.25 & 1.0013 & 0.0018 \\
\hline s\$1 & 2658-03E & SAP $16 B 1-67.00$ & 6.686 & 0.011 & 0.026 & 0.000 & 6.667 & 99.70 & 43.92 & 0.46 & 0.003696 & \pm 0.000004 & 0.210 & 1.83E-15 & 0.27 & 1.0013 & 0.0018 \\
\hline S\$1 & $2658-03 F$ & SAP $1603-67.00$ & 6.736 & 0.011 & 0.000 & -0.001 & 7.010 & 104.10 & 46.15 & 0.79 & 0.003696 & \pm 0.000004 & 0.121 & 1.05E-15 & 0.30 & 1.0013 & 0.0018 \\
\hline st1 & $2658-03 G$ & SAP $16 B 1-67.00$ & 6.731 & 0.012 & 0.000 & -0.001 & 6.998 & 104.00 & 46.07 & 0.74 & 0.003696 & \pm 0.000004 & 0.122 & 1.07E-15 & 0.35 & 1.0013 & 0.0018 \\
\hline s11 & $2658-03 \mathrm{H}$ & SAP $1601-67.00$ & 6.809 & 0.011 & 0.000 & 0.001 & 6.636 & 97.50 & 43.72 & 1.04 & 0.003696 & $\therefore 0.000004$ & 0.089 & 7.74E-16 & 0.45 & 1.0013 & 0.0018 \\
\hline st1 & $2658-031$ & SAP 160167.00 & 17.183 & 0.012 & 0.000 & 0.005 & 15.827 & 92.10 & 102.56 & 2.19 & 0.003696 & $\doteqdot 0.000004$ & 0.112 & $9.76 E-16$ & 0.99 & 1.0013 & 0.0018 \\
\hline s11 & $2658.03 \mathrm{U}$ & SAP $1601-67.00$ & 33.720 & 0.011 & 0.000 & 0.023 & 7.058 & 51.40 & 46.46 & 11.90 & 0.003696 & \pm 0.000004 & 0.014 & 1.23E-16 & 2.47 & 1.0013 & 0.0018 \\
\hline $\mathrm{s} 12$ & $2659-01 \mathrm{~A}$ & SAP $1601-68.00$ & 17.810 & 0.018 & 0.000 & 0.045 & 4.648 & 26.10 & 30.73 & 2.45 & 0.003696 & $\div 0.000004$ & 0.163 & $1.42 \varepsilon-15$ & 0.10 & 10013 & 0.0018 \\
\hline s12 & $2659-01 B$ & SAP $1601-68.00$ & 7.447 & 0.012 & 0.006 & 0.004 & 6.377 & 85.60 & 42.03 & 0.51 & 0.003696 & \pm 0.000004 & 0.286 & 2.50E-15 & 0.20 & 1.0013 & 0.0018 \\
\hline \$12 & $2659-01 \mathrm{C}$ & SAP $1601-68.00$ & 6.670 & 0.010 & 0.000 & 0.000 & 6.558 & 98.30 & 43.21 & 0.64 & 0.003696 & \pm 0.000004 & 0.164 & 1.44E-15 & 0.22 & 1.0013 & 0.0018 \\
\hline s12 & 2659.010 & SAP $1681-68.00$ & 6.942 & 0.012 & 0.009 & 0.001 & 6.786 & 97.80 & 44.69 & 0.70 & 0.003696 & $\mp 0.000004$ & 0.160 & 1.43E-15 & 0.25 & 1.0013 & 0.0018 \\
\hline s12 & 2659-01E & SAP $1601-68.00$ & 7.242 & 0.012 & 0.000 & 0.001 & 6.891 & 95.20 & 45.38 & 0.62 & 0.003696 & $\doteq 0.000004$ & 0.201 & $1.79 E-15$ & 0.27 & 1.0013 & 0.0018 \\
\hline $\mathrm{s} 12$ & $265901 \mathrm{~F}$ & SAP $1601-68.00$ & 7.060 & 0.012 & 0.002 & 0.001 & 6.866 & 97.30 & 45.21 & 0.30 & 0.003696 & \pm 0.000004 & 0.462 & 4.06E-15 & 0.30 & 1.0013 & 0.0018 \\
\hline $\mathrm{s} 12$ & $2659-01 G$ & SAP $1691-68.00$ & 6.646 & 0.012 & 0.015 & 0.000 & 6.579 & 99.00 & 43.34 & 0.14 & 0.003696 & \pm 0.000004 & 1.284 & $1.12 E-14$ & 0.35 & 1.0013 & 0.0013 \\
\hline $\mathrm{s} 12$ & 2659-0th & SAP $1601-68.00$ & 6.472 & 0.012 & 0.017 & 0.000 & 6.426 & 99.30 & 42.34 & 0.12 & 0.003696 & \pm 0.0000004 & 2.570 & $2.24 E-14$ & 0.45 & 1.0013 & 0.0018 \\
\hline $\mathrm{s} 12$ & $2659-011$ & SAP 1601.68 .00 & 6.551 & 0.012 & 0.019 & 0.001 & 6.303 & 96.20 & 41.55 & 0.36 & 0.003696 & \pm 0.000004 & 2.399 & $2.10 E-14$ & 0.99 & 1.0013 & 0.0018 \\
\hline$\$ 12$ & $2659-013$ & SAP $1601-68.00$ & 8.284 & 0.012 & 0.900 & 0.003 & 7.250 & 87.50 & 47.71 & 0.71 & 0.003696 & \pm 0.000004 & 0.229 & $2.05 E-15$ & 2.47 & 1.0013 & 0.0018 \\
\hline s12 & $2659-02 \mathrm{~A}$ & SAP $160 \leqslant-68.00$ & 20.555 & 0.022 & 0.000 & 0.047 & 6.626 & 32.20 & 43.65 & 3.43 & 0.003696 & \pm 0.000004 & 0.116 & $1.01 E-15$ & 0.10 & 1.0013 & 0.0018 \\
\hline s12 & $2659-02 B$ & SAP $160 \div-68.00$ & 7.990 & 0.013 & 0.015 & 0.006 & 6.198 & 77.60 & 40.86 & 0.58 & 0.003696 & \pm 0.000004 & 0.286 & $2.33 E-15$ & 0.20 & 1.0013 & 0.0018 \\
\hline $\mathrm{s} 12$ & $2659.02 \mathrm{C}$ & SAP $1601-68.00$ & 6.324 & 0.011 & 0.011 & -0.002 & 6.900 & 109.20 & 45.43 & 0.81 & 0.003696 & \pm 0.000004 & 0.116 & 1.02E-15 & 0.22 & 1.0013 & 0.0018 \\
\hline $\mathrm{s} 12$ & $2659-020$ & SAP $1601-68.00$ & 6.428 & 0.013 & 0.023 & -0.001 & 6.798 & 105.80 & 44.77 & 0.81 & 0.003696 & \pm 0.000004 & 0.110 & $9.68 \mathrm{E}-16$ & 0.25 & $1.00 \div 3$ & 0.0018 \\
\hline $\mathrm{s} 12$ & $2659-02 E$ & SAP 160$\}-68.00$ & 6.392 & 0.012 & 0.000 & -0.001 & 6.705 & 104.90 & 44.16 & 0.82 & 0.003696 & \pm 0.000004 & 0.110 & $9.77 E-16$ & 0.27 & 1.0013 & 0.0018 \\
\hline $\mathrm{s} 12$ & $2659-02 F$ & SAP $1601-68.00$ & 6.523 & 0.012 & 0.009 & -0.001 & 6.835 & 104.80 & 45.01 & 0.79 & 0.003696 & \pm 0.000004 & 0.122 & t.07E-15 & 0.30 & 1.0013 & 0.0018 \\
\hline s12 & $2659-02 \mathrm{G}$ & SAP $1601-68.00$ & 6.695 & 0.012 & 0.000 & 0.000 & 6.796 & 101.50 & 44.76 & 0.46 & 0.003696 & \pm 0.000004 & 0.235 & 2.09E-15 & 0.35 & 1.0013 & 0.0018 \\
\hline $\mathrm{s} 12$ & $2659-02 \mathrm{H}$ & SAP $1601-68.00$ & 6.731 & 0.012 & 0.009 & 0.000 & 6.695 & 99.50 & 44.10 & 0.29 & 0.003696 & \pm 0.000004 & 0.443 & $3.87 E-15$ & 0.40 & $1.00 \div 3$ & 0.0018 \\
\hline $\mathrm{s} 12$ & $2659-02 t$ & SAP $1601-68.00$ & 6.588 & 0.012 & 0.008 & 0.000 & 6.581 & 99.90 & 43.36 & 0.16 & 0.003696 & \pm 0.000004 & 1.066 & 9.32E-15 & 0.45 & 1.0013 & 0.0018 \\
\hline s12 & 2659.025 & SAP $1601-68.00$ & 6.497 & 0.012 & 0.019 & 0.000 & 6.453 & 99.30 & 42.53 & 0.13 & 0.003696 & \pm 0.000004 & 3.194 & $2.78 E-14$ & 0.59 & 1.0013 & 0.0018 \\
\hline$\$ 12$ & $2659-02 \mathrm{~K}$ & SAP $1601-68.00$ & 6.561 & 0.012 & 0.022 & 0.000 & 6.476 & 98.70 & 42.67 & 0.15 & 0.003696 & \pm 0.000004 & 1.382 & $121 E-14$ & 0.79 & 1.0013 & 0.0018 \\
\hline$\$ 12$ & $2659-02 \mathrm{~L}$ & SAP $1601-68.00$ & 6.718 & 0.012 & 0.080 & 0.001 & 6.530 & 97.20 & 43.02 & 0.36 & 0.003696 & \pm 0.000004 & 0.338 & $2.98 E-15$ & 0.99 & 1.0013 & 0.0018 \\
\hline $\mathrm{s} 12$ & $2659-02 \mathrm{M}$ & SAP $1601-68.00$ & 7.873 & 0.012 & 0.000 & 0.005 & 6.341 & 80.60 & 41.79 & 0.65 & 0.003696 & \pm 0.000004 & 0.232 & $2.05 E-15$ & 2.47 & 1.0013 & 0.0018 \\
\hline sł2 & $2659-83 \mathrm{~A}$ & SAP $1601-68.00$ & 8.998 & 0.014 & 0.028 & 0.010 & 6.037 & 67.10 & 39.81 & 1.01 & 0.003696 & \pm 0.000004 & 0.170 & $1.47 E-15$ & 0.10 & 1.0013 & 0.0018 \\
\hline$s 12$ & $2659-03 B$ & SAP $1601-68.00$ & 6.560 & 0.012 & 0.010 & 0.001 & 6.400 & 97.60 & 42.18 & 0.34 & 0.003696 & \pm 0.000004 & 0.301 & $2.63 E-15$ & 0.20 & 1.0013 & 0.0018 \\
\hline$s: 2$ & $2659-03 \mathrm{C}$ & SAP $1601-68.00$ & 6.578 & 0.012 & 0.020 & 0.000 & 6.533 & 99.30 & 43.04 & 0.13 & 0.003698 & \pm 0.000004 & 1.935 & $1.67 E-14$ & 0.30 & 1.0013 & 0.0018 \\
\hline $3: 2$ & 2659-03D & SAP $1601-68.00$ & 6.592 & 0.012 & 0.024 & 0.000 & 6.545 & 99.30 & 43.12 & 0.18 & 0.003696 & \pm 0.000004 & 0.869 & $7.58 E-15$ & 0.35 & 1.0013 & 0.0018 \\
\hline
\end{tabular}




\begin{tabular}{|c|c|c|c|c|c|c|c|c|c|c|c|c|c|c|c|c|c|}
\hline \\
\hline Sample & $\begin{array}{l}\text { asin } \\
\text { ID\# }\end{array}$ & $\begin{array}{c}\text { Drill Hole - } \\
\text { Depth }\end{array}$ & ${ }^{40} \mathrm{Ar} r^{39} \mathrm{Ar}$ & ${ }^{38} \mathrm{Ar} r^{39} \mathrm{Ar}$ & ${ }^{37} \mathrm{Ar} r^{39} \mathrm{Ar}$ & ${ }^{36} \mathrm{Ar}{ }^{39} \mathrm{Ar}$ & ${ }^{40^{*}} \mathrm{Ar} r^{39} \mathrm{Ar}$ & $\%{ }^{40^{\circ}} \mathrm{Ar}$ & $\begin{array}{l}\text { Age } \\
(\mathrm{Ma})\end{array}$ & $\stackrel{ \pm}{ \pm}$ & & $\mathrm{J}$ & $\%^{40} \mathrm{Ar}$ & $\begin{array}{l}{ }^{40} \mathrm{Ar} \\
\text { (Moles) }\end{array}$ & $\begin{array}{c}\text { Laser } \\
\text { Power }(\mathrm{W})\end{array}$ & $\begin{array}{l}{ }^{40} \mathrm{Ar} r^{36} \mathrm{Ar} \\
\text { Discr. }\end{array}$ & \pm \\
\hline$\$ 12$ & $2659-03 E$ & SAP $16 B 1-68.00$ & 6.488 & 0.012 & 0.028 & 0.000 & 6.429 & 99.10 & 42.36 & 0.41 & 0.003696 & \pm 0.000004 & 0.299 & $2.52 E-15$ & 0.40 & 1.0013 & 0.0018 \\
\hline$\$ 12$ & $2659-03 F$ & SAP 1601-68.00 & 6.317 & 0.012 & 0.050 & 0.001 & 6.024 & 95.40 & 39.73 & 0.81 & 0.003696 & \pm 0.000004 & 0.115 & $9.99 E-16$ & 0.45 & 1.0013 & 0.0018 \\
\hline$\$ 12$ & $2659-03 G$ & SAP $1601-68.00$ & 6.312 & 0.015 & 0.104 & 0.001 & 5.914 & 93.70 & 39.01 & 1.83 & 0.003696 & \pm 0.000004 & 0.047 & $4.11 E-16$ & 0.50 & 1.0013 & 0.0018 \\
\hline S12 & $2659-03 H$ & SAP $1601-68.00$ & 6.876 & 0.017 & 0.066 & 0.005 & 5.549 & 80.70 & 36.63 & 4.59 & 0.003696 & \pm 0.000004 & 0.019 & 1. $66 \varepsilon-16$ & 0.54 & 1.0013 & 0.0018 \\
\hline s12 & $2659-031$ & SAP $160 \div-68.00$ & 9.220 & 0.011 & 0.073 & 0.004 & 8.151 & 88.40 & 53.55 & 4.82 & 0.003696 & \pm 0.000004 & 0.024 & $2.03 E-16$ & 0.64 & 1.0013 & 0.0018 \\
\hline$s \leqslant 2$ & $2659.03 \mathrm{~J}$ & SAP $1601-68.00$ & 9.055 & 0.012 & 0.033 & -0.003 & 10.078 & 111.30 & 65.98 & 4.67 & 0.003696 & \pm 0.000004 & 0.023 & 1.99E-15 & 0.79 & 1.0013 & 0.0018 \\
\hline $\mathrm{s} 12$ & 2659-03K & SAP $1601-68.00$ & 8.097 & 0.020 & 0.046 & 0.006 & 6.369 & 78.70 & 41.97 & 7.82 & 0.003696 & \pm 0.000004 & 0.012 & $1.04 E-16$ & 0.99 & 1.0013 & 0.0018 \\
\hline$s \leqslant 2$ & $2659-031$ & SAP $1601-68.00$ & 11.124 & 0.013 & 0.057 & 0.023 & 4.236 & 38.10 & 28.03 & 4.06 & 0.003696 & \pm 0.000004 & 0.039 & $3.36 \mathrm{E}-1 \hat{\mathrm{o}}$ & 1.99 & 1.0013 & 0.0018 \\
\hline St2 & 2659-03M & SAP $1601-68.00$ & 13.960 & 0.039 & 0.888 & 0.058 & -2.988 & -21.40 & -20.04 & 29.17 & 0.003696 & \pm 0.000004 & 0.006 & $4.98 E-17$ & 2.97 & 1.0013 & 0.0018 \\
\hline $\mathrm{s} \$ 3$ & $2660-01 \mathrm{~A}$ & SAP $1601-69.00$ & 13.009 & 0.016 & 0.000 & 0.027 & 5.083 & 39.10 & 33.58 & 3.06 & 0.003696 & \pm 0.000004 & 0.063 & $5.56 E-16$ & 0.10 & 1.0016 & 0.0018 \\
\hline$s+3$ & $2660-01 B$ & SAP $1601-69.00$ & 10.342 & 0.015 & 0.038 & 0.016 & 5.469 & 52.90 & 36.10 & 1.00 & 0.003696 & \pm 0.000004 & 0.243 & $2.12 E-15$ & 0.20 & 1.0016 & 0.0018 \\
\hline $\mathrm{s} \$ 3$ & $2660-01 C$ & SAP $1601-69.00$ & 11.158 & 0.016 & 0.059 & 0.020 & 5.216 & 46.80 & 34.45 & 1.89 & 0.003696 & \pm 0.000004 & 0.106 & $9.42 E-16$ & 0.22 & 1.0016 & 0.0018 \\
\hline$\$ \div 3$ & $2660-010$ & SAP $1601-69.00$ & 12.947 & 0.018 & 0.027 & 0.029 & 4.475 & 34.60 & 29.59 & 2.96 & 0.003696 & \pm 0.000004 & 0.062 & $5.54 E-16$ & 0.25 & 1.0016 & 0.0018 \\
\hline$S_{13}$ & $2660-01 E$ & SAP $1601-69.00$ & 14.562 & 0.019 & 0.057 & 0.032 & 5.133 & 35.20 & 33.90 & 4.01 & 0.003696 & \pm 0.000004 & 0.051 & $4.69 E-16$ & 0.27 & 1.0016 & 0.0018 \\
\hline S13 & $2660-01 \%$ & SAP $1601-69.00$ & 13.314 & 0.018 & 0.043 & 0.023 & 6.509 & 48.90 & 42.88 & 3.72 & 0.003696 & \pm 0.000004 & 0.052 & $4.78 E-16$ & 0.30 & 1.0016 & 0.0018 \\
\hline$\$ 13$ & $2660-01 G$ & SAP $1601-69.00$ & 9.172 & 0.013 & 0.013 & 0.009 & 6.510 & 71.00 & 42.90 & 1.24 & 0.003696 & $\div 0.000004$ & 0.127 & $1.14 E-15$ & 0.35 & 1.0016 & 0.0018 \\
\hline$s 13$ & $2660-01 \mathrm{H}$ & SAP $1601-69.00$ & 7.737 & 0.013 & 0.029 & 0.003 & 6.836 & 88.40 & 45.02 & 0.24 & 0.003696 & \pm 0.000004 & 0.880 & $7.68 \mathrm{E}-15$ & 0.45 & 1.0016 & 0.0018 \\
\hline \$13 & $2660-011$ & SAP $1601-69.00$ & 7.293 & 0.012 & 0.063 & 0.003 & 6.307 & 86.50 & 41.57 & 0.18 & 0.003696 & \pm 0.000004 & 1.357 & $1.18 E-14$ & 0.99 & 1.0016 & 0.0018 \\
\hline $\mathrm{s} 13$ & $2660-013$ & SAP $1681-69.00$ & $\$ 3.350$ & 0.016 & 0.105 & 0.023 & 6.661 & 49.90 & 43.88 & 1.99 & 0.003696 & \pm 0.000004 & 0.146 & $1.32 E-15$ & 2.47 & 1.0016 & 0.0018 \\
\hline $\mathrm{s} 13$ & $2660-02 \mathrm{~A}$ & SAP $1601-69.00$ & 29.093 & 0.014 & 0.000 & 0.051 & 14.125 & 48.60 & 91.81 & 11.70 & 0.003696 & \pm 0.000004 & 0.035 & $3.08 \mathrm{E}-10$ & 0.10 & $\$ .0016$ & 0.0018 \\
\hline $\mathrm{s} 13$ & $2660-02 B$ & SAP $1601-69.00$ & 12.607 & 0.015 & 0.000 & 0.016 & 7.864 & 62.40 & 51.69 & 3.35 & 0.003696 & \pm 0.000004 & 0.053 & $4,60 \mathrm{E}-1 \hat{0}$ & 0.20 & 1.0016 & 0.0018 \\
\hline s13 & $2860-02 \mathrm{C}$ & SAP $1601-69.00$ & 16.588 & 0.014 & 0.000 & 0.024 & 9.402 & 56.70 & 61.63 & 7.67 & 0.003696 & $=0.000004$ & 0.032 & $2,77 E-16$ & 0.22 & 1.0016 & 0.0018 \\
\hline $\mathrm{s} 13$ & $2660-020$ & SAP $1601-69.00$ & 21.198 & 0.014 & 0.000 & 0.048 & 6.907 & 32.60 & 45.48 & 7.33 & 0.003696 & \pm 0.000004 & 0.041 & 3.57E-16 & 0.25 & 1.0016 & 0.0018 \\
\hline$\$ 13$ & $2660-02 E$ & SAP $1601-69.00$ & 14.032 & 0.014 & 0.000 & 0.015 & 9.484 & 67.60 & 62.16 & 2.95 & 0.003696 & \pm 0.000004 & 0.062 & $5.34 E-16$ & 0.27 & 1.0016 & 0.0018 \\
\hline S13 & $2660-02 \mathrm{~F}$ & SAP $1601-69.00$ & 11.294 & 0.011 & 0.000 & 0.003 & 10.391 & 92.00 & 67.99 & 2.20 & 0.003696 & \pm 0.000004 & 0.070 & $6.00 \mathrm{E}-16$ & 0.30 & 1.0016 & 0.0018 \\
\hline s13 & $2660-026$ & SAP $1601-69.00$ & 9.756 & 0.012 & 0.000 & 0.004 & 8.680 & 89.00 & 56.97 & 1.50 & 0.003696 & \pm 0.000004 & 0.087 & $7.45 \mathrm{E}-16$ & 0.35 & 1.0016 & 0.0018 \\
\hline s13 & $2660-02 H$ & SAP $1601-69.00$ & 8.302 & 0.013 & 0.000 & 0.002 & 7.653 & 92.20 & 50.32 & 1.00 & 0.003696 & \pm 0.000004 & 0.120 & $1.04 \mathrm{E}-15$ & 0.45 & 1.0016 & 0.0018 \\
\hline $\mathrm{s} 13$ & $2650-021$ & SAP $1601-69.00$ & 8.129 & 0.013 & 0.046 & 0.007 & 6.059 & 74.50 & 39.96 & 1.71 & 0.003696 & \pm 0.000004 & 0.067 & $5.82 E-1 \hat{o}$ & 0.54 & 1.0016 & 0.0018 \\
\hline 513 & $2660-02 \mathrm{~J}$ & SAP $1601-69.00$ & 9.990 & 0.015 & 0.153 & 0.017 & 4.848 & 48.50 & 32.04 & 1.62 & 0.003696 & $\mp 0.000004$ & 0.104 & $8.95 E-16$ & 0.69 & 1.0016 & 0.0018 \\
\hline $\mathrm{s} 13$ & $2660-02 K$ & SAP $1601-69.00$ & 18.424 & 0.017 & 0.081 & 0.020 & 12.450 & 67.60 & 81.16 & 2.78 & 0.003696 & $\div 0.000004$ & 0.130 & 1. $13 E \cdot 15$ & 0.99 & 1.0016 & 0.0018 \\
\hline$\$ 13$ & $2660-02 \mathrm{~L}$ & SAP $1601-69.00$ & 96.636 & 0.025 & 0.000 & 0.090 & 70.099 & 72.50 & 415.63 & 8.86 & 0.003696 & \pm 0.000004 & 0.240 & $2.09 E-15$ & 2.47 & 1.0016 & 0.0018 \\
\hline$s 13$ & $2660-03 \mathrm{~A}$ & SAP $1601-69.00$ & 20.976 & 0.019 & 0.202 & 0.040 & 9.061 & 43.20 & 59.43 & 10.59 & 0.003696 & \pm 0.000004 & 0.026 & $2.29 E-16$ & 0.10 & 1.0016 & 0.0018 \\
\hline s13 & $2660-03 B$ & SAP $1601-69.00$ & 8.661 & 0.007 & 0.183 & -0.006 & 10.434 & 120.20 & 68.14 & 10.72 & 0.003696 & \pm 0.000004 & 0.010 & $8.36 E-17$ & 0.20 & 1.0016 & 0.0018 \\
\hline$s_{13}$ & $2660-03 \mathrm{C}$ & SAP $1601-69.00$ & $13.12 \uparrow$ & 0.020 & 0.000 & 0.008 & 10.669 & 81.30 & 69.78 & 15.67 & 0.003696 & $\div 0.000004$ & 0.011 & $9.38 E-17$ & 0.22 & 1.0016 & 0.0018 \\
\hline$\$ 13$ & $2660-03 D$ & SAP $1601+69.00$ & 16.830 & 0.018 & 0.638 & 0.043 & 4.116 & 24.40 & 27.24 & 9.54 & 0.003696 & \pm 0.000004 & 0.023 & 1.96E-16 & 0.25 & 1.0016 & 0.0018 \\
\hline $\mathrm{s} 13$ & $2660-83 E$ & SAP $1601-69.00$ & 11.478 & 0.012 & 0.057 & -0.001 & $\$ 1.799$ & 102.80 & 77.00 & 4.96 & 0.003696 & \pm 0.000004 & 0.030 & 2.57E-10 & 0.27 & 1.0016 & 0.0018 \\
\hline $\mathrm{s} 13$ & $2660-03 F$ & SAP $1601-69.00$ & 9.427 & 0.009 & 0.121 & -0.005 & 80.991 & 116.60 & 71.84 & 4.65 & 0.003696 & \pm 0.000004 & 0.025 & $2.15 E-16$ & 0.30 & 1.0016 & 0.0018 \\
\hline$\$ 13$ & $2660-03 G$ & SAP $1601-69.00$ & 8.430 & 0.011 & 0.076 & -0.001 & 8.776 & 104.10 & 57.59 & 3.01 & 0.003696 & \pm 0.000004 & 0.035 & $3.05 E-16$ & 0.35 & 1.0016 & 0.0018 \\
\hline$\$ 13$ & $2660-03 \mathrm{H}$ & SAP $1601-69.00$ & 7.879 & 0.013 & 0.093 & 0.004 & 6.628 & 84.10 & 43.66 & 2.48 & 0.003696 & \pm 0.000004 & 0.038 & $3.28 E-16$ & 0.45 & 1.0016 & 0.0018 \\
\hline$\$ 13$ & $2660-033$ & SAP $1601-69.00$ & 8.998 & 0.016 & 0.355 & 0.010 & 6.090 & 67.70 & 40.16 & 3.21 & 0.003696 & \pm 0.000004 & 0.040 & $3.51 E-16$ & 0.54 & 1.0016 & 0.0016 \\
\hline$\$ 13$ & 2660.03 & SAP $1601-69.00$ & 10.660 & 0.017 & 0.358 & 0.016 & 6.108 & 57.30 & 40.28 & 4.29 & 0.003696 & \pm 0.000004 & 0.033 & $2.89 E-16$ & 0.69 & 1.0016 & 0.0018 \\
\hline $\mathrm{s} 13$ & $2660-03 K$ & SAP $1601-69.00$ & $\$ 8.077$ & 0.020 & 0.128 & 0.011 & $\$ 4.799$ & 81.90 & 96.07 & 6.46 & 0.003696 & \pm 0.000004 & 0.033 & $2.84 E-16$ & 0.99 & 1.0016 & 0.0018 \\
\hline $\mathrm{s} 13$ & $2660-03 \mathrm{~L}$ & SAP $1601-69.00$ & 53.199 & 0.048 & 1.407 & 0.105 & 22.211 & 41.70 & 142.34 & 29.60 & 0.003696 & \pm 0.000004 & 0.024 & $2.05 E-16$ & 2.47 & 1.0016 & 0.0018 \\
\hline s14 & $2656-01 \mathrm{~A}$ & SAP 2499-83.10 & 9.003 & 0.014 & 0.007 & 0.014 & 4.783 & 53.10 & 31.61 & 0.93 & 0.003696 & \pm 0.000004 & 0.214 & 1.86E-15 & 0.10 & 1.0025 & 0.0018 \\
\hline s14 & $2656-018$ & SAP 2499-83.10 & 6.848 & 0.012 & 0.002 & 0.002 & 0.309 & 92.10 & 41.59 & 0.26 & 0.003696 & \pm 0.000004 & 0.488 & $4.25 \mathrm{E}-15$ & 0.20 & 1.0025 & 0.0018 \\
\hline S14 & $2656-01 c$ & SAP 2489-83.10 & 7.121 & 0.012 & 0.000 & 0.001 & 6.956 & 97.70 & 45.79 & 0.22 & 0.003698 & \pm 0.000004 & 0.668 & 5.83E-15 & 0.22 & 1.0025 & 0.0018 \\
\hline$S \$ 4$ & $2656-010$ & SAP $2499-83.10$ & 7.165 & 0.012 & 0.000 & 0.000 & 7.129 & 99.50 & 46.92 & 0.21 & 0.003696 & \pm 0.000004 & 0.738 & $6.47 E-15$ & 0.25 & 1.0025 & 0.0018 \\
\hline
\end{tabular}




\begin{tabular}{|c|c|c|c|c|c|c|c|c|c|c|c|c|c|c|c|c|c|}
\hline \multirow{3}{*}{$\begin{array}{c}\text { Sample } \\
\text { S14 }\end{array}$} & \multirow{3}{*}{$\begin{array}{c}\begin{array}{c}\text { Bin } \\
\text { ID\# }\end{array} \\
\text { 2656-01E }\end{array}$} & \multirow{3}{*}{$\begin{array}{c}\text { Drill Hole - } \\
\text { Depth }\end{array}$} & \multirow{3}{*}{$\frac{{ }^{40} \mathrm{Ar}{ }^{39} \mathrm{Ar}}{7.273}$} & \multirow{3}{*}{$\begin{array}{c}{ }^{38} \mathrm{Ar} r^{39} \mathrm{Ar} \\
0.012\end{array}$} & \multirow{3}{*}{$\frac{{ }^{37} \mathrm{Ar} /{ }^{39} \mathrm{Ar}}{0.000}$} & \multirow{3}{*}{${ }_{0.000}{ }^{36} \mathrm{Ar}^{39} \mathrm{Ar}$} & \multirow{3}{*}{${ }^{40} \mathrm{Ar} r^{39} \mathrm{Ar}$} & pendix ic & & \multirow{3}{*}{$\begin{array}{c}\begin{array}{c} \pm \\
(\mathrm{Ma})\end{array} \\
0.24\end{array}$} & \multirow{2}{*}{\multicolumn{2}{|c|}{3}} & \multirow[b]{2}{*}{$\%{ }^{40} \mathrm{Ar}$} & \multirow[b]{2}{*}{$\begin{array}{l}{ }^{40} \mathrm{Ar} \\
\text { (Moles) }\end{array}$} & \multirow[b]{2}{*}{$\begin{array}{c}\text { Laser } \\
\text { Power }(W)\end{array}$} & \multirow[b]{2}{*}{$\begin{array}{l}{ }^{46} \mathrm{Ar} r^{36} \mathrm{Ar} \\
\text { Discr. }\end{array}$} & \\
\hline & & & & & & & & \multirow{2}{*}{$\%{ }^{40^{\circ}} \mathrm{Ar}$} & \multirow{2}{*}{$\begin{array}{l}\begin{array}{l}\text { Age } \\
\text { (Ma) }\end{array} \\
47.85\end{array}$} & & & & & & & & \pm \\
\hline & & & & & & & & & & & 0.003696 & \pm 0.000004 & 0.601 & $5.25 \varepsilon-15$ & 0.27 & 1.0025 & 0.0018 \\
\hline S14 & $2656-01 \mathrm{~F}$ & SAP 2499-83.10 & 7.258 & 0.012 & 0.000 & 0.000 & 7.218 & 99.50 & 47.50 & 0.29 & 0.003696 & \pm 0.000004 & 0.424 & $3.68 \mathrm{E}-15$ & 0.30 & 1.0025 & 0.0018 \\
\hline$\$ 14$ & $2656-016$ & SAP $2499-83.10$ & 7.243 & 0.012 & 0.000 & 0.000 & 7.336 & 101.30 & 48.26 & 0.34 & 0.003696 & \pm 0.000004 & 0.356 & $3.13 \mathrm{E}-15$ & 0.35 & 1.0025 & 0.0018 \\
\hline S14 & $2656-0 \div \mathrm{H}$ & SAP $2499-83.10$ & 7.289 & 0.011 & 0.000 & 0.000 & 7.299 & 100.30 & 48.02 & 0.42 & 0.003696 & \pm 0.000004 & 0.255 & $2.24 \mathrm{E}-15$ & 0.45 & 1.0025 & 0.0018 \\
\hline$S 14$ & $2656-011$ & SAP 2499-83.10 & 6.857 & 0.012 & 0.006 & 0.000 & 6.991 & 102.00 & 46.02 & 0.41 & 0.003696 & \pm 0.000004 & 0.288 & $2.51 \mathrm{E}-15$ & 0.99 & 1.0025 & 0.0018 \\
\hline St4 & $2656-01 \mathrm{~J}$ & SAP $2499-83.10$ & 7.506 & 0.013 & 0.000 & 0.000 & 7.405 & 98.70 & 48.71 & 0.76 & 0.003696 & \pm 0.000004 & 0.144 & 1.26E-15 & 2.47 & 1.0025 & 0.0018 \\
\hline S14 & $2656-02 \mathrm{~A}$ & SAP 2499-83.10 & 10.835 & 0.018 & 0.000 & 0.019 & 5.133 & 47.40 & 33.90 & 1.64 & 0.003696 & \pm 0.000004 & 0.139 & $1.21 E-15$ & 0.30 & 1.0025 & 0.0018 \\
\hline$\$ 14$ & $2656-028$ & SAP 2499-83.10 & 8.070 & 0.013 & 0.001 & 0.007 & 5.864 & 72.70 & 38.68 & 0.55 & 0.003696 & $\neq 0.000004$ & 0.316 & $2.75 E-15$ & 0.20 & 1.0025 & $0.00 \div 8$ \\
\hline S14 & $2656-02 \mathrm{C}$ & SAP $2499-83.10$ & 7.182 & 0.012 & 0.021 & 0.001 & 6.804 & 94.70 & 44.81 & 0.64 & 0.003698 & \pm 0.000004 & 0.176 & $1.53 E-15$ & 0.22 & 1.0025 & 0.0018 \\
\hline \$14 & $2656-02 D$ & SAP $2499-83.10$ & 7.380 & 0.012 & 0.015 & 0.000 & 7.296 & 98.90 & 48.01 & 0.54 & 0.003696 & \pm 0.000004 & 0.206 & 1. $.80 E-15$ & 0.25 & 1.0025 & 0.0018 \\
\hline$\$ 14$ & $2656-02 E$ & SAP $2499-83.10$ & 7.310 & 0.012 & 0.031 & 0.000 & 7.381 & 103.00 & 48.56 & 0.46 & 0.003696 & \pm 0.000004 & 0.257 & $2.25 \mathrm{E}-15$ & 0.27 & 1.0025 & 0.0018 \\
\hline$S 14$ & $2656-02 F$ & SAP 2499-83.10 & 7.291 & 0.012 & 0.005 & 0.000 & 7.160 & 98.20 & 47.12 & 0.37 & 0.003696 & \pm 0.000004 & 0.329 & $2.88 \mathrm{E}-15$ & 0.30 & 1.0025 & 0.0018 \\
\hline S14 & $2656-026$ & SAP 2499.83.10 & 7.267 & 0.013 & 0.013 & 0.001 & 7.081 & 97.50 & 46.61 & 0.22 & 0.003696 & \pm 0.000004 & 0.636 & $5.56 E-15$ & 0.35 & 1.0025 & 0.0018 \\
\hline S14 & $2656-02 \mathrm{H}$ & SAP 2499-83.10 & 7.268 & 0.012 & 0.005 & 0.000 & 7.138 & 98.20 & 46.98 & 0.20 & 0.003696 & $\mp 0.000004$ & 0.922 & $8.02 E-15$ & 0.45 & 1.0025 & 0.0018 \\
\hline $\mathrm{S} 14$ & $2656-021$ & SAP $2499-83.10$ & 7.385 & 0.012 & 0.002 & 0.001 & 7.213 & 97.70 & 47.46 & 0.26 & 0.003696 & \pm 0.000004 & 0.584 & $5.08 E-15$ & 0.99 & 1.0025 & 0.0018 \\
\hline$\$ 14$ & $2656-02 J$ & SAP 2499-83.10 & 7.703 & 0.013 & 0.013 & 0.002 & 7.134 & 92.60 & 46.95 & 0.62 & 0.003696 & $\mp 0.000004$ & 0.214 & $1.88 E-15$ & 2.47 & 1.0025 & 0.0018 \\
\hline S14 & $2656-03 \mathrm{~A}$ & SAP $2499-83.10$ & 10.181 & 0.015 & 0.001 & 0.019 & 4.526 & 44.50 & 29.93 & 1.23 & 0.003696 & \pm 0.0000004 & 0.197 & $1.72 E-15$ & 0.10 & 1.0025 & 0.0018 \\
\hline S14 & 2656.038 & SAP 2499-83.10 & 7.555 & 0.013 & 0.004 & 0.006 & 5.766 & 76.30 & 38.04 & 0.41 & 0.003696 & \pm 0.000004 & 0.418 & $3.66 E-15$ & 0.20 & 1.0025 & 0.0018 \\
\hline \$14 & $2656-03 \mathrm{C}$ & SAP $2499-83.10$ & 6.982 & 0.012 & 0.023 & 0.003 & 6.196 & 88.80 & 40.85 & 0.80 & 0.003696 & \pm 0.000004 & 0.146 & 1.27E-15 & 0.22 & 1.0025 & 0.0018 \\
\hline s14 & $2656-030$ & SAP $2499-83.10$ & 6.906 & 0.011 & 0.004 & 0.000 & 7.018 & 101.60 & 46.20 & 0.73 & 0.003696 & $\mp 0.000004$ & 0.132 & 1.15E-15 & 0.25 & 1.0025 & 0.0018 \\
\hline S14 & 2656-03E & SAP $2499-83.10$ & 7.054 & 0.011 & 0.027 & 0.000 & 6.969 & 98.80 & 45.88 & 0.64 & 0.003696 & \pm 0.000004 & 0.171 & 1.49E-15 & 0.27 & 1.0013 & 0.0018 \\
\hline S14 & $2656-03 F$ & SAP $2499-83.10$ & 7.106 & 0.012 & 0.018 & 0.000 & 7.075 & 99.60 & 46.57 & 0.42 & 0.003696 & \pm 0.000004 & 0.296 & $2.59 E-15$ & 0.30 & 1.0013 & 0.0018 \\
\hline S14 & $2656-03 G$ & SAP 2499.83 .10 & 7.166 & 0.011 & 0.000 & 0.001 & 6.993 & 97.60 & 46.03 & 0.24 & 0.003696 & \pm 0.000004 & 0.585 & $5.12 E-15$ & 0.35 & 1.0013 & 0.0018 \\
\hline s14 & $2656-03 H$ & SAP $2499-83.10$ & 7.284 & 0.012 & 0.008 & 0.001 & 7.099 & 97.50 & 46.72 & 0.18 & 0.003696 & \pm 0.000004 & 1.523 & $1.33 E-14$ & 0.45 & 1.0013 & 0.0018 \\
\hline s14 & $2656-039$ & SAP $2499-83.10$ & 10.359 & 0.013 & 0.011 & 0.003 & 9.525 & 91.90 & 62.42 & 0.25 & 0.003696 & \pm 0.000004 & 1.486 & $1.30 E-14$ & 0.99 & 1.0013 & 0.0018 \\
\hline S14 & $2656.03 \mathrm{~J}$ & SAP 2499.83 .10 & 12.929 & 0.011 & 0.023 & 0.007 & 10.803 & 83.60 & 70.64 & 0.72 & 0.003696 & \pm 0.000004 & 0.384 & 3.35E-15 & 2.47 & 1.0013 & 0.0018 \\
\hline$\$ 15$ & $2666-01 \mathrm{~A}$ & SAP 0999.75.70 & 31.208 & 0.033 & 0.000 & 0.042 & 18.832 & 60.30 & 121.39 & t0.32 & 0.003696 & \pm 0.000004 & 0.043 & $3.77 E-16$ & 0.10 & 1.0012 & 0.0017 \\
\hline s15 & $2656-01 B$ & SAP 0999-75.70 & 8.326 & 0.011 & 0.000 & 0.004 & 7.179 & 86.20 & 47.24 & 2.60 & 0.003696 & \pm 0.000004 & 0.041 & $3.54 E-16$ & 0.20 & 1.0012 & 0.0017 \\
\hline s15 & $2666-01 c$ & SAP 0999-75.70 & 7.976 & 0.017 & 0.094 & 0.003 & 7208 & 90.40 & 47.43 & 5.73 & 0.003696 & \pm 0.000004 & 0.016 & 1.35E-16 & 0.22 & 1.0012 & 0.0017 \\
\hline $\mathrm{s} 15$ & $2686-010$ & SAP $0999-75.70$ & 7.817 & 0.011 & 0.000 & -0.002 & 8.472 & 108.40 & 55.63 & 7.08 & 0.003696 & $\div 0.000004$ & 0.013 & $1.02 E-16$ & 0.25 & 1.0012 & 0.0017 \\
\hline$\$ 15$ & 2666-01E & SAP $0999-75.70$ & 8.603 & 0.024 & 0.000 & -0.013 & 12.399 & 144.10 & 80.83 & 10.55 & 0.003696 & \pm 0.000004 & 0.009 & $6.96 E-17$ & 0.27 & 1.0012 & 0.0017 \\
\hline S15 & $2666.01 \mathrm{~F}$ & SAP 0999.75.70 & 8.750 & 0.019 & 0.000 & -0.014 & $\$ 2.786$ & $\$ 46.10$ & 83.30 & 11.14 & 0.003696 & $\mp 0.000004$ & 0.009 & $6.57 E-17$ & 0.30 & 1.0012 & 0.0017 \\
\hline$\$ 15$ & $2666-016$ & SAP $0999-75.70$ & 9.866 & 0.018 & 0.000 & -0.004 & 30.916 & 110.60 & 71.35 & 9.22 & 0.003696 & \pm 0.000004 & 0.012 & 8.69E-17 & 0.35 & 1.0012 & 0.0017 \\
\hline$S 15$ & $2666-01 H$ & SAP 0999-75.70 & 22.350 & 0.019 & 0.141 & 0.005 & 20.969 & 93.80 & 134.66 & 25.47 & 0.003696 & $\div 0.000004$ & 0.010 & $6.82 E-17$ & 0.45 & 1.0012 & 0.0017 \\
\hline \$15 & $2666-01\}$ & SAP 0999-75.70 & 69.514 & 0.023 & 2.177 & 0.006 & 68.098 & 97.80 & 405.00 & 12.50 & 0.003696 & \pm 0.000004 & 0.059 & $4.93 E-16$ & 0.99 & 1.0012 & 0.0017 \\
\hline$\$ 15$ & $2666-01 \mathrm{~J}$ & SAP 0999.75.70 & 208.084 & 0.016 & 1.806 & -0.063 & 227.044 & 109.00 & 1099.24 & 57.02 & 0.003696 & \pm 0.000004 & 0.035 & $2.83 E-16$ & 2.47 & 1.0012 & 0.0017 \\
\hline $\mathrm{s} 15$ & $2666-02 \mathrm{~A}$ & SAP 0999-75.70 & 19.900 & 0.020 & 0.115 & 0.046 & 6.362 & 32.00 & 41.93 & 3.24 & 0.003696 & $=0.000004$ & 0.147 & $1.28 E-15$ & 0.10 & 1.0012 & 0.0017 \\
\hline \$15 & $2666-028$ & SAP 0999.75 .70 & 8.921 & 0.013 & 0.091 & 0.002 & 8.203 & 92.00 & 53.88 & 0.59 & 0.003696 & \pm 0.000004 & 0.244 & 2.14E-15 & 0.20 & 1.0012 & 0.0017 \\
\hline \$15 & $2666-02 \mathrm{C}$ & SAP 0999-75.70 & 8.724 & 0.012 & 0.083 & 0.002 & 8.073 & 92.50 & 53.04 & 0.86 & 0.003696 & \pm 0.000004 & 0.143 & 1.24E-15 & 0.22 & 1.0012 & 0.0017 \\
\hline s15 & $2666-020$ & SAP 0999.75.70 & 7.722 & 0.012 & 0.120 & 0.002 & 7.054 & 91.30 & 46.43 & 1.27 & 0.003696 & \pm 0.000004 & 0.078 & $6.76 E-16$ & 0.25 & 1.0012 & 0.0017 \\
\hline s15 & $2666-02 E$ & SAP 0999-75.70 & 7.121 & 0.009 & 0.024 & 0.002 & 6.666 & 93.60 & 43.91 & 2.17 & 0.003696 & \pm 0.000004 & 0.040 & $3.54 E-16$ & 0.27 & 1.0012 & 0.0017 \\
\hline S15 & $2666-02 F$ & SAP 09B9-75.70 & 6.876 & 0.010 & 0.016 & 0.003 & $5.66 t$ & 84.80 & 37.35 & 2.76 & 0.003696 & $\mp 0.000004$ & 0.029 & $2.59 E-16$ & 0.30 & $1.00 \div 2$ & 0.0017 \\
\hline $\mathrm{s} 15$ & $2666-02 G$ & SAP 0999.75.70 & 6.048 & 0.012 & 0.000 & 0.001 & 5.865 & 97.00 & 38.69 & 2.30 & 0.003696 & \pm 0.000004 & 0.031 & $2.73 z-16$ & 0.35 & 1.0012 & 0.0017 \\
\hline \$15 & $2666-02 H$ & SAP 0999.75.70 & 5.823 & 0.009 & 0.101 & -0.001 & 6.057 & 104.00 & 39.94 & 2.64 & 0.003696 & $\mp 0.000004$ & 0.025 & $2.22 E-16$ & 0.45 & 1.0012 & 0.0017 \\
\hline s15 & $2666-021$ & SAP 0999-75.70 & 10.672 & 0.012 & 0.066 & 0.003 & 9.643 & 90.40 & 63.18 & 2.17 & 0.003696 & $\mp 0.000004$ & 0.056 & $4.84 E-16$ & 0.99 & 1.0012 & 0.0017 \\
\hline$\$ 15$ & $2666-02 \mathrm{~J}$ & SAP $0999-75.70$ & 14.763 & 0.004 & 0.000 & 0.010 & 11.738 & 79.50 & 76.62 & 13.93 & 0.003696 & \pm 0.000004 & 0.012 & $1.07 E-16$ & 2.47 & 1.0012 & 0.0017 \\
\hline
\end{tabular}




\begin{tabular}{|c|c|c|c|c|c|c|c|c|c|c|c|c|c|c|c|c|c|}
\hline \multicolumn{18}{|c|}{ Appendix (Continued) } \\
\hline Sample & $\begin{array}{l}\text { Ein } \\
\text { ID\# }\end{array}$ & $\begin{array}{l}\text { Drill Hole - } \\
\text { Depth }\end{array}$ & ${ }^{45} \mathrm{Ar}{ }^{39} \mathrm{Ar}$ & ${ }^{38} \mathrm{Ar} /{ }^{39} \mathrm{Ar}$ & ${ }^{37} \mathrm{Ar} /{ }^{39} \mathrm{Ar}$ & ${ }^{36} \mathrm{Ar} /{ }^{39} \mathrm{Ar}$ & ${ }^{40} \mathrm{Ar} /{ }^{39} \mathrm{Ar}$ & $\%{ }^{46^{\circ}} \mathrm{Ar}$ & $\begin{array}{l}\text { Age } \\
\text { (Ma) }\end{array}$ & $\stackrel{ \pm}{ \pm}$ & $J$ & & $\%{ }^{40} \mathrm{Ar}$ & $\begin{array}{l}{ }^{40} \mathrm{Ar} \\
\text { (Moles) }\end{array}$ & $\begin{array}{c}\text { Laser } \\
\text { Power }(W)\end{array}$ & $\begin{array}{l}{ }^{40} \mathrm{Ar} /{ }^{36} \mathrm{Ar} \\
\text { Discr. }\end{array}$ & \pm \\
\hline s15 & $2666-03 \mathrm{~A}$ & SAP 0999-75.70 & 8.847 & 0.014 & 0.000 & 0.011 & 5.509 & 52.30 & 36.36 & 2.80 & 0.003696 & \pm 0.000004 & 0.038 & $3.33 \mathrm{E}-16$ & 0.10 & 1.0012 & 0.0017 \\
\hline$\$ 15$ & $2666-038$ & SAP 0999-75.70 & 7.858 & 0.012 & 0.014 & 0.003 & 6.944 & 88.40 & 45.72 & 1.02 & 0.003696 & \pm 0.000004 & 0.097 & $8.46 E-16$ & 0.20 & 1.0012 & 0.0017 \\
\hline$\$ 15$ & $2666-03 \mathrm{C}$ & SAP 0999.75.70 & 7.450 & 0.012 & 0.000 & 0.000 & 7.331 & 98.40 & 48.23 & 1.65 & 0.003696 & \pm 0.000004 & 0.053 & 4.67E-16 & 0.22 & 1.0012 & 0.0017 \\
\hline S15 & $2666-03 D$ & SAP 0989-75.70 & 7.326 & 0.011 & 0.207 & 0.002 & 0.853 & 93.50 & 45.13 & 2.25 & 0.003696 & \pm 0.000004 & 0.040 & $3.43 \mathrm{E}-16$ & 0.25 & 1.0012 & 0.0017 \\
\hline \$15 & $2666-03 E$ & SAP 0999-75.70 & 6.791 & 0.013 & 0.000 & -0.001 & 7.143 & 105.20 & 47.01 & 3.43 & 0.003696 & \pm 0.000004 & 0.021 & \$. $78 E-16$ & 0.27 & 1.0012 & 0.0017 \\
\hline S15 & $2666-03 \mathrm{~F}$ & SAP 0999-75.70 & 6.948 & 0.009 & 0.000 & -0.003 & 7.745 & 111.50 & 50.92 & 5.70 & 0.003696 & \pm 0.000004 & 0.014 & 1.19E-16 & 0.30 & 1.0012 & 0.0017 \\
\hline$\$ 15$ & $2666-03 G$ & SAP $0999-75.70$ & 7.865 & 0.012 & 0.000 & 0.008 & 5.502 & 70.00 & 36.32 & 5.06 & 0.003696 & \pm 0.000004 & 0.018 & $1.54 \mathrm{E}-16$ & 0.35 & 1.0012 & 0.0017 \\
\hline S15 & $2666-03 \mathrm{H}$ & SAP $0999-75.70$ & 9.396 & 0.014 & 0.000 & 0.011 & 6.046 & 64.40 & 39.87 & 4.10 & 0.003696 & $\mp 0.000004$ & 0.026 & $2.19 E-16$ & 0.45 & 1.0012 & 0.0017 \\
\hline$\$ 15$ & $2666-031$ & SAP 0999-75.70 & 9.542 & 0.012 & 0.209 & 0.004 & 8.295 & 86.90 & 54.48 & 2.14 & 0.003696 & \pm 0.000004 & 0.051 & $4.38 E-16$ & 0.99 & 1.0012 & 0.0017 \\
\hline S15 & $2666-03 \mathrm{~J}$ & SAP 0999.75 .70 & 15.331 & 0.060 & 0.495 & 0.044 & 2.452 & 16.00 & 16.27 & 29.67 & 0.003696 & \pm 0.000004 & 0.006 & $4.92 E-17$ & 2.47 & 1.0012 & 0.0017 \\
\hline s16 & $2667.01 \mathrm{~A}$ & SAP $3702-60.55$ & -1.191 & -0.057 & 0.000 & 0.062 & -19.387 & $\% 1627.2$ & -134.14 & 154.25 & 0.003696 & \pm 0.000004 & 0.000 & $4.32 E-18$ & 0.10 & 1.0012 & 0.0017 \\
\hline s16 & $2667-018$ & SAP $3702-60.55$ & 23.434 & 0.029 & 0.000 & 0.075 & 1.253 & 5.30 & 8.34 & 7.45 & 0.003696 & \pm 0.000004 & 0.045 & 4.08E-16 & 0.20 & 1.0012 & 0.0017 \\
\hline s16 & $2667-01 \mathrm{C}$ & SAP $3702-60.55$ & 5.569 & 0.014 & 0.000 & 0.011 & 2.253 & 40.50 & 14.96 & 5.89 & 0.003696 & \pm 0.000004 & 0.013 & $1.31 \mathrm{E}-16$ & 0.22 & 1.0012 & 0.0017 \\
\hline s16 & 2667-010 & SAP $3702-60.55$ & 4.522 & 0.006 & 0.000 & 0.007 & 2.327 & 51.50 & 15.45 & 5.56 & 0.003696 & \pm 0.000004 & 0.010 & $1.14 \mathrm{E}-16$ & 0.25 & 1.0012 & 0.0017 \\
\hline$\$ 16$ & $2667-01 E$ & SAP 3702-60.55 & 6.020 & 0.010 & 0.000 & 0.014 & 1.957 & 32.50 & 13.00 & 7.09 & 0.003696 & \pm 0.000004 & 0.011 & $1.26 \mathrm{E}-16$ & 0.27 & 1.0012 & 0.0017 \\
\hline s16 & $2667-01 \mathrm{~F}$ & SAP $3702-60.55$ & 8.829 & 0.015 & 0.000 & 0.031 & -0.205 & -2.30 & -1.37 & 6.16 & 0.003696 & $\mp 0.000004$ & 0.018 & $1.93 \mathrm{E}-16$ & 0.30 & 1.0012 & 0.0017 \\
\hline \$16 & $2667-016$ & SAP 3702-60.55 & 14.179 & 0.017 & 0.131 & 0.040 & 2.382 & 16.80 & 15.81 & 4.83 & 0.003696 & \pm 0.000004 & 0.047 & $4.51 \mathrm{E}-16$ & 0.35 & 1.0012 & 0.0017 \\
\hline s16 & 2687-01H & SAP $3702-60.55$ & 10.712 & 0.814 & 0.078 & 0.015 & 6.231 & 58.20 & 41.07 & 1.02 & 0.003696 & \pm 0.000004 & 0.223 & $2.00 \mathrm{E}-15$ & 0.45 & 1.0012 & 0.0017 \\
\hline s16 & $2667-0.11$ & SAP $3702-60.55$ & 11.470 & 0.014 & 0.086 & 0.022 & 4.917 & 42.90 & 32.49 & 0.99 & 0.003696 & \pm 0.000004 & 0.302 & $2.68 \mathrm{E}-15$ & 0.99 & 1.0012 & 0.0017 \\
\hline s16 & 2667-01 J & SAP $3702-60.55$ & 61.359 & 0.040 & 0.000 & 0.188 & 5.830 & 9.50 & 38.46 & 11.80 & 0.003696 & \pm 0.000004 & 0.121 & $1.11 E-15$ & 2.47 & 1.0012 & 0.0017 \\
\hline si6 & $2867-02 \mathrm{~A}$ & SAP $3702-60.55$ & 843.672 & 1.169 & 0.000 & 2.809 & 13.626 & 1.60 & 88.64 & 3649.07 & 0.003696 & \pm 0.000004 & 0.018 & $1.54 \mathrm{E}-16$ & 0.10 & 1.0012 & 0.0017 \\
\hline S16 & $2667-028$ & SAP $3702-60.55$ & 407.985 & 0.411 & 0.000 & 1.200 & 53.408 & 13.10 & 325.00 & 453.45 & 0.003696 & \pm 0.000004 & 0.030 & $2.67 E-16$ & 0.20 & 1.0012 & 0.0017 \\
\hline$\$ 16$ & $2667-02 \mathrm{C}$ & SAP $3702-60.55$ & 64.565 & 0.239 & 0.000 & 0.104 & 30.752 & 50.00 & $\{94.21$ & 271.33 & 0.003696 & $\mp 0.000004$ & 0.003 & $1.82 E-17$ & 0.22 & 1.0012 & 0.0017 \\
\hline S16 & $2667-020$ & SAP $3702-60.55$ & 70.826 & 0.537 & 0.000 & 0.639 & 117.951 & -166.5 & -1033.03 & 944.32 & 0.003696 & \pm 0.000004 & 0.002 & 1.44E-17 & 0.25 & 1.0012 & 0.0017 \\
\hline$\$ 16$ & $2667-02 E$ & SAP $3702-60.55$ & 66.626 & 0.195 & 3.892 & 0.515 & -85.473 & -127.9 & -684.94 & 652.29 & 0.003696 & \pm 0.000004 & 0.002 & $1.24 E-17$ & 0.27 & 1.0012 & 0.0017 \\
\hline s16 & $2667-02 F$ & SAP $3702-60.55$ & 88.003 & 0.246 & 0.000 & 0.207 & 26.724 & 30.40 & 169.93 & 349.18 & 0.003696 & \pm 0.000004 & 0.003 & $1.83 \mathrm{E}-17$ & 0.30 & 1.0012 & 0.0017 \\
\hline s16 & $2667-02 \mathrm{G}$ & SAP 3702-60.55 & 79.060 & 0.234 & 0.000 & 0.376 & -32.056 & 40.50 & -227.51 & 342.10 & 0.003696 & \pm 0.000004 & 0.004 & $2.14 \mathrm{E}-17$ & 0.35 & 1.0012 & 0.0017 \\
\hline s16 & $2667-02 \mathrm{H}$ & SAP $3702-60.55$ & 145.301 & 0.057 & 0.000 & 0.436 & 16.410 & 11.30 & 106.23 & 276.10 & 0.003696 & $\mp 0.000004$ & 0.008 & $5.90 \mathrm{E}-17$ & 0.45 & 1.0012 & 0.0017 \\
\hline S16 & $2667-021$ & SAP $3702-60.55$ & 367.791 & 0.242 & 0.000 & 0.837 & $\$ 20.497$ & 32.80 & 664.55 & 256.44 & 0.003696 & $\mp 0.000004$ & 0.030 & $2.50 \mathrm{E}-16$ & 0.99 & 1.0012 & 0.0017 \\
\hline S16 & $2667-02 J$ & SAP $3702-60.55$ & 423.218 & 0.618 & 9.909 & 0.752 & 203.283 & 47.70 & 1010.97 & 539.77 & 0.003696 & \pm 0.000004 & 0.014 & $1.04 \mathrm{E}-16$ & 2.47 & 1.0012 & 0.0017 \\
\hline st6 & 2667-03A & SAP $3702-60.55$ & 4.364 & 0.023 & 0.000 & 0.004 & 3.255 & 74.60 & 21.58 & 5.61 & 0.003696 & \pm 0.000004 & 0.009 & $7.91 E-17$ & 0.10 & 1.0012 & 0.0017 \\
\hline S16 & $2667-038$ & SAP $3702-60.55$ & 5.080 & 0.014 & 0.065 & 0.001 & 4.838 & 95.20 & 31.97 & 2.91 & 0.003696 & \pm 0.000004 & 0.023 & 1.97E-16 & 0.20 & 1.0012 & 0.0017 \\
\hline$S 16$ & $2667-03 \mathrm{C}$ & SAP $3702-60.55$ & 3.668 & 0.012 & 0.000 & -0.015 & 8.075 & 220.20 & 53.06 & 12.57 & 0.003696 & \pm 0.000004 & 0.003 & $2.50 E-17$ & 0.22 & 1.0012 & 0.0017 \\
\hline$s 16$ & $2667-03 D$ & SAP 37D2-60.55 & 3.457 & 0.038 & 0.350 & 0.003 & 2.627 & 76.00 & 17.43 & 15.95 & 0.003696 & \pm 0.000004 & 0.003 & $1.72 E-13$ & 0.25 & 1.0012 & 0.0017 \\
\hline$\$ 16$ & 2667-03E & SAP 3702-60.55 & 4.085 & 0.013 & 0.004 & 0.005 & 2.495 & 61.10 & 16.56 & 13.48 & 0.003696 & $\stackrel{ \pm 0.008004}{0}$ & 0.004 & $2.41 E-17$ & 0.27 & 1.0012 & 0.0017 \\
\hline$\$ 16$ & $2667-03 F$ & SAP $3702-60.55$ & 4.748 & 0.030 & 0.425 & -0.006 & 6.632 & 139.70 & 43.69 & 21.65 & 0.003696 & $\div 0.000004$ & 0.003 & $1.43 E-17$ & 0.30 & 1.0012 & 0.0017 \\
\hline s16 & $2667-036$ & SAP $3702-60.55$ & 4.346 & 0.021 & 0.098 & -0.007 & 6.496 & 149.50 & 42.80 & 19.45 & 0.003696 & \pm 0.000004 & 0.002 & 1.23E- 17 & 0.35 & 1.0012 & 0.0017 \\
\hline s16 & $2667-03 \mathrm{H}$ & SAP $3702-60.55$ & 11.773 & 0.097 & 0.000 & -0.058 & 28.983 & 246.20 & 183.59 & 69.63 & 0.003696 & \pm 0.000004 & 0.002 & $2.64 E-18$ & 0.45 & 1.0012 & 0.0017 \\
\hline s16 & $2667-031$ & SAP $3792-60.55$ & 9.814 & 0.020 & 2.771 & 0.065 & -9.141 & -93.00 & -62.00 & 39.33 & 0.003696 & \pm 0.000004 & 0.003 & $2.49 \mathrm{E}-17$ & 0.99 & 1.0007 & 0.0017 \\
\hline$\$ 16$ & $2667-031$ & SAP $3702-60.55$ & 27.314 & -0.044 & 0.000 & -0.081 & 51.175 & 187.40 & 312.53 & 106.66 & 0.003696 & \pm 0.000004 & 0.003 & $1.78 E-17$ & 2.47 & 1.0007 & 0.0017 \\
\hline s17 & 2673-01A & SAP $3702-62.008$ & 11.961 & 0.024 & 0.06 & 0.036 & 1.313 & 11.00 & 8.80 & 3.48 & 0.003722 & \pm 0.000004 & 0.057 & $4.97 E-16$ & 0.10 & 1.0014 & 0.0018 \\
\hline s17 & $2673-018$ & SAP $3702-62.00 \mathrm{~B}$ & 4.145 & 0.014 & 0.028 & 0.009 & 1.348 & 32.50 & 9.03 & 1.18 & 0.003722 & $\mp 0.000004$ & 0.059 & $5.09 E-16$ & 0.20 & 1.0014 & 0.0018 \\
\hline s17 & $2673-01 \mathrm{C}$ & SAP $3702-62.008$ & 3.303 & 0.011 & 0.015 & 0.002 & 2.684 & 81.30 & 17.94 & 0.53 & 0.003722 & $\doteqdot 0.000004$ & 0.107 & $9.32 E-16$ & 0.22 & 1.0014 & 0.0018 \\
\hline$\$ 17$ & $2673-010$ & SAP $3702-62.008$ & 3.149 & 0.011 & 0.050 & 0.001 & 2.712 & 86.10 & 18.12 & 0.95 & 0.003722 & \pm 0.000004 & 0.047 & $4.12 E-16$ & 0.25 & 1.0014 & 0.0018 \\
\hline s17 & 2673-0:E & SAP 37D2-62.008 & 3.034 & 0.013 & 0.148 & 0.001 & 2.804 & 92.40 & 18.73 & 1.45 & 0.003722 & \pm 0.000004 & 0.028 & $2.43 E-16$ & 0.27 & 1.0014 & 0.0018 \\
\hline$\$ 17$ & 2673-01F & SAP 37D2-62.008 & 2.967 & 0.012 & 0.227 & 0.006 & 1.329 & 44.80 & 8.90 & 1.71 & 0.003722 & $\mp 0.000004$ & 0.024 & $2.04 E-16$ & 0.30 & 1.0014 & 0.0018 \\
\hline$S 17$ & $2673-016$ & SAP $3702-62.00 B$ & 3.206 & 0.014 & 0.087 & 0.007 & 1.218 & 37.90 & 8.15 & 1.18 & 0.003722 & \pm 0.000004 & 0.040 & $3.40 E-16$ & 0.35 & 1.0014 & 0.0018 \\
\hline
\end{tabular}




\begin{tabular}{|c|c|c|c|c|c|c|c|c|c|c|c|c|c|c|c|c|c|}
\hline \multicolumn{18}{|c|}{ Appendix (Continued) } \\
\hline Sample & $\begin{array}{l}\text { gain } \\
\text { ID\# }\end{array}$ & $\begin{array}{l}\text { Drill Hole - } \\
\text { Depth }\end{array}$ & ${ }^{40} \mathrm{Ar} /{ }^{39} \mathrm{Ar}$ & ${ }^{38} \mathrm{Ar} r^{39} \mathrm{Ar}$ & ${ }^{37} \mathrm{Ar} r^{39} \mathrm{Ar}$ & ${ }^{36} \mathrm{Ar} r^{39} \mathrm{Ar}$ & ${ }^{40^{\circ}} \mathrm{Ar} /^{39} \mathrm{Ar}$ & $\%{ }^{40^{\circ}} \mathrm{Ar}$ & $\begin{array}{l}\text { Age } \\
\text { (Ma) }\end{array}$ & $\stackrel{ \pm}{ \pm}$ & & $\mathrm{J}$ & $\%{ }^{40} \mathrm{Ar}$ & $\begin{array}{l}{ }^{40} \mathrm{Ar} \\
\text { (Moles) }\end{array}$ & $\begin{array}{c}\text { Laser } \\
\text { power }(W)\end{array}$ & $\begin{array}{l}{ }^{40} \mathrm{Ar} r^{36} \mathrm{Ar} \\
\text { Discr. }\end{array}$ & \pm \\
\hline$\$ 17$ & 2673-01H & SAP $3702-62.008$ & 3.530 & 0.015 & 0.082 & 0.009 & 0.910 & 25.80 & 6.10 & 0.95 & 0.003722 & $\div 0.000004$ & 0.060 & $5.21 E-16$ & 0.45 & 1.0014 & 0.0018 \\
\hline \$17 & $2673-011$ & SAP $3702-62.008$ & 3.328 & 0.016 & 0.247 & 0.010 & 0.302 & 9.10 & 2.02 & 3.52 & 0.003722 & \pm 0.000004 & 0.013 & $1.07 E-16$ & 0.99 & 1.0014 & 0.0018 \\
\hline s47 & $2673-04 J$ & SAP $3702-62.008$ & 10.483 & 0.027 & t. 127 & 0.043 & -2.049 & -19.50 & -13.81 & 11.66 & 0.003722 & \pm 0.000004 & 0.013 & $1.01 E-16$ & 2.47 & 1.0014 & 0.0018 \\
\hline S17 & $2673-02 A$ & SAP $3702-62.008$ & 5.653 & 0.009 & 0.000 & 0.012 & 2.067 & 36.60 & 13.82 & 4.54 & 0.003722 & \pm 0.000004 & 0.015 & $1.34 E-16$ & 0.10 & 1.0014 & 0.0018 \\
\hline s 37 & $2673-028$ & SAP $3702-62.008$ & 3.426 & 0.012 & 0.000 & 0.002 & 2.829 & 82.60 & 18.90 & 0.85 & 0.003722 & $\mp 0.000004$ & 0.053 & 4.63E-16 & 0.20 & 1.0014 & 0.0018 \\
\hline$\$ 17$ & $2673-02 \mathrm{C}$ & SAP $3702-62.008$ & 3.335 & 0.008 & 0.000 & .0 .001 & 3.569 & 107.00 & 23.81 & 1.95 & 0.003722 & \pm 0.000004 & 0.019 & $1.71 E-16$ & 0.22 & 1.0014 & 0.0018 \\
\hline$s 17$ & $2673-020$ & SAP $3702-62.008$ & 3.126 & 0.012 & 0.000 & 0.003 & 2.154 & 68.90 & 14.41 & 3.06 & 0.003722 & $\div 0.000004$ & 0.012 & $1.08 E-16$ & 0.25 & 1.0014 & 0.0018 \\
\hline \$17 & $2673-02 E$ & $\mathrm{SAP}^{3702-62.008}$ & $2.78 \xi$ & 0.015 & 0.034 & 0.006 & 1.075 & 38.70 & 7.21 & 4.12 & 0.003722 & \pm 0.000004 & 0.008 & $3.52 E-17$ & 0.27 & 1.0014 & 0.0018 \\
\hline \$17 & $2673.02 F$ & SAP $3702-62.008$ & 2.663 & 0.010 & 0.173 & 0.005 & 1.064 & 40.00 & 7.13 & 5.38 & 0.003722 & \pm 0.000004 & 0.006 & $5.60 E-17$ & 0.30 & 1.0014 & 0.0018 \\
\hline \$17 & $2673-02 G$ & SAP $3702-62.008$ & 2.491 & 0.010 & 0.097 & 0.004 & $\{.196$ & 48.00 & 8.01 & 5.36 & 0.003722 & \pm 0.000004 & 0.006 & $5.08 \mathrm{E}-17$ & 0.35 & 1.0014 & 0.0018 \\
\hline $\mathrm{s} 17$ & $2673-02 \mathrm{H}$ & SAP $3702-62.00 B$ & 3.999 & 0.008 & 0.000 & -0.002 & 4.532 & 113.30 & 30.18 & 16.75 & 0.003722 & \pm 0.000004 & 0.002 & $2.33 E-17$ & 0.45 & 1.0014 & 0.0018 \\
\hline s17 & $2673-021$ & SAP $3702-62.00 \mathrm{~B}$ & 3.731 & 0.012 & 0.021 & -0.006 & 5.406 & 144.90 & 35.94 & 8.66 & 0.003722 & \pm 0.000004 & 0.005 & 4.54E-17 & 0.99 & 1.0014 & 0.0018 \\
\hline \$17 & $2673-025$ & SAP $3702-62.00 B$ & 6.764 & -0.002 & 0.000 & -0.017 & 11.701 & 173.00 & 76.91 & 65.67 & 0.003722 & \pm 0.000004 & 0.001 & 1.17E-17 & 2.47 & 1.0014 & 0.0018 \\
\hline$\$ 17$ & $2673-03 \mathrm{~A}$ & SAP 3702-62.00B & 28.461 & 0.032 & 0.000 & 0.076 & 5.612 & 19.90 & 37.30 & 8.49 & 0.003722 & \pm 0.000004 & 0.051 & $4.47 E-16$ & 0.10 & 1.0014 & 0.0018 \\
\hline \$17 & $2673-03 B$ & SAP $3702-62.00 \mathrm{~B}$ & 6.741 & 0.014 & 0.000 & 0.016 & 2.036 & 30.20 & 13.62 & 1.88 & 0.003722 & \pm 0.000004 & 0.055 & $4.88 \mathrm{E}-16$ & 0.20 & 1.0014 & 0.0018 \\
\hline \$17 & $2673-03 \mathrm{C}$ & SAP $3702-62.00 B$ & 2.943 & 0.013 & 0.000 & 0.001 & 2.566 & 87.20 & 17.15 & 0.70 & 0.003722 & \pm 0.000004 & 0.053 & 4.66E-16 & 0.22 & 1.0014 & 0.0018 \\
\hline s17 & $2673-030$ & SAP 3702-62.00B & 2.895 & 0.012 & 0.000 & 0.001 & 2.561 & 88.50 & 17.11 & 1.00 & 0.003722 & \pm 0.000004 & 0.031 & $2.72 \mathrm{E}-16$ & 0.25 & 1.0014 & 0.0048 \\
\hline$\$ 17$ & $2673-03 E$ & SAP 3702-62.00B & 3.376 & 0.013 & 0.000 & 0.000 & 3.448 & 102.10 & 23.00 & 2.22 & 0.003722 & \pm 0.000004 & 0.016 & $1.43 E-16$ & 0.27 & 1.0014 & 0.0018 \\
\hline S17 & $2673-03 F$ & SAP $3702-62.00 \mathrm{~B}$ & 4.680 & 0.013 & 0.000 & 0.011 & 1.503 & 32.10 & 10.06 & 3.38 & 0.003722 & $\mp 0.000004$ & 0.015 & $1.36 \mathrm{E}-16$ & 0.30 & 1.0014 & 0.0018 \\
\hline s17 & $2673-036$ & SAP $3702-62.00 B$ & 4.876 & 0.016 & 0.000 & 0.012 & 1.382 & 28.30 & 9.25 & 2.10 & 0.003722 & \pm 0.000004 & 0.028 & $2.40 E-16$ & 0.35 & 1.0014 & 0.0018 \\
\hline s17 & $2673-034$ & SAP $3702-62.00 B$ & 3.321 & 0.012 & 0.000 & 0.002 & 2.729 & 82.20 & 18.23 & १.68 & 0.003722 & $\mp 0.000004$ & 0.022 & 1.89E-16 & 0.45 & 0.9986 & 0.0019 \\
\hline \$17 & $2673-034$ & SAP $3702-62.00 \mathrm{~B}$ & 3.682 & 0.014 & 0.000 & 0.009 & 1.080 & 29.30 & 7.24 & 3.11 & 0.003722 & \pm 0.000004 & 0.013 & 1.12E-16 & 0.99 & 0.9986 & 0.0019 \\
\hline s17 & $2673-03 \mathrm{~J}$ & SAP 3702-62.00B & 18.956 & 0.040 & 0.000 & 0.089 & .7 .268 & -38.30 & -49.48 & 24.27 & 0.003722 & \pm 0.000004 & 0.009 & 7.64E-17 & 2.47 & 0.9986 & 0.0019 \\
\hline S 18 & $2674-01 \mathrm{~A}$ & SAP $3702-62.50$ & 4.456 & 0.018 & 0.000 & 0.000 & 4.478 & 100.50 & 29.82 & 16.00 & 0.003722 & $\mp 0.000004$ & 0.003 & 3.10E-17 & 0.10 & 0.9986 & 0.0019 \\
\hline Sis & $2674-01 B$ & $\mathrm{SAP}_{3702-62.50}$ & 4.688 & 0.015 & 0.030 & 0.010 & 1.831 & 39.10 & 12.25 & 1.45 & 0.003722 & $\mp 0.000004$ & 0.045 & $3.98 E-16$ & 0.20 & 0.9986 & 0.0019 \\
\hline s18 & $2674-01 C$ & SAP $3702-62.50$ & 2.567 & 0.012 & 0.000 & 0.003 & 1.643 & 64.00 & 11.80 & 2.04 & 0.003722 & $\nsubseteq 0.000004$ & 0.016 & $1.47 E-16$ & 0.22 & 0.9986 & 0.0019 \\
\hline$\$ 18$ & $2674-010$ & SAP $3702-62.50$ & 2.865 & 0.013 & 0.000 & 0.002 & 2.339 & 81.70 & 15.64 & 2.91 & 0.003722 & \pm 0.000004 & 0.012 & 1.18E-16 & 0.25 & 0.9986 & 0.0019 \\
\hline s18 & 2674-04E & SAP 3702-62.50 & 2.999 & $0.0+2$ & 0.000 & 0.000 & 2.875 & 95.90 & 19.21 & 3.36 & 0.003722 & \pm 0.000004 & 0.011 & $1.06 E-16$ & 0.27 & 0.9986 & 0.0019 \\
\hline$\$ 18$ & $2674-01 \mathrm{~F}$ & SAP $3702-62.50$ & 3.020 & 0.013 & 0.000 & 0.003 & 2.271 & 75.20 & 15.19 & 2.55 & 0.003722 & \pm 0.000004 & 0.015 & 1.41E-16 & 0.30 & 0.9986 & 0.0019 \\
\hline $\mathrm{S} 18$ & $2674-01 G$ & SAP $3702-62.50$ & 2.782 & 0.012 & 0.000 & 0.002 & 2.103 & 75.60 & 14.07 & 0.89 & 0.003722 & \pm 0.000004 & 0.038 & $3.56 E-16$ & 0.35 & 0.9986 & 0.0019 \\
\hline$s 18$ & $2674-01 \mathrm{H}$ & SAP $3702-62.50$ & 2.409 & 0.013 & 0.000 & 0.001 & 2.125 & 88.20 & 14.21 & 0.14 & 0.003722 & \pm 0.000004 & 0.264 & $2.33 E-15$ & 0.45 & 0.9986 & 0.0019 \\
\hline $\mathrm{s} 18$ & 2674-011 & SAP $3702-62.50$ & 2.807 & 0.014 & 0.003 & 0.003 & 1.930 & 68.80 & 12.91 & 0.25 & 0.003722 & \pm 0.000004 & 0.236 & $2.07 E-15$ & 0.99 & 0.9986 & 0.0019 \\
\hline \$18 & $2674-01 \mathrm{~s}$ & SAP $3702-62.50$ & 7.992 & 0.014 & 0.049 & 0.021 & 1.828 & 22.90 & 12.24 & 2.24 & 0.003722 & \pm 0.000004 & 0.053 & $4.88 E-16$ & 2.47 & 0.9986 & 0.0019 \\
\hline S18 & $2674-02 A$ & SAP $3702-62.50$ & 342.740 & 0.221 & 1.480 & 1.161 & -0.367 & -0.10 & -2.47 & 110.64 & 0.003722 & \pm 0.000004 & 0.190 & 1.65E-15 & 0.10 & 0.9986 & 0.0019 \\
\hline$\$ 18$ & $2674-02 B$ & SAP $3702-62.50$ & 69.491 & 0.064 & 0.024 & 0.231 & 1.119 & 1.60 & 7.50 & 16.91 & 0.003722 & $\div 0.000004$ & 0.097 & $8.46 E-16$ & 0.20 & 0.9986 & 0.0019 \\
\hline S18 & $2674.02 \mathrm{C}$ & SAP $3702-62.50$ & 91.966 & 0.057 & 0.000 & 0.266 & $\$ 3.426$ & 14.60 & 87.97 & 21.33 & 0.003722 & $\mp 0.000004$ & 0.081 & 7.21E+16 & 0.25 & 0.9986 & 0.0019 \\
\hline$\$ 18$ & $2674-020$ & SAP $3702-62.50$ & 23.493 & 0.022 & 0.223 & 0.067 & 3.635 & 15.50 & 24.25 & 5.32 & 0.003722 & \pm 0.000004 & 0.083 & $7.35 E-16$ & 0.30 & 0.9986 & 0.0019 \\
\hline S18 & $2674-02 \mathrm{E}$ & SAP $3702-62.50$ & 21.525 & 0.022 & 0.000 & 0.057 & 4.609 & 21.40 & 30.69 & 7.35 & 0.003722 & \pm 0.000004 & 0.042 & $3.76 E-16$ & 0.35 & 0.9986 & 0.0019 \\
\hline S18 & $2674-02 F$ & SAP $3702-62.50$ & 28.956 & 0.023 & 0.231 & 0.065 & 9.735 & 33.60 & 64.21 & 11.37 & 0.003722 & \pm 0.000004 & 0.036 & 3.30E-16 & 0.40 & 0.9986 & 0.0019 \\
\hline$S 18$ & $2674-02 G$ & SAP $3702-62.50$ & 32.590 & 0.030 & t. 175 & 0.082 & 8.596 & 26.40 & 56.81 & 15.88 & 0.003722 & \pm 0.000004 & 0.029 & $2.66 E-16$ & 0.45 & 0.9986 & 0.0019 \\
\hline S18 & $2674-02 \mathrm{H}$ & SAP $3702-62.50$ & 19.091 & 0.022 & 0.063 & 0.042 & 6.589 & 34.50 & 43.71 & 10.59 & 0.003722 & \pm 0.000004 & 0.022 & $2.09 E-16$ & 0.54 & 0.9986 & 0.0019 \\
\hline$\$ 18$ & $2674-021$ & SAP 3702-62.50 & 25.151 & 0.022 & 0.452 & 0.073 & 3.753 & 14.90 & 25.03 & 6.89 & 0.003722 & \pm 0.000004 & 0.063 & $5.67 E-16$ & 0.99 & 0.9986 & 0.0019 \\
\hline$\$ 18$ & $2674-02,5$ & SAP $3702-62.50$ & 197.296 & 0.102 & 1.742 & 0.569 & 29.371 & 14.90 & 187.16 & 82.60 & 0.003722 & $\div 0.000004$ & 0.051 & $4.73 E-16$ & 2.47 & 0.9986 & 0.0019 \\
\hline s18 & $2674-03 \mathrm{~A}$ & SAP $3702-62.50$ & 23.984 & 0.027 & 0.287 & 0.071 & 3.014 & 12.60 & 20.13 & 6.07 & 0.003722 & \pm 0.000004 & 0.096 & $8.42 E-16$ & 0.10 & 0.9986 & 0.0019 \\
\hline$S_{18}$ & $2674.03 B$ & SAP $3702-62.50$ & 8.870 & 0.016 & 0.133 & 0.017 & 3.874 & 43.70 & 25.83 & 1.61 & 0.003722 & $\mp 0.000004$ & 0.096 & $8.35 E-16$ & 0.20 & 0.9986 & 0.0019 \\
\hline$S 18$ & $2674-03 C$ & SAP $3702-62.50$ & 7.475 & 0.013 & 0.092 & 0.001 & 7.050 & 94.30 & 46.73 & 0.81 & 0.003722 & \pm 0.000004 & 0.135 & 1.17E-15 & 0.25 & 0.9986 & 0.0019 \\
\hline
\end{tabular}




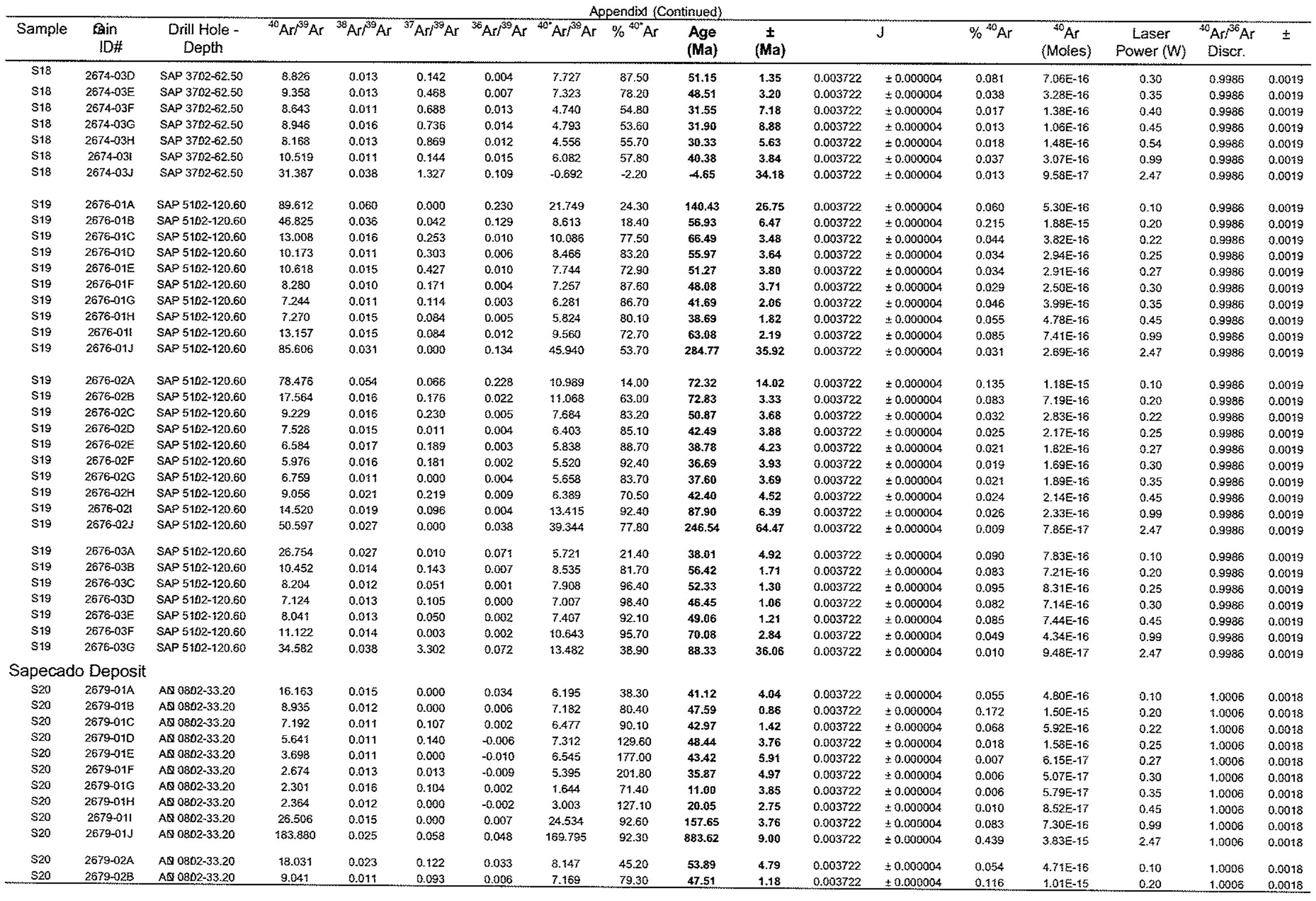




\begin{tabular}{|c|c|c|c|c|c|c|c|c|c|c|c|c|c|c|c|c|c|}
\hline \multicolumn{18}{|c|}{ Appendixl (Continued) } \\
\hline Sample & $\begin{array}{l}\text { Gain } \\
\text { ID\# }\end{array}$ & $\begin{array}{l}\text { Drill Hole - } \\
\text { Depth }\end{array}$ & ${ }^{40} \mathrm{Ar} r^{39} \mathrm{Ar}$ & ${ }^{38} \mathrm{Ar} /{ }^{39} \mathrm{Ar}$ & ${ }^{37} \mathrm{Ar}{ }^{39} \mathrm{Ar}$ & ${ }^{36} \mathrm{Ar} r^{39} \mathrm{Ar}$ & ${ }^{40^{*}} \mathrm{Ar} r^{39} \mathrm{Ar}$ & $\%{ }^{40} \mathrm{Ar}$ & $\begin{array}{l}\text { Age } \\
\text { (Ma) }\end{array}$ & $\stackrel{ \pm}{ \pm}$ & & J & $\%^{40} \mathrm{Ar}$ & $\begin{array}{l}{ }^{40} \mathrm{Ar} \\
\text { (Moles) }\end{array}$ & $\begin{array}{c}\text { Laser } \\
\text { Power }(W)\end{array}$ & $\begin{array}{l}{ }^{40} \mathrm{Ar} t^{36} \mathrm{Ar} \\
\text { Discr. }\end{array}$ & \pm \\
\hline$\$ 20$ & $2679-02 \mathrm{C}$ & AQ 0802-33.20 & 7.240 & 0.010 & 0.075 & -0.001 & 7.485 & 103.40 & 49.57 & 2.30 & 0.003722 & $\mp 0.000004$ & 0.037 & $3.26 E-16$ & 0.22 & 1.0006 & 0.0018 \\
\hline$\$ 20$ & $2679-020$ & AN 0802-33.20 & 5.929 & 0.014 & 0.382 & 0.008 & 3.520 & 59.40 & 23.48 & 5.64 & 0.003722 & \pm 0.000004 & 0.013 & \$. $12 E-16$ & 0.25 & 1.0006 & 0.0018 \\
\hline$\$ 20$ & 2679-02E & A\& $0802-33.20$ & 4292 & 0.010 & 0.224 & 0.014 & 8.376 & $\$ 95.10$ & 55.38 & 7.70 & 0.003722 & $\doteqdot 0.000004$ & 0.006 & $5.12 E-17$ & 0.27 & 1.0006 & 0.0018 \\
\hline$\$ 20$ & $2679-02 F$ & $A Q 0802-33.20$ & 3.089 & 0.010 & 0.119 & -0.003 & 4.103 & $\$ 32.80$ & 27.34 & 728 & 0.003722 & \pm 0.000004 & 0.005 & $3.57 \mathrm{E}-17$ & 0.30 & 1.0006 & 0.0018 \\
\hline$\$ 20$ & $2679-02 G$ & $A B 0862-33.20$ & 3.206 & 0.015 & 0.000 & -0.008 & $5.45 t$ & 170.10 & 36.24 & 7.28 & 0.003722 & \pm 0.000004 & 0.005 & 4.03E-17 & 0.35 & 0.9988 & 0.0017 \\
\hline$\$ 20$ & $2679-02 H$ & AQ 0302-33.20 & 3.320 & 0.017 & 0.000 & -0.017 & 8.260 & 248.90 & 54.63 & 7.50 & 0.003722 & $\mp 0.000004$ & 0.005 & $3.78 E-17$ & 0.45 & 0.9988 & 0.0017 \\
\hline$\$ 20$ & $2679-02 \xi$ & 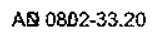 & 19.630 & 0.017 & 0.000 & 0.001 & 19.280 & 98.20 & 125.02 & 5.83 & 0.003722 & $\therefore 0.000004$ & 0.041 & $3.57 E-16$ & 0.99 & 0.9988 & 0.0017 \\
\hline $\mathrm{s} 20$ & $2679-023$ & $A B 08 B 2-33.20$ & 126.460 & 0.025 & 0.000 & 0.030 & 117.606 & 93.00 & 655.00 & 10.10 & 0.003722 & \pm 0.000004 & 0.186 & $1.63 E-15$ & 2.47 & 0.9988 & 0.0017 \\
\hline$\$ 20$ & 2679-03A & $A Q 0802-33.20$ & 12.915 & 0.016 & 0.000 & 0.025 & 5.451 & 42.20 & 36.24 & 3.35 & 0.003722 & \pm 0.000004 & 0.055 & $4.84 E-16$ & 0.10 & 0.9988 & 0.0017 \\
\hline s2o & $2679-03 B$ & AN $0802-33.20$ & 8.438 & 0.012 & 0.025 & 0.005 & 6.923 & 82.00 & 45.89 & 0.83 & 0.003722 & \pm 0.000004 & 0.165 & $1.44 E-15$ & 0.20 & 0.9988 & 0.0017 \\
\hline$\$ 20$ & $2679-03 \mathrm{C}$ & AN $08 D 2-33.20$ & 6.743 & 0.012 & 0.000 & 0.001 & 6.532 & 96.90 & 43.33 & 1.59 & 0.003722 & \pm 0.000004 & 0.052 & $4.56 \mathrm{E}-16$ & 0.22 & 0.9988 & 0.0017 \\
\hline $\mathrm{s} 20$ & $2679-030$ & AE $0802-33.20$ & 4.423 & 0.018 & 0.000 & 0.000 & 4.281 & 96.80 & 28.52 & 3.84 & 0.003722 & \pm 0.000004 & 0.014 & 1.24E-16 & 0.25 & 0.9988 & 0.0017 \\
\hline$\$ 20$ & 2679-83E & AQ $0802-33.20$ & 2.983 & 0.018 & 0.002 & 0.000 & 2.859 & 95.90 & 19.10 & 5.33 & 0.003722 & $\mp 0.000004$ & 0.007 & $6.06 \varepsilon-17$ & 0.27 & 0.9988 & 0.0017 \\
\hline$\$ 20$ & $2679.03 \mathrm{~F}$ & AN $0802-33.20$ & 2.277 & 0.012 & 0.198 & 0.002 & 1.828 & 80.30 & 12.23 & 5.51 & 0.003722 & \pm 0.000004 & 0.005 & $4.20 E-17$ & 0.30 & 0.9988 & 0.0017 \\
\hline $\mathrm{s} 20$ & $2679-036$ & AN $0802-33.20$ & 2.725 & 0.012 & 0.000 & -0.003 & 3.635 & 133.40 & 24.24 & 5.33 & 0.003722 & \pm 0.000004 & 0.006 & $5.47 E-1 ?$ & 0.35 & 0.9988 & 0.0017 \\
\hline$\$ 20$ & $2679-03 \mathrm{H}$ & Aه 0802.33 .20 & 2.831 & 0.014 & 0.085 & -0.003 & 3.770 & 133.20 & 25.14 & 6.90 & 0.003722 & \pm 0.000004 & 0.005 & 4.41E-17 & 0.45 & 0.9988 & 0.0017 \\
\hline$\$ 20$ & $2679-031$ & AN $0802-33.20$ & 29.312 & 0.014 & 0.121 & 0.004 & 28.056 & 95.70 & 179.19 & 4.90 & 0.003722 & \pm 0.000004 & 0.070 & $6.10 E-16$ & 0.99 & 0.9988 & 0.0017 \\
\hline$\$ 20$ & $2679-03 \mathrm{~s}$ & AN 0802-33.20 & 74.773 & 0.017 & 0.000 & 0.034 & 64.864 & 86.70 & 390.15 & 7.82 & 0.003722 & \pm 0.000004 & 0.157 & $1.37 E-15$ & 2.47 & 0.9988 & 0.0017 \\
\hline s21 & $2680-01 \mathrm{~A}$ & AN $0802-84,15$ & 8.572 & $0.0 \div 4$ & 0.000 & 0.018 & 3.213 & 37.50 & 21.44 & 7.90 & 0.003722 & \pm 0.000004 & 0.013 & 1. $18 E-16$ & 0.10 & 0.9988 & 0.0017 \\
\hline s21 & $2680-01 B$ & $A \otimes 0802-84.15$ & 6.682 & 0.015 & 0.096 & 0.010 & 3.634 & 54.40 & 24.24 & 1.71 & 0.003722 & \pm 0.000004 & 0.054 & $4.76 E-16$ & 0.20 & 0.9988 & 0.0017 \\
\hline \$21 & $2680-01 \mathrm{C}$ & AN 0802-84.15 & 6.713 & 0.013 & 0.177 & 0.004 & 5.511 & 82.10 & 36.63 & 1.94 & 0.003722 & $\mp 0.000004$ & 0.045 & $4.02 E-16$ & 0.22 & 0.9988 & 0.0017 \\
\hline$\$ 23$ & $2680-010$ & $A \otimes 0802-84.15$ & 8.037 & 0.013 & 0.076 & 0.002 & 7.540 & 93.80 & 49.93 & 0.99 & 0.003722 & \pm 0.000004 & 0.110 & $9.61 E-16$ & 0.25 & 0.9988 & 0.0017 \\
\hline \$21 & 2680-01E & AN 0802-84.15 & 7.599 & 0.012 & 0.052 & 0.000 & 7.699 & 101.30 & 50.97 & 1.00 & 0.003722 & \pm 0.000004 & 0.102 & 9.03E-16 & 0.27 & 0.9988 & 0.0017 \\
\hline \$21 & $2680-01 F$ & $A \otimes 08 D 2-84,15$ & 7.283 & 0.011 & 0.061 & 0.000 & 7.312 & 190.40 & 48.44 & 1.43 & 0.003722 & \pm 0.000004 & 0.066 & $5.90 E-16$ & 0.30 & 0.9988 & 0.0017 \\
\hline s21 & $2680-01 \mathrm{G}$ & AS $0802-84.15$ & 7.130 & 0.012 & 0.000 & -0.002 & 7.769 & 109.00 & 51.43 & 1.05 & 0.003722 & \pm 0.000004 & 0.078 & $6.93 \mathrm{E}-16$ & 0.35 & 0.9988 & 0.0017 \\
\hline$\$ 21$ & 2680-01H & $A \otimes 0802-84.15$ & 6.217 & 0.012 & 0.106 & -0.002 & 6.781 & 109.10 & 44.97 & 0.97 & 0.003722 & \pm 0.000004 & 0.080 & 7.10E-16 & 0.45 & 0.9988 & 0.0017 \\
\hline$\$ 21$ & $2680-011$ & $A N 08 D 2-84,15$ & 5.328 & 0.014 & 0.165 & 0.004 & 4.191 & 78.70 & 27.92 & 0.59 & 0.003722 & $\mp 0.000004$ & 0.152 & $1.34 E-15$ & 0.99 & 0.9988 & 0.0017 \\
\hline s21 & $2680-01 \mathrm{~J}$ & AS $0802-84.15$ & 8.000 & 0.014 & 0.218 & 0.006 & 6.240 & 78.00 & 41.42 & 3.44 & 0.003722 & $\doteq 0.000004$ & 0.032 & $2.97 E-16$ & 2.47 & 0.9988 & 0.0017 \\
\hline$\$ 21$ & $2680-02 \mathrm{~A}$ & Aه $0802-84.15$ & 10.627 & 0.015 & 0.084 & 0.019 & 4.876 & 45.90 & 32.45 & 4.24 & 0.003722 & $\mp 0.000004$ & 0.032 & $2.84 E-16$ & 0.10 & 0.9988 & 0.0017 \\
\hline s21 & $2680-02 B$ & AN $0802-84.15$ & 6.758 & 0.014 & 0.132 & 0.010 & 3.957 & 58.60 & 26.38 & 1.62 & 0.003722 & $\mp 0.000004$ & 0.061 & $5.31 E-16$ & 0.20 & 0.9988 & 0.0017 \\
\hline s21 & $2680-02 \mathrm{C}$ & AN $0802-84.15$ & 8.355 & 0.014 & 0.109 & 0.006 & 6.556 & 78.50 & 43.50 & 2.43 & 0.003722 & \pm 0.000004 & 0.044 & $3.85 E-16$ & 0.22 & 0.9988 & 0.0017 \\
\hline s21 & $2680-020$ & AQ 0802-84.15 & 9.106 & 0.012 & 0.139 & 0.005 & 7.569 & 83.10 & 50.12 & 1.85 & 0.003722 & \pm 0.000004 & 0.064 & $5.59 E-16$ & 0.25 & 0.9988 & 0.0017 \\
\hline \$21 & $2680-02 E$ & AQ $0802-84.15$ & 7.719 & 0.012 & 0.081 & 0.002 & 7.078 & $9 t .70$ & 46.91 & 1.20 & 0.003722 & \pm 0.000004 & 0.085 & 7. $44 E-16$ & 0.27 & 0.9988 & 0.0017 \\
\hline$\$ 21$ & $2680-02 F$ & AD $0802-84.15$ & 6.842 & 0.011 & 0.130 & 0.000 & 6.830 & 99.80 & 45.29 & 1.14 & 0.003722 & \pm 0.000004 & 0.070 & $6.19 \mathrm{E}-16$ & 0.30 & 0.9988 & 0.0017 \\
\hline$\$ 21$ & $2630-02 G$ & AN $08 D 2-84.15$ & 5.893 & 0.012 & 0.078 & 0.001 & 5.721 & 97.10 & 38.01 & 1.02 & 0.003722 & \pm 0.000004 & 0.072 & $6.38 E-16$ & 0.35 & 0.9988 & 0.0017 \\
\hline s2t & $2680-02 \mathrm{H}$ & AN $0802-84.15$ & 5.103 & 0.012 & 0.133 & 0.001 & 4.810 & 94.30 & 32.01 & 0.92 & 0.003722 & \pm 0.000004 & 0.074 & $6.51 E-16$ & 0.45 & 0.9988 & 0.0017 \\
\hline \$21 & 2680.021 & AS $0802-84.15$ & 5.064 & 0.013 & 0.256 & 0.004 & 3.923 & 77.50 & 26.15 & 0.82 & 0.003722 & \pm 0.000004 & 0.099 & $8.69 E-16$ & 0.99 & 0.9988 & 0.0017 \\
\hline \$21 & $2680-02 \mathrm{~J}$ & AN $0802-84.15$ & 13.770 & 0.017 & 0.000 & 0.037 & 2.749 & 20.00 & 18.36 & 5.20 & 0.003722 & \pm 0.000004 & 0.039 & $3.49 E-16$ & 2.47 & 0.9988 & 0.0017 \\
\hline$\$ 21$ & $2680-03 \mathrm{~A}$ & $A Q 0802-84.15$ & 6.078 & 0.048 & 0.000 & 0.011 & 2.955 & 48.60 & 19.74 & 44.55 & 0.003722 & \pm 0.000004 & 0.002 & $1.79 E-17$ & 0.10 & 0.9988 & 0.0017 \\
\hline s21 & $2680-83 B$ & AQ $0802-84.15$ & 8.065 & 0.016 & 0.027 & 0.015 & 3.618 & 44.90 & 24.43 & 2.75 & 0.003722 & \pm 0.000004 & 0.042 & $3.65 E-16$ & 0.20 & 0.9988 & 0.0017 \\
\hline s21 & $2680-03 \mathrm{C}$ & AN $0802-84.15$ & 4.526 & 0.013 & 0.000 & -0.001 & 4.941 & 109.20 & 32.88 & 2.81 & 0.003722 & \pm 0.000004 & 0.019 & 1.73E-16 & 0.22 & 0.9988 & 0.0017 \\
\hline$\$ 21$ & $2680-03 \mathrm{D}$ & AQ 0802-84.15 & 7.427 & 0.013 & 0.000 & -0.001 & 7.766 & 104.60 & 51.41 & 4.35 & 0.003722 & \pm 0.000004 & 0.021 & $1.90 \mathrm{E}-16$ & 0.25 & 0.9988 & 0.0017 \\
\hline s21 & 2680-03E & AN $0802-84.15$ & 9.615 & 0.015 & 0.082 & 0.008 & 7.122 & 74.10 & 47.20 & 4.59 & 0.003722 & \pm 0.000004 & 0.029 & $2.61 E-16$ & 0.27 & 0.9988 & 0.0017 \\
\hline$\$ 21$ & $2680-03 F$ & AQ 0802-84.15 & 8.885 & 0.011 & 0.004 & -0.001 & 9.243 & 104.00 & 61.02 & 3.51 & 0.003722 & $=0.000004$ & 0.031 & $2.88 E-16$ & 0.30 & 0.9988 & 0.0017 \\
\hline$\$ 21$ & $2680-03 G$ & AN 0802-84.15 & 8.403 & 0.012 & 0.033 & 0.001 & 8.254 & 98.20 & 54.59 & 1.07 & 0.003722 & \pm 0.000004 & 0.101 & $8.89 E-16$ & 0.35 & 0.9988 & 0.0017 \\
\hline s21 & $2680-03 \mathrm{H}$ & AE $0802-84.15$ & 6.284 & 0.012 & 0.114 & 0.000 & 6.347 & 101.00 & 42.12 & 0.66 & 0.003722 & $\mp 0.000004$ & 0.132 & \$.17E-15 & 0.45 & 0.9988 & 0.0017 \\
\hline$\$ 21$ & $2680-031$ & $A Q 0802.84 .15$ & 4.734 & 0.014 & 0.062 & 0.005 & 3.307 & 69.90 & 22.07 & 0.57 & 0.003722 & \pm 0.000004 & 0.152 & t.35E-15 & 0.99 & 0.9988 & 0.0017 \\
\hline
\end{tabular}


Appendixl (Continued)

\begin{tabular}{|c|c|c|c|c|c|c|c|c|c|c|c|c|c|c|c|c|c|}
\hline \multirow{3}{*}{$\begin{array}{c}\text { Sample } \\
\$ 21\end{array}$} & \multirow{3}{*}{$\begin{array}{c}\begin{array}{c}\text { Gain } \\
\text { ID\# }\end{array} \\
2620-035\end{array}$} & \multirow{3}{*}{$\begin{array}{c}\begin{array}{c}\text { Orill Hole - } \\
\text { Depth }\end{array} \\
\text { As } 0802-84.15\end{array}$} & \multirow{3}{*}{$\frac{{ }^{40} \mathrm{Ar}{ }^{39} \mathrm{Ar}}{11.943}$} & \multirow{3}{*}{$\frac{{ }^{38} \mathrm{Ar} r^{39} \mathrm{Ar}}{0.025}$} & \multirow{3}{*}{$\frac{{ }^{37} \mathrm{Ar} f^{39} \mathrm{Ar}}{0.401}$} & \multirow{3}{*}{$\frac{{ }^{36} \mathrm{Ar} /{ }^{39} \mathrm{Ar}}{0.026}$} & \multirow{3}{*}{$\frac{{ }^{40^{\circ}} \mathrm{Ar} r^{39} \mathrm{Ar}}{4.287}$} & Dendix (C) & (inued) & \multirow{3}{*}{$\begin{array}{c}\begin{array}{c} \pm \\
(\mathrm{Ma})\end{array} \\
6.31\end{array}$} & \multirow{2}{*}{\multicolumn{2}{|c|}{$J$}} & \multirow{3}{*}{$\frac{\%^{40} \mathrm{Ar}}{0.030}$} & \multirow{3}{*}{$\begin{array}{l}{ }^{40} \mathrm{Ar} \\
\text { (Moles) }\end{array}$} & \multirow{3}{*}{$\frac{\begin{array}{c}\text { Laser } \\
\text { Power }(W)\end{array}}{2.47}$} & \multirow{3}{*}{$\begin{array}{l}{ }^{40} \mathrm{Ar} r^{36} \mathrm{Ar} \\
\text { Discr. } \\
0.9988\end{array}$} & \\
\hline & & & & & & & & \multirow{2}{*}{$\frac{\%^{46^{n} \mathrm{Ar}}}{35.90}$} & \multirow{2}{*}{$\begin{array}{l}\begin{array}{c}\text { Age } \\
(\mathrm{Ma})\end{array} \\
28.56\end{array}$} & & & & & & & & \pm \\
\hline & & & & & & & & & & & 0.003722 & \pm 0.000004 & & & & & \\
\hline s22 & $2681-01 \mathrm{~A}$ & AQ $1502-53.30$ & 11.948 & 0.018 & 0.101 & 0.023 & 5.154 & 43.10 & 34.28 & 1.74 & 0.003722 & \pm 0.000004 & 0.119 & $1.04 E-15$ & 0.10 & 0.9988 & 0.0017 \\
\hline \$22 & $2687-018$ & AS $1502-53.30$ & 5.463 & 0.012 & 0.027 & 0.002 & 4.763 & 87.20 & 31.70 & 0.43 & 0.003722 & \pm 0.000004 & 0.225 & $1.96 E-15$ & 0.20 & 0.9988 & 0.0017 \\
\hline$\$ 22$ & $2681-01 c$ & AS $1502-53.30$ & 5.159 & 0.012 & 0.026 & 0.001 & 4.954 & 96.00 & 32.97 & 0.21 & 0.003722 & \pm 0.000004 & 0.441 & $3.85 E-15$ & 0.22 & 0.9988 & 0.0017 \\
\hline $\mathrm{s} 22$ & $2681-010$ & AQ $1502-53.30$ & 5.286 & 0.012 & 0.026 & 0.001 & 5.321 & 96.90 & 34.06 & 0.27 & 0.003722 & \pm 0.000004 & 0.329 & $2.85 E-15$ & 0.25 & 0.9988 & 0.0017 \\
\hline $\mathrm{s} 22$ & 2681-01E & AS $\div 502-53.30$ & 5.565 & 0.012 & 0.043 & 0.000 & 5.426 & 97.50 & 36.07 & 0.36 & 0.003722 & \pm 0.000004 & 0.207 & $4.78 \mathrm{E}-15$ & 0.27 & 0.9988 & 0.0017 \\
\hline S22 & $2681-01 \mathrm{~F}$ & AN $1502-53.30$ & 5.932 & 0.012 & 0.058 & 0.001 & 5.669 & 95.60 & 37.67 & 0.53 & 0.003722 & $\mp 0.000004$ & 0.151 & $1.29 E-15$ & 0.30 & 0.9988 & 0.0017 \\
\hline $\mathrm{s} 22$ & $2681-01 \mathrm{G}$ & AS 1502.53 .30 & 6.145 & 0.012 & 0.033 & 0.000 & 6.247 & 101.70 & 41.47 & 0.56 & 0.003722 & \pm 0.000004 & 0.150 & $1.29 E-15$ & 0.35 & 0.9988 & 0.0017 \\
\hline s22 & $2681-01 \mathrm{H}$ & AS 1502.53 .30 & 5.319 & 0.014 & 0.064 & 0.000 & 5.218 & 98.10 & 34.70 & 0.76 & 0.003722 & $\div 0.000004$ & 0.094 & $8.07 E-16$ & 0.45 & 0.9988 & 0.0017 \\
\hline $\mathrm{s} 22$ & $2681-031$ & AS $1502-53.30$ & 4.888 & 0.012 & 0.052 & 0.000 & 4.828 & 98.80 & 32.13 & 1.18 & 0.003722 & \pm 0.000004 & 0.049 & $4.08 E-16$ & 0.99 & 0.9988 & 0.0017 \\
\hline $\mathrm{s} 22$ & 2681.015 & AQ $1502-53.30$ & 9.772 & 0.018 & 0.000 & 0.012 & 6.102 & 62.40 & 40.51 & 4.13 & 0.003722 & \pm 0.000004 & 0.029 & $2.32 E-16$ & 2.47 & 0.9988 & 0.0017 \\
\hline $\mathrm{s} 22$ & $2683-02 A$ & $A Q 1502-53.30$ & 27.932 & 0.026 & 0.142 & 0.071 & 7.042 & 25.20 & 46.68 & 4.07 & 0.003722 & \pm 0.000004 & 0.170 & $1.48 E-15$ & 0.10 & 0.9988 & 0.0017 \\
\hline $\mathrm{s} 22$ & 2681.028 & AQ 1502-53.30 & 5.926 & 0.012 & 0.068 & 0.003 & 5.035 & 85.00 & 33.50 & 0.53 & 0.003722 & \pm 0.000004 & 0.160 & 1.40E-15 & 0.20 & 0.9988 & 0.0017 \\
\hline $\mathrm{s} 22$ & $2681-02 \mathrm{C}$ & A\& $1502-53.30$ & 5.690 & 0.012 & 0.042 & 0.000 & 5.565 & 97.80 & 36.98 & 0.64 & 0.003722 & $=0.000004$ & 0.131 & \{.15E-15 & 0.22 & 0.9988 & 0.0017 \\
\hline \$22 & $2681-020$ & AQ $1502-53.30$ & 8.073 & 0.012 & 0.014 & 0.000 & 5.945 & 97.90 & 39.48 & 0.63 & 0.003722 & \pm 0.000004 & 0.134 & \$.15E-15 & 0.25 & 0.9988 & 0.0017 \\
\hline $\mathrm{s} 22$ & $2681-02 E$ & $A S 1502-53.30$ & 5.822 & 0.012 & 0.022 & 0.000 & 5.839 & 100.30 & 38.79 & 0.25 & 0.003722 & \pm 0.000004 & 0.381 & 3.33E-15 & 0.27 & 0.9988 & 0.0017 \\
\hline $\mathrm{s} 22$ & $2681-02 F$ & AQ $\{502.53 .30$ & 5.931 & 0.012 & 0.015 & 0.000 & 5.877 & 99.10 & 39.04 & 0.18 & 0.003722 & \pm 0.000004 & 0.712 & $6.23 E-15$ & 0.30 & 0.9988 & 0.0017 \\
\hline \$22 & $2681-02 G$ & AN $1502-53.30$ & 6.149 & 0.012 & 0.015 & 0.000 & 6.038 & 98.20 & 40.09 & 0.18 & 0.003722 & \pm 0.000004 & 0.716 & $6.27 E-15$ & 0.35 & 0.9988 & 0.0017 \\
\hline$\$ 22$ & $2681-02 \mathrm{H}$ & AD $1502-53.30$ & 6.643 & 0.012 & 0.023 & 0.000 & 6.541 & 98.50 & 43.40 & 0.23 & 0.003722 & \pm 0.000004 & 0.663 & $5.82 E-15$ & 0.45 & 0.9988 & 0.0017 \\
\hline $\mathrm{s} 22$ & 2681-021 & $A Q 1502-53.30$ & 5.540 & 0.013 & 0.063 & $0.00 t$ & 5.267 & 95.10 & 35.02 & 0.63 & 0.003722 & \pm 0.000004 & 0.115 & $1.03 E-15$ & 0.99 & 0.9988 & 0.0017 \\
\hline$s 22$ & $2683-02 J$ & $A \mathbb{A} 1502-53.30$ & 8.070 & 0.016 & 0.800 & 0.012 & 4.494 & 55.70 & 29.92 & 1.99 & 0.003722 & \pm 0.000004 & 0.057 & $5.32 E-16$ & 2.47 & 0.9988 & 0.0017 \\
\hline \$22 & $2681-03 \mathrm{~A}$ & AN $1502-53.30$ & 144.136 & 0.090 & 0.031 & 0.466 & 6.302 & 4.40 & 41.83 & 17.20 & 0.003722 & \pm 0.000004 & 0.431 & $3.75 E-15$ & 0.10 & 0.9988 & 0.0017 \\
\hline s22 & $2681-038$ & $A \mathbb{A} 1502-53.30$ & 8.714 & 0.014 & 0.131 & 0.010 & 5.912 & 67.90 & 39.27 & 1.77 & 0.003722 & \pm 0.000004 & 0.073 & $6.41 E-16$ & 0.20 & 0.9988 & 0.0017 \\
\hline $\mathrm{s} 22$ & $2681.03 \mathrm{C}$ & AN 1502.53 .30 & 8.042 & 0.012 & 0.148 & 0.006 & 6.399 & 79.60 & 42.47 & 1.87 & 0.003722 & \pm 0.000004 & 0.059 & $5.13 E-16$ & 0.22 & 0.9988 & 0.0017 \\
\hline$\$ 22$ & $2681-030$ & $A \mathbb{1} 1502-53.30$ & 9.773 & 0.012 & 0.139 & 0.006 & 8.111 & 83.00 & 53.66 & 1.65 & 0.003722 & \pm 0.000004 & 0.095 & $8.31 E-36$ & 0.25 & 0.9988 & 0.0017 \\
\hline $\mathrm{s} 22$ & 2681-03E & AS $1502-53.30$ & 9.873 & 0.012 & 0.048 & 0.004 & 8.783 & 89.00 & 58.03 & 0.69 & 0.003722 & \pm 0.000004 & 0.236 & $2.06 \mathrm{E}-15$ & 0.27 & 0.9988 & 0.0017 \\
\hline $\mathrm{s} 22$ & $2681-03 \mathrm{~F}$ & $A Q 1502-53.30$ & 8.320 & 0.011 & 0.059 & 0.000 & 8.331 & 100.10 & 55.09 & 0.68 & 0.003722 & $\div 0.000004$ & 0.177 & $1.55 E-15$ & 0.30 & 0.9988 & 0.0017 \\
\hline 522 & $2681-03 G$ & AN $1502-53.30$ & 6.189 & 0.011 & 0.078 & -0.002 & 6.765 & 109.30 & 44.87 & 1.45 & 0.003722 & \pm 0.000004 & 0.053 & $4.85 \mathrm{E}-16$ & 0.35 & 0.9988 & 0.0017 \\
\hline$s 22$ & 2681-03H & $A \Xi 1502-53.30$ & 4.774 & 0.011 & 0.000 & 0.000 & 4.651 & 97.50 & 30.97 & 1.22 & 0.003722 & \pm 0.000004 & 0.049 & $4.43 E-16$ & 0.45 & 0.9988 & 0.0017 \\
\hline$\$ 22$ & $2681-039$ & AN $1502-53.30$ & 5.194 & 0.014 & 0.039 & 0.001 & 4.796 & 92.30 & 31.92 & 0.39 & 0.003722 & $\div 0.000004$ & 0.222 & \{.95E-15 & 0.99 & 0.9988 & 0.0017 \\
\hline s22 & $2681-03 \mathrm{~J}$ & $A \Delta 1502-53.30$ & 6.699 & 0.014 & 0.053 & 0.007 & 4.724 & 70.50 & 31.45 & 1.11 & 0.003722 & \pm 0.000004 & 0.098 & $8.73 E-16$ & 2.47 & 1.0012 & 0.0017 \\
\hline$\$ 23$ & $2682-01 \mathrm{~A}$ & A® $1502-87.65$ & 26.455 & 0.026 & 0.065 & 0.079 & 3.144 & 11.90 & 20.99 & 2.16 & 0.003722 & $\div 0.000004$ & $0.5 \div 0$ & $4.45 E-15$ & 0.10 & 1.0012 & 0.0017 \\
\hline$\$ 23$ & $2682-0 ! B$ & $A \otimes 1502-87.65$ & 5.413 & 0.012 & 0.003 & 0.005 & 3.937 & 72.70 & 26.24 & 0.54 & 0.003722 & \pm 0.000004 & 0.201 & $1.75 E-15$ & 0.20 & 1.0012 & 0.0017 \\
\hline$\$ 23$ & $2682-01 \mathrm{C}$ & A太 $1502-87.65$ & 4.618 & 0.012 & 0.051 & 0.002 & 4.140 & 89.60 & 27.58 & 0.49 & 0.003722 & \pm 0.000004 & 0.142 & $1.24 E-15$ & 0.22 & 1.0012 & 0.0017 \\
\hline$\$ 23$ & $2682-010$ & Aه $3502-87.65$ & 5.089 & 0.013 & 0.010 & 0.001 & 4.806 & 94.40 & 31.98 & 0.38 & 0.003722 & \pm 0.000004 & 0.203 & $1.78 E-15$ & 0.25 & 1.0012 & 0.0017 \\
\hline$\$ 23$ & 2682-0tE & AN $15 D 2-87.65$ & 5.008 & 0.012 & 0.026 & 0.001 & 4.812 & 96.10 & 32.03 & 0.22 & 0.003722 & \pm 0.000004 & 0.330 & $2.88 E-15$ & 0.27 & 1.0012 & 0.0017 \\
\hline$\$ 23$ & $2682-01 \mathrm{~F}$ & AQ $\$ 502-87.65$ & 4.918 & 0.012 & 0.012 & 0.000 & 4.807 & 97.80 & 31.99 & 0.16 & 0.003722 & \pm 0.000004 & 0.590 & $5.15 \mathrm{E}-15$ & 0.30 & 1.0012 & 0.0017 \\
\hline$\$ 23$ & $2682-016$ & AN $1502-87.65$ & 4.927 & 0.012 & 0.007 & 0.000 & 4.798 & 97.40 & 31.93 & 0.14 & 0.003722 & \pm 0.000004 & 0.760 & $6.63 E-15$ & 0.35 & 1.0012 & 0.0017 \\
\hline$\$ 23$ & 2682-01H & AE $1502-87.65$ & 4.964 & 0.012 & 0.010 & 0.001 & 4.808 & 96.90 & 32.00 & 0.15 & 0.003722 & \pm 0.000004 & 0.718 & $6.29 \varepsilon-15$ & 0.45 & 1.0012 & 0.0017 \\
\hline$\$ 23$ & 2682.013 & $A Q 15 D 2-87.65$ & 4.909 & 0.013 & 0.006 & 0.001 & 4.645 & 94.60 & 30.92 & 0.22 & 0.003722 & \pm 0.000004 & 0.440 & $3.85 E-15$ & 0.99 & 1.0012 & 0.0017 \\
\hline$\$ 23$ & $2682-013$ & AN 1502-87.65 & 6.104 & 0.012 & 0.012 & 0.007 & 4.147 & 67.90 & 27.63 & 0.96 & 0.003722 & \pm 0.000004 & 0.116 & 1.04E-15 & 2.47 & 1.0012 & 0.0017 \\
\hline s23 & $2682-02 A$ & $A \otimes 1502-87.65$ & 4.160 & 0.011 & 0.000 & 0.001 & 3.912 & 94.00 & 26.08 & 1.78 & 0.003722 & \pm 0.000004 & 0.030 & $2.87 E-16$ & 0.10 & 1.0012 & 0.0017 \\
\hline $\mathrm{s} 23$ & $2682-028$ & AQ $1502-87.65$ & 3.747 & 0.011 & 0.010 & 0.000 & 3.895 & 104.00 & 25.97 & 0.42 & 0.003722 & \pm 0.000004 & 0.133 & $\{.17 E-15$ & 0.20 & 1.0012 & 0.0017 \\
\hline S23 & $2682-02 \mathrm{C}$ & $A B 1502-87.65$ & 3.701 & 0.013 & 0.009 & 0.000 & 3.788 & 102.40 & 25.26 & 0.38 & 0.003722 & $\div 0.000004$ & 0.137 & \{.20E-15 & 0.22 & 1.0012 & 0.0017 \\
\hline s23 & $2682-020$ & AN $1502-87.65$ & 4.233 & 0.013 & 0.008 & 0.000 & 4.241 & 100.20 & 28.26 & 0.32 & 0.003722 & \pm 0.000004 & 0.205 & $1.79 E-15$ & 0.25 & 1.0012 & 0.0017 \\
\hline $\mathrm{s} 23$ & $2682-02 E$ & $A Q 1502-87.65$ & 4.714 & 0.012 & 0.004 & 0.000 & 4.578 & 97.10 & 30.48 & 0.19 & 0.003722 & \pm 0.000004 & 0.450 & $3.94 E-15$ & 0.27 & 1.0012 & 0.0017 \\
\hline
\end{tabular}




\begin{tabular}{|c|c|c|c|c|c|c|c|c|c|c|c|c|c|c|c|c|c|}
\hline \multicolumn{18}{|c|}{ Appendix (Continued) } \\
\hline Sample & $\begin{array}{l}\text { fâin } \\
\text { ID\# }\end{array}$ & $\begin{array}{l}\text { Drill Hole- } \\
\text { Depth }\end{array}$ & ${ }^{40} \mathrm{Ar}{ }^{39} \mathrm{Ar}$ & ${ }^{38} \mathrm{Ar}{ }^{39} \mathrm{Ar}$ & ${ }^{37} \mathrm{Ar}{ }^{39} \mathrm{Ar}$ & ${ }^{36} \mathrm{Ar}{ }^{39} \mathrm{Ar}$ & ${ }^{40^{*}} \mathrm{Ar} /{ }^{39} \mathrm{Ar}$ & $\%{ }^{40} \mathrm{Ar}$ & $\begin{array}{l}\text { Age } \\
\text { (Ma) }\end{array}$ & $\underset{\text { (Ma) }}{\stackrel{ \pm}{*}}$ & $J$ & $\%{ }^{40} \mathrm{Ar}$ & $\begin{array}{l}{ }^{40} \mathrm{Ar} \\
\text { (Moles) }\end{array}$ & $\begin{array}{c}\text { Laser } \\
\text { Power }(W)\end{array}$ & $\begin{array}{l}{ }^{40} \mathrm{Ar} 1^{36} \mathrm{Ar} \\
\text { Discr. }\end{array}$ & \pm & \\
\hline$\$ 23$ & $2682-02 \mathrm{~F}$ & AN $1502-87.65$ & 4.799 & 0.012 & 0.002 & 0.000 & 4.758 & 99.20 & 31.67 & 0.14 & 0.003722 & $\doteqdot 0.000004$ & 0.728 & $6.36 E-15$ & 0.30 & 1.0012 & 0.0047 \\
\hline$\$ 23$ & $2682-02 G$ & AN $1502-87.65$ & 4.844 & 0.012 & 0.002 & 0.000 & 4.825 & 99.60 & 32.11 & 0.11 & 0.003722 & \pm 0.000004 & 1.223 & $1.07 E-14$ & 0.35 & 1.0012 & 0.0017 \\
\hline s23 & $2682-02 \mathrm{H}$ & AN $1502-87.65$ & 4.973 & 0.011 & 0.002 & 0.000 & 4.971 & 100.00 & 33.07 & 0.11 & 0.003722 & \pm 0.000004 & 1.559 & $1.36 E-14$ & 0.45 & 1.0012 & 0.0017 \\
\hline s23 & $2682-021$ & $A Q 1502-87.65$ & 5.030 & 0.012 & 0.000 & 0.000 & 4.925 & 97.90 & 32.77 & 0.12 & 0.003722 & \pm 0.000004 & 1.419 & $1.24 E-14$ & 0.99 & 1.0012 & 0.0057 \\
\hline$\$ 23$ & $2682-02 \mathrm{~J}$ & $A Q 1502-87.65$ & 5.608 & 0.013 & 0.000 & 0.004 & 4.526 & 80.70 & 30.13 & 0.54 & 0.003722 & $\div 0.000004$ & 0.162 & $1.43 E-15$ & 2.47 & $1.00 \div 2$ & $0.00 \div 7$ \\
\hline s23 & $2682-03 \mathrm{~A}$ & AQ $1502-87.65$ & 3.996 & 0.011 & 0.000 & -0.007 & 6.156 & 154.10 & 40.87 & 2.65 & 0.003722 & \pm 0.000004 & 0.019 & $1.66 E-16$ & 0.10 & 1.0012 & 0.0017 \\
\hline$\$ 23$ & $2682-038$ & $A Q 1502-87.65$ & 3.851 & 0.012 & 0.000 & 0.000 & 3.924 & 101.90 & 26.16 & 0.41 & 0.003722 & \pm 0.000004 & 0.149 & $1.29 E-15$ & 0.20 & 1.0012 & 0.0017 \\
\hline$\$ 23$ & $2682-03 \mathrm{C}$ & AQ $1502-87.65$ & 4.693 & 0.012 & 0.000 & 0.000 & 4.670 & 99.50 & 31.09 & 0.23 & 0.003722 & \pm 0.000004 & 0.310 & $2.70 E-15$ & 0.22 & 1.0012 & 0.0017 \\
\hline $\mathrm{s} 23$ & $2682-030$ & AE $1502-87.65$ & 4.812 & 0.012 & 0.000 & 0.000 & 4.881 & 101.40 & 32.48 & 0.22 & 0.003722 & $\mp 0.000004$ & 0.415 & $3.62 E-15$ & 0.25 & 1.0012 & 0.0017 \\
\hline$\$ 23$ & 2682-03E & AS 1502-87.65 & 4.828 & 0.012 & 0.000 & 0.000 & 4.829 & 100.00 & 32.14 & 0.16 & 0.003722 & \pm 0.000004 & 0.537 & $4.68 \mathrm{E}-15$ & 0.27 & 1.0012 & 0.0017 \\
\hline$\$ 23$ & $2682-03 \mathrm{~F}$ & $A \otimes 1502-87.65$ & 4.947 & 0.012 & 0.000 & 0.000 & 5.013 & 101.40 & 33.35 & 0.20 & 0.003722 & \pm 0.000004 & 0.457 & $3.97 E-15$ & 0.30 & 1.0012 & 0.0017 \\
\hline s23 & $2682-03 \mathrm{G}$ & AN $1502-87.65$ & 4.982 & 0.011 & 0.000 & 0.000 & 5.065 & 101.70 & 33.70 & 0.22 & 0.003722 & \pm 0.000004 & 0.378 & 3.30E-15 & 0.35 & 1.0012 & 0.0017 \\
\hline \$23 & $2682-034-$ & AQ $1502-87.65$ & 4.929 & 0.013 & 0.000 & 0.000 & 4.821 & 97.80 & 32.09 & 0.43 & 0.003722 & \pm 0.000004 & 0.179 & 1.55E-15 & 0.45 & 1.0012 & 0.0017 \\
\hline s23 & $2682-031$ & AN 1502-87.65 & 4.927 & 0.011 & 0.000 & 0.001 & 4.771 & 96.80 & 31.76 & 1.07 & 0.003722 & \pm 0.000004 & 0.059 & $5.01 \mathrm{E}-1 \hat{0}$ & 0.99 & 1.0012 & 0.0017 \\
\hline $\mathrm{S} 23$ & $2682-03 \mathrm{~J}$ & $A N \leqslant 502-87.65$ & 5.504 & 0.012 & 0.081 & 0.004 & 4.198 & 76.30 & 27.97 & 1.13 & 0.003722 & \pm 0.000004 & 0.065 & $5.53 E-16$ & 2.47 & 1.0012 & 0.0017 \\
\hline \multirow{2}{*}{\multicolumn{2}{|c|}{$\begin{array}{c}\text { Jpicall fill } \\
\text { system blanck }\end{array}$}} & $\begin{array}{c}{ }^{40} \mathrm{Ar} \\
(\mathrm{nA}) \\
\end{array}$ & \pm & $\begin{array}{l}{ }^{39} \mathrm{Ar} \\
(\mathrm{nA})\end{array}$ & \pm & $\begin{array}{l}{ }^{38} \mathrm{Ar} \\
(\mathrm{nA})\end{array}$ & \pm & $\begin{array}{l}{ }^{37} \mathrm{Ar} \\
(\mathrm{nA})\end{array}$ & \pm & $\begin{array}{l}{ }^{36} \mathrm{Ar} \\
(\mathrm{nA})\end{array}$ & \pm & \multicolumn{3}{|c|}{ Air pipette ${ }^{40} \mathrm{Ar} /{ }^{35} \mathrm{Ar}$} & \multicolumn{3}{|l|}{ \pm} \\
\hline & & 0.00661 & 0.00007 & 0.000065 & 0.00001 & 0.000032 & 0.000004 & 0.00032 & 0.00001 & 0.00011 & 0.000004 & & 1.0010 & & 0.0018 & & \\
\hline
\end{tabular}


Anexo 5 - Relação da Amostras, Coordenadas e Procedimentos Analíticos Aplicados

\begin{tabular}{|c|c|c|c|c|c|c|c|c|c|c|c|c|c|}
\hline \multicolumn{14}{|c|}{ Amostras Coletadas em Afloramentos } \\
\hline \multirow[t]{2}{*}{ Amostra } & \multicolumn{3}{|c|}{$\begin{array}{l}\text { Coordenadas Locais } \\
(\mathrm{m})\end{array}$} & \multirow[t]{2}{*}{ Tipo } & \multirow[t]{2}{*}{ Petrografia } & \multirow[t]{2}{*}{ MEV } & \multirow[t]{2}{*}{ DR-X } & \multirow[t]{2}{*}{ Rietveld } & \multirow[t]{2}{*}{ Mössbauer } & MES & Anális & e Química & $\begin{array}{c}\text { Isótopos } \\
\text { C e O }\end{array}$ \\
\hline & Este & Norte & Altitude & & & & & & & & MBR & ACTLAB & \\
\hline & & & & & Am & iostras & do Gru & po 1 & & & & & \\
\hline $\mathrm{MACl2l}$ & 2450 & -820 & 1022 & $\mathrm{DA}$ & $\mathrm{X}$ & & & & & & & & \\
\hline MAC122 & 2250 & -800 & 960 & FS & $\mathrm{X}$ & & & & & & & & \\
\hline $\mathrm{MAC} 130$ & 2425 & -830 & 1002 & DA & $\mathrm{X}$ & $\mathrm{X}$ & $\mathrm{X}$ & & & & & $\mathrm{X}$ & \\
\hline MACl31 & 2429 & -829 & 1003 & $\mathrm{DA}$ & $\mathrm{X}$ & & $\mathrm{X}$ & & & & & $\mathrm{X}$ & \\
\hline $\mathrm{MAC} 132$ & 2435 & -827 & 1003 & DA & $X$ & & $\mathrm{X}$ & & & & & $\mathrm{X}$ & \\
\hline $\mathrm{MACl} 33$ & 2440 & -823 & 1004 & $\mathrm{MC}$ & $\mathrm{X}$ & & $\mathrm{X}$ & & & & & $x$ & \\
\hline MACl34 & 2443 & -818 & 1004 & DA & $X$ & & $\mathrm{X}$ & & & $\mathrm{X}$ & & $\mathrm{X}$ & \\
\hline MACl35 & 2448 & -815 & 1005 & $\mathrm{DA}$ & $X$ & $\mathrm{X}$ & $\mathrm{X}$ & & & & & $\mathrm{X}$ & \\
\hline MAC136 & 2449 & -814 & 1005 & $\mathrm{MC}$ & $X$ & & $\mathrm{X}$ & & & & & $X$ & \\
\hline MAC137 & 2452 & -812 & 1006 & DA & $\mathrm{X}$ & & $\mathrm{X}$ & & & $X$ & & $\mathrm{X}$ & \\
\hline MAC138 & 2456 & -812 & 1006 & DA & $\mathrm{X}$ & & $\mathrm{X}$ & & & & & $\mathrm{X}$ & \\
\hline MAC139 & 2460 & -809 & 1006 & $\mathrm{DA}$ & $\mathrm{X}$ & & $X$ & & & $\mathrm{X}$ & & $\mathrm{X}$ & \\
\hline $\mathrm{MAC} 140$ & 2370 & -837 & 997 & FS & $\mathrm{X}$ & $\mathrm{X}$ & $\mathrm{X}$ & & & & & $X$ & \\
\hline MACl4I & 2400 & -840 & 998 & FS & $\mathrm{X}$ & $X$ & $X$ & & & & & $X$ & \\
\hline & & & & & $\mathbf{A m}$ & lostras & do Gru & 002 & & & & & \\
\hline $\mathrm{MACl}$ & 2340 & -650 & 920 & ID-DL & $\mathrm{X}$ & & & & & & & $\mathrm{X}$ & \\
\hline MAC4 & 2426 & -805 & 1008 & ID & $\mathrm{X}$ & & $X$ & & & & $X$ & $\mathrm{X}$ & \\
\hline MAC5 & 2461 & -789 & 1012 & $\mathrm{ID}$ & $\mathrm{X}$ & & $\mathrm{X}$ & & & & $X$ & $\mathrm{X}$ & \\
\hline MAC5A & 2461 & -789 & 1012 & ID-HM & & & & & & & & $\mathrm{X}$ & \\
\hline MAC6 & 2464 & -763 & 1011 & ID-HM & & $X$ & & & & & & $\mathrm{X}$ & \\
\hline MAC6A & 2464 & -763 & 1011 & ID-HM & & & & & & $\mathrm{X}$ & & $\mathrm{X}$ & \\
\hline MAC7 & 2481 & -731 & 1011 & ID & $\mathrm{X}$ & & $\mathrm{X}$ & & & & $X$ & $X$ & \\
\hline MAC7A & 2481 & .731 & 1011 & ID-HM & & & & & & & & $X$ & \\
\hline MAC8 & 2489 & -699 & 1012 & ID & $X$ & & $X$ & & & & $X$ & $X$ & \\
\hline MAC8A & 2489 & .699 & 1012 & ID-HM & & & & & & & & $\mathrm{X}$ & \\
\hline MAC9 & 2506 & -659 & $10: 2$ & ID & $\mathrm{X}$ & & $\mathrm{X}$ & & & & $\mathrm{X}$ & $X$ & \\
\hline MAC 10 & 2511 & -618 & 1010 & ID & $X$ & & $X$ & & & & $X$ & $X$ & \\
\hline MACl0A & 2511 & -618 & 1010 & ID-HM & & & & & & & & $\mathrm{X}$ & \\
\hline MACl1 & 2509 & -584 & 1012 & ID & $\mathrm{X}$ & & $X$ & & & & $\mathrm{X}$ & $X$ & \\
\hline MACl1A & 2509 & -584 & 1012 & ID-HM & & & & & & & & $\mathrm{X}$ & \\
\hline MAC16 & 1980 & -530 & 917 & ID-DL & & $\mathrm{X}$ & & & & & & $X$ & \\
\hline MAC81 & 2040 & -490 & 954 & ID-DL & & & & & & & & $X$ & \\
\hline МАC96 & 1980 & -500 & 932 & ID & $\mathrm{X}$ & $X$ & $\mathrm{X}$ & & $\mathrm{X}$ & $\mathrm{X}$ & $\mathrm{X}$ & $\mathrm{X}$ & \\
\hline $\mathrm{MAC} 100$ & 2436 & -793 & 1009 & ID-DL & & & & & $\mathrm{X}$ & & & $\mathrm{X}$ & \\
\hline MAC101 & 2476 & -512 & 1017 & ID•DL & $X$ & & & & & $X$ & & & \\
\hline MAC 102 & 2420 & -810 & 1008 & ID-DL & $\mathrm{X}$ & & & & & $\mathrm{X}$ & & $\mathrm{X}$ & \\
\hline MAC103 & 2422 & -810 & 1008 & ID-DL & $X$ & & & & & & & $\mathrm{X}$ & \\
\hline ISO1 & 2420 & -810 & 1008 & ID-DL & $X$ & & & & & & & & $\mathrm{X}$ \\
\hline ISO2 & 2422 & -808 & 1007 & ID-DL & $X$ & & & & & & & & $X$ \\
\hline 1503 & 2423 & -807 & 1009 & ID-DI. & $X$ & & & & & & & & $X$ \\
\hline ISO4 & 2430 & -804 & 1009 & ID DL & $\mathrm{X}$ & & & & & & & & $\mathrm{X}$ \\
\hline ISO6 & 2434 & -797 & 1009 & ID-DL & $\mathrm{X}$ & & & & & & & & $X$ \\
\hline 1508 & 2448 & -793 & 1014 & ID-DL & $X$ & & & & & & & & $X$ \\
\hline 1509 & 2462 & -791 & 1014 & ID-DL & $X$ & & & & & & & & $\mathrm{X}$ \\
\hline ISO11 & 2464 & -783 & 1012 & ID-DL & $X$ & & & & & $\mathrm{X}$ & & & $\mathrm{X}$ \\
\hline ISO12 & 2467 & -775 & 1012 & ID -DL & $X$ & & & & & & & & $\mathrm{X}$ \\
\hline 15014 & 2470 & -770 & 1014 & ID-DL & $X$ & & & & & & & & $X$ \\
\hline ISO15 & 2470 & -768 & 1015 & ID-DL & $\mathrm{X}$ & & & & & & & & $X$ \\
\hline ISO16 & 2464 & -765 & 1013 & ID-DL & $\mathrm{X}$ & & & & & & & & $X$ \\
\hline ISO18 & 2476 & -752 & 1012 & ID-DL & $\mathrm{X}$ & & & & & $X$ & & & $X$ \\
\hline ISO19 & 2479 & -745 & 1013 & ID-DL & $X$ & & & & & $X$ & & & $X$ \\
\hline ISO20 & 2480 & -742 & 1012 & ID.DL & $X$ & & & & & $X$ & & & $X$ \\
\hline ISO21 & 2482 & -734 & 1012 & ID-DL & $X$ & & & & & $X$ & & & $X$ \\
\hline ISO23 & 2487 & -722 & 1013 & ID-DL & $\mathrm{X}$ & & & & & $X$ & & & $X$ \\
\hline ISO24 & 2488 & -717 & 1013 & ID-DL & $X$ & & & & & $\mathrm{X}$ & & & $X$ \\
\hline ISO25 & 2492 & -709 & 1015 & ID-DL & $X$ & & & & & & & & $X$ \\
\hline ISO26 & 2496 & -696 & 1013 & ID-DL & $X$ & & & & & $\mathrm{X}$ & & & $X$ \\
\hline ISO27 & 2497 & -692 & 1013 & ID-DL & $X$ & & & & & & & & $\mathrm{X}$ \\
\hline ISO28 & 2501 & -680 & 1012 & ID-DL & $\mathrm{X}$ & & & & & & & & $\mathrm{X}$ \\
\hline $1 \mathrm{SO} 29$ & 2504 & -669 & 1012 & ID.DL & $\mathrm{X}$ & & & & & $\mathrm{X}$ & & & $X$ \\
\hline 15030 & 2506 & -660 & 1012 & ID-DL & $\mathrm{X}$ & & & & & & & & $X$ \\
\hline ISO32 & 2508 & -647 & 1011 & ID-DL & $\mathrm{X}$ & & & & & & & & $X$ \\
\hline ISO34 & 2509 & -640 & 1011 & ID-DL & $\mathrm{X}$ & $X$ & & & & $X$ & & & $\mathrm{X}$ \\
\hline
\end{tabular}




\begin{tabular}{|c|c|c|c|c|c|c|c|c|c|c|c|c|c|}
\hline \multirow[t]{2}{*}{ Amostra } & \multicolumn{3}{|c|}{$\begin{array}{l}\text { Coordenadas Locais } \\
\qquad(\mathrm{m})\end{array}$} & \multirow[t]{2}{*}{ Tipo } & \multirow[t]{2}{*}{ Petrografia } & \multirow[t]{2}{*}{ MEV } & \multirow[t]{2}{*}{ DR-X } & \multirow[t]{2}{*}{ Rietveld } & \multirow[t]{2}{*}{ Mössbauer } & \multirow[t]{2}{*}{ MES } & \multicolumn{2}{|c|}{ Análise Química } & \multirow[t]{2}{*}{$\begin{array}{c}\text { Isótopos } \\
\text { C e O }\end{array}$} \\
\hline & Este & Norte & Altitude & & & & & & & & MBR & ACTLAB & \\
\hline ISO36 & 2511 & -619 & 1011 & ID-DL & $X$ & $\mathrm{X}$ & & & & & & & $\mathrm{X}$ \\
\hline ISO37 & 2511 & -619 & 1011 & ID-DL & $X$ & & & & & $\mathrm{X}$ & & & $X$ \\
\hline ISO38 & 2512 & -600 & 1012 & ID-DL & $\mathrm{X}$ & $\mathrm{X}$ & & & & & & & $X$ \\
\hline ISO39 & 2513 & -587 & 1013 & ID.DL & $X$ & $X$ & & & & $X$ & & & $X$ \\
\hline ISO40 & 2507 & -577 & 1013 & ID-DL & $\mathrm{X}$ & $\mathrm{X}$ & & & & & & & $X$ \\
\hline 15042 & 2511 & -567 & 1013 & ID.DL & $X$ & $\mathrm{X}$ & & & & & & & $X$ \\
\hline ISO43 & 2509 & -562 & 1013 & ID-DL & $X$ & & & & & $X$ & & & $X$ \\
\hline ISO45 & 2503 & -547 & 1015 & ID-DL & $X$ & & & & & & & & $\mathrm{X}$ \\
\hline ISO46 & 2500 & -541 & 1014 & ID-DL & $x$ & & & & & & & & $\mathrm{X}$ \\
\hline ISO47 & 2498 & .535 & 1014 & ID-DL & $X$ & & & & & $X$ & & & $X$ \\
\hline ISO48 & 2492 & -527 & 1015 & ID-DL & $\mathrm{X}$ & & & & & & & & $\mathrm{X}$ \\
\hline ISO49 & 2489 & -524 & 1015 & ID-DL & $\mathrm{X}$ & & & & & & & & $X$ \\
\hline ISO50 & 2484 & -519 & 1015 & ID.DL & $\mathrm{X}$ & & & & & $\mathrm{X}$ & & & $\mathrm{X}$ \\
\hline ISO51 & 2476 & -512 & 1017 & ID-DL & $\mathrm{X}$ & & & & & & & & $\mathrm{X}$ \\
\hline ISO52 & 2471 & .507 & 1019 & ID-DL & $\mathrm{X}$ & & & & & & & & $\mathrm{X}$ \\
\hline 1SO53 & 2469 & -505 & 1020 & ID-DL & $\mathrm{X}$ & & & & & $\mathrm{X}$ & & & $X$ \\
\hline & & & & & An & 10stras & do Gru & 03 & & & & & \\
\hline MAC2 & 1589 & -511 & 1050 & $\mathrm{HO}$ & $X$ & & $\mathrm{X}$ & & & $X$ & $\mathrm{X}$ & $\mathrm{X}$ & \\
\hline MAC $3 A$ & 2272 & .753 & 939 & $\mathrm{~PB}$ & $\mathrm{X}$ & & $X$ & & & & $X$ & $\mathrm{X}$ & \\
\hline $\mathrm{MAC} 12$ & 2300 & -720 & 920 & SO & $X$ & & $X$ & & & & $\mathrm{X}$ & & \\
\hline MAC13 & 2280 & -720 & 920 & PB & $X$ & & & & & & $\mathrm{X}$ & & \\
\hline $\mathrm{MACl} 4$ & 2464 & -610 & 920 & SO & $X$ & & $X$ & & & & $\mathrm{X}$ & & \\
\hline $\mathrm{MACl} 14 \mathrm{~A}$ & 2464 & -610 & 969 & MB & & & & & & & $X$ & $X$ & \\
\hline $\mathrm{MACl4B}$ & 2464 & -610 & 969 & $\mathrm{~PB}$ & & & & & & & $X$ & $\mathrm{X}$ & \\
\hline MACI5 & 1965 & -529 & 917 & PB & $\mathrm{X}$ & & $\mathrm{X}$ & & & & & & \\
\hline MAC 17 & 2270 & -735 & 931 & SO & $\mathrm{X}$ & & $\mathrm{X}$ & & & & $\mathrm{X}$ & $X$ & \\
\hline MAC18 & 2308 & .717 & 928 & so & $\mathrm{X}$ & & $X$ & & & & $\mathrm{X}$ & & \\
\hline MACl9 & 2483 & -655 & 978 & SO & $\mathrm{X}$ & $\mathrm{X}$ & $X$ & & & & $\mathrm{X}$ & & \\
\hline MAC20 & 1943 & -500 & 929 & So & $\mathrm{X}$ & & $X$ & & & & $\mathrm{X}$ & $\mathrm{X}$ & \\
\hline MAC44 & 1930 & -530 & 899 & $\mathrm{HO}$ & $\mathrm{X}$ & & & & & & $\mathrm{X}$ & $\mathrm{X}$ & \\
\hline MAC49 & 2930 & -450 & 1210 & $\mathrm{SO}$ & $X$ & & & & & & $\mathrm{X}$ & & \\
\hline MAC54 & 1859 & -623 & 908 & SO & $\mathrm{X}$ & $\mathrm{X}$ & $X$ & & & & $\mathrm{X}$ & & \\
\hline MAC55 & 1847 & -572 & 914 & so & $\mathrm{X}$ & & & & & & $\mathrm{X}$ & & \\
\hline MAC56 & 1883 & -578 & 908 & so & $\mathrm{X}$ & & & & & & $\mathrm{X}$ & & \\
\hline MAC57 & 2181 & -543 & 925 & SO & $\mathrm{X}$ & $\mathrm{X}$ & & & & & $X$ & & \\
\hline MAC58 & 2235 & -560 & 925 & SO & $\mathrm{X}$ & & & & & & $\mathrm{X}$ & & \\
\hline MAC59 & 2413 & -636 & 954 & SO & $\mathrm{X}$ & $X$ & $x$ & & & & $\mathrm{X}$ & & \\
\hline MAC59H & 2413 & -636 & 954 & MB & & & & & & & $\mathrm{X}$ & $X$ & \\
\hline MAC59I & 2413 & -636 & 954 & $\mathrm{~PB}$ & & & & & & & $\mathrm{X}$ & $x$ & \\
\hline MAC60 & 2930 & -450 & 1210 & $\mathrm{SO}$ & $X$ & & $\mathrm{X}$ & & & & $\mathrm{X}$ & $\mathrm{X}$ & \\
\hline MAC62 & 1230 & -410 & 1229 & $\mathrm{HO}$ & $X$ & $X$ & $X$ & & & $X$ & $\mathrm{X}$ & & \\
\hline MAC63 & 1435 & -578 & 1155 & So & & & & & & & $\mathrm{X}$ & & \\
\hline MAC67 & 2289 & -579 & 918 & $\mathrm{HO}$ & $\mathrm{X}$ & & $\mathrm{X}$ & $\mathrm{X}$ & $X$ & & $X$ & $X$ & \\
\hline MAC68 & 1862 & .499 & 965 & $\mathrm{HO}$ & $\mathrm{X}$ & & $\mathrm{X}$ & & $X$ & & $X$ & $X$ & \\
\hline MAC69 & 2320 & -568 & 918 & SO & $X$ & & & & & & $\mathrm{X}$ & & \\
\hline MAC77 & 2356 & -642 & 920 & $\mathrm{SO}$ & $\mathrm{X}$ & & & & & & $X$ & & \\
\hline MAC84 & 2380 & .670 & 922 & $\mathrm{HO}$ & $X$ & & & & & & $\mathrm{X}$ & $\mathrm{X}$ & \\
\hline MAC97 & 1980 & -500 & 932 & $\mathrm{HO}$ & $\mathrm{X}$ & $\mathrm{X}$ & $\mathrm{X}$ & $X$ & $\mathrm{X}$ & & $\mathrm{X}$ & $X$ & \\
\hline $\mathrm{MAC} 105 \mathrm{~A}$ & 1400 & .425 & 1167 & $\mathrm{HO}$ & $\mathrm{X}$ & & $\mathrm{X}$ & & $\mathrm{X}$ & & $X$ & $X$ & \\
\hline $\mathrm{MACl05B}$ & 1400 & -425 & 1167 & $\mathrm{HO}$ & $X$ & & & & & & $X$ & $X$ & \\
\hline $\mathrm{MACl} 107$ & 2350 & $\sim 650$ & 928 & PB & $X$ & & & & & & $\mathrm{X}$ & $\mathrm{X}$ & \\
\hline $\mathrm{MACl} 12$ & 1300 & -410 & 1210 & $\mathrm{HO}$ & $\mathrm{X}$ & & & & & & $\mathrm{X}$ & & \\
\hline MACl15 & 1350 & -420 & 1208 & $\mathrm{HO}$ & $X$ & & & & & & $X$ & $\mathrm{X}$ & \\
\hline MAC126A & 2425 & -603 & 957 & MB & & & $\mathrm{X}$ & & $\mathrm{X}$ & & $\mathrm{X}$ & $\mathrm{X}$ & \\
\hline $\mathrm{MACl26B}$ & 2425 & -603 & 957 & PB & & & $X$ & & $\mathrm{X}$ & & $\mathrm{X}$ & $\mathrm{x}$ & \\
\hline $\mathrm{MACl} 27 \mathrm{~A}$ & 2423 & .625 & 956 & MB & & & $X$ & $\mathrm{X}$ & $\mathrm{X}$ & $\mathrm{X}$ & $\mathrm{X}$ & $\mathrm{X}$ & \\
\hline $\mathrm{MAC} 127 \mathrm{~B}$ & 2423 & -625 & 956 & $\mathrm{~PB}$ & & & $x$ & $X$ & $\mathrm{X}$ & & $\mathrm{X}$ & $\mathrm{X}$ & \\
\hline $\mathrm{MAC} 128 \mathrm{~A}$ & 2418 & -649 & 951 & $\mathrm{MB}$ & & & $X$ & & $X$ & & $X$ & $\mathrm{X}$ & \\
\hline $\mathrm{MAC} 128 \mathrm{~B}$ & 2418 & -649 & 951 & PB & & & $X$ & & $\mathrm{X}$ & & $\mathrm{X}$ & $\mathrm{X}$ & \\
\hline $\mathrm{MACl} 29 \mathrm{~A}$ & 2459 & -594 & 966 & MB & & & $\mathrm{X}$ & & $X$ & & $\mathrm{X}$ & $\mathrm{X}$ & \\
\hline $\mathrm{MAC} 129 \mathrm{~B}$ & 2459 & .594 & 966 & PB & & & $\mathrm{X}$ & & $\mathrm{X}$ & & $\mathrm{X}$ & $\mathrm{X}$ & \\
\hline
\end{tabular}


Amostras Coletadas em Furos de Sonda

\begin{tabular}{|c|c|c|c|c|c|c|c|c|c|c|}
\hline \multirow{2}{*}{$\begin{array}{l}\text { Furo de } \\
\text { Sonda }\end{array}$} & \multirow{2}{*}{$\begin{array}{l}\text { Profundidade de } \\
\text { Coleta da Amostra } \\
\text { (m) }\end{array}$} & \multirow[t]{2}{*}{ Tipo } & \multirow[t]{3}{*}{ Petrografial } & \multirow[t]{2}{*}{ Densiclade } & \multirow[t]{2}{*}{ MEV } & \multirow[t]{2}{*}{$\mathrm{DR}-\mathrm{X}$} & \multirow[t]{3}{*}{ Rietveld Mössbatuer } & \multirow[t]{2}{*}{ MES } & \multicolumn{2}{|c|}{ Analises Químicas } \\
\hline & & & & & & & & & MBR & ACTLAB \\
\hline \multicolumn{9}{|c|}{ Amostras do Grupo 1} & & \\
\hline PZ-03 & 69.0 & QD & $\mathrm{X}$ & & $\mathrm{X}$ & $\mathrm{X}$ & & & & $\mathrm{X}$ \\
\hline $\mathrm{PZ} \sim 03$ & 83.0 & QD & $X$ & & & $\mathrm{X}$ & & & & $\mathrm{X}$ \\
\hline $\mathrm{PZ}-03$ & 103.0 & QD & $X$ & & & $X$ & & $X$ & & $x$ \\
\hline PZ-03 & 122.0 & QD & $X$ & & $\mathrm{X}$ & $\mathrm{X}$ & & & & $\mathrm{X}$ \\
\hline PZ-03 & 138.0 & QD & $\mathrm{X}$ & & & $X$ & & & & $X$ \\
\hline PZ-03 & 152.0 & QD & $\mathrm{X}$ & & & $X$ & & $\mathrm{X}$ & & $\mathrm{X}$ \\
\hline$P Z-03$ & 170.0 & QD & $\mathrm{X}$ & & & $\mathrm{X}$ & & & & $\mathrm{X}$ \\
\hline PZ-03 & 185.0 & QD & $\mathrm{X}$ & & & $\mathrm{X}$ & & $\mathrm{X}$ & & $X$ \\
\hline $\mathrm{PZ}-03$ & 196.0 & QD & $X$ & & & $\mathrm{x}$ & & & & $X$ \\
\hline & & & & Amostras d & 0 Grup & & & & & \\
\hline PZ-55 & 27.0 & ID & & $\mathrm{X}$ & & & & & & $\mathrm{X}$ \\
\hline$P Z-55$ & 37.0 & ID & & $\mathrm{X}$ & & & & & & \\
\hline PZ-55 & 61.0 & ID & & $X$ & & & & & & $\mathrm{X}$ \\
\hline PZ-55 & 150.0 & $\mathrm{ID}$ & & $\mathrm{X}$ & & & & & & \\
\hline PZ-55 & 151.0 & ID & & $X$ & & & & & & \\
\hline $\mathrm{PZ}-55$ & 168.0 & ID & & $X$ & & & & & & \\
\hline $\mathrm{PZ}-55$ & 176.0 & ID & & $\mathrm{X}$ & & & & & & \\
\hline PZ,-03 & 18.0 & QI & $X$ & & & $X$ & & & & $x$ \\
\hline PZ-03 & 23,0 & QI & $X$ & & $X$ & $\mathrm{X}$ & & & & $\mathrm{X}$ \\
\hline $\mathrm{PZ}-03$ & 36,0 & QI & $\mathrm{X}$ & & & $\mathrm{X}$ & & & & $X$ \\
\hline PZ-03 & 50,0 & QI & $\mathrm{X}$ & & & $\mathrm{X}$ & & & & $\mathrm{X}$ \\
\hline$P Z-54$ & 80.0 & Ql & $\mathrm{X}$ & & & $\mathrm{X}$ & & & & $X$ \\
\hline PZ-54 & 85.0 & QI & $\mathrm{X}$ & & & $X$ & & & & $X$ \\
\hline PZ.54 & 120.0 & QI & $X$ & & $\mathrm{X}$ & $\mathrm{X}$ & & & & $\mathrm{X}$ \\
\hline PZ-54 & 124.0 & QI & $X$ & & & $X$ & & & & $\mathrm{X}$ \\
\hline FSD09-99 & 29.5 & ID & $X$ & & & & & & $\mathrm{X}$ & \\
\hline FSD09-99 & 32.7 & ID & $X$ & & & $X$ & & & $X$ & \\
\hline FSD09-99 & 32.8 & ID & $X$ & & & & & & $X$ & \\
\hline FSD09-99 & 33.2 & ID & $\mathrm{X}$ & & & $\mathrm{X}$ & & & $X$ & \\
\hline FSD09-99 & 46.0 & ID & $\mathrm{X}$ & & & & & & $X$ & \\
\hline & & & & Amostras d & o Grupo & & & & & \\
\hline FSD08-99 & 2.20 & SO & & $\mathrm{X}$ & & & & & $\mathrm{X}$ & \\
\hline FSD08-99 & 4.80 & SO & & $X$ & & & & & $X$ & $X$ \\
\hline FSD08-99 & 7.30 & so & & $X$ & & & & & $X$ & $X$ \\
\hline FSD08-99 & $\$ 2.50$ & SO & & $X$ & & & & & $X$ & $\mathrm{X}$ \\
\hline FSD08 99 & 13.20 & $\mathrm{SO}$ & & $X$ & & & & & $X$ & \\
\hline FSD08-99 & 14.70 & SO & & $X$ & & & & & $\mathrm{X}$ & $\mathrm{X}$ \\
\hline FSD08-99 & 14.80 & SO & & $X$ & & & & & $X$ & \\
\hline FSD08-99 & 16.80 & SO & & $X$ & & & & & $X$ & $X$ \\
\hline FSD08-99 & 17.00 & $\mathrm{SO}$ & & $X$ & & & & & $X$ & \\
\hline FSD08-99 & 19,00 & $\mathrm{SO}$ & & $\mathrm{X}$ & & & & & $X$ & $\mathrm{X}$ \\
\hline FSD09.99 & 3.50 & $\mathrm{SO}$ & & $\mathrm{X}$ & & & & & $X$ & $x$ \\
\hline FSD09-99 & 4.10 & SO & & $\mathrm{X}$ & & & & & $\mathrm{X}$ & \\
\hline FSD09.99 & 8.60 & SO & & $\mathrm{X}$ & & & & & $X$ & $\mathrm{X}$ \\
\hline FSD09-99 & 10.50 & SO & & $X$ & & & & & $X$ & $X$ \\
\hline FSD09.99 & 12.50 & SO & & $X$ & & & & & $X$ & \\
\hline FSD09-99 & 13.50 & SO & & $X$ & & & & & $\mathrm{X}$ & \\
\hline FSD09-99 & 19.70 & SO & & $X$ & & & & & $X$ & \\
\hline FSD09-99 & 20.90 & SO & & $X$ & & & & & $X$ & \\
\hline FSD09-99 & 24.70 & $\mathrm{SO}$ & & $X$ & & & & & $X$ & $X$ \\
\hline FSD09-99 & 27.70 & SO & & $X$ & & & & & $X$ & $X$ \\
\hline FSD09-99 & 28.70 & SO & & $X$ & & & & & $X$ & $X$ \\
\hline F'SD $11-99$ & 2.50 & SO & $\mathrm{X}$ & $\mathrm{X}$ & $X$ & & & & $X$ & \\
\hline FSD1 1 99 & 4.80 & so & & $X$ & & & & & $X$ & $X$ \\
\hline FSD11-99 & 5.50 & SO & & $X$ & & & & & $X$ & \\
\hline FSD1 1.99 & 5.70 & So & & $\mathrm{X}$ & & & & & $\mathrm{X}$ & $X$ \\
\hline FSD11-99 & 5.80 & SO & & $X$ & & & & & $X$ & \\
\hline FSD $11-99$ & 6.50 & SO & & $X$ & & & & & $X$ & \\
\hline FSD 11.99 & 6.80 & SO & & $X$ & & & & & $X$ & \\
\hline FSD 11-99 & 7.00 & SO & & $\mathrm{X}$ & & & & & $\mathrm{X}$ & \\
\hline FSD $11-99$ & 7.10 & SO & & $X$ & & & & & $X$ & $X$ \\
\hline ESD 11.99 & 8.30 & SO & & $\mathrm{X}$ & & & & & $X$ & \\
\hline
\end{tabular}




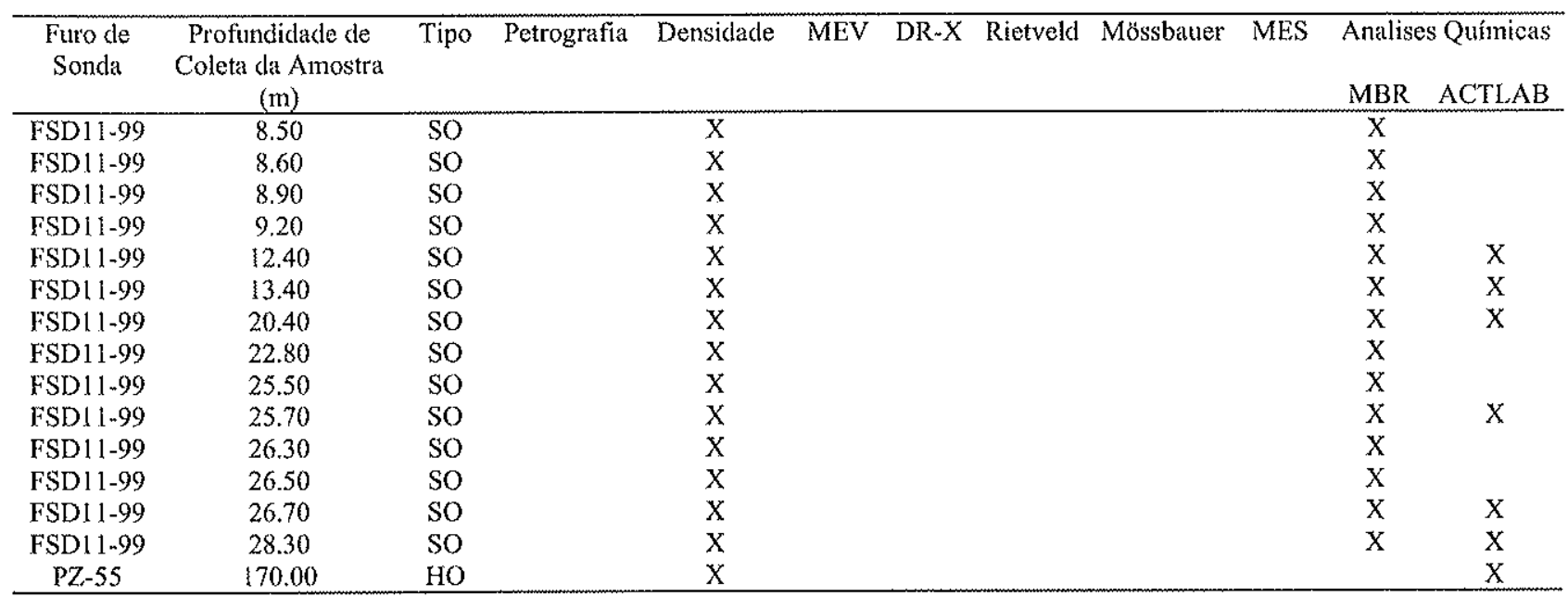

Grupo 1: $\mathrm{DA}=$ Dolomito argiloso, $\mathrm{FS}=$ Filito sericítico, $\mathrm{MC}=$ Metachert.

Grupo 2: ID=Itabirito dolomítico, $\mathrm{Q}=\mathrm{Quartzo}$ itabirito, $\mathrm{ID}-\mathrm{HM}=\mathrm{Banda}$ hematítica do itabirito dolomítico, ID-DL = Banda dolomítica do itabirito dolomítico.

Grupo 3: $\mathrm{HO}=$ Minério compacto, $\mathrm{SO}=$ Minério friável, $\mathrm{MB}=\mathrm{Banda}$ maciça do minério friável, $\mathrm{PB}=$ Banda porosa do minério friável. 


\section{REFERÊNCIAS BIBLIOGRÁFICAS}

AINSWORTH C., SUMMER M.E., HURST V.J. (1985) Effect of aluminium substitution in goethite on phosphorus adsorption: I. Adsorption and isotope exchange. Soil Sci Soc Am J 49: 1142-1149.

ALKMIM F.F., MARSHAK S. (1998) Transamazonian orogeny in the São Francisco craton, Minas Gerais, Brazil: evidence for Paleoproterozoic collision and collapse in the Quadrilátero Ferrífero. Precambrian Research 90: 29-58.

ALMEIDA F.F.M. (1977) O Cráton do Rio São Francisco. Revista Brasileira de Geociências 7: 349-364.

ARORA M., GOVIL P.K., CHARAN S.N., UDAY RAJ B., BALARAM V., MANIKYAMBA C., CHATTERJEE A.K., NAQVI S.M. (1995) Geochemistry and origin of Archean banded iron-formation from the Bababudan Schist Belt, India. Economic Geology 90: 2040-2057.

BABINSKI M., CHEMALE JR. F., VAN SCHMUS W.R. (1995) Cronoestratigrafia do Supergrupo Minas e provável correlação de suas formações ferriferas com similares da África do Sul e Austrália. Geochimica Brasiliensis 9: 33-46.

BABINSKI M., CHEMALE JR. F., VAN SCHMUS W.R. (1995) The Pb/Pb ages of the Minas Supergroup carbonate rocks, Quadrilátero Ferrífero, Brazil. Precambrian Research 72: 235-245.

BALTAZAR O.F., RAPOSO F.O. (1993) Programa Levantamentos Geológicos Básicos do Brasil (Folha SF.23-Xm-BmI, Mariana). Estado de Minas Gerais. Esc. 1:100.000. CPRM/DNPM, Brasília.

BANNER J.L., HANSON G.N., MEYERS W.J. (1988) Rare earth elements and Nd isotopic variations in regionally extensive dolomites from the Burlington-Keokuk Formation (Mississippian): implications for REE mobility during carbonate diagenesis. Journal of Sedimentary Petrology 58: 415-432.

BANNER J.L., HANSON G.N. (1990) Calculation of simultaneous isotopic and trace element variations during water-rock interaction with applications to carbonate diagenesis. Geochimica et Cosmochimica Acta 54: 3123-3137.

BARBOSA O. (1965) Quadro povisório de superfícies de erosão e aplainamento no Brasil (inferências paleoclimáticas e econômicas). Revista Brasileira de Geografia: 105-106.

BAU M. (1991) Rare-earth element mobility during hydrothermal and metamorphic fluid-rock interaction and the significance of the oxidation state of europium. Chemical Geology 93: 219-230.

BAU M. (1993) Effects of syn- and post-depositional processes on the rare-earth element distribution in Precambrian iron-formations. European Journal of Mineralogy 1993: 257267. 
BAU M. (1996) Controls on the fractionation of isovalent trace elements in magmatic and aqueous systems: evidence from $\mathrm{Y} / \mathrm{Ho}, \mathrm{Zr} / \mathrm{Hf}$, and lanthanide tetrad effect. Contribution to Mineralogy and Petrology 123: 323-333.

BAU M., MÖLLER P. (1993) Rare earth element systematics of the chemically precipitated component in early Precambrian iron formations and the evolution of the terrestrial atmosphere-hydrosphere-lithosphere system. Geochimica et Cosmochimica Acta 57: 2239-2249.

BAU M., DULSKI P. (1996) Distribution of yttrium and rare-earth elements in the Penge and Kuruman iron-formations, Transvaal Supergroup, South Africa. Precambrian Research 79: $37-55$.

BECKER R.H., CLAYTON R.N. (1972) Carbon isotopic evidence for the origin of a banded iron-formation in Western Australia. Geochimica et Cosmochimica Acta 36: 577-595.

BEKKER A., SIAL A.N., KARHU J.A., FERREIRA V.P., NOCE C.M., KAUFMAN A.J., ROMANO A.W., PIMENTEL M.M. (2003) Chemostratigraphy of carbonates from the Minas Supergroup, Quadrilátero Ferrífero (Iron Quadrangle), Brazil: a stratrigraphic record of early Proterozoic atmospheric, biogeochemical and climatic change. American Journal of Science 303: 865-904.

BEUKES N.J. (1980) Lithofacies and stratigraphy of the Kuruman and Griquatown ironformations, northern Cape Province, South Africa. Transactions of the Geological Society of South Africa 83: 69-86.

BEUKES N.J. (1984) Sedimentology of the Kuruman and Griquatown Iron-formations, Transvaal Supergroup, Griqualand West, South Africa. Precambrian Research 24: 47-84.

BEUKES N.J., KLEIN C. (1990) Geochemistry and sedimentology of a facies transition - from microbanded to granular iron-formation - in the early Proterozoic Transvaal Supergroup, South Africa. Precambrian Research 47: 99-139.

BEUKES N.J., KLEIN C., KAUFMAN A.J., HAYES J.M. (1990) Carbonate petrography, kerogen distribution, and carbon and oxigen isotope variations in an early Proterozoic transition from limestone to iron-formation deposition, Transvaal Supergroup, South Africa, Economic Geology 85: 663-690.

BEUKES N.J., GUTZMER J., MUKHOPADHYAY J. (2002) The geology and genesis of highgrade iron ore deposits. In: IRON ORE 2002. Proceedings, Australasian Institute of Mining and Metallurgy, Perth, pp 23-29.

BODNAR R.J., VITYK M.O. (1994) Interpretation of microthermometric data for $\mathrm{H}_{2} \mathrm{O}-\mathrm{NaCl}$ fluid inclusions In: DE VIVO B., FREZZOTI M. (eds) Fluid inclusions in minerals: methods and applications. Pontignano, Italia, pp 117-130.

BOULANGÉ B., CARVALHO A., VARAJÃO C.A.C., VARAJÃO A.F. (1997) The bauxite of the Quadrilátero Ferrifero In: CARVALHO A., BOULANGÉ B., MELFI A.J., LUCAS Y. (eds) Brazilian Bauxites. USP/FAPESP/ORSTOM, São Paulo/Paris, pp 165-194.

CABRAL, A.R., ROCHA FILHO, O.G., and JONES, R.D., (2003) Hydrothermal origin of soft hematite ore in the Quadrilátero Ferrifero of Minas Gerais, Brazil: petrographic evidence from the Gongo Soco iron ore deposit. Applied Earth Sciense (Trans. Inst. Min. Metall.B), 112: B279-B286. 
CARMO I.O. (2004) Geocronologia do Intemperismo Cenozóico no Sudeste do Brasil Departamento de Geologia. Tese de doutorado. Universidade Federal do Rio de Janeiro, Rio de Janeiro, pp 134.

CARMO I.O., VASCONCELOS P.M. (2003) 40Ar/39Ar Geochronology of weathering profiles in southeastern Brazil. In: IV SOUTH AMERICAN SYMPOSIUM ON ISOTOPE GEOLOGY, Anais, Salvador, pp 49-52.

CARMO I.O., VASCONCELOS P. (2004) Geochronological evidence for pervasive Miocene weathering, Minas Gerais, Brazil. Earth Surface Processes and Landforms 29: 13031320.

CASQUET R.Q. (1995) Caracterização mineralógica e tecnológica do minério de ferro itabiritico da Mina Alegria Sul, Ouro Preto-MG. Dissertação de mestrado. Escola de Engenharia. Universidade Federal de Minas Gerais, Belo Horizonte, pp 240.

CHAUVET A., FAURE M., DOSSIN I., CHARVET J. (1994) A three-stage structural evolution of the Quadrilátero Ferrifero: consequences for the Neoproterozoic age and the formation of gold concentrations of the Ouro Preto area, Minas Gerais, Brazil. Precambrian Research 68: 139-167.

CHEMALE JR. F., ROSIÈRE C.A., Endo I (1994) The tectonic evolution of the Quadrilátero Ferrífero, Minas Gerais, Brazil. Precambrian Research 65: 25-54.

CHILDS, C.W., BAKER-SHERMAN (1984) Moessbauer spectra and parameters of standard samples 1. Lower Hutt, New Zealand, Department of Scientific and Industrial Research, New Zealand Soil Bureau, pp. 50.

CORDANI U.G., KAWASHITA K., MÜlLER G., QUADE H., REIMER V., ROESER H. (1980) Interpretação tectônica e petrológica de dados geocronológicos do embasamento na borda sudeste do Quadrilátero Ferrífero. Anais da Academia Brasileira de Ciências 52: 785-799.

CORNELL, R.M. (1988) The influence of some divalent cations on the transformation of ferrihydrate into more crystalline products. Clays and Clay Minerals 23: 329-332.

CORNELL, R.M., SCHWERTMANN, U. (1996) The Iron Oxides. Weinheim; New York; Basel; Cambridge; Tokyo, VCH, pp. 573.

CROWLEY T.J., NORTH G.R. (1991) The last 100 million years Paleoclimatology. Oxford Univ. Press, London/New York, pp 183-211.

DALSTRA, H.J., HARDING, A.E., TAYLOR, D. (2002) Genesis of high-grade hematite orebodies of the Hamersley Province, Western Australia - a reply. Economic Geology, 97: 174-176.

DALSTRA H.J., GUEDES S. (2004) Giant hydrotermal hematite deposits with Mg-Fe metasomatism: a comparison of the Carajás, Hamersley, and other iron mines. Economic Geology 99: 1793-1800.

DAMMER D., CHIVAS A.R., McDOUGALL I. (1996) Isotopic dating of supergene manganese oxides from the Groote Eylandt deposit, Northern Territory, Australia. Economic Geology 91: 386-401.

DAMMER D., McDOUGAL I., CHIVAS A.R. (1999) Timing of weathering-induced alteration of manganese deposits in Western Australia: evidence from $\mathrm{K} / \mathrm{Ar}$ and ${ }^{40} \mathrm{Ar} /{ }^{39} \mathrm{Ar}$ dating. Economic Geology 94: 87-108. 
DANIELSON A., MÖLLER P., DULSKI P. (1992) The europium anomalies in banded iron formations and the thermal history of the oceanic crust. Chemical Geology 97: 89-100.

DAVIS B., HIPPERT J. (2000) Dome empacement and formation of kilometre-scale synclines in a granite-greenstone terrain (Quadrilátero Ferrífero, southeastern Brazil). Precambrian Research 102: 99-121,

DE BAAR H.J.W., BACON M.D., BREWER P.G., BRULAND K.W. (1985) Rare earth elements in the Pacific and Atlantic Oceans. Geochimica et Cosmochimica Acta 49: 1943-1959.

DERRY L.A., JACOBSEN S.B. (1990) The chemical evolution of Precambrian seawater:Evidence from REEs in banded iron formations. Geochimica et Cosmochimica Acta 54: 2965-2977.

DERRY L.A., KAUFMAN A.J., JACOBSEN S.B. (1992) Sedimentary cycling and environmental change in the late Proterozoic: evidence from stable and radiogenic isotopes. Geochimica et Cosmochimica Acta 56: 1317-1329.

DORR II J.V.N. (1964) Supergene iron ores of Minas Gerais, Brazil. Economic Geology 59: 1203-1240.

DORR II J.V.N. (1965) Nature and origin of the high-grade hematite ores of Minas Gerais, Brazil, Economic Geology 60: 1-46.

DORR II J.V.N. (1969) Physiographic, stratigraphic and structural development of the Quadrilátero Ferrífero, Minas Gerais, Brazil. USGS Professional Papers, Washington, 641-A, p A $-A_{103}$.

DORR II J.V.N. (1973) Iron-formation in South America. Economic Geology 68: 1005-1022.

DYMEK RF, KLEIN C. (1988) Chemistry, petrology and origin of banded iron-formation lithologies from the $3800 \mathrm{Ma}$ Isua supracrustal belt, West Greenland. Precambrian Research 39: 247-302.

EICHLER J. (1968) O enriquecimento residual e supergênico dos itabiritos através do intemperismo. Geologia: 29-40.

ELDERFIELD H. (1988) The oceanic chemistry of the rare-earth elements Phil. Trans. Roy. Soc., London, pp 105-126.

ELDERFIELD H., UPSTILL-GODDARD R., SHOLKOVITZ E.R. (1990) The rare earth elements in rivers, estuaries, and coastal seas and their significance to the composition of ocean waters. Geochimica et Cosmochimica Acta 54.

EWERS W.E., MORRIS R.C. (1981) Studies of the Dales Gorge Member of the Brockman Iron Formation, Western Australia. Economic Geology 76: 1929-1953.

FENG Y., VASCONCELOS P. (2001) Quaternary continental weathering geochronology by laser-heating ${ }^{40} \mathrm{Ar} /{ }^{39} \mathrm{Ar}$ analysis of supergene cryptomelane. Geology 29: 635-638.

FLECK R.J., SUTTER J.F., ELLIOT D.H. (1977) Interpretation of discordant 40Ar/39Ar agespectra of Mesozoic tholeiites from Antarctica. Geochimica et Cosmochimica Acta 41: $15-32$.

FLORAN RJ, PAPIKE J.J. (1978) Mineralogy and petrology of the Gunflint Iron Formation, Minnesota-Ontario: correlation of compositional and Assemblage variations at low to moderate grade. Journal of Petrology 19: 215-288. 
FRAKES L.A. (1979) Climates Throughout Geologic Time. Elsevier, Amsterdam/Lausanne/New York.

FYSH, S.A., CLARK, P.E. (1982) Aluminous hematite: a Mössbauer study. Phy. Chem. Miner. 8: $257-267$.

GNANESHWAR RAO T., NAQVI S.M. (1995) Geochemistry, depositional environment and tectonic setting of the BIF's of the late Archean Chitradurga Schist Belt, India. Chemical Geology 121: 217-243.

GOMES J.C.M. (1986) As minas de Águas Claras, Mutuca, Pico e outros depósitos de minério de ferro no Quadrilátero Ferrífero, Minas Gerais In: SCHOBBENHAUS C., COELHO C.E.S. (eds) Principais Depósitos Minerais do Brasil. DNPM/CPRM, Brasília, pp 65-75.

GOODE A.D.T., HALL W.D.M., BUNTING J.A. (1983) The Nabberu basin of Western Australia In: TRENDALL A.F., MORRIS R.C. (eds) Iron-Formation Facts and Problems. Elsevier, Amsterdam-Oxford-New York-Tokyo, pp 295-323.

GROSS G.A. (1980) A classification of iron formations based on depositional environments. The Canadian Mineralogist 18: 215-222.

GROSS G.A. (1983) Tectonic systems and the deposition of iron-formation. Precambrian Research 20: 171-187.

GRUNER J.W. (1937) Hydrothermal leachingof iron ores of the Lake Superior type - a modified theory. Economic Geology 32: 121-130.

GUEDES S.C., ROSIÈRE C.A., MARLEY M., LOBATO L.M. (2002) Carbonate alteration associated with the Carajás high-grade hematite deposits, Brazil. In: IRON ORE 2002, Proceedings, Perth, pp 63-66.

GUILD P.W. (1953) Iron deposits of the Congonhas District, Minas Gerais, Brazil. Economic Geology 48: 639-676.

HACKSPACHER P.C. (1979) Strukturelle und texturelle untersuchungen zur internem deformation des eisenreicherzkoerpers der grube "Aguas Claras" bei Belo Horizonte/Minas Gerais, Brasilien. Ph.D. Thesis. Claust Geol Abh, pp 164.

HACKSPACHER, P.C., OLIVEIRA JR., V.T., SIEMES, H., ROSIÈRE, C.A., MORENO, M.M.T. (2001) Textures of hematitic and itabiritic iron ores in the Conceição Mine, Quadrilátero Ferrifero, Minas Gerais, Brazil. Z. dt. geol. Ges. 152: 467-478.

HALL W.D.M., GOODE A.D.T. (1978) The early Proterozoic Nabberu basin and associated iron formations of western Australia. Precambrian Research 7: 129-184.

HARDER E.C., CHAMBERLAIN R.T. (1915) The geology of the central Minas Gerais, Brazil. Journal of Geology 23: 341-378, 385-424.

HÉNOCQUE O., RUFFET G., COLIN F. (1998) ${ }^{40} \mathrm{Ar} /{ }^{39} \mathrm{Ar}$ dating of African manganese pisolites: implications for Cenozoic climatic changes. Mineralogical Magazine 62A: 606607.

HÉNOCQUE O., RUFFET G., COLIN F., FERAUD G. (1998) ${ }^{40} \mathrm{Ar}-{ }^{39} \mathrm{Ar}$ dating of West African lateritic cryptomelanes. Geochimica et Cosmochimica Acta 62: 2739-2756.

HERZ N. (1978) Metamorfic rocks of the Quadrilatero Ferriffero, Minas Gerais, Brazil. USGS Professional Paper, Washington, 641-C, p. $\mathrm{C}_{1}-\mathrm{C}_{81}$. 
HORSTMANN U.E., HÄLBICH I.W. (1995) Chemical composition of banded iron-formations of the Griqualand West Sequence, Northern Cape Province, South Africa, in comparison with other Precambrian iron formations. Precambrian Research 72: 109-145.

ISLEY A.E. (1995) Hydrothermal plumes and the delivery of iron to banded iron formation. The Journal of Geology 103: 169-185.

JAMES H.L. (1954) Sedimentary facies of iron-formation. Economic Geology 49: 235-293.

KARHU J.A., HOLLAND H.D. (1996) Carbon isotopes and the rise of atmospheric oxygen. Geology 24: 867-870.

KATO Y,, NAKAMURA K. (2003) Origin and global tectonic significance of Early Archean cherts from the Marble Bar greenstone belt, Pilbara craton, Western Australia. Precambrian Research 125: 191-243.

KATO Y., OHTA I., TSUNEMATSU T., WATANABE Y., ISOZAKI Y., MARUYAMA S., IMAI N. (1998) Rare earth element variations in mid-Archean banded iron formations: Implications for the chemistry of ocean and plate tectonics. Geochimica et Cosmochimica Acta 62: 3475-3497.

KAUFMAN A.J. (1996) Geochemical and mineralogic effects of contact metamorphism on banded iron-formation: an example from the Transvaal Basin, South Africa. Precambrian Research 79: 171-194.

KAUFMAN A.J., HAYES J.M., KLEIN C. (1990) Primary and diagenetic controls of isotopic compositions of iron-formation carbonates. Geochimica et Cosmochimica Acta 54: 34613473.

KAUFMAN A.J., KNOLL A.H., NARBONNE G.M. (1997) Isotopes, ice ages, and terminal Proterozoic Earth history, National Academy of Science Proceedings, 94. pp 6600-6605.

KHAN R.M.K., NAQVI S.M. (1996) Geology, geochemistry and genesis of BIF of the Kushtagi Schist Belt, Archean Dharwar Craton, India. Mineralium Deposita 31: 123-133.

KIMBERLEY M.M. (1989) Exhalative origins of iron formations. Ore Geology Reviews 5: 13145.

KING LC (1956) A geomorfologia do Brasil oriental, Revista Brasileira de Geografia: 3-121.

KLEIN C., FINK R.P. (1976) Petrology of the Sokoman Iron Formation in the Howells River Area, at the Western Edge of the Labrador Trough. Economic Geology 71: 453-487.

KLEIN C., BEUKES N.J. (1989) Geochemistry and sedimentology of a facies transition from limestone to iron-formation deposition in the Early Proterozoic Transvaal Supergroup, South Africa. Economic Geology 84: 1733-1774.

KLEIN C., BEUKES N.J. (1992) Time distribution, stratigraphy, and sedimentologic setting, and geochemistry of Precambrian iron-formations In: SCHOPF J.W., KLEIN C. (eds) The Proterozoic Biosphere. Cambridge University Press, Cambridge, pp 139-146.

KLEIN C., LADEIRA E.A. (2000) Geochemistry and petrology of some Proterozoic banded iron-formations of the Quadrilátero Ferrifero, Minas Gerais, Brazil. Economic Geology 95: $405-428$.

KLEMM D.D. (2000) The formation of Palaeoproterozoic banded iron formations and their associated $\mathrm{Fe}$ and $\mathrm{Mn}$ deposits, with reference to the Griqualand West deposits, South Africa. Journal of African Earth Sciences 30: 1-24. 
KNEESHAW, M., KEPERT, D.A. (2002) Genesis of high-grade hematite orebodies of the Hamersley Province, Western Australia - a discussion. Economic Geology 97: 173-176.

LADEIRA E.A., VIVEIROS J.F.M. (1984) Hipótese sobre a estruturação do Quadrilátero Ferrífero com base nos dados disponíveis. Boletim da Sociedade Brasileira de Geologia de Minas Gerais 4.

LAGOEIRO L.E. (1998) Transformation of magnetite to hematite and its influence on the dissolution of iron oxide minerals. Journal of Metamorphic Geology 16: 415-423.

LASCELLES D. (2002) A new look at old rocks - an alternative model for the origin of in situ iron deposits derived from banded iron formation. In: Iron Ore 2002. Proceedings, Australasian Institute of Mining and Metallurgy, Perth, pp 107-126.

LI J-W., VASCONCELOS P. (2002) Cenozoic continental weathering and its implications for the palaeoclimate: evidence from ${ }^{40} \mathrm{Ar} /{ }^{39} \mathrm{Ar}$ geochronology of supergene $\mathrm{K}-\mathrm{Mn}$ oxides in Mt Tabor, central Queensland, Australia. Earth and Planetary Science Letters 200: 223239.

LIMA M.R., SALARD-CHEBOLDAEFF M. (1981) Palynologie des bassins de Gandarela et Fonseca (Eocene de L'etat de Minas Gerais, Bresil). Boletim Instituto de Geociências Universidade de São Paulo 12: 33-54.

LINDENMAYER Z.G., LAUX J.H., Teixeira J.B.G. (2001) Considerações sobre a origem das formações ferríferas da Formação Carajás, Serra dos Carajás. Revista Brasileira de Geociências 31: 21-28.

LOBATO L.M., ROSIÈRE C.A., BAARS F.J., SILVA R.C.F., ZUCCHETI M., RIOS F.J., SEOANE J.C.S., PIMENTEL M.M., LINDENMAYER Z.G., MENDES G.E., MACIEL A.L. (2004) Timing of hydrothermal iron mineralisation, Carajás Province. In: I SIMPÓSIO BRASILEIRO DE EXPLORAÇÃO MINERAL. Anais, Ouro Preto, CD ROM.

MACAMBIRA J.B., SCHRANK A. (2002) Químio-estratigrafia e evolução dos jaspilitos da Formação Carajás (PA). Revista Brasileira de Geociências 32: 567-578.

MAIZATTO J.R. (2001) Análise bioestratigráfica, paleoecológica e sedimentológica das bacias Terciárias do Gandarela e Fonseca - Quadrilátero Ferrifero - com base nos aspectos palinológicos e sedimentares. Tese de doutorado. Escola de Minas, Departamento de Geologia. Universidade Federal de Ouro Preto, Ouro Preto, pp 249.

MANIKYAMBA C., BALARAM V., NAQVI S.M. (1993) Geochemical signatures of polygenetic origin of a banded iron formation (BIF) of the Archean Sandur greenstone belt (schist belt) Karnataka nucleus, India. Precambrian Research 61: 137-164.

MANIKYAMBA C. (1998) Petrology and geochemistry of mixed oxide-silicate facies banded iron formations from Sandur Schist Belt, India. Journal Geological Society of India 52: 651-661.

MARSHAK S., ALKMIM F.F. (1989) Proterozoic contraction/extension tectonics of the southern São Francisco craton region, Minas Gerais, Brazil. Tectonics 8: 551-571.

MARSHAK S., ALKMIM F.F., JORDT-EVANGELISTA H. (1992) Proterozoic crustal extension and generation of domo-and-keel structure in the Archean granite-greenstone terrane. Nature 357: 491-493.

McCREA J.M. (1950) On the isotope chemistry of carbonates and paleotemperature scale. Jour Chem Phys 18: 849-857. 
McDOUGALL I., HARRISON T.M. (1999) Geochronology and Thermochronology by the ${ }^{40} A r{ }^{39}$ Ar Method. Oxford University Press.

McLENNAN S.B. (1989) Rare earth elements in sedimentary rocks. Influence of provenance and sedimentary processes In: LIPIN B.R., MCKAY G.A. (eds) Geochemistry and Mineralogy of the Rare Earth Elements. Mineralogical Society of America, Washington, pp 169-200.

MELFI A.J, PEDRO G., NALOVIC L., QUEIROZ NETTO J.P. (1976) Etude sur l'altération géochimique des itabiritites du Brésil. Cah. ORSTOM, Sér. Pédologie XIV: 179-192.

MERRIHUE C., TURNER G. (1966) Potassium-argon dating by activation with fast neutrons. Journal of Geophysical Research 71: 2852-2857.

MOREY G.B. (1999) High-grade ore deposits of the Mesabi Range, Minnesota - product of a continental scale Proterozoic groundwater flow system. Economic Geology 94: 133-142.

MORRIS R.C. (1985) Genesis of iron ore in banded iron-formation by supergene and supergenemetamorphic processes - a conceptual model In: Wolf KH (ed) Handbook of Stratam Bound and Stratiform Ore Deposits. Elsevier, Amsterdam, pp 73-235.

MORRIS R.C. (1987) Iron ores derived by enrichment of banded iron formation In: Hein JR (ed) Siliceous sedimentary rock hosted ores and petroleum. Van Nostrand Reinhold, New York, pp 231-267.

MORRIS R.C. (1993) Genetic modeling for banded iron formation of the Hamersley Group, Pilbara Craton, Western Australia. Precambrian Research 60: 243-286.

MORRIS, R.C., (2002) Discussion and reply. Opaque mineralogy and magnetic properties of selected banded iron-formations, Hamersley basin, Western Australia. Australian Journal of Earth Sciences 49: 579-586.

MORRIS, R.C., (2002) Genesis of high-grade hematite orebodies of the Hamersley Province, Western Australia - a discussion. Economic Geology 97: 177-181.

MORRIS R.C. (2002) Iron ore genesis and post-ore metasomatism at Mount Tom Price Iron Ore 2002. In: IRON ORE 2002. Proceedings, Australasian Institute of Mining and Metallurgy, Perth, pp 3-13.

MURAD, E., SCHWERTMANN, U. (1986) The influence of Al-substitution and crystallinity on room temperature Mössbauer spectrum of hematite. Clays and Clay minerals 34: 1-6.

NAHON D.B. (1986) Evolution of Iron Crusts in Tropical Landscapes In: COHEN S.M., DETHIER D.P. (eds) Rate of Chemical Weathering of Rocks and Minerals. Academic Press, New York, pp 169-191.

NIMER E. (1989) Climatologia do Brasil. IBGE - Superintendência de Recursos Naturais e Meio Ambiente.

NOCE C.M. (1995) Geocronologia dos eventos magmáticos, sedimentares e metamórficos na região do Quadrilátero Ferrifero, Minas Gerais. Tese de doutorado. Instituto de Geociências. Universidade de São Paulo, São Paulo, pp 128.

NOZAKI Y., ZHANG J., AMAKAWA H. (1997) The fractionation between Y and Ho in the marine environment. Earth and Planetary Science Letters 148: 329-340.

OHMOTO, H. (2003) Nonredox transformations of magnetite-hematite in hydrothermal systems. Economic Geology 98: 157-161. 
OLIVAREZ A.M., OWEN R.M. (1991) The europium anomaly of seawater: implications for fluvial versus hydrothermal REE inputs to the oceans. Chemical Geology 92: 317-328.

PARK C.F. (1959) Origin of hard hematite in itabirite. Economic Geology 54.

PERRY JR. E.C., TAN F.C., G.B. M. (1973) Geology and stable isotope geochemistry of the Biwabik Iron Formation, Northern Minnesota. Economic Geology 68: 1110-1225.

PIMENTA H.P., PACHECO T.A., CARDOSO M.B. (1999) Caracterização tecnológica de minérios de ferro para sinterização. In: II SIMPÓSIO BRASILEIRO DE MINÉRIO DE FERRO. Anais, Ouro Preto, pp 1-20.

PINHEIRO J.C.F. (2000) A Mineração Brasileira de Ferro e a Reestruturação do Setor Siderírgico, Universidade Estadual de Campinas - UNICAMP, Campinas.

PIRES F.R.M. (1979) Structural geology and stratigraphy at the junction of the Serra do Curral anticline and the Moeda syncline, Quadrilatero Ferrifero, Minas Gerais, Brazil. Ph.D. Thesis. Michigan Tech. University, Ann Arbor, pp 220.

PIRES F.R.M. (1995) Textural and mineralogical variations during metamorphism of the Proterozoic Itabira Iron Formation in the Quadrilátero Ferrifero, Minas Gerais, Brazil. Anais da Academia Brasileira de Ciências 67: 77-105.

PIRES F.R.M., FROST B.R. (2004) Parageneses generated by the oxidation during metamorphism of the Itabira iron formation in the Quadrilatero Ferrifero, Minas Gerais, Brazil. In: ICAM 2004 - INTERNATIONAL CONGRESS ON APLLIED MINERALOGY. Anais, Águas de Lindóia.

POMERENE J.B. (1964) Geology and mineral deposits of the Belo Horizonte, Ibirite and Macacos quadrangles, USGS Professional Paper, 341-D, pp 1- 84.

POWELL C.M.A., OLIVER N.H.S., LI Z.X., MARTIN D.M.B., RONASZECHI J. (1999) Synorogenic hydrothermal origin for giant Hamersley iron oxide bodies. Geology 27: 175-178.

QUARESMA L.F. (2001) Balanço Mineral Brasileiro 2001- Ferro. Departamento Nacional da Produção Mineral, Brasília, pp 1-27.

RAMANAIDOU E. (1989) Genèse d'un gisement latéritique. Evolution supergène des itabirites protérozo de la mine de fer de Capanema, Minas Gerais, Brésil. Ph.D. Thesis. UFR Sciences fondamentales et appliquées. Université de Poitiers, pp 183.

RAMANAIDOU E., NAHON D., DECARREAU A., MELFi A.J. (1996) Hematite and goethite from duricrusts developed by lateritic chemical weathering of Precambrian banded iron formations, Minas Gerais, Brazil. Clays and Clay Minerals 44: 22-31.

RAMOS M.C.D. (1997) O minério de ferro da Mina do Andrade: características geológicas, texturais e metalúrgicas. Dissertação de mestrado. Instituto de Geociências, Departamento de Geologia. Universidade Federal de Minas Gerais - UFMG, Belo Horizonte, pp 165.

RENGER F.E., NOCE C.M., ROMANO A.W., MACHADO N. (1994) Evolução sedimentar do Supergrupo Minas: $500 \mathrm{Ma}$. de registro geológico no Quadrilátero Ferrífero, Minas Gerais, Brasil. Geonomos 2: 1-11.

RENNE P.R. (1998) K-Ar and 40Ar/39Ar dating Dating and earthquakes. Review of Quaternary geochronology and its application to paleoseismology. NUREG/CR 5562, pp 2-129, 122* 169. 
RENNE P.R. (2000) K-Ar and ${ }^{40} \mathrm{Ar} /{ }^{39} \mathrm{Ar}$ dating In: Lettis WR (ed) Quaternary Geochronology Methods and Application. AGU, pp 77-100.

RIBEIRO D.T. (2003) Enriquecimento Supergênico de Formações Ferriferas Bandadas: Estruturas de Colapso e Desordem. Tese de doutorado. Instituto de Geociências. Universidade Federal do Rio de Janeiro, Rio de Janeiro, pp 123.

RIBEIRO D.T., ZAVAGLIA G. (1998) Bacias Terciárias e enriquecimento de minério de ferro In: SIMPÓSIO DE GEOLOGIA DE MINAS GERAIS, 9. Belo Horizonte, Anais, 14: 139140.

RIBEIRO D.T., CARVALHO R.M. (2002) Simulation of weathered iron ore facies: integrating leaching concepts and geostatistical model In: ARMSTRONG M., BETTINI C., CHAMPIGNY N., GALli A., REMACRE A. (eds) Geostatistics Rio 2000. Kluwer, Dordrecht, pp 101-115.

RIBEIRO D.T., PIRES F.R.M., CARVALHO R.M. (2002) Supergene iron ore and disorder. In: IRON ORE 2002. Proceedings, Australasian Institute of Mining and Metallurgy, Perth, pp 81-90.

RIVERS J. (1998) Mineralogy and geochemistry of carbonates from Tom Price Mine in Hamersley Group rocks School of Earth Scienses. Honours thesis. The University of Tasmania, Hobart, pp 100.

ROSIÈRE C.A. (1981) Strukturelle und texturelle untersuchungen in der eisenerzlagerstaette "Pico de Itabira" bei itabirito, Minas Gerais, Brasilien. Ph.D. Thesis. Clausthaler Geowissenschaftliche Dissertationen 9, Clausthal Zellerfeld, pp 302.

ROSIÈRE C.A. (1983) A recristalização do minério de ferro da jazida do Pico do Itabirito no Quadrilátero Ferrífero, MG e suas implicações genéticas. In: SIMPÓSIO DE GEOLOGIA DE MINAS GERAIS, 2. SBG/Núcleo de Minas Gerais, Belo Horizonte, Anais, pp 173-174.

ROSIÈRE C.A., CHEMALE JR. F., GUIMARÃES M.L.V. (1993) Um modelo para a evolução microestrutural dos minérios de ferro do Quadrilátero Ferrífero: Parte I - estruturas e recristalização. Geonomos 1: 65-84.

ROSIÈRE C.A., CHEMALE Jr. F. (2000) Itabiritos e minérios de ferro de alto teor do Quadrilátero Ferrífero - Uma visão geral e discussão. Geonomos 8: 27-43.

ROSIÈRE C.A., SIEMES H., QUADE H., BROKMEIER H., JANSEN E.M. (2001) Microstructures, textures and deformation mechanisms in hematite. Journal of Structural Geology 23: 1429-1440.

ROSIÈRE C.A., RIOS F.J. (2004) The origin of hematite in high grade iron ores based on infrared microscopy and fluid inclusion studies: the example of the Conceição mine, Quadrilátero Ferrífero, Brazil. Economic Geology 99: 61 1-624.

RUFFET G., INNOCENT C., MICHARD A., FERAUD G., BEAUVAIS A., NAHON D., HAMELIN B. (1996) A geochronological ${ }^{40} \mathrm{Ar} /{ }^{39} \mathrm{Ar}$ and ${ }^{87} \mathrm{Rb} /{ }^{87} \mathrm{Sr}$ study of K-Mn oxides from the weathering sequence of Azul, Brazil. Geochimica et Cosmochimica Acta 60: 2219-2232.

RUFFET G., INNOCENT C., NAHON D., FERAUD G., HAMELIN B. (1996) Geochronological study of weathering profile by ${ }^{40} \mathrm{Ar}{ }^{39} \mathrm{Ar}$ analysis of supergene $\mathrm{K}-\mathrm{Mn}$ oxides. Terra Abstracts 7, pp. 350. 
SANT'ANNA L.G., SCHORSCHER H.D., RICCOMINI C. (1997) Cenozoic tectonics of the Fonseca Basin region, eastern Quadrilátero Ferrífero, MG, Brazil. Journal of South American Earth Sciences 10: 275-284.

SCHOBBENHAUS C. (ed) (1984) Geologia do Brasil, texto explicativo do mapa geológico do Brasil e da área oceânica adjacente incluindo depósitos minerais. Escala 1:2.500.000. DNPM, Rio de Janeiro.

SCHWERTMANN, U., CAMBIER, P., MURAD, E. (1985) Properties of goethites of varying crystallinity. Clays and Clay Minerals 33: 369-378.

SHIMIZU H., UMEMOTTO N., MASUDA A., APPEL P.W.U. (1990) Sources of ironformations in the Archean Isua and Malene supracrustals, West Greenland: evidence from La-Ce and Sm-Nd isotopic data and REE abundances. Geochimica et Cosmochimica Acta 54: 1147-1154.

SIAL A.N., FERREIRA V.P., ALMEIDA A.R., ROMANO A.W., PARENTE C.V., DA COSTA M.L., SANTOS V.H. (2000) Carbon isotope fluctuations in Precambrian carbonate sequences of several localities in Brazil. Anais da Academia Brasileira de Ciências 72: 539-558.

SILVA R.C.F. (2004) Caracterização petrográfica e geoquímica de jaspilitos e minérios de ferro, Província Mineral Carajás, Pará: implicações para a mineralização de ferro, Instituto de Geociências. Dissertação de mestrado. Universidade Federal de Minas Gerais-UFMG, Belo Horizonte, pp 151.

SILVA R.C.F., LOBATO L.M., ROSIÈRE C.A. (2005) Petrografia e geoquímica em jaspilitos e minérios hidrotermais de ferro dos depósitos da Serra Norte (N1, N4E, N4W e N5E), Província Mineral Carajás, Pará. In: I SIMPÓSIO BRASILEIRO DE METALOGENIA. Anais, Gramado, CD ROM.

SILVA R.R.R. (2004) Sistemas de reagentes surfatantes na flotação catiônica reversa de minério de ferro. Dissertação de mestrado. Escola de Engenharia. Universidade Federal de Minas Gerais - UFMG, Belo Horizonte, pp 257.

SILVA R.V.G. (1999) Efeito da alumina na flotação de um minério misto hematitico-itabirítico da Mina do Pico. Dissertação de mestrado. Escola de Engenharia. Universidade Federal de Minas Gerais - UFMG, Belo Horizonte, pp 174.

SIMONSON B.M. (1985) Sedimentological constraints on the origin of Precambrian ironformations. Geollogical Society of American Bulletins 104: 244-252.

SIMONSON B.M. (1996) Was the depostion of large Precambrian iron formations linked to major marine transgressions? The Journal of Geology 104: 665-676.

SIMONSON B.M., SCHUBEL K.A., HASSLER S.W. (1993) Carbonate sedimentology of the early Precambrian Hamersley Group of Western Australia. Precambrian Research 60: 287-335.

SOUZA P.C., MÜLLER G. (1984) Primeiras estruturas algais comprovadas na Formação Gandarela, Quadrilátero Ferrífero. Revista Escola de Minas de Ouro Preto 2: 13-21.

SPIER C.A., OLIVEIRA S.M.B., ROSIÈRE C.A. (2003) Geology and geochemistry of the Águas Claras and Pico iron mines, Quadrilátero Ferrífero, Minas Gerais, Brazil. Mineralium Deposita 38: 751-774. 
SPIER C.A., OLIVEIRA S.M.B., SIAL A.N., RIOS F.J. (2005a) Geochemistry and genesis of the banded iron formations of the Cauê Formation, Quadrilatero Ferrifero, Minas Gerais, Brazil. Precambrian Research (submitted).

SPIER C.A., VASCONCELOS P.M., OLIVEIRA S.M.B. $(2005 \mathrm{~b}){ }^{40} \mathrm{Ar} /{ }^{39} \mathrm{Ar}$ Geochronology and the evolution of lateritic iron deposits in the Quadrilátero Ferrifero, Minas Gerais, Brazil. Chemical Geology (submitted).

STEIGER R.H., JAGER E. (1977) Subcommission on geochronology: Convention on the use of decay constants in geo- and cosmochronology. Earth and Planetary Science Letters 36: 359-362.

TAYLOR D., DALSTRA H.J., HARDING A.E., BROADBENT G.C., BARLEY M.E. (2001) Genesis of high-grade hematite orebodies of the Hamerley Province, Western Australia. Economic Geology 96: 837-873.

TAYLOR S.R., MCLENNAN S.B. (1985) The Continental Crust: Its Composition and Evolution. Blackwell.

TEIXEIRA W., FIGUEIREDO M.C.H. (1991) An outline of Early Proterozoic crustal evolution in the São Francisco craton, Brazil: a review. Precambrian Research 53: 1-22.

TEX Report (2002) Iron ore manual 2001-2002, The TEX Report Ltd, Tokyo, pp 331.

THORNE W.S., HAGEMANN S.G., BARLEY M.E. (2004) Petrographic and geochemical evidence for hydrothermal evolution of the North Deposit, Mt Tom Price, Western Australia. Mineralium Deposita.

TRENDALL A.F. (1973) Varve cycles in the Weeli Wolli Formation of the Precambrian Hamersley Group, Western Australia. Economic Geology 68: 1089-1097.

TRENDALL A.F. (2002) The significance of iron-formation in the Precambrian stratigraphic record In: ALTERMANN W., CORCORAN P.L. (eds) Precambrian Sedimentary Environments: A Modern Approach to Ancient Depositional Systems. Blackwell Sciense.

TRENDALL A.F., BLOCKLEY J.G. (1970) The iron formations of the Precambrian Hamersley Group, Western Australia, with special reference to the associated crocidolite, Western Australia Geologycal Survey Bulletim 119, pp. 365.

TRZASKOS-LIPSKI B. (2001) Os atributos estruturais do minério de ferro granulado da Mina de Casa de Pedra, Congonhas - MG, e sua resposta no processo de redução em altoforno Escola de Minas, Departamento de Geologia. Dissertação de mestrado. Universidade Federal de Ouro Preto - UFOP, Ouro Preto, pp 136.

TUCKER M.E., WRIGHT V.P. (1990) Carbonate Sedimentology. Blackwell Scientific Publications, London.

VAN SCHALKWYK J.F., BEUKES N.J. (1986) The Sishen iron ore deposit Mineral deposits of southern Africa. Geological Society of South Africa, Johannesburg, pp 157-182.

VARAJÃO C.A.C. (1991) A questão das superfícies de erosão do Quadrilátero Ferrífero, Minas Gerais. Revista Brasileira de Geociências 21: 138-145.

VARAJÃO C.A.C., BRUAND A., RAMANAIDOU E.R., GILKES R.J. (2002) Microporosity of BIF hosted massive hematite ore. Anais da Academia Brasileira de Ciências 74: 113126.

VASCONCELOS P.M. (1992) Timing and rates of evolution of hydrochemical systems in semiarid and humid environments by application of ${ }^{40} \mathrm{~K}_{-}^{40} \mathrm{Ar}$ and laser-heating ${ }^{40} \mathrm{Ar}-{ }^{39} \mathrm{Ar}$ 
dating of K-bearing weathering product minerals. Ph.D. Thesis. University of California, Berkeley.

VASCONCELOS P.M. (1999) ${ }^{40} \mathrm{Ar} /{ }^{39} \mathrm{Ar}$ geochronology of supergene processes in ore deposits. Economic Geology 12: 73-113.

VASCONCELOS P.M. (1999) K-Ar and ${ }^{40} \mathrm{Ar} /{ }^{39} \mathrm{Ar}$ geochronology of weathering processes. Annu. Rev. Earth Planet. Sci. 27: 183-229.

VASCONCELOS P.M., BECKER T.A., RENNE P.R., BRIMHALL G.H. (1992) Age and duration of weathering by ${ }^{40} \mathrm{~K}-{ }^{40} \mathrm{Ar}$ and ${ }^{40} \mathrm{Ar} /{ }^{39} \mathrm{Ar}$ analysis of potassium-manganese oxides. Science 258: $451-455$.

VASCONCELOS P.M., BRIMHALl G.H., BECKER T.A., RENNE P.R. (1994) ${ }^{40} \mathrm{Ar} /{ }^{39} \mathrm{Ar}$ analysis of supergene jarosite and alunite: Implications to the paleoweathering history of the western USA and West Africa. Geochimica et Cosmochimica Acta 58: 401-420.

VASCONCELOS P.M., RENNE P.R., BRIMHALL G.H., BECKER T.A. (1994) Direct dating of weathering phenomena by ${ }^{40} \mathrm{Ar}{ }^{39} \mathrm{Ar}$ and $\mathrm{K}-\mathrm{Ar}$ analysis of supergene $\mathrm{K}-\mathrm{Mn}$ oxides. Geochimica et Cosmochimica Acta 58: 1635-1665.

VASCONCELOS P.M., RENNE P.R., BECKER T.A., WENK H-R (1995) Mechanisms and kinetics of atmospheric, radiogenic and nucleogenic argon release from cryptomelanes during ${ }^{40} \mathrm{Ar} /{ }^{39} \mathrm{Ar}$ analysis. Geochimica et Cosmochimica Acta 59: 2057-2070.

VASCONCELOS P.M., ONOE A.T., KAWASHITA K., SOARES A.J., TEIXEIRA W. (2002) ${ }^{40} \mathrm{Ar}{ }^{39} \mathrm{Ar}$ Geochronology at the Instituto de Geociências, USP: Instrumentation, Analytical Procedures, and Calibration. Anais da Academia Brasileira de Ciências 74: 297-342.

VEIZER J., HOEFS J., LOWE D.R., THURSTON P.C. (1989) Geochemistry of Precambrian carbonates: II. Archean greenstone belts and Archean sea water. Geochimica et Cosmochimica Acta 53: 859-871.

VEIZER J., CLAYTON R.N., HINTON R.W., VON BURN V., MASON T.R., BUCK S.G., HOEFS J. (1990) Geochemistry of Precambrian carbonates: 3-shelf seas and non-marine environments of the Archean. Geochimica et Cosmochimica Acta 54: 2717-2729.

VEIZER J., CLAYTON R.N., HINTON R.W. (1992) Geochemistry of Precambrian carbonates: IV. Early Paleoproterozoic (2.25 $10.25 \mathrm{Ga}$ ) seawater. Geochimica et Cosmochimica Acta 56: $2487-2501$.

VERÍSSIMO C. (1999) Jazida de Alegria: Gênese e tipologia dos minérios de ferro (Minas 3, 4 e 5 Porção Ocidental), Instituto de Geociências e Ciências Exatas. Tese de doutorado. Universidade Estadual Paulista - UNESP, Rio Claro, pp 234.

VERÍSSIMO C.U.V., SCHRANK A., PIRES F.R.M., HASUi Y., ZANARDO A., PARENTE C.V. (2002) Geochemical study of the itabirite iron ores of the Alegria mine Quadrilátero Ferrifero, Minas Gerais, Brazil. In: IRON ORE 2002. Proceedings, Australasian Institute of Mining and Metallurgy, Perth, p. 95-103.

VIEL R.S., MOREIRA P.C.H., ALKMIM F.F. (1987) Faciologia da Formação Cauê e gênese do minério de ferro friável da Mina de Águas Claras, Serra do Curral-Minas Gerais. In: SIMPÓSIO SOBRE SISTEMAS DEPOSICIONAIS NO PRÉ-CAMBRIANO. Sociedade Brasileira de Geologia - Núcleo MG, Anais, Ouro Preto, pp 137-153.

VILLAÇA J.N. (1981) Alguns aspectos sedimentares da Formação Moeda. Boletim da Sociedade Brasileira de Geologia de Minas Gerais 2: 93-137. 
VILLAÇA J.N., MOURA L.A.M. (1981) Uranium in the Precambrian Moeda Formation, Minas Gerais, Brazil, USGS Professional Paper 1161-T. Washington, pp $\mathrm{T}_{1}-\mathrm{T}_{14}$.

WALDE D.H.G. (1986) Geologia do ferro In: SCHOBBENHAUS C., COELHO C.E.S. (eds) Principais Depósitos Minerais do Brasil. Ferro e metais da induistria do aço. Departamento Nacional da Produção Mineral, Brasília, pp 501.

WALKER, J.C.G. (1984) Suboxic diagenesis in banded iron-formations. Nature 309: 340-342.

WALKER, J.C.G. (1987) Was the Archean biosphere upside down? Nature 329: 710-712.

WALLACE R.M. (1965) Geology and mineral resources of the Pico do Itabirito District, Minas Gerais, Brazil, USGS Professional Paper 341-F. Washington, pp 68.

WEBB A.D., DICKENS G.R., OLIVER N.H.S. (2004) Carbonate alteration of the Upper Mount McRae Shale beneath the martite-microplaty hematite ore deposit at Mount Whaleback, Westen Australia. Mineralium Deposita.

WEBB A.D., DICKENS G.R., OLIVER N.H.S. (2003) From banded iron-formation to iron ore: geochemical and mineralogical constraints from across the Hamersley Province, Western Australia. Chemical Geology 197: 215-251.

YOUNG R.A., PAIVA-SANTOS C.O., LARSON A.C. (1998) User's guide to program DBWS9807 for Rietveld analysis of $X$-Ray and neutron powder diffraction patterns with a ' $P C^{\prime \prime}$ and various other computers. Georgia Institute of Technology, Atlanta.

ZAVAGLIA G. (1995) Condicionantes geológicos do comportamento dos minérios de ferro do Depósito de Tamanduá (MG) no processo metalúrgico de redução direta, Escola de Minas, Departamento de Geologia. Dissertação de mestrado. Universidade Federal de Ouro Preto - UFOP, Ouro Preto, pp 200.

ZUCCHETI M., LOBATO L.M. (2005) Alteração hidrotermal a hematita das rochas máficas encaixantes dos depósitos de ferro N4 e N5, Serra dos Carajás, Pará. In: I SIMPÓSIO BRASILEIRO DE METALOGENIA. Anais, Gramado, CD ROM. 